\title{
Geology of Central
}

Dickinson County

Michigan

GEOLOGIGAL SURVEY PROFESIONAL PAPER 310

Prepared in cooperation with the Geological Survey Division, Michigan Department of Conservation 


\section{Geology of Central}

\section{Dickinson County}

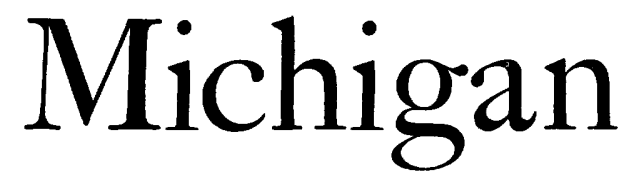

By H. L. JAMES, L. D. CLARK, C. A. LAMEY, and F. J. PETTIJOHN

In collaboration with JACOB FREEDMAN, JAMES TROW, and $\mathrm{K}$. L. WIER

GEOLOGICAL SURVEY PROFESSIONAL PAPER 310

Prepared in cooperation with the Geological

Survey Division, Michigan Department of

Conservation

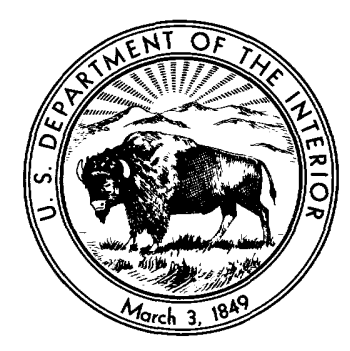

UNITED STATES GOVERNMENT PRINTING OFFICE, WASHINGTON : 1961 
UNITED STATES DEPARTMENT OF THE INTERIOR

STEWART L. UDALL, Secretary

GEOLOGIGAL SURVEY

Thomas B. Nolan, Director

For sale by the Superintendent of Documents, U.S. Government Printing Office

Washington 25, D.C. 


\section{CONTENTS}

Abstract Chapter A. Introduction, by H. L. James.

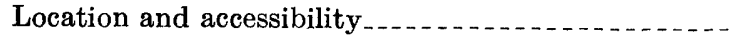
Field work and organization of the report .......... Previous work and summary of the literature...... Topography and vegetation............................ Chapter B. General geology, by H. L. James and F. J. Pettijohn, with a section on the aeromagnetic survey, by K. L. Wier

Preliminary statement of geology

Lower Precambrian rocks ..... . . . . . . . . . . . . . . . .

Granite gneiss of the Norway Lake area...... Occurrence.....................................

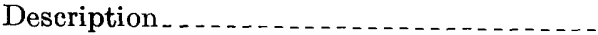
Age relations

Dickinson group

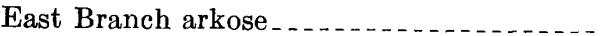

Solberg schist $\ldots \ldots$

General features. .................

Skunk Creek member.....

Six-Mile Lake amphibolite. ............

Dickinson group (undivided) .............

Conditions of deposition of the Dickinson

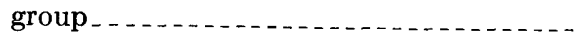

Evidence for Lower Precambrian position.Correlation . . . . . . . . . . . . . . . . . . .

Hardwood gneiss

Banded gray gneiss . . . . .

Gneissic granite . . . .

Occurrence

Description . .

Composition . . .

Age relations ........................

Porphyritic red granite

Description and composition . . . . . . .

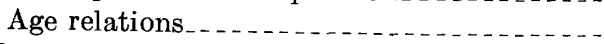

Middle Precambrian rocks

Chocolay group.

Fern Creek formation . . .

Sturgeon quartzite.

Randville dolomite ...................

Description ......................

Thickness and stratigraphic relations..

Conditions of deposition..........

Menominee group

Felch formation.

Description

Thickness and stratigraphic relations..

Conditions of deposition.........

Vulcan iron-formation

Description

Thickness and stratigraphic relations..

Conditions of origin
Chapter B. General geology-Continued

Middle Precambrian rocks-Continued

Baraga group ........ 46

Hemlock formation . . . . . . . .

Michigamme slate....... 48

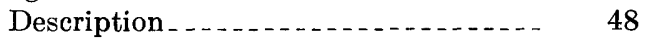

Thickness and stratigraphic relations_. $\quad 51$

Badwater greenstone................. 53

Conditions of deposition of the Baraga group.

Upper Middle Precambrian intrusive rocks......... 54

Metadiabase and metagabbro .............. 54

Description . . . 54

Age relations.......... 54

Pegmatite, granite, and hornblende diorite_._. $\quad 55$

Description...................... 56

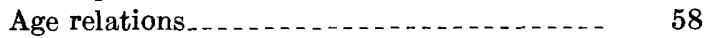

Upper Precambrian rocks (Keweenawan)-diabase_- $\quad 58$

Rocks of Paleozoic age..................... 58

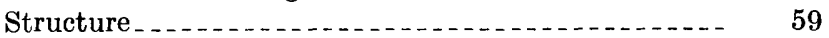

Sagola basin ........ 60

Northern crystalline block _._._.

Felch trough

Western segment.................. 63

Central segment.................... 63

Eastern segment_................. 64

Central crystalline block

Calumet trough $\ldots$

Southern crystalline block _. _.............. 68

Summary and conclusions regarding structural

development. ......................... 70

Late Lower Precambrian orogeny...... $\quad 71$

Late Middle Precambrian orogeny, and preceding events.......................

Late Paleozoic(?) warping . . . . . . . . . . .

Late Middle Precambrian metamorphism

Relation of the late Middle Precambrian metamorphism to deformation..........

Relation of the late Middle Precambrian metamorphism to granitic intrusion .....

Retrograde metamorphism and related features................................

Precambrian weathering

Geologic history

History of Lower Precambrian rocks . . . . . .

History of Middle and Upper Precambrian rocks.

Economic geology

Definition of "iron ore"

History of mining and exploration........

Occurrence and origin of high-grade ores........

III 
Chapter B. General geology-Continued

Economic geology-Continued

Utilization of iron-formation as low-grade ore . General considerations................. Vulcan iron-formation as low-grade ore .... Skunk Creek member as a low-grade ore... Reserves

Possibilities for iron ore in the areas east of central Dickinson County.................

Other materials of economic interest. ........ Dolomite . . . . . . . . . . . .

"Terrazzo" . .

Uranium . .

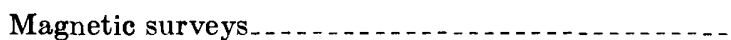

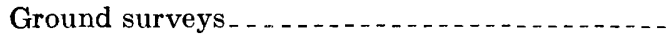
Methods.................................

Interpretation.............................

Aeromagnetic survey, by K. L. Wier....... Reliability of the aeromagnetic data ...... Correlation of anomalies with geology ..... Sagola basin ....................... Northern crystalline block . . . . . . . . . Felch trough Central crystalline block Calumet trough Southern crystalline block . . .........

Chapter C. Precambrian geology of the Norway Lake area, Dickinson County, Mich., by Lorin D. Clark

General geology . . . . .

Lower Precambrian rocks... . . . . . . . . . . . . . .

Chlorite schist and quartzite . . . . . . . . .

Granite gneiss

General character.

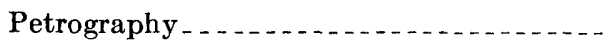

Structural relations . . . . . . . . . . . . . . .

Age

East Branch arkose. ...............

General character.........................

Petrography and petrology

Thickness.............................

Structural and stratigraphic relations.....-

Age and correlation ..................

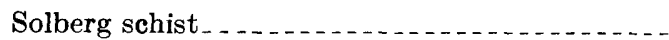

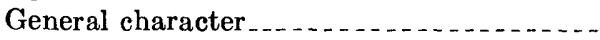

Age. . . . . . . . . . . .

Middle Precambrian rocks . .

Sturgeon quartzite

Randville dolomite

Vulcan iron-formation and associated slates....

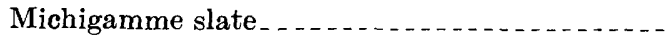
Graphitic and associated slates.........

Red slates and graywackes.............. General character.................... Age

Metadiabase dikes and related rocks . . . . . . . . . . . General character........................ Structural relations Age ............

Pegmatites

Structural geology

Foliation and lineation . .

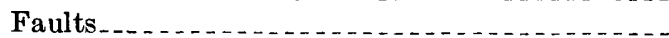

Structure of the East Branch arkose Structure of Middle Precambrian rocks........
Chapter C. Precambrian geology of the Norway Lake area, Dickinson County, Mich.-Continued

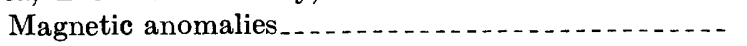

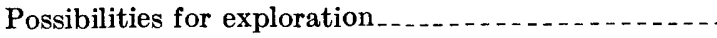

Chapter D. Geology of the Felch Mountain district, by Carl A. Lamey

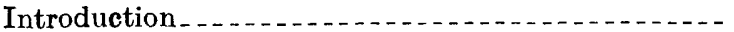

Previous work and literature

Scope of present investigation.

Field and laboratory methods. .............

Personnel and acknowledgments..............

General description of the area mapped...........

Topography and surface features..........

Outline of the geology

Stratigraphic succession . . . . . .

Lower Precambrian rocks... . . . . . . . . . . . . . . . .

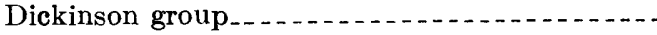

Solberg schist and Skunk Creek member...

Description of the Solberg schist $\ldots . . .$.

Description of the Skunk Creek member.

Six-Mile Lake amphibolite. ............

General description.................

Petrography

Banded gray gneiss . . . . . . . . .

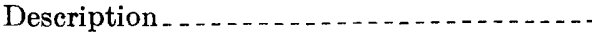

Petrography . . . . . . .

Origin

Southern granitic complex $\ldots \ldots \ldots$

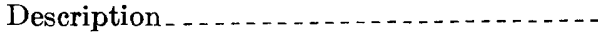

Petrography . . . . .

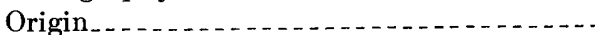

Middle and Upper Precambrian rocks ... . . . . . .

Chocolay group...........................

Sturgeon quartzite Occurrence and characteristies.......

Petrography ........................

Randville dolomite. .................... Occurrence and characteristics........

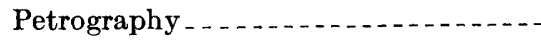

Menominee group.....

Felch formation. . . . . Garnet-grunerite schist .......... Quartzitic mica schist.............. Ferruginous quartz-mica schist and quartzite ...........................

Feldspathic quartz-mica schist

Vulcan iron-formation . . . . . . . . . . . . . Petrography . . . .

Dikes and small intrusions ................. Metadiabase (amphibolite) .............

Granite pegmatite and granite .......... Petrography of the granite pegmatite . Petrography of the fine-grained granite

Diabase... . . . . . . . . . . . . . .

Rocks of Paleozoic age ..........

Pleistocene glacial deposits ......................

Age relations of the granitic rocks ........ Metamorphism ..............................

Regional metamorphism . . . . . . Sturgeon quartzite.....................

Randville dolomite

Vulcan iron-formation and other ferruginous rocks..............................

Local -hydrothermal or retrograde metamorphism.
Page 
Chapter D. Geology of the Felch Mountain district-Con Structure

Precambrian rocks. . . Paleozoic rocks. . . .

Summary of geologic history

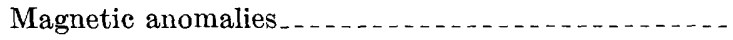
Economic geology

Chapter E. Geology of the Calumet trough and vicinity, by Jacob Freedman, H. L. James, and James Trow

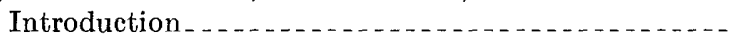

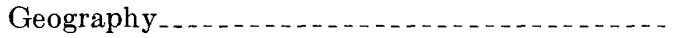
Field work and preparation of the report...... General geology .......... Lower Precambrian rocks....................... Amphibolite.............................. Micaceous quartzite and biotite-quartz schist. -

Hardwood gneiss

Description Garnet-hornblende-pyroxene gneiss.... Plagioclase-quartz gneiss............. Hornblende-pyroxene gneiss.......... Plagioclase amphibolite.............. Amphibolite

Garnet-quartz-mica schist Quartzite...............................

Origin and relations to other rocks ...... Gneissic granitic rocks

Gneissic granite . . . . . .

Quartz diorite............................

Rocks other than granite and quartz

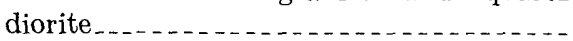

Origin and relations to other rocks .......

Middle Precambrian rocks. ... . .

Chocolay group

Fern Creek formation

Sturgeon quartzite....................

Lower sericitic quartzite . . . . . . . . . .

Vitreous quartzite. ................

Thickness and relations to adjacent formations.

Randville dolomite

Description

Thickness and relations to adjacent formations
Chapter E. Geology of the Calumet trough and vicinityContinued

Middle Precambrian rocks-Continued

Menominee group

Felch formation

Vulcan iron-formation

Description ...........................

Thickness and relations to adjacent formations.

Baraga group .......... 157

Michigamme slate............. 157

Description....................... 157

Thickness and relations to adjacent formations............... 159

Badwater greenstone........ 160

Late Middle Precambrian intrusive rocks. . ... 160

Basic intrusive rocks _............. 160

Metagabbro in the biotite zone...... 160

Metadiabase and metagabbro in the garnet and staurolite zones._._. $\quad 161$

Granitic intrusive rocks _. . . . . 161

Pegmatite and aplite............. 161

Granite_._._.

Upper Precambrian rocks_._. 162

Rock of Paleozoic age . . . . . . 162

Pleistocene glacial deposits......

Structure _... . . . . . .

Structures in the crystalline blocks......... 163

Structures in the Calumet trough $\ldots \ldots \ldots 5$

First Creek area

Area between State Route M-95 and Pine Creek. ................. 166

Crystal Lake-Calumet area . . . . . . . . . 166

East-central part of the Calumet trough _. $\quad 167$

Pine Creek belt of Sturgeon quartzite _. . . 167

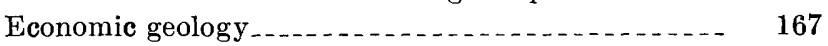

Exploration and production 168

Character of the iron-formation and ore...... 168

Magnetic anomalies and extent of the iron-

formation................ 170

Calumet belt ............ 170

Middle belt ........ 170

Hancock belt....... 171

References cited .

Index . .

\section{ILLUSTRATIONS}

[All plates are in pocket]

1. Generalized geologic map of a part of northern Michigan.

2. Precambrian geology of central Dickinson County.

3. Geology and topography in the Rian quarry area, sec. 33, T. 42 N., R. 28 W.

4. Geologic and magnetic maps of parts of secs. $7-12,14,15$, T. 41 N., Rs. 28,29 W.

5. Geologic map of a part of the banded gray gneiss in secs. 20,29 , and 30, T. 42 N., R. 28 W.

6. Generalized geologic map of northern Michigan showing metamorphic zones.

7. Magnetic map of parts of secs. 1, 2, and 3, T. 42 N., R. 30 W., and secs. 33 and 34, T. 43 N., R. 30 W.

8. Aeromagnetic total-intensity profiles. 
Plate 9. Geologic map of the East Branch arkose belt.

10. Geologic and topographic map of parts of secs. 7, 8, 17, and 18, T. 42 N., R. 28 W.

11. Map of magnetic data in the vicinity of the Deerhunt exploration.

12. Outcrop map of an area of granitic complex in the southern part of the Felch Mountain district.

13. Magnetic maps of the Felch Mountain district.

FIGURE

1. Index maps.

2. Map showing distribution of strata of Paleozoic age in central Dickinson County

7. Photograph showing crossbedding in the East Branch arkose

8. Nose of fold in the East Branch arkose

9-11. Photomicrographs of rocks from the East Branch arkose

12, 13. Photomicrographs of the Solbert schist

14, 15. Photomicrographs of the Six-Mile Lake amphibolite

16, 17. Photographs of the Hardwood gneiss

18, 19. Photomicrographs of the Hardwood gneiss

20. Photomicrograph of plagioclase-pyroxene rock that occurs as layers within hornblende-pyroxene gneiss (Hardwood)

21. Photograph of the banded gray gneiss

22-24. Photomicrographs of gneissic granite

25. Porphyritic red granite

26. Three field sketches illustrating occurrences of amphibolite dikes in sec. 28, T. 42 N., R. 30 W

27-30. Photomicrographs of Sturgeon quartzite

31, 32. Photographs of the Randville dolomite in the Norway Lake area

33, 34. Photomicrographs of the Randville dolomite

35. Photograph of hand specimen of garnet-grunerite-biotite rock from Felch formation

36-38. Photomicrographs of the Felch formation

39. Sketch map of the Felch trough showing major synclinal structures.

40-42. Photomicrographs of Vulcan iron-formation from the Deerhunt exploration . . .

43, 44. Photographs of gray-banded iron-formation (Vulcan)

45-48. Photomicrographs of oolitic iron-formation (Vulcan)

49. Photograph of gruneritic iron-formation (Vulcan)

50-53. Photomicrographs of volcanic rocks of the Hemlock formation, from sec. 2, T. 42 N., R. $30 \mathrm{~W}$.

54-57. Photomicrographs of rocks from the Michigamme slate

58, 59. Photomicrographs of rocks from the Michigamme slate

60. Geologic and magnetic data in the Hancock exploration

61, 62. Photomicrographs of the Badwater greenstone.

63-65. Photomicrographs of metamorphosed basic intrusive rocks

66, 67. Photographs of pegmatite and granite dikes

68. Diagrams showing orientation of dikes in T. 42 N., R. 30 W

69. Sketch showing relations between dikes in outcrop near center of sec. 24, T. 42 N., R. 30 W

70-71. Photomicrographs of younger granite

72. Sketch of outcrop near north quarter corner, sec. 2 , T. 41 N., R. 28 W

73. Photomicrograph of sandy oolitic dolomite

74. Major structural units in central Dickinson County

75. Sketch showing structural elements in the central crystalline block and area adjacent to the north.......

76. Sketch showing possible structural pattern in and around a domelike intrusion.

77. Cross section of the Groveland area.

78. Cross section of the Felch trough

79. Sketch showing how a block of sediments may be trapped by nonsimultaneous development of faults

80. Section across Sturgeon Pond drill holes . . .

81. Aerial photograph showing distribution pattern of Sturgeon quartzite in the southwest part of T. 41 N., R. $29 \mathrm{~W}$

82. Sketch illustrating possible mechanism for structural control

83, 84. Photomicrographs of polished sections of iron-formation, showing effect of metamorphism on grain size

85-87. Photomicrographs of polished sections of Vulcan iron-formation

88-90. Photomicrographs of iron-rich Skunk Creek member of the Solberg schist

91. Magnetic profiles in the Randville-Sagola area . .

92-93. Photomicrographs of feldspars in granite gneiss and arkose

94. Geologic and magnetic map of parts of secs. 1 and 2, T. 42 N., R. 29 W. showing slate within the Randville dolomite.

95. Sketch of the northeast face of the Calumet pit

96. Orientation diagrams of foliations and lineations in the western parts of the central and southern crystalline blocks

97. Orientation diagrams of joints in gneissic granite and in the Michigamme slate

98. Level maps of the Calumet mine. 


\section{TABLES}

TABLE 1. Sequence and character of rocks in central Dickinson County

2. Analyses of granite gneiss from the central crystalline block

3. Comparison of analyses of amphibolite with typical tholeiite

4. Analysis of red porphyritic granite from NE $1 / 4 \mathrm{SE}_{1 / 4}^{1 / 4}$ sec. $21, \mathrm{~T} .42 \mathrm{~N}$, R. $30 \mathrm{~W}$

5. Summary of tentative corclusions regarding metamorphism of principal types of iron-formation

6. Mineral assemblages in the chlorite, biotite, garnet, and staurolite zones of metamorphism.....

7. Shipments of iron ore from the central Dickinson County area, in long tons._.

8. Types of rock giving rise to magnetic anomalies in central Dickinson County

9. Sequence of Precambrian rocks in the Norway Lake area

10. Chemical and mineralogical composition of porphyritic red granite gneiss

11. Comparison of physical characteristics of arkose and recomposed granite

12. Stratigraphic succession in the Felch Mountain district, according to Smyth, 1899.

13. Stratigraphic succession in the Felch Mountain district, according to Van Hise and Leith (1911)

14. Stratigraphic succession in the Felch Mountain district, according to Leith, Lund, and Leith (1935)

15. Probable rock succession for the Felch Mountain district.

16. Rosiwal analyses showing composition of three samples of amphibolite from the banded gray gneiss in sec. 29 , T. 42 N., R. $28 \mathrm{~W}$

17. Chemical analysis of massive granite from the southern granitic complex, Felch Mountain district

18. Rosiwal analyses showing composition of amphibolite from the southern granitic complex, Felch Mountain district

19. Subdivision of the Sturgeon quartzite into lithologic types, Felch Mountain district

20. Stratigraphic table of the Menominee group, Felch Mountain district

21. Structural trends in the Felch Mountain district.

22. Summary of geologic history of the Felch Mountain district

23. Rock units in the Calumet trough and vicinity -

24. Modes of amphibolites from the central crystalline block.

25. Modes of micaceous quartzite and biotite schist inclusions in the gneissic granite

26. Modes of the Hardwood gneiss .

27. Modes of rocks from the gneissic granite complex

28. Thickness and description of Felch formation in sec. 8, T. 41 N., R. 28 W 
$-$
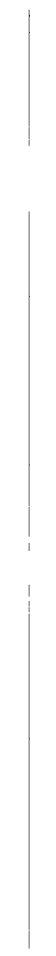


\title{
GEOLOGY OF GENTRAL DIGKINSON GOUNTY, MIGHIGAN
}

\author{
By H. L. James, L. D. Clark, C. A. Lamey, and F. J. Pettijohn \\ In collaboration with $\mathrm{J}_{\text {ACOB }}$ Freedman, James Trow, and K. L. Wier
}

\begin{abstract}
The central Dickinson County map area is in the northern peninsula of Michigan, within the upland between Lake Superior and Lake Michigan. This upland is a wooded plateau of low relief that rises to an altitude of about 1,600 feet, or 1,000 feet above the level of Lake Superior. The present surface of the region is the exhumed Precambrian surface, modified principally by Pleistocene glacial scour and deposition. The maximum altitude in central Dickinson County is about 1,500 feet, and the local relief is about 200 feet. The characteristic topography in areas underlain by crystalline rocks is one of rocky knobs separated by small discontinuous swamps; that in areas underlain by younger metasedimentary and metavolcanic rocks is a rolling surface, with widely scattered outcrops separated by extensive till-covered areas of poorly integrated drainage and many swamps. The major stream is the Sturgeon River, a tributary of the Menominee River which empties into Lake Michigan. The area is sparsely populated; the largest town is Sagola, with about 250 inhabitants.

The rocks of central Dickinson County can be divided into three broad groups that are separated by major unconformities. The oldest sequence of rocks is Lower Precambrian (Archean of previous reports). It consists of metasedimentary and metavoleanic rocks, the Dickinson group, and an underlying granite gneiss. The Dickinson group comprises three apparently conformably formations: (1) the East Branch arkose, made up of metamorphosed arkose and arkosic conglomerate with interlayered metavolcanic flows and tuffs, which rest with profound unconformity on the older, much sheared granite gneiss; (2) the Solberg schist, which consists of fineto medium-grained biotite and hornblende schists and quartzmica schists that are in part of sedimentary and in part of volcanic origin. Included with the schist is the Skunk Creek member, a magnetite-rich bed about 100 feet thick; and (3) the Six-Mile Lake amphibolite, a massive hornblende-plagioclase rock of basaltic composition. The Hardwood gneiss, a complex of light- and dark-colored crystalline rocks in the extreme eastern part of the area, is probably equivalent in age to part of the Dickinson group.

The rocks of the Dickinson group and the Hardwood gneiss occur in the northern half of central Dickinson County. They are bordered on the south by a mass of Lower Precambrian granitic rock which underlies a belt several miles wide across the central part of the map area. The contact between the two groups of rocks is marked by a belt of banded gneiss about a mile wide that consists of interlayered amphibolite and granitic rock, and the main body of granitic rock contains abundant lenses and layers of amphibolite.

The Lower Precambrian rocks are overlain with profound unconformity by Middle Precambrian strata. These strata are assigned to the Animikie series (Huronian of earlier reports), which is divided, in ascending order, into three groups: the Chocolay group-comprising the Fern Creek formation (0-70 ft thick, ) the Sturgeon quartzite $(0-1,850 \mathrm{ft})$, and the Randville dolomite $(0-2,000 \mathrm{ft})$; the Menominee group-comprising the Felch formation (20-200 ft) and the Vulcan iron-formation $(0-400 \mathrm{ft})$; and the Baraga group-comprising the Hemlock formation $(0-3,000 \mathrm{ft}$, mostly volcanic rock), the Michigamme slate $(5,000 \mathrm{ft}$ of graywacke and schist), and the Badwater greenstone $(2,500 \mathrm{ft})$. The three groups are separated by relatively minor unconformities or by disconformities. These rocks are cut by scattered dikes and sills of basic intrusive rock, some of which form bodies several hundred feet thick, and by small bodies of late Middle Precambrian granite, aplite, and pegmatite. The Lower and Middle Precambrian rocks have been metamorphosed regionally; within central Dickinson County the intensity of metamorphism ranges from that of the chlorite zone to that of the staurolite zone. An eastward-trending belt across the central part of the area is within the staurolite zone: north of this belt the intensity falls off to that of the chlorite zone, and to the southwest it falls off to that of the biotite zone. Rocks of equivalent age, therefore, are quite different in texture and mineralogy from one part of the area to another; for example, the Randville dolomite in the northern part of central Dickinson County is a fine-grained dolomite with some interbedded argillaceous layers, whereas 6 miles to the south it is a coarse-grained marble with abundant tremolite and diopside. The youngest Precambrian rocks, and the only ones not affected by the metamorphism, are a few widely scattered diabase dikes of Keweenawan age.

The third major sequence of rocks in the area consists of sandstone and dolomite of Cambrian and Ordovician age. These strata are flat lying or low dipping and rest on the bevelled edges of the Precambrian rocks; they occur as small outliers, which coalesce to form an unbroken sheet, approximately at the east border of the map area. The Cambrian and Ordovician rocks postdate all structural disturbances of the area except epeirogenic movements. They are overlain only by the unconsolidated glacial deposits of Pleistocene age.

Central Dickson County is divided into six major structural units. The northern crystalline block occupies much of the north half of the map area; it is flanked on the north by the Sagola basin of Animikie strata and on the south by the Felch trough, which is a faulted complex syncline that extends as a narrow eastward-trending belt across the center of the area.
\end{abstract}


The central crystalline block is bordered on the north by the Felch trough and on the south by the Calumet trough, which also is a faulted synclinal structure containing Animikie strata. The south limits of the Calumet trough are indefinite except where it is flanked by the southern crystalline block. The relative positions of these major units are controlled principally by high-angle reverse faults, most of which strike eastward. The structural pattern that predates the Animikie sedimentation does not appear to have been greatly disturbed by the late Middle Precambrian deformation; under compressive stress the crystalline blocks apparently rode outward over the younger strata on ramplike shears, crumpling the younger strata into tight folds but without significantly changing the relative positions of units within the crystalline blocks. One of the remarkable features of the structure is that the younger metasedimentary strata adjacent to the crystalline blocks are almost everywhere overturned so as to dip beneath the older rocks.

The principal material of economic interest in central Dickinson County is the Vulcan iron-formation; of lesser importance are the iron-rich Skunk Creek member of the Solberg chist, and the Randville dolomite. The extent of the Vulcan ironformation, which is strongly magnetic, is well established from outcrops and physical exploration coupled with ground and airborne magnetic surveys. The formation attains a maximum thickness of about 400 feet, but in many places it is absent because of erosion prior to deposition of overlying beds of the Michigamme slate. Most of the formation is within the Felch trough and in the eastern part of the Calumet trough. The Vulcan iron-formation in the Felch trough is contained as the youngest beds in tight synclines, whereas that in the Calumet area is in steeply dipping beds, most of which reach the Precambrian surface on anticlinal structures. The rock consists chiefiy of alternating layers of iron oxides (magnetite and specularite) and granular quartz, which is recrystallized chert. The iron content typically is about 34 percent. Very locally, and there only to depths of a few feet, the silica has been leached from the rock so as to form shipping-grade ore; most of this surficial material was mined out 75 years ago. Because the Felch and Calumet areas are within the staurolite zone of metamorphism, the grain size of the constituent minerals in the iron-formation is relatively coarse, so that the material is actual or potential low-grade "concentrating" ore.

The Skunk Creek member of the Solberg schist is known only from magnetic surveys and about half a dozen drill holes. It occurs as a nearly vertical bed, about 100 feet thick, that can be traced for at least 14 miles in an easterly direction across the north part of the map area. The iron content is about 30 percent, most of which is in the form of magnetite.

This report consists of five chapters. Chapter A, Introduction, presents general topics such as nature of the field work, summary of the literature, and description of the topography. Chapter B, General geology, is an extensive summary of the geology of the entire area. Chapter C, Geology of the Norway Lake area, describes the northeastern part of the map area. This area contains all the known exposures of the East Branch arkose and most of the exposures of the pre-East Branch granite gneiss. These rocks in most places are in fault contact with Randville dolomite and Michigamme slate to the north. Chapter D, Geology of the Felch Mountain district, describes the Felch trough and its environs. The trough is a narrow downfaulted and downfolded structure containing Animikie strata that are flanked by older gneiss and granite. Chapter E, Geology of the Calumet trough and vicinity, describes the southern third of central Dickinson County. A large part of this area is underlain by schist and graywacke of the Michigamme slate, the metamorphic grade of which ranges from that of the biotite zone to that of the staurolite zone. The only occurrences of the Fern Creek formation and of the Badwater greenstone in central Dickinson County are in the southwestern part of this area. 


\title{
Chapter A. INTRODUCTION
}

\author{
By H. L. James
}

The iron-bearing districts of the Lake Superior region were studied in detail by the U.S. Geological Survey during the period 1880-1910. The results were published in a series of monographs, the final one of which, Monograph 52, was published in 1911 as a summary of the geology of the entire region. Then for nearly 30 years, relatively little geologic work was done in Michigan by the Federal and State surveys, and although a considerable amount of geologic examination was made by mining companies, most of it was of a nonsystematic nature and little of it was published. During this period the iron-mining industry vastly expanded its production. The search for ore to maintain the high rate of extraction has become increasingly difficult and costly, and the need for more detailed systematic geologic studies has become increasingly apparent.

In 1937 the Geological Survey Division of the Michigan Department of Conservation began a study of the Menominee range of southern Dickinson County. Fieldwork in that area was carried on for 5 years by Carl E. Dutton and Carl A. Lamey, and the results were published in the form of progress reports. In 1943 a cooperative program was established between the U.S. Geological Survey and the Michigan Geological Survey Division, and in 1944 field study was begun in the area covered by the present report.

The major purposes of the investigation in central Dickson County were to establish in greater detail the extent of the several known belts of iron-formation; to investigate, through detailed mapping, the possibilities of previously unknown areas of ironformation; and to establish stratigraphic, structural, and metamorphic patterns that could be used to predict the distribution and character of the iron-rich rocks in the area to the east that is mantled with Paleozoic rocks. The more detailed study has tended to reduce rather than enlarge the area within central Dickson County probably underlain by the principal iron-formation, but it has established the position and extent of a previously little-known iron-formationthe Skunk Creek member of the Solberg schist.
The study of central Dickinson County was carried out as part of a cooperative program with the Geological Survey Division of the Michigan Department of Conservation. The advice and continued active interest of F. G. Pardee, former State Geologist and former president of the Lake Superior Iron Ore Association, and of G. E. Eddy, also former State Geologist and now director of the Michigan Department of Conservation, have been of inestimable value, as has been the support of W. L. Daoust, present State Geologist, and other members of the Geological Survey Division.

It is a pleasure to record the cooperation and assistance given by various mining companies. The M. A. Hanna Co., major holders of mineral rights in the area, supplied much information concerning past and present exploration and permitted examination of drill core; the cordial cooperation extended by workers and officials of that company is gratefully acknowledged. Thanks are due the Jones and Laughlin Ore Co. and Pickands, Mather and Co. for permission to examine drill core from older explorations.

The writers are indebted to many colleagues of the U.S. Geological Survey for advice, assistance, and technical support: Leonard Shapiro prepared eight chemical analyses of granites from the area; J. Anthony Denson prepared the photomicrographs used for illustrations; C. E. Dutton and P. E. Hotz provided beneficial criticism of the manuscript; R. W. Bayley and W. P. Pratt aided materially in compilation of data. Acknowledgments to field assistants and others are found in the separate chapters dealing with the geology of individual areas.

\section{LOCATION AND ACCESSIBILITY}

The central Dickinson County area is in the northern peninsula of Michigan (see fig. 1), and is bounded approximately by meridians $87^{\circ} 41^{\prime}$ and $88^{\circ} 06^{\prime}$ and parallels $45^{\circ} 54^{\prime}$ and $46^{\circ} 05^{\prime}$. The unit measures about 20 by 13 miles and totals 273 square miles. The Menominee district, commonly referred to as the "old" 

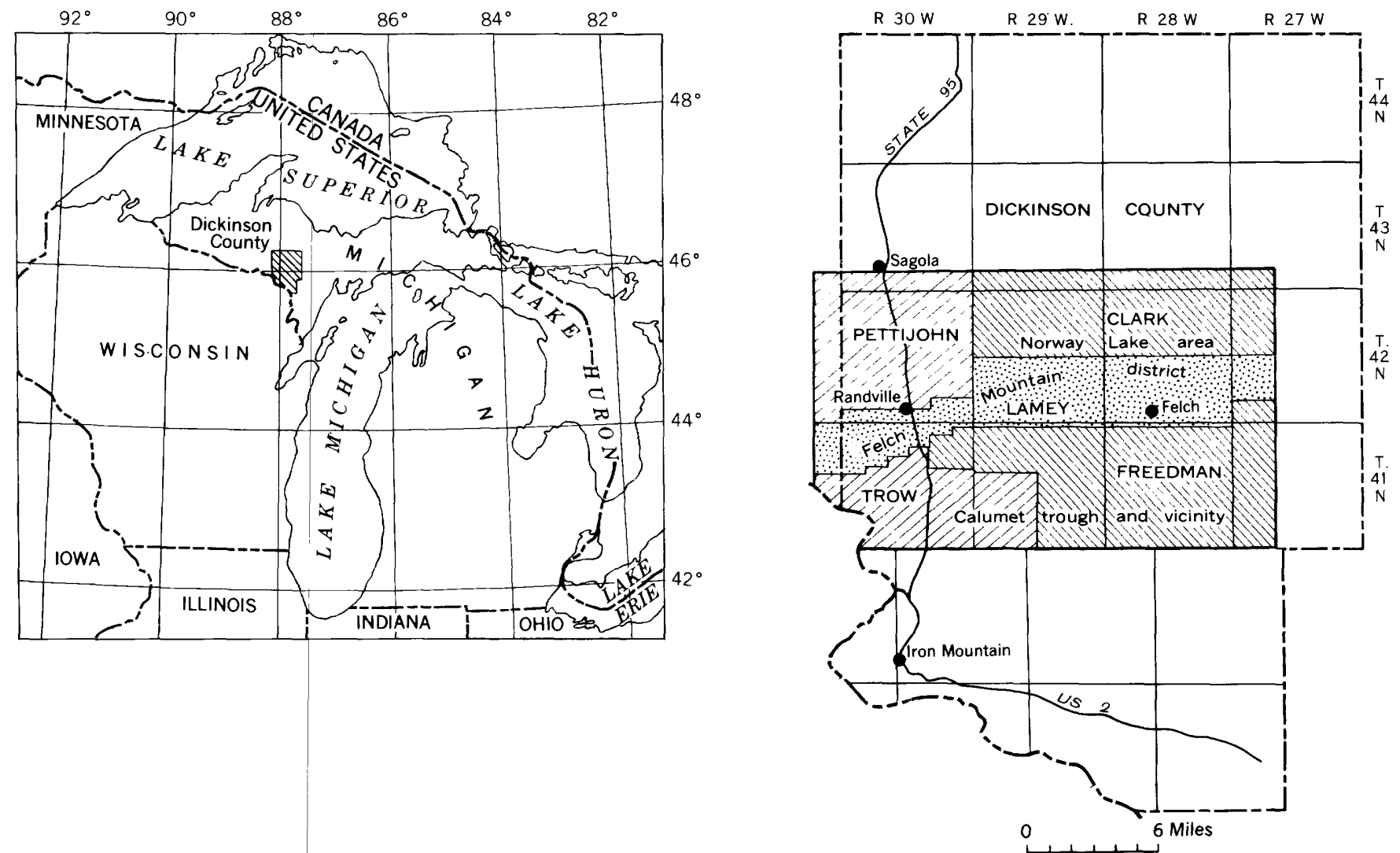

Figure 1.-Index maps.

or "eastern" Menominee, lies directly to the south. The Iron River-Crystal Falls district ("western Menominee") lies 10 to 25 miles to westward.

State Route M95 extends northward from Iron Mountain, in southwestern Dickinson County, through the western margin of the area. Highway M69 extends eastward, from a junction with M95 at the village of Randville, through Felch, Foster City, and Hardwood, thence to Escanaba on Lake Michigan. Many secondary roads branch off from these two highways, and few places within the area are more than 2 miles from a passable road. A main line of the Chicago, Milwaukee, St. Paul, and Pacific Railroad is approximately parallel to State Route M95. A spur line of the Chicago and North Western Railway Co. enters the area from the east and extends westward to the village of Felch.

The area is thinly populated. The village of Sagola in the extreme northwest corner of the map area is the largest community; it has a population of about 250. The village of Felch, in the eastern part of the area, has a population of about 175 . Other communities are Randville, Foster City, and Hardwood, each with fewer than 100 inhabitants.

\section{FIELDWORK AND ORGANIZATION OF THE REPORT}

The fieldwork in the area covered by this report extended over a period of 7 years (1944-50). In 1944 Lamey began field mapping in the Felch Mountain district and continued field work each season through 1950. The Norway Lake are was mapped by Clark in 1947 and 1948. The western part of the Calumet district was mapped during the period $1947-50$ by Trow, the work being essentially a continuation of mapping done by him in previous years in southern Dickinson County as a doctoral study at the University of Chicago. The eastern part of the Calumet district was mapped by Freedman in 1948-50. The geology of T. 42 N., R. 30 W., was mapped by Pettijohn, 1948-49. In 1944 and 1945 the work was under the direction of C. E. Dutton; work done after 1945, and the preparation of the report, were under the nominal direction of James.

Methods of mapping differed from area to area, mainly because topographic base maps were not available. In general, however, all outcrops were mapped except in the interior parts of larger granitic bodies. Most of the area was mapped on aerial photographs, but the Felch Mountain district was mapped 
by pace-and-compass methods, by means of which outcrops and magnetic data were located with respect to section corners.

Magnetic surveys constitute an integral part of the study. The Felch Mountain district was surveyed from lines spaced about 400 feet apart, along which readings were taken at 40 -foot intervals with a Lake Superior model dip needle. The data were compiled at a scale of 400 feet to the inch but later were compiled as magnetic-contour maps at smaller scale. An area southeast of Sagola, in the northwest part of central Dickinson County, was surveyed with a Hotchkiss Superdip, and smaller areas were surveyed with a Schmidt-type vertical magnetometer. Data from the aeromagnetic survey of Dickinson County by Wier, Balsley, and Pratt (1953) were used extensively in the geologic interpretations.

The area covered by this report was mapped by geologists who, to a considerable extent, worked independently. In the pages that follow will be found separate chapters on the Norway Lake area, by Clark and on the Felch Mountain district, by Lamey. A chapter on the area of T. 42 N., R. 30 W., originally prepared as an independent report by Pettijohn, has been incorporated with the section on general geology. The chapter on the Calumet trough and its environs has been written by James, utilizing preliminary text material prepared by Freedman and Trow. Compilation of the general map of the area and preparation of Chapters $\mathrm{A}$ and $\mathrm{B}$ have been the responsibility of James, who has been assisted by K. L. Wier, R. W. Bayley, and W. P. Pratt.

Many of the geologists involved in the study are connected with universities and devote only part of each year to Geological Survey work, so it has not been feasible to prepare a completely integrated report on the entire area. In the separate chapters some duplication is inevitable, particularly in those parts that deal with stratigraphy. Also, a certain amount of disagreement on some of the more elusive geologic problems has naturally developed during the course of the work, and although most of the differences have been reconciled by yearly field conferences and other discussions, no attempt has been made to enforce majority opinions.

In the section of the report on general geology (chapter B) emphasis is placed on geologic features and problems that are common to the entire area or to two or more of the areas covered by separate chapters. The purpose of that section is to provide an overall view of the geology of this area of com- plex rocks. Some features of the geology of central Dickinson County-metamorphism, for exampleshow important progressive changes that are not particularly evident within a given part of the area and are therefore discussed in considerable detail in the section on general geology. The regional setting is described, as well as the implications as to possible extension of the iron-formations eastward beneath the Paleozoic cover. In general, an attempt has been made to summarize, compare, and contrast data, the detailed expressions of which are to be found in the areal descriptions.

The chapters on the individual areas are largely self-contained, although some of the broader aspects of the geology are not treated as extensively as they might be in separate publications, much of this material having been merged into the general discussion of the problems common to the whole area.

\section{PREVIOUS WORK AND SUMMARY OF THE LITERATURE}

The major publications dealing with the geology of Central Dickinson County are U.S. Geological Survey Monograph 36 (Clements and Smyth, 1899) and Monograph 52 (Van Hise and Leith, 1911). In Monograph 36 the geology of the Felch Mountain district and the Sturgeon River tongue (Sagola Basin in this report) is described. In Monograph 52, the geology of the southern part of central Dickinson County is described under the heading "Calumet district." Monograph 46 (Bayley, 1904) describes the geology of the Menominee district immediately to the south. The literature on the area prior to 1911 is tabulated and summarized in these publications and will not be discussed here.

In the monographs referred to, the major aspects of the geology of the region are established. The present work provides much greater detail on the geology and adds a considerable amount of information concerning the structural pattern of the area, but insofar as the stratigraphy and distribution of the Animikie strata are concerned, only in a few places are serious modifications or changes required in the maps and conclusions presented in the older monographs. These publications stand as a monument to geologic work of outstanding excellence.

Since publication of Monograph 52 in 1911, relatively little has been published concerning the geology of central Dickinson County, although a number of papers discuss features within the area in relation to broader problems. A bibliography of reports published since 1912 follows. 


\section{Annotated list of reports published since 1912}

1914

Allen, R. C., and Barrett, L. P., 1914, Contributions to the geology of Northern Michigan and Wisconsin: Michigan Geol. and Biol. Survey Pub. 18, Chapter 2, Geol. Series 15.

Allen and Barrett propose a threefold division of the Huronian series in various areas of Michigan, including the Felch Mountain, Calumet, and Sturgeon Tongue (Sagola Basin) districts, instead of twofold division given in Monographs 36 and 52. The classification and correlation of Allen and Barrett for the rocks of central Dickinson County are listed below.

\begin{tabular}{|c|c|c|c|}
\hline & Sturgeon 1 & Felch Mountain & Calumet \\
\hline Upper Huronian. .. & $\begin{array}{l}\text { Micaceous quartz- } \\
\text { ite and slate. }\end{array}$ & $\begin{array}{l}\text { Mica schist. Fer- } \\
\text { ruginous and mi- } \\
\text { caceous quartzite. }\end{array}$ & \\
\hline Middle Huronian . - & $\begin{array}{l}\text { Iron-formation } \\
\text { (Negaunee). }\end{array}$ & $\begin{array}{l}\text { Vulcan iron-forma- } \\
\text { tion. Felch } \\
\text { schist. }\end{array}$ & $\begin{array}{l}\text { Hanbury slate. } \\
\text { Vulcan iron-forma- } \\
\text { tion. } \\
\text { Felch schist. }\end{array}$ \\
\hline Lower Huronian.... & $\begin{array}{l}\text { Randville dolo- } \\
\text { mite. } \\
\text { Sturgeon quartz- } \\
\text { ite. }\end{array}$ & $\begin{array}{l}\text { Randville dolo- } \\
\text { mite. } \\
\text { Sturgeon quartz- } \\
\text { ite. }\end{array}$ & $\begin{array}{l}\text { Randville dolo- } \\
\text { mite. } \\
\text { Sturgeon quartz- } \\
\text { ite. }\end{array}$ \\
\hline
\end{tabular}

'Area known as the Sagola Basin in this report.

\section{5}

Allen, R. C., and Leith, C. K., 1915, Discussion of correlation of pre-Cambrian formations of Lake Superior region: Jour. Geol., v. 23, p. 703-729.

\section{6}

Allen, R. C., Smith, R. A., and Barrett, L. P., 1916, Geological Map of Michigan: Michigan Geol. Survey.

Map incorporates numerous changes based on field work by Michigan State Survey.

\section{7}

Leverett, Frank, 1917, Surface geology and agricultural conditions of Michigan: Michigan Geol. and Biol. Survey Pub. 25 (Geol. Series 2).

General description of surficial features in the area including central Dickinson County.

\section{0}

Allen, R. C., 1920, Correlation of formations of Huronian group in Michigan: Am. Inst. Min. and Metall. Eng. Trans., v. 63, p. 188-212. Discussion by A. C. Lane, W. O. Hotchkiss, E. F. Burchard, L. P. Barrett, Carl Zapffe, C. E. Siebenthal, and E. C. Harder: Mining and Metall. no. 157, p. 1-6, Jan. 1920.

Allen presents important new evidence to prove the existence of an unconformity between his Middle and the Upper Huronian in the Menominee range of southern Dickinson County, and discusses the general implications with regard to subdivision of the Huronian and use of the term Animikie. Allen describes drill core containing as much as 78 feet of conglomerate. The conglomerate overlies the Vulcan iron-formation and is at the base of the Hanbury slate (abandoned name).

1929

Leverett, Frank, 1929, Moraines and shore lines of the Lake Superior Basin: U. S. Geol. Survey Prof. Paper 154A.

This report is a general discussion of the glacial history of the entire Lake Superior region. The general map (fig. 5) of this report shows central Dickinson County as covered by drift of substage 4 of the Wisconsin stage. The area is referred to very briefly in the text.

\section{1}

Lamey, C. A., 1931, Granite intrusions in the Huronian formations of northern Michigan: Jour. Geol., v. 39, p. 288-295.

See note below, under Dickey, R. M., 1938.

\section{3}

Lamey, C. A., 1933, The intrusive relations of the Republic granite: Jour. Geol., v. 41, p. 487-500.

See note below, under Dickey, R. M., 1938.

\section{4}

Lamey, C. A., 1934, Some metamorphic effects of the Republic granite: Jour. Geol., v. 42, p. 248-263.

See note below, under Dickey, R. M., 1938.

\section{5}

Leith, C. K., Lund, R. J., and Leith, A., 1935, Pre-Cambrian rocks of the Lake Superior region: U. S. Geol. Survey Prof. Paper 184.

In this report, the authors issue a new map of the Lake Superior region and discuss briefly modifications necessary in the geologic concepts expressed in Monograph 52, published in 1911. Mention is made in the text of changes in map pattern in the vicinity of Felch, based on unpublished maps by N. H. Stearns and C. O. Swanson, but these changes are scarcely noticeable at the published scale $(1: 1,000,000)$. The subdivision and correlation of the Huronian (Animikie of this report) proposed by Allen and Barrett (1914) are here accepted; the Vulcan is placed in the Middle Huronian, correlative with the Negaunee of the Marquette district, instead of in the Upper Huronian as proposed in Monograph 52.

\section{6}

Dickey, R. M., 1936, The granitic sequence in the southern complex of Upper Michigan: Jour. Geol., v. 44, p. 317-340.

See note below, under Dickey, R. M., 1938.

Martin, Helen M., The centennial geological map of the northern peninsula of Michigan: Michigan Dept. of Conserv., Geol. Survey Div. Pub. 39, Geol. Ser. 33.

Scale $1: 500,000$. Little or no change made in the geology of the central Dickinson County area from that shown in Professional Paper 184 (Leith, Lund, Leith, 1935).

\section{8}

Dickey, R. M., 1938, The Ford River granite of the southern complex of Michigan: Jour. Geol., v. 46, p. 321-335.

In this and in previously listed papers by Lamey and Dickey, discussion centers around the age of the granite that lies between the central Dickinson County area and the Marquette district. Lamey describes granite dikes that cut known Huronian strata (Animikie of this report) in a number of placesincluding the Felch area and other areas of central Dickinson County-and the widespread metamorphism of upper Huronian rocks; he concludes that much of the granite of the crystalline blocks is post-Huronian in age. In his first paper Dickey supports the older view that the bulk of the granite is pre- 
Huronian in age. In the 1938 publication he describes the outcrops in the Floodwood area, which lies about 5 miles north of the central Dickinson County unit. Here Dickey shows that a granite containing large masses of pebbly quartzite is clearly truncated by later ferruginous quartzite. On the assumption that the included quartzite is of early Huronian age, and that the overlying quartzite is of middle Huronian age, he concludes that the granite is post-early Huronian and pre-middle Huronian in age. He states, however, that the possibility of a pre-Huronian age for the included quartzite cannot be ruled out.

It should be pointed out that Lamey and Dickey disagree only in terms of abundance of post-Huronian and pre-Huronian granite; both agree that granite of both ages is present.

Lake Superior Iron Ore Association, 1938, Lake Superior Iron Ores: Cleveland, Ohio, 364 p.

Location, production statistics, and brief history of mining is given for each Lake Superior property, including those of central Dickinson County.

\section{0}

Tyler, S. A., Marsden, R. W., Grout, F. F., and Thiel, G. G., 1940 , Studies of the Lake Superior pre-Cambrian by accessory mineral methods: Geol. Soc. America Bull., v. 51, p. 1429-1538.

In this paper the results of extensive investigations into the accessory minerals of Lake Superior rocks, granites in particular, are reported. The authors conclude that the variety of zircon present may be significant in terms of age of the rock.

A number of specimens from the central Dickinson County area were included in the study. In general, the conclusions based on the character of the zircon crystals is in keeping with the accepted relative ages of the rocks.

\section{3}

Pettijohn, F. J., 1943, Basal Huronian conglomerates of Menominee and Calumet districts, Michigan: Jour. Geol., v. 51, p. 387-397.

Five localities in central and southern Dickinson County were mapped in detail to show the relationship between the crystalline rocks and the overlying Huronian rocks (Animikie of this report). Basal conglomerates and evidence of erosional truncation of the granite were found in each. One of these areas is in sec. $20, T .41 \mathrm{~N}$., R. $30 \mathrm{~W}$., within central Dickinson County; the others are in southern Dickinson County. In this paper Pettijohn also defines a succession of beds consisting chiefly of argillite, slate, arkosite, and conglomerate lying between the vitreous Sturgeon quartzite and the basement complex. This succession is named the Fern Creek formation. Some of the beds are interpreted as tillite.

Higgins, J. W., 1947, Structural petrology of the Pine Creek area, Dickinson County, Michigan: Jour. Geology, v. 55, p. $476-489$.

This paper reports the results of petrofabric study on the belt of Sturgeon quartzite and adjacent granite that extends from sec. 20 , T. 41 N., R. 29 W. (in central Dickinson County), southeastward for a distance of about 15 miles. The belt was mapped jointly by Higgins and James W. Trow (see below).
1948

Trow, James W., 1948, The Sturgeon quartzite of the Menominee district, Michigan: Unpublished $P h . D$. thesis at Univ. of Chicago, $60 \mathrm{p}$.

Report on the general geology of the area covered by Higgins' report (1947) on structural petrology. Includes outcrop map of the belt, also detailed maps of selected areas.

\section{9}

Richardson, E. J., Jr., 1949, Some Lower Huronian stromatolites of northern Michigan: Fieldiana Geology, Chicago Natural Hist. Mus., v. 10, no. 8, p. 47-62.

A description and classification of algal structures in the Precambrian dolomites of northern Michigan is given. Included are descriptions of stromatolites in the northeastern part of central Dickinson County.

\section{0}

Dutton, Carl E., 1950, Progress of geologic work in Iron and Dickinson Counties, Michigan: U. S. Geol. Survey Cir. 84.

This is a brief review, accompanied by maps, of current work of the U.S. Geological Survey in the region.

Stead, F. W., Davis, F. J., Nelson, R. A., and Reinhardt, P. W., 1950, Airborne radioactivity survey of parts of Marquette, Dickinson, and Baraga Counties, Michigan : U. S. Geol. Survey (Map and brief text printed on map sheet).

The area surveyed includes the northernmost part of the central Dickinson county unit. The map shows several areas that yield greater-than-average radioactive values to the airborne instrument.

\section{3}

Wier, K. L., Balsley, J. R., and Pratt, W. P., 1953, Aeromagnetic survey of part of Dickinson County, Michigan, with preliminary geologic interpretation: U. S. Geol. Survey Geophys. Invest. Prelim. Rept. GP 115.

Dickinson County was surveyed with an airborne magnetometer, fiown at an elevation of 500 feet along lines a third of a mile apart. The magnetic profiles and a map showing the location of crests of anomalies are given in the report.

\section{5}

James, H. L., 1955, Zones of regional metamorphism in the Precambrian of northern Michigan: Geol. Soc. America Bull. v. 66, p. $1455-1488$.

A map that includes central Dickinson County is presented, on which are shown metamorphic-zone boundaries.

\section{8}

Dutton, C. E., 1958, Precambrian geology of parts of Iron and Dickinson Counties, Michigan: Mich. Basin Geol. Soc., 40 p. A guidebook for a field conference in the area.

James, H. L., 1958, Stratigraphy of pre-Keweenawan rocks in parts of northern Michigan: U. S. Geol. Survey Prof. Paper 314-C, p. 27-44.

This paper presents a summary of stratigraphic nomenclature for an area that includes central Dickinson County. The reasons for abandonment of the term Huronian in favor of Animikie are given. 


\section{TOPOGRAPHY AND VEGETATION}

The central Dickinson County area is part of the general upland that lies between Lake Superior and Lake Michigan. The elevation ranges approximately from 1,100 feet to 1,500 feet above sea level, or about 500 to 900 feet above the level of Lake Superior.

Most of the area is characterized by low discontinuous ridges or knobs separated by low ground that commonly is swampy. Although the relief is not more than a few hundred feet, much of the country is rough in detail and difficult to traverse. A thick growth of hardwoods, consisting principally of maple, elm, birch, poplar, ash, and basswood-with a scattering of balsam, spruce, hemlock, and pine-covers most of the higher ground. In the intervening swamps and low ground, cedar, black spruce, tamarack, and alder predominate. White pine, red (Norway) pine, jack pine, and oak are abundant in some of the more sandy tracts. Small farms are scattered through the area, the largest concentration being in an eastward-trending belt extending through Randville and Felch. The chief products are potatoes, dairy goods, and hay. One of the largest farm areas is just west of Felch, in an area underlain in part by limestone of Ordovician age.

The Sturgeon River and its tributaries drain most of central Dickinson County, with peripheral parts being drained by the Ford River in the northeast and the Menominee River in the southwest. These streams drain into Lake Michigan. In general, drainage is rather poor and swamps are widespread. Stream gradients vary widely; most of the streams have long reaches of sluggish or swampy water separated by short stretches of rapids over rock outcrops or bouldery moraine.

Areas underlain by older Precambrian crystalline rocks and by quartzite are rocky, with many low but steep cliffs and bluffs. In these areas the influence of rock structure on the topography is pronounced; most of the ridges are parallel to bedding, shear zones, or gneissic structure, all of which trend eastward over most of the area.

Areas underlain by younger Precambrian metasedimentary rocks other than quartzite have a more subdued topography that has been strongly modified in most places, by glacial scour and deposition, as for example in the Calumet district. In general, these areas form undulating lowlands that border the rocky highlands of crystalline rocks. The topography of areas of Paleozoic strata is characterized by broad, rolling hills, some of which are of considerable height; one of the highest points on the map area is the crest of a broad hill west of Felch, a hill which is underlain by nearly flat lying sandstone and dolomite.

The present surface owes much of its character to glacial action. The ice of the Wisconsin stage, with a center in Labrador, divided in the Lake Superior region into great lobes that followed the Lake Superior and Lake Michigan basins (Leverett, 1929) and finally overrode the entire intervening highland. In the Wisconsin stage, ice entered central Dickinson County from the east, spreading from the Green Bay lobe of the Lake Michigan basin. The trend of ice movement is marked by abundant glacial grooving of rock outcrops and by formation of elliptical hills (drumlins), notably in the northeastern part of the area. Because this trend is parallel or subparallel to the geologic structure, the gross aspects of the topography were modified only slightly in many areas, but drainage doubtless was changed profoundly.

A still-stand in the retreat of the Wisconsin ice now is marked by a broad moraine that extends southward from the northwest corner of the map area along the west side of T. 42 N., R. 30 W. This hummocky tract stands well above the surrounding area. Swamps are numerous on the back (eastern) side of the ridge whereas a broad plain of sandy outwash borders it on the west. According to Leverett (1929), this moraine is part of the system belonging to substage 4 of Wisconsin ice. It continues northward into northern Dickinson County, thence west across Iron County, and into northern Wisconsin.

Except in the northeast part of the area, which in part is covered with sandy outwash related to a later stand of Wisconsin ice, the remainder of central Dickinson County is largely mantled by ground moraine, a bouldery, sandy clay deposit with a great range in thickness. In much of the central rocky part of the area the moraine is present only in interridge patches, whereas in the areas underlain by weaker Precambrian or Paleozoic strata it is almost continuous and probably attains a thickness of as much as 200 feet. This till forms a plain with undulating or rolling surface throughout most of the southeast and southwest parts of central Dickinson County. 


\title{
Chapter B. GENERAL GEOLOGY
}

\author{
By H. L. James and F. J. Pettijohn
}

The regional setting of the central Dickinson County area is shown on plate 1 . The area is near the southeast margin of the exposed part of the Canadian shield in the Lake Superior region. Low-dipping strata of Paleozoic age overlie the Precambrian rocks along the east border of the mapped area and form numerous isolated patches within the area.

The Menominee range, now largely dormant but once a major producer of iron ore, lies directly south of the mapped area and shares many of the geologic problems discussed in this report. The Iron RiverCrystal Falls district is 10 to 25 miles to the west, and the highly productive Marquette district, and its southwestward extension toward Republic, is 20 to 30 miles northward.
Considerable geologic similarity exists between the Felch district of central Dickinson County and the Marquette and Menominee districts. The stratigraphic succession is approximately equivalent in each, and each has a predominant eastward trend. The Iron River-Crystal Falls district, on the other hand, differs radically in both stratigraphy and structural pattern.

\section{PRELIMINARY STATEMENT OF GEOLOGY}

A brief review of the geology of central Dickinson County is given at this point so that the reader may gain a general perspective. The stratigraphic relationships are summarized in table 1 . The stratigraphic sequence in relationship to other parts of northern Michigan has been presented in a previous paper

TABLE 1.-Sequence and character of rocks in central Dickinson County

\begin{tabular}{|c|c|c|c|}
\hline Quaternary ............... & \multirow{2}{*}{\multicolumn{3}{|c|}{$\begin{array}{l}\text { Till, sand, gravel. } \\
\text {-Unconformity } \\
\text { Sandstone and dolomite (flat-lying or low-dipping) } \\
\text {-Unconformity }\end{array}$}} \\
\hline Cambrian and Ordovician & & & \\
\hline Upper Precambrian....... & \multirow{2}{*}{\multicolumn{2}{|c|}{$\begin{array}{l}\text { Keweenawan } \\
\text { Intrusive contact- } \\
\text { Intrusic intrusive rocks conta ct- } \\
\text { Metadiabase and metagabbro }\end{array}$}} & Rare diabase dikes. \\
\hline \multirow{4}{*}{ Middle Precambrian $\ldots . . .}$. & & & Dikes and sills; now chloritic and amphibolitic rocks. \\
\hline & \multirow{3}{*}{ 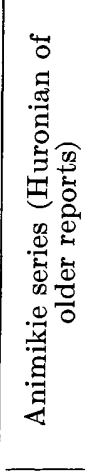 } & Baraga group........... & $\begin{array}{l}\text { Badwater greenstone. Chloritized basic flows, possibly some tuffs. } \\
\text { Michigamme slate. Graywacke and slate, in places metamorphosed } \\
\text { to granulite and schist; locally staurolitic. } \\
\text { Hemlock formation. Mainly light-colored felsite. Present only in } \\
\text { northwestern part of area; very poorly exposed. }\end{array}$ \\
\hline & & Menominee group $\ldots \ldots$ & $\begin{array}{l}\text { Vulcan iron-formation. Thin-bedded rock composed of chert, } \\
\text { magnetite, specularite; locally with grunerite and garnet. } \\
\text { Felch formation. Schist, locally with thin quartzite layers. }\end{array}$ \\
\hline & & Chocolay group.... & $\begin{array}{l}\text { Randville dolomite. Mostly massive white, gray or pinkish; locally } \\
\text { with algal structures. } \\
\text { Sturgeon quartzite. Main part massive, vitreous; upper and lower } \\
\text { parts schistose. } \\
\text { Fern Creek formation. Thin unit, mainly conglomerate in this } \\
\text { area; includes tillite elsewhere. }\end{array}$ \\
\hline \multirow[t]{4}{*}{ Lower Precambrian....... } & \multirow{2}{*}{\multicolumn{2}{|c|}{$\begin{array}{l}\text { Post-Dickinson crystalline rocks_- } \\
\text {-Intrusive or replacement contact- }\end{array}$}} & $\begin{array}{l}\text { Gneissic granite, banded gray gneiss, and red porphyritic granite. } \\
\text { Emplacement accompanied by profound deformation, meta- } \\
\text { morphism, and modification of preexisting rocks. }\end{array}$ \\
\hline & & & $\begin{array}{l}\text { Hardwood gneass. Strongly bedded dark- and light-colored gneisses, } \\
\text { probably originally volcanic rocks and intrusive basic rocks for } \\
\text { the most part. Stratigraphic position uncertain; may be essen- } \\
\text { tially part of the Dickinson group. }\end{array}$ \\
\hline & \multicolumn{2}{|c|}{ Dickinson group. ................ } & $\begin{array}{l}\text { Six-Mile Lake amphibolite. Massive hornblende-plagioclase rock, } \\
\text { considered to be metamorphosed basaltic volcanic rocks. } \\
\text { Solberg schist. Biotite-hornblende schists, quartz-mica schist. } \\
\text { Includes interbedded iron-rich Skunk Creek member. } \\
\text { East Branch arkose. Arkose and conglomerate, with interbedded } \\
\text { metamorphosed basaltic flows and rhyolitic tuffs. }\end{array}$ \\
\hline & \multicolumn{3}{|c|}{-Profound unconformity } \\
\hline
\end{tabular}


(James, 1958), in which are given the reasons for using Animikie in preference to the familiar term Huronian, and the basis for subdivision of the Animikie series into the Chocolay, Menominee, Baraga, and Paint River groups.

The general geologic map of the area (pl. 2) shows only the Precambrian rocks. About one-third of the area is underlain by Middle Precambrian sedimentary rocks (Animikie series); the remaining two-thirds is underlain by crystalline rocks that are chiefly Lower Precambrian. The Lower Precambrian rocks form broad islandlike masses flanked or surrounded by the Middle Precambrian sedimentary rocks. Upper Precambrian rocks - that is, the Keweenawan-are represented in this area only by scattered diabase dikes.

Sedimentary rocks of Cambrian and Ordovician age, preserved in isolated patches, rest with profound unconformity on the beveled edge of the Precambrian rocks. These flat-lying or gently dipping beds, consisting principally of sandstone, are outliers of the strata of Paleozoic age that form a continuous cover in the area immediately to the east. Distribution of these rocks is shown separately, on figure 2 .

The rocks assigned to the Lower Precambrian sequence consist principally of granite and gneiss, but much of the northern part of the map area is underlain by a series of metamorphosed sedimentary and volcanic rocks, the Dickinson group. These rocks lie unconformably on an older gneissic granite and in turn are intruded by granite of late Lower Precambrian age. A broad zone of banded gneiss marks the contact. The Dickinson group is made up the following stratigraphic units:

1. The East Branch arkose. This formation consists principally of conglomerate and arkose, with interbedded tuffs and basic volcanic flows. The conglomerates contain pebbles and cobbles of vitreous quartzite and equigranular red granite. The arkose is abundantly crossbedded.

2. The Solberg schist. This formation consists principally of dark quartzose biotite and hornblende schist and light-colored quartz-mica schist that in places can be classed as micaceous quartzite. Interbedded with the biotite and hornblende schist is the Skunk Creek member, which is a thin-layered, magnetite-rich rock.

3. Six-Mile Lake amphibolite. This is a dark massive rock consisting principally of hornblende and plagioclase. It appears to represent original basic flows.

The Hardwood gneiss, which comprises a group of light-and dark-colored gneisses that probably were volcanic rocks and basic intrusives originally, is a unit of uncertain stratigraphic position. It may be equivalent to part of the Dickinson group. It is present only in a small area at the east margin of central Dickinson County.

The major occurrences of pre-Animikie granite are in the central and southern parts of the area, where it forms rocky uplands. Most of the rock is a pink or gray gneiss, locally with abundant large inclusions of amphibolite and metamorphosed sediments. The inclusions are generally in structural parallelism with the foliation and lineation of the enclosing rock.

The Animikie strata which rest with profound unconformity on the rocks described above, are divided into three major divisions: the Chocolay group (oldest), the Menominee group, and the Baraga group (youngest). The unconformity at the base of the series is exposed at three places in the central Dickinson County area. The Chocolay group (lower Huronian of other reports) comprises, from oldest to youngest, the Fern Creek formation, the Sturgeon quartzite, and the Randville dolomite. The Fern Creek formation, a really insignificant unit, consists of conglomerate and arkose lying between the Sturgeon quartzite and the older gneiss. The Sturgeon quartzite is a major stratigraphic unit, locally as much as 2,000 feet thick; it consists chiefly of vitreous white quartzite. The Randville dolomite, which conformably overlies the Sturgeon, attains a maximum thickness of about 2,000 feet; it consists mainly of massive dolomite that locally shows algal structures. In much of the area the Randville is a coarse tremolitic marble. The rocks of the Menominee group (middle Huronian of older reports) overlie the Randville dolomite with a probable minor unconformity. The basal member is the Felch formation, a thin assemblage of various micaceous and ferruginous schists with thin layers of quartzite. This is overlain conformably by the Vulcan iron-formation. The ironformation is a thin-layered rock made up of alternating layers of recrystallized chert and iron minerals, principally magnetite and specularite.

The Baraga group (upper Huronian of older reports) is separated from the Menominee group by an important unconformity, though the contact is not visible within this area. In places these strata rest on rocks older than the Vulcan iron-formation and locally may rest directly on the pre-Animikie gneiss or schist. The Baraga group comprises three formations: the Hemlock formation, the Michigamme slate, and the Badwater greenstone. The Hemlock formation, present only in the northwestern part of the area, appears to consist chiefly of quartz-bearing felsite, probably 


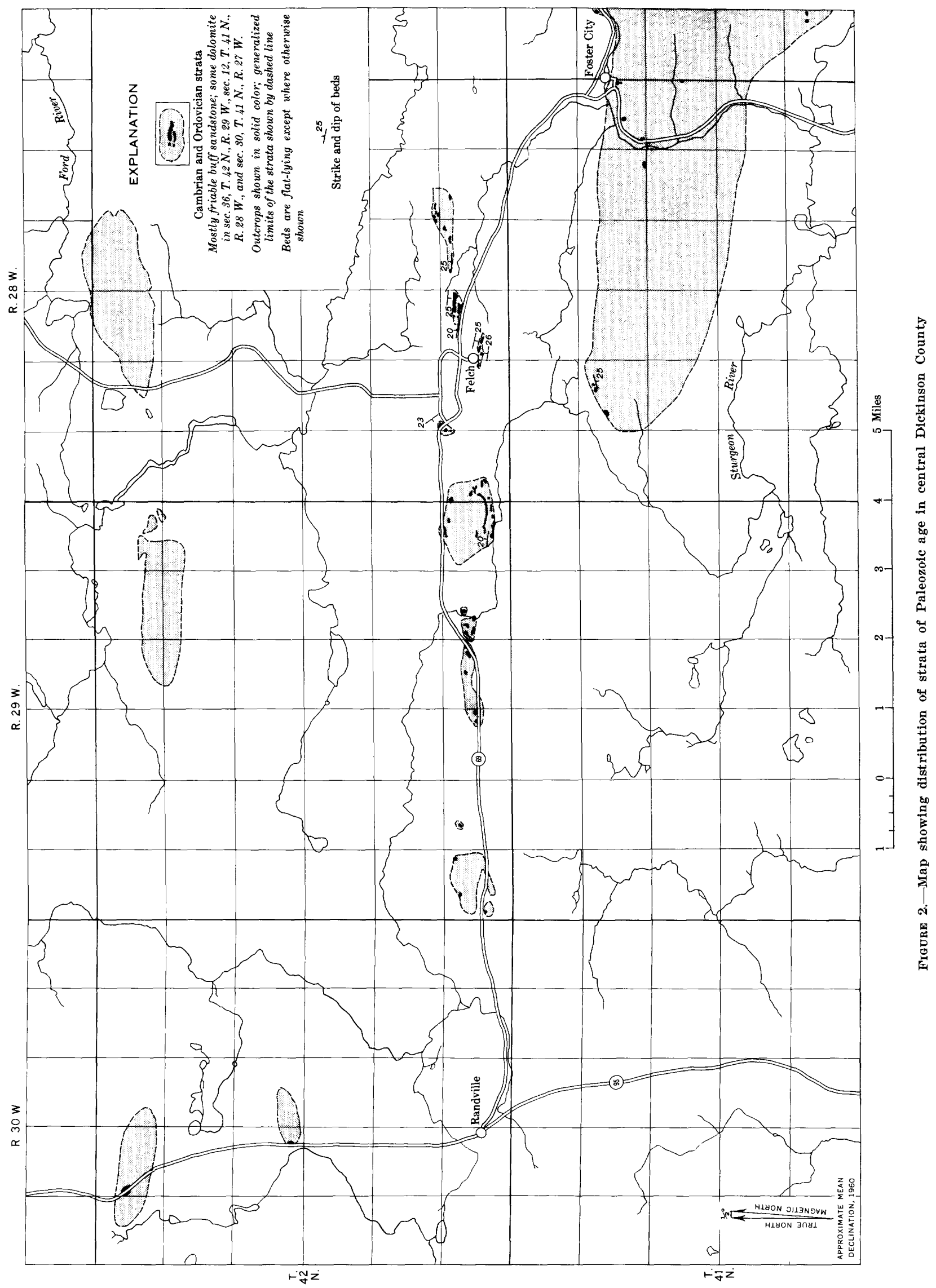


originally a rhyolitic tuff. The Michigamme slate consists principally of metamorphosed graywacke and micaceous schist, although graphitic and ferruginous slates are present in the northernmost part of the area. The Badwater greenstone unit is made up chiefly of chloritized basic volcanic flows and agglomerates, and is generally classified as greenstone.

Metadiabase and metagabbro of late Middle Precambrian age occur as dikes and sills in all parts of central Dickinson County. These rocks are cut by later dikes and small masses of pegmatite, granite, and hornblende diorite, which in turn are cut by a few thin dikes of fresh diabase of Keweenawan age. The diabase is the youngest Precambrian rock in the area.

Faults that trend east or east-northeast dominate the structural pattern. The Animikie strata occur in three distinct troughs or basins between areas of crystalline rocks; from north to south these are:

1. The Sagola basin (south part only). The eastern part of this area, formerly known as the Sturgeon River tongue, is underlain by Randville dolomite that is succeeded unconformably by rocks of the Baraga group, with a small patch of Vulcan ironformation of the Menominee group being preserved at the Deerhunt exploration. The geology of the western part of the south margin of the Sagola basin is very poorly known; the area appears to be underlain by northwestward-dipping volcanic rocks of the Hemlock formation, which overlie lower Middle Precambrian schists and underlie the Michigamme slate.

2. The Felch trough. The Felch trough (or district) is a narrow complex belt of folded and faulted Animikie rocks; it extends across the center of central Dickinson County.

3. The Calumet trough (or district). This is a wide belt underlain principally by the Michigamme slate. The general absence of older Animikie strata is in part due to faulting and in part due to removal of these units by erosion prior to deposition of the Michigamme.

All of the Lower Precambrian rocks are metamorphosed and show evidence of strong internal deformation. Metamorphism of the Middle Precambrian rocks is strong only in the central part of the area, principally affecting the rocks of the Felch trough and the Calumet district. In the northern and southwestern parts of the area, the Animikie strata are only weakly metamorphosed.

\section{LOWER PRECAMBRIAN ROCKS}

The relative ages of many of the Lower Precambrian rocks are highly uncertain and only tentative assignments can be made. The sedimentary and volcanic rocks that make up the Dickinson group probably rest unconformably on granite gneiss; they increase in metamorphic grade toward the south and grade into a broad belt of layered gneiss that appears to be the border facies of a granite batholith, the major part of which is south of the Felch trough. This granite, therefore, is assumed to be largely of post-Dickinson age and comparable to the Algoman granite elsewhere in the Lake Superior region. Age relations between the Dickinson group and the porphyritic red granite of T. 42 N., R. 30 W., are not clear; probably the porphyritic red granite is the younger rock, at least in its present form. The age of the Hardwood gneiss also is uncertain, but field evidence indicates that this gneiss formed part of the mantle into which the post-Dickinson granite was intruded. This would suggest that the Hardwood is comparable in age to strata of the Dickinson group.

All the pre-Animikie rocks have been profoundly altered by dynamothermal metamorphism, although parts of the East Branch arkose still retain clear-cut sedimentary features. The pre-Animikie rocks characteristically have strong planar and linear structures, in contrast to Animikie rocks, in which such structures generally are absent, except near fold axes, even in rocks of equivalent metamorphic grade. Pebbles are stretched, mineral orientation (especially in the amphibolites) is striking, and the larger feldspar phenocrysts of the granites typically are granulated and drawn out into augenlike forms.

\section{GRANITE GNEISS OF THE NORWAY LAKE AREA}

\section{OCCURRENCE}

Granite gneiss forms several masses in T. 42 N., Rs. 28,29 , and $30 \mathrm{~W}$. It is well exposed in many areas; outcrops are especially extensive in secs. 7 and 8, T. 42 N., R. 28 W., and in sec. 12 , T. 42 N., R. 29 W.

\section{DESCRIPTION}

The rock is not uniform throughout, but in general it is a red foliated medium-to coarse-grained granite gneiss that shows abundant evidence of very strong deformation. A common rock type is a reddish porphyritic granite gneiss, with phenocrysts (or augen), of pink perthitic microcline approximately 1 to 2 inches long. The microcline crystals occur as podlike forms of rudely elliptical outline, with the longer axes parallel to foliation (figs. 5, 6). The foliation is marked by foils of biotite, muscovite and chlorite that curve around the feldspar pods. Lineation is not prominent. Pink to light orange fine-grained massive granite is exposed in a number of places, as in the 
$\mathrm{SE}^{\mathrm{I}} / 4$ sec. 2 , T. 42 N., R. $28 \mathrm{~W}$., and similar rock is intimately mixed with the augen gneiss in sec. 7, T. 42 N., R. 28 W. The mutual relations between the two rocks are difficult to determine. The appearance of the finer grained granite suggests that it may be the product of extreme granulation (figs. 3, 4). No evidence was found to indicate that the red porphyritic rock has been intruded into the finer grained granite, yet the absence of porphyritic granite pebbles in the conglomerates of the overlying East Branch arkose suggests that it is younger. The interpretation favored by the author is that the porphyritic rock was developed by post-Dickinson porphyroblastic growth of feldspar in a mashed granite of pre-Dickinson age. Evidence of strong shearing of the granite may also be seen in the SWI $/ 4 \mathrm{SW} / 4$ sec. 2 , T. 42 N., R. 28 W., where the granite, here a quartz-rich variety, has been broken into rounded cobblelike fragments in a granulated matrix.

The gneiss contains scattered inclusions of dark fine-grained chloritic schist as much as several tens of feet wide. The present composition-chiefly chlorite, quartz, and feldspar, with accessory calcite, leucoxene, magnetite, epidote, titanite, and garnet-indicates that the schist was originally a basic volcanic rock. In two or three areas the gneiss contains small bodies of quartzite a few tens of feet across.

\section{AGE RELATIONS}

In no place is the contact of the granite gneiss with the adjacent East Branch arkose clearly exposed. The absence of contact metamorphic effects in the arkose and the occurrence in the conglomerate of scattered pebbles similar in lithologic character to the equigranular granite gneiss indicate, however, that the gneiss is the older rock. No pebbles of porphyritic rock have been found with conglomerate, but as stated previously, the porphyritic phases may have been produced by post-Dickinson reconstitution of granulated parts of the gneiss. The problem is discussed further in the section on the Dickinson group later in this report.

Many unmapped basic dikes cut the granite. The dikes are dark and fine grained; they approach amphibolite in present composition. Some probably are of late Lower Precambrian age; others are of late Middle Precambrian age.

\section{DICKINSON GROUP}

The strata assigned to the Dickinson group are best exposed in T. 42 N., R. 28 W. and in the adjacent part of T. 42 N., R. 29 W. In this area it has been possible to divide the group into three apparently conformable major units: the East Branch arkose, the Solberg schist, and the Six-Mile Lake amphibolite. Each of these appears to attain a maximum thickness of 2,000 to 4,000 feet. The Solberg schist contains a bed of iron-rich rock-the Skunk Creek member, which is about 100 feet thick. The rocks are steeply dipping, with an easterly strike. There is relatively little evidence of major folding, so that except for the part probably repeated along an eastward-trending trending fault, the outcrop width may approximate the true thickness of the beds. A total thickness of 10,000 to 12,000 feet is indicated.

As shown on the map (pl. 2), the Dickinson group has been subdivided only in the outcrop area noted above. However, many of the magnetic anomalies that can be directly related to lithology in the outcrops may be traced with reasonable certainty across much of the map area, and the presence of strata of the Dickinson group may be inferred even though it is not feasible to indicate formations. An area of about 10 square miles in the northwest corner of the map area also probably is underlain by undivided Dickinson group strata.

\section{EAST BRANCH ARKOSE}

The East Branch arkose is the oldest formation of the Dickinson group. It crops out abundantly in the northern part of T. 42 N., R. 28 W., and in the northeastern part of T. 42 N., R. 29 W. Magnificent glacially polished exposures are present along the East Branch of the Sturgeon River, for which the unit is named, especially in secs. 7, 8, 17, and 18 (see map, pl. 10), and in secs. 10 and 11, T. 42 N., R. 28 W. (figs. 7 and 8). The rock is exposed in several outcrops in secs. 3 and 4, T. 42 N., R. 29 W.; here it appears to be an isolated infold in the granite gneiss. A drill hole at the east edge of sec. 13, T. 42 N., R. $30 \mathrm{~W}$., several miles west of the outcrop area of the formation, cuts rock that appears to be a sheared conglomerate.

The formation consists of thick-bedded arkose with many beds of coarse conglomerate, interbedded with metamorphosed tuffs and basic volcanic flows. The conglomerates, though not the dominant rock type, are the most striking feature of the formation. The beds typically are 10 to 30 feet in thickness. The pebbles in the conglomerate have been drawn out into lenses that, on a horizontal surface across the nearly vertical beds, have a length-to-width ratio of about $3: 1$. In most parts of the area this shearing is parallel to bedding - that is, eastward-but in a few places it is at an angle (fig. 8). Linear structure is not pronounced; most of the flattened pebbles have a length in vertical section about equal to that in horizontal section. In 


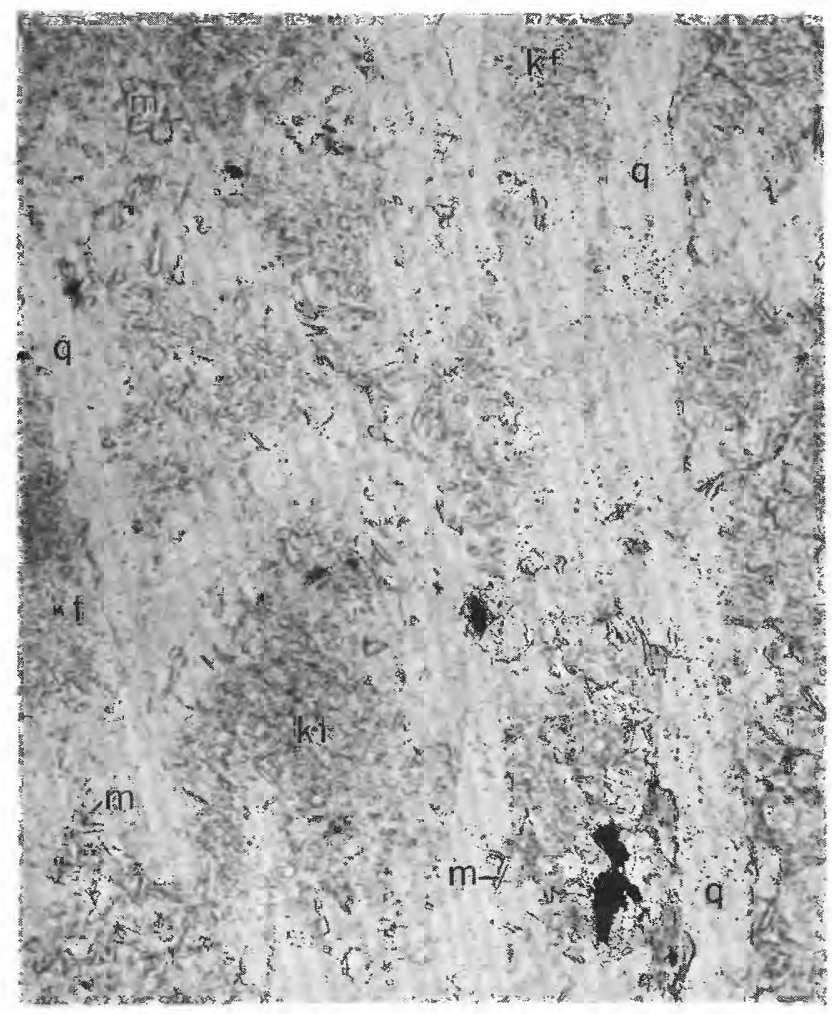

Figure 3.-Ordinary light.

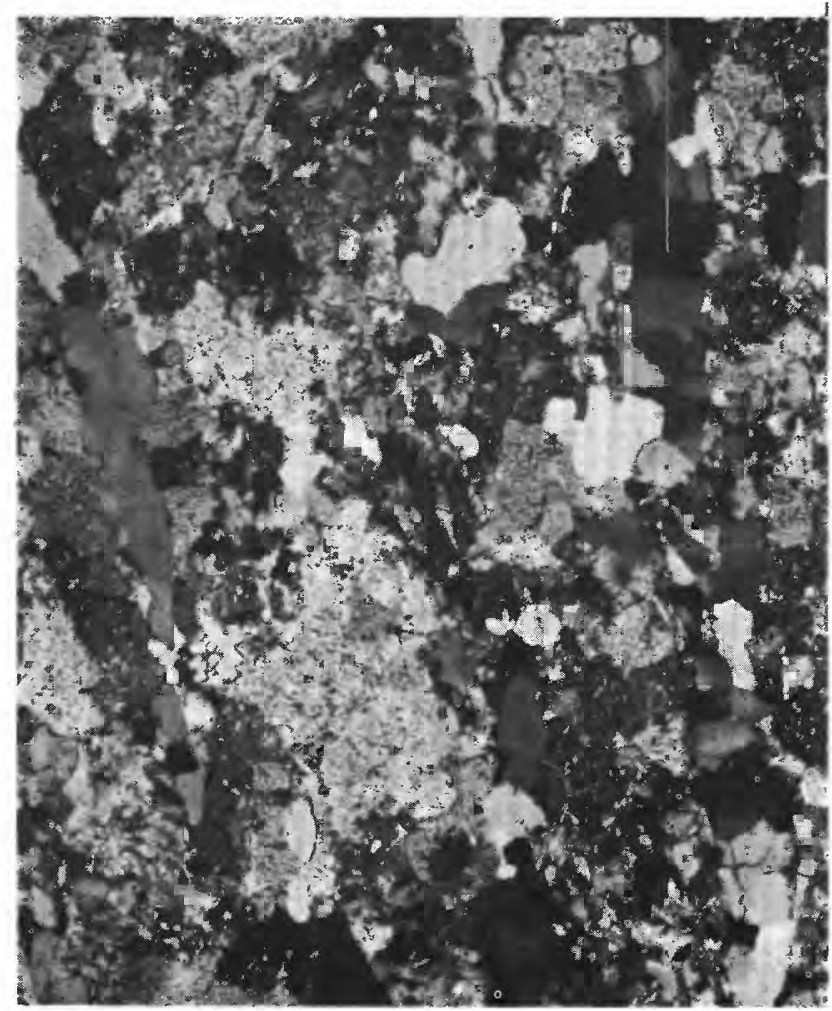

Figure 4,-Crossed nicols.

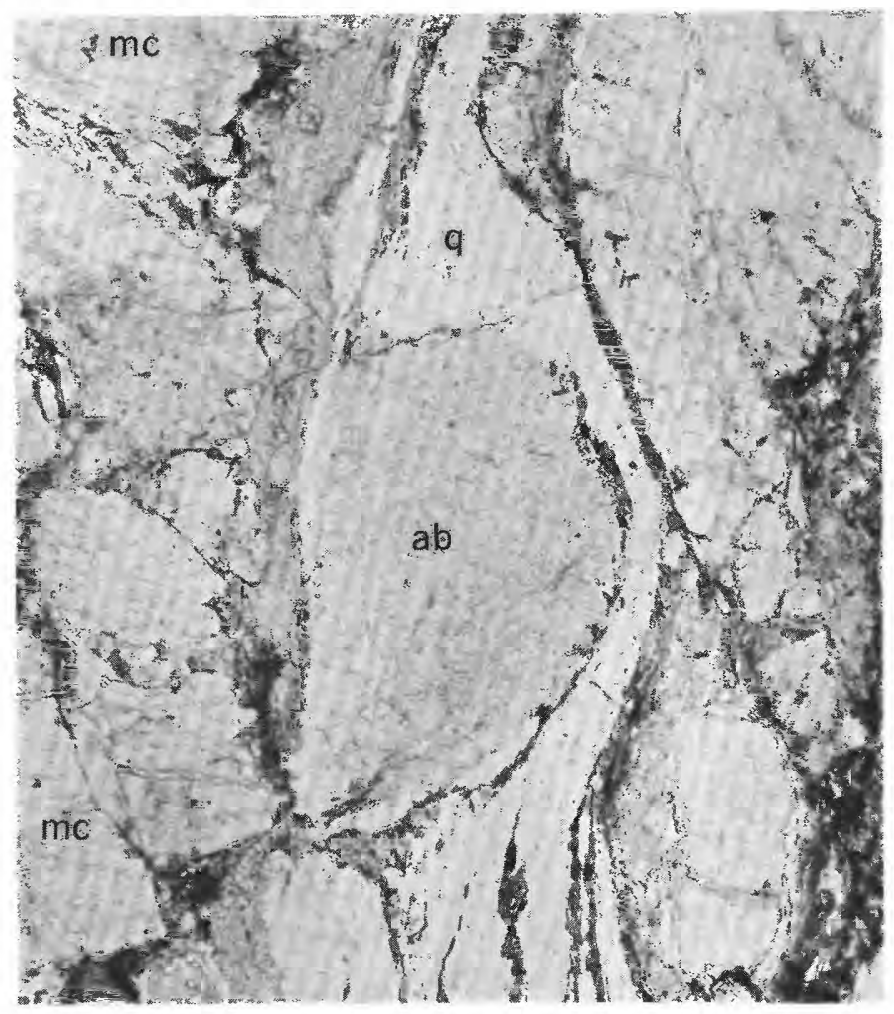

FIGURE 5.-Ordinary light.

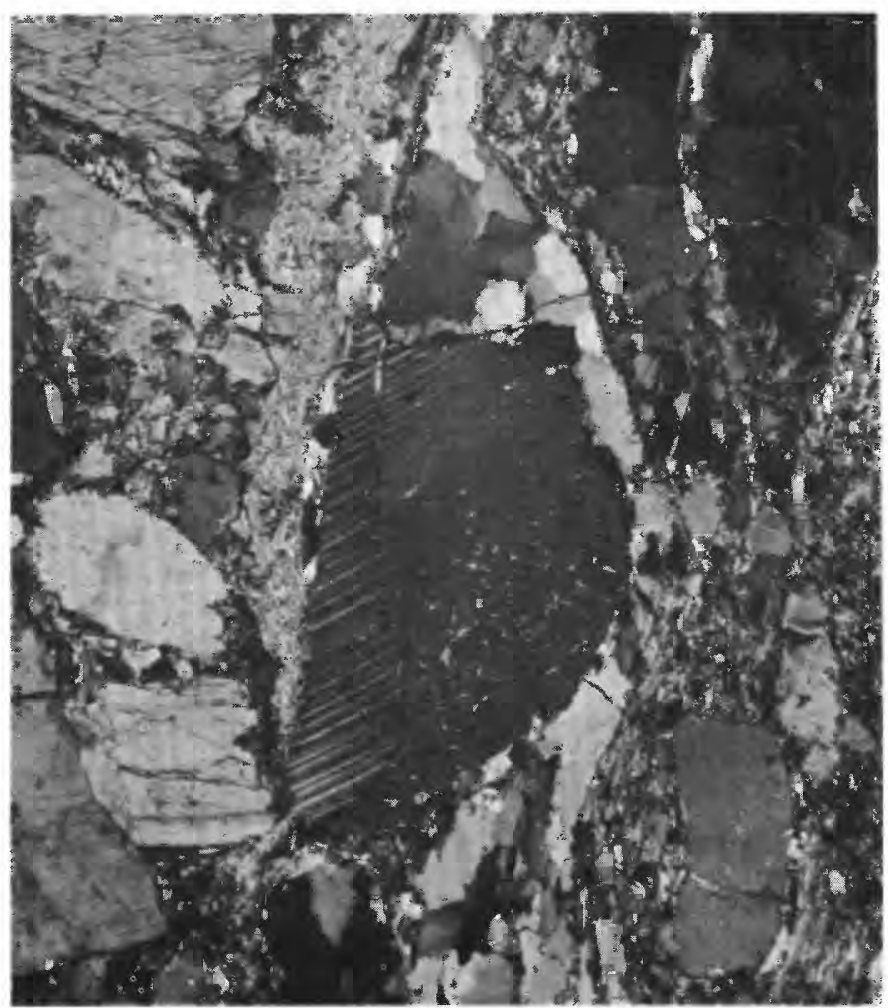

Figure 6.-Crossed nicols.

FiguREs 3-6.-PHOTOMICROGRAPHS OF GRANITE GNEISS FROM THE NORWAY LAKE AREA

3, 4. Fine-grained facies from $S E 1 / 4$ sec. $2, T .42$ N., R. 28 W. Irregular grains of potassium feldspar $(k f)$ showing extensive alteration to muscovite $(m)$, with veinlets and blebs of quartz (q). Albite, similar in habit to orthoclase, also present. $\times$ 40. Specimen LC-51-48.
5, 6. Porphyritic facles, from NW1/4 sec. $8, T$. $42 \mathrm{~N}$., R. $28 \mathrm{~W}$. Large deformed crystals of albite $(a b)$ and perthitic microcline $(m c)$ in matrix of quartz $(g)$ and partly chloritized fine-grained muscovite. $\times 20$. Specimen LC-64-48. 


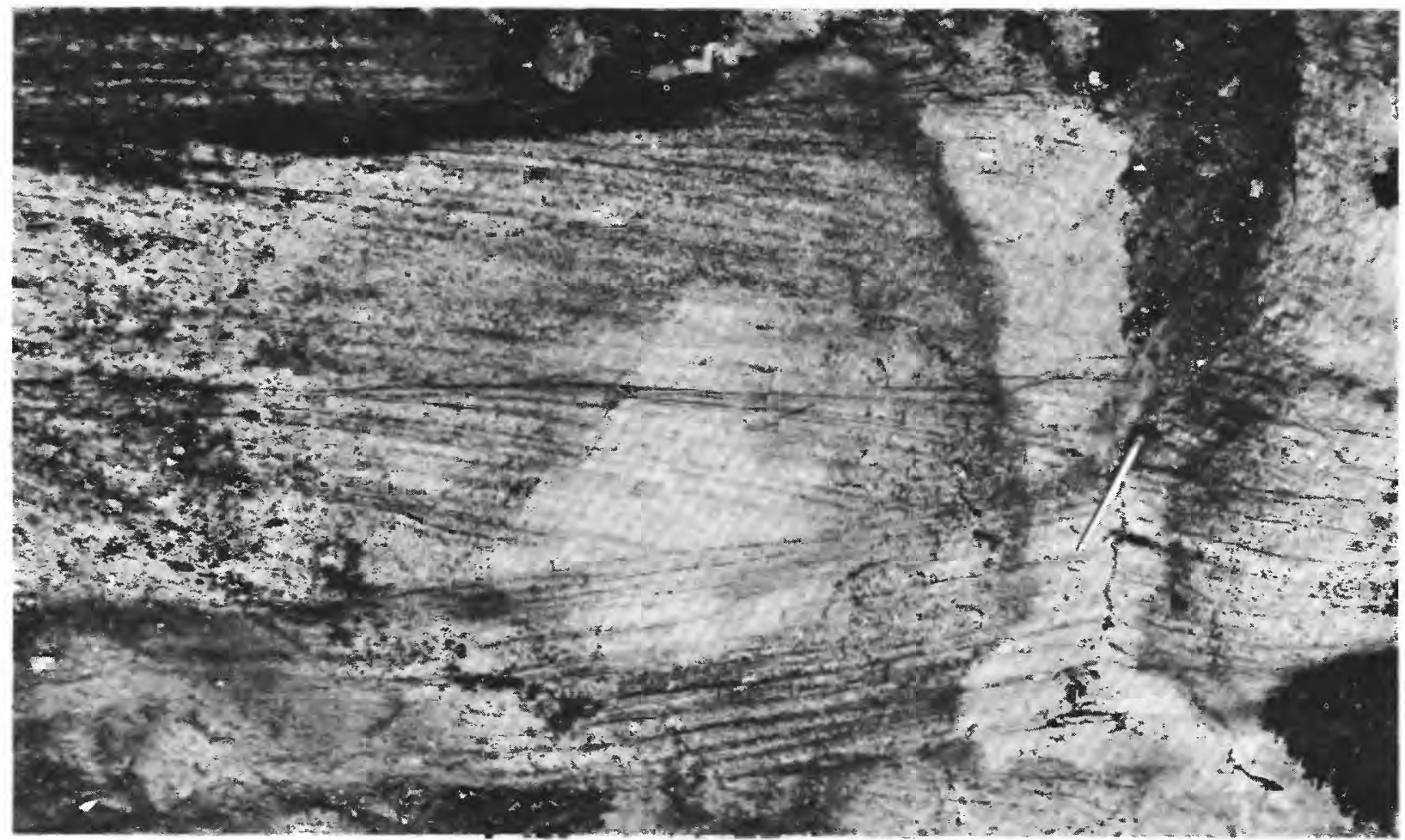

FrgURE 7.-Photograph showing crossbedding in the East Branch arkose. Horizontal surface; original top direction toward lower edge of photograph.

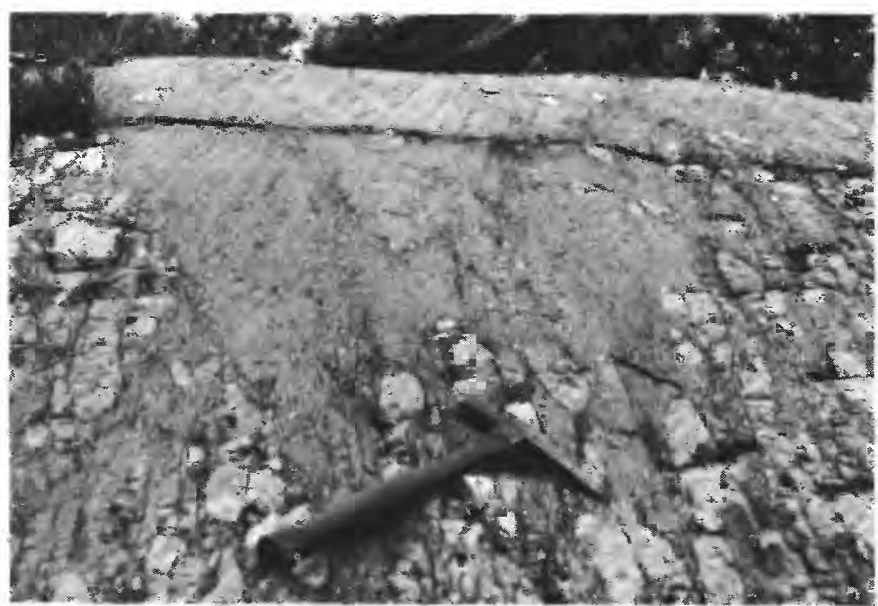

Figure 8.- Nose of fold in the East Branch arkose, as marked by contact of arkose and conglomerate. Note that pebbles are drawn out at an angle to the original bedding.

a few places a nearly vertical linear structure marked by grooving of the pebbles is evident. Vitreous quartzite is the dominant rock type among the pebbles, with granite gneiss, slate or schist, and quartz being of lesser abundance. Some of the quarzite pebbles show well-defined bedding.

The arkose is pink to gray, massive, and abundantly cross-bedded (fig. 7). In many outcrops and in hand specimens it closely resembles a granite gneiss, but the well-defined crossbeddings is complete proof of its sedimentary origin. Photomicrographs of the rock are shown in figures 9 and 10 . In the more southerly outcrops of the East Branch arkose, dark-gray finegrained tuffs are interbedded with the arkose; the rock consists principally of quartz and untwinned feldspar, with scattered grains of epidote, biotite, and carbonate. Rounded grains of opalescent quartz are present in some layers. Metabasalt flows are not uncommon. The rock is black and hornblende-rich (fig. 11). In the outcrops in the NW'/4 sec. 17, T. 42 N., R. 28 W., the originally scoriaceous top of one of these flows can be seen. Some of the metamorphosed flows are moderately magnetic and give rise to the aeromagnetic anomalies shown on the general map of the district (pl. 2). These anomalies continue both westward and eastward into areas devoid of outcrops and are of considerable help in interpretation of the geology.

The relationship between the East Branch arkose and the adjacent granite gneiss can be established only by indirect evidence, as no exposure of the actual contact has been found. However, the contact appears to be one of unconformity rather than intrusion. The 


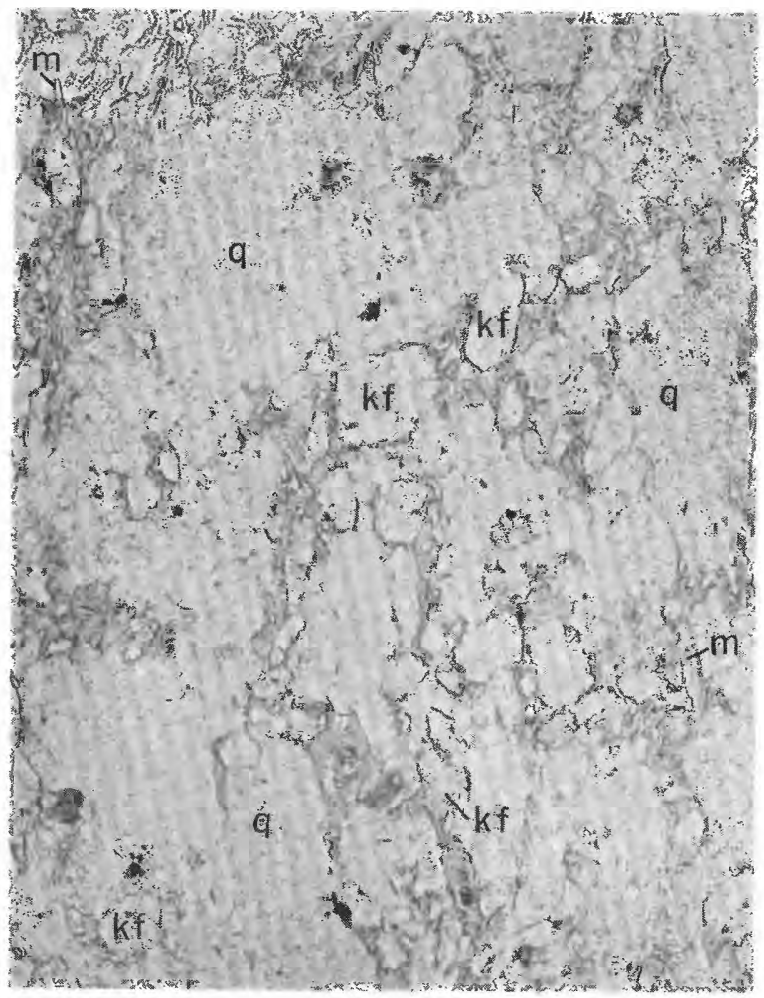

FIGURE 9,-Ordinary light.

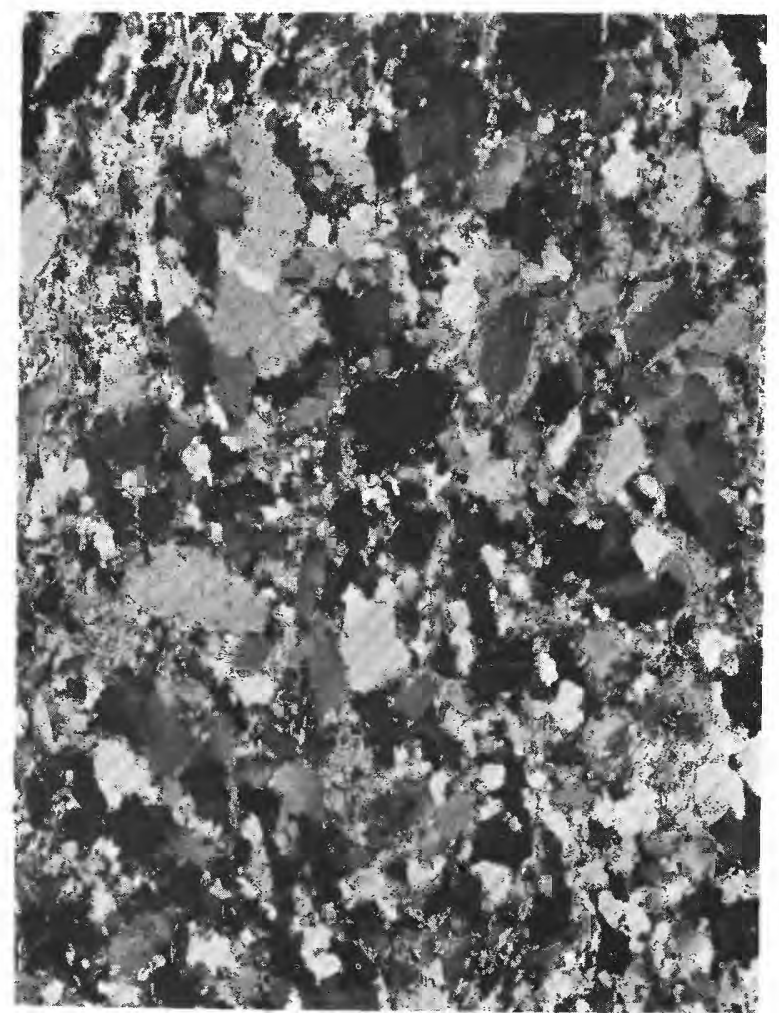

FIGURE 10,-Crossed nicols.

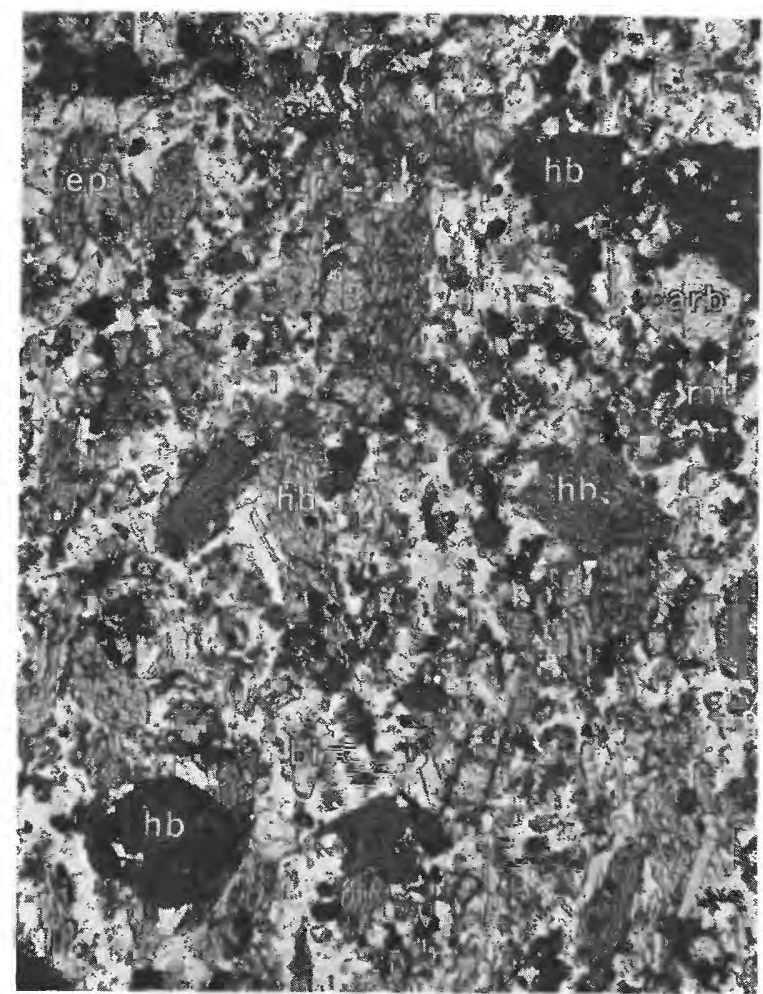

FIGURE 11.- Ordinary light.
FInURES 9-11.-PHOTOMICROGRAPHS OF ROCKS FROM THE EAST BRANCH ARKOSE.

9, 10. Arkose, from NW1/4 sec. 7, T. 42 N., R. 28 W. Quartz $(q)$ forms large areas with sutured contacts; orthoclase $(o r)$ in rounded gains. Muscovite $(m)$ occurs interstitially. Note irregular sutured contacts within large areas of quartz. $\times 35$. Specimen LC-65-47.

11. Metabasalt, interbedded with arkose in $N W 1 / 4$ sec. 7, T. 42 N., R. 28 W. Composed of blue-green hornblende $(h b)$, epidote $(e p)$, carbonate (carb), biotite $(b i)$, magnetite $(m t)$ in matrix of fine-grained feldspar and quartz. $\times 60$. Specimen LC-60-47. 
principal evidence for this view may be summed up as follows:

1. The beds immediately adjacent to the granite gneiss show not the slightest indication of contact metamorphism. Actually, a gradual increase in metamorphic grade is noticed proceeding away from the granite gneiss and toward the granite mass several miles to the south.

2. No dikes of the granite gneiss are found in the arkose.

3. Pebbles similar in lithologic character to the finer grained parts of the granite gneiss are found in the conglomerates.

The formation is divided into two structural units by a fault, in part marked by a basic dike, that extends westward from near the northeast corner of sec. 11, T. 42 N., R. 28 W. into sec. 15, T. 42 N., R. 29 W. The fault is within the formation except for its western end, where for about 2 miles it is in the contact between the arkose and the granite gneiss to the south. Further evidence for the fault is the presence of a narrow slice of granite gneiss within the formation in the $\mathrm{SE} / 4 \mathrm{NE} / 4$ sec. 10, T. 42 N., R. 28 W. Here, top directions show that the arkose faces south on both sides of the wedge of gneiss. The fault thus divides the arkose series into two blocks, so that although the outcrop width is more than a mile in some places, the maximum true thickness is probably not more than 2,500 feet. The formation appears to thin to the west; in sec. 16, T. 42 N., R. 29 W., it is not more than 1,000 feet thick and is interbedded with schist similar to parts of the overlying Solberg schist. A drill hole at the east margin of sec. 13, T. 42 N., R. 30 W., encountered a sheared conglomerate, indicating that the block of arkose north of the medial fault continues for at least 4 miles beyond the west end of the outcrops.

\section{SOLBERG SCHIST}

\section{GENERAL FEATURES}

The Solberg schist lies immediately south of the East Branch arkose. A considerable amount of interbedding of arkose and schist is evident in the outcrops, so that location of the contact between the units is somewhat arbitrary. In general, the formation is poorly exposed, although excellent outcrops may be seen in secs. 16, and 17, T. 42 N., R. 28 W. near Solberg Lake. Except for two small outcrops of schist near the center of sec. 27, T. 42 N., R. 30 W., the formation is not exposed west of sec. $23, T$. 42 N., R. 29 W., nor east of sec. 11, T. 42 N., R. 28 W. However, by means of the magnetic anomaly produced by the interbedded iron-rich Skunk Creek member, the unit can be traced with certainty as an eastward trending belt across most of the map area.

The more northerly exposures of the unit consist chiefly of dark fine-grained hornblende and biotite schists. Locally, muscovite is an abundant constituent. Some outcrops show a banding, essentially parallel to the foliation, which may represent original layering. In one place, near the south edge of sec. $13, \mathrm{~T} .42 \mathrm{~N}$., R. $29 \mathrm{~W}$., the schist is interbedded with coarse clastic material similar to rock of the East Branch arkose.

The more southerly exposures of the Solberg schist consist of quartz-mica schist, parts of which might be better termed micaceous quartzite (figs. 12, 13). This rock is exposed in the north part of sec. 24, T. $42 \mathrm{~N}$., R. 29 W., and secs. 21 and 22, T. 42 N., R. 28 W. In general, the rock is massive, gray, and well banded. The banding, which consists of alternation of quartzitic and micaceous layers, almost certainly represents original bedding.

Linear structure is strongly developed in all the schists, especially in the hornblendic varieties. It is marked by orientation of hornblende needles and by biotite. The lineation is in the plane of foliation and in general plunges eastward at a low angle.

Little is known of the gross structure of the Solberg schist. Except for the belt of east-southeast-trending outcrops in secs. 21 and 22 , T. 42 N., R. 28 W., the available evidence indicates little divergence from an east or east-northeast strike. No folding of consequence can be seen in the outcrops. Nevertheless, the distribution pattern of the unit indicates that structural complexity does exist. In T. 42 N., R. 28 W., the belt of Solberg schist gradually widens to the east until it is about twice the normal width, yet the magnetic anomaly caused by interbedded iron-formation of the Skunk Creek member (described below) shows that no major folding is present, and observed dips remain consistently steep. In part this is attributed to the thickening of the basic intrusives that lie north of the iron-formation, but this would account for only part of the increase. Furthermore, the apparent stratigraphic distance of the iron-formation above the lower (north) contact of the schist shows a considerable increase in the easterly direction.

As a result of these structural uncertainties, it is difficult to give a thickness for the Solberg schist. The minimum value is about 3,500 feet, and the true thickness may be double this figure. 


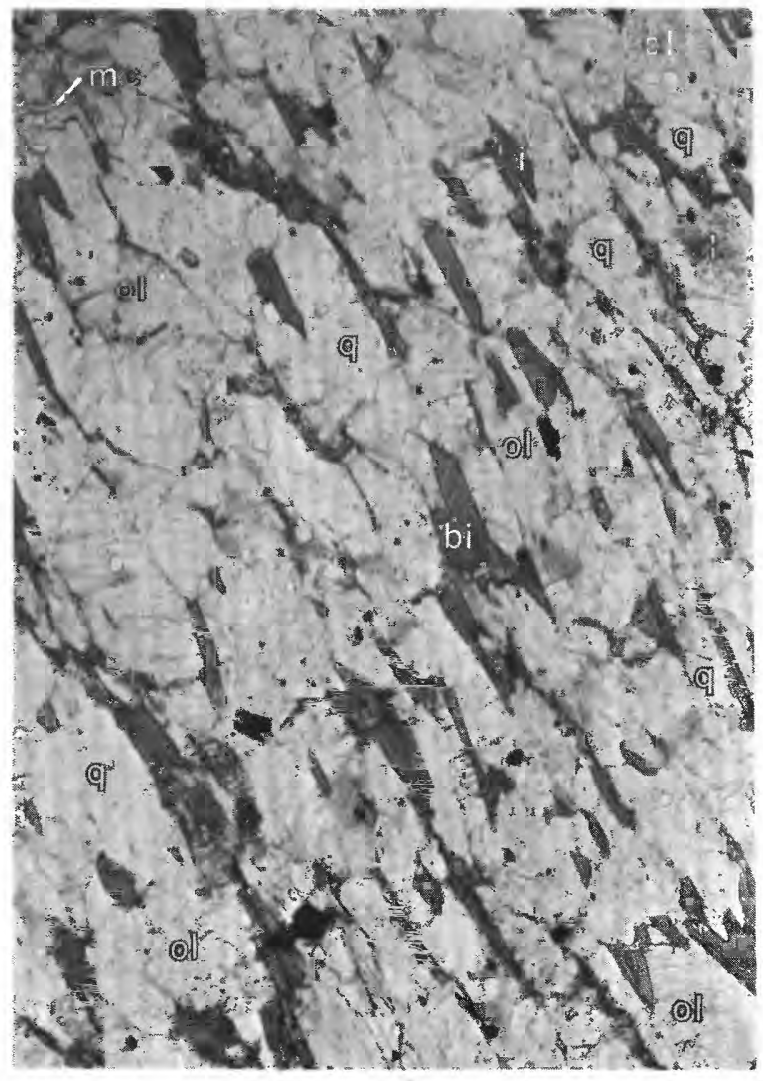

Figure 12.- Ordinary light.

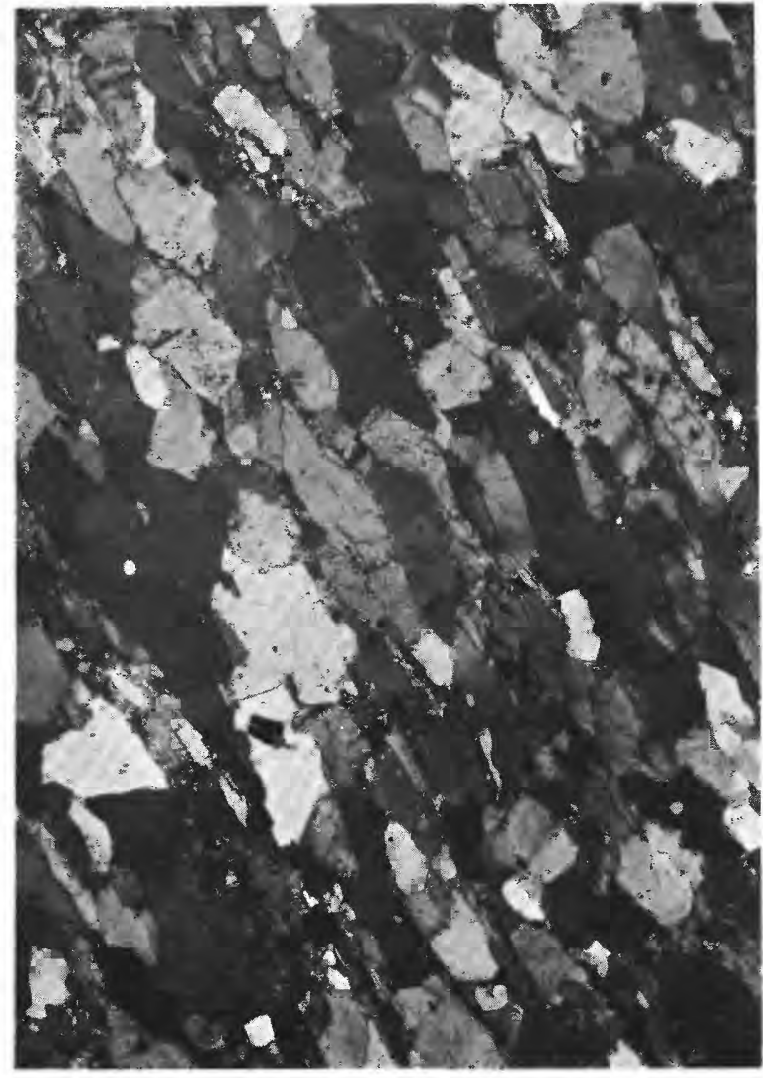

Figure 13,-Crossed nicols.

Figures 12, 13.-Photomicrographs of the Solberg schist. Quartz-mica schist, with abundant oligoclase (ol) that is slightly cloudier than the quartz ( $q$ ). Strongly oriented biotite (bi), partly chloritized, and scarce muscovite $(m c) . \times 33$. Specimen CL-18-50a.

SKUNK CREEK MEMBER

The Skunk Creek member of the Solberg schist is a bed of iron-formation. This bed gives rise to a very strong magnetic anomaly, by means of which the ironformation can be traced in a belt across most of the map area, from the east edge of the area, through $\mathrm{T}$. 42 N., R. 28 W., and T. 42 N., R. 29 W. Correlation of the anomaly becomes uncertain in T. 42 N., R. 30 W., although even here the iron-formation probably is present; the main difficulty is in deciding which of the anomalies it is related to. The iron-formation is not exposed at the surface except in the NE $1 / 4$ sec. 23 , T. 42 N., R. 29 W. In an outcrop in the SEx/4 sec. 16 , T. 42 N., R. 28 W. a garnet-grunerite-magnetite rock is interbedded with the schist; it represents a gradational facies between the schist and the iron-formation, most of which lies south of the outcrop.

The Skunk Creek member has been penetrated by drill holes in several places. It is chiefly from this drill core that information concerning the lithologic character has been obtained, although none of the holes has cut the entire unit. The distinctive part of the formation is a thin-banded rock consisting of alternating layers of granular quartz (probably originally chert), magnetite, and various mixtures of hornblende, biotite, grunerite, garnet, and epidote (see figs. 88-90). This material grades into biotitehornblende schist, containing magnetite-rich layers, by interbedding at both the upper and lower contacts. The iron-formation is cut by many thin dikes of coarse pegmatite; garnet and tourmaline are commonly developed near the contacts.

The thickness of the Skunk Creek member is somewhat uncertain because of the small amount of data available, but it is about 100 feet.

\section{SIX-MILE LAKE AMPHIBOLITE}

The Six-Mile Lake amphibolite is the most southerly unit of the Dickinson group. It is well exposed in a series of low knobs and ridges in a belt that extends in a broad arc, 8 miles long, from sec. 27 , T. 42 N., R. 28 W., to sec. 29, T. 42 N., R. 29 W. The unit is named for Six-Mile Lake, south of which there are excellent exposures in sec. 22, T. 42 N., R. 29 W.

In outcrops the amphibolite is a dark-almost black -massive fine-to medium-grained rock in which hornblende is the major constituent. In thin section (figs. 14,15 ), feldspar (andesine or oligoclase) is abundant; 


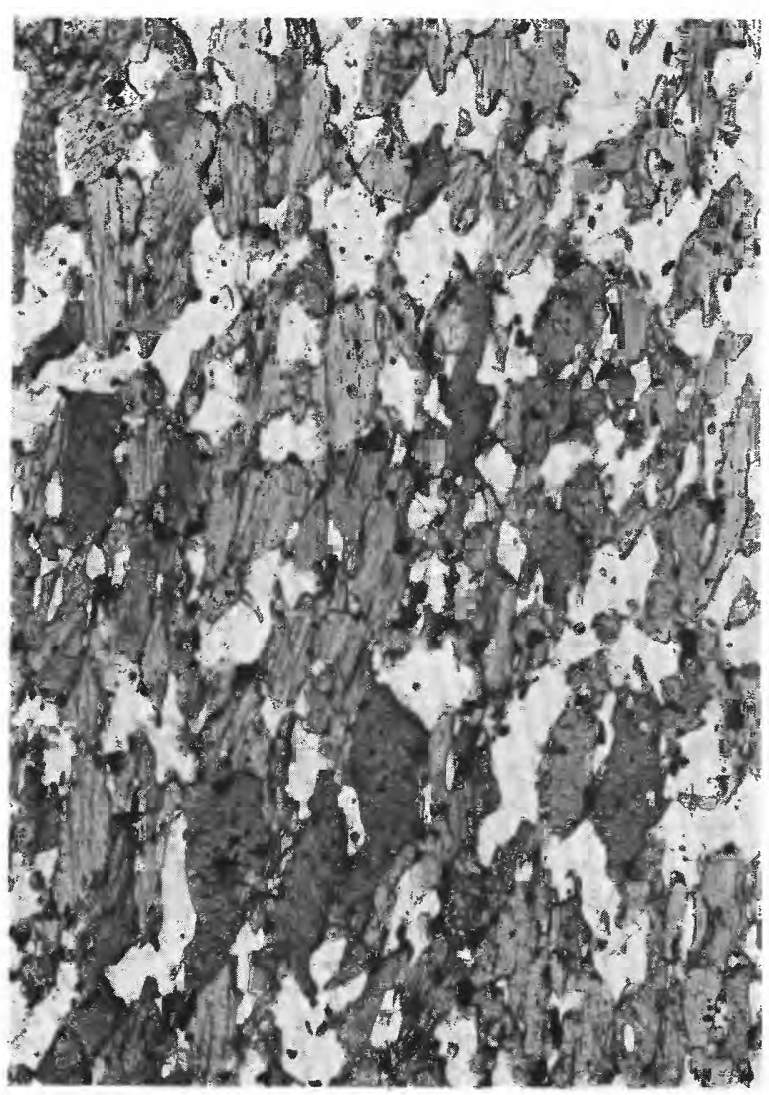

Figure 14.- Ordinary light.

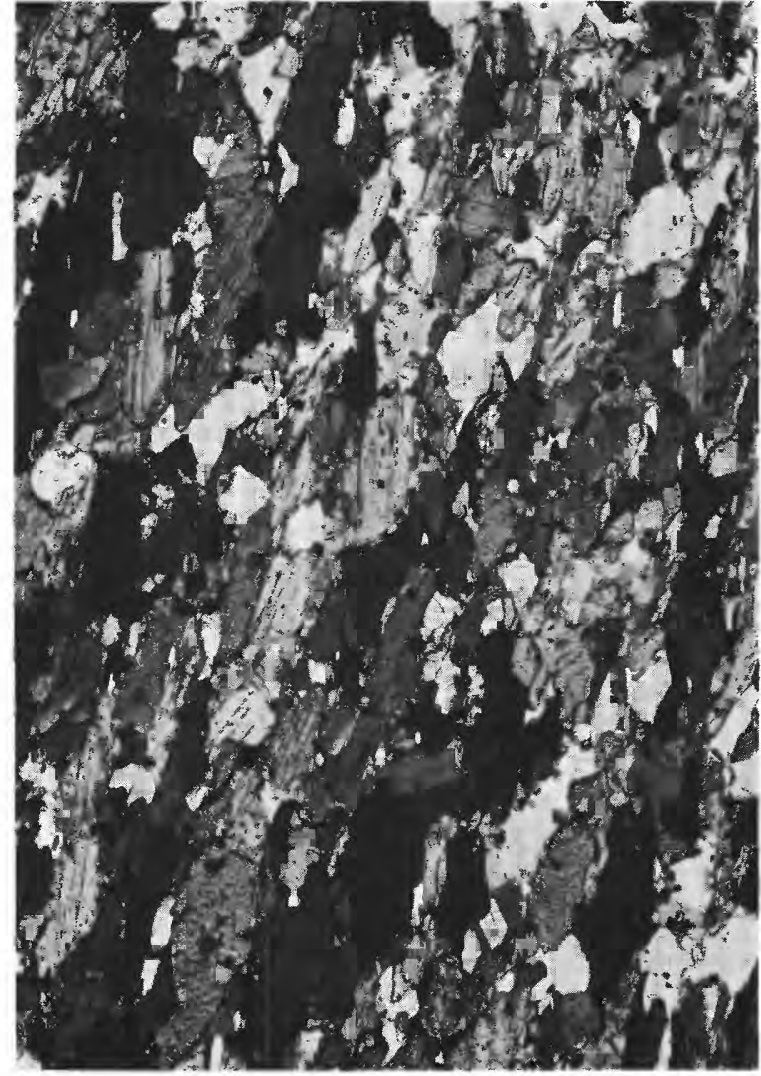

Figure 15.-Crossed nicols.

FigURes 14, 15.-Photomicrographs of the Six-Mile Lake amphibolite. Rock consists of brownish-green hornblende and twinned andesine, with a scattering of small magnetite grains. $\times 33$. Specimen CL-1-50.

in hand specimens it is less noticeable but gives a faint salt-and-pepper appearance to the rock, especially on surfaces broken across the foliation. Compositional layering is evident in some places, but in general the rock is homogeneous. The more southerly outcrops approach banded gneiss in character. Foliation parallel to the compositional layering is generally present, but may be subordinate to a strong linear structure that characterizes the rock. The lineation, which is marked by orientation of hornblende needles, plunges eastward at a low angle. In almost every outcrop the amphibolite is cut by dikes, pods, or irregular bodies of younger pegmatite.

The nature of the contact between the Six-Mile Lake amphibolite and the Solberg schist that lies to the north is not known, but the rocks appear to be conformable. The amphibolite is bounded on the south by a banded gray gneiss, which probably represents the metamorphic front of the granite mass that lies mostly south of the Felch trough. As might be expected, this zone is not strictly stratigraphic. West of the outcrop belt of amphibolite the gray gneiss appears to encroach progressively on the strata of the Dickinson group, so that in T. 42 N., R. 30 W., to judge from its position with respect to the magnetic anomaly of the Skunk Creek member, it breaks through the amphibolite and is probably in contact with the Solberg schist. Amphibolite is a dominant constituent of the banded gray gneiss and is found as abundant inclusions in the granite to the south; there can be little doubt that the present Six-Mile Lake amphibolite is but a relic of an originally volcanic series of greater thickness.

\section{DICKINSON GROUP (UNDIVIDEDI)}

Rocks assigned to the Dickinson group underlie a considerable area in the northwest part of central Dickinson County, but subdivision of the group into individual formations is not possible because of the paucity of exposures. The area underlain by strata of the Dickinson group is divided into two parts by the Carey's 'Spur trough, and as the parts present somewhat different problems, they are discussed separately below.

Area south of the Carey's Spur trough.-This area is directly along the strike of the type locality of the Dickinson group in T. 42 N., Rs. 28 and 29 W., and several magnetic anomalies known to be caused by 
units of Dickinson group continue westward into $\mathrm{T}$. 42 N., R. 30 W. (pl. 2). Several of the rock types separately differentiated in the type locality can be recognized in T. 42 N., R. 30 W., but the only wellexposed material is a biotite schist that forms two large outcrops just north of the river in sec. 27. The rock is dark and medium grained; in addition to biotite it contains abundant quartz and lesser amounts of feldspar, hornblende, and garnet. It probably is part of the Solberg schist. Original bedding is vaguely discernible; it is at a low angle to the cleavage in some places and nearly parallel in others. Small elongate pods of lighter colored rock that probably represent original calcareous concretions are locally present; they are distributed parallel to original bedding but are alongate in the cleavage direction.

A well-defined magnetic anomaly lies immediately south of the schist outcrops referred to above. It probably is continuous with a somewhat stronger anomaly known to be caused by the iron-rich Skunk Creek member farther east. Some doubt exists as to whether the correlation of anomalies in sec. 25 is valid (see magnetic profiles on pl. 8), and in the absence of either outcrops or drill holes the extension of the Skunk Creek member beyond the center of sec. 25 does not seem warranted at this time.

Many of the large outcrops of pegmatite in secs. 23, 24,26 , and 27 contain inclusions of biotite and hornblende schist, and schist commonly forms narrow selvages at the margins of the exposures. In all likelihood the exposed areas of pegmatite represent very nearly the true limit of this rock, and the intervening areas are underlain by schist.

No arkose or conglomerate similar to that of the East Branch arkose was seen in T. 42 N., R. 30 W.

With one possible exception, the contact of the Dickinson group with the red porphyritic granite is not exposed. The exception is near the center of sec. 21 , where granite is in contact with massive amphibolite. In the absence of other exposures one cannot be sure whether the amphibolite is the older rock or whether it is part of a large dike.

Area north of the Carey's Spur trough.-The northwestern part of T. 42 N., R. 30 W. and adjacent areas appear to be underlain mainly by green schist, some of which is magnetite rich. The observed strike of the rocks is northwestward, as is the trend of the magnetic anomalies recorded by the aeromagnetic survey. The schist, poorly exposed and deeply oxidized, crops out on the Peavy Falls road near the center of sec. 36, T. 43 N., R. 31 W. Schist is also encountered in low exposures and in old test pits in the $\mathrm{SW} / 4 \mathrm{sec} .31, \mathrm{~T}$. $43 \mathrm{~N}$., R. $30 \mathrm{~W}$., and in two drill holes in the northern part of that section. Similar material occurs in the rock piles of a test pit in the SWI $/ 4 \mathrm{SW}^{\mathrm{T}} / 4 \mathrm{sec} .4, \mathrm{~T} .42$ N., R. $30 \mathrm{~W}$., about 200 feet west of Highway M-95.

The most common rock type is a dark chloritic schist locally rich in magnetite that is in part altered to martite. Less common is a light-colored schist containing numerous small milky-blue quartz "eyes". The rock encountered in the drill holes in the northern part of sec. 31 appears to be a sheared vesicular and agglomeratic greenstone. The rock shows strong foliation and lineation. In the upper parts of the drill holes, beneath the capping sandstone of Cambrian age, the schist is deeply oxidized to a soft reddish or greenish clayey rock. The dark schists were probably once basaltic flows or tuffs whereas the quartz-bearing schists were probably acid flows or tuffs.

The schists are assumed to be cut off on the southeast by the Bush Creek fault-in fact, one of the chief items of evidence leading to the concept of this fault is the termination of several magnetic anomalies approximately along a line-so that there is little direct evidence bearing on the age relations of these rocks to similar rock south of the fault. Northwest of the mapped area the schist can be traced by drill holes and magnetic anomalies for about 5 miles (Bayley, R. W. 1959; Gair and Wier, 1956). Drill-hole evidence given by Gair and Wier indicates a pre-Randville age for the schists.

\section{CONDITIONS OF DEPOSTTION OF THE DICKINSON GROUP}

The Dickinson group represents a relatively normal sedimentary-volcanic sequence of a type not uncommon either in the Precambrian or in younger rocks. The record begins with deposition of the coarse clastics of the East Branch arkose, which continued with periodic outbursts of volcanic activity. As the topographic relief of the adjacent land areas was reduced, finer-grained sediments were laid down and interbedded with volcanic tuffs. For a brief period, clastic sedimentation ceased and the Skunk Creek member was deposited, probably as a chemical sediment consisting principally of chert, magnetite, and sedimentary iron silicates. Clastic sedimentation was then resumed, with deposition of graywacke-type deposits, which subsequently were metamorphosed to quartz-mica schists. Volcanism then became dominant, and a great thickness of basaltic flows and tuffs, was deposited in the basin of deposition. The Six-Mile Lake amphibolite probably is but a small remnant of this volcanic sequence.

The source of the quartzite pebbles in the East Branch arkose is not known. Presumably they were 
derived from an older sedimentary sequence now represented only by small inclusions in the preDickinson granite gneiss.

\section{EVIDENCE FOR A LOWER PRECAMBRIAN POSITION}

The lines of evidence that indicate Lower Precambrian age for the Dickinson group are tenuous, yet in total they are fairly conclusive. In all previous reports on the district the East Branch arkose has been correlated with the Sturgeon quartzite and has been considered to underlie conformably the Randville dolomite to the north. The evidence that seems to rule out this correlation is summarized as follows:

1. The arkose with its thick beds of conglomerate, tuff, and volcanic flows bears little resemblance to the massive vitreous Sturgeon quartzite.

2. Observations of crossbedding, made in many places, show that the tops consistently face southward, away from the dolomite which it was previously assumed to underlie. Furthermore, in many places the two are separated by gneiss of prearkose age.

3. The internal deformation shown by stretching of the pebbles throughout the conglomerates finds no comparable reflection in the adjacent dolomite, where intraformational breccias and algal structures are preserved without deformation (compare figs. 8 and 32 ).

4. The arkose is definitely much more highly metamorphosed than the adjacent dolomite, which is essentially without metamorphic effects.

5. Tyler, Marsden, Thiel, and Grout, in their study of the accesory minerals of the Lake Superior rocks (1940), examined a specimen of the conglomerate and found it to contain zircon of the hyacinth variety. These authors consider hyacinth diagnostic of the early pre-Animikie granites, whereas the late pre-Animikie granites contain both hyacinth and malacon varieties. The absence of malacon suggests, as does the field evidence, that the rock is older than the late pre-Animikie intrusives.

The broader relations in the region strongly favor Lower Precambrian position for the Dickinson group. The major considerations are as follows:

1. The Felch trough, though complicated by much faulting, is essentially a synclinal structure defined by Animikie strata, so that the rocks on either side should be older.

2. The gray gneiss that borders the Felch trough on the north is almost certainly a "mixed rock" resulting from emplacement of granite of ba- tholitic dimensions into the Six-Mile Lake amphibolite. Direct evidence is available in sec. 20 , T. 41 N., R. $30 \mathrm{~W}$. for the pre-Sturgeon age of the granite; therefore the conclusion seems warranted that the amphibolite also is pre-Sturgeon.

3. The rocks of the Dickinson group show abundant evidence of metamorphism under high-stress conditions: the pebbles in the conglomerates are strongly drawn out and lineation due to growth of metamorphic minerals is very pronounced in the schists and amphibolites. In contrast, the Animikie rocks in adjacent areas - even those of equivalent metamorphic grade-show neither internal deformation of sedimentary features nor pronounced orientation of metamorphic minerals. Algal structures in the Randville dolomite and ooliths in the iron-formation are preserved without essential change in form. In the amphibolites that cut Animikie strata mineral orientation is noticeable only at the borders of the bodies; elsewhere it is lacking.

\section{CORRELATION}

Lower Precambrian sedimentary units are widespread in Minnesota, Ontario, and Quebec (for a general appraisal of these rocks see Pettijohn, 1943), and in some respects it is surprising that they are so poorly represented in Michigan. In Minnesota the Knife Lake group is of pre-Animikie age (Grout, and others, 1951). This group of rocks, which includes conglomerate, slate, arkose, graywacke, thin iron-formation, tuffs, agglomerates, and flows, rests with profound unconformity on the Saganaga granite (Lower Precambrian) and in turn is intruded by the pre-Animikie Algoman granite.

The lithology and structural position of the Dickinson group are similar to those of the Knife Lake. This, of course, certainly does not mean that the two are to be considered correlative, but it does suggest deposition under comparable conditions during the same general division of geologic time. In actual age, however, the two units could be separated by many millions of years.

\section{HARDWOOD GNEISS}

The Hardwood gneiss is a complex of metamorphosed volcanic, igneous, and sedimentary rocks that underlies parts of secs. 5, 7, 8, and 9, T. 41 N., R. 27 W. In this area it is well exposed in a series of low knobs and ridges, and in roadside cuts along Highway M-69, just east of the community of Hardwood. Photographs of outcrops are shown on figures 16,17 . Though known only in a relatively small area, the unit contains some 


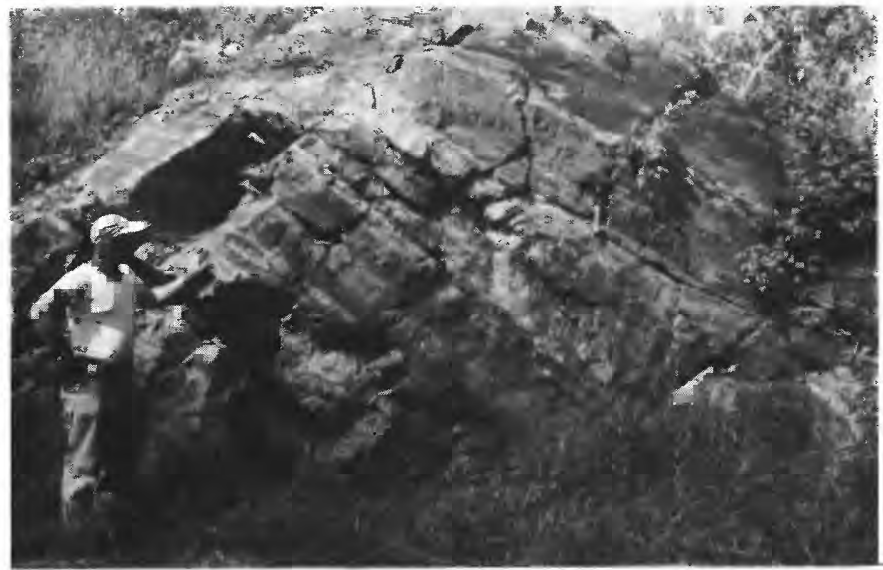

FIGURE 16

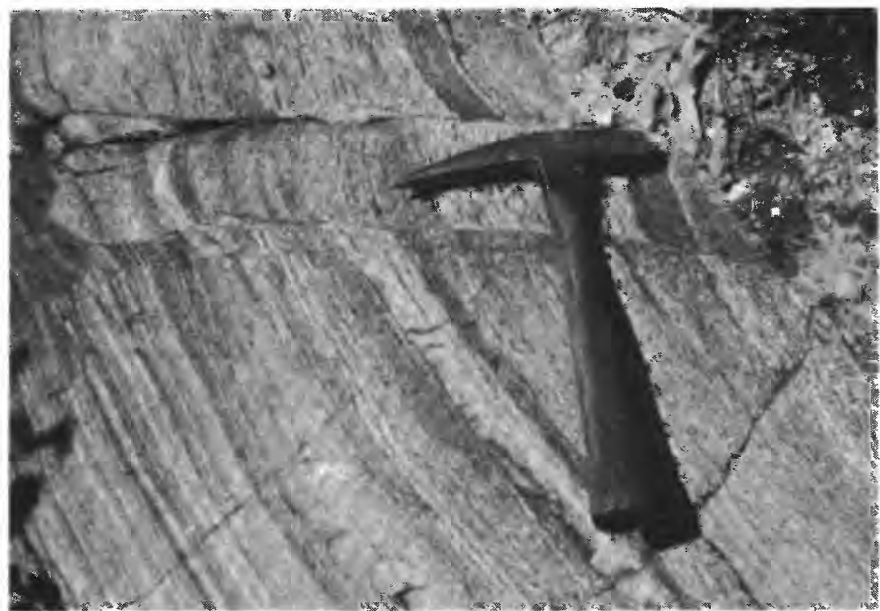

FigURE 17

FIGURES 16, 17.-PHOTOGRAPHS OF THE HARDWOOD GNEISS.

16. Hardwood gneiss showing prominent layering. Roadcut at north side of State Route M-69, in sec. 8, T. 41 N., R. $27 \mathrm{~W}$.

17. Detail of exposure shown in figure 16 .

highly distinctive rocks, many of which are quite unlike any others in Dickinson County, or, within the writer's experience, in Michigan.

In general, the gneiss is strongly layered, with individual layers ranging from a fraction of an inch to a few feet in thickness. The dominant rock type is a dark-medium-grained gneiss composed of hornblende, plagioclase, and pyroxene. Interlayered with this rock are beds of dark gneiss but of different grain size, beds of dark vitreous-lustered rock with alternating light and dark laminae, garnet-quartz-mica schist, and light-colored rock that resembles quartzite. Some of the layers are rich in magnetite. These rocks are described in further detail in Chapter $\mathrm{E}$ of this report and are illustrated on figures 16 to 20 .

The gneiss appears to have been originally a volcanic sequence, at least in part tuffaceous, with some inter-

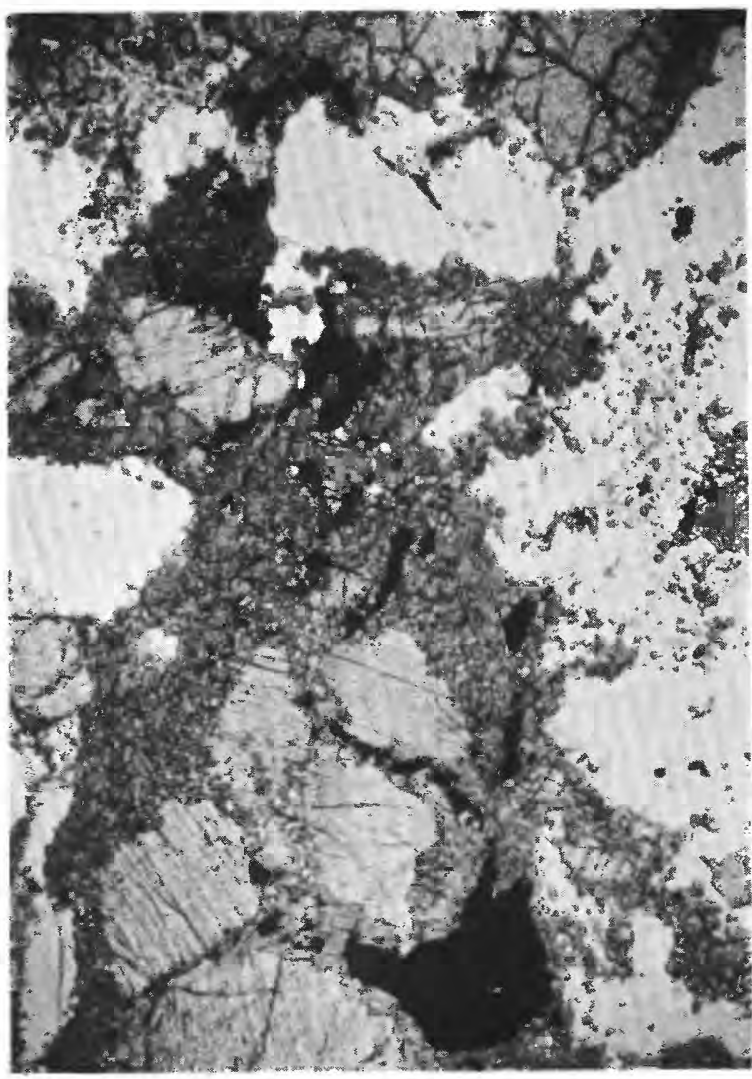

Figure 18

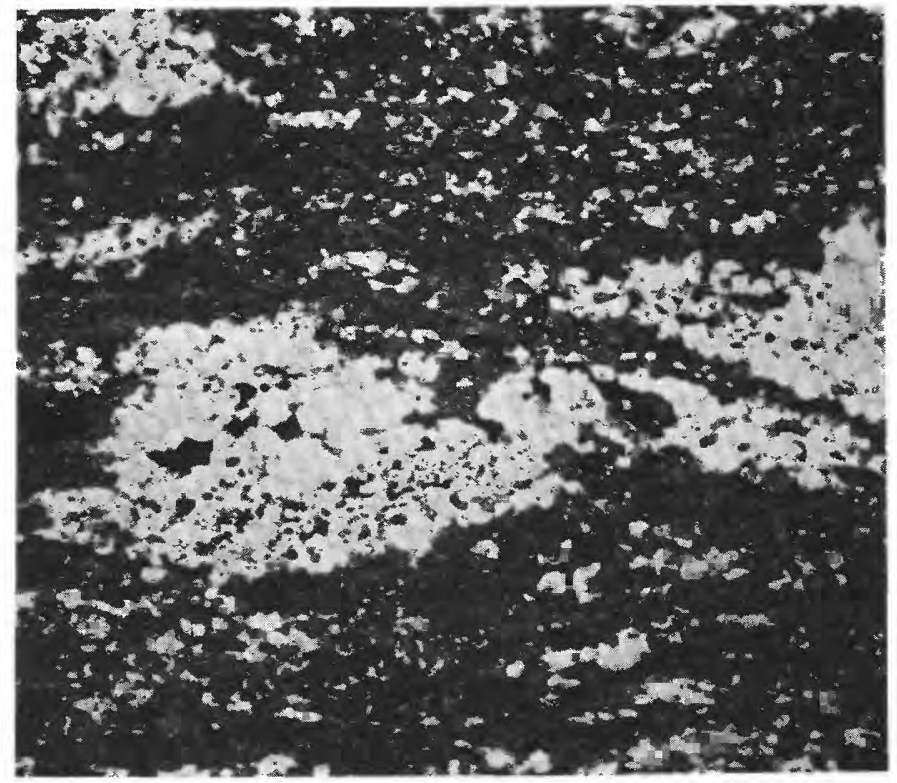

Figure 19

FIGURES 18, 19.-PHOTOMICROGRAPHS OF THE HARDWOOD GNEISS.

18. Garnet-hornblende-pyroxene gneiss. Enstatite (light gray) peripherally altered to hornblende (dark gray) and magnetite (black). Andesine (white) and garnet (large fractured grain at upper edge) also present. Ordinary light, $\times 40$. Specimen JF-557.

19. Plagioclase amphibolite. Lenticular areas of shattered and healed andesine and quartz. With hornblende (dark gray) and magnetite (black). Ordinary light, $\times 40$. Specimen JF-717. 


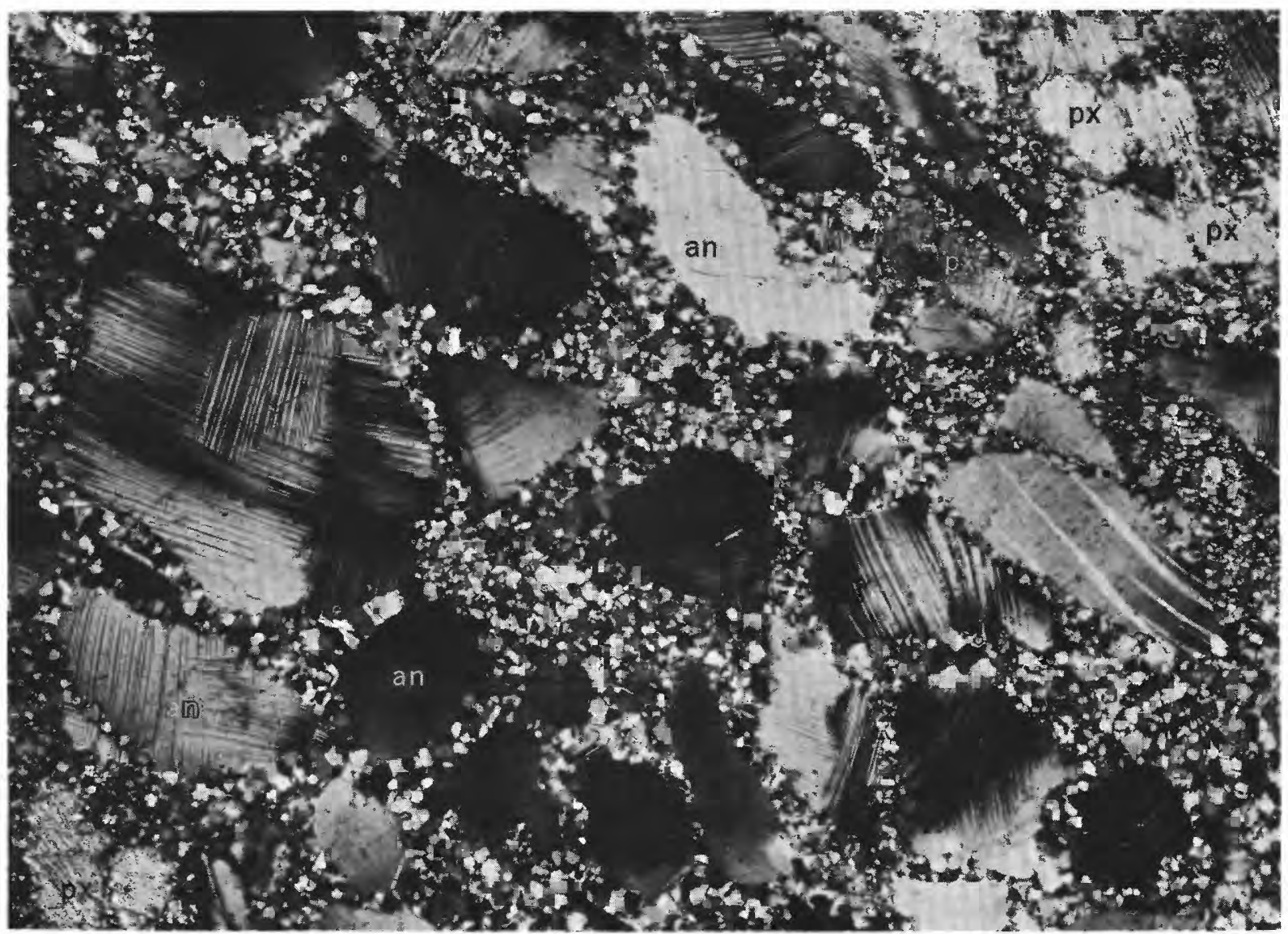

FTGURE 20.-Photomicrograph of plagioclase-pyroxene rock that occurs as layers within hornblende-pyroxene gneiss (Hardwood). Andesine grains $(a n)$ with twisted twin lamellae and granulated borders. Pyroxene $(p x)$ in lower left and upper right, rimmed with a small amount of green hornblende that is not distinguishable in the photograph. Matrix is andesine; possibly includes some quartz. Crossed nicols, $X 40$. Specimen JF-555-C.

bedded sedimentary rocks, intruded by gabbro sills. The rocks have been dynamothermally metamorphosed under conditions that resulted in the alteration of most of the original pyroxene in the igneous facies to hornblende and garnet, and the development of mica, hornblende, and plagioclase in rocks that appear to have originally been acidic volcanics.

The Hardwood gneiss, as seen in the exposures, is folded along axes that plunge eastward at low angles, and the general structure appears to be an eastward plunging syncline.

The most westerly exposure of the Hardwood gneiss is in sec. 7, T. 41 N., R. 27 W., just west of the secondary road leading north from M69, and almost on the east line of the section. The outcrop is deeply weathered. Most of the rock appears to be quartzite, in part micaceous and garnetiferous, but at the extreme western part of the "grass roots" outcrop is a small amount of a sheared micaceous rock with ovalshaped pods of quartz as much as 2 inches in length. The rock may be a deformed conglomerate, but the evidence is rather weak. Possibly the rock is a product of shearing and the pods of quartz are not pebbles but simply represent segmented quartz veins.

The lack of similarity of the Hardwood gneiss to any known Animikie rocks and the fact that it possesses the metamorphic characteristics similar to rocks of the Dickinson group suggest that it belongs with Lower Precambrian rocks, though its relationship to the Dickinson group and to the gneissic granite that lies directly to the west is not entirely clear. The conglomerate(?) may indicate that the Hardwood rests unconformably on the granite. This would imply that it is younger than either the granite or the Dickinson group, which is intruded by the granite. But inasmuch as the gneiss has been subjected to dynamothermal metamorphism of the same type which produced the present features of the Dickinson rocks (in contrast to the dominantly thermal metamorphism of the Middle Precambrian strata), this interpretation does not seem too likely. Alternately, two other possibilities may be suggested: 1) The Hardwood is part of the Dickinson group. As noted earlier in the discussion of the Dickinson group, the Solberg schist opens 
into a pattern V-shaped to the east. The Hardwood gneiss may be part of the Solberg schist sequence, missing elsewhere because of lack of exposure or faulting, or because of facies changes along the strike; or 2) The Hardwood gneiss is younger than the described members of the Dickinson group and belongs stratigraphically above the Six Mile Lake amphibolite. Elsewhere the rock of equivalent age may have been incorporated in the granite. At the present time, the latter view seems the more probable.

\section{BANDED GRAY GNEISS}

The unit designated banded gray gneiss occurs as a belt that extends entirely across the map area in an easterly direction, with a width of approximately a mile. Most of the belt is directly north of the Felch trough, but in the northern part of T. 42 N., R. 30 W., it borders the trough on both sides. The gneiss is well exposed in many places, particularly in the area north and northwest of the town of Felch (secs. 29 and 30, T. 42 N., R. 28 W., and sec. 25 , T. 42 N., R. $29 \mathrm{~W}$.), in the southern part of sec. 30, T. 42 N., R. 29 W., and in sec. 32, T. 42 N., R. 30 W.

The gneiss is a well-banded rock, with layers of unlike composition and color. Light-colored layers of granitic composition and texture alternate with dark layers composed principally of biotite or of hornblende (fig. 21). In the outcrop, most of the gneiss weathers to a ribbed surface, owing to differential erosion of the banded rock. Thicknesses of individual layers range widely; typically they are from a fraction of an inch to several inches, but in places, the layers of amphibolite are as much as 100 feet in thickness.

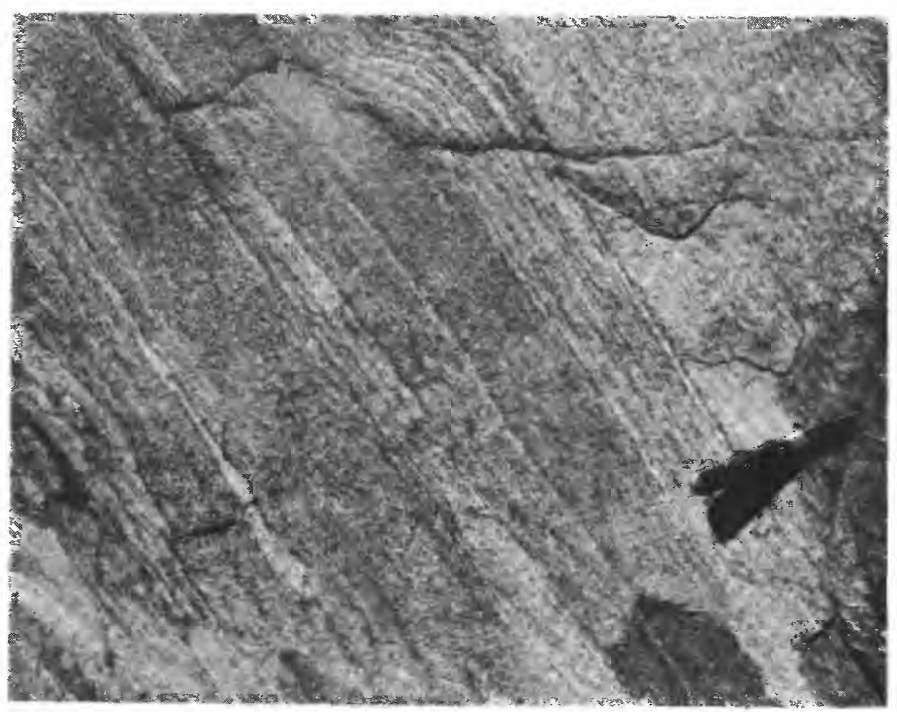

Figure 21.-Photograph of the banded gray gneiss. Closeup of exposure in sec. 30, T. 42 N., R. 29 W. Rock shown here is more thinly layered than most of the banded gray gneiss.
Two of these amphibolite layers are quarried in the south part of sec. 30, T. 42 N., R. 29 W. The fine baning of some parts of the gneiss may be in part inherited from preexisting material, possibly fine-banded tuffs and sediments that were interlayered with massive flows. But in places massive amphibolite can be seen to fray out abruptly into the banded gneiss. The granitic layers, like the dark layers, are foliated; streaks and laminae of dark minerals are typical. The lighter layers are composed of quartz, plagioclase $\left(A n_{10-15}\right)$, microcline, and brown biotite; relative proportions vary widely. The amphibolite consists essentially of green hornblende and plagioclase (gradationally zoned from $\mathrm{An}_{50}$ to $\mathrm{An}_{20}$ ), with variables amounts of quartz, microcline, sphene, and magnetite.

The typical amphibolite layers consist of strongly oriented greenish-yellow to bluish-green hornblende ( 65 to 75 percent), plagioclase ( 15 to 20 percent), and quartz (5 to 10 percent). Sphene, the chief accessory mineral, occurs as numerous small grains.

The layers of granitic gneiss consist of a mediumgrained aggregate of feldspar, quartz, and biotite. The quartz and feldspar occur as an intergrowth of somewhat elongate and parallel grains. The feldspar, which is approximately twice as abundant as quartz, is principally microcline but includes also a little plagioclase. The biotite, forming no more than 5 percent of the rock, occurs as parallel flakes.

Varied opinions as to the origin of the banded gneiss have been expressed. Smyth expressed the view that the amphibolite layers are altered basic dikes or silllike bodies injected into the granite (Clements and Smyth, 1899, p. 397). Dickey examined the outcrops near Randville and concluded that the "gneiss has been developed through the intimate intrusion of Keewatin-type schists, generally along cleavage planes, by granite" (Dickey, 1936, p. 323). Accordingly he termed the rock an "injection gneiss."

The fraying out of amphibolite layers along the strike shows that the granitic material is younger than the amphibolite. The gneissic complex may well be the result of partial replacement and granitization of amphibolite of the Dickinson group. Perhaps the more homogeneous granite south of the Felch trough represents the end-stage of this granitization process.

The rock probably represents a reaction zone between the rocks of the Dickinson group (principally amphibolite) and granite of post-Dickinson age, the main body of which lies to the south. Although in a broad way it is parallel to the bedding of the Dickinson group sedimentary and volcanic rocks, the gneiss development appears to have been gradually transgressive toward the west. The most westerly outcrops 
of Six-Mile Lake amphibolite are in sec. 29, T. 42 N., R. 29 W. In T. 42 N., R. 30 W., the outcrop relationships, particularly when considered with respect to the magnetic anomaly that is caused by the Skunk Creek member, suggest that the amphibolite has been converted entirely to gneiss. The outcrops near the center of sec. 27 of this township, though classed as schist, approach gneiss in character, which may indicate that the gneissic "front" here is within the Solberg schist.

In most of the map area the gneiss is separated from the granite to the south by infolded Animikie rocks or by faults. In the northern part of T. $41 \mathrm{~N}$., R. $30 \mathrm{~W}$., the gneiss-granite contact is south of the trough. In this area the character of the rock changes gradually from banded gneiss into gneissic granite with many dark stringers and schlieren. Location of the contact, therefore, is quite arbitrary within the transition zone.

\section{GNEISSIC GRANITE}

\section{OCCURRENCE}

Gneissic granite, probably upper Lower Precambrian, underlies approximately half of the southern portion of the map area. It forms two large masses or blocks that dominate the structural pattern. The northern block occupies a belt approximately 18 miles long by 1 to 3 miles wide, chiefly in the north parts of T. 41 N., Rs. 27, 28, 29, and 30 W. The southern block underlies about 11 square miles in Central Dickinson County and extends beyond the map area into southern Dickinson County. The north block has been examined in greater detail than the south block, but neither has been completely studied; in general, outcrop mapping has been confined to marginal areas. The rock is well exposed, forming bare, rounded bluffs, many of which are glacially polished and striated.

\section{DESCRIPTION}

The granite is varied in composition and texture. The most common rock is a massive pink to gray medium-to coarse-grained foliated microcline-albite granite (figs. 22-24), much of which is porphyritic in aspect. The granite grades into quartz diorite that consists essentially of quartz, oligoclase, and biotite; no readily definable contacts have been observed between the various types of granitic rock. In the porphyritic rock, the large crystals most commonly are pink microcline, but some thin sections examined contain albite of similar habit (fig. 24). These large crystals have granulated borders and are set in a groundmass consisting of microcline, quartz, oligoclase (or albite), biotite, and muscovite. In some parts of the area, inclusions (or relics) ${ }^{x}$ are abundant, and in such areas incomplete assimilation or replacement has resulted in a wide variety of rocks of intermediate type; in a few outcrops gross layering in the granite shows what may be relict folds. Foliation, marked by orientation of augenlike feldspar phenocrysts and by biotite or hornblende-rich layers and laminae, generally is well developed, though locally it is absent. Lineation ordinarily is not a pronounced structural feature though it may be observed in many outcrops; it is best shown by amphibolite inclusions. Inclusions are conformable with foliation and lineation; the apparent transverse trend shown locally by amphibolite is due to emergence at the surface of low-plunging thin sheets or pods of included rock. In several places the gneiss contains pegmatitic veins and layers that have been deformed equally with the gneiss. Later pegmatite and granite of post-Animikie age is present in a few localities. Basic dikes, most of which are altered to amphibolite, are not uncommon.

In the block of granite gneiss between the Felch and Calumet troughs, the types of included material seem to show a broadly zonal pattern. The most northerly belt, adjacent to the Felch trough or to the banded gneiss, is marked by amphibolite inclusions that locally are very abundant, particularly in the eastern part of this block. These inclusions range in size from pencillike lenses to bodies 100 feet or more in width and several hundred feet in length at the outcrop surface. Most but not all the amphibolite inclusions have sharp contacts with the enclosing granite. The amphibolite consists of green hornblende and twinned plagioclase (oligoclase or andesine), with minor quartz. In the southwestern part of the area, south of the Toby Lake fault, the granite contains many poorly defined inclusions or relics of a granular gray rock that resembles graywacke. Locally, as in outcrops near the center of the SWI/4 sec. 18, T. 41 N., R. $29 \mathrm{~W}$., the included rock is a fine-grained quartzite; in other places it is a quartz-mica gneiss or schist. The "graywacke" inclusions are much less distinct than those of amphibolite. Commonly they appear to

\footnotetext{
1 Much of the terminology dealing with granitic complexes unfortunately is subjective in character. A podlike body of amphibolite enclosed in granite may be referred to as an "inclusion", implying that the amphibolite has been engulfed and perhaps transported in a granite magma, or it may be referred to as a "remnant" or "relic," implying that it represents unreplaced material that has survived a cycle of granitization produced by activity of solutions on rock in place. Similarly, choice between "phenocryst" (igneous) and "metacryst" (metamorphic) may depend wholly on the writer's concept of origin of the rock, rather than on a measurable physical property. Other like pairs are "injection" and "permeation"; "assimilation" and "replacement"; "orthogneiss" and "paragneiss.' Insofar as feasible, the descriptions in this report will be on the basis of physical properties, but in many cases this is not possible, because of the lack of appropriate objective terms.
} 


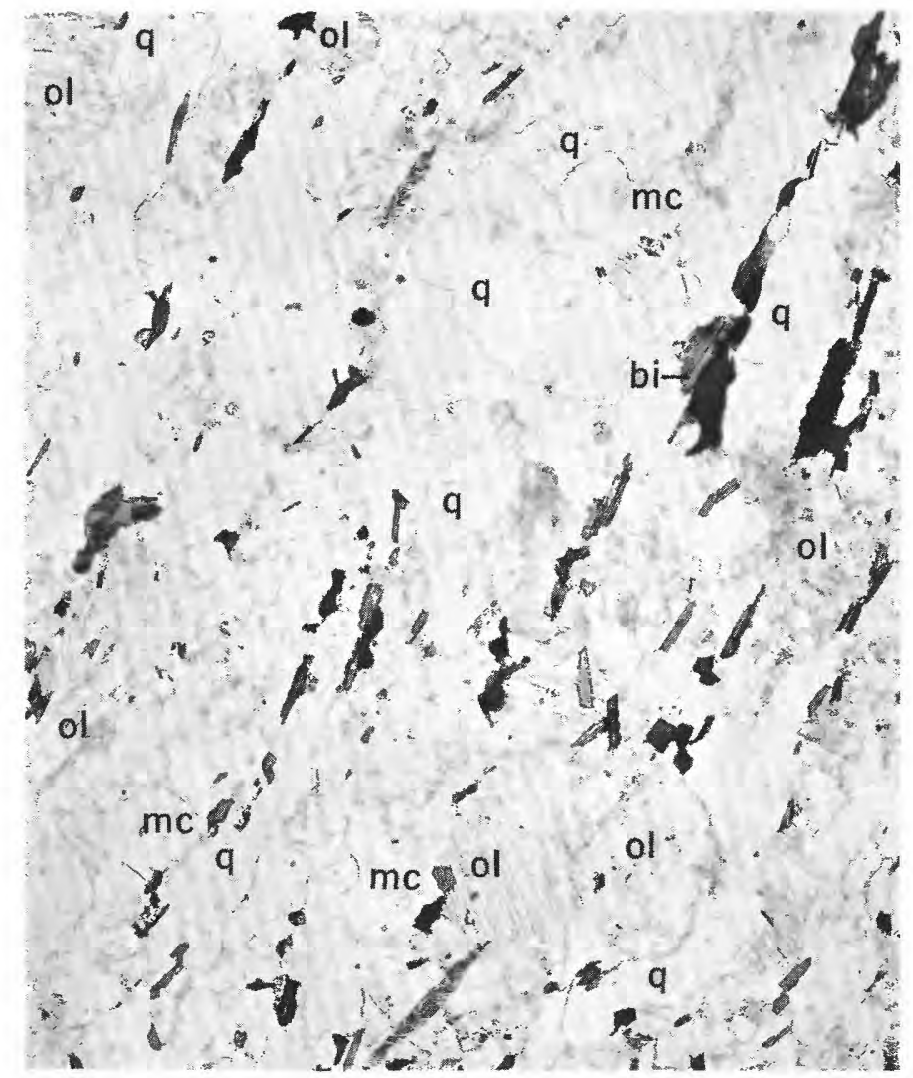

FIGURE 22.- Ordinary light.

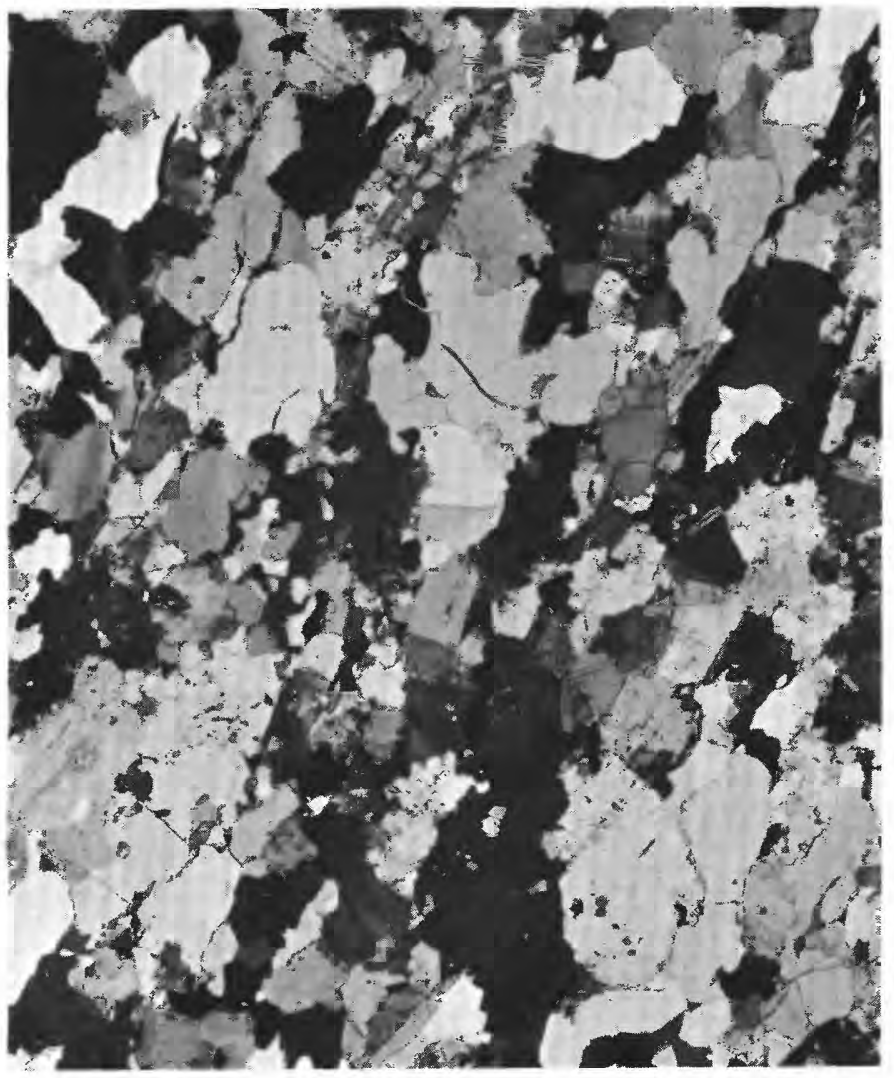

FIGURE 23,-Crossed nicols.

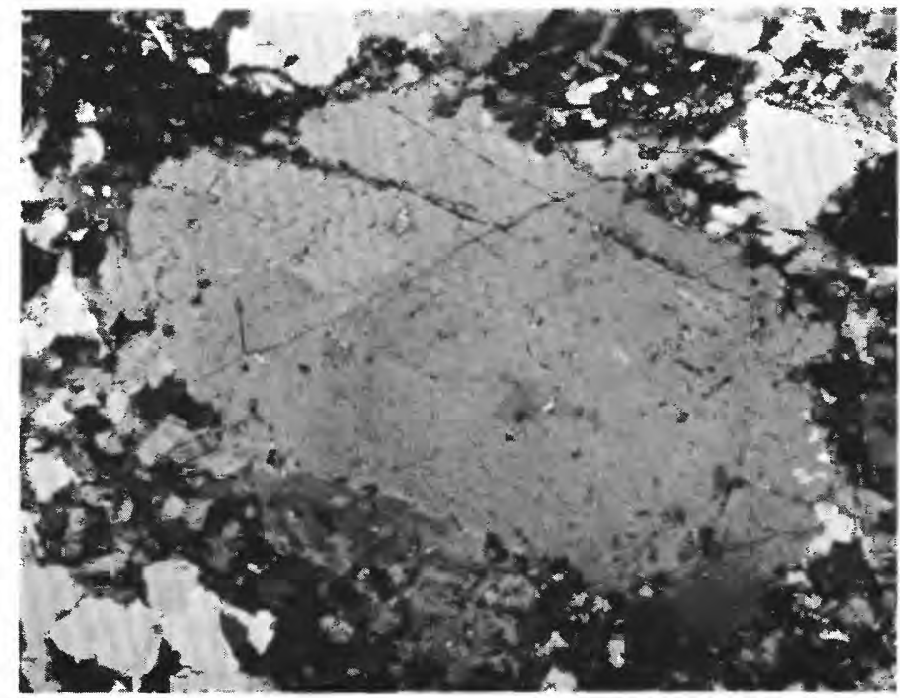

FIGURE 24.-Crossed nicols.

FIGURES 22-24.-PHOTOMICROGRAPHS OF GNEISSIC GRANITE.

22, 23. Foliated microcline-oligoclase granite. Microcline $(m c)$ in clear grains, not perthitic; oligoclase (ol) clouded by slight alteration, most grains bordered by narrow rim of clear albite. Quartz $(q)$ in large unstrained anhedra. Biotite $(b i)$ in disconnected shreds. $\times 12$. Specimen $\mathrm{HJ}-235 \mathrm{~b}-48$.

24. Porphyritic gneissic granite from NW1/4 sec. 9, T. 41 N., R. 30 W. Large crystal of albite with granulated borders in matrix of quartz (large clear grains) and microcline, with scattered fine flakes of partly chloritized biotite. Crossed nicols, $\times 18$. Specimen JT-413. 
be merely slightly darker finer grained gneissic phases of the granite.

The granite gneiss is marked by prominent planar structures-layering, deformed feldspar phenocrysts (see figs. 22-24), foliation, and inclusions-and, less prominently, by linear structures. These structures have varied origins. Some, like the layering of amphibolite and metasedimentary rock, are relict from the preexisting terrane; some, like the augen shapes of feldspars, probably are contemporaneous in origin with the emplacement of the granite. The structural and textural features of the crystalline complex suggest an origin under conditions of high stress, with temperatures near or at that required for development of magma. In such an environment fluid and ionic diffusion approaches a maximum and parts of the body will actually be molten; under stress the rock flows plastically, with resultant drawing out of the more resistant units and deformation of earlier formed potash feldspar and albite phenocrysts. Uniformity of chemical composition and texture in bodies of granite measured in square miles of surface area suggest that large bodies of magma did exist, whether by melting and homogenization of preexisting rock or by invasion from greater depths, but the general picture that emerges is one in which diffusive processes grade imperceptibly into magmatism; the results of granitization and magmatic activity are inseparable.

The planar elements of the northern mass describe a broad arc; in the western part the strikes are generally east-northeast to northeast, in the central part approximately east, and in the eastern part they are west-northwest to northwest. In this block the linear elements plunge at low angles that, in general, are westerly in the west part and easterly in the east part. It is evident, therefore, that although the block is now defined chiefly by unconformable contacts with the Middle Precambrian and by later faults, the early structural elements corresponded in a broad way with those of later origin. In detail, however, they are at variance, and regular truncation of foliation and lineation may be noted at the contact with Middle Precambrian rocks.

The relationship between the structure of the crystalline blocks and that of the Animikie sedimentary rocks is discussed later in this chapter, under "Structure".

\section{COMPOSITION}

New chemical analyses have been made of two specimens from the block of granite gneiss that lies between the Felch and Calumet troughs, one from the eastern part and one from near the west margin. The rock from the eastern area $(A$, table 2$)$ is a coarse- grained foliated pinkish-gray granite. The rock from the western area $(B$, table 2$)$ is a pink, coarse-grained, porphyritic, foliated microcline granite. Under $C$, (table 2) is given the average of six analyses of granite and granite gneiss given in Monograph 36 (Clements and Smyth, 1899). The specimens analyzed were all from the granitic rock bordering the Felch trough on the south.

TABLE 2.-Analyses of granite gneiss from the central crystaline

\begin{tabular}{|c|c|c|c|}
\hline & $A$ & $B$ & $\boldsymbol{C}$ \\
\hline $\mathrm{SiO}_{2 \ldots} \ldots \ldots$ & 70. 92 & 73.39 & 73. 13 \\
\hline $\mathrm{Al}_{2} \mathrm{O}_{3} \ldots$ & 16. 95 & 13. 68 & 14. 19 \\
\hline $\mathrm{Fe}_{2} \mathrm{O}_{3} \ldots$ & .82 & .65 & .82 \\
\hline $\mathrm{FeO}$ & 1. 78 & 1. 18 & .72 \\
\hline $\mathrm{MgO}_{\ldots} \ldots$ & .07 & .20 & .45 \\
\hline $\mathrm{CaO} \ldots \ldots$ & 1. 47 & 1. 20 & .79 \\
\hline $\mathrm{Na}_{2} \mathrm{O}_{\ldots}$ & 3. 90 & 4. 72 & 3. 12 \\
\hline $\mathrm{K}_{2} \mathrm{O}_{\ldots} \ldots$ & 3. 16 & 4. 12 & 5. 64 \\
\hline $\mathrm{H}_{2} \mathrm{O}-\ldots$ & .08 & .07 & .15 \\
\hline $\mathrm{H}_{2} \mathrm{O}+\ldots$ & .04 & .27 & .46 \\
\hline $\mathrm{TiO}_{2} \ldots \ldots$ & .21 & .16 & .19 \\
\hline $\mathrm{P}_{2} \mathrm{O}_{5} \ldots \ldots$ & .18 & .16 & .02 \\
\hline $\mathrm{CO}_{2} \ldots \ldots$ & .06 & .34 & None \\
\hline \multirow[t]{2}{*}{$\mathrm{MnO}_{\ldots} \ldots$} & .03 & .02 & Tr. \\
\hline & 99.67 & 100. 16 & 99. 68 \\
\hline
\end{tabular}

A. Granite gneiss from first outcrop on west side of road south of Rian's quarry SE1/4SW1/4 sec. 33 , T. 42 N., R. 28 W. Sample HJ-234-48. Analyst: Leonard Shapiro, U.S. Geological Survey.

B. Granite gneiss from the NE1/4SW1/4 sec. 22 , T. 41 N., R. 30 W.; 2,200 feet east, 1,600 feet north of southwest corner of section. Sample HJ-229-48. Analyst: Leonard Shapiro, U.S. Geological Survey.

C. A verage of 6 analyses of granite and granite gneiss from near the south border of the Felch trough. (Clements and Smyth, 1899, p. 389, p. 391.)

The composition of the amphibolite, as determined on a specimen from sec. 32 , T. 42 N., R. 28 W., by Clements and Smyth $(1899$, p. 397), is given under " $A$ " in table 3 , together with an analysis of typical tholeiite " $B$ " for comparison.

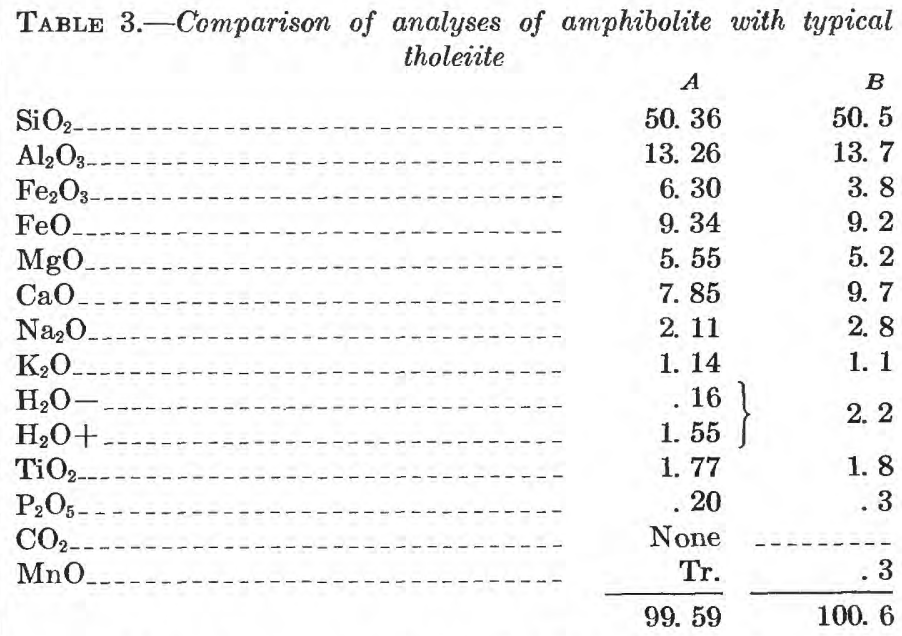

A. Amphibolite, from outcrop 1,140 ft north, 1,000 ft west of southeast corner, sec. 32 , T. 42 N., R. 28 W. (Clements and Smyth, 1899, p. 397).

B. A verage composition of tholeiitic rocks of the Hebridean province, as given by Turner and Verhoogen (1951, p. 194-195). 
The close agreement between the analysis of amphibolite and that of tholeiite rocks of the Hebridean province strongly suggests that the amphibolites originated as basic volcanic or intrusive rocks.

\section{AGE RELATIONS}

Although the granite gneiss may include a small amount of intrusive rock of post-Animikie age, the major part is much older. Basal contacts of the Sturgeon quartzite with the granite gneiss of the northern block are exposed in the Browning Creek area (sec. 20 , T. 41 N., R. 30 W.) and in sec. 36, T. 42 N., R. $29 \mathrm{~W}$. The Browning Creek area has been described by Pettijohn (1943). Briefly, the exposures at this locality show a sericitic quartzite with thin layers of conglomerate resting on granite gneiss, the foliation of which strikes almost normal to the contact. The rock in sec. 36 is poorly exposed, and relations are not especially clear. Little can be added to the description given by Smyth in Monograph 36 (Clements and Smyth, 1899, pp. 401-42), which is as follows:

In a locality already referred to, on the south bank of the Sturgeon, in sec. 36, T. 42 N., R. 29 W., where the Sturgeon quartzite is in visible contact with the Archean, the quartzite is underlain by a considerable thickness of very fissile muscovite-biotite gneiss, which incloses rather sparingly obscure pebbles of granite and quartz. This gneiss, which no doubt was an arkose rich in feldspar, has recrystallized and afterward been sheared; the coarse micas to which the fissility is due, together with other new materials, have grown between the fractured surfaces and recemented the broken mass.

The basal contact of the Fern Creek formation with the older gneiss of the southern block is exposed in the Pine Creek area, in the north part of sec. 32, T. 41 N., R. 29 W. This locality and several of similar type along the strike to the southeast are described by Bayley in Monograph 46 (1904) and by Pettijohn (1943). At the Pine Creek locality a plaster of conglomerate rests on the granite, which is cut by quartz veins truncated at the contact.

The age of the granite gneiss with respect to other Lower Precambrian rocks is not entirely clear, although reasonable conclusions may be drawn on the basis of relations within and at the borders of the northern mass. The evidence seems adequate to show that the granite was intruded into the rocks of the Dickinson group, with a resulting broad zone of reaction gneiss. As has been discussed earlier, the relationships with the Hardwood gneiss are obscure, but the Hardwood probably is at least roughly contemporaneous with the Dickinson group and thus is older than the granite.

Granitic intrusives in the upper Lower Precambrian are classed as Algoman in most parts of the Canadian shield. There is no assurance that the granitic gneiss under discussion is actually contemporaneous with Algoman granite elsewhere, but at least a rude correlation in time is indicated.

\section{PORPHYRITIC RED GRANITE}

Porphyritic red granite is present in two apparently separate elongate oval areas in the central part of $T$. 42 N., R. $30 \mathrm{~W}$. The larger of the two, traversed by the railroad and State Route M-95, is best exposed at its western end; it is about 4 square miles in area. Outcrops of the granite are conspicuous, massive, and domelike, and much of the area underlain by the unit is a rocky upland.

\section{DESCRIPTION AND COMPOSITION}

The rock is generally homogeneous and coarse grained. Inclusions are rare, but dark schlieren and compositional layering locally are present, as in the roadside outcrops $1 \frac{1}{2}$ miles north of Randville on State Route M-95. Lenticular to tabular pink feldspars about half an inch long are abundant and impart a porphyritic appearance to the rock. Some of the feldspars are euhedral, but most are in fact augen (fig. 25), and on horizontal surfaces a foliation pro-

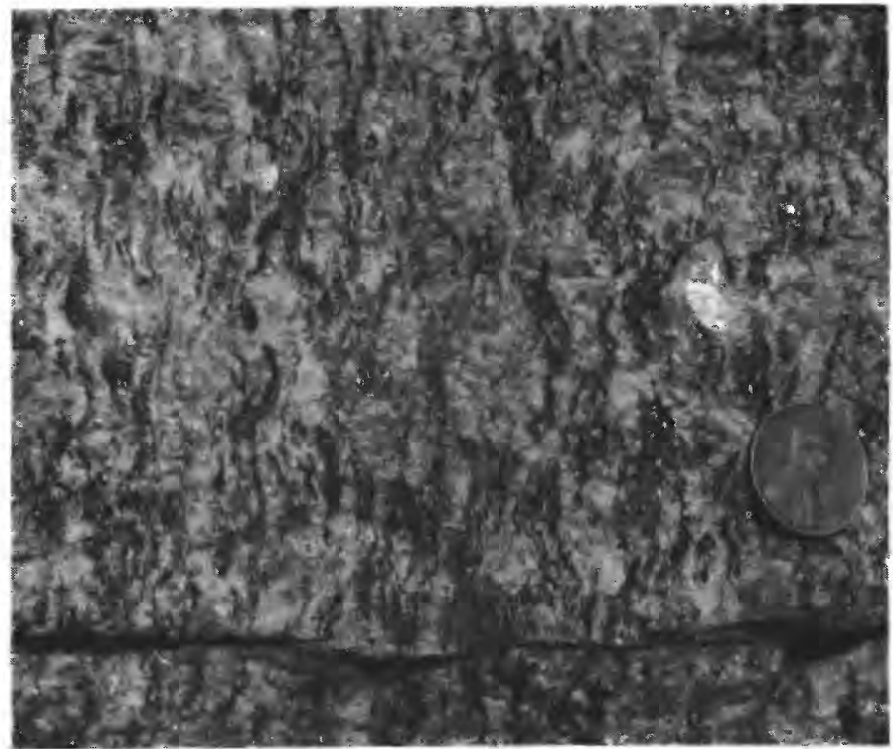

Figure 25.-Porphyritic red granite. Closeup of roadside exposure in sec. 21 , T. 42 N., R. 30 W. Nearly vertical surface.

duced by oriented feldspars is faint to distinct. In vertical sections the structure is easily seen. In most exposures, steeply plunging lineation, marked by orientation of both microcline augen and biotite, is well developed, and in places it is the dominant structure. 
The feldspars form about two-thirds of the rock; quartz and biotite make up the remaining one-third. Quartz itself makes up 10 to 20 percent of the rock The cores of many of the microcline phenocrysts are white or colorless and are mantled with feldspar that is salmon pink or red. In thin section the microcline crystals have indefinite borders against a finer grained aggregate of microcline, oligoclase that is reddish and kaolinized, and quartz. The relationships suggest granulation of the borders of original tabular microclines followed by recrystallization of the granulated material. The analysis of a typical specimen of the red porphyritic granite is given in table 4 .

The rock is a fairly normal granite in composition, aberrant only in that the alumina content, like that of the granite gneiss of the Norway Lake area, is relatively high.

TABLE 4.-Analysis of red porphyritic granite from NEY4SEY4 sec. 21 , T. 42 N., R. $30 \mathrm{~W}$.

[Analyst, Leonard Shapiro, U.S. Geological Survey. Specimen HJ-233-48, from roadside outcrop 1 mile north of Randville. See fig. 25]

\begin{tabular}{|c|c|c|}
\hline $\mathrm{SiO}_{2}$ & 71. 14 & $\mathrm{H}_{2} \mathrm{O}$ \\
\hline $\mathrm{Al}_{2} \mathrm{O}_{3} \ldots$ & 15. 10 & $\mathrm{H}_{2} \mathrm{O}+\ldots$ \\
\hline $\mathrm{Fe}_{2} \mathrm{O}_{3 \ldots} \ldots$ & .97 & $\mathrm{TiO}_{2 \ldots} \ldots \ldots$ \\
\hline $\mathrm{FeO}$ & 2. 97 & $\mathrm{P}_{2} \mathrm{O}_{5} \ldots \ldots$ \\
\hline $\mathrm{MgO}_{\ldots} \ldots \ldots$ & .21 & $\mathrm{CO}_{2} \ldots \ldots$ \\
\hline $\mathrm{CaO}_{\ldots} \ldots$ & 1.08 & $\mathrm{MnO}$ \\
\hline $\mathrm{Na}_{2} \mathrm{O}_{\ldots} \ldots$ & 2. 80 & \\
\hline - n & 5. 40 & \\
\hline
\end{tabular}

\section{AGE RELATIONS}

Comparison of the internal structure of the red porphyritic granite with that of Middle Precambrian rocks and of known younger granite shows that the porphyritic granite is definitely pre-Animikie, but no clear-cut evidence is available as to its age relation to other Lower Precambrian rocks. Part of the preDickinson granite gneiss of the Norway Lake area is red and porphyritic, yet no pebbles of the material appear in the conglomerates of the East Branch arkose. The suggestion was made earlier in this chapter that the porphyritic rock resulted from post-Dickinson development of feldspar porphyblasts in granulated pre-Dickinson granite. This view, extended to the red porphyritic granite gneiss under discussion, would imply that the rock masses are of pre-Dickinson age and thus equivalent to the granite gneiss of the Norway Lake area, but that the present mineralogic character and texture is the result of later regeneration of feldspars, probably during the metamorphic cycle that accompanied the emplacement of the postDickinson, pre-Animikie granite in the area. Studies of accessory minerals (Tyler, Marsden, Grout, and Thiel, 1940) show that the red porphyritic granite contains both hyacinth and malacon varieties of zircon. These authors consider the hyacinth variety to be diagnostic of the early pre-Animikie intrusives, whereas malacon is present in both upper pre-Animikie (Lower Precambrian) and post-Animikie (upper Middle Precambrian) intrusive rocks. The internal structure of the red porphyritic granite would seem to rule out the possibility of a post-Animikie age. The evidence from the zircons thus could be interpreted to mean that the granite has affinities with both the preDickinson granite and the post-Dickinson intrusion and metamorphism.

The attitudes of foliation in the larger of the two bodies of the gneissic granite in T. 42 N., R. $30 \mathrm{~W}$. appear to define a domelike structure, at least for the west end of the mass. The trend of foliation gradually swings from northeast in sec. 21 to north in sec. 29 , to west in sec. 28. Dips are steeply outward. In the eastern part of this mass structural closure of foliation is not demonstrated, though there is some convergence of strikes. Exposures are not adequate to show the structure of the smaller of the two bodies of gneissic granite, but the available structural evidence is consistent with the idea that this too is a dome.

Metamorphosed basic dikes are rather common in the red porphyritic granite, though they are not shown separately on the map. They are most numerous in sec. 28, T. 42 N., R. 30 W. and are exposed in and adjacent to cuts along the highway and railroad.

These rocks, probably once diabase, are now fine grained amphibolites that consist mainly of needles of black hornblende. The dikes range in width from a foot or so to 20 or 30 feet. They are somewhat irregular in form, and although they are in general tabular, they tend to pinch and swell. Details of three ocurrences are shown in figure 26. Many are substantially concordant with the foliation of the enclosing granite gneiss, but others are clearly crosscutting. All are slightly schistose, particularly near the walls, and many have a narrow border zone of biotite schist which may be due to a metamorphic reaction between the dike and the country rock. The age of the dikes is somewhat uncertain. They are later than the foliation of the granite, and are earlier than the aplite and pegmatite dikes that also cut the gneissic granite. They could be either upper Lower Precambrian or upper Middle Precambrian.

\section{MIDDLE PRECAMBRIAN ROCKS}

The Middle Precambrian is represented in central Dickinson County chiefly by a thick section of sedimentary rocks, the Animikie series (Huronian series of previous reports), which is subdivided into the 


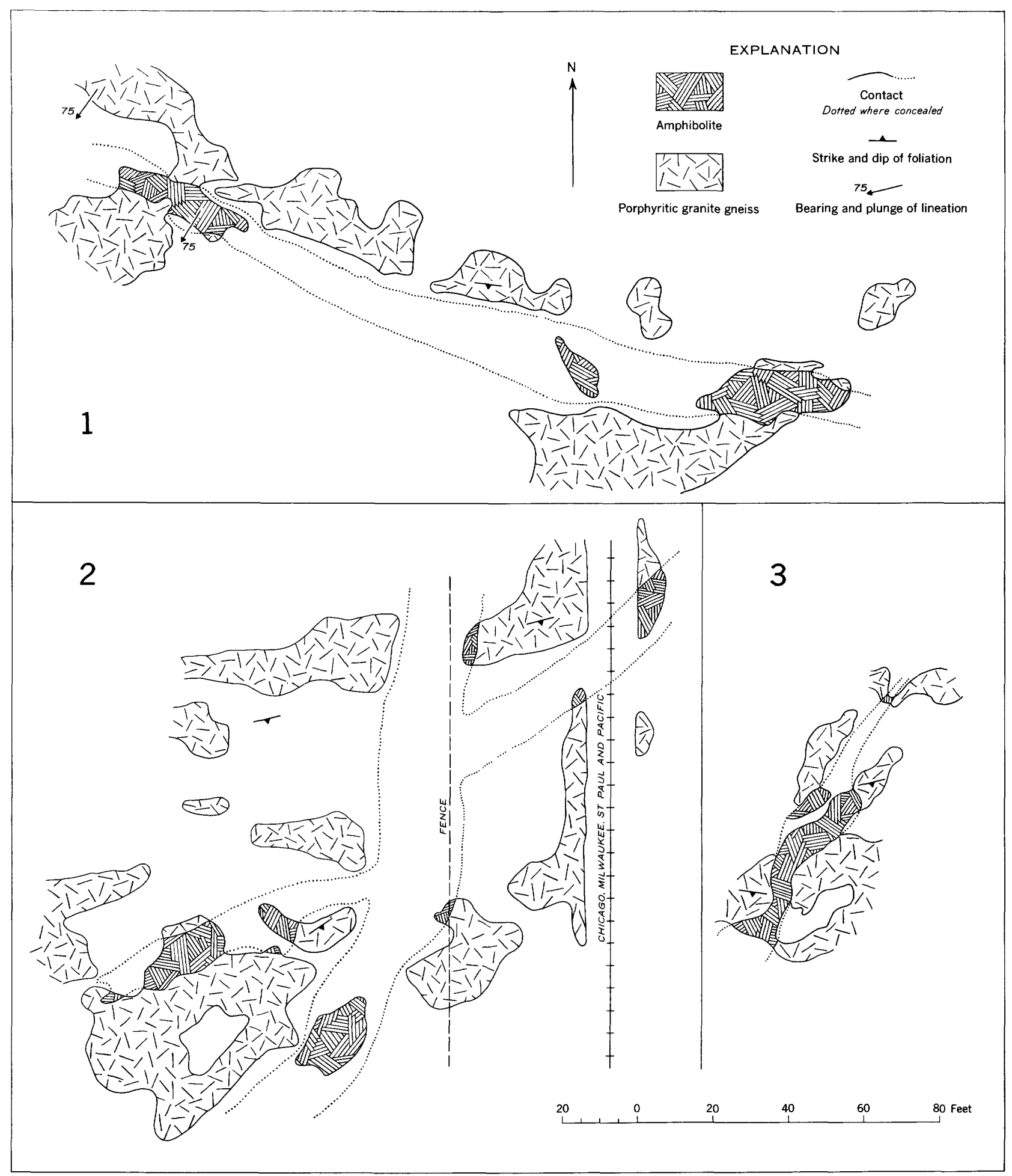

FigUre 26.-Three field sketches illustrating occurrences of amphibolite dikes in sec. 28 , T. 42 N., R. 30 W. 
Chocolay group, the Menominee group, and the Baraga group. The subdivisions of these units, together with a comparable tabulation of the rocks of the Marquette Range, are as follows:

\begin{tabular}{|c|c|c|c|}
\hline \multicolumn{3}{|c|}{ Central Dickinson County } & Marquette district \\
\hline \multirow{3}{*}{ 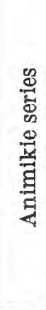 } & Baraga group & $\begin{array}{l}\text { Badwater greenstone- } \\
\text { Mich higamme sla te } \\
\text { (slate, schist, gray- } \\
\text { wacke). } \\
\text { Hemlock formation } \\
\text { (volcanic). }\end{array}$ & Michigamme slate. \\
\hline & Menominee group & $\begin{array}{l}\text { Vulcan iron-formation } \\
\text { Felch formation. }\end{array}$ & $\begin{array}{l}\text { Negaunee iron-forma- } \\
\text { tion. } \\
\text { Siamo slate. } \\
\text { Ajibik quartzite. }\end{array}$ \\
\hline & Chocolay group.... & $\begin{array}{l}\text { Randrille dolomite } \\
\text { Sturgeon quartzite }\end{array}$ & $\begin{array}{l}\text { Kona dolomite. } \\
\text { Mesnard quartzite. }\end{array}$ \\
\hline
\end{tabular}

In general the strata are not well exposed, except for the Sturgeon quartzite. The rocks of the Baraga group are especially susceptible to weathering, and many square miles known or believed to be underlain by these strata are without outcrop. As a result, the distribution of some units must be inferred from very inadequate data, and many uncertainties in map pattern exist.

\section{CHOCOLAY GROUP}

The Chocolay groups consists of three conformable formations-the Fern Creek, Sturgeon, and Randville - each of which rests directly on the older granite gneiss in some parts of Dickinson County.

\section{FERN CREEK FORMATION}

The Fern Creek formation was named by Pettijohn (1943); it is a sequence of clastic sedimentary beds (containing some tillite) that rests directly on the granite gneiss in southern Dickinson County. These strata were grouped with the Sturgeon quartzite by Bayley (1904), but are sufficiently different in lithologic character to warrant separation from the quartzite proper, at least in some areas.

The Fern Creek formation is known only in one small area of central Dickinson County, at the line between secs. 29 and 32, T. 41 N., R. 29 W. Here it consists principally of a thin conglomerate plaster on the granite gneiss. The locality is described in further detail in Chapter $\mathrm{E}$ of this report.

The Fern Creek formation is essentially concordant with the Sturgeon quartzite, although detailed mapping in some areas indicates a possible divergence of a few degrees. The formation appears to be the basal phase of a clastic sequence, and is separated from the Sturgeon quartzite only because of distinctive lithologic character. Its occurrence in isolated patches probably is due to topographic relief of the surface on which it was deposited. Because of the tillite in this formation (Pettijohn, 1943), however, the possibility must be considered that the Fern Creek may be a continental deposit separated by a slight unconformity from the Sturgeon quartzite. In this view, the occurrence as isolated patches between the Surgeon and the granite gneiss might be due, in considerable measure, to post-Fern Creek erosion.

\section{STURGEON QUARTZITE}

The Sturgeon quartzite is a major stratigraphic unit in both central and southern Dickinson County. The formation was named by Smyth (Clements and Smyth, 1899, p. 398) on the basis of outcrops along the Sturgeon River in secs. 35 and 36, T. 42 N., R. 29 W. The Sturgeon occupies the same stratigraphic position as the Mesnard quartzite of the Marquette range, with which it is lithologically almost identical.

Within the map area the Sturgeon quartzite occurs in three principal belts. The most northerly belt extends in an arc from sec. 18, T. 41 N., R. 30 W., to sec. 35 , T. 42 N., R. 29 W. This belt, approximately 11 miles in length, contains several gaps in exposure, one of which is 2 miles long. The middle belt is an arc, almost parallel to the northern belt, that extends from sec. 20 , T. 41 N., R. 30 W., to sec. 12 , T. 41 N., R. $30 \mathrm{~W}$., a distance of about 6 miles. The southern belt, which contains the most extensive exposures, extends from the south margin of the map area northward to sec. 20, T. 41 N., R. 29 W. A few scattered outcrops are present elsewhere in the Felch trough, and a narrow body of quartzite, apparently bounded by gneiss, is present in sec. 29, T. 42 N., R. 28 W. So far as known, the Sturgeon quartzite is not present in the more northerly part of the map area.

Within the belts described above, the quartzite forms many bold well-defined outcrops, some of which are as much as a quarter of a mile long. In general, the rock is resistant to erosion, and in many places it is topographically part of the upland formed by the older granite gneiss.

Description.-The major rock type is a massive pure vitreous quartzite in which bedding is not readily discernible. The color ranges from white to gray, locally with a pinkish or purplish tinge. Close examination will reveal crossbedding and ripple marking in most of the more extensive outcrops. Bedding planes are obscure except for ripple-marked surfaces, which commonly are coated with a thin film of mica. By means of crossbedding and ripple marks, top directions can be determined with certainty; they show that the beds are overturned in most of the area. In thin 


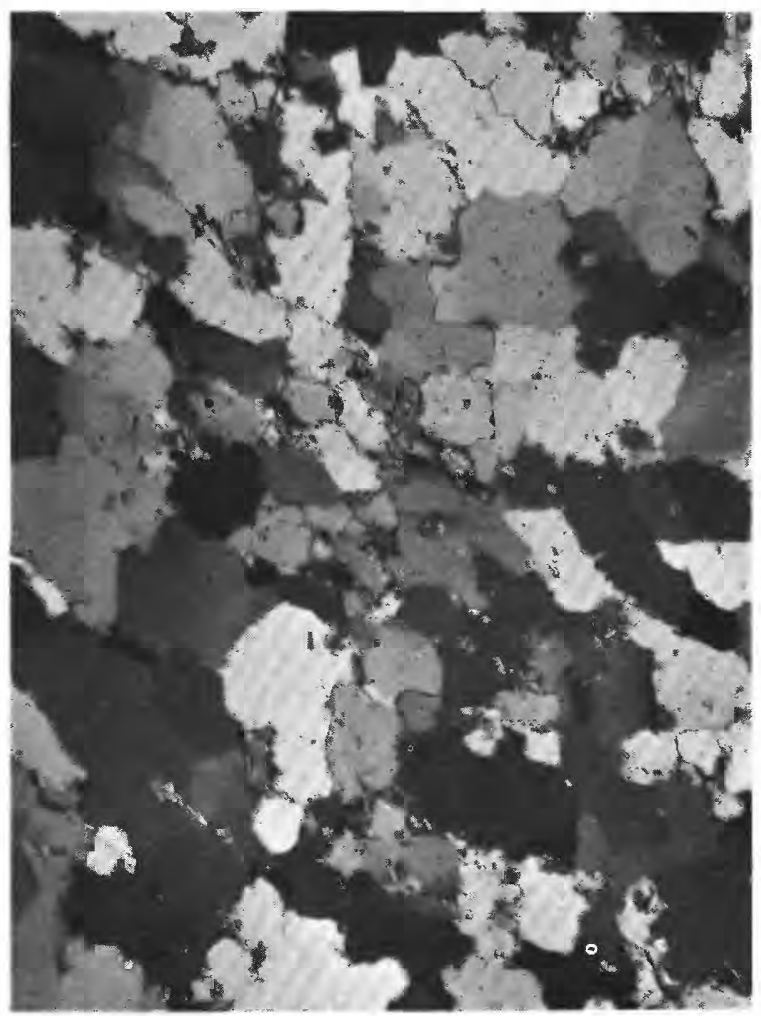

Figure 27

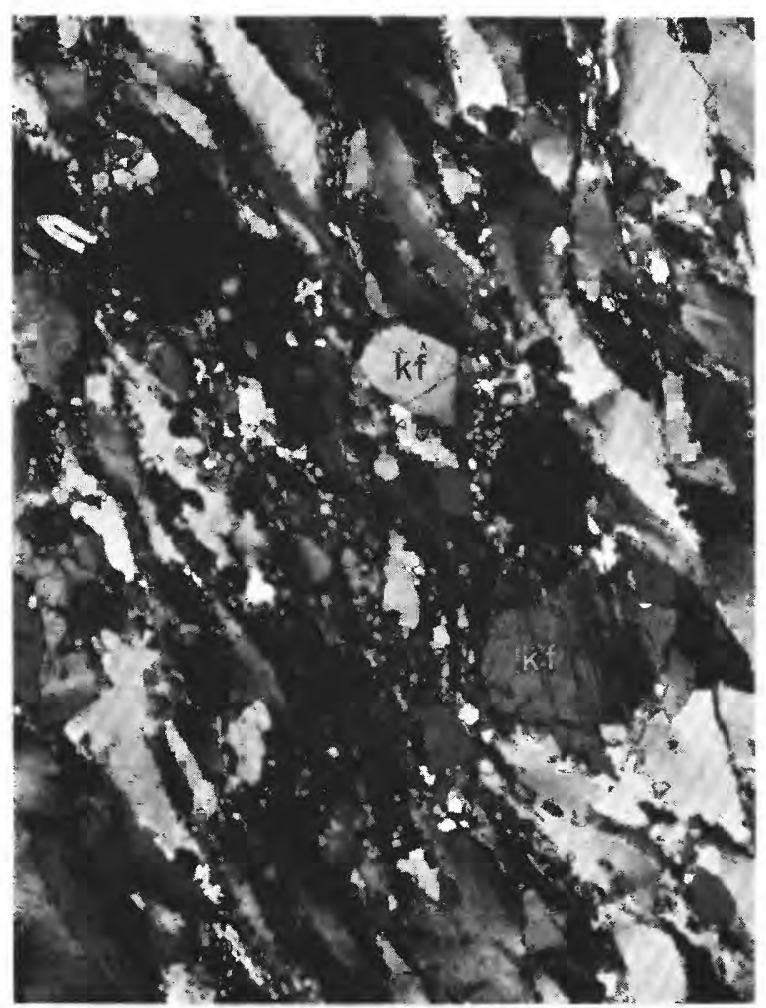

FIGURE 28

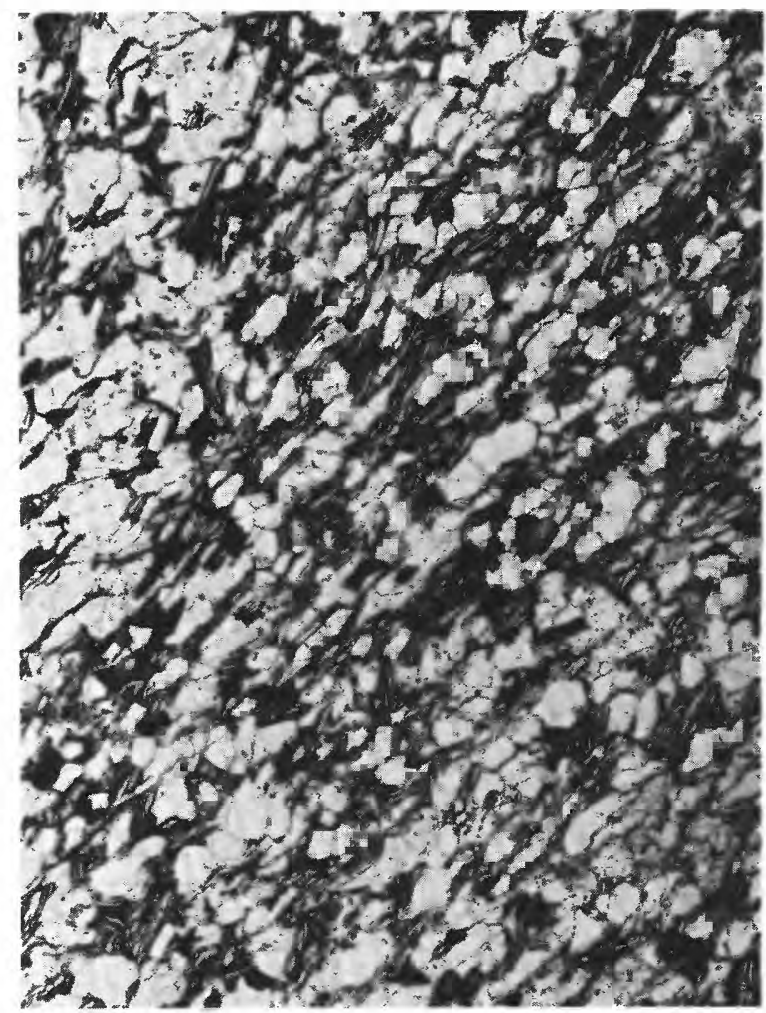

FIGURE 29

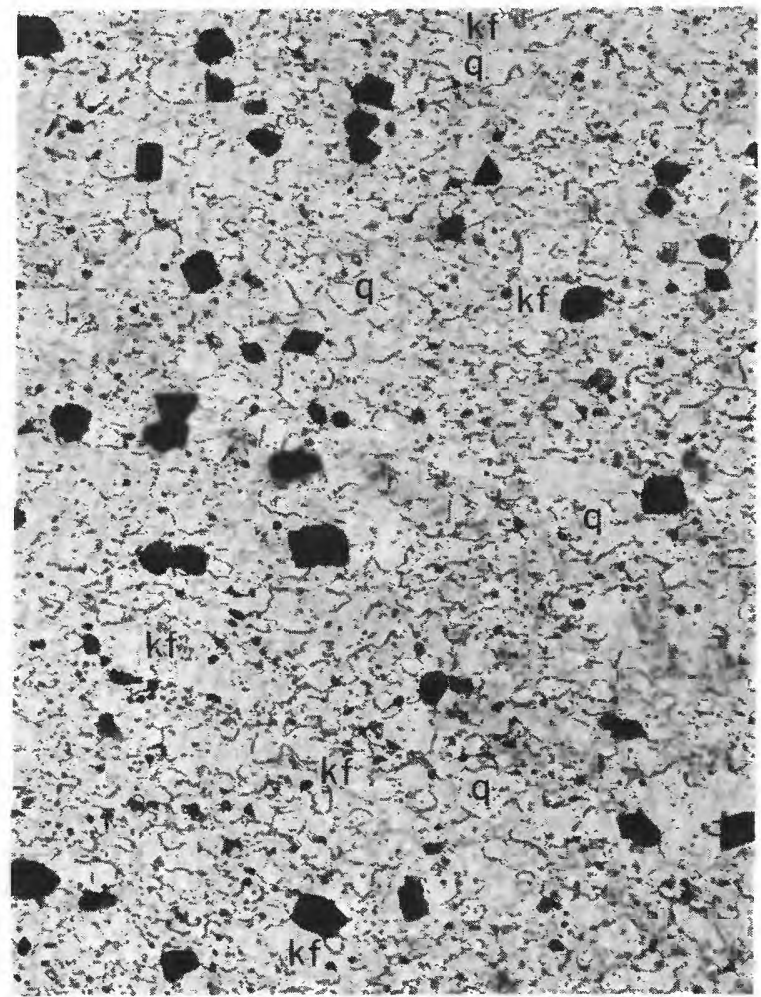

FIGURE 30

FIGURES 27-30--PHOTOMICROGRAPHS OF STURGEON QUARTZITE.

27. Vitreous quartzite, normal type. Sutured aggregate of unstrained quartz grains with 5 percent or less muscovite as fine shreds. Some dimensional orientation of the quartz grains parallel to foliation defined by the mica. Crossed nicols, $\times 45$ Specimen JT-393.

28. Strongly deformed vitreous quartzite, with a few rounded to angular grains of potassium feldspar $(k f)$. Quartz shows strain shadows and granulation of grain boundaries. Crossed nicols, $\times 33$. Specimen CL-14-48.
29. Micaceous quartzite. Mica partly altered to red hematite (black in photograph) Quartz clear white. Abundant potassium(?) feldspar as cloudy grains interstitial to the quartz. Ordinary light, $\times 33$. Specimen CL-20-47.

30. Fine-grained magnetite-bearing quartzite. Consists of quartz $(q)$ and potassium feldspar $(\mathrm{k})$, with seattered graims of magnetite (black) in matrix of potasisium feldspar $(k f)$. Ordinary light, $\times 66$. Specimen $\mathrm{CL}-9-46$. 
section most of the rock is composed chiefly of coarse, interlocking quartz grains (fig. 27), with some grains of feldspar and muscovite. In many specimens the grain outlines are elongate and irregular, and the quartz shows strain shadows (fig. 28).

The lower part of the Sturgeon quartzite is typically somewhat micaceous or chloritic, and may be distinctly greenish in color. In places it is a quartz-sericite schist, as in the outcrops in sec. 20 , T. 41 N., R. 30 W., and in test pits in sec. 34, T. 42 N., R. 30 W. Because it is more fissile, this part of the Sturgeon is not widely exposed.

In the northern belt of the Sturgeon, and to a lesser extent in the middle belt, the upper part of the quartzite appears to be ferruginous, although exposures are as rare as those of the lower micaceous part. The rock exposed in the large outcrop adjacent to the highway in sec. 10, T. 41 N., R. 30 W., and in low outcrops at the west margin of the outcrop belt in sec. 7, T. 41 N., R. 30 W., is a sugary fine-grained feldspathic quartzite with disseminated small crystals of magnetite that may make up as much as 10 percent of the rock (fig. 30). A small amount of pyrite also is present. In sec. 32, T. 42 N., R. 29 W., the rock contains abundant mica, which is extensively altered to hematite (fig. 29). The texture and the interstitial habit of the feldspar suggest that the rock may owe its fine grain to granulation and reconstitution rather than original deposition. Coarse-grained magnetite, clearly of secondary origin, was observed in quartzite outcrops adjacent to the magnetic anomaly in sec. 4, T. 41 N., R. 30 W. (Wier, Balsley, and Pratt, 1953).

Thickness and stratigraphic relations.-The thickness of the Sturgeon quartzite is difficult to determine because of general lack of exposures in critical areas and because of faulting; nowhere in the map area can a continuous section of the formation be examined. Despite the uncertainties, however, reasonable approximations can be given and certain broad variations noted.

The Sturgeon is thickest in the southern part of the map area, in secs. $29,30,31$, and 32 , T. 41 N., R. 29 W. In places the outcrop width of apparently unfaulted strata is about 2,000 feet with an average dip of $70^{\circ}$, which indicates that the minimum stratigraphic thickness is about 1,850 feet. The thickness of the Sturgeon is more difficult to determine in the central and northern belts, but as shown on cross section $A-A^{\prime}$ and $B-B^{\prime}$ (pl. 2), it appears to be 800 to 1,000 feet. This figure is probably a maximum value; an estimate based on outcrop data alone would suggest a value closer to 500 feet. Eastward along the Felch trough, the formation becomes progressively thinner, although determination is exceedingly difficult because of the numerous faults and poor exposure. In sec. 26, T. 42 N., R. 29 W., the maximum value is not greater than 400 feet, and in the area east of Felch a thickness of not more than 200 feet seems probable. The Sturgeon is either very thin or absent in the northern part of central Dickinson County, and a short distance north of the map area, the Randville dolomite rests directly on the granite gneiss in the exposures in the $\mathrm{NE} 1 / 4$ SE $1 / 4$ sec. 15, T. 43 N., R. 29 W. Despite the uncertainties in individual measurements, therefore, the Sturgeon evidently has a great range in thickness, and the thickness gradually increases from practically nothing in the north to nearly 2,000 feet in the southern part of Central Dickinson County. The variation in thickness is almost certainly due to original sedimentation rather than truncation in post-Sturgeon time, for no unconformity with the overlying Randville dolomite is indicated anywhere.

Conditions of deposition.-The Sturgeon quartzite was deposited as a clean quartz sand in a sea that was gradually advancing over a low-lying land surface of crystalline rocks. The persistence of current bedding and ripple marks through 1,000 feet or more of section shows that the basin of deposition was slowly sinking at a rate equivalent to the rate of sedimentation, so as to maintain shallow-water conditions. The purity of the quartzite suggests that the sand was continually reworked and that the crossbedding is due to construction of offshore bars and spits, rather than to deltaic deposition. Almost certainly the quartzite is not time-equivalent throughout the region.

\section{RANDVILLE DOLOMTTE}

The Randville dolomite, named by Smyth (Clements and Smyth, 1899) for the village of Randville in sec. 33 , T. 42 N., R. 30 W., is a widespread and important stratigraphic unit in Central Dickinson County. In general, however, it is poorly exposed and its extent is inferred from widely scattered outcrops, from drill holes, and from other geologic data. The Randville dolomite is similar in almost all aspects of lithologic character and stratigraphic position to the Kona dolomite of the Marquette district.

Except for two outcrops, one in sec. 31, T. 41 N., R. $29 \mathrm{~W}$., and one in sec. 11, T. 41 N., R. 30 W., the Randville dolomite is not exposed in the area south of the Felch trough, although underground workings and drill holes have shown it to be present in the Calumet mine area, in sec. 8, T. 41 N., R. 28 W. The Randville is inferred to be present in belts parallel to the Sturgeon quartzite, but it may well be missing in much of the area because of pre-Michigamme deforma- 
tion and erosion. Within the Felch trough the dolomite is on both flanks of a faulted synclinal structure. From the vicinity of the Groveland mine, outcrops are fairly numerous on the north flank westward to within half a mile of the village of Randville, and excellent exposures may be seen in several quarries. West of this point only one probable outcrop is known, in the NW1/4 sec. $5, T .41$ N., R. 30 W. The south flank of the syncline is known from test pits and drill holes directly south of the Groveland mine, from fairly extensive outcrops in the $\mathrm{S} 1 / 2$ secs. 35 and $36, T$. $42 \mathrm{~N}$., R. $30 \mathrm{~W}$., and from drill holes in sec. 5, T. 41 N., R. $30 \mathrm{~W}$. From the Groveland mine east to the Sturgeon River, dolomite is inferred but is not exposed except in secs. 34 and 35, T. 42 N., R. 29 W. Between here and the east end of the Felch trough, the dolomite is known from outcrops and drill holes in secs. 32 and 33, T. 42 N., R. 28 W., and in a belt of outcrops in the SE $1 / 4$ sec. 32, and at Rian's quarry in sec. 33. The most easterly occurrence of dolomite is in the area of the Metronite quarry in sec. 26, T. 42 N., R. 28 W.

One of the most extensive areas of outcrop of Randville dolomite in Central Dickinson County is at the south margin of the Sagola basin, in sec. 35, T. 43 N., R. 29 W., secs. 1 and 2, T. 42 N., R. 29 W., and secs. 3 , 4, 5, and 6, T. 42 N., R. 28 W. The broad belt shown on the map crossing the northern part of T. $42 \mathrm{~N}$., R. 30 W., and the adjacent part of T. 42 N., R. 29., is inferred on the basis of exceedingly scanty evidence. The formation is well exposed at the east end, in sec. 4, T. 42 N., R. 29 W., and two small outcrops are known in sec. 16, T. 42 N., R. 30 W., but the 6-mile gap between is virtually devoid of bedrock exposure. Two outcrops are present near the joint corner of secs. 1 and 11, T. 42 N., R. $30 \mathrm{~W}$.; the rock is a siliceous breccia similar to silicified parts of the Randville in other parts of the region.

\section{DESCRIPTION}

The dolomite, though originally rather uniform, has been extensively modified by metamorphism in some parts of Central Dickinson County, notably in the Felch trough. In the northern part of the area, however, the rock is no more altered than most dolomites that are much younger.

Clark (see Chapter C of this report) has divided the exposed part of the Randville in the northern part of the area into three parts: an upper dolomite, and a lower dolomite, both with minor slate layers, separated by an intermediate slate member. The upper and lower members consist principally of light-gray to reddish massive to thin-bedded fine-grained dolomite. Outcrops characteristically have a dark slightly porous surface on which bedding and other internal features of the rock are accentuated. The slates are poorly exposed, except in sec. 1, T. 42 N., R. 29 W. Here the rock is dominantly sericitic slate with layers of black slate, quartzite, pebble conglomerate, and dolomite in some outcrops. Some of the slate contains fairly abundant disseminated magnetite, which gives rise to a moderate magnetic anomaly. Inasmuch as these slate and conglomerate beds occur at the axis of a synclinal structure, they may represent the basal beds of the Felch formation, which typically is magnetic.

Locally, the dolomite contains thin layers of intraformational breccia or conglomerate (fig. 31). Thin

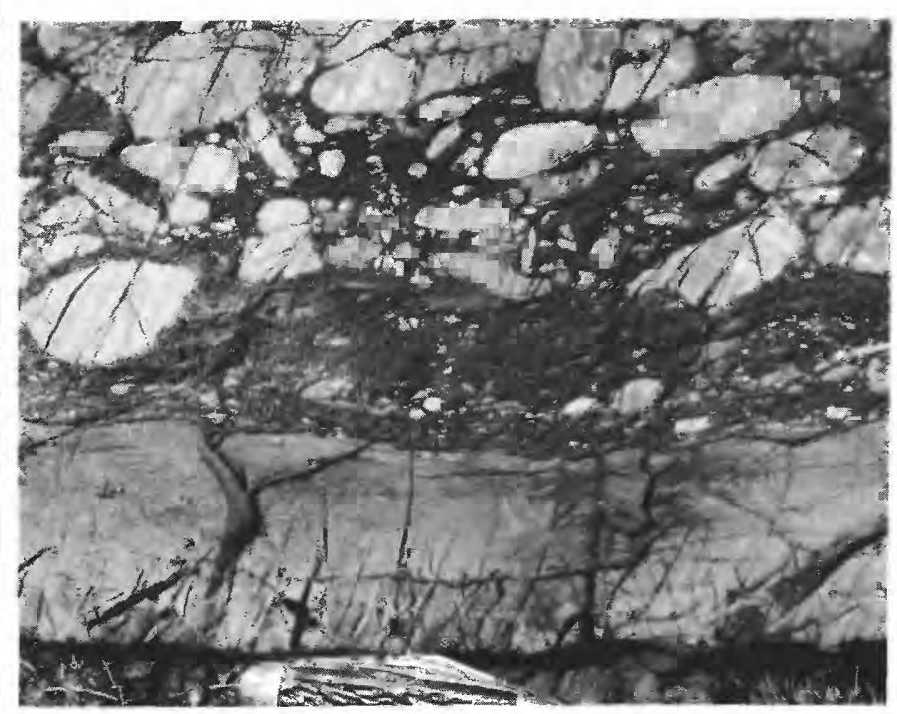

FIGURE 31

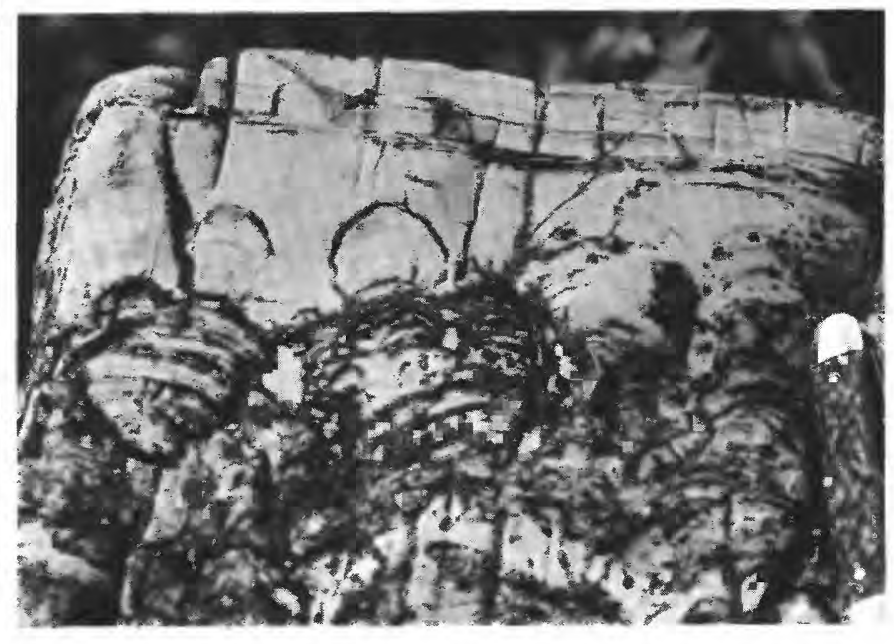

Figure 32

FIgURES 31, 32.-PHOTOGRAPHS OF THE RANDVILLE DOLOMITE IN THE NORWAY LAKE AREA.

31. Intraformational breccia. Dolomite fragements in a dark matrix of dolomite and secondary quartz. Width of feld, 7 inches.

32. Algal structures, marked by secondary quartz (dark). 


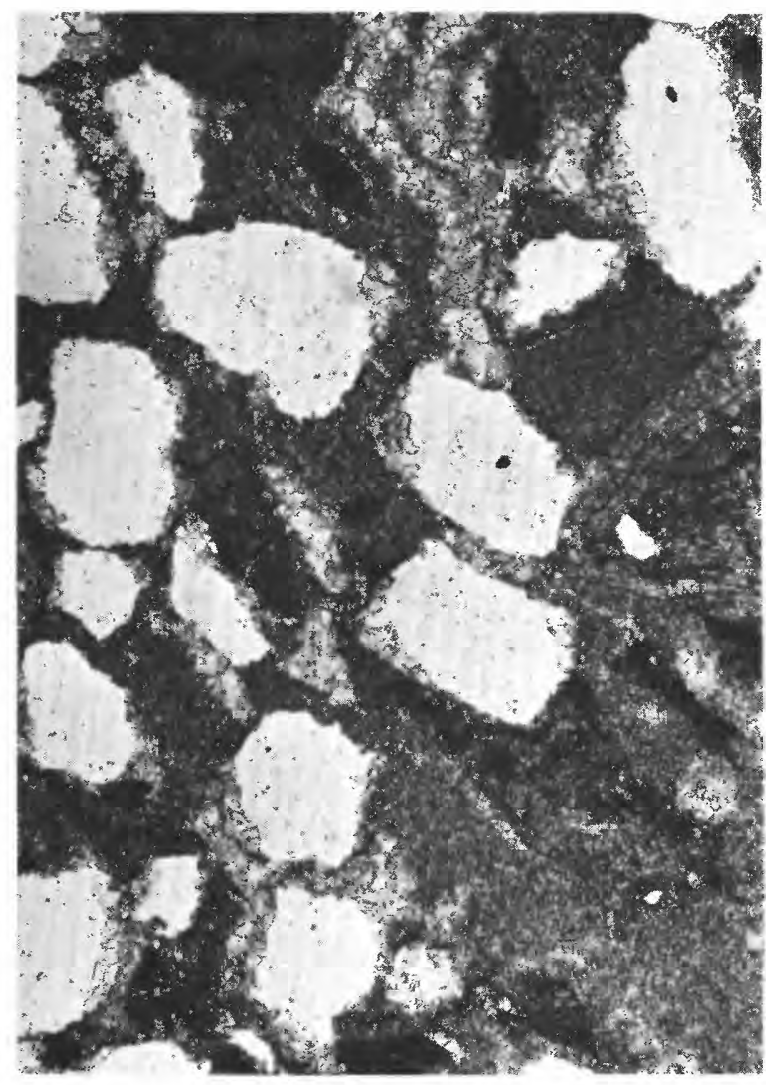

FIGURE 33

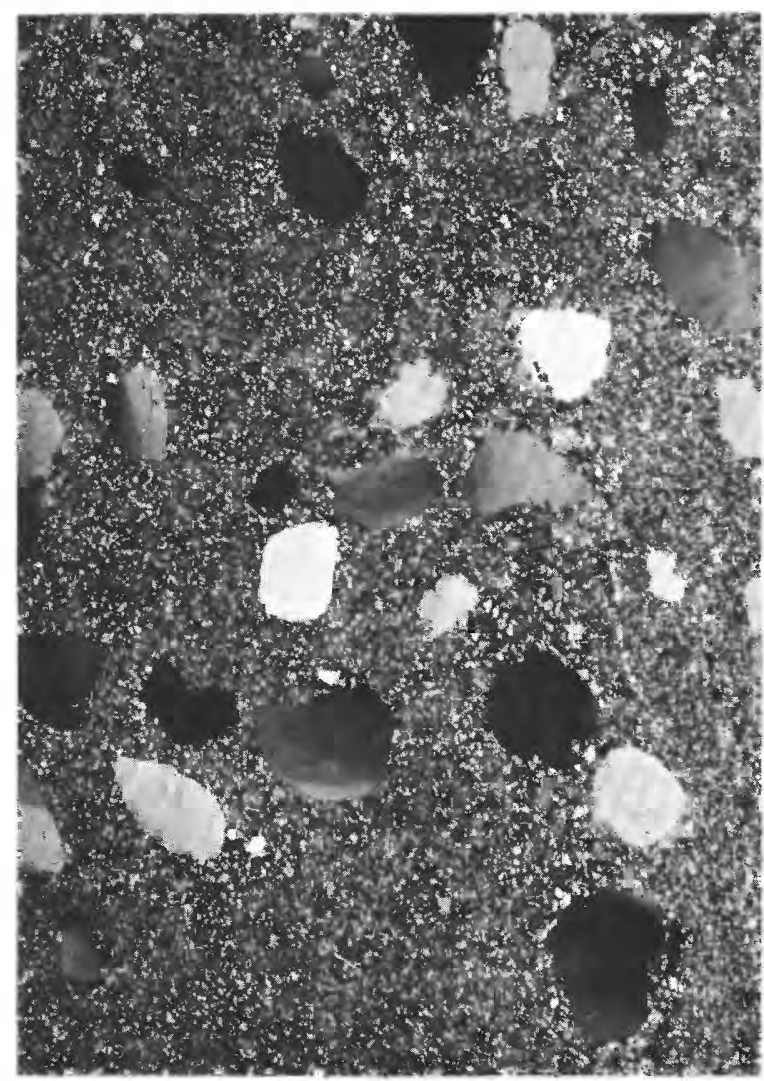

FIGURE 34

Figures 33, 34.-PHOTOMICROGRAPHS OF THE RANDVILLE DOLOMITE.

33. Sandy dolomite from the Norway Lake area, sec. 6, T, 42 N., R. 28 W. Clastic quartz grains, marginally replaced by carbonate, in matrix of dark fine-grained carbonate veined by secondary carbonate. Shell-like form at right margin. Ordinary light, $\times 33$. Specimen $\mathrm{HJ}_{-}-219-48$.

beds or quartzite are present in some parts of the formation and layers containing abundant sand grains are fairly common (fig. 33). Much of the dolomite is cut by seams of cherty silica, and in a few places, the rock is wholly silicified (fig. 34), with retention of all details - even the color - of unsilicified rock. The most distinctive feature of the dolomite, however, is the presence of stromatolites ("algal structures"), which are illustrated in figure 32. The stromatolites are domal or concentrically banded structures, convex upward. They vary greatly in size; in this area the best exposed forms are typically 1 to 3 inches in diameter and 2 to 6 inches high. The structure is typically marked by discontinuous laminae of silica. Though doubt has been expressed by some as to the organic origin of the structures, most geologists accept the view that they are fossilized algal colonies, as the structures have no systematic relation to the structure of the rock or to metamorphism. Minor folds are present in the stromatolite beds in some areas, and are distinguishable without difficulty. In some locali-
34. Silicified sandy dolomite. Clastic quartz grains in matrix of fine-grained quartz Texture and color in hand specimens exactly like that of unsilicified dolomite in adjacent parts of the outcrop. Norway Lake area, sec. 6, T. 42 N., R. 28 W. Crossed nicols, $\times 33$. Specimen HK-218a-48.

ties, such as at Lake Antoine in southern Dickinson County, the stromatolites themselves are deformed in harmony with other structural elements in the rock. The form of the stromatolites consistently is convex to the stratigraphically upper side of the bed, so that it may be used as a reliable criterion for top directions. The V-shape junctions always point downward. Furthermore, a field association is generally noted between stromatolites and evidences of shallow-water deposition such as ripple marks, sandy layers, and thin bedding.

Stromatolite structures are reported in virtually all dolomites of later Precambrian sequences, in western United States and Canada, in Australia, South Africa, and Fennoscandia. Despite the absence of actual organic material, there seems little reason to doubt that they represent algal colonies or reefs, developed in near-shore environments.

The dolomite of the Felch trough, and of the Calumet mine farther south, has been strongly metamorphosed, in contrast to that of the northern area. Also it appears 
to be more uniform than that of the area to the north. Except in one drill hole, stromatolites have not been observed. Sandy or quartzitic layers are rare, but this may be due in large part to development of tremolite and diopside by metamorphic reactions between original carbonate and siliceous material. In most exposures the dolomite is massive, thick bedded, and coarse grained. On a fresh break it is light colored-typically white or bluish gray - but weathered surfaces are sooty gray, tan, or brown. Tremolite, generally in blades and plates about a quarter of an inch long, is present throughout. It is clearly related to original compositional differences in the rock; the purer layers of the dolomite may contain only a few widely scattered crystals, whereas other layers, generally much thinner, may consist of 75 percent tremolite. On exposed surfaces the tremolite crystals are especially prominent because of their greater resistance to weathering. Other secondary minerals are: colorless to pale green diopside, which is locally very abundant; chlorite and serpentine, as greenish patches; quartz, as podlike masses and veinlets; calcic plagioclase; mica (muscovite and phlogopite); black tourmaline; and sulfides (mostly pyrite). A small amount of scapolite was found in dolomite adjacent to a granite dike at the Metronite quarry in sec. 26, T. 42 N., R. 28 W.

\section{THICKNESS AND STRATIGRAPHIC RELATIONS}

The contact between the Randville and the underlying Sturgeon quartzite has not been seen at any place in the area. The upper part of the Sturgeon is fine grained and in part micaceous, and possibly the transition beds between the two formations are of easily weathered schistose material. The contact between the Randville and the overlying Felch formation likewise is not exposed, but it has been crossed by drill holes in many parts of the Felch trough and Calumet mine area. The change from massive dolomite to schist and quartzite is abrupt; mutual relations both within this area and elsewhere in the region indicate that the contact is one of disconformity or slight unconformity.

Estimation of thickness of the Randville is beset by usual difficulties in the area-absence of outcrops in critical areas, and structural complexity. But there are indications that the thickness varies considerably from place to place. In the exposed belt just east of the village of Randville, the thickness is less than 600 feet. In the fault segment south of Felch, in the SWI $/ 4$ sec. 33 , T. 42 N., R. 28 W., the thickness appears to be about 400 feet. No accurate estimate can be made in the northern part of the area, but the thickness of the Randville must be considerably greater than that in the Felch area-possibly as much as 2,000 feet. For comparison with these values, it may be mentioned that in southern Dickinson County the thickness is estimated at 1,000 to 1,500 feet, and in the Fence River area (about 15 miles northwest of Central Dickinson County) a section 1,600 feet thick is well exposed (Wier and Kennedy, 1951).

\section{CONDITIONS OF DEPOSITION}

Like the Sturgeon quartzite, the Randville dolomite appears to have been deposited in a shallow-water environment, in a sea that was gradually advancing over a low-lying crystalline terrain. The evidence for shallow water consists of the local occurrence of sandy layers, intraformational conglomerates, ripple marks, mud cracks, and crossbedding (the latter two outside the Central Dickinson County area), and probable algal reefs.

\section{MENOMINEE GROUP}

The Menominee groups comprises two conformable formations: the Felch formation and the Vulcan ironformation.

\section{FELCH FORMATION}

The Felch formation comprises all strata that lie between the Randville dolomite and the Vulcan ironformation. Most of the Felch formation is in the Felch trough and the Calumet mine area, but the formation probably is present in the northern part of the map area at the Deerhunt exploration, and the slate and conglomerate included with the Randville dolomite in sec. 1, T. 42 N., R. 29 W., may belong to this stratigraphic unit. The formation is not widely exposed, but drill holes and test pits supply much information. The fact that some parts of the formation contain magnetite and yield pronounced magnetic anomalies is of considerable aid in tracing the pattern of distribution.

The formation occurs in two principal belts in the Felch trough. The most westerly belt extends from the west margin of the map area, in sec. 7, T. 41 N., R. $30 \mathrm{~W}$., through the Groveland mine area, and into sec. 34 , T. 42 N., R. 29 W. In this belt, the formation is folded into one or two major synclines, which in places are deep enough to contain the overlying Vulcan ironformation. The formation crops out near the common corner of secs. $5,6,7$, and $8, T$ T. 41 N., R. $30 \mathrm{~W}$. It is encountered in drill holes north and south of the exposure of iron-formation in sec. 5 and in drill holes in sec. 34, T. 42 N., R. 30 W. Its distribution is also known from numerous outcrops and drill holes in secs. 35 and 36, T. 42 N., R. 30 W.; many drill holes, test pits, and one or two outcrops in sec. 31, T. 42 N., R. 29 W.; and several drill holes and test pits in secs. 32 and 33, T. 42 N., R. $29 \mathrm{~W}$. Throughout this belt the area known or inferred to be underlain by the Felch formation is marked by moderate to strong magnetic anomalies.

The east belt of Felch formation extends both east and west from the town of Felch for approximately $2 \frac{x}{2}$ miles. It is divided into two parts. A northern area, 
known chiefly from drill holes, borders the iron-formation of the Felch ridge in the north parts of secs. 32 and 33, T. 42 N., R. 28 W. A southern area lies south of an inferred fault and extends from sec. $36, T .42 \mathrm{~N}$., R. $29 \mathrm{~W}$., to sec. 35, T. 42 N., R. $28 \mathrm{~W}$. The rock is exposed in numerous low outcrops in sec. $33, \mathrm{~T} .42 \mathrm{~N}$., R. $28 \mathrm{~W}$., and adjacent parts of sec. 32 . It is intersected in many drill holes in sec. 31 .

The Felch formation is not exposed at the surface south of the Felch trough, but it was encountered in the first and second levels of the Calumet mine in sec. 8, T. 41 N., R. $28 \mathrm{~W}$., and in several drill holes in the same section. At the Deerhunt exploration in sec. 35, T. 43 N., R. 29 W., ferruginous slate and graywacke are found on the dump of old test pits adjacent to the iron-formation. These rocks probably are to be correlated with the Felch formation, but the area is so small and information so scanty it is included with the iron-formation on the maps of the area.

\section{DESCRIPTION}

The Felch formation is a heterogeneous group of rocks that includes quartzite, quartz-mica schist, magnetite-bearing quartzite and schists, and gruneritegarnet-magnetic rocks. Associated with these rocks in many places are intrusive masses of basic rock now largely metamorphosed to amphibolite. The rarious rock types are described in greater detail by Lamey in Chapter D of this report.

Not all these rock types are present in any one area; in fact, the differences in the lithologic character of the Felch formation from place to place have led the authors of this report to define the Felch simply in terms of its stratigraphic position-that it, as the strata between the Randville dolomite and the Vulcan iron-formation-rather than in terms of a specific lithologic assemblage. Nevertheless, despite its lack of uniformity, the Felch formation does contain some very distinctive rock types. The grunerite-garnet-magnetite rock, for example, is an unusual lithologic type, one not found in other stratigraphic units in this area. It is a coarse-grained rock with garnet anhedra typically about a quarter of an inch in diameter in a dark foliated matrix of biotite, amphibole, and magnetite (fig. 35, 37, and 38). In the weathered outcrop the garnets are reddish brown and stand out in relief. This rock type is well exposed near the southwest corner of sec. 5, T. 41 N., R. 30 W., near the west quarter corner of sec. 36, T. 42 N., R. 30 W., and in the SEL/4 sec. 33 , T. 42 N., R. $28 \mathrm{~W}$. In each of these areas the rock is associated with metamorphosed basic intrusives (only locally separated on the maps).

Most of the Felch formation is a quartz-mica schist, some of which is magnetite-bearing (fig. 36). Grains

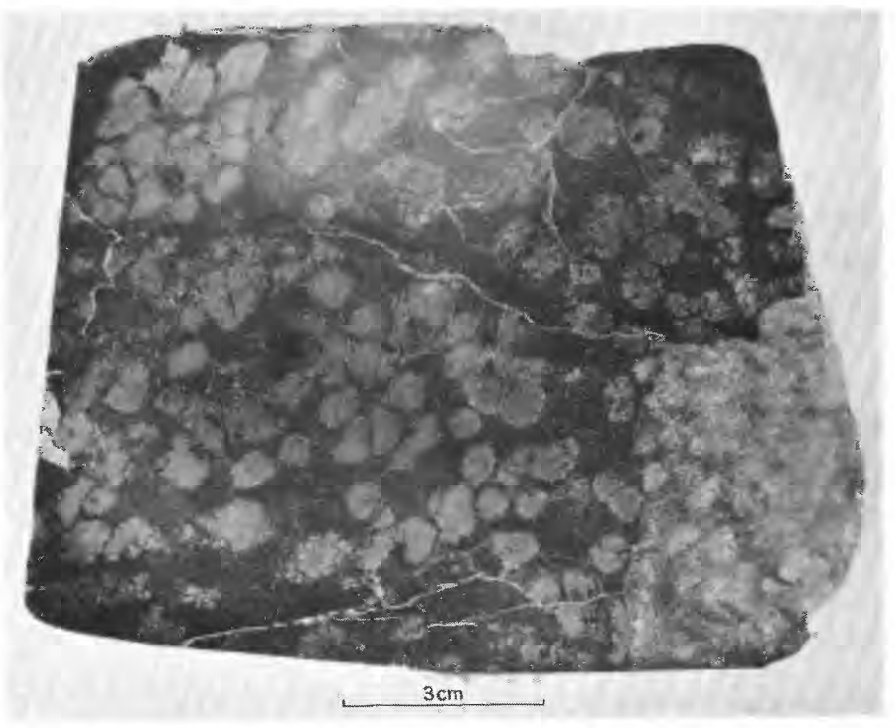

FIGURE 35.-Photograph of hand specimen of garnet-grunerite-biotite rock from Felch formation. Large garnets (gray), with irregular borders, in matrix of dark grunerite and biotite. From outcrop in SE1/4 sec. 33, T. 42 N., R. 28 W. Polished surface. Scale in centimeters. Specimen HJ-57-51.

of clastic quartz are abundant in some layers, and in a few places are so abundant that the rock approaches a quartzite, similar to that which occurs at the base of the Vulcan iron-formation in the Menominee Range.

\section{THICKNESS AND STRATIGRAPHIC RELATIONS}

The thickness of the Felch formation is as widely variable as its lithologic character. The range is from 5 feet to perhaps a few hundred feet, as shown in cross sections (discussed later in this report) of the Groveland mine (fig. 77), Felch area (fig. 78), Rian's quarry area (pl. 3), and Sturgeon Pond area (fig. 80). The average thickness is probably not more than 50 feet.

A minor unconformity may separate the Randville dolomite from the overlying Felch formation. The evidence lies in variations in thickness of the Randville, in the abrupt passage from chemical to clastic sediments, and in the known presence of such an unconformity in other Michigan districts. The variations in thickness and lithologic character of the Felch probably also are to be considered a reflection of a postRandville disturbance. Deposition on a slightly warped surface, parts of which may have been emergent, would account for the present character of the unit. No conglomerate has been observed in these beds, although some of the ferruginous quartzite present in outcrops along the old railroad grade about 1,000 feet west of the east quarter corner of sec. 32, T. 42 N., R. 28 W., contains clastic grains as much a quarter inch in diameter.

The contact relationships between the Felch formation and the overlying Vulcan iron-formation likewise are variable. In most parts of the area the rock grades 


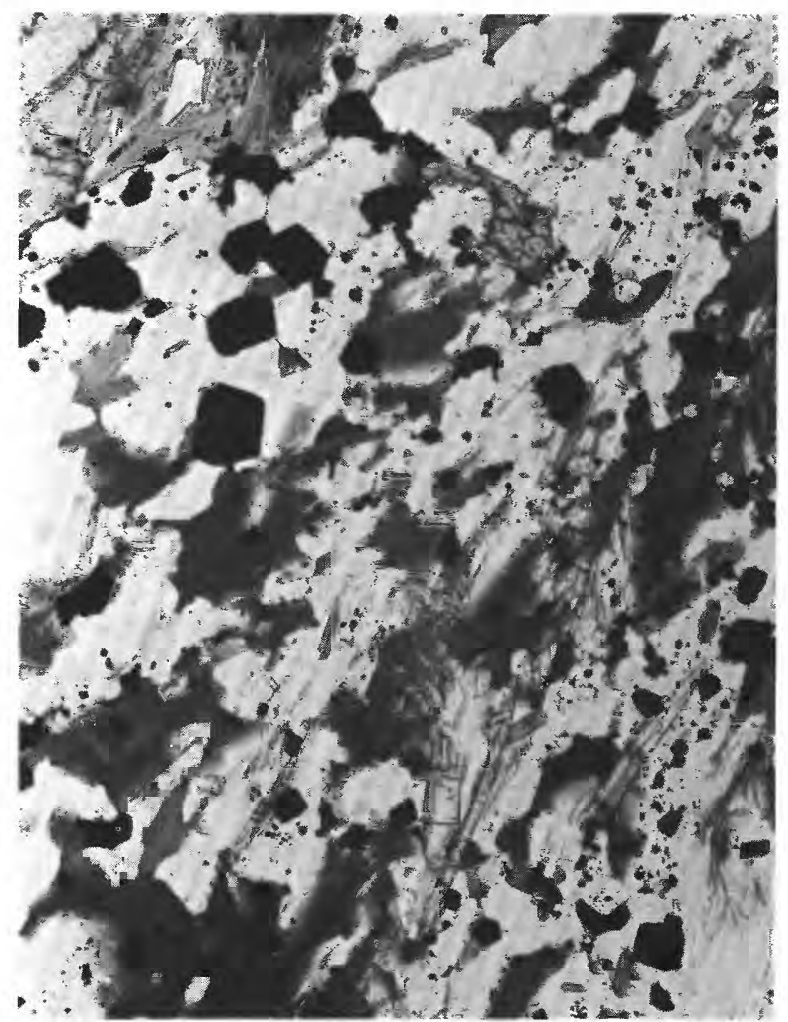

FIGURE 36

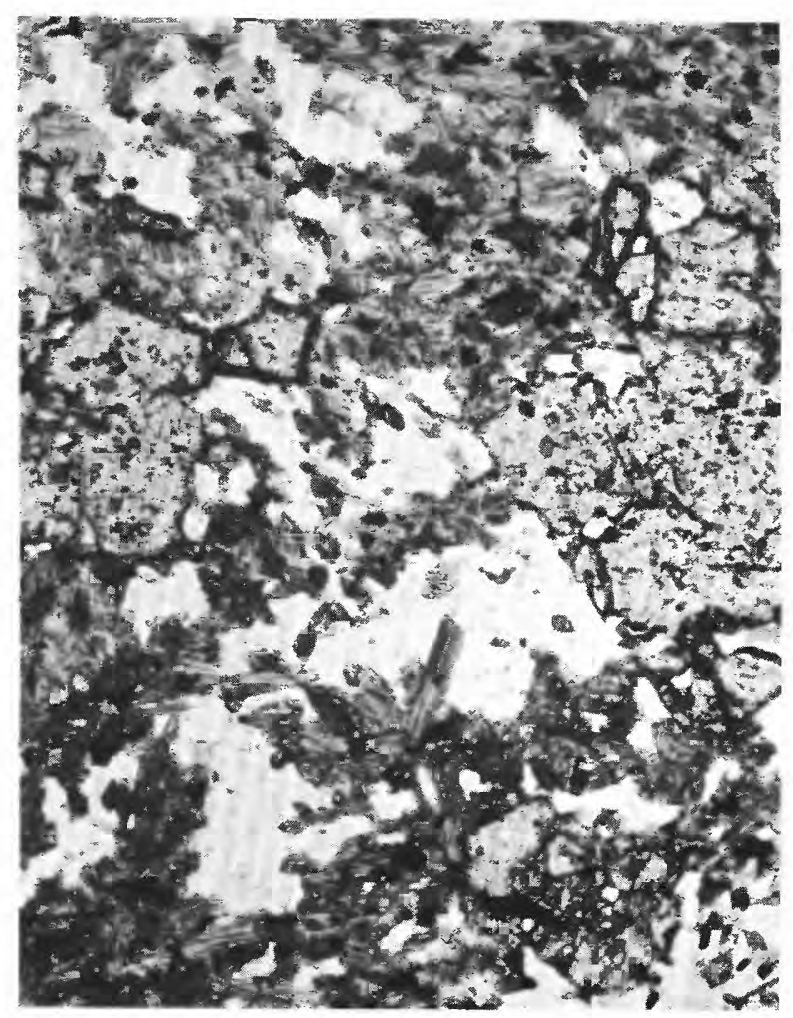

FIGURE 38

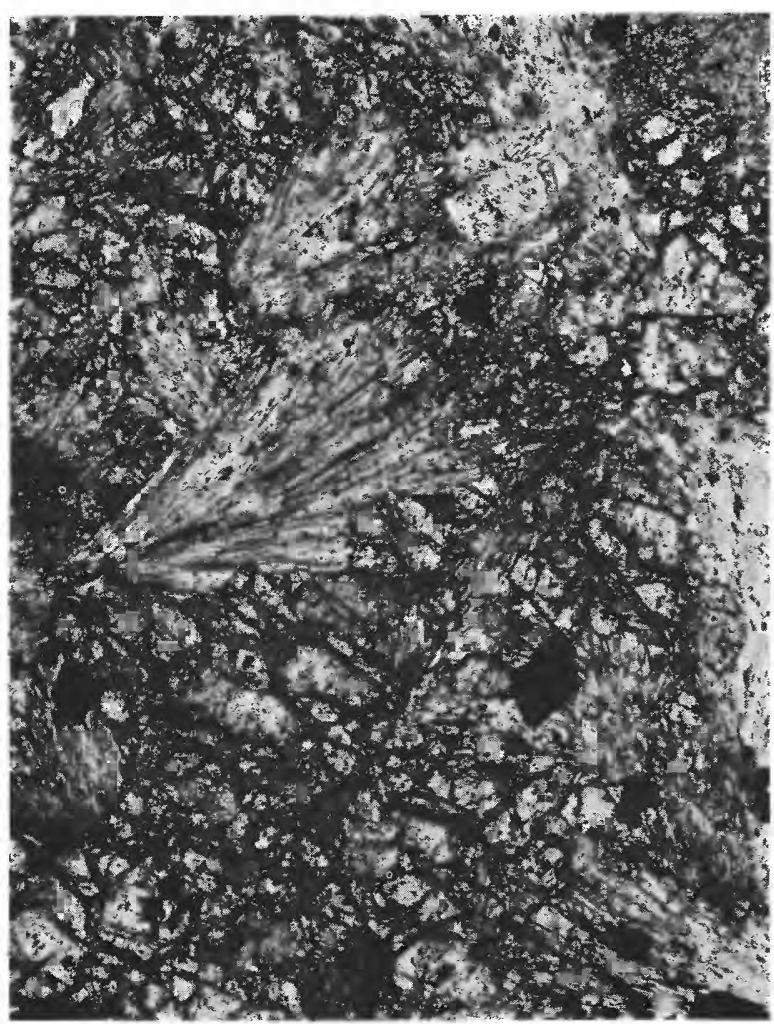

Figure 37
FIGURES 36-38.-PHOTOMICROGRAPHS OF THE FELCH FORMATION

36. Quartz-mica schist, magnetic. Biotite (dark gray), muscovite (light gray with cleavage traces), magnetite (black), garnet (mottled gray, in upper right) in quartz matrix. Ordinary light, $\times 33$. Specimen $\mathrm{CL}-48 \mathrm{~F}-267$.

37. Coarse garnet-grunerite schist. Partly oxidized. Grunerite in radiating sheaves; garnet dark, with irregular fractures (as in lower left corner). Scattered grains of magentite. Ordinary light, $\times 33$. Specimen CL-2-47.

38. Garnet-grunerite schist, with magnetite (black) and quartz (white). Grunerite in short prismatic crystals showing cleavage. Garnet mottled dark gray. Ordinary light, $\times 66$. Specimen CL-8-47. 
from a ferruginous schist, locally with quartzite layers, into cherty iron-formation that contains visible clastic grains of quartz. But in a number of places-for example, the $\mathrm{SE} / 4$ sec. 33, T. 42 N., R. 28 W.-the transition beds consist of the distinctive garnet-grunerite-magnetite rock. Such rock is iron-formation in the sense that it contains a high iron content of probable sedimentary origin, but inasmuch as it differs strongly from the banded cherty iron-formation that makes up most of the Vulcan iron-formation, it is assigned to the Felch formation.

\section{CONDITIONS OF DEPOSITION}

Deposition of the Felch formation may be considered the consequence of a moderate structural disturbance at the close of Randville deposition. The beds are predominantly clastic and are the products of a brief interlude between periods of chemical sedimentation, which are represented by the underlying Randville dolomite and the overlying Vulcan iron-formation.

VULCAN IRON-FORMATION

The Vulcan iron-formation of Central Dickinson County, though of considerable economic importance, underlies a total area of less than 1 square mile. This includes a large area in sec. 17, T. 41 N., R. 28 W., in which the iron-formation is mantled by sandstone of Cambrian age. Further exploration probably will not add much to the area of Vulcan iron-formation; the coverage afforded by the aeromagnetic survey virtually rules out the possibility that any appreciable amount of this strongly magnetic rock has gone undetected.

The iron-formation is resistant to erosion and commonly is well exposed. This is particularly noticeable in the Felch trough, where the iron-formation of the Groveland mine area and that of the Felch ridge forms prominent outcrop ridges flanked by sandstone of Cambrian age.

The principal area of iron-formation is the Felch trough, where the rock is contained in several synclines of varying depth. From west to east, these are referred to as the Randville syncline, extending from sec. 5, T. $41 \mathrm{~N}$. , R. 30 W., to the north part of sec. 36, T. 42 N., R. $30 \mathrm{~W}$.; the Groveland syncline, extending from the center part of sec. 36, T. 42 N., R. 30 W., through the Groveland mine, to sec. 34, T. 42 N., R. 29 W.; the Sturgeon Pond syncline, in sec. 31, T. 42 N., R. 28 W.; the Felch Ridge syncline in the north parts of sec. 32 and 33, T. 42 N., R. $28 \mathrm{~W}$.; and the Rian quarry syncline in sees. 33 and 34, T. 42 N., R. 28 W. The positions of these structures are indicated on figure 39.

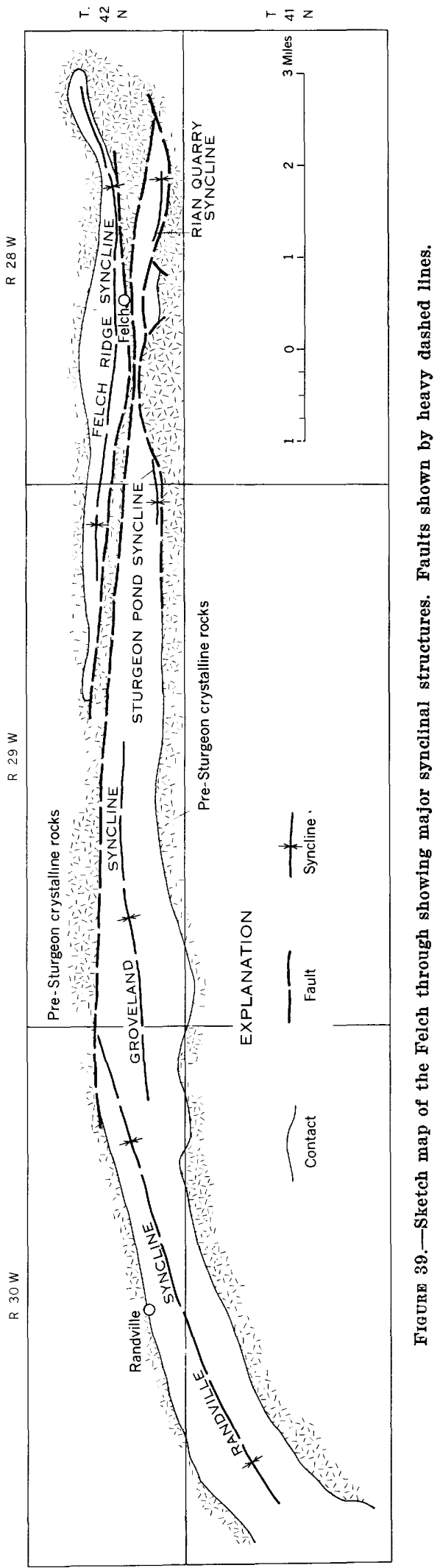


The Randville syncline is a deeply eroded structure that contains only remnants of Vulcan iron-formation in narrow, canoe-shaped troughs. The major occurrence of iron-formation is in sec. 5, T. 41 N., R. 30 W., where the Vulcan is exposed in a prominent outcrop. Six holes drilled by the M. A. Hanna Co. established within close limits the extent of the iron-formation beyond the outcrop. The remaining areas of ironformation shown as patches along the trend of the Randville syncline are chiefly inferred from observed high magnetic values. Drill holes in the NE1/4SE1/4 sec. 34 and in the NEx/4SWT/4 sec. $35, T$. 42 N., R. 30 W., and a test pit in the north part sec. $36, T$ T. 42 N., R. $30 \mathrm{~W}$., provide the only positive evidence for its presence in these areas.

The iron-formation of the Groveland syncline is well exposed in the pit of the old Groveland mine, which has recently been enlarged by the M. A. Hanna Co. Outcrops are abundant along the western part of the syncline, west of the Groveland mine, in sec. 36 T. 42 N., R. $30 \mathrm{~W}$. The three narrow areas of iron-formation in sec. 33 , T. 42 N., R. 29 W., about 2 miles east of the Groveland, are mapped on the basis of high magnetic anomalies and two drill holes that intersected the rock. The outcrop along the ridge adjacent to the Groveland was described in the Jackson report (1849) and appears to represent the first discovery of ironformation in the area of this report.

In the Sturgeon Pond area, in the SW1/4 sec. 31 T. 42 N., R. 28 W., iron-formation is known from outcrops and a number of test pits and drill holes. Because of deep oxidation, the iron-formation in this area is not strongly magnetic.

The most extensive outcrops of iron-formation in central Dickinson County are along the Felch ridge, just north of the village of Felch. The rock is here exposed almost continuously for a mile.

Southeast of Felch, in the SE1/4 sec. 33, T. 42 N., R. $28 \mathrm{~W}$., the Vulcan is well exposed in a group of low outcrops that lie immediately north of the granite. This area was mapped by plane table (pl. 3). A mile west of these outcrops, and a quarter of a mile east of the center of sec. 32, some iron-formation has been uncovered in test pits. A drill hole at this locality cut only 10 feet of iron-formation; probably the rock is contained in a narrow shallow syncline.

The Vulcan iron-formation is present in three separate areas of the Calumet trough. It has been extensively explored by underground workings and by drill holes at the Calumet mine and adjacent areas, where it is visible in the caved workings of the mine and may be examined with little difficulty. The only certain natural exposure of Vulcan iron-formation in the Calu- met trough is in the north part of sec. $15, \mathrm{~T} .41 \mathrm{~N}$, R. $29 \mathrm{~W}$., where it forms a small outcrop immediately south of the granite. Two drill holes adjacent to the outcrop show the iron-formation to be in contact with the granite and less than 50 feet thick (see pl. 4 for map of sec. 15). Drill holes in sec. 17, T. 41 N., R. $28 \mathrm{~W}$., have encountered iron-formation beneath a cover of sandstone of Cambrian age. The area is one of high broad magnetic anomaly; presumably the iron-formation is at the crest of an anticlinal structure.

The only known occurrence of Vulcan iron-formation north of the Felch trough is at the Deerhunt exploration in sec. 35, T. 43 N., R. 29 W. Bedrock at this locality is concealed by 5 to 20 feet of glacial sands. The iron-formation, together with some ferruginous slate, has been exposed in a number of test pits. Several holes have been drilled in the vicinity to locate extensions of the iron-formation, but without success. The absence of a major magnetic anomaly in the area is interpreted to mean that the Vulcan is here preserved only as a small remnant, and that the bulk of the unit was removed by erosion prior to deposition of the younger slates.

\section{DESCRIPTION}

Except for the rock at the Deerhunt exploration the Vulcan iron-formation is within a zone of moderate to high grade metamorphism. The metamorphosed rock is distinguished chiefly by coarseness of grain and by the presence of grunerite and garnet.

The iron-formation at the Deerhunt exploration is composed chiefly of dense reddish metachert (jasper), fine-grained specular hematite, and soft red hematite. The rock appears to be irregularly banded and is considerably brecciated and veined by chert and iron oxides. Some of the cherty layers of the rock are oolitic (figs. 40-42), but exposures are too few to determine how general this structure is. The ooliths now consists of reddish hematite and metachert. Because of the extensive oxidation it is not certain whether this hematite is primary or whether it has resulted from oxidation of an earlier mineral. The microscope shows the metachert to be fine grained but somewhat irregular in grain size. Polished sections show that martite is abundant (fig. 42), and it appears that magnetite originally was a major constituent of some layers.

The Vulcan iron-formation in the Felch trough contains several fairly distinctive rock types. Two of these-gray-banded iron-formation and oolitic ironformation-account for more than 90 percent of the observed material. The gray-banded iron-formation appears to be the dominant type in the lower part of the formation. It is exposed in sec. 5, T. $41 \mathrm{~N}$., $R$. $30 \mathrm{~W}$., and in the $\mathrm{SE} x / 4$ sec. 33, T. $42 \mathrm{~N}$., R. $28 \mathrm{~W}$. It 


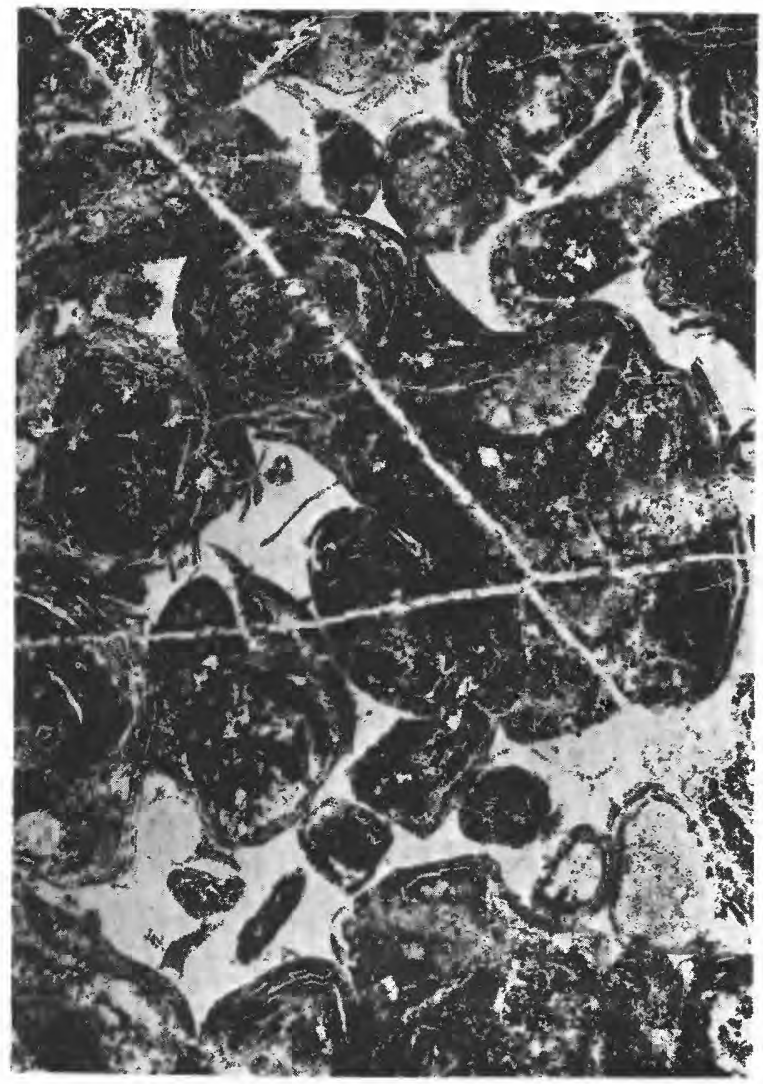

Figure 40.-Ordinary light.

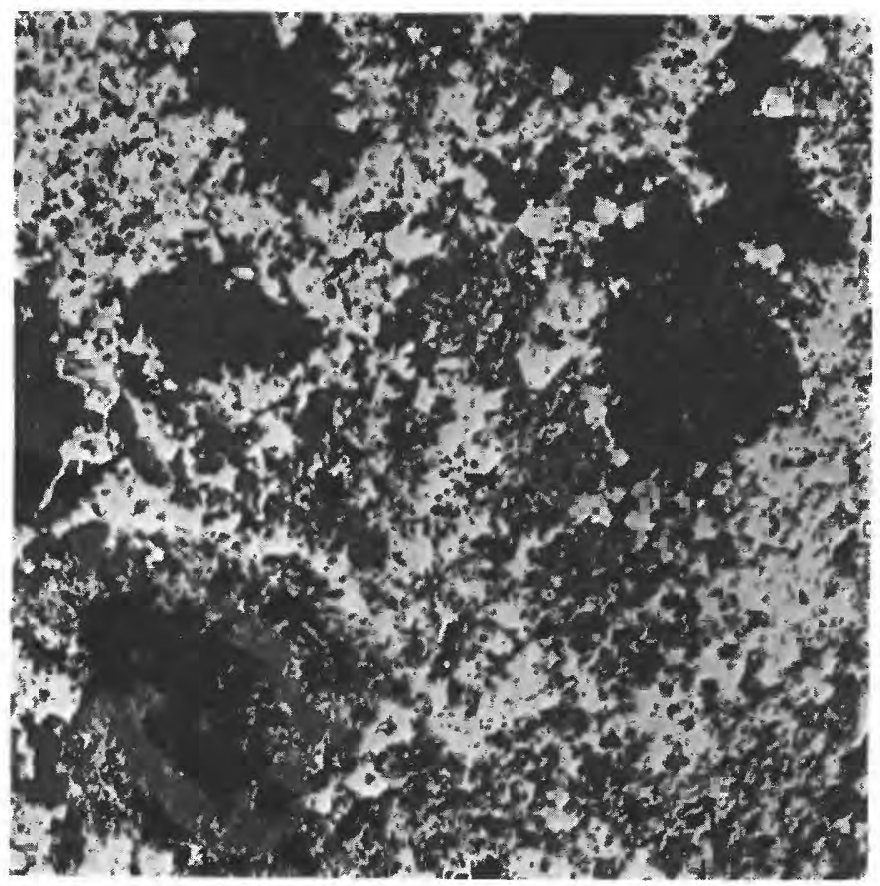

FIGURE 42

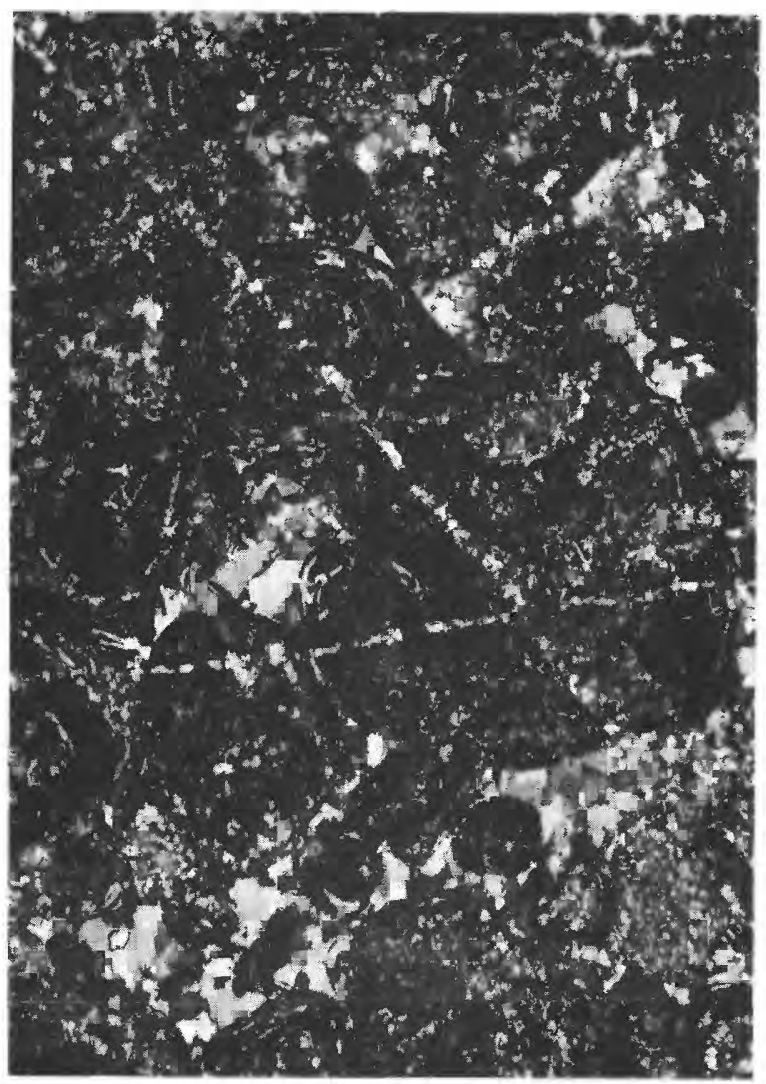

Figure 41.-Crossed nicols.

FIGURES 40-42.-PHOTOMICROGRAPHS OF VULCAN IRON-FORMA TION FROM THE DEERHUNT EXPLORATION.

40, 41. Oolitic rock. Hematite in chert matrix, cut by vernlets of quartz. $\times 33$ Specimen HJ-55B-51.

42. Polished section. Rock consists chiefly of hematite (white) after magnetite. $\times 160$. Specimen HJ-56-51. 
is a dark tough evenly bedded rock, consisting of alternate layers, typically 0.1 to 0.3 inches in thickness, of metachert and iron oxides (fig. 43, 44). The metachert is light-gray saccharoidal quartz; the iron oxides are principally fine-grained magnetite with a small amount of specularite. Many of the magnetite layers contain dark-gray to yellowish blades of grunerite, and some laminae are composed entirely of this mineral.
Thin layers showing oolitic structure are present locally in gray banded iron-formation but are relatively uncommon. The rock, on account of its high content of magnetite, is very strongly magnetic. Microscope examination reveals scattered grains of an isotropic garnet, a blue-green amphibole, calcite, chlorite, and muscovite, in addition to the constituents mentioned above.

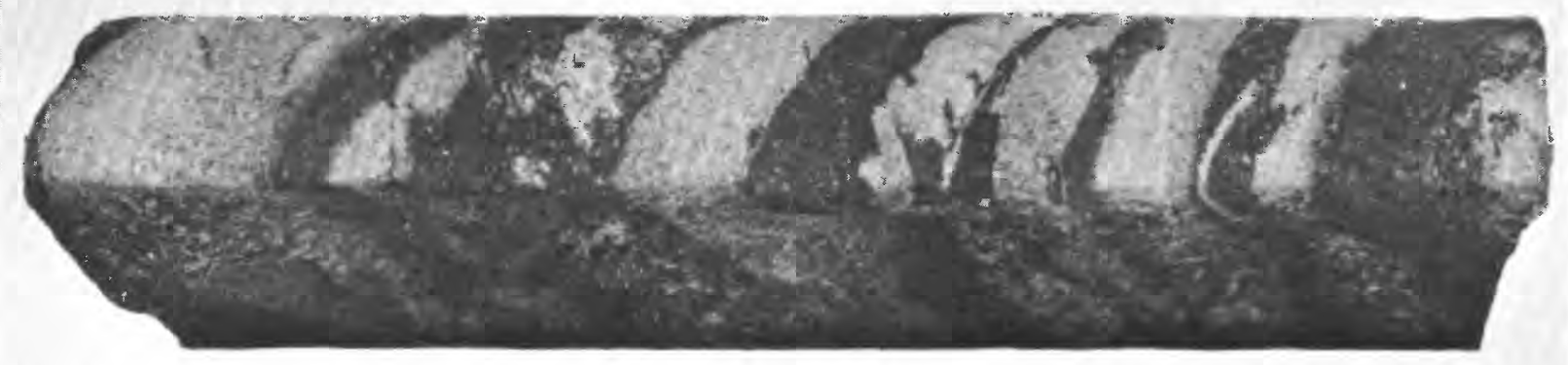

$2 \mathrm{~cm}$

Figure 43

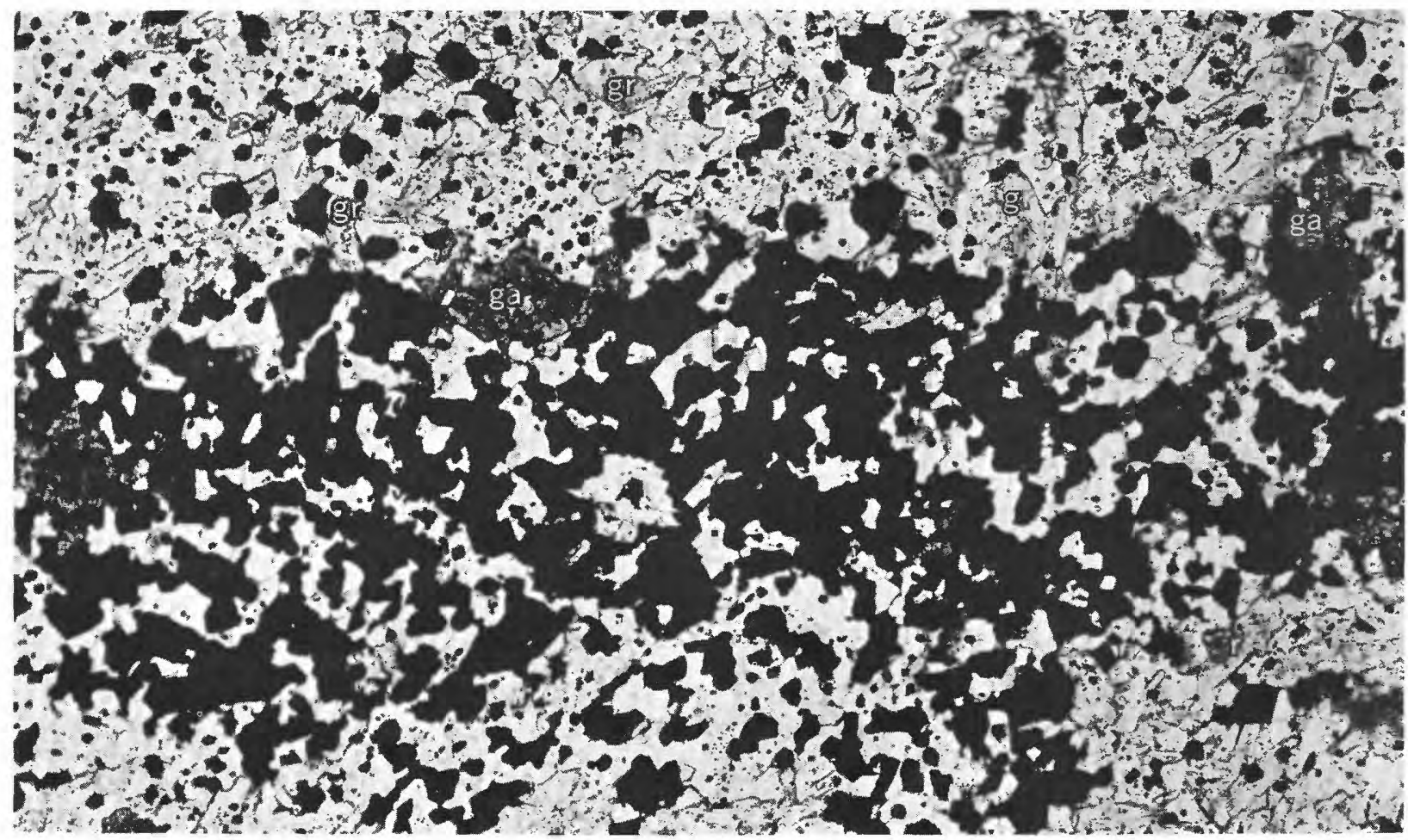

Figure 44

FIGURES 43, 44,-PHOTOGRAPHS OF GRAY-BANDED IRON-FORMATION (VULCAN).

43. Split core from drill hole in sec. 34, T. 42 N., R. 28 W. Layers of granular quartz (white) alternating with layers of magnetite and minor grunerite. Specimen HJ-101-51.
44. Photomicrograph showing layer dominantly of magnetite (black) with some quartz interbedded with layers of quartz, grunerite ( $g r)$, magnetite, and scattered garnet $(g a)$. Ordinary light, $\times 66$. Specimen HJ-58-51 
Oolitic iron-formation appears to be the dominant rock type in the upper part of the Vulcan that is preserved in the district. It is especially well exposed on the Felch ridge, both in natural outcrops and in roadcuts in the $\mathrm{N}^{1} / 2$ sec. 32 and 33, T. 42 N., R. 28 W. The rock consists of uneven irregular layers of reddish to gray metachert (jasper) alternating with layers that consist principally of specularite. The metachert layers are characteristically oolitic. The ooliths range from 0.3 to $2 \mathrm{~mm}$ in diameter; they show as bright red spots in hand specimens and are especially noticeable on the polished surfaces of drill core. The microscope shows that the ooliths are composed of specularite and quartz in a quartz matrix (fig. 45, 46). Concentric ringing may be seen in some grains, but more commonly it has been destroyed by recrystallization of both silica and hematite. Clastic grains of quartz are present in some of the oolitic layers; some form the cores of ooliths. Veinlets, pods, and isolated grains of coarsegrained specularite are common in this variety of iron-formation. Most of the specularite layers contain disseminated magnetite, so that the rock is moderately magnetic. Garnet, blue-green amphibole, grunerite, and muscovite are common accessories. Grunerite-bearing oolitic rock is illustrated in figures 47,48 .

Grunerite-magnetite iron-formation is a minor lithologic type in some areas. The rock is evenly bedded, with thin layers of garnetiferous grunerite ..lternating with layers predominantly of magnetite (fig. 49).

The iron-formation exposed in pits and trenches in the $\mathrm{N} \mathrm{T} / 2$ sec. 32 , T. 42 N., R. 28 W., north of the main outcrop ridge, is extensively veined by coarse-grained ankerite, and in places is deeply oxidized. The introduction of carbonate probably is related to faulting or shearing. Similar carbonate occurs with granulated grunerite and magnetite in outcrops in sec. 36, T. 42 N., R. 30 W.

The iron-formation of the Calumet district is different in appearance from most of that in the Felch trough principally because of the presence of soft red hematite as seams, veinlets, and stains. In general however, the rock resembles the "gray-banded ironformation" of the Felch trough, to which it probably is equivalent. The rock consists of alternating thin layers of dark dense bluish iron oxide and sugary quartz; both are coated with stains of red or yellow iron oxide. The iron oxide layers are mixtures of magnetite and martite, with some specularite. In material near the surface, martite is predominant and the rock is nonmagnetic or only slightly so, whereas in drill cores from greater depth the alteration of the magnetite is less intense and the rock is strongly magnetic.
THICKNESS AND STRATIGRAPHIC RELATIONS

The Vulcan iron-formation is not present in its original thickness in any part of central Dickinson County, because of erosion prior to deposition of the Baraga group, or erosion during post-Animikie time, or a combination of both. The Vulcan is in contact with younger rocks (other than Cambrian) only in the Calumet mine area and at the Deerhunt exploration. In the Calumet area (pl. 4, sec. 8) the maximum thickness of the iron-formation is not more than 150 feet. In places it is much thinner, and within half a mile west of the Calumet mine the Vulcan probably pinches out entirely because of erosion prior to deposition of the Michigamme slate. The absence of magnetic anomalies parallel to the belts of Sturgeon quartzite in the southwest part of T. 41 N., R. 29 W., and the central part of T. 41 N., R. 30 W., indicates that this pre-Michigamme erosional truncation was widespread. The iron-formation at the Deerhunt exploration in the north part of the area appears to be merely an erosional remnant lying between Randville dolomite and younger slates.

Within the Felch trough the Vulcan is contained within crenulated synclines in which no younger rocks have been preserved. How much of the original Vulcan iron-formation is represented is not known; the greatest stratigraphic thickness that may be inferred is at the Groveland mine, where cross sections indicate a maximum thickness of 400 feet. Minor folding and crumpling doubtless account for part of this, and it seems likely that the true stratigraphic thickness represented is on the order of 250 feet. In the Menominee range of southern Dickinson County, the Vulcan iron-formation, which consists of the Traders, Brier, Curry, and Loretto members (James, 1958), has a total thickness of about 650 feet (Bayley, 1904, p. 361). The Menominee range subdivisions cannot be recognized in the Felch district, although in a general way the lower part of the iron-formation ("graybanded") in the Felch area has certain similarities to the Traders member, whereas the upper part is similar to the Curry, especially in that each is characteristically oolitic.

\section{CONDITIONS OF ORIGIN}

The iron-formation owes its present character both to original sedimentation and to metamorphism.

The primary types of iron-formation can be divided into four facies - sulfide, carbonate, silicate, and oxide - on the basis of the dominant original iron mineral (James, 1954). The metamorphism of these primary types of iron-formation, described in a separate paper (James, 1955), is summed up in table 5 . 


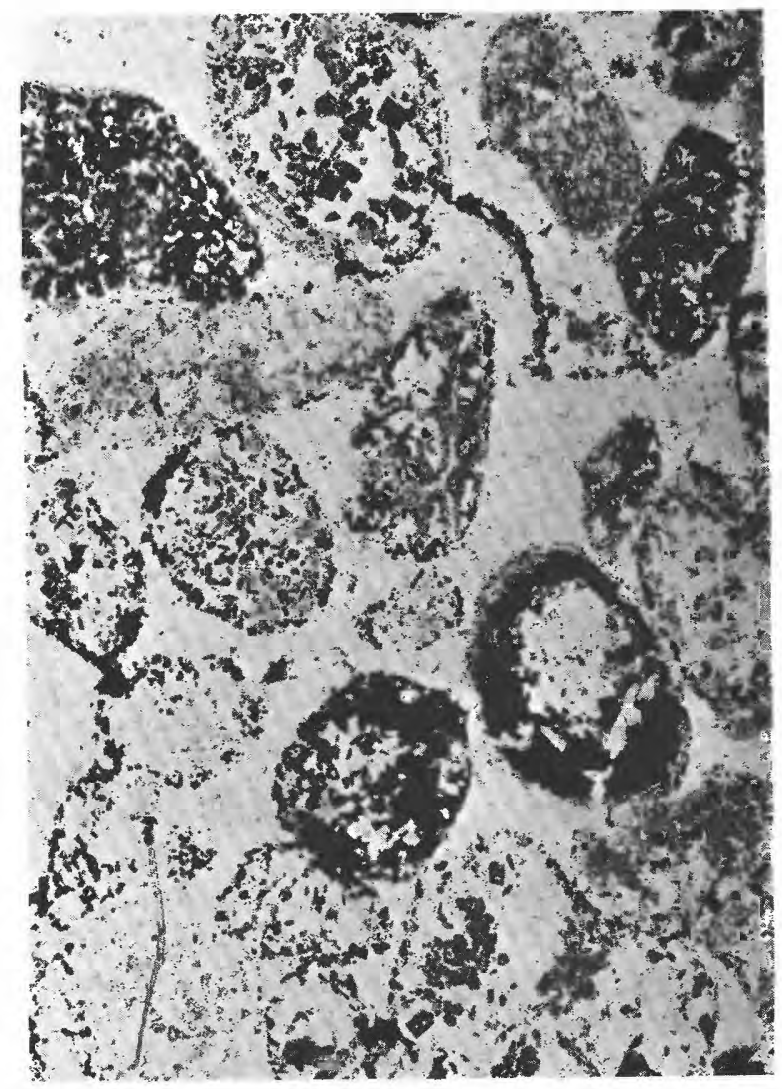

Figure 45.-Ordinary light.

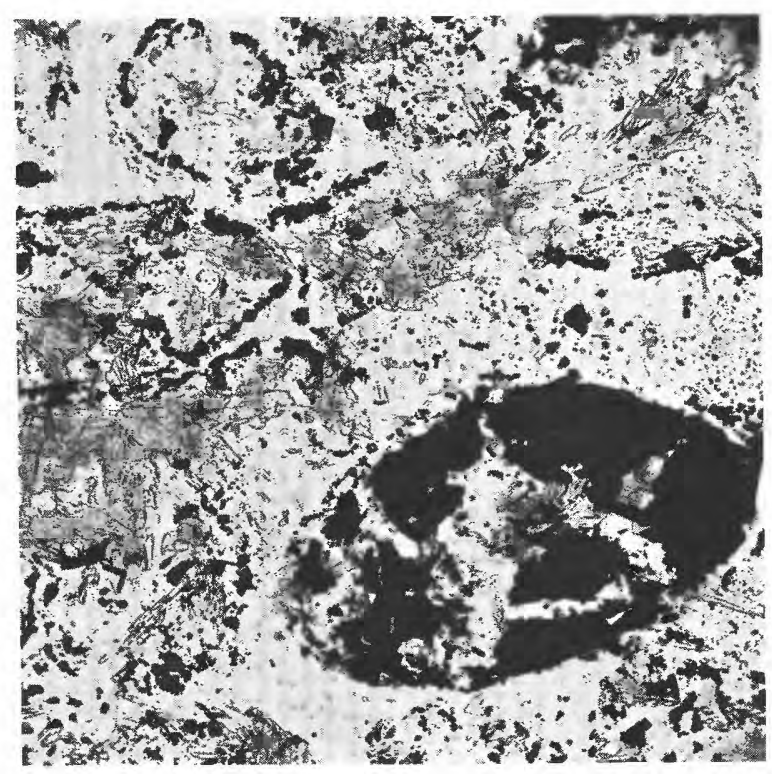

Figure 47.-Ordinary light.

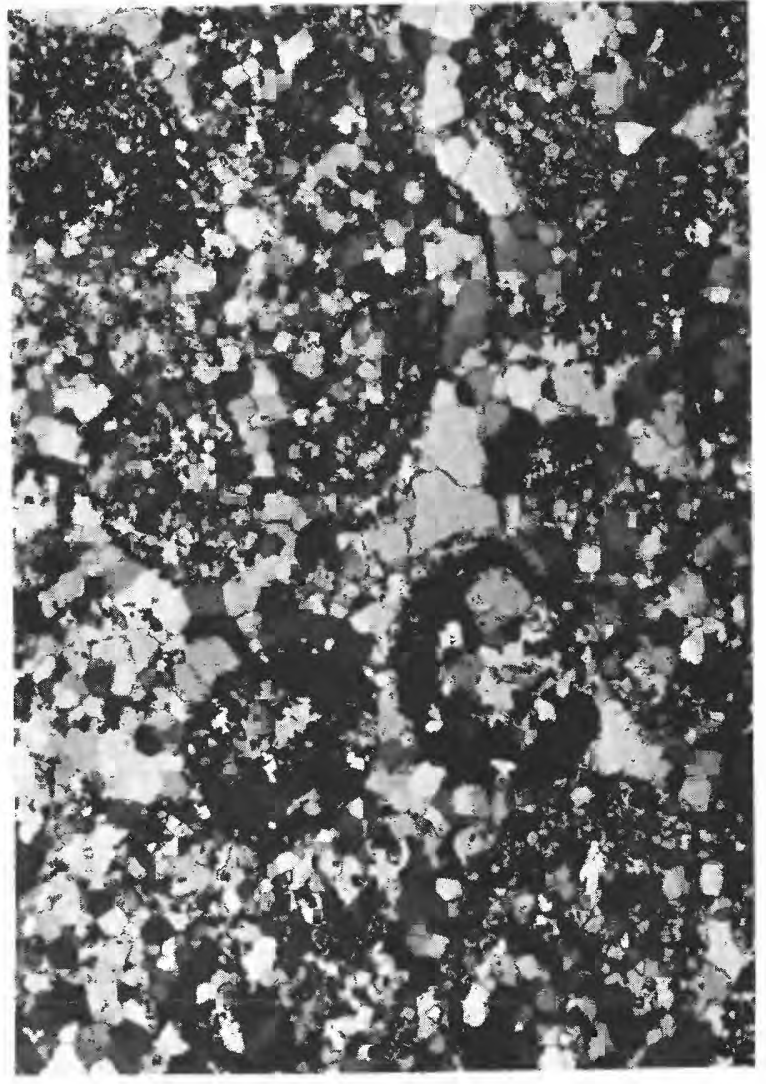

Figure 46.-Crossed nicols.

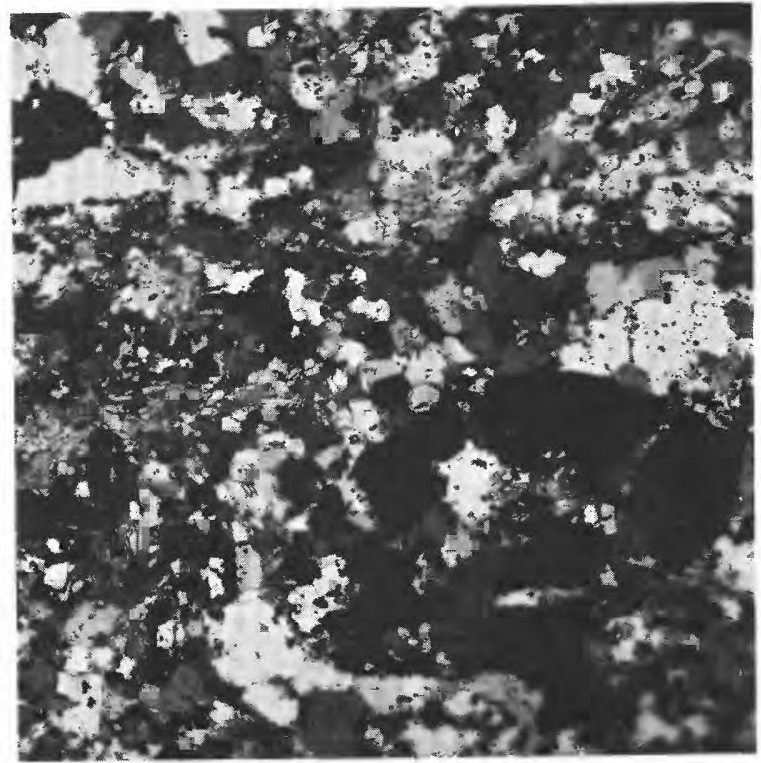

Figure 48.-Crossed nicols.

FIGURES 45-48.-PHOTOMICROGRAPHS OF OOLITIC IRON-FORMATION (VULCAN).

45, 46. Hematite-quartz ooliths and granules in matrix of recrystallized chert. Note absence of deformation, recrystallization of quartz across original oolith boundaries, and recrystallization of hematite to crystal aggregates. $\times 33$. Specimen CL-18-49.
47, 48. Grunerite-bearing oolitic rock. Large granule at lower right is principally specular hematite; granules at upper left are outlined by magnetite grains, contain quartz and grumerite (dark gray, bladed). Matrix is quartz with some grunerite and magnetite. $\times 41$. Specimen $\mathrm{HJ}-225-48$. 
TABLE 5.-Summary of tentative conclusions regarding metamorphism of principal types of iron-formation from James, 1955. Major constituents in capital letters

\begin{tabular}{|c|c|c|c|c|c|}
\hline \multicolumn{3}{|c|}{ Sedimentary } & \multicolumn{3}{|c|}{ Metamorphic } \\
\hline & Facies & Composition ${ }^{1}$ & Low Grade 2 & Intermediate ${ }^{3}$ & High Grade \\
\hline \multicolumn{2}{|c|}{ Sulfide } & $\begin{array}{l}\text { Ferrous sulfide } \\
\text { Organic carbon } \\
\text { "Clay" }\end{array}$ & $\begin{array}{l}\text { PYRITE } \\
\text { CARBON (amorphous) } \\
\text { QUARTZ } \\
\text { Sericite }\end{array}$ & $\begin{array}{l}\text { PYRITE } \\
\text { GRAPHITE } \\
\text { QUARTZ } \\
\text { Micas } \\
\text { Garnet (rare) }\end{array}$ & $\begin{array}{l}\text { PYRITE } \\
\text { GRAPHITE } \\
\text { Pyrrhotite (?) } \\
\text { Micas-garnet }\end{array}$ \\
\hline \multicolumn{2}{|c|}{ Carbonate } & $\begin{array}{l}\text { Carbonate } \\
\text { Chert } \\
\text { Greenalite }\end{array}$ & $\begin{array}{l}\text { CARBONATE } \\
\text { QUARTZ } \\
\text { Stilpnomelane } \\
\text { Minnesotaite }\end{array}$ & $\begin{array}{l}\text { GRUNERITE } \\
\text { QUARTZ } \\
\text { Magnetite } \\
\text { Carbonate }\end{array}$ & $\begin{array}{l}\text { GRUNERITE } \\
\text { QUARTZ } \\
\text { Magnetite } \\
\text { Pyroxene }\end{array}$ \\
\hline 密 & Nonelastic & $\begin{array}{l}\text { Greenalite } \\
\text { Chert } \\
\text { Carbonate } \\
\text { Magnetite }\end{array}$ & $\begin{array}{l}\text { MINNESOTAITE } \\
\text { STILPNOMELANE } \\
\text { QUARTZ } \\
\text { CARBONATE } \\
\text { Magnetite }\end{array}$ & $\begin{array}{l}\text { GRUNERITE } \\
\text { QUARTZ } \\
\text { Magnetite }\end{array}$ & $\begin{array}{l}\text { GRUNERITE } \\
\text { QUARTZ } \\
\text { Magnetite } \\
\text { Pyroxene }\end{array}$ \\
\hline \multirow{2}{*}{$\frac{9}{0}$} & $\begin{array}{l}\text { Magnetite- } \\
\text { banded }\end{array}$ & $\begin{array}{l}\text { Magnetite } \\
\text { Carbonate } \\
\text { Greenalite } \\
\text { Chert }\end{array}$ & $\begin{array}{l}\text { MAGNETITE } \\
\text { STILPNOMELANE } \\
\text { MINNESOTAITE } \\
\text { CARBONATE } \\
\text { QUARTZ }\end{array}$ & $\begin{array}{l}\text { MAGNETITE } \\
\text { GRUNERITE } \\
\text { QUARTZ } \\
\text { Garnet }\end{array}$ & $\begin{array}{l}\text { MAGNETITE } \\
\text { GRUNERITE } \\
\text { QUARTZ } \\
\text { Pyroxene } \\
\text { Garnet }\end{array}$ \\
\hline & $\begin{array}{l}\text { Hematite- } \\
\text { banded }\end{array}$ & $\begin{array}{l}\text { Ferric oxide } \\
\text { Chert } \\
\text { Magnetite } \\
\text { Calcite }\end{array}$ & $\begin{array}{l}\text { HEMATITE } \\
\text { QUARTZ } \\
\text { Magnetite } \\
\text { Calcite }\end{array}$ & $\begin{array}{l}\text { SPECULAR } \\
\text { HEMATITE } \\
\text { QUARTZ } \\
\text { Magnetite } \\
\text { Calcite }\end{array}$ & $\begin{array}{l}\text { SPECULAR } \\
\text { HEMATITE } \\
\text { QUARTZ } \\
\text { Magnetite } \\
\text { Calcite }\end{array}$ \\
\hline
\end{tabular}

1 Inferred

2 Chlorite and biotite zones.

3 Garnet and staurolite zones.

Sillimanite zone, essentially. Inferred for some rocks.

Diameter of typical grains in relatively pure layers of chert.

The Vulcan iron-formation of central Dickinson County is classed as a primary-oxide facies. It was made up originally ${ }^{2}$ of various mixtures of magnetite, hematite, and chert for the most part. The gray banded iron-formation, consisting of thinly bedded quartz and magnetite with minor specularite and fairly abundant grunerite, represents a primary magnetite-rich facies and the oolitic iron-formation represents a primary hematite facies. The principal effect of metamorphism on these original rocks has been recrystallization to coarser grain size; except for the relatively minor development of grunerite, hornblende, garnet, and mica in zones of intermediate- or

2 Primary or original minerals are considered here to include both direct precipitates and products of diagenesis. high-grade metamorphism, the mineralogic composition of the rock has not been changed and the chemical content has remained nearly constant. The contrast in grain size between iron-formation in the zone of lowgrade metamorphism and that in higher zones is apparent from comparison of rock from the Deerhunt exploration (figs. 40-42), which is in a zone of low-grade metamorphism, and that of the Felch trough (figs. 43-48).

The iron-formations are considered to be marine chemical sediments. They probably were deposited in relatively shallow basins adjacent to land areas of low relief that were being intensely weathered under tropical or subtropical conditions. Under these conditions the iron and silica content of streams is many times that in streams of the temperate. climates, and 


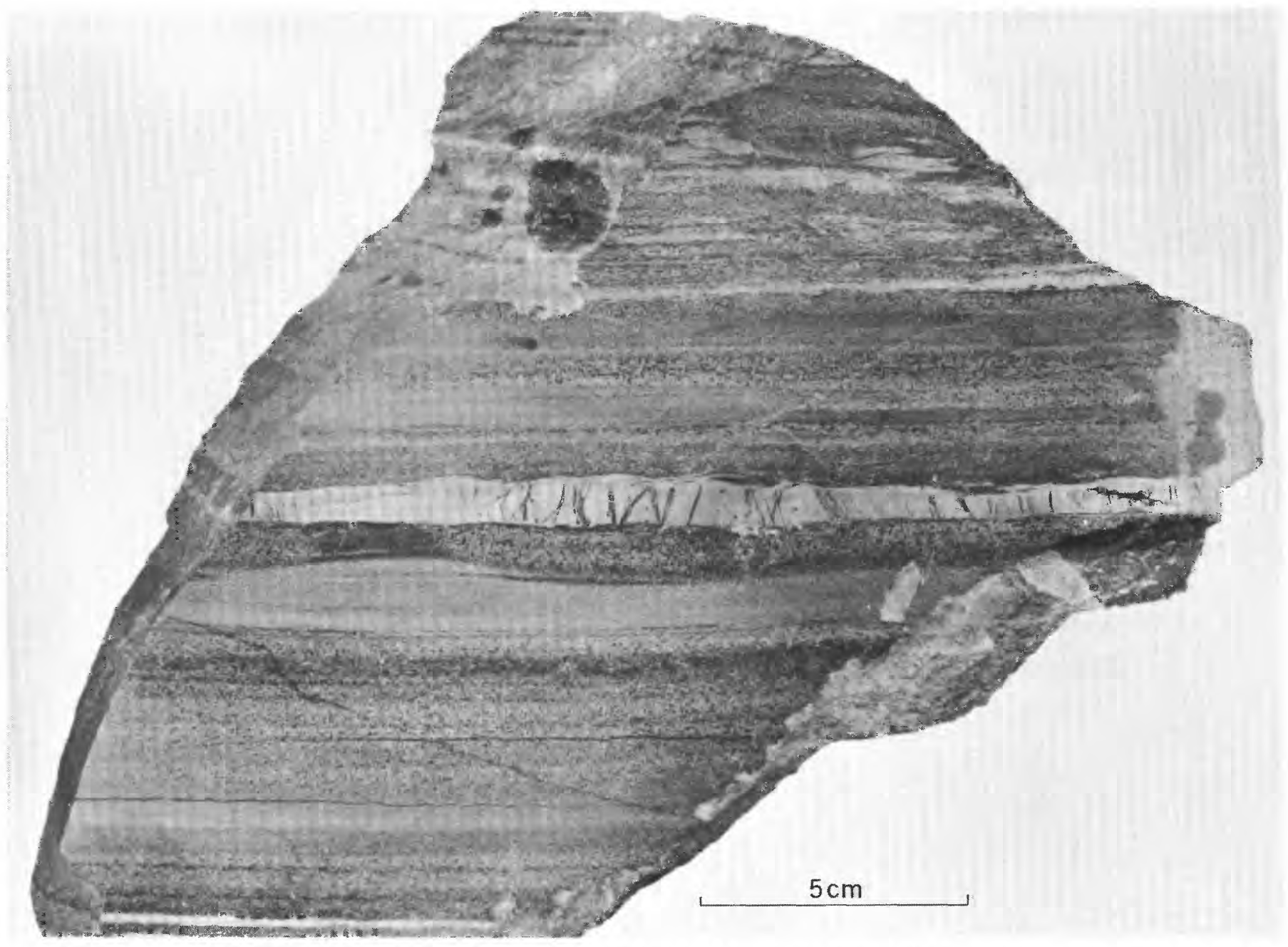

Figure 49.-Photograph of gruneritic iron-formation (Vulcan). Light-colored layers (as in center) are magnetite, gray layers are mainly magnetite and grunerite, dark layers mainly grunerite with small crystals of garnet. From the Groveland mine. Specimen HJ-168-51.

clastic load is very light. The basins of deposition probably were restricted-that is, separated from the open ocean by barriers, not necessarily emergent, which would inhibit circulation and permit development of abnormal oxidation potentials. The concept of the restricted basin is required to explain the deposition of sulfide and ferrous carbonate rocks, inasmuch as the waters in almost all of the open ocean are oxidizing from surface to bottom. Restricted basins are also indicated by the lack of stratigraphic correlation in iron-formation from range to range in the Lake Superior region. Even within Dickinson County the units of the Vulcan iron-formation of the Menominee range do not persist as far north as the Felch trough.

\section{BARAGA GROUP}

The Baraga group consists of three formations in this area: the Hemlock formation, the Michigamme slate, and the Badwater greenstone.

\section{HEMLOCK FORMATION}

Within central Dickinson County the Hemlock is present only in the northwest part of the mapped area. Information concerning the unit is exceedingly scant -in fact, only half a dozen outcrops have been located. Two shallow drill holes and magnetic surveys furnish the only additional data.

The rock exposed is well-bedded grayish-green to reddish rhyolitic tuff or felsite, with a somewhat scoriaceous appearance on the weathered surface. Some layers contain rounded quartz grains, some of which are opalescent. Seen under the microscope, some of the quartz grains have crystal outlines and others are clearly crystal fragments (figs. 50, 51). Patchy areas of devitrified glass are present (fig. 52). The matrix is principally quartz and sericite. Magnetite, with secondary quartz in the pressure shadows, is sparsely distributed through the rock. These rhyolitic tuffs are similar to parts of the Hemlock 


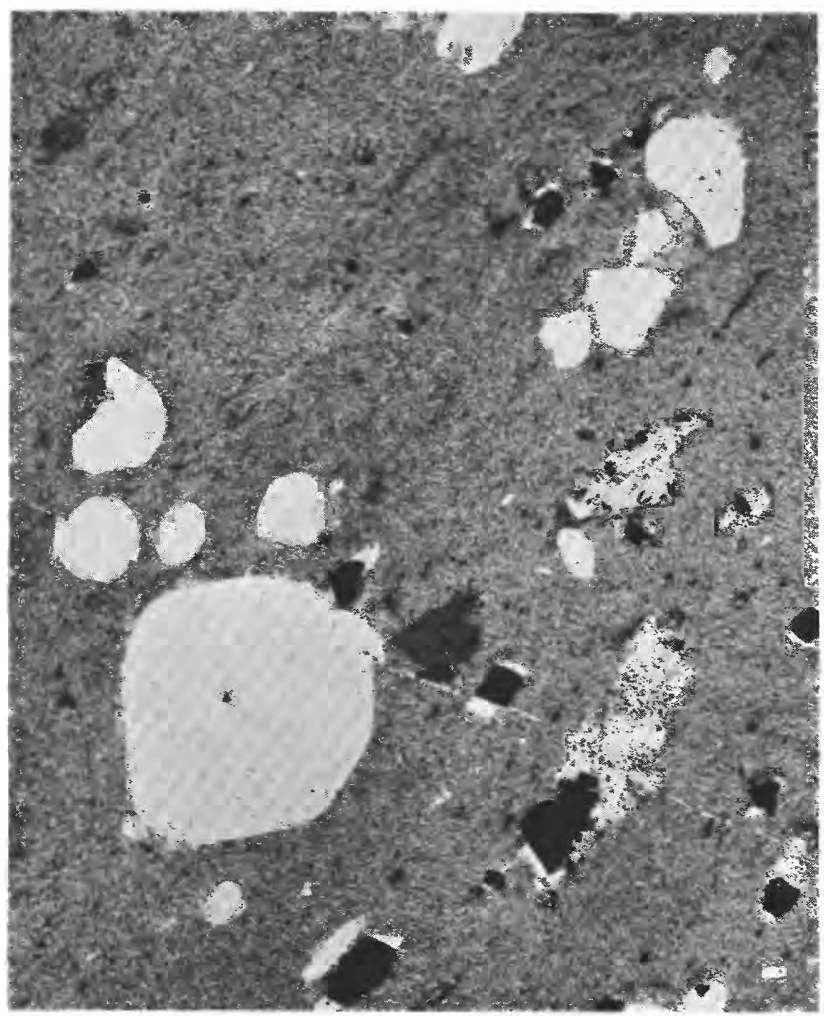

FIGURE 50

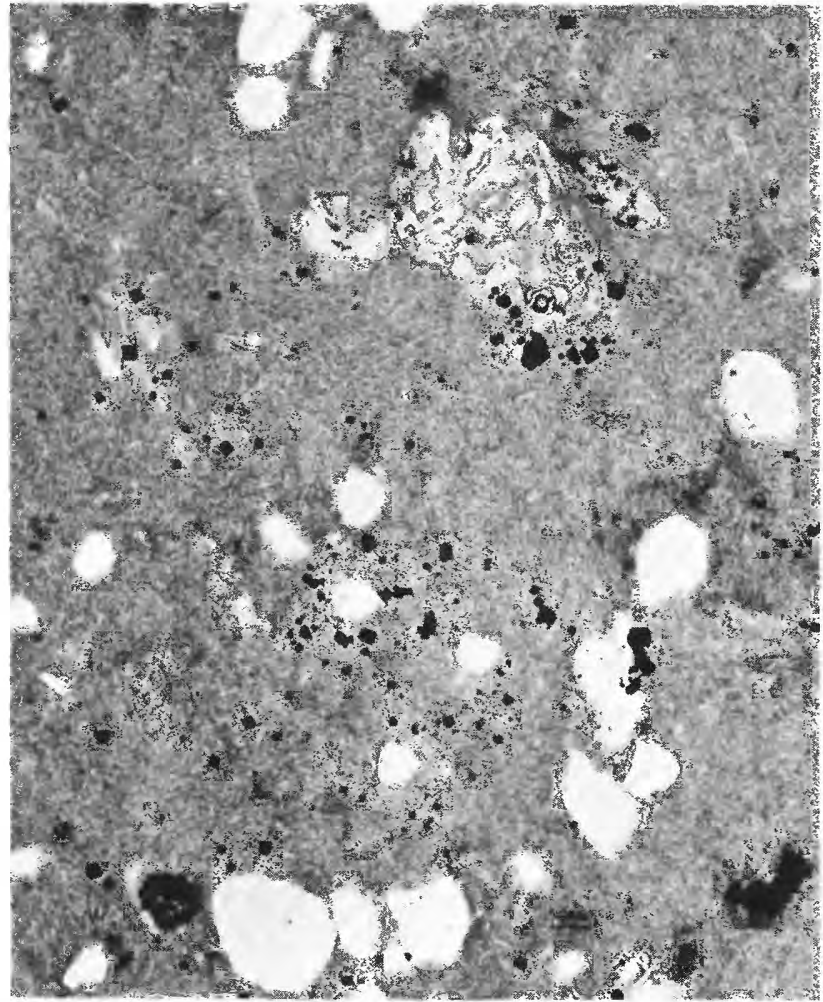

Figure 52

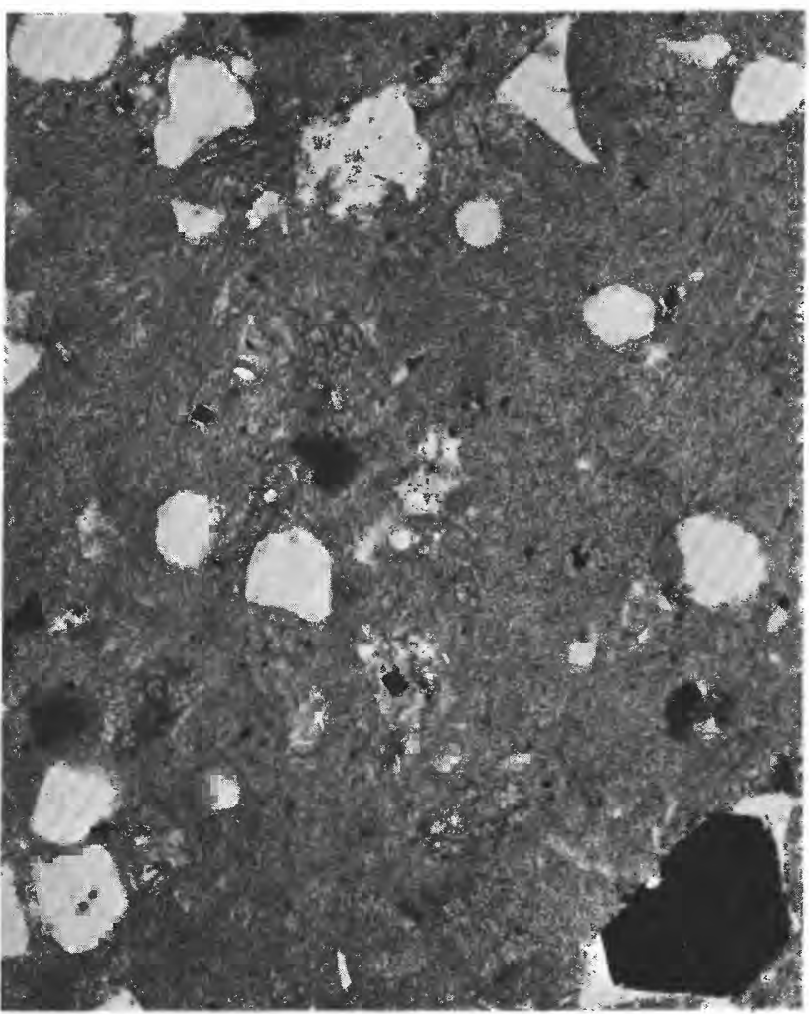

FIGURE 51

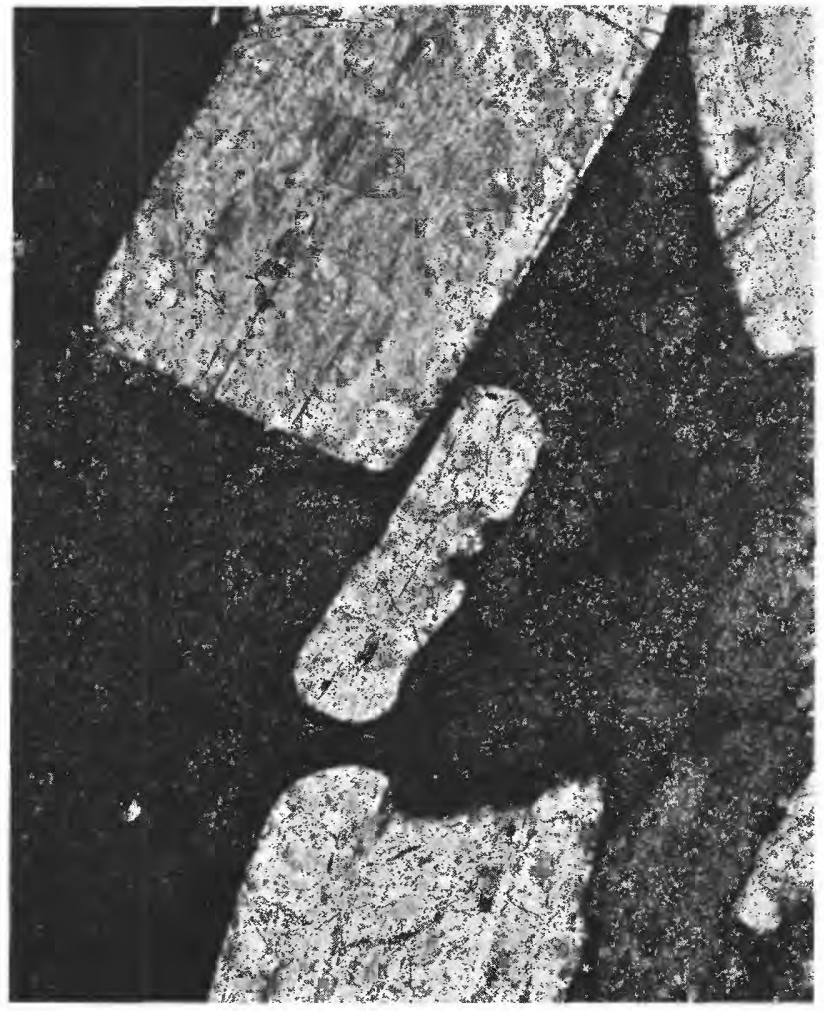

FigURE 53

FIgURES 50-53.-PHOTOMICROGRAPHS OF VOLCANIC ROCKS OF THE HEMLOCK FORMATION, FROM SEC, 2 , T. 42 N., R. 30 W. 50. Rhyolite tuff with large partly resorbed quartz phenocryst, in matrix of quartz and sericite with scattered magnetite. Ordinar

51. Rhyolite tuff with angular fragments of quartz crystals. Note secondary quartz in "pressure shadows" of large magnetite crystal.

52. Rhyolite tuff with irregular fragment of devitrified glass, now quartz and sericite. Ordinary light, $\times 35$. Specimen 49-MC-310. 53. Porphyritic meta-andesite cut by drill hole. Phenocrysts now chlorite and albite. Ordinary light, $\times 12$. Specimen HJ-96-52. 
formation in the Michigamme Mountain area, 9 miles to the northwest, as described by Gair and Wier (1956).

Most of the material cut in the two drill holes in the south part of sec. 2 is a decomposed greenish to reddish rock with scattered crystals of martite. It appears to be a deeply weathered volcanic rock. The more westerly of the two holes passed through this material into a coarsely porphyritic meta-andesite(?). This rock (fig. 53) contains large plagioclase crystals, now albite, in a fine-grained matrix consisting chiefly of greenish chlorite, leucoxene, and tiny albite plates. A few of the phenocrysts appear to be crystal fragments, and some ill-defined patches may be devitrified glass.

Very little is known of the structure or thickness of the Hemlock formation. The only attitude determinable indicates a northwest strike, with a dip to the northeast. Scour and fill structures show the tops to be to the northeast. The ground magnetic survey of the area (pl. 7) confirms this general strike and dip. The volcanic beds probably rest unconformably on greenstone schist that is even more poorly exposed. In the Michigamme Mountain area about 8 miles to the northwest, the Hemlock is separated from Lower Precambrian rocks by Goodrich quartzite and Randville dolomite (Gair and Wier, 1956). Whether or not these rocks underlie the Hemlock in T. 42 N., R. 30 W., and vicinity is not known. Plate 3 of Monograph 36 (Clements and Smyth, 1899) shows a small exposure of Randville dolomite in sec. 33, T. 43 N., R. 30 W., just east of Sagola, but the revision of this map in Monograph 52 (Van Hise and Leith, 1912, pl. 22) does not show this outcrop. Dolomite has also been reported from near the center of sec. 3, T. 42 N., R. 30 W. Careful search has failed to locate an exposure at either locality.

The position of the upper (northeast) contact of the Hemlock formation is not known, as the overlying Michigamme slate is not exposed within the area of T. 42 N., R. 30 W., and vicinity. Slate and graywake assigned to the Michigamme are exposed in secs. 33 and 34, T. 43 N., R. 29 W., and were uncovered by a pipeline trench in sec. 32 of the same township. As drawn on the map ( $\mathrm{pl} .2$ ), the Hemlock formation is about 2,000 feet in thickness, but this figure obviously could be greatly in error. The absence of this formation in other parts of the map area is attributed to nondeposition; considered regionally, the Hemlock formation thins out rapidly from the type area in eastern Iron County, and the pattern in central Dickinson County is believed to represent the feather edge of original distribution.

\section{MICHIGAMME SLATE}

The major area underlain by Michigamme slate in central Dickinson County is the Calumet trough and its extension to the west and southwest. Rocks assigned to the Michigamme also occur along the north margin of the map area; this strip is the south edge of the Sagola basin. Except in a few areas, the Michigamme is poorly exposed, and many square miles probably underlain by these strata are entirely without outcrop. Exposures generally are small and barely rise above the general level of the area; many, especially in the northern belt where the metamorphic grade is low, are of the "grass-roots" type.

The most extensive area of outcrop of Michigamme is in the western part of the Calumet trough, in sec. 19, T. 41 N., R. 29 W., and secs. 23,24 , and 26, T. 41 N., R. $30 \mathrm{~W}$. There the rock is a crystalline schist that is exposed in a series of low knobs and discontinuous ridges that trend nearly eastward. East of this area the Michigamme forms a belt of outcrops adjacent to the West Branch of the Sturgeon River, in sec. 24, T. 41 N., R. 29 W., and secs. 19, 20, and 21, T. 41 N., R. 28 W. The stratigraphically lower part of the Michigamme is exposed in sec. 15, T. 41 N., R. 29 W., and in sec. 12 of the same township and in the area adjacent to the east. A broad area of Michigamme in the southeast part of the map-approximately 25 square miles-is represented by only two outcrops in sec. 24, T. 41 N., R. 28 W., and test pits in sec. 30, T. 41 N., R. 27 W., but in part this is due to the extensive mantle of sandstone of Cambrian age. Slate, graywake, and volcanic rocks, which appear to belong to stratigraphically upper parts of the Michigamme, are exposed in scattered outcrops adjacent to the Menominee River in the southwest part of the map area.

The northern belt of rocks probably equivalent to Michigamme is very poorly exposed. The principal outcrops are in sec. 32, T. 43 N., R. 28 W., and in secs. 33 and 34, T. 43 N., R. 29 W., along the East Branch of the Sturgeon River.

\section{DESCRIPTION}

The Michigamme slate in central Dickinson County contains several different rock types, partly because of original sedimentary differences and partly because of variations in the degree of metamorphism. The rocks are dominantly clastic in origin; only the ironformation at the Hancock exploration in sec. 30, T. 41 N., R. 27 W., described under a separate heading as a questionable part of the Michigamme, is of chemical origin. Strata that lie near the base of the formation, exposed in the outcrops immediately south of the 
North Calumet fault in a discontinuous belt extending from the Calumet mine to sec. 15, T. 41 N., R. 29 W., and in the northern part of Central Dickinson County in sec. 32 , T. 43 N., R. 28 W., and secs. 33 and 34, T. 43 N., R. 29 W., show greater differences in lithologic character than other parts of the formation. In the northern belt (Sagola basin), where the rocks are of low metamorphic grade, they consist of red slate, graphitic slate (in sec. 32, T. 43 N., R. 28 W.), and sandy friable graywacke. In the Calumet area, which is one of moderate to intense metamorphism, the lower beds of the Michigamme consist principally of metamorphosed graywacke, but also present are beds of massive garnet-mica schist, with garnets 0.05 to 0.10 inches in diameter making up as much as 50 percent of the rock, and magnetite-bearing quartzmica schists. Test pits along this belt are recorded as having encountered "slaty iron-formation" in a number of places, but probably the rock is oxidized schist rather than iron-formation. In general, however, the basal parts of the Michigamme appear to be somewhat more iron-rich than the remainder of the formation.

By far the greatest part of the exposed Michigamme slate in central Dickinson County is within the zone of moderate to intense metamorphism, and the rock consists of alternating layers of graywacke granulite and schist, in beds ranging from less than a foot to several feet in thickness. The granulite (here used in the sense of a massive fine- to medium-grained rock with interlocking equidimensional grains) consists of 50 to 75 percent quartz, feldspar (mainly oligoclase), biotite, and muscovite (figs. 54-57). The schist is light to dark gray and lustrous; it is composed chiefly of quartz, biotite, and muscovite (figs. 58, 59). Garnet and epidote are common accessory minerals and locally are abundant but rarely if ever occur together. Chlorite is commonly present as an alteration product of biotite. Staurolite schist, in which the staurolite is now largely altered to sericite, chlorite, and quartz, is locally interbedded with graywacke granulite in the north parts of sec. 19, T. 41 N., R. 29 W., and sec. 24, T. 41 N., R. 30 W., and in the NWT/4 sec. 19, T. 41 N., R. 28 W. (fig. 59). The staurolite occurs as disseminated euhedral crystals as much as half an inch in length.

Graded bedding and concretionary structures may be observed in the graywake at many places in secs. 23, 24, and 26, T. 41 N., R. $30 \mathrm{~W}$. The graded bedding, displayed by beds less than an inch to a foot or so in thickness shows the beds to be generally overturned. These layers, which consisted originally of a gradation from coarser clastic material at the base to finer- grained material in the upper part, are now "reverse graded" insofar as grain size is concerned. The upper parts of the beds, being originally more argillaceous, have recrystallized to mica schist that now is coarser than the granulitic material that forms the lower parts. Concretionary structures are locally present in the same outcrop area but in general are scarce. These concretions are 1 to 3 inches in length, with an ovalshaped cross section. They are less micaceous than the enclosing rock, and some are rimmed with a scattering of small wine-colored garnets. The structures represent original calcareous concretions such as are common to the Michigamme slate in many parts of northern Michigan. In less disturbed areas these concretions are typically elliptical. The lack of significant distortion of the concretions in the Calumet rocks is in particular contrast to the intense internal deformation shown by the older granites and gneisses.

Iron-formation that possibly is part of the Michigamme slate has been explored by a number of test pits and trenches and three drill holes at the Hancock exploration in sec. 30, T. 41 N., R. 27 W. (fig. 60). The rock exposed consists of iron-formation, oxidized ferruginous schist, and graywacke (or quartzite). The iron-formation is thin-layered to laminated with layers of bluish martite (after magnetite) and granular chert. The rock contains a considerable amount of greenish to gray claylike material as irregular laminae and small patches. The associated schists and graywacke are also ferruginous, chiefly by reason of alteration of original micaceous minerals to hematite.

Three holes were drilled in the vicinity about 50 years ago. According to the records, the most northeasterly hole cut "white sandstone" from bedrock surface to 227 feet, then entered "soaprock, quartz, and ore". The other holes are reported to have encountered only "mica schist."

As shown on figure 60 , one or more magnetic anomalies of uncertain trend are present; one anomaly, at least, is related to the iron-formation, which is slightly magnetic in some specimens.

The stratigraphic position and correlation of the rocks at the Hancock exploration are uncertain. They may represent a ferruginous horizon within the Michigamme, an interpretation that is favored by the similarity of the associated rocks to the Michigamme slate. Alternately, the rocks may be Vulcan ironformation exposed on an anticlinal structure; the absence of a major magnetic anomaly is against this correlation, though it is possible that the rock is only a remnant of Vulcan on the folded pre-Michigamme erosion surface. 


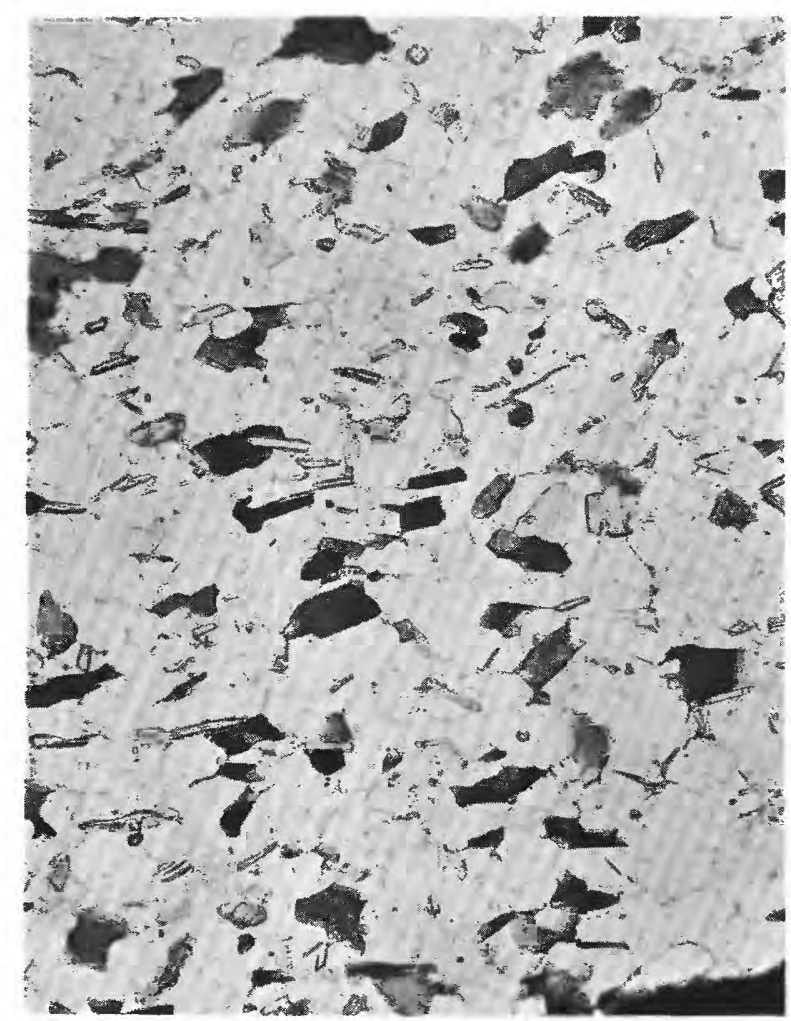

FiguRE 54.-Ordinary light.

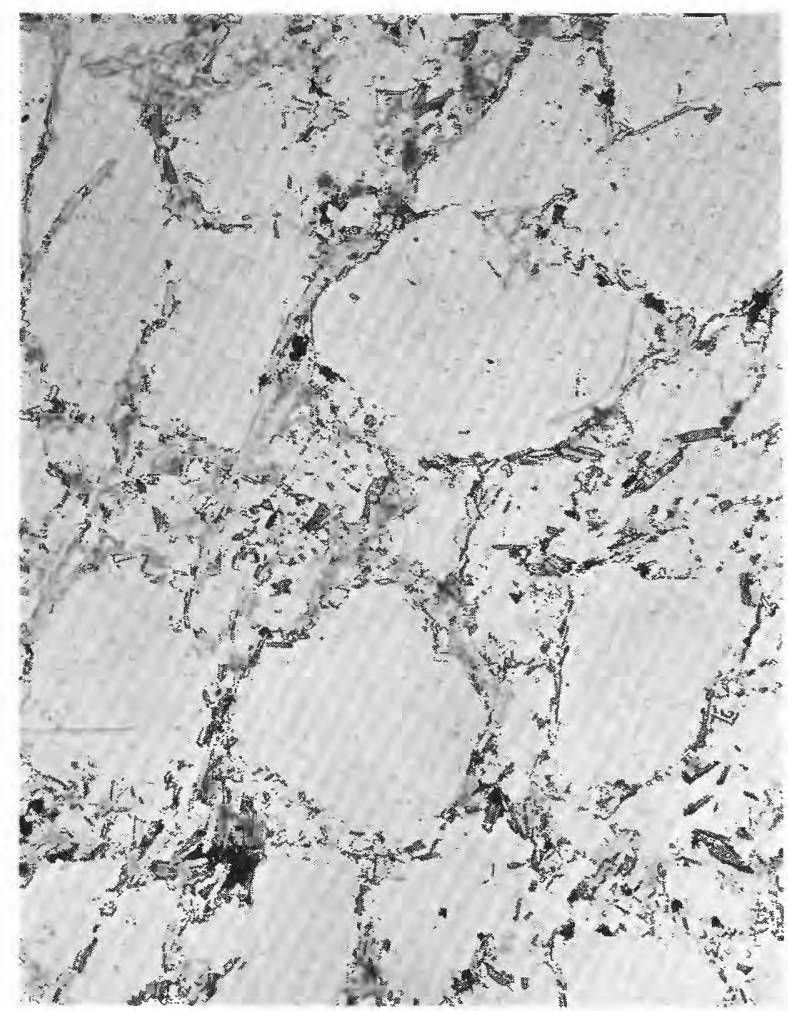

FIGURE 56,-Ordinary light.

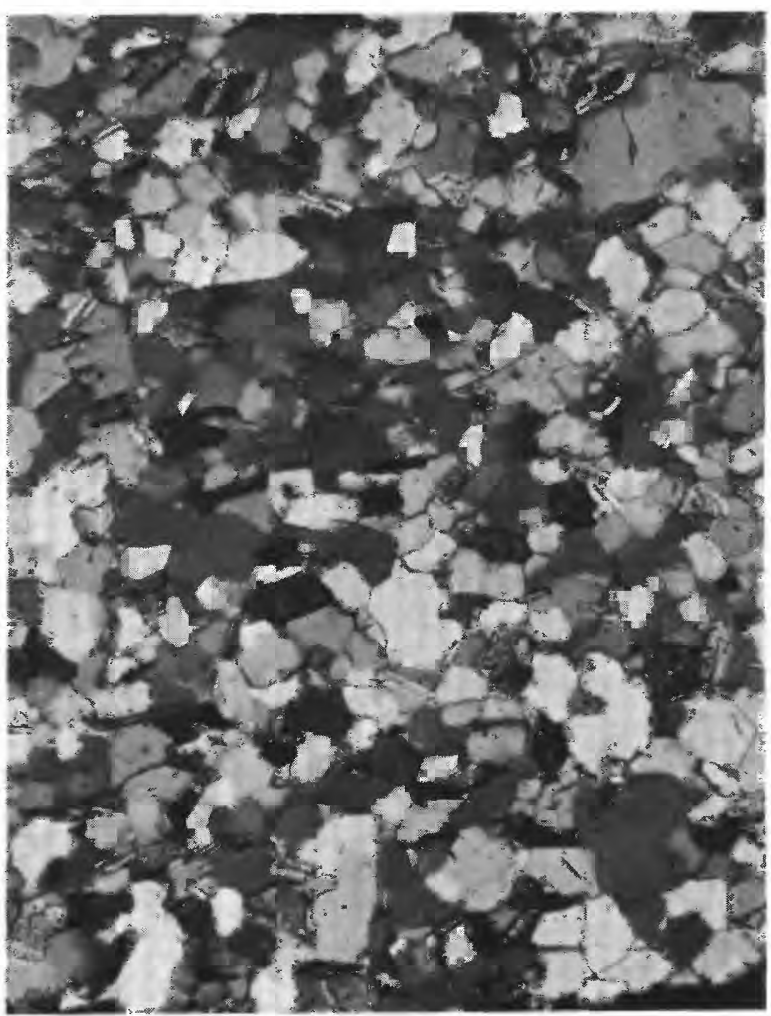

Figure 55.-Crossed nicols.

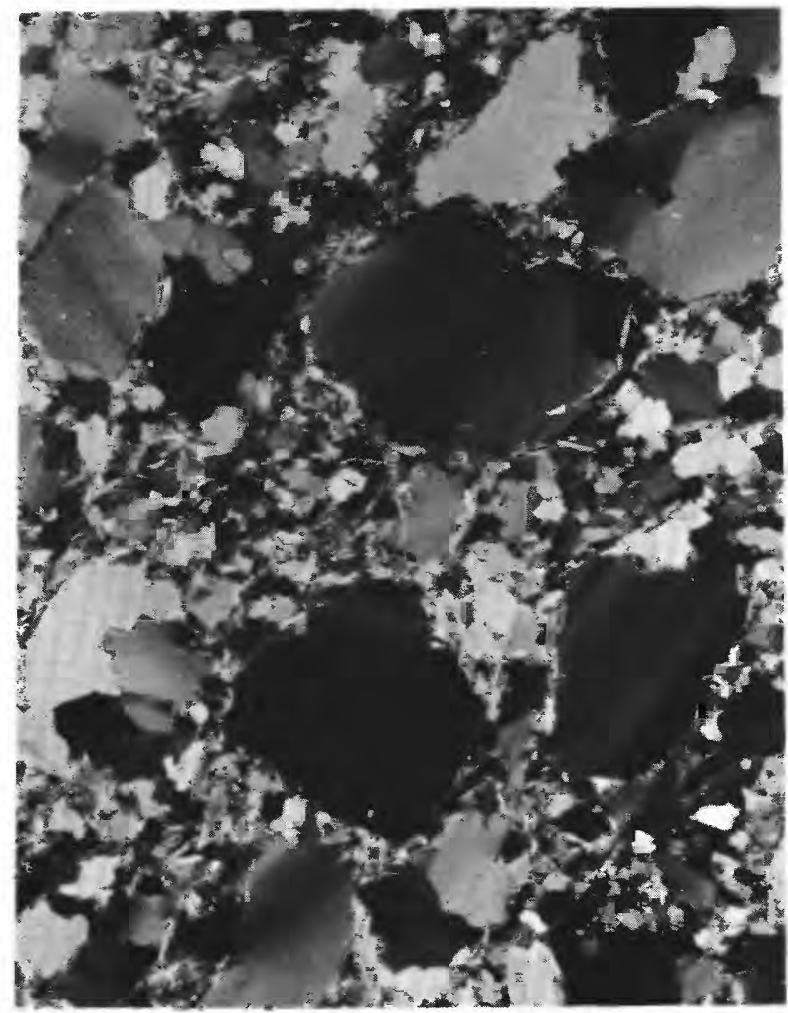

Figure 57.-Crossed nicols.

FInURES 54-57.-PHOTOMICROGRAPHS OF ROCKS FROM THE MICHIGAMME SLATE.

54, 55. Typical granulite. Sutured grains of quartz and untwinned oligoclase, with biotite (dark) and muscovite (gray to white). Specimen from sec. $24, T$. 41 N., R. 30 W. $\times 60$. Specimen JT-301.
56, 57 Coarse-grained graywacke, from SE1/4 sec. 20, T. 41 N., R. 30 W. Large strained quartz grains separated by biotite, muscovite, and intergrown quartz and feldspar. $\times 30$. Specimen JT-314. 
THICKNESS AND STRATIGRAPHIC RELATIONS

The thickness of the Michigamme slate in central Dickinson County is impossible to determine accurately. In secs. 23,24 , and $26, T$. 41 N., R. 30 W., the

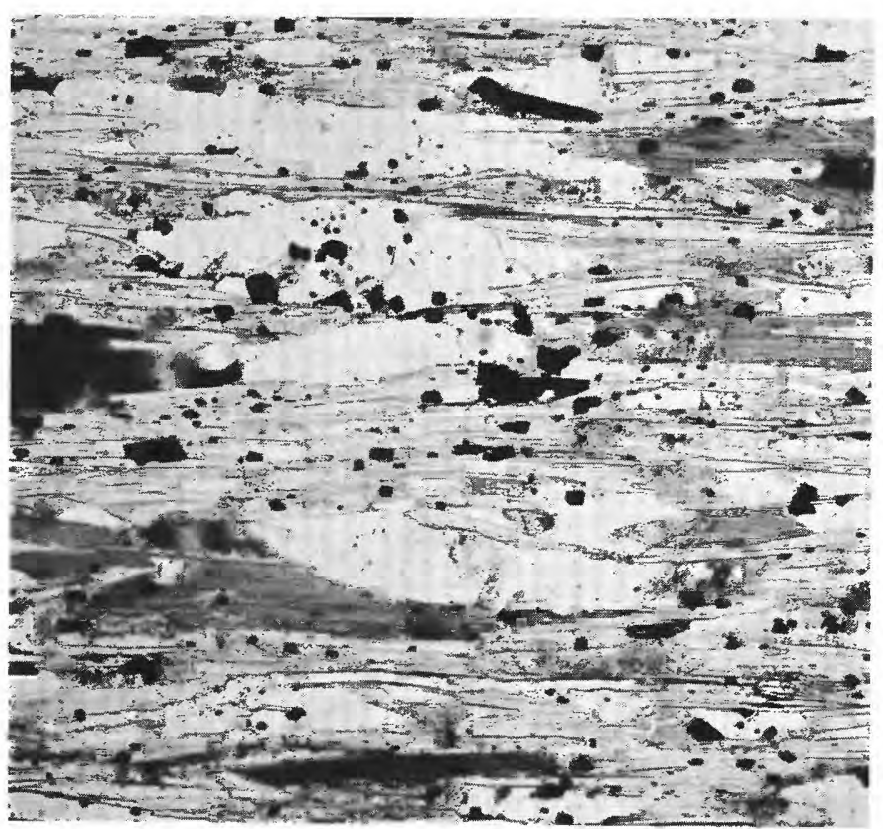

FIGURE 58

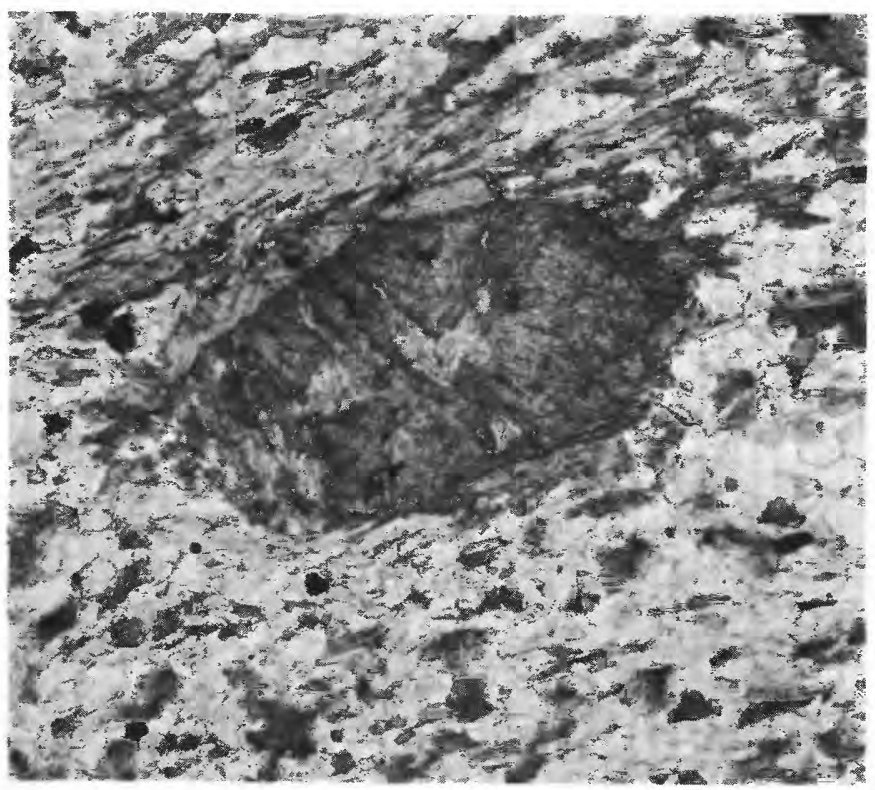

Figure 59

FICURES 58, 59.-PHOTOMICROGRAPHS OF ROCKS FROM THE MICHIGAMME SLATE.

58. Biotite-muscovite schist, from NW1/4 sec. 21, T. 41 N., R. 29 W. Elongate grains of quartz (clear) and sericitized plagioclase (cloudy), separated by muscovite and biotite, and peppered with magnetite (black). Ordinary light, $\times 60$. Specimen JT-515.

59. Staurolite schist, from sec. 19 , T. 41 N., R. 28 W. Stuarolite completely altered to aggregate of sericite, chlorite, and quartz. Ordinary light, $\times 10$. Specimen JF-623A. rock is fairly well exposed for a cross-strike distance of about a mile. Dips are steep $\left(65^{\circ}\right.$ to $\left.90^{\circ}\right)$ and observed top directions are consistently to the south. The formation is in fault contact with older granite on the north, and a covered interval separates it from the Badwater greenstone to the southwest. These relations suggest a minimum thickness of about 5,000 feet and a possible maximum of about 11,000 feet.

The Michigamme slate is underlain by volcanic rocks of the Hemlock formation in the northwest part of the area. It appears, however, that the Hemlock was not everywhere deposited in the central Dickinson County area; in most places, the Michigamme slate is the basal member of the Baraga group. The relationship between the Michigamme slate and older strata has been observed only in the Calumet mine area and in sec. 15, T. 41 N., R. 29 W. At the Calumet mine, underground workings and drill holes cut the contact. Drill holes, such as Nos. 2 and 4 (see pl. 4 for map of sec. 8 , T. 41 N., R. 28 W.), pass through hundreds of feet of uniform massive oxidized graywacke granulite, thence into Vulcan iron-formation. The transition beds consist of schist which in all places observed is deeply oxidized. No volcanic rock or conglomerate is present. A contact between oxidized schist and Vulcan iron-formation is exposed in the north side of the Calumet mine cave, as shown on cross section $A-A^{\prime}$, plate 4 . This schist probably is the infolded basal beds of the Michigamme slate. The inferred structure is somewhat doubtful, however, and it is possible that the schist, rather than being younger, actually is stratigraphically below the Vulcan.

Despite the absence of positive indication of unconformity at the few points where the contact has been observed, indirect evidence suggests that in much of the area considerable thicknesses of underlying beds were removed hy erosion prior to deposition of the Michigamme - and, elsewhere, the Hemlock. The absence of Vulcan iron-formation-as indicated by absence of magnetic anomalies-in belts parallel to the Sturgeon quartzite in the southwest part of T. 41 N., R. $29 \mathrm{~W}$., and the central part of T. 41 N., R. $30 \mathrm{~W}$., is almost certainly to be ascribed to pre-Michigamme erosion. Similarly, in the northern part of the map area, the Vulcan iron-formation is generally absent along the south flank of the Sagola basin, except for a small amount, considered to be an erosional remnant, at the Deerhunt exploration. Regionally, the evidence for unconformity between the Menominee group and the Baraga group is conclusive. The unconformity is visible in many places in the Marquette district (Van Hise and Leith, 1911) and has been described by Allen (1920) in the Menominee range of southern 


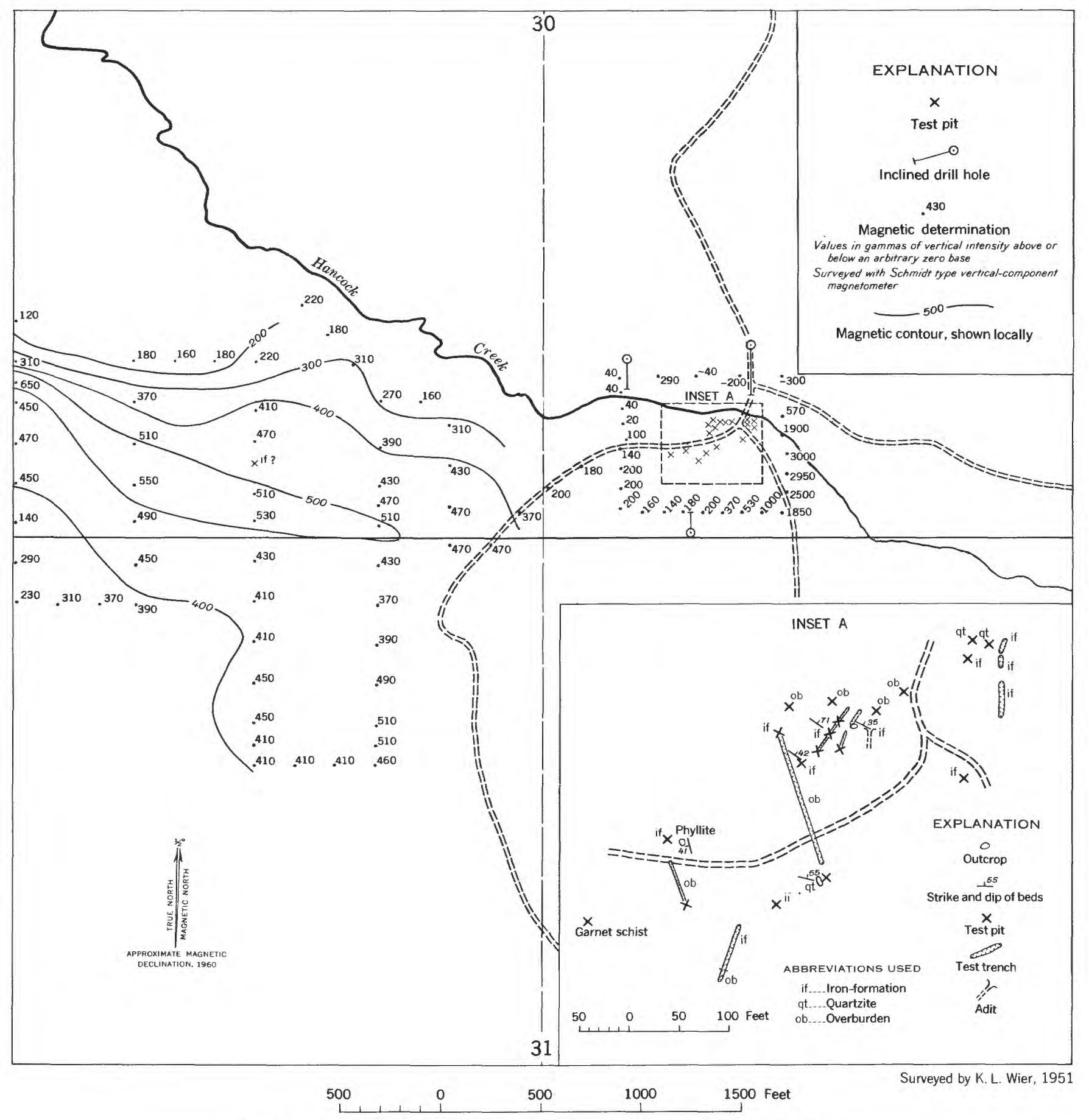

FigURE 60.-Geologic and magnetic data in the Hancock exploration area. 
Dickinson County. This area is particularly instructive, in that as much as 78 feet of coarse conglomerate was found in certain drill holes, yet in most places there is little or no physical evidence for the unconformity.

\section{BADWATER GREENSTONE}

The Badwater greenstone consists principally of chloritized basaltic flows, some of which show ellipsoidal or agglomerate structures. In general, the greenstones are massive fine-grained greenish rocks that under the microscope can be seen to retain some of the primary volcanic textures. The rocks now are fine-grained aggregates of albite, chlorite, clinozoisite, carbonate, greenish-brown biotite, and leucoxene (figs. 61, 62). Some are amygdaloidal, the amygdules now containing the same minerals as the groundmass but much coarser in grain (fig. 62). In secs. 31 and 32 , the greenstone is intruded by a broad dikelike mass of altered gabbro.

In sec. 24, T. 41 N., R. 31 W., adjacent to First Creek, outcrops show rock that appears to be metamorphosed tuff tightly folded with fine-grained graywacke. The folds plunge in a general westerly direction, and the graywacke appears to be the older rock.

Iron-rich rocks have been exposed in test pits in sec. 33, T. 41 N., R. $30 \mathrm{~W}$, along the north margin of the greenstone belt. Most of the material appears to be deeply oxidized graywacke and slate (and possibly

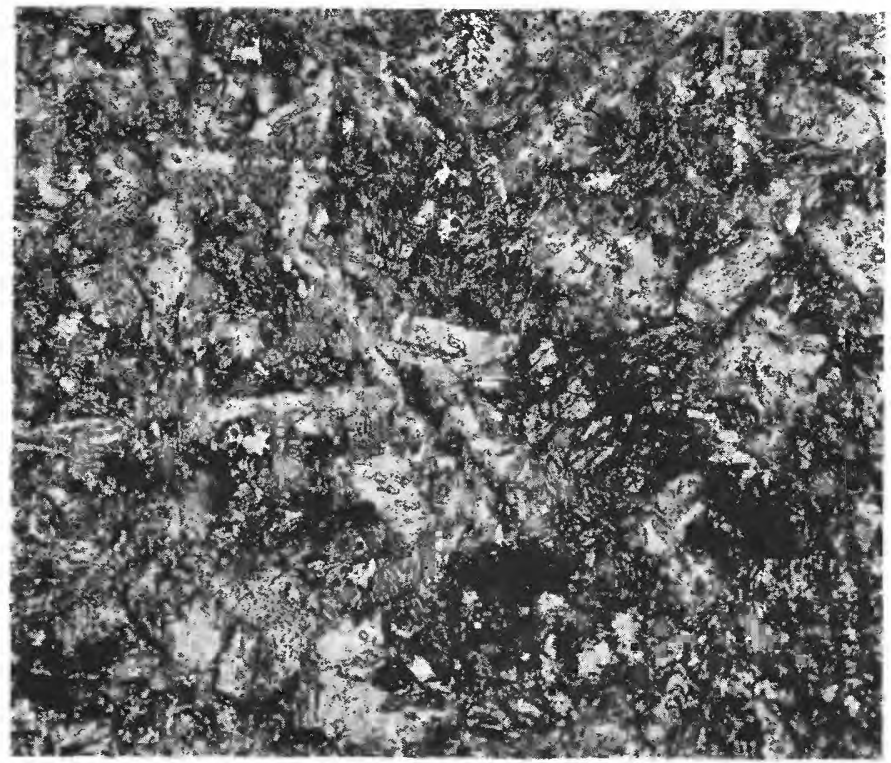

FIGURE 61 tuff) rather than iron-formation, and the rock is tentatively included with the Michigamme slate.

The relationships of the Badwater greenstone to the Michigamme slate have been worked out in southern Dickinson County and in eastern Iron County, where it has been established that the greenstone is the younger rock and that it is conformable with the Michigamme (James, 1958). As the greenstone is the youngest Animikie unit present in central Dickinson County, the thickness preserved is a minimum; in areas adjacent to the west it attains a thickness of several miles.

\section{CONDITIONS OF DEPOSITION OF THE BARAGA GROUP}

The Baraga group is a suite of rocks utterly unlike those of the Menominee and Chocolay groups, which consist essentially of clean sands and chemical precipitates-products of orogenically stable conditions. The Hemlock formation, the Michigamme slate, and the Badwater greenstone, in contrast, comprise a typical "eugeosynclinal" assemblage; the thick deposits of clastic and volcanic material are the products of a structurally unstable environment marked by strong relief of the adjacent land area, active subsidence of the basin of deposition, and submarine volcanism. Deposition of such a thick series of clastic materials indicates that the adjacent land areas were being continually rejuvenated during that period. In consequence, it may be expected that the unconformity will

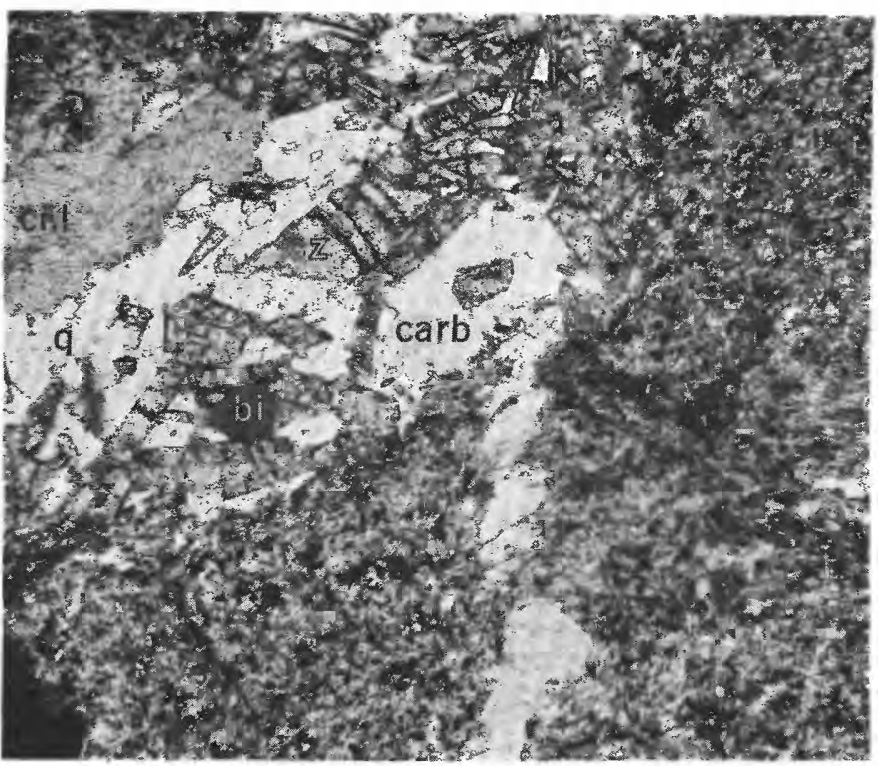

FigURe 62

FIGURES 61, 62.-PHOTOMICROGRAPHS OF ROCKS FROM THE MICHIGAMME SLATE.

61. Massive greenstone, from SE1/4 sec. $32, T, 41 \mathrm{~N}, \mathrm{R}, 30 \mathrm{~W}$ Original intersertal texture preserved by form of plagioclase laths. Rock now consists of albite, chlorite, clinozoisite, actinolitic hornblende, carbonate, and leucoxene. Ordinary light, $\times 70$. Specimen JT-526.
62. Amygdaloidal greenstone, from NW1/4 sec. $32, T .41$ N., R. 30 W. Original amygdule area (upper left) now contains coarse prisms of clinozoisite (cz) in carbonate (carb), quartz $(q)$, chlorite $(c h l)$, and biotite $(b i)$. Ordinary light, $\times 50$. Specimen $\mathrm{J} \mathrm{T}-521$ 
be a progressive one; in some areas older rocks will not have been covered until later stages of Michigamme sedimentation, and, of course, some areas will have remained emergent for the entire period.

\section{UPPER MIDDLE PRECAMBRIAN INTRUSIVE ROCKS}

\section{METADIABASE AND METAGABBRO}

Metamorphosed basic intrusives are common in many parts of central Dickinson County, but only the larger bodies are shown on the general map of the area. The major occurrence is in T. 42 N., Rs. 28 and $29 \mathrm{~W}$., where a dike or sill-like body can be traced for about 8 miles. At the eastern end, the outcrops suggest that it has the form of a stock, but west of this it branches into two well-defined dikes, the larger of which is about 400 feet wide. Extensive outcrops of a body of metagabbro are present at the south margin of the iron-formation ridge, just north of the town of Felch; a smaller mass occurs in the $\mathrm{SE} 1 / 4$ sec. 33, T. 42 N., R. 28 W., about half a mile southeast of Felch. At these two localities the rock is probably in the form of sills in the Felch formation and Vulcan iron-formation.

Several narrow dikes cut the Sturgeon quartzitegranite gneiss contact in the southwestern part of the area, as in sec. 20, T. 41 N., R. $30 \mathrm{~W}$ :, and a dikelike mass of altered gabbro about 800 feet thick intrudes the greenstone in secs. 31 and 32, T. 41 N., R. 30 W.

\section{DESCRMPTON}

The basic intrusives vary considerably in appearance from place to place in the area, in part because of original differences in grain size and texture, and in greater part because of variation in the degree of metamorphism. In general, they are massive nonfoliated rocks: greenstones in zones of low-grade metamorphism, black amphibolites in zones of moderate or intense metamorphism. A primary porphyritic texture is preserved in many of the rocks, notably in the large dike that crosses T. $42 \mathrm{~N}$. in an easterly direction, and in the sheetlike mass in the southwestern part of the area. Both rocks show stubby dark phenocrysts that originally were augite but now are amphibole.

The basic intrusives clearly have been metamorphosed in the post-Animikie epoch of metamorphism, inasmuch as the present mineral content of the rocks is in harmony with the metamorphic grade shown by associated Animikie rocks (James, 1955). In areas of relatively low metamorphic grade, as in the southwestern part of central Dickinson Country, the original textures are well preserved, as shown by the metagabbro illustrated on figure 63 . This rock shows com- plete alteration of the feldspars to albite, clinozoisite, and other fine-grained materials, and of original augite to actinolitic hornblende, green biotite, and clinozoisite. Dikes at intermediate level of metamorphism also show preservation of original texture (fig. 64), but the rock is an aggregate of oligoclase, blue-green hornblende, biotite, and epidote, with accessory apatite, sphene, quartz, and magnetite. The magnetite in these dikes commonly is in the characteristic skeletal crystals found in many diabases and gabbros.

In the central and eastern parts of the map area, the basic intrusives have been entirely reconstituted to unfoliated amphibolite. These rocks now consist chiefly of green hornblende and untwinned andesine, with minor biotite, and little trace of the original texture remains (fig. 65).

\section{AGE RELATIONS}

The metamorphosed basic intrusive rocks are younger than all Precambrian sedimentary and volcanic rocks in central Dickinson County and are cut only by the upper Middle Precambrian granite and pegmatite and by diabase of Keweenawan age. In many places in the southwestern part of the area, metadiabase dikes cut the contact between Lower Precambrian gneiss and Sturgeon quartzite. Sills are present in the Felch formation at several localities, and the mass immediately north of the village of Felch appears to be a sill in the Vulcan iron-formation. No dikes have been observed cutting the sedimentary rocks of the Michigamme, but the post-Michigamme age is established by the dikelike intrusive into the Badwater greenstone in sec. 32, T. 41 N., R. 30 W. It is true, of course, that in many parts of central Dickinson County the dikes cut only Lower Precambrian rocks. Age assignment of such dikes must be made solely on the basis of lithologic similarity with those of known age and, inasmuch as basic intrusives of the Lower Precambrian may be present also, the possibility of erroneous classification exists.

That the basic intrusives were emplaced prior to the post-Animikie metamorphism is clearly shown by the metamorphic changes undergone. Some of the intrusive bodies were emplaced prior to deformationor contemporaneous with it-and some are later. In the southwestern part of the area the dikes cutting the Sturgeon quartzite have been intruded along fault zones, locally crossing the faults without displacement, and are thus postdeformation, whereas the sill-like masses in the Felch trough appear to have been folded with the Animikie strata. In general, the metadiabase and metagabbro appear to be correlative with similar rock occurring as sills and dikes in the Nagaunee iron-formation of the Marquette district. 


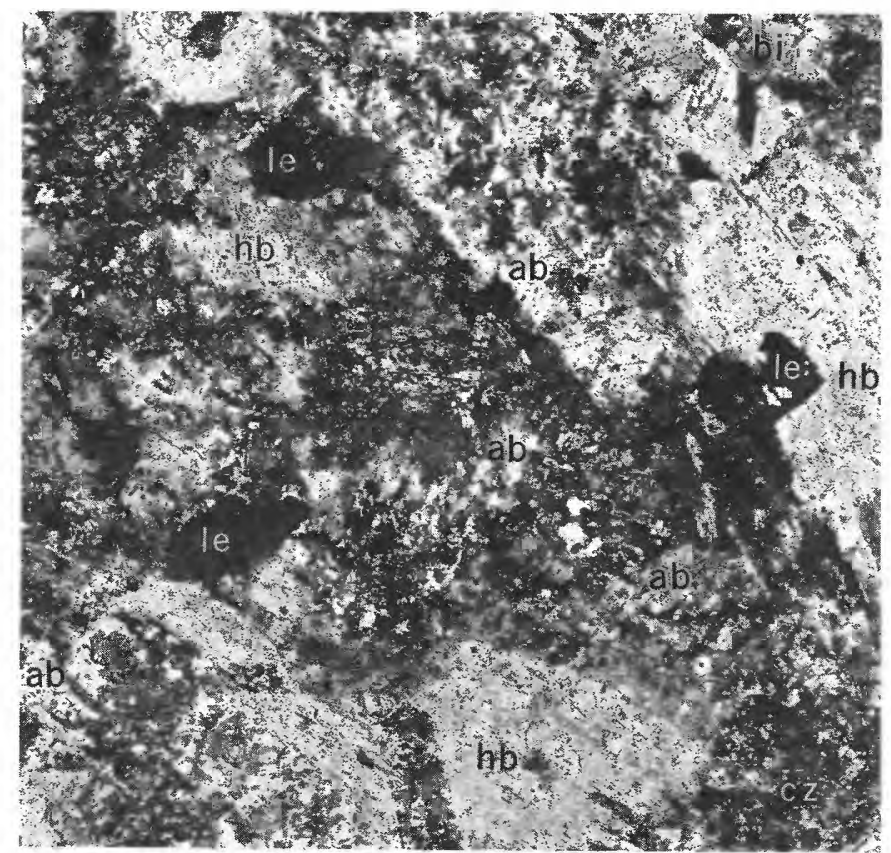

FIGURE 63

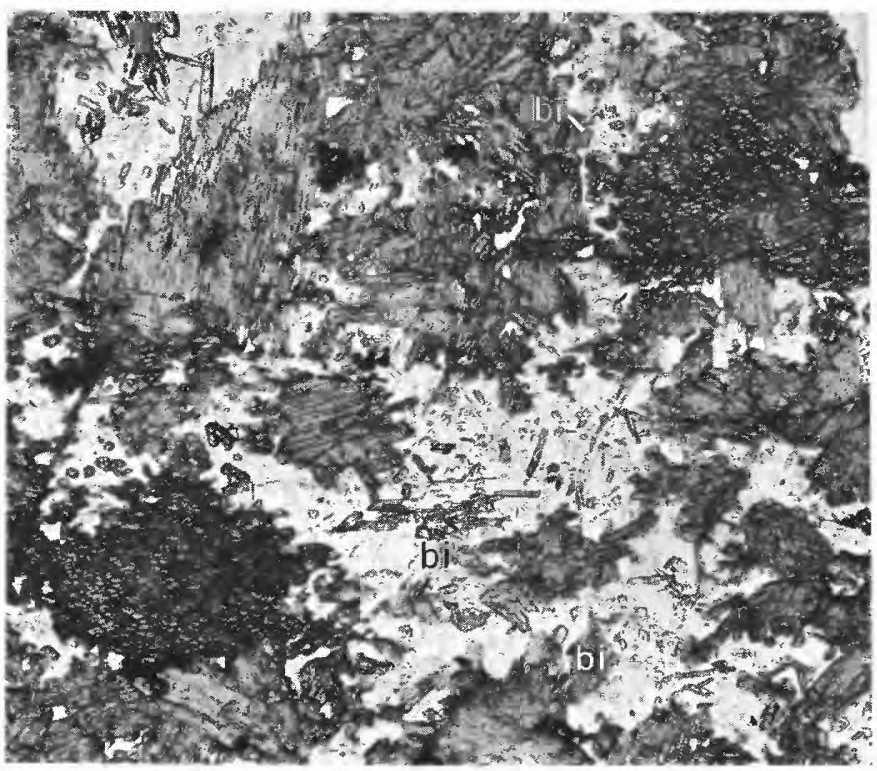

Figure 65

PEGMATITE, GRANITE, AND HORNBLENDE DIORITE

Dikes and small masses of upper Middle Precambrian granitic rock are abundant throughout an eastward-trending belt that closely parallels the Felch trough. In the area just north of the village of Felch almost every outcrop of the banded gray gneiss is cut by one or more small pegmatite dikes. Most of the dikes are less than 10 feet wide, and although some maintain a straight course for a hundred feet or more, the majority branch and split in irregular fashion. A narrow dike is shown in figure 66. A detail

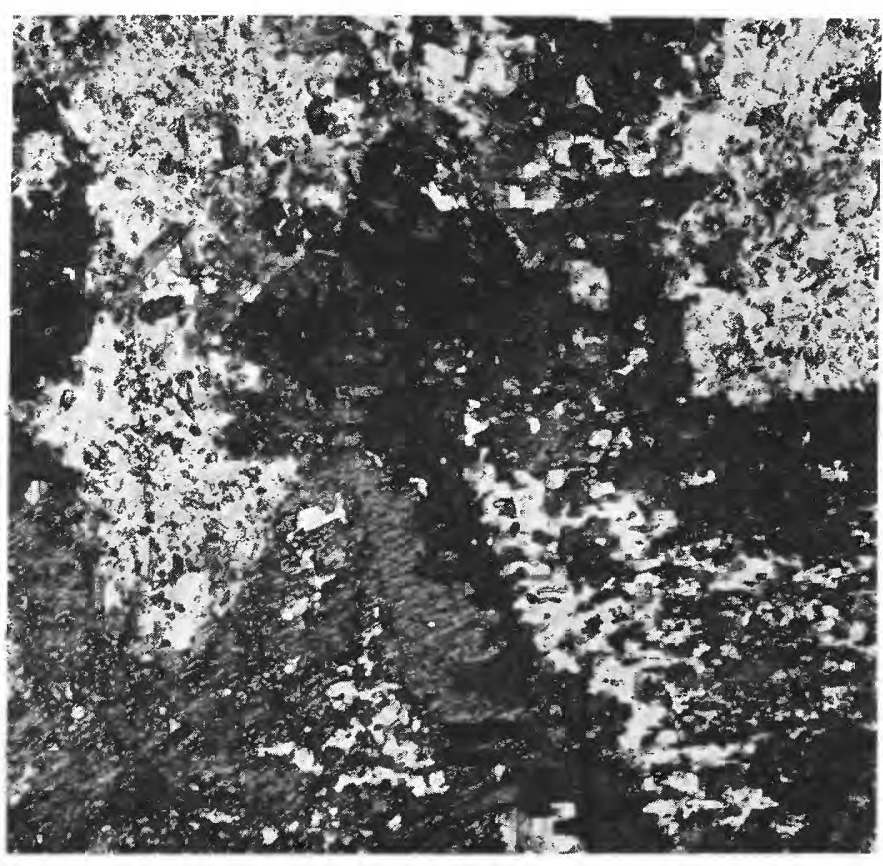

FIGURE 64

FIG URES 63-65.-PHOTOMICROGRAPHS OF METAMORPHOSED BASIC INTRUSIVE ROCKS.

63. Metagabbro, from SE1/4 sec. 32, T. 41 N., R. 30 W. Original coarse gabbroic texture preserved. Original pyroxene completely altered to pale-green actinolitic hornblende $(h b)$, original labradorite to albite $(a b)$ and clinozoisite $(c z)$, original magnetite-ilmenite to leucoxene (le). Biotite (bi) also present. Biotite zone of metamorphism. Ordinary light, $\times 35$. Specimen JT-525.

64. Metadiabase, from dike in Sturgeon quartzite in sec. 20, T. 41 N., R. 30 W. Original texture preserved. Pyroxene altered to blue-green hornblende (dark gray), labradorite to oligoclase, plus epidote and biotite. Note relict skeletal crystal of magnetite-ilmenite near center. Garnet zone of metamorphism. Ordinary light, $\times 40$. Specimen HJ-119-50.

65. Metadiabase, from large dike crossing center of sec. 17, T. 42 N., R. 28 W. Relict texture visible in hand specimen but not in thin section. Rock composed of green hornblende and andesine $\left(\mathrm{An}_{35}\right)$, with accessory biotite $(b i)$, quartz and magnetite Probably staurolite zone of metamorphism. Ordinary light, $\times 33$. Specimen HJ-60-51.

of the relationships mapped by Lehner in sec. $29, \mathrm{~T}$. 42 N., R. 28 W. is shown on plate 5 . In the western part of the belt, notably in secs. $23,24,26$, and 27 , T. 42 N., R. 30 W., pegmatite forms great outcrops as much as 1,000 feet long and hundreds of feet wide. The pre-Animikie red porphyritic granite in T. $42 \mathrm{~N}$., R. $30 \mathrm{~W}$. is cut by many narrow pegmatite and aplitic granite dikes, most of which trend eastward (fig. 68). The pegmatite is the younger rock (fig. 69).

The granite in the Felch trough forms sharpwalled dikes 2 to 10 feet in width cutting Huronian sedimentary rocks. Good exposures of these dikes may be seen in the dolomite quarry in sec. 35, T. 42 N., R. $30 \mathrm{~W}$.; at the Groveland mine; along the ironformation ridge at Felch; and at the Metronite quarry (fig. 67 ) in sec. 26, T. 42 N., R. 28 W.

Hornblende diorite forms several outcrops in secs. 29 and 30, T. 42 N., R. 30 W. It is considered postAnimikie on the basis of its lack of alteration and 
its similarity to post-Animikie intrusive rocks in the Lake Mary quadrangle a short distance to the west.
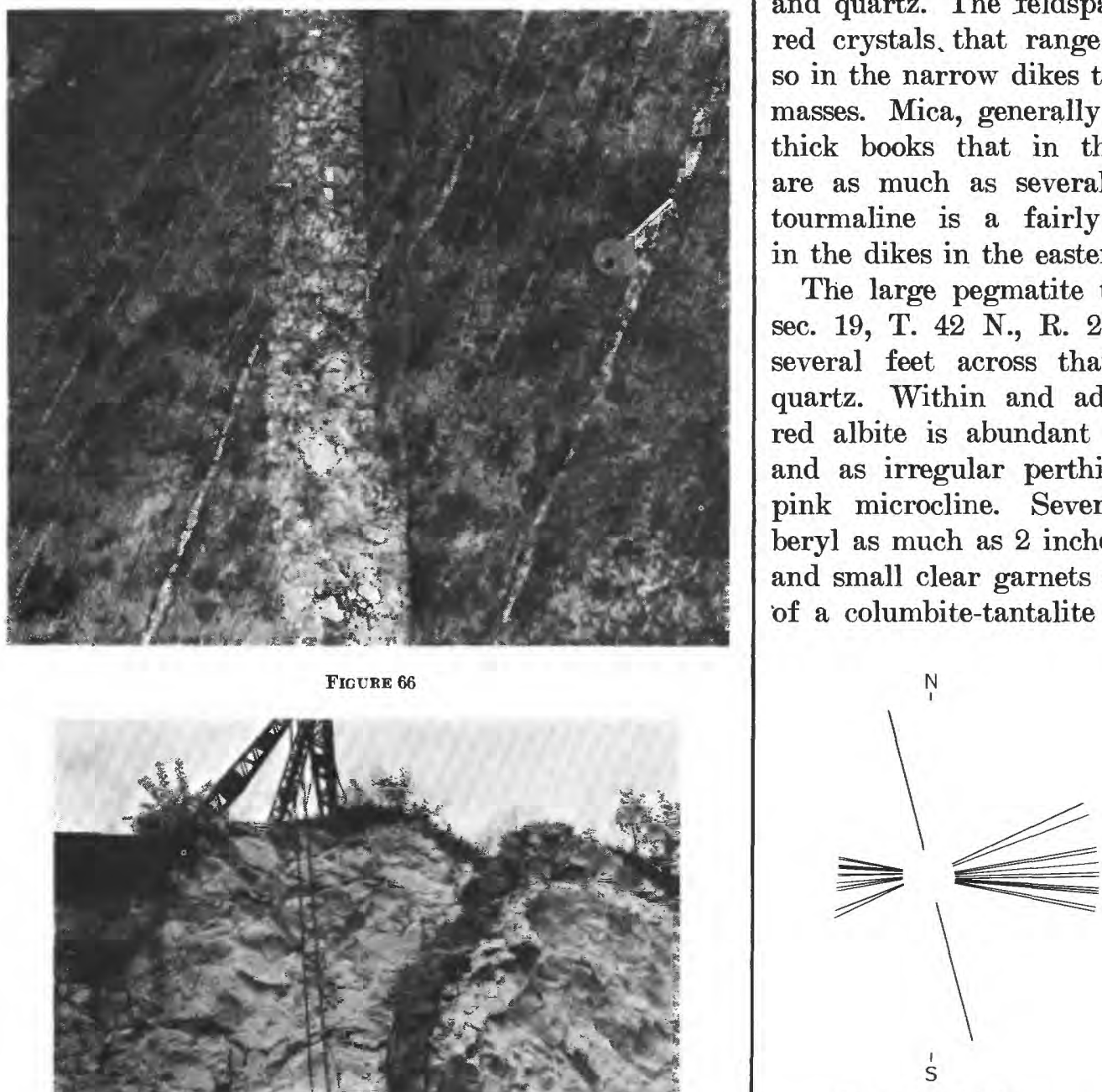

Twenty pegmatite dikes

\section{DESCRIPTION}

The pegmatites are pink to gray coarse-grained rocks composed principally of potassium feldspar and quartz. The feldspar forms large gray to fleshred crystals, that range in length from an inch or so in the narrow dikes to a foot or more in the large masses. Mica, generally muscovite, occurs chiefly as thick books that in the coarsergrained pegmatites are as much as several inches in diameter. Black tourmaline is a fairly common accessory mineral in the dikes in the eastern part of the belt.

The large pegmatite that is quarried in the $\mathrm{SE}^{\mathrm{x}} / 4$ sec. 19 , T. 42 N., R. 29 W., has an irregular core several feet across that consists mainly of glassy quartz. Within and adjacent to this core, salmonred albite is abundant as borders to glassy quartz and as irregular perthitic stringers throughout the pink microcline. Several crystals of greenishgray beryl as much as 2 inches in diameter were observed, and small clear garnets are common. A broken piece of a columbite-tantalite crystal, about 2 inches long,

Frgure 68.-Diagrams showing orientation of dikes in $T$. $42 \mathrm{~N}$., R. $30 \mathrm{~W}$.

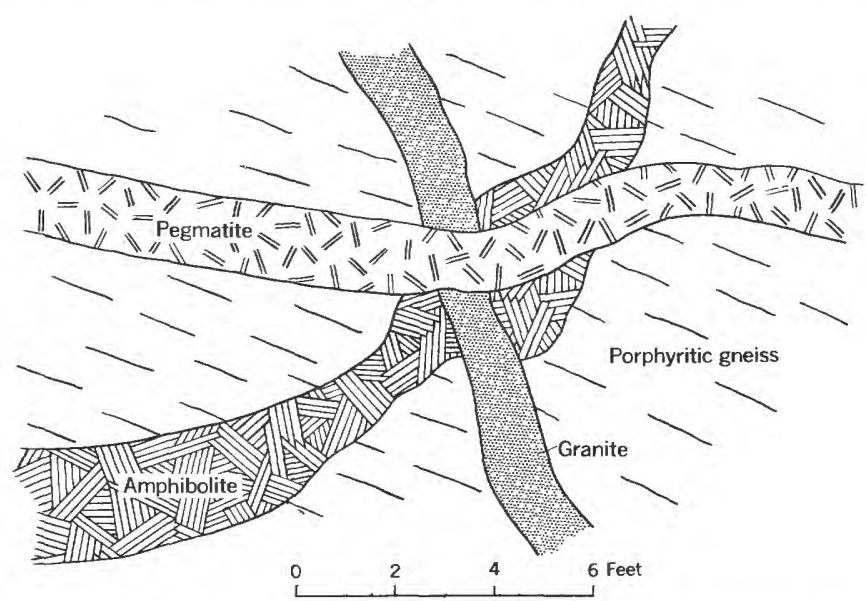

Frgure 69.--Sketch showing relations between dikes in outcrop near center of sec. 24, T. 42 N., R. $30 \mathrm{~W}$.

7. Granite dike cutting Randville dolomite at the Metronite quarry in sec. $26, T$. 42 N., R. 28 W. 


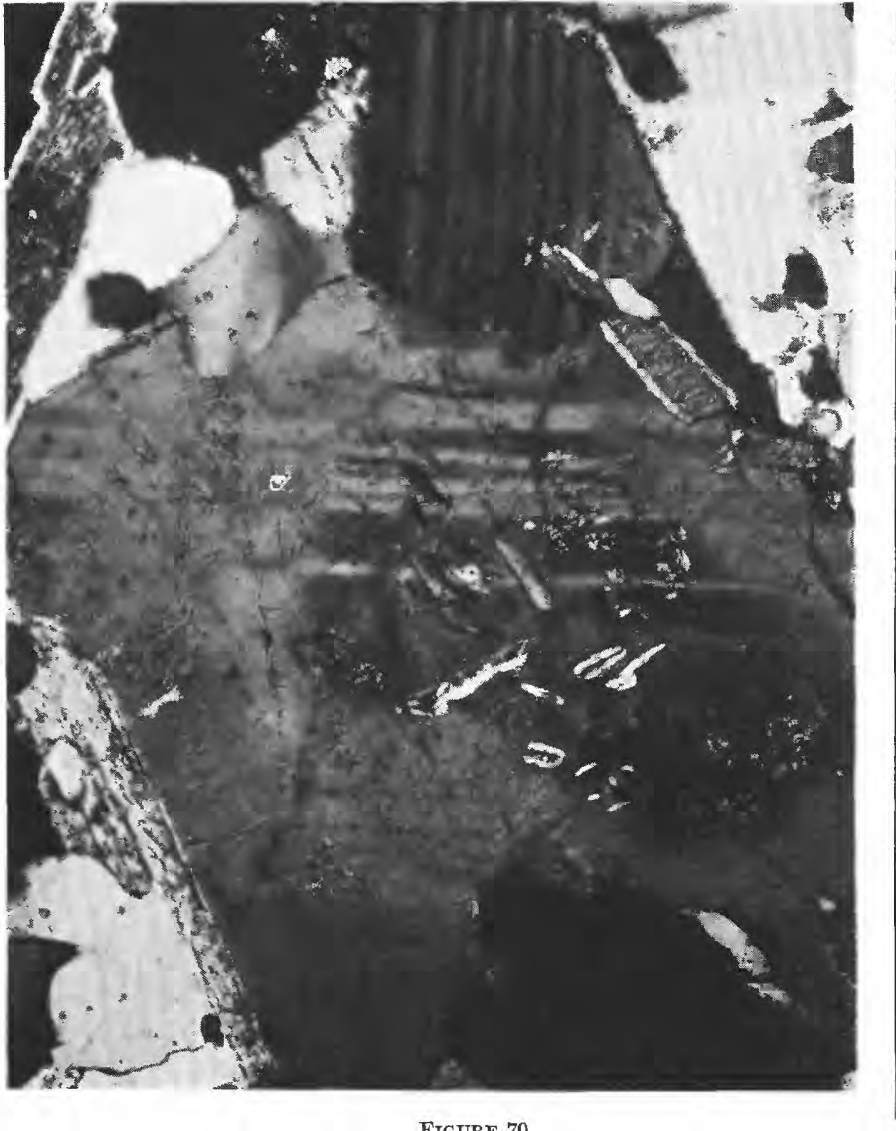

Figure 70

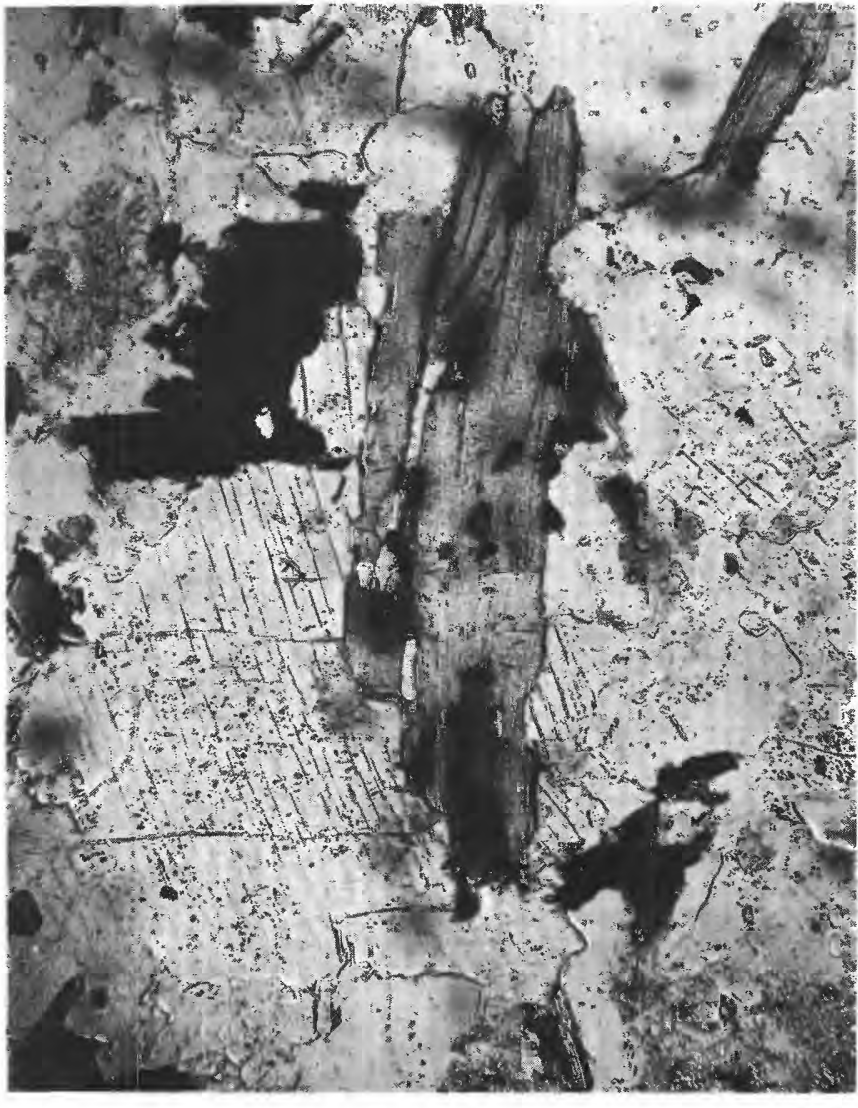

FigURE 71

FirURES 70, 71.-PHOTOMICROGRAPHS OF POST-ANIMIKIE GRANITE.

70. Faintly zoned oligoclase typical of younger granite. More calcic core partly altered to sericite. From dike cutting Sturgeon quartzite in sec. 12, T. 41 N., R. $30 \mathrm{~W}$. Crossed nicols, $\times 95$. Specimen HJ-220-48.

was collected by the late David Archie of Iron Mountain from the waste pile; the crystal has adhering pieces of the typical salmon-red albite, so it doubtless came from the core zone of the pegmatite. A similar beryl-bearing pegmatite has been quarried in the south part of sec. 30 , T. 42 N., R. 29 W.; it also contains dark partly chloritized garnets as much as an inch in diameter.

The granite is typically gray to red, equigranular, and fine to medium grained, though in a few dikes the rock has coarse-grained pegmatitic patches. Miarolitic cavities are not common except in dikes that are transitional into pegmatite; in the dike at the Metronite quarry (see fig. 67) a few cavities were lined with clusters of small flesh-colored cubes of fluorite. The microscope shows the texture of the granite to be hypidiomorphic granular. Plagioclase (oligoclase), perthitic microline, quartz, biotite, and muscovite are the essential minerals; the last two minerals are scarce in some dikes, particularly
71. Biotite showing pleochroic halos around tiny sphene or zircon inclusions. Typical of the younger granite. Ordinary light, $\times 95$. Specimen HJ-222a-48.

those in the Felch district. Commonly the plagioclase shows a slight but definite gradational zoning (fig. 70), with the more calcic cores being somewhat sericitized. Small amounts of epidote and chlorite (after biotite) are generally present. Myrmekitic intergrowths of quartz and albite are not uncommon, and in many sections examined the biotite is darkened by pleochroic haloes caused by tiny inclusions of sphene or zircon (fig. 71). An analysis of this postAnimikie granite follows.

\section{Analysis of a post-Animikie granite}

[Medium-grained gray granite, from dike cutting Randville dolomite in NE1/4 sec. 11, T. 41 N., R. 30 W. Specimen HJ-232-48. Analyst: Leonard Shapiro, U.S. Geological Survey]

\begin{tabular}{|c|c|c|}
\hline $\mathrm{SiO}_{2} \ldots \ldots$ & 70.09 & $\mathrm{H}_{2} \mathrm{O}-\ldots$ \\
\hline $\mathrm{Al}_{2} \mathrm{O}_{3}$ & 15. 46 & $\mathrm{H}_{2} \mathrm{O}+\ldots$ \\
\hline $\mathrm{e}_{2} \mathrm{O}_{3} \ldots \ldots \ldots$ & 1. 92 & $\mathrm{TiO}_{2} \ldots$ \\
\hline $\mathrm{FeO}_{\ldots} \ldots$ & 2. 46 & $\mathrm{P}_{2} \mathrm{O}_{5}$ \\
\hline $\mathrm{IgO}_{\ldots} \ldots \ldots$ & .31 & $\mathrm{CO}_{2} \ldots \ldots$ \\
\hline $\mathrm{aO}_{\ldots} \ldots$ & 2. 26 & $\mathrm{MnO}_{\ldots} \ldots \ldots$ \\
\hline $\mathrm{a}_{2} \mathrm{O}_{-}$ & 4. 10 & \\
\hline 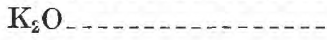 & 2. 20 & \\
\hline
\end{tabular}




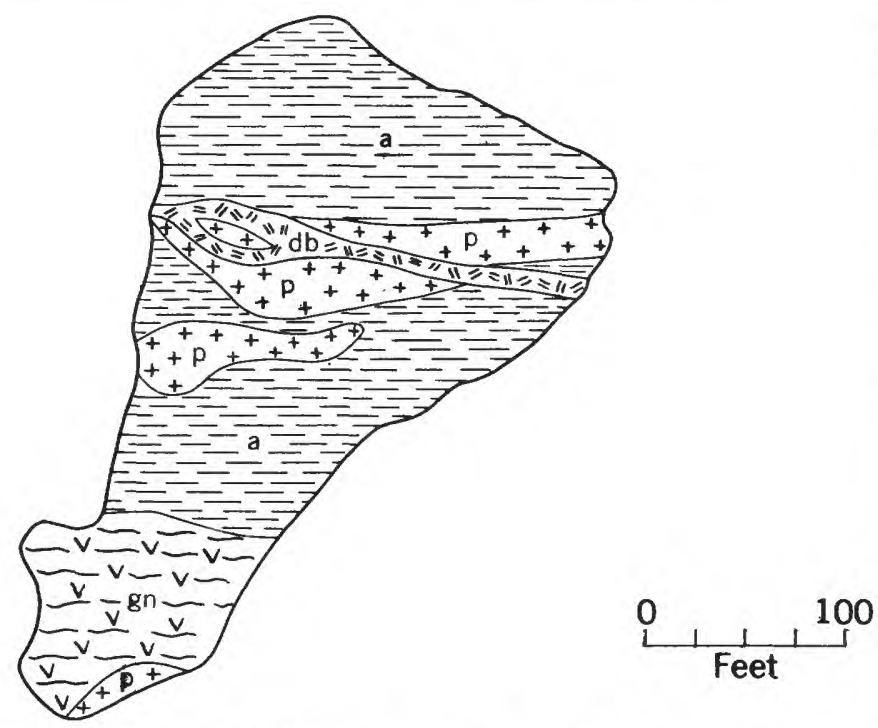

Figure 72.- Sketch of outcrop near the north quarter corner, sec. 2, T. 41 N., R. 28 W., showing post Animikie pegmatite (peg) cutting pre-Animikie amphibolite $(a m)$ and granite gneiss $(g n)$ and in turn being cut by Keweenawan diabase $(a b)$.

The hornblende diorite crops out in secs. 29 and 30, T. 42 N., R. $30 \mathrm{~W}$. The rock is a medium- to coarse-grained diorite, in part pegmatitic, rather dark on fresh fracture but weathering to a lighter color. It consists of about 75 percent plagioclase in discrete crystals with a purplish hue, and needles or plates of black hornblende. Under the microscope, the texture is hypidiomorphic granular. Biotite and quartz are present in minor amounts; the latter is present chiefly as bleblike inclusions in the hornblende. The plagioclase is andesine in unaltered subhedral crystals with complex twinning habit. Some of the crystals are faintly zoned. Magnetite occurs as an accessory, typically surrounded by clusters of sphene. The pegmatitic parts are much more irregular in texture. Quartz is more abundant, and garnet is present as small clear grains.

\section{AGE RELATIONS}

Except for the Keweenawan diabase dikes, described below, the pegmatite and granite are the youngest of the Precambrian rocks in this region. They show no deformational effects and clearly were intruded later than the late Middle Precambrian orogeny. Figure 72 is a sketch showing relations between diabase, pegmatite, and gneiss in sec. $2, \mathrm{~T}$. 41 N., R. 28 W. The pegmatite and granite appear to have been intruded later than the thermal metamorphism of the region, which itself is later than the structural deformation, at least in part of the area. However, even though the dikes now exposed are not the cause of the metamorphism, both the granitic intrusion and the metamorphism doubtless were consequences of the same deep-seated thermal activity.

The relationship between the granite and the pegmatite is not entirely clear. In areas where both pegmatite and granite are present, the two are similar in habit but do not intersect. In T. 42 N., R. 30 W. the pegmatite cuts finer grained dikes of aplitic aspect (fig. 69). The absolute age of the postAnimikie granitic rocks probably is 1,700 to 1,800 million years (James, 1958).

\section{UPPER PRECAMBRIAN ROCKS (KEWEENAWAN)- DIABASE}

The youngest Precambrian rock known in central Dickinson County is unaltered diabase of Keweenawan age. The rock forms narrow widely scattered dikes, the most accessible of which is exposed adjacent to County Road 581, a short distance north of the center of sec. 29 , T. 42 N., R. 28 W. Other dikes are present in the southern part of secs. 31 and 32 , T. 42 N., R. 28 W., and in sec. 35 of the same township. A 3-foot, eastward-trending dike cuts the granite gneiss in the $\mathrm{NE}^{1} / 4 \mathrm{NW}^{1} / 4$ sec. $14, \mathrm{~T} .41 \mathrm{~N}, \mathrm{R}$. $30 \mathrm{~W}$. A tiny dike of basalt, only an inch or so in width, cuts older metadiabase in the outcrop adjacent to the Felch post office.

The rock ranges from dense basalt to fine-grained diabase, depending upon the width of the dike. Most dikes are moderately magnetic, and the largestthat in sec. 29, T. 42 N., R. 28 W.--is inversely polarized so that it yields a negative magnetic anomaly. This peculiar property is also shown by fresh diabase dikes of this age in other parts of Michigan (Balsley, James, and Wier, 1949). The rock is composed chiefly of augite and labradorite. Interstitial micropegmatite composed of vermicular quartz and sodic plagioclase is common, generally associated with needles of apatite, rare zircon, and skeletal crystals of magnetite-ilmenite.

The age relation of the diabase to the upper Middle Precambrian granitic rock is clearly shown in outcrops in sec. 2, T. 41 N., R. 28 W., illustrated in figure 72 , where the diabase cuts the pegmatite.

\section{ROCKS OF PALEOZOIC AGE}

Flat-lying or low-dipping strata of Cambrian and Ordovician age rest with profound unconformity on the beveled edges of the Precambrian rocks. These younger rocks occur as isolated patches that increase in size to the east, and a short distance beyond the margin of the map area the Paleozoic mantle is unbroken. The distribution within central Dickinson 
County is shown on figure 2. The best exposures of the rock are in roadcuts in sec. 4, T. 42 N., R. 30 W.; in roadcuts in the south part of sec. $12, \mathrm{~T} .41 \mathrm{~N} ., \mathrm{R}$. $27 \mathrm{~W}$.; and along the broad hill 2 to 3 miles west of the town of Felch.

Gray to buff sandstone is the predominant rock; it consists of well-sorted well-rounded quartz grains loosely cemented to a friable aggregate, though in some outcrops the rock is well cemented and massive. Thin sections of such material show quartz grains in a matrix of dolomitic carbonate that embays the quartz in irregular fashion. Rhomb-shaped crystals of feldspar are numerous in the dolomitic carbonate; in large part at least they are due to overgrowths on original clastics grains, as many contain cores showing microline twinning.

The sandstone typically forms beds 1 to 3 feet in thickness. Cross-bedding is common. Where underlain by resistant rock, such as Vulcan iron-formation or Sturgeon quartzite, the basal beds are coarsely conglomeratic, but these beds appear to be of only local extent. Where the basement rock is less resistant, the sandstone may be underlain by a sandy layer of lateritic red and yellow iron oxides, as in the northern part of sec. 32 , T. 42 N., R. 28 W., where the bedrock is Randville dolomite.

Paleozoic rock other than sandstone is present in sec. 36, T. 42 N., R. 29 W., where the Paleozoic strata form a broad high hill, and in poorly exposed beds south of Foster City. In sec. 36 the sandstone grades upward into crystalline dolomite through transition beds of sandy dolomite that in part are oolitic (fig. 73) and glauconitic. These transition beds are exposed in roadcuts about 400 feet south of the northeast corner of sec. 36. Higher on the hill in this same section the dolomite is well bedded, with a sugary texture. It contains scattered granules of glauconite. Algal structures are present in outcrops adjacent to the power line that crosses the crest of the hill.

The thickness of the beds now preserved is, of course, largely governed by the accidents of erosion. In sec. 36, T. 42 N., R. 29 W., the total thickness of beds is about 300 feet, of which probably 200 feet is sandstone. However, since the sandstone is a basal deposit on a surface of some relief, original thicknesses doubtless vary widely. In the Calumet district, drill holes in sec. 17, T. 41 N., R. 28 W., are reported to have cut as much as 270 feet of sandstone before entering Precambrian rocks.

Drilling has shown that sandstone occurs at depths of hundreds of feet below the surface of the Precambrian rocks, apparently as fillings of cracks and fissures in the Precambrian rocks. Such sandstone

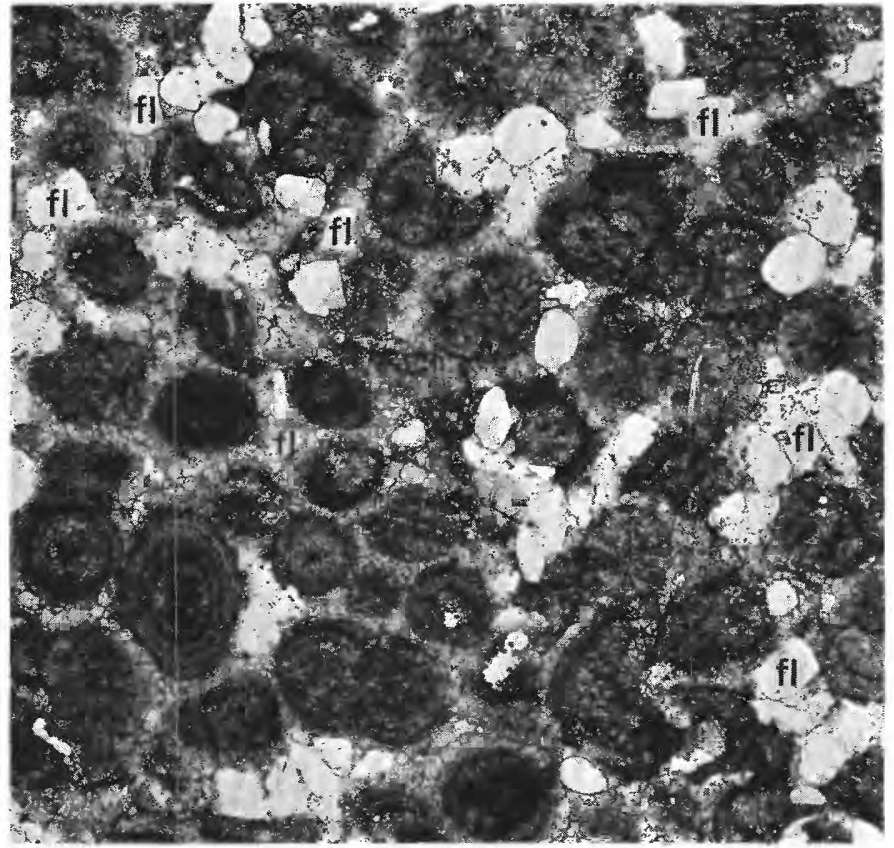

Figure 73.-Photomicrograph of sandy oolitic dolomite. Majority of clastic grains are clear quartz, but some are feldspar $(f l)$ with tabular or rhombic outlines due to overgrowth on original clastic core. Many of the ooliths show uniaxial cross under crossed nicols as a result of radial structure. Ordinary light, $X 25$. Specimen HJ-154-51.

fillings are particularly abundant in the vicinity of faults.

In Monograph 52 (1911), Van Hise and Leith refer to the sandstone of the Felch area as "Lake Superior sandstone, supposedly of Upper Cambrian age" (p. 304) and to that in the Calumet area as "Potsdam." The overlying dolomite is referred to as the Hermansville, of Cambro-Ordovician age. The distribution of Paleozoic strata in the Felch area is shown by Hamblin (1958, pl. 4), who classified the basal sandstone as Munising formation of Upper Cambrian age and the dolomite as Au Train formation of Middle Ordovician (Black River) age.

\section{STRUCTURE}

The distribution of rock units in central Dickinson County is governed chiefly by faults and folds that are of late Middle Precambrian origin, but a structural pattern that predates the Middle Precambrian is also evident in some areas. Later movements of slight importance along Precambrian faults have locally disturbed the overlapping Paleozoic strata.

The principal trend of structural elements of all ages is easterly, with a gradual swing to more northerly trends in both the eastern and western parts of the area. The pattern is dominated by a series of high-angle faults of large displacement. For convenience of discussion the area is divided into six 


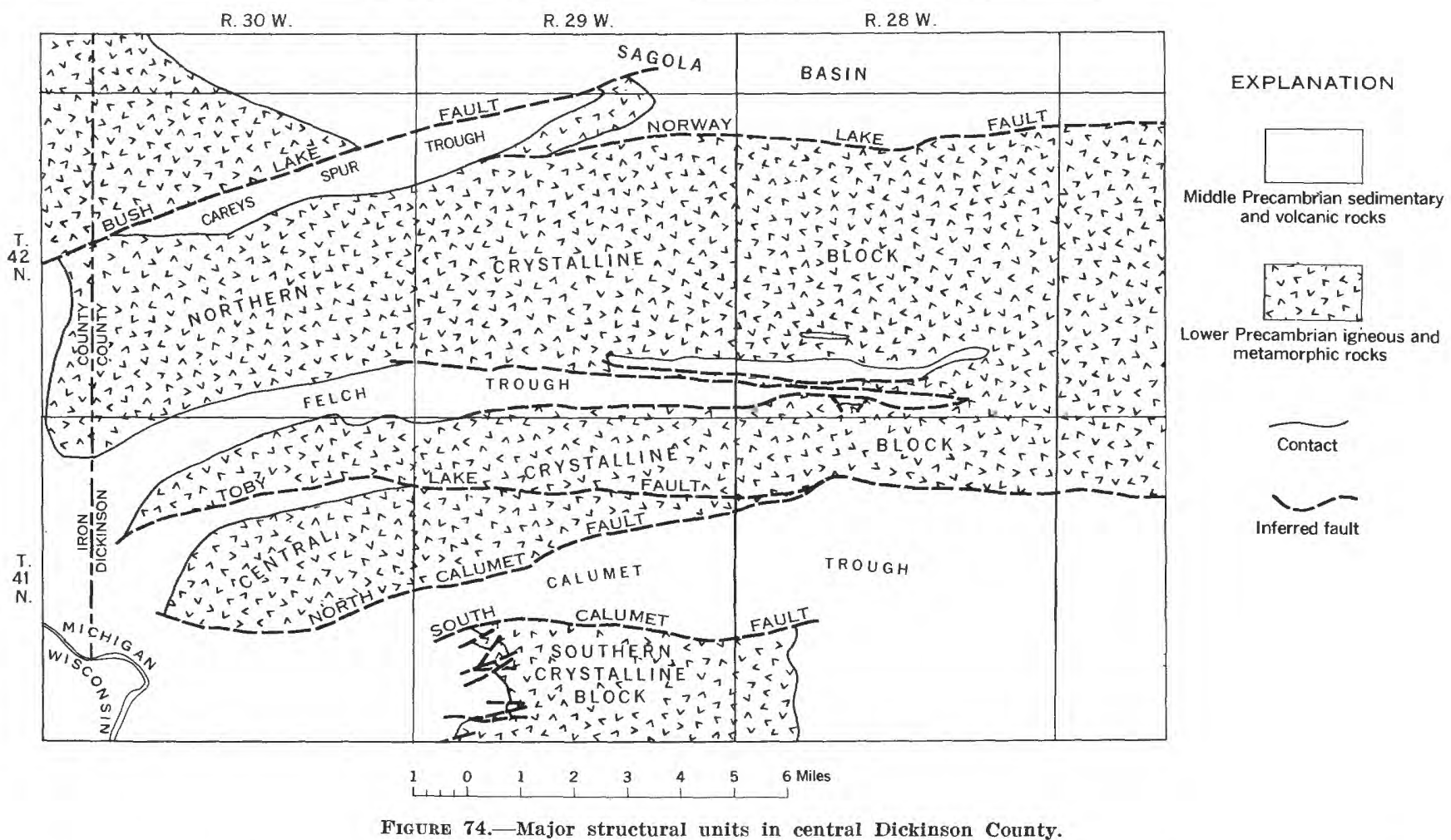

major structural units: the Sagola basin, the northern crystalline block, the Felch trough, the central crystalline block, the Calumet trough, and the southern crystalline block (fig. 74). These units are for the most part separated by major faults. In general, the faults are inferred chiefly on the basis of anomalous positions of the various stratigraphic and lithologic units. Only in a few places is there direct evidence of a fault, but as will be shown in the discussion following, the sum total of the indirect evidence is fairly conclusive.

\section{SAGOLA BASIN}

The Sagola basin referred to here is an extensive area of Animikie rocks in the northern part of Dickinson County and in adjacent parts of Iron County. The portion of the basin that lies within central Dickinson County is a complex structural unit, the southern boundary of which is poorly defined. Two faults are inferred, the Bush Lake fault and the Norway Lake fault; together they form the principal contacts between the sedimentary rocks and the crystalline block to the south.

The Norway Lake fault is fairly well defined in T. 42 N., R. 28 W., and T. 42 N., R. 29 W., where it separates Randville dolomite from granite gneiss and the East Branch arkose. In sec. 3, T. 42 N., R. $28 \mathrm{~W}$., the dolomite that is exposed contains undistorted stromatolites that show the top directions to be toward the deformed and metamorphosed older granite and arkose that are exposed only a few hundred feet to the south. The top directions of the dolomite rule out the possibility that the contact is one of unconformity, and a fault seems the proper explanation. Farther west, in secs. 1 and 2, T. 42 N., R. $29 \mathrm{~W}$., where the northerly trends of bedding in the dolomite are opposed to the general trend of the unit, a fault is again indicated. The fault probably continues westward into T. 42 N., R. 30 W., as the contact between the sedimentary strata of the Carey's Spur trough and the older crystalline rocks.

The Bush Lake fault is defined in T. 42 N., R. 30 W. chiefly on the basis of apparent truncation of southeastward-trending magnetic anomalies in the Sagola area. To the east the fault is inferred from outcrop relationship and drill-hole data in sec. 34, T. $43 \mathrm{~N}$, R. $29 \mathrm{~W}$., and adjacent areas. The most northerly of the drill holes in the $\mathrm{SE} / 4$ sec. 34 encountered red slate that probably is of the Michigamme slate, whereas those immediately to the south entered much older granite gneiss. The fault continues westward for several miles, across the Lake Mary quadrangle (Bayley, 1959, p. 99).

The structure of the strata within this block is very imperfectly known. That folds are present in the dolomite is quite apparent, especially in secs. 1 and 2, T. 42 N., R. 29 W., but no consistent trends can be established. Presumably, the granite gneiss 
mass in sec. 3, T. 42 N., R. 29 W., is an anticlinal block bordered by the unconformably overlying Randville dolomite (the Sturgeon quartzite appears to be absent throughout the Sagola basin). In the Sagola area (northern part of T. 42 N., R. 30 W.) the trend of the volcanic rocks of the Hemlock formation is established as northwest by scattered outcrops and magnetic anomalies; a northeast dip is indicated in outcrop and by the form of the magnetic profiles. The structure of the slates and graywackes is even more obscure than that of the Randville dolomite; folding is indicated by divergent strikes, but the information is far too scanty to permit structural analysis.

\section{NORTHERN CRYSTALLINE BLOCK}

The northern crystalline block is a lithologically heterogeneous unit. The principal rocks are the metamorphosed Lower Precambrian sedimentary and volcanic rocks of the Dickinson group, which rest unconformably on granite gneiss. These rocks grade southward into a banded gneiss believed to be related in origin to the emplacement of upper Lower Precambrian granite. In the western part of the area are large masses of red porphyritic granite, which probably are intrusive into the Dickinson strata.

The structural trends appear to predate the Animikie. The nearly vertical strata of the Dickinson group are disposed in linear belts that show little indication of internal folding. This linearity of the structure is shown most clearly by the Skunk Creek member of the Solberg schist as inferred from the magnetic anomaly caused by that bed. Except for a probable fault break near the center of T. $42 \mathrm{~N}$., R. $28 \mathrm{~W}$., this bed follows a nearly straight course for about 15 miles from the east edge of the map area into T. 42 N., R. 30 W. Beyond here the correlation of the anomaly is not clear, but almost certainly the bed itself continues to the west margin of Dickinson County, where it probably is erosionally truncated by Animikie strata. This unit, therefore, may be reasonably inferred to form a steeply dipping but otherwise unfolded belt 20 miles in length.

Faults parallel or nearly parallel to the trend of strata of the Dickinson group probably are common, though few have been mapped. One of these faults in the northern parts of T. 42 N., R. 28 W., and T. 42 N., R. 29 W. brings up a block of underlying gneiss in secs. 13, 14, 15, and 16, T. 42 N., R. 29 W., and appears to duplicate the East Branch arkose in T. 42 N., R. $28 \mathrm{~W}$. A small sliver of gneiss is present along the fault in sec. 10 of that township. A metadiabase dike follows the fault in secs. 7 and 8, T. $42 \mathrm{~N}$., R. $28 \mathrm{~W}$.
A narrow belt of vitreous quartzite can be traced for nearly a mile in secs. 28 and 2, T. 42 N., R. 28 W. The rock resembles the Sturgeon quartzite and probably represents an infolded or infaulted block.

The western part of the northern crystalline block is characterized by large masses of red porphyritic granite. Outcrops of the enclosing rock are so scarce that little can be determined directly as to the structural relations. As stated earlier in this report, the granite bodies may be actually pre-Dickinson in age, but their present mineralogic composition and texture were developed during the post-Dickinson, pre-Animikie, epoch of metamorphism. Structural trends indicated by the aeromagnetic survey show some deflection around the granite masses, especially on the south flank of the major body. The internal structures of the red porphyritic granite bodies seem to have relatively little relationship to the structural patterns shown by rocks in other parts of the area. The foliation of the largest mass is nearly parallel to the inferred boundaries, and the dips are steeply outward, thus defining a broad domal structure. Linear elements, such as elongation of quartz and feldspar, plunge steeply downdip. The foliation (fig. 25) is a deformational feature defined by augenshaped feldspars and biotite-plaited S-planes; the granulated boundaries of the augen indicate that the deformation was either contemporaneous with or later than the formation of the feldspar. The lack of correlation between the linear structures in the granite with that shown by the banded gray gneiss to the south is puzzling, as both probably are of equivalent age. Possibly steeply dipping borders to the domes exerted an overriding influence on the regional strain pattern.

Rock of Animikie age appears to occupy a narrow trough which extends from sec. 16 , T. 42 N., R. 30 W., northeastward into the northwest part of T. 42 N., R. $29 \mathrm{~W}$. This area, scarcely a mile wide, is here referred to as the Carey's Spur trough. The rocks within this trough are very poorly exposed. Randville dolomite crops out along the railroad track in sec. 16 , T. 42 N., R. $30 \mathrm{~W}$. and in the $\mathrm{NW}^{\mathrm{T} / 4} \mathrm{NE}^{\mathrm{T} / 4}$ of the same section. The dolomite of these outcrops is fine grained and quite unlike the coarse marbles of the Felch trough. In sec. 11 and also in sec. 1 are small outcrops of fine-grained and chertlike rock that is interpreted as silicified dolomite. In one outcrop it has the brecciated structure characteristic of parts of the Randville. Judged from the trend of these outcrops the strike is about N. $80^{\circ}$ E.

An outcrop of quartzite, referred to as Ajibik quartzite, is shown on plate 3 of U. S. Geological 


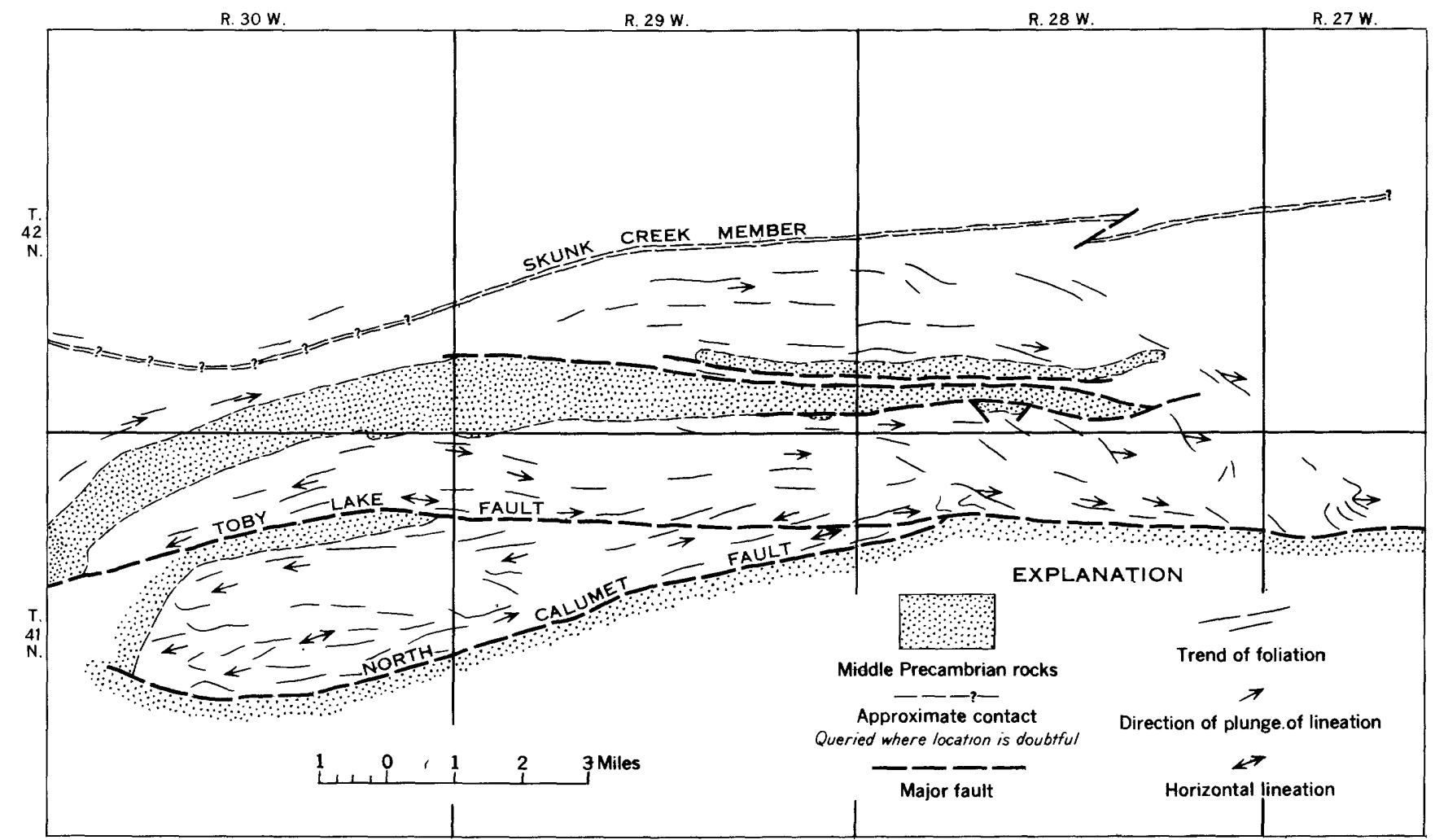

Figure 75.-Sketch showing structural elements in the central erystalline block and area adjacent to the north. Middle Precambrian rocks stippled.

Sürvey Monograph 36 (Clements and Smyth, 1899). The supposed outcrop occurs near the center of sec. 16 , T. 42 N., R. 30 W. An extended search of this areanow largely cleared of forest-failed to disclose any outcrop. The absence of any important magnetic anomaly in the Carey's Spur trough and the narrowness of this structure lead to the conclusion that the structure is a shallow one containing only dolomite.

The Carey's Spur trough appears to transgress the structural trend indicated by magnetic anomalies in the schist complex to the northwest. The contact between the rocks in it and the schist is probably a fault.

At both the southwest and southeast parts of the northern crystalline block, the trend and foliation of the Six-Mile Lake amphibolite and the banded gray gneiss show a progressive divergence from the more northerly (lower) beds of the Dickinson group. This divergence is shown in relation to structural features of the central crystalline block in figure 75 . In T. 42 N., R. 28 W., the Skunk Creek member strikes uniformly about N. $80^{\circ} \mathrm{E}$., whereas the trend of the amphibolite and gneiss gradually swings from easterly to about S. $60^{\circ}$ E. Some of this spread may be accounted for by the stocklike mass of metadiabase in secs. 11 and 14 of this township, but even discount- ing the intrusive, the distance between the East Branch arkose and the Six-Mile Lake amphibolite increases from about 1 mile at the west edge of the township to about 3 miles at the east edge. Probably the V-shaped pattern is not due to folding, for the magnetic anomaly of the Skunk Creek member, which follows the north branch of the "V", has no counterpart in the southeasterly branch. Furthermore, the distance of the Skunk Creek member from the East Branch arkose also shows progressive increase to the east. The divergence is not as clearly shown at the west end of the northern crystalline block, in part because of the scarcity of data, but is equally as strong. The magnetic anomalies in the southwest part of T. 42 N., R. 30 W., strike west or even northwest, whereas the foliation of the gray gneiss swings from west to S. $40^{\circ} \mathrm{W}$. In neither eastern nor western areas is the spread between the contacts due to lessening of dip.

The divergence probably is part of the deformational pattern surrounding the post-Dickinson granite mass to the south. The planar and linear structures appear to define an elongate dome (see fig. 75), with a major axis near and more or less parallel to the present south margin of the central crystalline block. In such a structure, beds may be greatly 


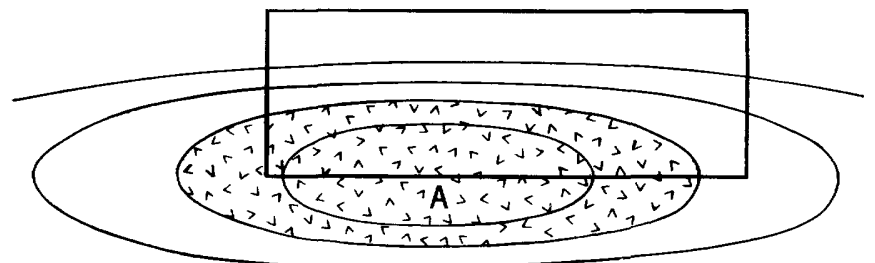

FigURE 76.- Sketch showing possible structural pattern in and around a domelike intrusion (A). In heavy lines is outlined an area with structure somewhat comparable to that shown in figure $\mathbf{7 5}$.

thinned along the flanks and thickened elsewhere. The pattern produced is that of a series of ellipses of increasing ratio of long to short axis, as shown diagrammatically in figure 76 . The actual structural pattern would, of course, be much more complex on account of inhomogeneities in the preexisting lithologic and structural units. Furthermore, the pattern may be distorted by the presence of other domes in adjacent areas. The south-facing bulge shown by the magnetic anomalies in secs. 27,28 , and 29, T. 42 N., R. $30 \mathrm{~W}$., probably reflects the structural influence of the mass of red porphyritic granite to the north, which would distort the pattern whether it is older than Dickinson group or intrusive into it.

\section{FELCH TROUGH}

The Felch trough is essentially a synclinal structure that extends as a narrow belt across the middle of central Dickinson County. At no place is it more than a mile wide. At the east end it terminates against older gneiss; the :west end is probably truncated by unconformably overlying strata of the Baraga group. The north boundary may be in part a normal sedimentary contact between the basal Animikie strata and the older gneiss, but in part it is a fault. The south boundary of the trough is definitely a fault in the eastern part of the area, and is possibly a fault in the western part. For purposes of description, the trough is divided into three segments: the western, the central, and the eastern.

\section{WESTERN SEGMENT}

The western segment extends from sec. 12, T. 41 N., R. 31 W., at the west edge of the map area, northeastward into the north part of sec. 36, T. 42 N., R. $30 \mathrm{~W}$., where it overlaps the west end of the central segment. The main structure is a complex syncline, here referred to as the Randville syncline, which is marked by canoe-shaped patches of infolded Vulcan iron-formation that extend from sec. 5, T. $41 \mathrm{~N}$, R. 30 W., into sec. 36 , T. 42 N., R. 30 W. Southwest of sec. 5, magnetic anomalies, plus a few outcrops and one drill hole, indicate that the Felch formation is present in a broad syncline in which the schist is repeated in close folds. The Randville syncline, as well as the related synclines to the southwest, must. change direction of plunge several times. The axial plane of the syncline is inclined to the north, as indicated by the northward-dipping dolomite belt in secs. 34, 35, and 36, T. 42 N., R. 30 W. The dolomite that presumably forms the south flank of the syncline is known for certain only in sec. 5, T. 41 N., R. 30 W., and in the SEx/4 sec. 34 , T. 42 N., R. 30 W., where it has been penetrated by drill holes.

A fault quite possibly separates the northwarddipping beds of the trough from the belt of southward-dipping (overturned) Sturgeon quartzite that forms the south border of the trough, but no direct evidence is available. The nature of the contact between the granite gneiss and the belt of Sturgeon quartzite at the south margin of the trough is not known. The outcrop relationships in the south part of sec. 35, T. 42 N., R. 30 W., and the adjacent parts of sec. 2, T. $41 \mathrm{~N}$., R. $30 \mathrm{~W}$., suggest a sedimentary contact in this area, but the general scarcity of outcrops of granite gneiss adjacent to the quartzite-as compared, for example, with the more southerly belts of Sturgeon quartzite-indicates the possibility of a shear zone or fault in the covered ground. Such a fault could be the westward extension of the fault that forms the south boundary of the eastern part of the trough. Magnetic surveys show three welldefined magnetic anomalies in this covered area. The anomalies are arranged in echelon, at a small angle to the trend of the quartzite. Elsewhere in the region, magnetic anomalies of comparable magnitude are known to be related to metadiabase dikes, and it is possible that the anomalies in question are also due to moderately magnetic metadiabase dikes that have been intruded along a shear or fault zone.

\section{CENTRAL SEGMENT}

The central segment of the Felch trough extends from sec. 36, T. 42 N., R. 30 W., through the Groveland mine area, into sec. 35, T. 42 N., R. 29 W. The principal structure is the Groveland syncline, which, like the shallower Randville syncline to the west, contains several elongate patches of infolded Vulcan iron-formation. The synclinal structure is most clearly shown in the Groveland mine area, where outcrops, drill holes, and test pits have established contacts with the Randville dolomite on both the north and the south flanks (fig. 77). This is also the deepest part of the structure; it contains the greatest thickness of iron-formation in the Felch trough. The syncline is overturned, with a northward-dipping axial plane, and is doubtless complex, with folds of 


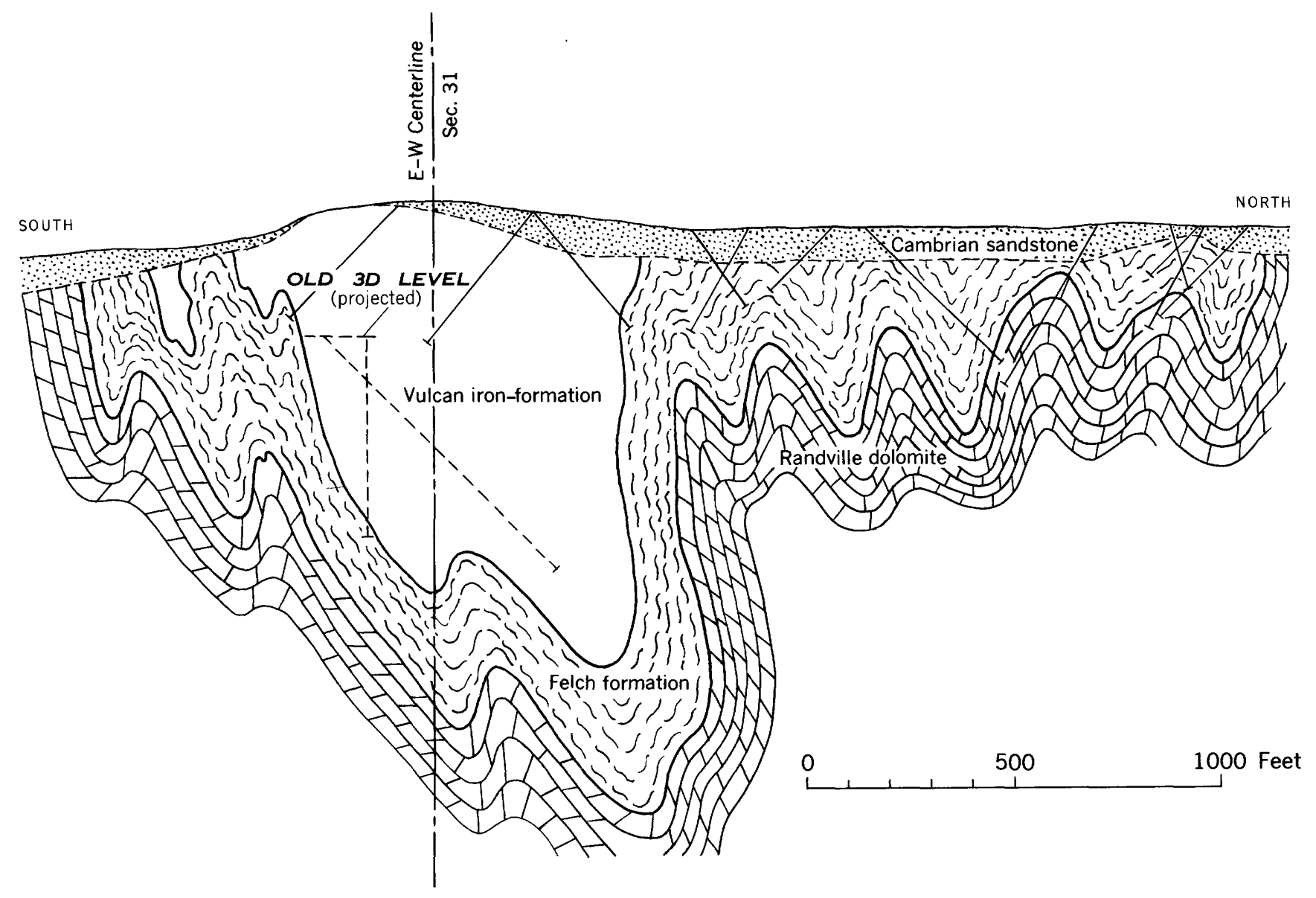

FrgURm 77.-Cross section of the Groveland area. Line of section is 3,000 feet east of west margin of sec. 31 , T. 42 N., R. 29 W.

several orders of magnitude. Some faults are almost certainly present. The plunge of the structure, as indicated by the inferred distribution of the Vulcan iron-formation, is undulating, but in general it is toward the Groveland mine area. As a result of the general westward plunge of the eastern part of the syncline, the Randville dolomite and the Sturgeon quartzite appear in the central parts of the trough in secs. 34 and 35, T. 42 N., R. 29 W.

The north and south flanks of the syncline are entirely inferred for a distance of nearly 3 miles east of the Groveland mine. The syncline is bounded on the north by a probable fault, a fault that is indicated at the east end (in sec. 35) by the presence of Randville dolomite within a few hundred feet of Lower Precambrian banded gneiss.

The Sturgeon quartzite that crops out south of the Groveland mine and continues to the east may not be structurally continuous with the belt of Sturgeon quartzite that forms the south border of the trough west of the Groveland. The western part of the quartzite belt is overturned, whereas the eastern part-to judge from the few observations available- is not. The nature of the contact between the east belt of quartzite and the granite gneiss to the south is not known; indeed, the presence of quartzite itself is largely inferred. On the maps the contact is shown as a normal sedimentary contact, but it may be the continuation of the fault to the east that is the boundary between the granite gneiss and the younger sedimentary rocks.

\section{EASTERN SEGMENT}

The eastern segment, lying between the Sturgeon River in sec. 35 , T. 42 N., R. 29 W., and the east end of the trough in sec. 26 , T. 42 N., R. 28 W. is a complex unit. It appears to consist of two faulted synclines separated by a narrow upthrust block of granite gneiss. The evidence for the block of gneiss is meager but consistent: gneiss is exposed in the NWI $/ 4$ sec. 35, T. 42 N., R. 29 W., with Randville dolomite a short distance to the north and south; granite and amphibolite are exposed just north of the center of sec. 32, T. 42 N., R. 28 W., with Randville dolomite a short distance to the north and Felch formation short distance to the southeast; in the 


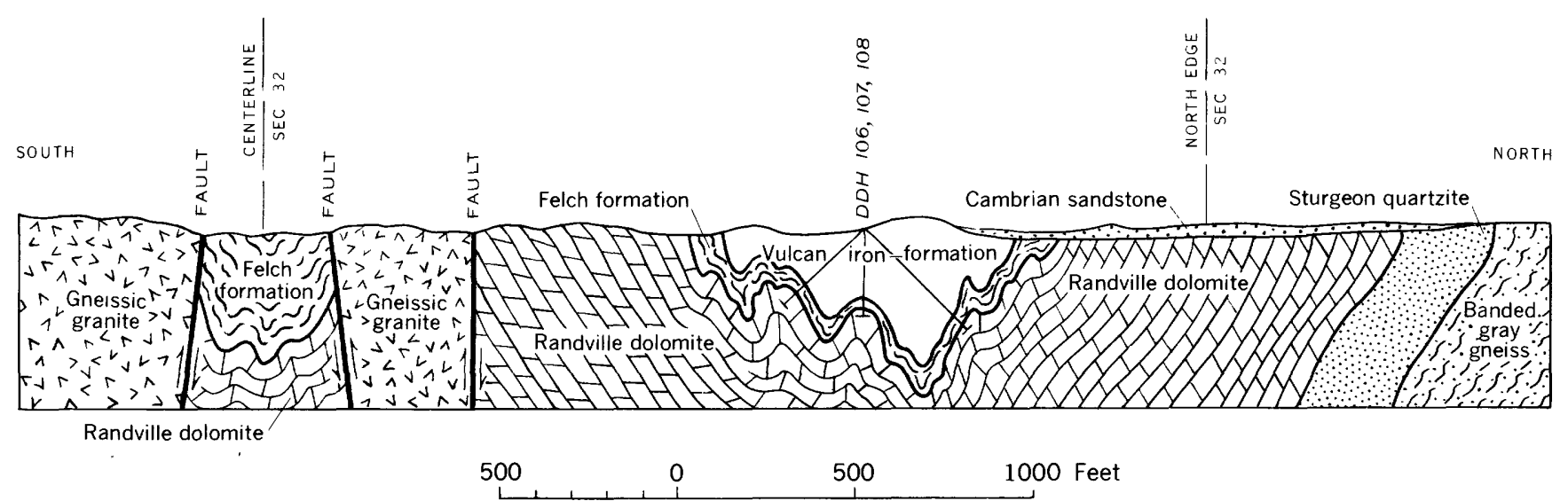

Figure 78.-Cross section of Felch trough. Line of section is 265 feet west of N-S center line of sec. 32 , T. 42 N., R. 28 W.

SE $1 / 4 \mathrm{NW}^{1} / 4$ sec. 34 , T. 42. N., R. 28 W., granite and amphibolite crop out, with Sturgeon quartzite to the north and Vulcan iron-formation, Felch formation, and Randville dolomite (known from drilling) to the south.

The north syncline-for convenience referred to as the Felch ridge syncline-is deepest in the immediate vicinity of the village of Felch. The structure of the Vulcan iron-formation has been proved by extensive drilling; a typical cross section is shown in figure 78. Beyond the west end of the Vulcan iron-formation in sec. 32, information is very scanty for a distance of more than 2 miles. Parallel belts of quartzite and dolomite are inferred, but their existence is by no means certain. Judged from the evidence at the west end of this belt, the syncline is gradually truncated by a nearly parallel fault, which, in the $\mathrm{NW} / 4$ sec. 35, T. $42 \mathrm{~N}$., R. $29 \mathrm{~W}$., separates dolomite from the medial block of granite gneiss. Evidence is also scanty concerning the east end of the syncline. It is assumed that the Randville dolomite, so well exposed at the Metronite quarry, is contained in a tight overturned canoe-shaped syncline, but the north flank and the eastern closure of Sturgeon quartzite are entirely inferred.

The south part of the eastern segment of the Felch trough appears to have a general synclinal structure, which is shown most clearly by the Vulcan iron-formation exposed in the $\mathrm{SE} / 4$ sec. $33, \mathrm{~T} .42 \mathrm{~N}$., R. $28 \mathrm{~W}$. In the outcrop area, the iron-formation is crenulated, so that although the individual dips are steep, the over-all aspect is one of nearly flat-lying strata and the syncline is shallow. Drilling east of the main outcrop area of Vulcan iron-formation shows that Randville dolomite is present at relatively shallow depth. Also shown on the map and cross section is a minor syncline that places Vulcan ironformation within less than 50 feet of the granite gneiss, from which it is separated by a major fault.
The continuation of the magnetic anomaly related to the Vulcan iron-information and the Felch formation into the area of sec. 35 , T. 42 N., R. 28 W., known to be underlain by granite gneiss, poses a problem. A possible solution is that the faults, though steep, may dip away from each other at sufficient angle so that their intersection plunges at a low angle to the east, permitting a wedge-shaped body of Felch formation to be preserved below this intersection. This entrapment at depth of a block of younger rock could be due to nonsimultaneous development of the fault pattern, as shown in figure 79.

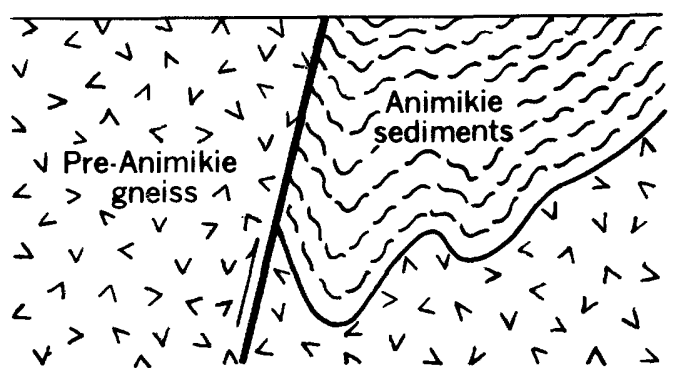

A

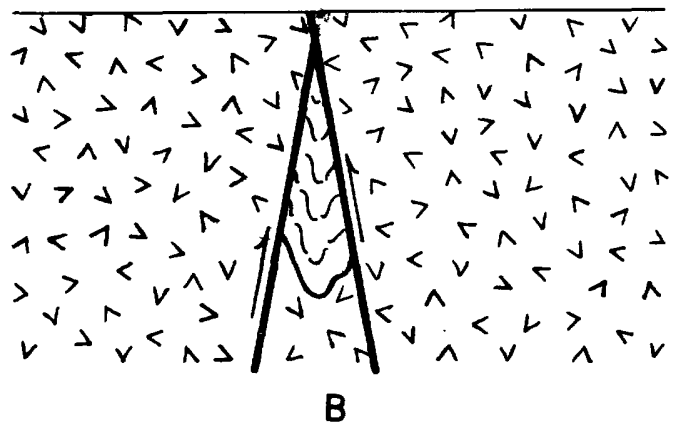

Frgure 79.- Sketch showing how a block of younger rock may be trapped by nonsimultaneous development of faults. Southward-dipping fault, shown in $A$, developed first; fault with north dip $(B)$ developed later. 


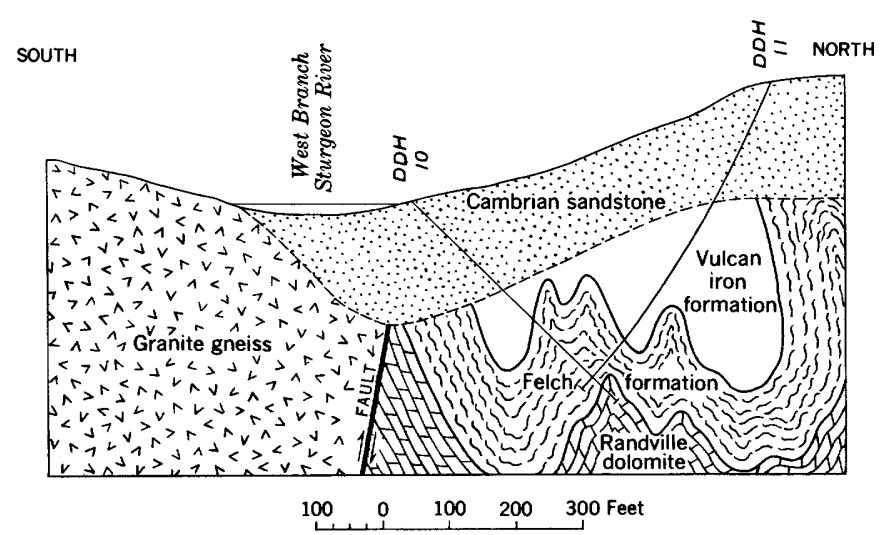

Frgure 80.- Section across Sturgeon Pond drill holes, SW $1 / 4$ sec. 31 , T. 42 N., R. 28 W. Line of section is 500 feet east of the west edge of sec. 31 .

West of the iron-formation outcrop area in the SEx 14 sec. 33, T. 42 N., R. 28 W., Felch formation appears to be the only rock exposed at the surface in the syncline for a distance of about 2 miles, except for a very small area of Vulcan iron-formation about 1,300 feet west of the east quarter corner of sec. 32, T. 42 N., R. 28 W. (not shown on pl. 2). The Felch formation, which consists principally of magnetitebearing micaceous quartzite in this area, probably occupies a broad outcrop area in part because of complex folding, and in part because of a greater than normal thickness. The Felch formation is entered by a number of drill holes in the east part of sec. 31, T. 42 N., R. 28 W., west of which the structure again deepens so as to contain Vulcan ironformation. The wide arc of Randville in sec. 36, $\mathrm{T}$. $42 \mathrm{~N}$., R. $29 \mathrm{~W}$., is almost entirely inferred, the only direct evidence being that from drill holes in the SWr $/ 4$ sec. 31, T. 42 N., R. 28 W. (fig. 80). The inference is based mainly on the knowledge, from drill holes and from the magnetic data, that Vulcan iron-formation and Felch formation occupy the syncline in sec. 31, T. 42 N., R. 28 W., and that Sturgeon quartzite is present along the strike of the belt in sec. 35, T. 42 N., R. 29 W. Between these strata must be Randville dolomite although the boundaries are purely hypothetical.

Except at the east end, the position of the fault that forms the south boundary of the trough with the granite gneiss is closely established in the segment of the Felch trough under discussion. The fault was crossed by a drill hole near the center of sec. 32, T. $42 \mathrm{~N}$., R. $28 \mathrm{~W}$; the hole drilled at $-45^{\circ}$ to the south started in Felch formation, passed through a zone of schist, pegmatite, and quartz veins, entered a breccia zone containing coarse tremolitic dolomite and possible quartzite, then entered granite gneiss. In sec. 31 , T. 42 N., R. 28 W., a hole 1,300 feet weșt,
880 feet south of the center of the section, was drilled at $-45^{\circ}$ south; it cut Vulcan iron-formation and Felch formation to a hole depth of 289 feet, then entered sandstone of Cambrian age, which continued to the end of the hole at 315 feet. The sandstone presumably is a fissure filling or clastic dike along or adjacent to the fault.

Of interest is the fact that bedded sandstone (Cambrian) is present for long distances along the north side of the fault, and that it dips northward at angles typically more than $20^{\circ}$. Lamey believes this dip is due to post-Cambrian movement along the fault, but in part the steep dips may be initial dips against the steep slope of the granite gneiss; evidence from the drilling in sec. $31, T .42$ N., R. $28 \mathrm{~W}$., also suggests that locally a steep-walled valley may have been present on the Precambrian surface along the fault (see fig. 80).

\section{CENTRAL CRYSTALLINE BLOCK}

The central crystalline block is sharply marked off from the Calumet trough to the south by the North Calumet fault, and it is probably separated from the Felch trough to the north in large part by faults. Topographically, it is a rocky upland underlain chiefly by granite gneiss and associated rocks. The western half of the block is broken by the Toby Lake fault. The forked western end of the block is marked by a reentrant of Sturgeon quartzite that rests with profound unconformity on the gneiss. The Hardwood gneiss is at the eastern end of the block.

The fault that forms part of the boundary with the Felch trough to the north breaks across the gneisssediment contact in at least two places. In sec. 36 , T. 42 N., R. 29 W., a small patch of Sturgeon quartzite only'a few hundred feet across lies south of the fault. In secs. 32 and 33, T. 42 N., R. 28 W., the fault cuts off a block of Sturgeon quartzite, Randville dolomite, and Felch formation. The east end of this block is believed to butt against a northeastwardtrending cross fault that separates the dolomite at Rian's quarry from amphibolite in a quarry a few hundred feet to the east. Similarly, the west end is considered to be truncated by a fault, which places outcrops of dolomite and gneiss within 100 feet of each other.

The Toby Lake fault, in T. 41 N., R. 29 W., is marked by a south-facing scarp about 50 feet high that cuts the foliation at a small but definite angle. As the granite gneiss on both sides of the fault is equally resistant, the scarp is not the result of differential erosion; it is a true fault scarp, one that probably is due to post-Cambrian movement 
along an older fault plane. In T. 41 N., R. 30 W., the fault is clearly revealed by the wedgelike termination of the eastward-projecting belt of sedimentary strata in sec. 12, and the westward termination of the more northerly belt in sec. 18. The apparent offset along the fault, in a horizontal plane, is nearly 5 miles, but, as may be inferred from across section $A-A^{\prime}$ on plate 2, the actual displacement may not be more than about 5,000 feet if it is assumed that movement was of the dip-slip type. In the $\mathrm{NE} / 4 \mathrm{NE} / 4$ sec. 11, T. 41 N., R. 30 W., the fault separates Randville dolomite from the gneiss. The dolomite and associated rocks are strongly sheared and intruded by younger granite. To the east the fault merges with the North Calumet fault.

The North Calumet fault separates granite gneiss from the Michigamme slate or from sandstone (Cambrian) for most of its length. However, in sec. 15, T. 41 N., R. 29 W. (see pl. 4), Vulcan iron-formation is present as a narrow strip about 1,000 feet long south of the fault; and in sec. $8, T$. 41 N., R. 28 W. (pl. 4), a belt of older rocks that includes Randville dolomite, Felch formation and Vulcan iron-formation lies south of the gneiss for a distance of about 1 mile. The fault has been crossed by several drill holes at these localities.

The sec. 8 hole, drilled at $-45^{\circ}$ to the south, started in weathered granite gneiss and schist, passed through a zone of oxidized, sheared rock about 50 feet wide containing some sandstone (Cambrian), then entered Randville dolomite. The sandstone probably is fissure filling along the fault break.

The structure within the crystalline block has not been completely studied, but the information available is adequate to permit some analysis. The generalized features of the structure are shown in figure 75. The general pattern of planar and linear elements suggests that the central crystalline block may be a narrow slice of a much larger domelike structure that includes the area immediately north of the Felch trough. The Felch trough itself appears to be a relatively superficial feature that scarcely breaks the pattern of the older structure. The lineation, when considered in longitudinal section, describes a broad dome with a flat, somewhat undulating top. The planar elements describe a broad arc, convex to the north, with most of the north flank lying north of the Felch trough. The east part of the central crystalline block is a segment of the east flank of this dome. Linear structures of the gneiss in this area plunge consistently to the east for about 7 miles, and at the nose of the structure the Hardwood gneiss appears. The concordant sheetlike am- phibolite inclusions as much as 100 feet in thickness, which are contained in the granite gneiss, probably are relics of a pre-granite series of bedded rocks, suggesting that the Hardwood simply represents a higher stratigraphic zone-preserved either as a more extensive sheetlike mass or a remnant of the original roof of the batholith. Consideration of the western end of the block indicates that the structure may have been truncated by pre-Animikie erosion to a greater depth than at the east end; some complexity of trend is present, especially in secs. 20,21 , and $22, \mathrm{~T} .41 \mathrm{~N}$., R. $30 \mathrm{~W}$., but there is little to indicate that the west margin of the dome is being approached. Comparison with the eastern end suggests that the west flank would lie several miles farther to the west.

The two marginal belts of the Sturgeon quartzite in the western part of the area are amazingly similar in pattern: both are abut 6 miles long, are arcuate to the northwest, and are terminated at the southwest by faults. Furthermore, the strata in each are overturned so that they dip beneath the granite gneiss at angles as low as $30^{\circ}$. This structural pattern is not easily explained, particularly in view of the fact that both in the Calumet trough and in the Felch trough proper the folds in most places are overturned in the opposite direction-that is, the axial planes dip to the north. The possibility has been suggested that the two belts were originally continuous and that they have been separated by strike slip along the Toby Lake fault, but there is little in the pattern to support this view; if this were so, the southern belt would have a form that geometrically would be a continuation of the southwest end of the northern belt.

The explanation that seems most reasonable to the present writer is based on the assumption that the crystalline blocks were the controlling elements in the post-Animikie structural development and that under lateral compression these blocks overrode the adjacent sediments, first from the south, then from the north. The problem and possible solution are discussed at greater length later in this report, under "Summary and conclusions regarding structural development." In this area, the first phase in the deformation appears to have resulted from compression that was relieved by thrust movement along shears that dipped southward, with consequent development in the Middle Precambrian sedimentary mantle of overturned folds with axial planes dipping to the southeast. The two belts of overturned quartzite are considered to be remnants of these folds. At later stages, the crystalline blocks yielded along shears dipping in the opposite direction so that the mantling 
strata were broken by northward-dipping faults or compressed into folds with northward-dipping axial planes. The Toby Lake fault and the North Calumet fault are considered to be representative of these shears; the upthrown side of each is on the north.

\section{CALUMET TROUGH}

The structural unit designated as the "Calumet trough" is well defined only in its central part. In the western and southwestern part of the map area it merges with the broad area of eastern Iron County underlain by rocks of the Baraga group. The eastern limit of the trough is indefinite because of the overlapping mantle of Paleozoic strata. The northern boundary, except in the extreme western part of the area, is clearly marked by the North Calumet fault, which has been discussed in relation to the central crystalline block. The South Calumet fault forms the boundary for about 6 miles, separating the Animikie rocks of the trough from the granite gneiss of the southern crystalline block. The bedrock in the Calumet trough, so far as known, consists chiefly of Michigamme slate, with Randville dolomite, Felch formation, and Vulcan iron-formation locally present along the north margin.

Very little is known of the structure. In the major outcrop area-sec. 19, T. 41 N., R. 29 W., and secs. 23, 24, and 26, T. 41 N., R. 30 W.-the beds dip steeply to the north, and the top directions, as indicated by graded bedding, are consistently to the south. Such simplicity of structure probably does not hold generally for the Calumet trough. Close folding can be established in the Calumet mine area, even though details are uncertain or obscure, and probably a comparable complexity is to be found in most places. South of the Calumet mine area, principally in the central parts of T. 41 N., R. 28 W., a major anticlinal arch is suggested by the magnetic data and by scanty drill-hole data. The magnetic anomaly, which almost certainly is due to the Vulcan iron-formation, in general trends eastward, becoming lower and broader in each direction away from secs. 16 and 17, T. 41 N., R. $28 \mathrm{~W}$. The change in character of the anomaly. probably is due to plunge of the fold on which the Vulcan iron-formation reaches the sandstone-mantled Precambrian bedrock surface. The structure, as indicated by the magnetic anomaly, cannot be traced with certainty beyond the east and west margins of T. 41 N., R. 28 W.

\section{SOUTHERN CRYSTALLINE BLOCK}

The unit here referred to as the "southern crystalline block" of central Dickinson County is only a small part of a much larger crystalline massif that extends for at least 15 miles to the southeast (see Bayley, 1904; Trow, 1948; Higgins, 1947). The area has been studied in detail only in the marginal areas, chiefly along the west flank.

Except for the flanking belt of Sturgeon quartzite on the west, the block is underlain for the most part by granite gneiss, locally with layers of amphibolite. The gneiss is cut by many dikes of metadiabase, most of which yield moderate magnetic anomalies. Most of the dikes trend eastward or northeastward, and several cut the quartzite along the west flank. The granitic rock at the east margin of the block probably is unconformably overlain by sedimentary rocks of the Baraga group. If the Sturgeon quartzite were present in thickness comparable to that on the west margin, it almost certainly would be exposed, and the Vulcan iron-formation, if present, would yield a strong magnetic anomaly. Within the crystalline area the principal trend of foliation is easterly, with a gradual swing to northeast in the west part of the block so that in sec. 31 , T. 41 N., R. 29 W., the foliation is nearly parallel to the unconformably overlying belt of Sturgeon quartzite.

The complex fault pattern shown by the Sturgeon quartzite belt in secs. $19,20,29,30,31$, and 32, T. 41 N., R. 29 W., is not easily explained. The area, known as the Pine Creek area, is the northern end of a Sturgeon quartzite belt studied by Trow (1948) and Higgins (1947). An aerial photograph of this area is shown as figure 81 .

Faults are the most prominent structural features of the belt, but some folding is present. The trends of bedding, ignoring the faults, define an eastwardtrending syncline, overturned to the south and plunging west. The axial area of this syncline is in the northern part of sec. 32 , T. 41 N., R. 29 W. The faults can be divided into two sets, one of which is nearly normal to the strike of bedding, and the other, and much less conspicuous, is parallel to the strike. The cross-strike faults have offsets of as much as threefourths of a mile and truncate the faults that strike parallel to bedding. The offset on the latter faults is not known, but as a result of the movement virtually the entire thickness of the quartzite is repeated in the north half of sec. 29.

The structure of the area has been analyzed by Higgins (1947), who considered the offsets to be subsidiary tear faults related to a principal tear fault that terminates the Pine Creek belt on the north, and that prior to the faulting the quartzite was folded into a "monocline that faced southwest", the northwest part of which is represented by the quartzite in 


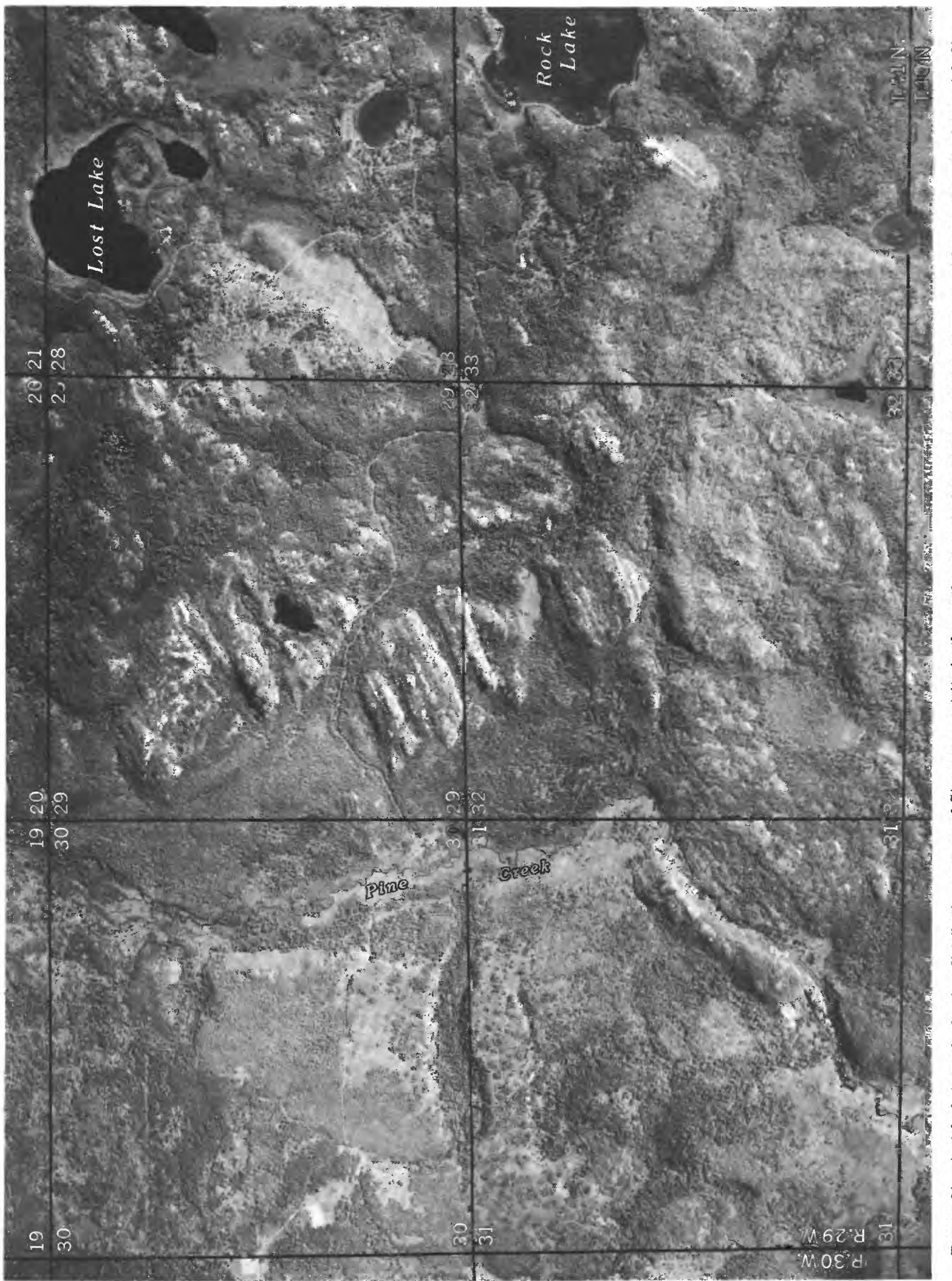


sec. 20, T. 41 N., R. 30 W. He states (p. 481) : "Although the present distance between the Pine Creek. and Browning Creek exposures of quartzite is about 6 miles, it is thought that, before faulting, the quartzites at these localities were connected parts of the Pine Creek monocline."; and (p. 489), "During the second phase of deformation this structure was displaced at its northwestern and southeastern ends by vertical tear faults that trend northeast. The aggregate displacement along faults at the northwestern end has been approximately 3.5 miles."

Several objections may be made to this concept, as follows:

1. The Pine Creek and Browning Creek segments cannot be restored to a continuous belt. Judging from figure 7 in Higgins' paper, these segments were considered to be separated by a single eastward-trending fault. Later mapping by Trow has shown that the areas are separated by two major faults, between which lies a broad belt of downfaulted Michigamme slate.

2. The Browning Creek belt strikes northeastward, whereas in the Pine Creek area the strikes are generally to the northwest. That this divergence is not simply due to fault twisting is suggested by the consistency of strike from fault block to fault block in the Pine Creek area.

3. The Pine Creek area is part of a belt that, in general, is overturned so that the beds dip steeply northeastward beneath the granite gneiss, whereas -the Browning Creek area is part of a belt in which the beds are overturned, also so as to dip beneath the granite gneiss but in an easterly or southerly direction.

Higgins presents a considerable body of petrofabric data, which is considered to support the concept of shear in a horizontal direction. Briefly, the diagrams of quartz-grain orientation in the quartzite show a girdle pattern in the horizontal plane, generally with two or four maxima. These diagrams are interpreted to indicate that the " $b$ " tectonic axis is vertical and that the " $a$ " axis of tectonic transport is indicated by the orientation of the maxima on the girdle. Considering the absence of megascopic evidence of horizontal shear in the direction of the maxima, and the variety of orientations that may be assumed by quartz, it would seem less hazardous to base conclusions regarding structure on other evidence. As stated by Cloos (1946, p. 32) : "The orienting mechanism of quartz is not fully understood; the interpretation of diagrams depends largely on hypothetical deductions." A more recent study by Balk (1952) on quartzite fabrics in the Green Mountains and the Berkshire Hills of New England shows that in quartzite strongly deformed in zones close to thrust faults, a girdle of $c$-axes lies close to the " $b c$ " fabric plane. Balk states (p. 424) : "All girdles are incomplete, with fabric maxima varying from 10 to 24 percent .... approaching the regional $b$-direction"; also (p. 425), "We regard this as a strong suggestion that girdles close to the $b c$-plane have been brought about by the specific mechanism of deformation along thrust faults . . . we must assume that the direction of thrusting, i.e., of tectonic transport, is perpendicular to the girdle plane."

The present writers believe that crystalline blocks yielded to north-south compression along steep ramplike shears of opposing dip along which movement took place first in one direction, then in the other. Except that these shears would be vertical or nearly so, the structural environment postulated is similar to the thrust-faulted area described by Balk. The horizontal girdles described by Higgins, when considered in the light of Balk's conclusion (cited above) that the direction of tectonic transport is "perpendicular to the girdle plane," thus can be taken to support the views presented here.

As a result of nonsimultaneous faulting along steeply dipping ramps, crystalline blocks have overridden the adjacent sediments with consequent compression of those strata into folds, some of which are overturned to the north and others to the south. The sequence of movements is difficult to establish and probably is different from one block to another. In this area, the first movements appear to have been along northward-dipping shears; southward movement of large units of the crystalline mass along these shears resulted in development of an overturned syncline. Later, the movement was along southwarddipping ramps, the major one of which would be the South Calumet fault.

\section{SUMMARY AND CONCLUSIONS REGARDING STRUCTURAL DEVELOPMENT}

The structural history of central Dickinson County, insofar as it may be inferred from the rocks, records two major orogenic intervals: the orogeny that closed the Lower Precambrian, and the orogeny that closed the Middle Precambrian. Both were accompanied by igneous intrusion and by metamorphism. Intervening structural disturbances of lesser consequence occurred after deposition of the Randville dolomite and after deposition of the Vulcan iron-formation; these movements presaged the profound deformation that was to close the Middle Precambrian. Iater, presumably in late Paleozoic time, the Cambrian and Ordovician 
rocks were uplifted, warped slightly, and locally faulted in broad epeirogenic movements.

\section{LATE LOWER PRECAMBRIAN OROGENY}

The orogeny that closed the Lower Precambrian in this area was an event of first magnitude. It resulted in emplacement of post-Dickinson batholithic masses of granite and in widespread development of gneisses and schists; the bulk of the granitic rock in Dickinson County appears to have been emplaced during this interval.

It is clear that the post-Dickinson granite intrusions were syntectonic and that movement continued after emplacement. This is shown by the conformity of foliation and lineation of deformational origin within the granite as compared with that of the country rock (see fig. 75). That this structural unity was not superimposed at a later date is indicated by the fact that these structures are conformable with the contacts and with the form and internal structure of inclusions, some of which are sheetlike masses as much as a hundred feet in thickness. Furthermore, as will be discussed later, this structural pattern is not harmonious with that of the deformation that closed the Middle Precambrian. The granite almost certainly originated in part by granitization of preexisting rock, as indicated by the broad zone of banded gneiss of granitic composition that surrounds the main intrusive mass in this area, and as indicated by local preservation of fold structures in the granite itself. But the sharp contacts with most inclusions and the chemical homogeneity of the bulk of the granite suggest that large parts of the rock consolidated from magma.

The major axis of the deformation within this area appears to lie in a N. $80^{\circ} \mathrm{E}$. direction. This is the major strike direction of bedded rocks, the long axes of the oval-shaped bodies of red porphyritic granite, the orientation of minor fold axes, and the orientation of linear structure in both the granite gneiss and country rock. Considering the Lower Precambrian rock in the northern two-thirds of this area in terms of tectonic coordinates, the " $b$ " axis strikes eastward and dips at low angles (less than $30^{\circ}$ ) to the east in the easterly part of this area, and to the west in the westerly part. In the absence of petrofabric analysis, the choice of direction for axes " $a$ " and " $c$ " is not certain. If " $a b$ " is assumed to lie in the most prominent plane of foliation, then " $a$ " is nearly vertical in the north-central part of this area-an orientation that is also suggested by grooving on pebbles of the East Branch arkose. But the foliation gradually swings into a more northerly strike at the east and west ends of this belt; furthermore, consideration of the minor folds, which have steeply dipping axial planes, would place the " $a$ " axis nearly horizontal, rather than nearly vertical. In any case, it may be assumed that the deformation involved a considerable crustal shortening, as indicated by the prevailing steep dips of once horizontal beds, a shortening that would only be in small part compensated for by intrusion of concordant bodies of granite. It also seems proper to assume that intrusion of the granite masses and continued deformation resulted in extensive differential movement in vertical direction along the steeply inclined foliation planes, with rotational movement around " $b$ ".

The structural pattern that emerged from the orogeny appears to have been similar in some aspects to the New Hampshire structures of Acadian age, as mapped by Billings and his colleagues. The rocks are disposed in long steeply dipping belts without notable folding, except on a small scale; the syntectonic masses of granite gneiss appear, in horizontal section, as oval-shaped bodies concordant with the foliation of the country rock.

LATE MIDDLE PRECAMBRIAN (POST-ANIMIKIE) OROGENY AND PRECEDING EVENTS

The Animikie strata were deposited on the beveled edges of rocks deformed in the post-Dickinson orogeny. The Chocolay group accumulated under orogenically stable conditions and is separated from the Menominee group by a very minor unconformity or disconformity, which records a mild disturbance that consisted of little more than broad warping of the depositional basin, possibly with local emergence and partial erosion of the Randville dolomite. After deposition of the Menominee group, the area was affected by movements similar to the warping after deposition of the Randville, but of greater intensity. Within this area, uplift was sufficient to permit erosion of the Vulcan iron-formation in many places, and locally, as in the southwest part of T. 41 N., R. 28 W., possibly of the entire Randville dolomite and Sturgeon quartzite as well.

The increase in orogenic activity during the period of time represented by Animikie strata, shown by the mild disturbance prior to deposition of the Felch formation and the moderate disturbance prior to deposition of the Michigamme slate, is reflected also in progressive change in the type of sediments deposited. The stable-shelf deposits of the Chocolay group, represented by the Sturgeon quartzite and Randville dolomite, give way to graywacke, slate, and basic volcanics of the Baraga group, as represented by the Hemlock formation, the Michigamme slate, and the Badwater greenstone. 

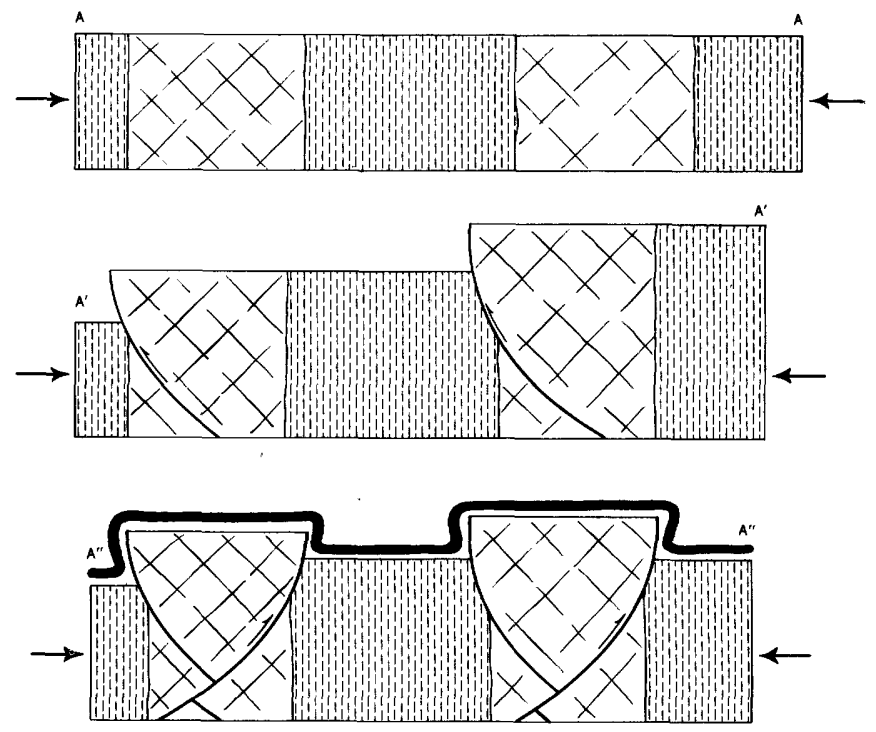

FIGURE 82.- Sketch illustrating possible mechanism for structural control by "ramp" movement of blocks of crystalline rock in basement. Under compressive stress, blocks yield approximately along 45-degree fractures that merge with vertical contacts. Nonsimultaneous movement permits thrusting and resultant overturning in draped sediments (black line) in opposing directions.

Deposition of Animikie strata (not completely represented in central Dickinson County) finally was halted by profound orogeny throughout much of the southern subprovince of the Canadian shield. The youngest rocks involved in Dickinson County are those of the Badwater greenstone of the Baraga group. In Dickinson County, metamorphism and intrusion of granite and pegmatite accompanied the structural disturbances; but, as has been pointed out earlier in this report, the three processes-metamorphism, deformation, and intrusion-did not operate simultaneously during the orogenic interval. In general, the deformation and metamorphism were not strictly concomitant, and, except at the axes of folds, the rocks underwent only minor internal distortion, in contrast to the profound internal distortion throughout rocks involved in the pre-Animikie orogeny. Within the Felch trough, which is an area of high metamorphic grade, oolitic structures within the Vulcan iron-formation show relatively little distortion (see fig. 45), and in the Calumet trough calcareous concretions in the Michigamme slate within the staurolite zone show only moderate extension. Linear structures that are present, such as fold axes, do not show the consistency of attitude found in the post-Dickinson, pre-Animikie structures. Plunges of folds, although in general low, are sharply reversed many times in the course of a few miles.

The major control in development of structure in the Animikie rocks appears to have been exerted by large masses of older granite gneiss. A peculiar and characteristic feature of the structure in the sedimentary rocks in central Dickinson County is that adjacent to the older gneiss the beds are overturned so as to tip beneath the older rock. This is shown most clearly by the belts of Sturgeon quartzite flanking the central and southern crystalline blocks. It is also well shown by the structure of the Felch trough, as for example, in sec. 35 , T. 42 N., R. 30 W., where the Animikie sedimentary rocks on the north side of the trough are overturned so as to dip northward at $60^{\circ}$ to $70^{\circ}$ and those on the south flank, less than a mile away, are overturned so as to dip southward at $35^{\circ}$ to $85^{\circ}$. A mechanism whereby this may be accomplished is outlined in figure 82. Under compression, it is postulated that the brittle crystalline masses will develop fractures in approximately $45^{\circ}$ relative to the stress. Under further stress it is assumed that a semirotational movement will take place along fault planes controlled in part by these shears and in part by steeply dipping internal foliation or by steeply dipping contacts with adjacent schists or foliates. The movement will continue on a given fault plane until no further relief is obtained from the horizontal compression-that is, until the movement is essentially vertical, without appreciable horizontal component. Similar fault planes will then develop elsewhere in the mass; the direction of dip chosen probably is in part fortuitous and in part governed by the anisotropy of the rock. In the sketch (fig. 82), for the sake of simplicity, only single faults are shown operative in a block at one time; actually, there could be many such slices. Also, the movement certainly would be in part cylindrical, so that early-formed ramps (and adjacent sedimentary rocks) would be rotated into positions of lower dip. Whether or not the sedimentary rocks will be simply draped over these basement faults or whether they themselves will be faulted will depend upon local conditions. The Animikie rock of the Felch trough have been faulted along a considerable part of the south margin, but the north flank appears to be largely unbroken, though overturned.

The late Middle Precambrian structural development in this area appears to have been largely in response to compression along a direction approximately $\mathrm{N} .10^{\circ} \mathrm{W}$., so that the major structures strike N. $80^{\circ} \mathrm{E}$., or nearly so. But inhomogeneities in the basement rocks would permit-or require-the development of ramp faults that resulted in divergent structural trends. Possible examples of this are to be found in the northward-striking segments of the Sturgeon quartzite belts in the south-central and southwestern parts of the map area. 
The post-Animikie structures are relatively superficial, at least in comparison with those of pre-Animikie age. This is shown most clearly in the central part of the map area, where the structures of the Felch trough cross the older structural trends without notably disturbing them. The Lower Precambrian rocks have not been folded along with the Animikie mantle. The folding in the sedimentary rocks probably was adjusted for in the underlying basement rocks largely by "card-deck" type of movement along the nearly vertical foliation-that is, by faulting along steep closely spaced planes. Many of these shears doubtless would extend into the sedimentary rocks, especially near the apices of folds, so that smooth generalized closure such as shown on the map for the synclinal nose in sec. 26, T. 42 N., R. 28 W., probably is highly inaccurate in detail; the actual pattern at the basal contact probably consists of a series of minor fault offsets.

\section{LATE PALEOZoIC(?) WARPING}

Paleozoic rocks are preserved in scattered patches over most of central Dickinson County as relics of a once continuous mantle. The broad warping necessary to raise these marine beds to their present elevation above 1,400 feet presumably occurred during the late Paleozoic, at the time of formation of the Michigan basin to the east. Some renewal of movement occurred along the old Precambrian fault planes. The most clear-cut evidence concerns the Toby Lake fault; for a distance of 7 miles, mostly in T. 41 N., R. 29 W., the fault is entirely within granite gneiss and is marked by an escarpment about 50 feet high. Since there is physically no difference in the granite on each side of the fault, this scarp cannot be considered a faultline scarp; it is a true fault scarp along which the modified Precambrian erosion surface has been offset approximately 50 feet. Farther east, in T. $41 \mathrm{~N}$., R. $28 \mathrm{~W}$., the fault (merged with the North Calumet fault) separates sandstone of Cambrian age on the south from granite gneiss to the north.

\section{METAMORPHISM}

Most of the Precambrian rocks of central Dickinson County bear the imprint of moderate or strong regional metamorphism. Along the north margin of the map area, however, and in the extreme southwest the rocks are only weakly metamorphosed.

Two major periods of metamorphism can be distinguished. The earlier metamorphism affects only the Lower Precambrian rocks and is closely related to emplacement of the post-Dickinson granite and concomitant deformation; it is truly dynamothermal metamorphism and resulted in the formation of schists and gneisses with strong planar and linear structures. The later metamorphism is part of the late Middle Precambrian epoch of deformation and intrusion but the relationship between metamorphism, intrusion, and deformation is much less intimate than it is for the earlier epoch. The late Middle Precambrian metamorphism is more local in extent; it is entirely thermal in some parts of the area, rather than dynamothermal, and bears no direct relationship to the observed bodies of associated younger granite.

In addition to the two periods of regional metamorphism, a period of retrograde metamorphism has affected many of the rocks. This retrograde metamorphism appears to be a waning effect of the late Middle Precambrian metamorphic epoch.

The Precambrian (middle Keweenawan?) diabases that were intruded later than the upper Middle Precambrian granite show no metamorphic effects; nor do the Paleozoic rocks.

\section{LATE LOWER PRECAMBRIAN METAMORPHISM}

The record of the late Lower Precambrian metamorphism is, of course, somewhat fragmentary. It is preserved in this area principally in the rocks of the Dickinson group, and, to a lesser extent, by the granite gneiss. A reasonably complete pattern emerges only in the crystalline terrane in the northeastern part of the area, immediately north and south of the Felch trough. In this region the metamorphism is intimately part of the series of events related to the emplacement of pre-Animikie granite, the major body of which now forms the central crystalline block. North of the granite, the finer grained sedimentary and the volcanic rocks of the Dickinson group have been converted into a series of banded gneisses, amphibolites, and mica and hornblende schists in a belt several miles wide. The conglomerate beds of the most northerly member, the East Branch arkose, retain much of their original character, but the finer-grained arkoses have been reconstituted into rock that closely resembles granite gneiss in appearance and composition. The basic flows interbedded with the East Branch arkose, though converted mineralogically to amphibolite, retain some of their original structure-vesicular tops, for example, are still recognizable-whereas in rocks of similar chemical and mineralogic composition closer to the granite, the original structures are entirely gone and metamorphic foliation and lineation are pronounced.

The belt of banded gneiss that separates the recognized rocks of the Dickinson group from the granite gneiss is of complex origin. In large part it probably resulted from granitization of preexisting rock rather 
than from actual intrusion of thin granitic sheets into a layered series. The variations in the spacing of the banding suggest that the original character of the rock may have exerted a controlling influence; the finer layered parts may represent original thin-bedded tuffs or sediments, whereas the massive amphibolite layers may represent original flows. Whether by actual intrusion of granitic material or through the agency of more dilute fluids, the bulk composition of this belt of rock very likely has been changed appreciably, in contrast with what seems to be essentially nonadditive metamorphism in rocks farther removed from the granite.

The rocks of the Hardwood gneiss furnish considerable data on the late Lower Precambrian metamorphism. The structural position of the rocks suggests that the gneiss is part of the original roof of the granite. The rocks are strongly deformed in accordance with the internal structures of the granite to the west. Many of the rocks of the gneiss originally were pyroxene-bearing gabbroic intrusives. The pyroxene is distorted, and it is partly, but not completely, altered to green hornblende and garnet. In some of the finer grained rocks that may have been crystal tuffs originally, the effects of shearing are pronounced and fine-grained pyroxene is abundant in the groundmass. Some of the feldspathic varieties show intense deformation of plagioclase, with fracturing, bending, and twisting of twin lamellae (fig. 20) but without mineralogic breakdown. The preservation of original pyroxene and plagioclase despite intense deformation is in contrast to the complete alteration of these minerals in amphibolites and schists farther removed from the granite; it suggests that the Hardwood gneiss was developed at temperatures at which magmatically crystallized oligoclase and augite are stable. High temperature is also attested to by the development of secondary pyroxene in some of the finer grained facies and by the general presence of garnet.

The relationship between the banded gneiss that separates the granite from the Six-Mile Lake amphibolite along the north flank and the Hardwood gneiss at the east nose of the granite dome is not clear. No rock comparable to the Hardwood has been observed on the north flank, despite extensive exposures, so it does not appear that the development of such rock is a part of the systematic scheme of metamorphism around the margin of the intrusive mass. The distribution patterns do suggest that the present rock type is dependent chiefly upon the original material; the rock that originally made up the Hardwood gneiss was of such a type (principally gabbro and basic and acid tuffs) as to record the metamorphism more adequately, whereas the inferred fine-grained, banded tuffs and flows along the north flank yielded a simpler mineralogic assemblage.

The granite itself records certain features related to the dynamic metamorphism. The principal effects were granulation of large feldspars and development of fine-grained microcline and albite. This presumably was due to dynamic action that continued even after the rock was largely consolidated. Other observed metamorphic features, such as alteration of feldspar to sericite and alteration of biotite to epidote and chlorite, probably are related to later periods of metamorphism.

\section{LATE MIDDLE PRECAMBRIAN METAMORPHISM}

All the Middle Precambrian rocks of northern Michigan, with the exception of the late acidic intrusives, were metamorphosed prior to Keweenawan time. Four nodes of high-grade metamorphism are present in northern Michigan and adjacent parts of Wisconsin (James, 1955). The position of these nodes and the distribution of lines of equal metamorphic intensity (isograds) in the region are shown in Plate 6. The boundaries between zones are not precisely located, in part because recognition is dependent upon exposure of rock of appropriate composition at critical positions, and in part because the isograds, shown as lines, probably are zones of some width. In general the possible error of position is on the order of half a mile, but it may be more in some places.

Central Dickinson County is adjacent to the Peavy node of metamorphism. The axis of maximum intensity extends in a westerly direction across the map area, centering approximately on the Felch trough, and the peak of the node is in eastern Iron County, about 3 miles west of the map area. Most of the area is within zones of intermediate intensity (garnet and staurolite), but the northern and southwestern parts are in lowgrade zones (chlorite and biotite). All rocks other than the late acidic intrusives and the Keweenawan diabase have been affected by the metamorphism and all give some evidence as to the intensity, but the metamorphic differences are most readily revealed by the Randville dolomite, the Vulcan iron-formation, the Michigamme slate, and the basic igneous rocks. The mineralogy of these rocks is summarized in table 6 . The basic igneous rocks probably show the most striking changes in mineralogy in response to metamorphism (figs. 63-65) ; in the lower zones, the rock is a fine-grained aggregate of albite, chlorite, actinolitic hornblende, epidote-clinozoisite, and biotite; in the garnet zone, the principal minerals are oligoclase, blue-green hornblende, and epidote; and in the staurolite zone, the rock is an amphibolite consisting chiefly of andesine and green hornblende. The Randville dolomite likewise is markedly 
different in higher zones as compared to lower zones. $\mid$ is a coarse-grained marble and the impure layers àre In the Norway Lake area, in the chlorite zone, the dolomite is very fine-grained rock with interbedded layers of shaly aspect, whereas in the Felch trough it coarse-grained tremolite and diopside. Other rocks, such as the vitreous Sturgeon quartzite, are much similar from one part of the area to another.

TABLE 6.-Mineral assemblages in the chlorite, biotite, garnet, and staurolite zones of metamorphism

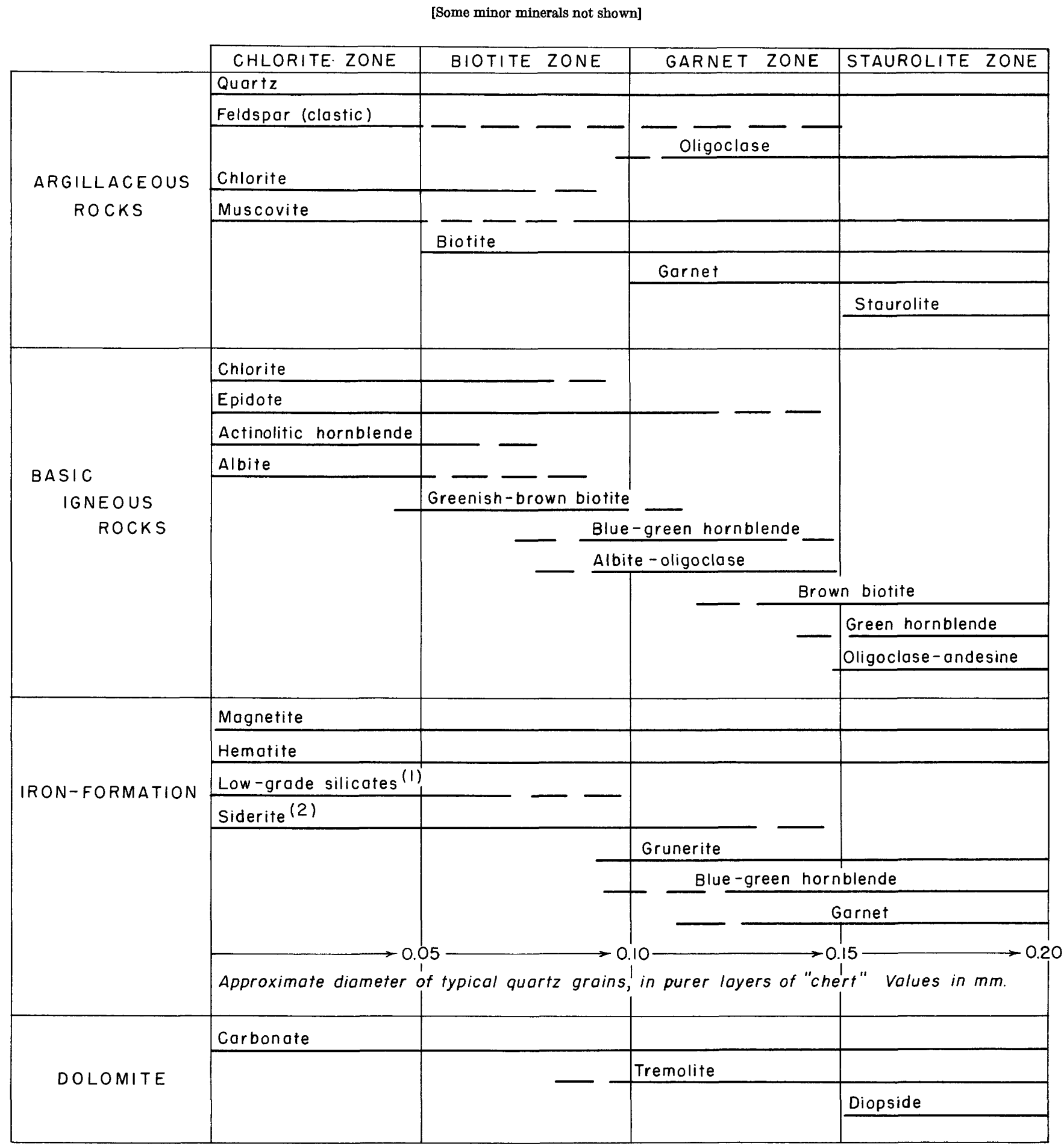

(1) Minnesotaite, stilpnomelane, chlorite. Not observed in Central Dickinson County.

(2) Not observed in Central Dickinson Caunty. 
RELATION OF THE LATE MIDDLE PRECAMBRIAN METAMORPHISM TO DEFORMATION

The post-Animikie metamorphism cannot be closely related to deformation, though doubtless both were part of the same general orogenic cycle. In the Felch trough, for example, the metamorphic minerals in rocks such as the Sturgeon quartzite, the Randville dolomite, the Vulcan iron-formation, and the basic intrusives do not show preferred orientation, although minerals such as grunerite, tremolite, hornblende, and dolomite might well be expected to reflect deforming forces. The lack of correlation between metamorphism and deformation is also shown strikingly by the metamorphosed but undeformed ooliths of the Vulcan iron-formation (see figs. 45-48). The conclusion seems inescapable that at least the peak of the temperature rise was attained after deformation had ceased.

The correlation in time between metamorphism and deformation may be somewhat closer in the Calumet trough than in the Felch trough. But even in the Calumet trough the metamorphism was not accompanied by intense internal deformation of the rocks; concretions in the graywackes are not notably deformed, and the garnets show no evidence of rotation.

In both the Felch and the Calumet troughs, however, the micaceous rocks show megascopically welldeveloped orientation. This may indicate that temperatures were high enough during deformation to permit formation of micas, even though the thermal peak was reached later than the deformation peak, but an alternate and equally plausible explanation is that the crystallization of the mica is mimetic along structural planes established by the premetamorphic deformation.

RELATION OF THE LATE MIDDLE PRECAMBRIAN METAMORPHISM TO GRANITIC INTRUSION

The upper Middle Precambrian granitic intrusives are small-consisting of relatively narrow, though locally abundant, dikes of pegmatite and granite. No direct relationship exists between these granitic dikes and the degree of metamorphism of the truncated strata; metamorphic minerals, such as grunerite and garnet in the iron-formation and diopside and tremolite in the dolomite, are no more abundant adjacent to a dike than they are elsewhere. The dikes appear to be postmetamorphic, as they show no apparent metamorphic changes. It is possible, however, that metamorphism may have gone unrecognized, as the igneous mineral assemblage would be relatively stable at the temperature attained during the metamorphic epoch.

The distribution of granitic dikes shows some correlation with the metamorphism, in that most are restricted to the areas of higher metamorphic grade. The converse does not appear to be true, however; for exam- ple, no granitic dikes are known in the Calumet trough, even though most of that area is in a metamorphic zone equally as high as that of the Felch trough, which is marked by granite intrusions. Both the metamorphism of country rock and magnetic activity probably reflect the existence of subjacent bodies of magma at that time. The long-continued flow of heat outward from such magne produced the thermal gradients now shown by the metamorphic zoning. Local structural conditions that permit fracturing of the roof could result in emplacement of dikes before, during, or after the country rocks had been thoroughly metamorphosed.

\section{RETROGRADE METAMORPHISM AND RELATED FEATURES}

Retrograde effects of slight or moderate intensity are widespread in the metamorphosed Middle Precambrian rocks of central Dickinson County. The effects are best exemplified by the schists and granulites of the Michigamme slate in the Calumet trough. In these rocks the biotite is partly altered-on the order of 10 percent-to green chlorite; staurolite, where present, is largely altered to a sericite-chlorite-quartz aggregate (see fig. 59). The garnets are also marginally altered to chlorite in some specimens.

In Chapter D of this report Lamey describes similar retrograde effects in Randville dolomite adjacent to granite dikes in the Felch trough. Megascopically, the chief feature of this metamorphism is an indefinite greenish coloration at the border of the dike, both within the dike and in the intruded rock. The greenish material in the dolomite comprises serpentine and chlorite, which in part are due to replacement of the earlier metamorphic silicates. Sulfides, chiefly pyrite with some pyrrhotite, occur as disseminated crystals and also as replacement of silicates.

\section{PRECAMBRIAN WEATHERING}

At many places in central Dickinson County, the Precambrian rocks were weathered to depths of 100 feet or more at some time between the post-Animikie orogeny and the beginning of the Paleozoic. The weathering effects are preserved at or beneath the margins of overlying Paleozoic strata; where the $\mathrm{Pa}$ leozoic cover has been removed the weathered mantle also has been largely or entirely stripped.

The products of the Precambrian weathering vary with the parent rock. The schists of the Dickinson group, as seen in drill core in sec. 20, T. 42 N., R. 29 W.; in grass-roots outcrops at the edge of Highway M95 in sec. 16 , T. $42 \mathrm{~N}$., R. $30 \mathrm{~W}$; ; in drill holes and test pits in the northwest part of T. 42 N., R. $30 \mathrm{~W}$. and in the southwest part of T. 43 N., R. 30 W., are altered to soft, porous, mottled red and green clayey material 
in which the original textures are fairly well preserved. The rock now appears to consist chiefly of hematite and clay, with relict mica and quartz, to a depth of about 100 feet. Schist of the Hardwood gneiss at the west margin of sec. 8, T. 41 N., R. 27 W., adjacent to sandstone of Cambrian age, is decomposed to a micaceous "sand" containing loose garnets. In the garnetiferous facies of the Felch formation the garnet is much more resistant to oxidation than grunerite, but in areas marked by intense oxidation it, too, is altered to soft hematitic materials. The quartz-mica facies of the Felch formation is altered to a sandy, hematitic rock. The Randville dolomite, at all places adjacent to the Cambrian overlap, is mantled by a residual capping of yellowish ochre that may be several feet deep. This material is test-pitted and explored in many places: in the $\mathrm{S} 1 / 2$ sec. 5, T. 42 N., R. 28 W.; in the NWI/ $/ 4$ sec. 32 , T. 42 N., R. 28 W.; in sec. 8 , T. 41 N., R. 28 W.; and in sec. 31 , T. 42 N., R. 29 W. Because of the normal proximity of the Randville to the Vulcan iron-formation-the two units are separated only by the Felch formation, which in some places is less than 20 feet thick -in many places this material has been mistaken for iron-formation. The vitreous Sturgeon quartzite is unaffected by the weathering, but some of the micaceous quartzite shows extensive replacement of the micas by hematite (see fig. 29).

Iron-formation in low-grade metamorphic zones is generally susceptible to weathering, and even the more highly metamorphosed Vulcan iron-formation, a completely crystalline rock that quite evidently formed erosion-resistant ridges on the Precambrian surface in this area, in many places shows effects of weathering that are not especially obvious. One of the chief features is alteration of magnetite to martite. At the Calumet mine area, for example, the iron-formation exposed beneath the Cambrian mantle consists mainly of nonmagnetic bluish martite interbedded with metachert, whereas in drill holes that cut the rock at depths of several hundred feet the iron-formation is similar in appearance, but the magnetite is unaltered and the rock is very strongly magnetic. The synclinal patch of iron-formation in the west part of sec. $31, \mathrm{~T} .42 \mathrm{~N}$, R. $28 \mathrm{~W}$., yields only small rather erratic magnetic anomalies; the magnetite appears to be largely oxidized to martite throughout. Perhaps it should be noted that not all the nonmagnetic iron-formation is due to alteration of magnetite - the upper part of the Vulcan, which is preserved at the Groveland and Felch ridge areas, is a primary hematite rock, part of which contains only a small amount of magnetite.

The depth of the Precambrian weathering, as preserved in the rocks exposed at the present surface, ranges from a mere film to several hundred feet. Else- where in the Lake Superior region, the evidence indicates that under exceptionally favorable structural and lithologic conditions iron-formation was altered to soft iron ores at depths in excess of 3,000 feet, and in many parts of the Canadian shield the Precambrian rocks beneath Paleozoic strata are deeply weathered (Baker, 1939).

\section{GEOLOGIC HISTORY}

Viewed broadly, the geologic history of the region centers around two major cycles of sedimentation and volcanic activity, one of which is represented by the Lower Precambrian Dickinson group and the other by Middle Precambrian Animikie strata. Each followed a period of profound erosion in which granitic and metamorphic rocks were exposed; each was terminated by an epoch of deformation, intrusion, and metamorphism. The evidence suggests a pre-Dickinson sedimentary cycle as well, but the record is too vague to be deciphered in this area. The overlapping Paleozoic strata preserve the partial record of a fourth cycle.

For convenience, the geologic history is discussed under two headings: Lower Precambrian, and Middle and Upper Precambrian.

\section{LOWER PRECAMBRIAN HISTORY}

Lower Precambrian history of central Dickinson County is incompletely known. The oldest known major body of rock is the granite gneiss of the Norway Lake area in T. 42 N., Rs. 28, 29, and 30 W. But this granite contains numerous small masses of chloritic schist that may represent older volcanic rocks, and it contains, in one or two places, small pods of quartzite. The record begins, therefore, with deposition of sandstone and possibly basic volcanic rocks, now preserved as relics in granite. This granite was subsequently exposed at the surface by deep erosion and mantled by sediments.

The first materials deposited upon the eroded granite were the sands and gravels that now make up the East Branch arkose. The gravel was derived chiefly from the granite and from the older quartzite, and the nature of the deposits suggests that the land was a surface of considerable relief. Explosive volcanic activity, now indicated by metamorphosed acidic tuffs and basic flows in the East Branch arkose, occurred sporadically. As the relief of the adjacent land area diminished, the sands and gravels gave way to finer grained sediments that now comprise the Solberg schist. Volcanic activity continued, as shown by interbedded hornblende schists. This epoch of sedimentation appears to have been terminated by great outpourings of basic lavas, which since have been metamorphosed to the Six-Mile Lake amphibolite. Igneous intrusion has obliterated the 
Lower Precambrian depositional record beyond that now represented by the Dickinson group, but judging from the nature of inclusions in the post-Dickinson granite, the known section was succeeded by a considerable thickness of basic volcanic rocks and by graywacke-type sediments.

The Lower Precambrian sedimentary and volcanic epoch was terminated by profound orogeny and the syntectonic intrusion of batholithic masses of granite. This orogenic cycle corresponds roughly to the Algoman interval in other parts of the Canadian shield. In the Dickinson County area it was the final recorded event of the Lower Precambrian, other than erosion.

After emplacement of the post-Animikie granite, with accompanying deformation and metamorphism of preexisting sedimentary and volcanic rocks, the region was exposed to erosion, and the granite and metamorphic rocks were reduced to a surface of low relief. This erosional interval, often referred to as the Eparchean interval, is generally considered to be the most profound break in the Precambrian history of the southern part of the Canadian shield, though it is not necessarily any greater than the break separating the Dickinson group from the pre-Dickinson granite gneiss.

\section{MIDDLE AND UPPER PRECAMBRIAN HISTORY}

The deposition of Animikie strata on the beveled surface of older rocks inaugurated the second major cycle of sedimentation. Like the older cycles, it was terminated by orogeny and igneous intrusion.

The conglomerates and arkoses of the Fern Creek formation, sparingly present in the area under discussion, represent sporadically distributed basal debris deposited on the eroded surface of Lower Precambrian rocks. Succeeding this unit is the Sturgeon quartzite, much of which was originally a clean, well-washed quartz sand. Deposition of these clastic materials was in turn succeeded by chemical and biochemical precipitation, which resulted in a thick unit of dolomite, the Randville. Both the Sturgeon and the Randville, which comprise the Chocolay group, show abundant current and ripple marking, the result of accumulation in shallow water agitated by currents and waves. After a brief interval of disturbance, now recorded by the sandy rocks of the Felch formation-the lower unit of the Menominee group-chemical sedimentation was resumed in the basin of deposition. But the precipitates were entirely different from those of the older rocks; they consisted principally of alternate layers of silica and iron oxides that consolidated to form the Vulcan iron-formation.

Deposition of the iron-rich strata was halted by a widespread but relatively minor structural disturbance. In many places, however, erosion prior to deposition of the Baraga group appears to have removed much of the Vulcan iron-formation and locally may have cut through to the basement rocks. Sedimentation was resumed, but the deposits are in great contrast to those of the earlier Animikie; they consist of volcanic tuffs (Hemlock formation), graywacke and slate (Michigamme slate), and submarine volcanic flows (Badwater greenstone), with an aggregate thickness of about 3 miles in this area.

The Animikie sedimentary cycle was terminated by orogeny during which the strata were strongly deformed and locally metamorphosed and intruded by granitic rock. In summary form, the events of the late Middle Precambrian orogenic epoch were as follows :

1. Uplift and folding of the Animikie strata.

2. Intrusion of dikes and sheets of diabase and gabbro, in part during deformation and in part after the deformation.

3. Metamorphism of the folded strata and of the basic intrusives. In the northern and southwestern parts of central Dickinson County, this metamorphism is of low intensity (chlorite and biotite zones); elsewere it is moderate to high (garnet and staurolite zones.)

4. Intrusion of pegmatite, aplite, granite, and diorite as narrow dikes and small masses, the intrusions being largely confined to an east-west belt adjacent to the Felch trough.

None of the Keweenawan rocks in the Lake Superior region, including the dikes referred to below, show the effects of the deformation, metamorphism, and intrusion, so that this epoch can not be properly referred to as Keweenawan, as was done by Leith, Lund, and Leith (1935); it is definitely pre-Keweenawan in age (James, 1955).

At some later period in the Precambrian, the Middle Precambrian rocks, including the granite, were cut by diabase dikes that are not metamorphosed. These dikes appear to be properly assigned to the Upper Precambrian (Keweenawan), and probably were related to the extrusion of the great volcanic flows that are present in the type area. The dikes are relatively few in number in central Dickinson County, but at least one of them gives rise to a negative magnetic anomaly such as characterizes similar dikes elsewhere in northern Michigan (Balsley, James, and Wier, 1949).

The absence of Keweenawan sedimentary rocks in the region that includes central Dickinson County is interpreted to mean that the area remained emergent from the end of the Middle Precambrian until late in Cambrian time. Presumably, it formed part of a highland that lay south of the Lake Superior basin in 
which the conglomerates, sandstones, shales, and volcanic rocks of the Keweenawan accumulated to a thickness of several miles. But it must be granted that the evidence is negative; conceivably, Keweenawan sediments might have been laid down and then stripped off prior to the Cambrian.

The major feature of the later part of the Precambrian record was a period of intense, deep weathering. This period has been inferred, of course, for many parts of the Lake Superior region because of the development of soft ores in the iron-formation, but in this area the evidence lies in widespread deep oxidation and alteration to clay in rocks of varied character.

The Paleozoic seas advanced over this deeply weathered terrain of low-to-moderate relief. Doubtless in most places the weathered mantle was stripped off by the encroaching seas, but locally it is preserved, at least in part. The first Paleozoic strata deposited were those of the Upper Cambrian. Deposition continued into the Ordovician, but whether younger Paleozoic strata were deposited is not known. These Paleozoic strata remain essentially flat-lying, but locally. have been broken by resumed movement along pre-existing faults. Pre-Pleistocene erosion removed all but scattered patches of the Paleozoic strata in this area, apparently in consequence of a broad regional uplift of the Lake Superior highland.

The final chapter in the recorded geologic history of the region is the advance of the Pleistocene ice sheets. In this area the only direct information is with regard to the ice of the Wisconsin stage, which entered from the Green Bay lobe and moved due west across the area. A broad recessional moraine related to a stillstand in the retreat of this ice trends northward along the western margin of central Dickinson County.

\section{ECONOMIC GEOLOGY}

Iron-formation and associated ores constitute the major mineral resource of central Dickinson County, although minor amounts of dolomite and other rocks are quarried for various purposes. Production of iron ore from the area is small, however, despite the fact that exploration and mining have been carried on intermittently for nearly 100 years. Approximately 475,000 tons of ore has been mined, chiefly during the period 1880-1913; the total value almost certainly is much less than the amount spent in exploration and development. Current investigations on recovery of iron from low-grade ores may usher in an era of sustained moderate production from the area.

\section{DEFINITION OF “IRON ORE"}

The term "iron ore" has a dual meaning in the Lake Superior region in that it may be applied either to the material mined or to the material shipped to the furnaces. The fundamental usage, however, is not the commonly accepted one-that is, material that can be mined at a profit-but rather it applies to furnace feed. Inasmuch as about three-fourths of the material mined is "direct shipping", the term "ore", used in the mining sense, is the same as the "ore" used in the metallurgical sense much of the time. But in 1958, for example, nearly half of the shipments was of material that had been treated so as to increase the iron content. This beneficiation product is referred to as "ore" in statistical records, and is graded to "ore specifications" just as is the direct-shipping ore, even though in the more usual sense the material treated is the ore and the product is the concentrate.

With the gradual increase in beneficiation and concentration, the duality in the definition of "ore" will stand out more clearly. At present the material mined for concentration is referred to as iron-formation, taconite, or low-grade ore.

The basic requirements for ore are set by the furnaces. Most of the acceptable material contains 51.50 percent or more iron and 5 to 12 percent silica. Other specifications are based on content of manganese, alumina, sulfur, and phosphorous, and on physical structure. A very small amount, about 0.6 percent of total shipments, is "siliceous ore"; this material, which typically contains 36 to 40 percent iron and 40 to 43 percent silica, is used only for special purposes and the demand is limited.

\section{HISTORY OF MINING AND EXPLORATION}

The first published record of iron ore in the area is found in the "Jackson report", published in the Senate Documents for the 31st Congress (Jackson, 1849), which contains geological notes by Bela Hubbard based on surveys by Wm. A. Burt in 1846 . On page 849 of that report the occurence of ore in the Felch area is noted, and the statements were made that "It is believed that this bed of ore is not far distant from the corner of townships 41 and $42 \mathrm{~N}$., between ranges 29 and $30 \mathrm{~W}$. ," and "It was found in a low ridge about three chains wide, course WNW. This ridge appeared to be nearly one mass of iron ore stratified and jointed; consequently it may be quarried with ease." The description is clearly of the ridge of iron-formation at the Groveland mine in sec. 31, T. 42 N., R. 29 W. The Foster-Whitney report of 1851, in the Senate Documents for the 32d Congress, contains on page 76 an analysis of ore $\left(\mathrm{Fe} 63.34 ; \mathrm{SiO}_{2}\right.$ 10.13) from T. 42 N., R. 28 W., collected by surveyor John Burt from " 13 chains south on the line between secs. 28 and 29." The ore was reported as finely granular and strongly magnetic. This material apparently 
came from the Felch ridge in either sec. 32 or $33, \mathrm{~T}$. 42 N., R. 28 W.

In 1873 a description of the Felch district was published in volume 1 of the Geological Survey of Michigan. This report, by T. B. Brooks (1873), was based chiefly on work by Raphael Pumpelly and Hermann Credner (Credner also published a paper separately in 1869 which contained some mention of the district). In the Brooks report the Felch district was referred to as the "North iron belt" of the Menominee range. The iron-formation ridges at Felch and Groveland are briefly described. Of interest is the mention of a "line of relatively feeble magnetic attractions in the north part of secs. $21,22,23$, and 24, T. 42 N., R. 29 W." This is the first and only previous note in the literature, so far as the writer is aware, of the magnetic anomaly caused by the Skunk Creek member of the Solberg schist.

By about 1880, hundreds of tests pits had been sunk and the Felch and Calumet areas became scenes of great activity; within the next few years most of the mines that were to contribute to the production from the region were developed. In the Annual Report for 1881 of the Commissioner of Mineral Statistics for the State of Michigan, the "principal" mines are stated to be the "Northwestern, Metropolitan, Calumet, and the Hecla", none of which had shipped ore at that time. By the succeeding year (1882), according to the Annual Report for that year, the Chicago \& Northwestern Railway had constructed a branch line into the district, and both the Northwestern and the Calumet mines were shipping ore. However, the flush of optimism had already waned, and the Commissioner noted (p. 266) :

It looks very doubtful if these mines are likely to furnish ore enough for shipment to compensate the company for the cost of this road.

The ore shows well on the surface, but at no point has it been found to hold in depth. The deposits are shallow basins of ore, or short surface lenses that soon work out. In some instances, as at the Northwestern, "the show" is a mere wash or veneering of ore over the rock. At this mine the owners uncovered what appeared, at a mere surface view, to be a very large deposit of fine, soft blue ore. Men journeyed 30 miles through the woods over the rough road that connected the mine with the railroad to see it. Its fame spread far and wide, and the Northwestern was boomed up as one of the most extraordinary deposits that the country afforded, which indeed it was, but in a sense quite the opposite of that which was held. The stock was sold as high as $\$ 22$ per share, the par value being $\$ 25$, and the number of shares 20,000 .

The owners may have purposely avoided to sink in this apparently promising deposit. Certain it was that a very limited investigation proved it to be valueless. It was simply a thin wash of ore lying upon the rock. If all of it were scraped up and saved there would not be ore enough to make a carload,
The boom ended almost before it began. The Calumet shipped ore for 3 years, the Northwestern for 2 years, and the Metropolitan for 6 years, and by 1888 all were shut down, as were numerous other prospects. As noted in the quotation above, all these mines opened and operated on rich ores of little depth; most appear to have been residual accumulations on the Precambrian surface beneath and at the margins of patches of Paleozoic rocks. Some were residual mantles on Randville dolomite.

The Groveland Iron Mining Co. was organized about 1886, and the Mineral Commissioner's Report for 1887 (p. 90) mentions that several shafts have been sunk and that "The company has mined 3,000 tons of ore." With characteristic optimism it was reported that the ore "analyzes above 60 percent in iron and within the Bessemer limits in phos." In 1891 the company finally shipped 1,049 tons and after a brief attempt at concentration of the low-grade ore, the property was abandoned.

For a 10 -year period-until 1901-activity was confined to scattered explorations. In 1895 the Pewabic Iron Co. sank a shaft in the SE1/4 sec. 34, T. $42 \mathrm{~N}$., R. $30 \mathrm{~W}$, and probably explored the iron-formation near the center of sec. 5, T. 41 N., R. 30 W., at the same time. The Deerhunt area, in sec. 35, T. $43 \mathrm{~N}$, R. $29 \mathrm{~W}$., was test-pitted in 1899 ; the magnetic anomaly in sec. 17, T. 41 N., R. 28 W., was explored by 8 drill holes in 1900; and the Hancock area, in sec. 30, T. 41 N., R. 27 W., was test-pitted and drilled about 1901.

In 1901 the Groveland mine was opened by Corrigan, McKinney Co., and in 1905 the Calumet mine was reopened by the Pickands, Mather Co., operating for the Calumet Ore Co. The Northwestern mine was worked briefly and shipped ore in 1902 and 1903. The Groveland and the Calumet operated until 1913, after which there was no further mining in the region until the current developments. The ore shipped in the 1901-13 era was entirely different from the high-grade residual ores that caused the "boom" in the 1880 's, as shown by the analyses of the 1913 shipments from the Calumet and the 1912 shipments from the Groveland. The analyses are "natural"-that is, of ore before drying at $212^{\circ} \mathrm{F}$.

\begin{tabular}{|c|c|c|c|c|c|c|c|c|c|c|}
\hline & $\mathrm{Fe}$ & $\mathbf{P}$ & $\mathrm{SiO}_{2}$ & Mn & $\mathrm{Al}_{2} \mathrm{O}_{3}$ & $\mathrm{CaO}$ & $\mathrm{MgO}$ & $\mathbf{s}$ & $\begin{array}{l}\text { Loss } \\
\text { on } \\
\text { igni- } \\
\text { tion }\end{array}$ & $\begin{array}{l}\text { Mois- } \\
\text { tur }\end{array}$ \\
\hline $\begin{array}{l}\text { Calumet. } \\
\text { Groveland. }\end{array}$ & $\begin{array}{l}37.72 \\
41.25\end{array}$ & $\begin{array}{r}0.020 \\
.036\end{array}$ & \begin{tabular}{|l|}
36.39 \\
26.28
\end{tabular} & $\begin{array}{r}0.24 \\
.95\end{array}$ & $\begin{array}{l}1.67 \\
1.27\end{array}$ & $\begin{array}{l}0.67 \\
2.12\end{array}$ & $\begin{array}{l}0.55 \\
3.22\end{array}$ & $\begin{array}{r}0.011 \\
.013\end{array}$ & $\begin{array}{l}1.28 \\
2.50\end{array}$ & $\begin{array}{l}\text { 4. } 50 \\
\text { 3. } 74\end{array}$ \\
\hline
\end{tabular}

At the present time, such material is classed as "siliceous ore", the market for which is exceedingly limited.

Except for a small amount of exploration, the district remained dormant for 35 years following the 
closing of the Groveland and Calumet in 1913. During this period the only investigations of note were the R. B. Whiteside drilling in 1930 of the Sturgeon Pond area, sec. 31 , T. 42 N., R. 28 W. (11 holes), and the Jones and Laughlin exploration, also in the thirties, of the Calumet area (12 holes) and the Deerhunt area (7 holes).

In 1948 the M. A. Hanna Co. inaugurated a program of thorough investigation of the iron-formation of central Dickinson County. About 130 holes, with a total footage of about 40,000 feet, were drilled within the mapped area during the period 1948-52. The purpose of the drilling was to determine the composition and physical properties of the rocks with a view toward utilization as low-grade ores. Almost all parts of the Felch trough were drilled. The belt extending from sec. 15, T. 41 N., R. 29 W., through the Calumet mine, to sec. 10, T. 41 N., R. 28 W., was tested. Holes were drilled at and adjacent to the old Deerhunt exploration, in the north-central part of the map area, and along the Skunk Creek member of the Solberg schist. Holes were drilled in other scattered areas; in general all sizable magnetic anomalies or known iron-formation were investigated. In 1951 an experimental plant was constructed at the site of the old Groveland mine in sec. 31 , T. 42 N., R. 29 W., for treatment of low-grade ore from the Groveland. The general scheme and flow sheet of the pilot plant were discussed in brief notes in trade papers (Mining Eng., July 1952; Eng. and Mining Jour., July 1952). The note in Mining Engineering reports a talk by E. P. Geist, plant superintendent, at the 1952 spring session of the Upper Peninsula division of A. I. M. E. It states: "A twostep beneficiation scheme is presently being used. It utilized both flotation and gravity methods. After crushing and grinding at 28 -mesh, the ore is passed over Humphrey spirals, making a coarse iron concentrate. Tailings from the spiral concentrate are then reground and floated to produce iron concentrate and a final tailing." The flow sheet reported in the Engineering and Mining Journal note shows grinding to 35-mesh and magnetic separation as a step between the Humphrey spirals and the flotation cells. The plant was dismantled in 1952 after shipment of 7,289 tons of concentrate.

The M. A. Hanna Co. began construction of a fullscale concentrating plant near the Groveland mine in 1957. The plant was completed in 1959 , but production records are not available at the time of the writing.

Production figures are shown in table 7 .

\section{OCCURRENCE AND ORIGIN OF HIGH-GRADE ORES}

The ore produced in the early years of development in the Felch district (1880-88) was of direct shipping grade with a probable iron content of 50 to 60 percent, but the ore bodies were soon exhausted. This ore was found as local surface concentrations without persistence in depth. Most of the ore was produced from the north parts of secs. 32 and 33, T. 42 N., R. 28 W., and from the Calumet area in sec. 8, T. 41 N., R. 28 W. In both areas the ore lay either at the margins or beneath the cover of sandstone of Cambrian age and is clearly a Precambrian residual mantle resulting from deep chemical weathering of the underlying rocks. Although the rock underlying the ore generally is Vulcan iron-formation, in a few places the ore rests on Randville dolomite. Part of this material is a wash from the adjacent iron-formation-locally it contains fragments of that rock-but the occurrence of a similar mantle on dolomite in places removed from iron-formation indicates that it is chiefly a residual accumulation comparable to some of the residual ores in southeastern United States. This material may be seen in place in the pits south of Highway $\mathrm{M} 69$, in the $\mathrm{SE} / 4 \mathrm{NW} / 4$ sec. 32 , T. 42 N., R. 28 W.

TABLE 7.-Shipments of iron ore from mines in the central Dickinson County area, in long tons

[Data from Lake Superior Iron Ore Association reports]

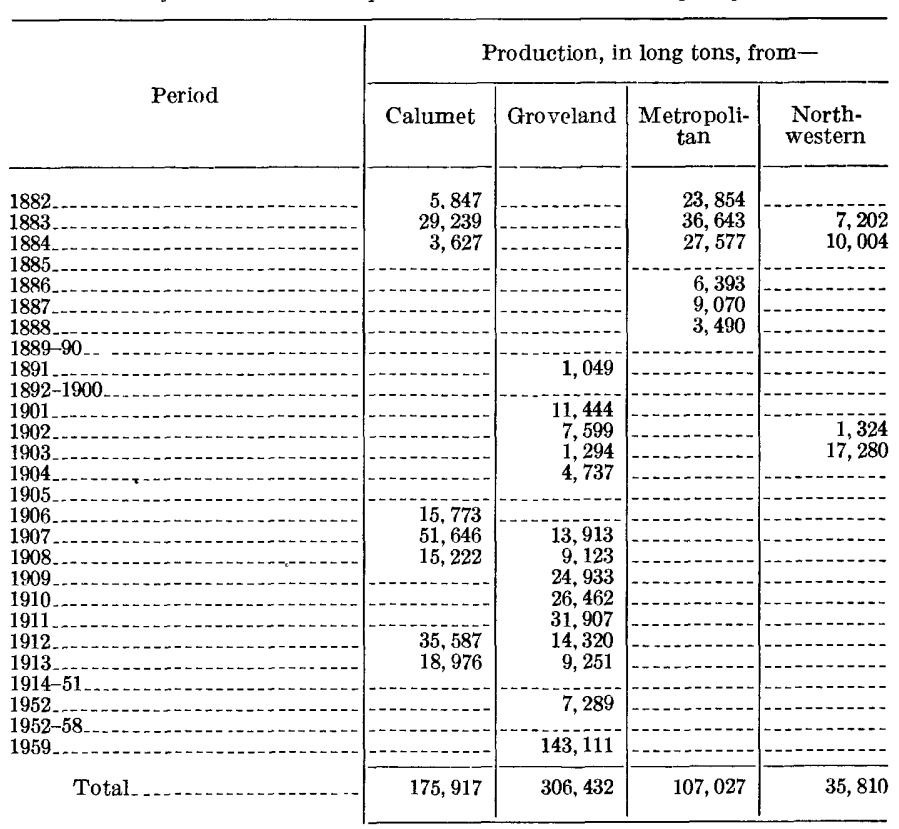

Grand total

625,186

Most of the high-grade ore mined appears to have consisted of soft masses of fine-grained blue hematite, although that resting on the dolomite is mostly yellowish ochre. The blue hematite ores are derived from the iron-formation mainly by simple leaching of the quartz from the interbanded chert layers. In this process, oxidizable minerals such as grunerite or carbonate are converted to soft red or yellow oxides, but 
except for alteration of magnetite to martite, the iron oxides remain unchanged and accumulate to form soft blue ore. In other parts of the Lake Superior region this leaching (or replacement) of the silica has been effective to depths in excess of 3,000 feet and the question may be raised as to why the ore bodies in central Dickinson County do not persist to greater depths, particularly in view of the fact that in areas such as the Calumet mine and sec. 31, T. 42 N., R. 28 W., the rocks show abundant evidence of oxidation to depths of several hundred feet. The answer lies in the nature of the silica. The formation of soft ores of the region is generally thought of in terms of oxidation, which it is in part-at least in areas where the iron-formation contained original carbonate and silicate of iron. But an even larger factor in the development of ore from the banded iron-formation is the removal or replacement of silica. The effectiveness of attack on silica by solutions, whether those solutions are of meteoric or hydrothermal origin, will be governed to a considerable extent by the grain size of the "chert"- that is, by the surface available for attack. In areas of low metamorphic grade the average diameter of the grains is on the order of $0.01 \mathrm{~mm}$, whereas in areas of moderate to high metamorphic grade, such as the Felch and Calumet areas, the average grain size is 0.15 to $0.20 \mathrm{~mm}$. Replacement or leaching of grains to a depth of $0.005 \mathrm{~mm}$ would completely remove the silica in the rock of low metamorphic grade, but in rock as coarse grained as that from Felch hardly more than 5 percent of the silica would be removed. Under conditions of intense chemical weathering, it would be possible to have removal of silica even in the coarsely crystalline rocks near the surface, where chemical activity is most pronounced, but it would be unlikely that such removal would extend to any appreciable depth.

\section{UTILIZATION OF IRON-FORMATION AS LOW-GRADE ORE}

GENERAL CONSIDERATIONS

A distinction is commonly made in the Lake Superior region between "beneficiation" and "concentration," though the difference is not clearly defined. In general, "beneficiation" refers to the treatment of oxidized iron-formation by the relatively simple methods of crushing, screening, and washing so as to increase the iron content or to improve the physical properties, whereas "concentration" refers to the recovery of iron from metamorphic phases of ironformation, in which the iron is in the form of specular hematite or magnetite. The metallurgical problems involved are much more clear cut than the terminology; separation of hydrated red and yellow oxides from oxidized iron-formation presents an entirely different problem from that involved in separation of discrete units of crystalline oxides from the hard metamorphic iron-formation. At present the great bulk of "beneficiated ore" is produced in the Minnesota ranges; the physical properties of most oxidized iron-formation in Michigan are not satisfactory for separation of iron.

In order for iron-formation to be acceptable as a low-grade ore for concentration at the present time, two major conditions must be met:

1. The iron must be dominantly in the form of hematite or magnetite. This excludes most iron-formation rocks' in which the iron is in the form of carbonate or silicate.

2. The grain size must be sufficiently coarse so as to permit grain-by-grain separation at economically feasible screen sizes - that is, on the order of 200-mesh. This excludes oxidized iron-formation and iron-formation in areas of low metamorphic grade.

In general, these conditions are fulfilled only by rocks from zones of moderate to high-grade metamorphism, where original hematite is converted to specularite and magnetite, original magnetite becomes more coarsely crystalline, carbonate probably is metamorphosed in part to magnetite, and original silicates are converted to minerals such as grunerite, garnet, and micas. The contrast in grain size of hematitic rocks that probably were originally similar sediments may be seen by reference to figures 83-84, which shows a polished section view of rock from Felch trough compared with that from an area of low metamorphic grade.

VULCAN IRON-FORMATION AS LOW-GRADE ORE

The bulk of the Vulcan iron-formation in central Dickinson County is in the Felch and Calumet areas, which are in zones of moderate to high metamorphic grade. In these areas the rocks are coarse grained, so that the very factor that militated against development of extensive bodies of high-grade shipping ore permits consideration of the material as a possible concentrating ore.

The appearance of various phases of iron-formation is shown in specimen and in thin section in figures 43 to 48 . Polished sections of the rock indicate that magnetite is the dominant mineral, although hematite is abundant in some of the rock (figs. 85-87). Magnetite and hematite appear to have existed in equilibrium during metamorphism of the rock; the platy appearance of magnetite in some specimens suggests that it may have replaced specular hematite and some hematite clearly replaces magnetite. 


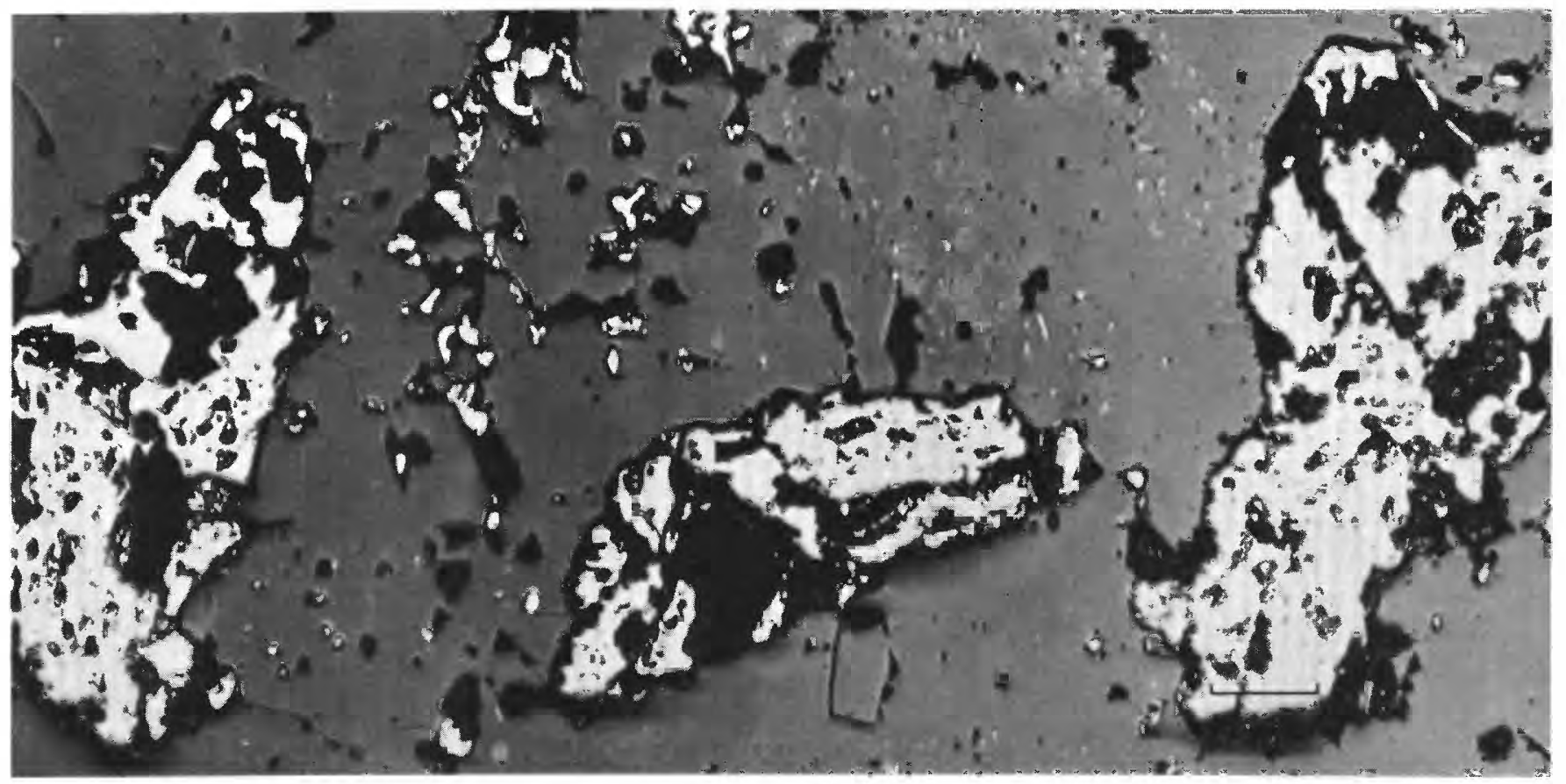

Figure 83

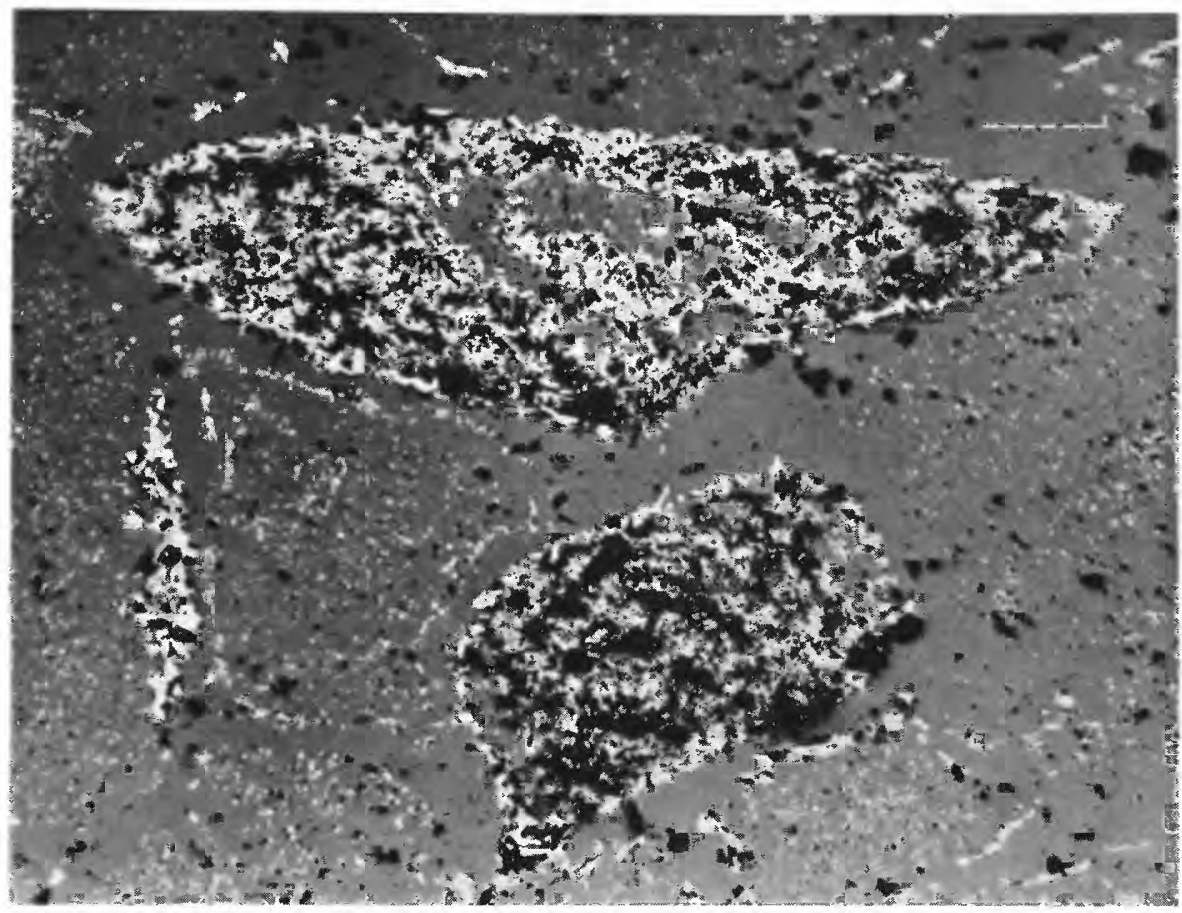

Figure 84

FIQURES 83, 84.-PHOTOMICROGRAPHS OF POLISHED SECTIONS OF IRON-FORMATION, SHOWING EFFECT OF METAMORPHISM ON GRAIN SIZE.

83. Hematite granules in Vulcan iron-formation. Hematite white. From sec. 32 , T. 42 N., R. 28 W. Polished section, $\times 170$. Bar scale at lower right gives width of 200-mesh screen opening. Note much larger grain size of hematite as compared with that in figure 84, which is from an area of much less intense metamorphism. Specimen $\mathrm{HJ}_{-50-51}$.
84. Hematite granule from the Bird exploration in eastern Iron County, in the chlorite zone of metamorphism. Hematite white, chert gray or black. Polished section, $\times 160$. Bar scale at upper right gives width of 200 -mesh screen opening. Specimen HJ-43-49. 


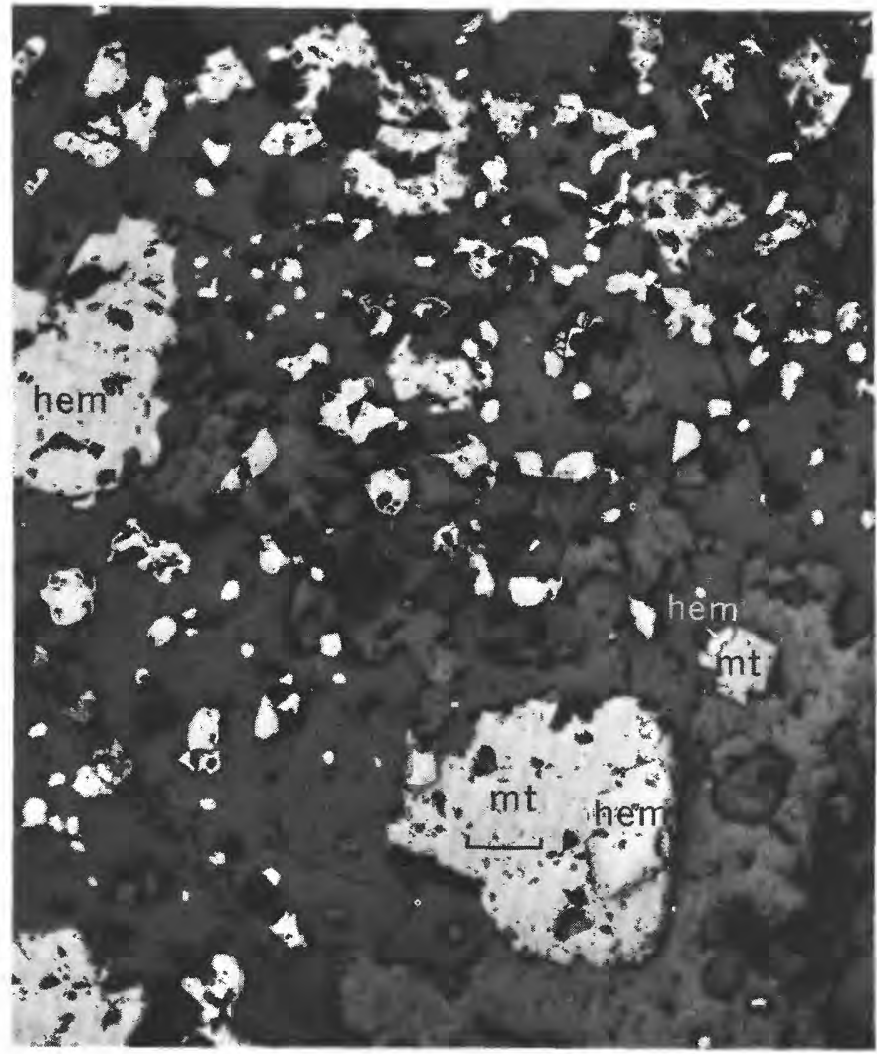

Figure 85

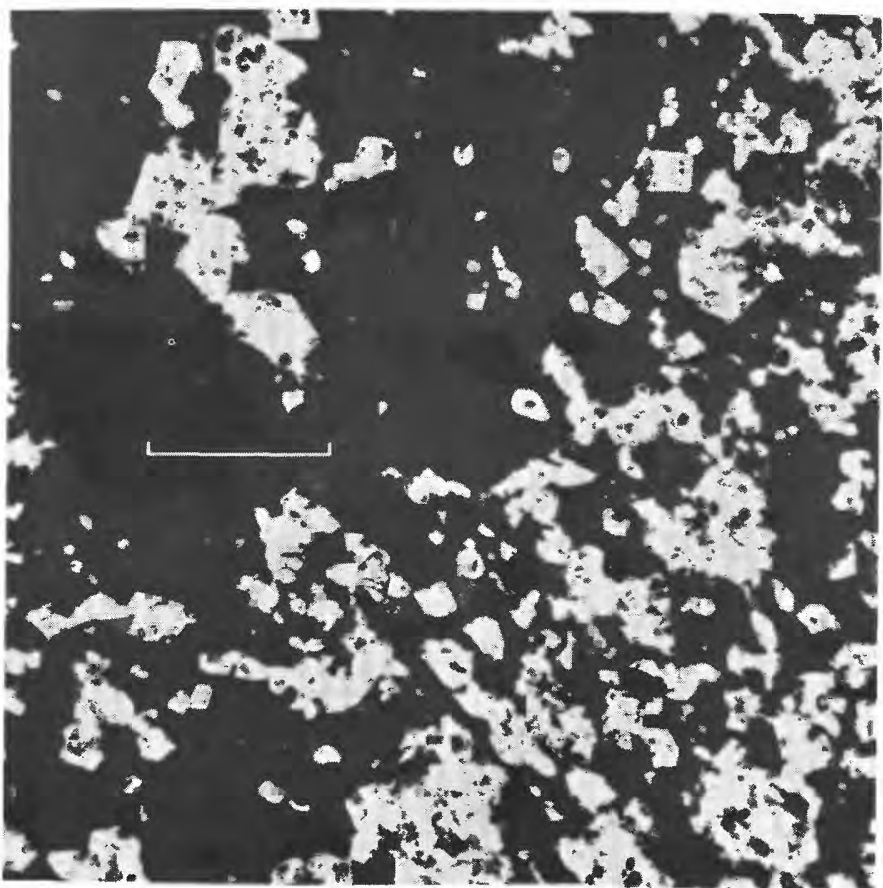

FIgURE 87

The iron formation in the Sturgeon Pond area (sec. 31, T. 42 N., R. 28 W.), the Calumet area (sec. 8, T. 41 N., R. 28 W.), the Hancock area (sec. 30 , T. 41 N., R. 27 W.), and the Deerhunt area (sec. 35, T. 43 N.,

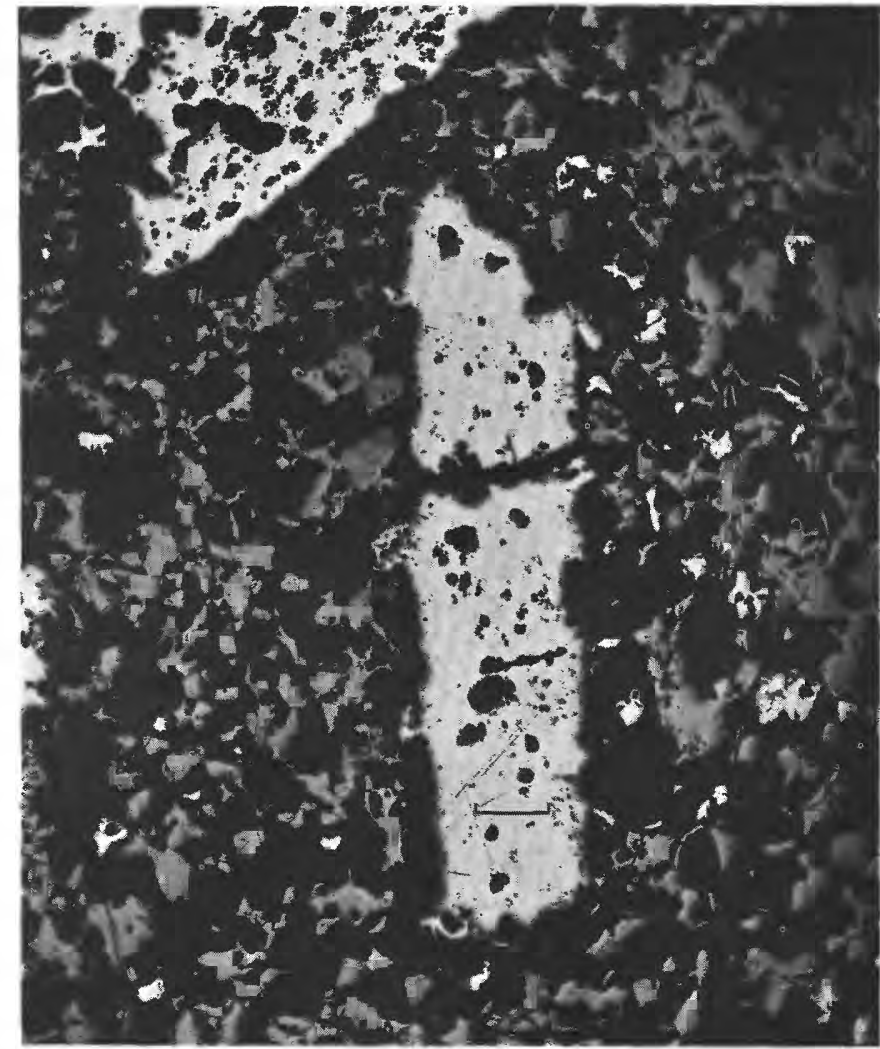

FIgURe 86

FIGURES 85-87.-PHOTOMICROGRAPHS OF POLISHED SECTIONS OF VULCAN IRON-FORMATION. BAR SCALE GIVES WIDTH OF 200. MESH SCREEN OPENING.

85. Magnetite $(m t)$ and hematite (hem) in iron-formation from the Groveland mine Matrix mostly quartz (dark). $\times 100$. Specimen HJ-169-51.

86. Large blades of specularite (white) in magnetite (gray) and quartz (black) From sec. 32, T. 42 N., R. 28 W. $\times 100$. Specimen HJ-226-48.

87. Martite, from the Calumet mine. Hematite (white) psuedomorphic after magnetite. Matrix (dark) is quartz. $\times 250$. Specimen HJ-147-51.

R. 29 W.) has been deeply oxidized. The magnetite has been largely converted to martite (hematite) and considerable redistribution of iron appears to have taken place. The alteration of magnetite to martite is illustrated in figure 42 , and in figure 87 . Because of the reduction of grain size through oxidation, this type of material is not as suitable for low-grade ore as the unaltered iron-formation such as makes up the ridges at Felch and the Groveland, even though the iron content is somewhat greater.

The unoxided iron-formation contains approximately 35 percent "soluble" iron-that is, iron that is recovered by acid leach. Iron in the form of insoluble silicates such as grunerite, or as sulfide, is not included in this value, so that the actual total iron content of the iron-formation is appreciably greater. As this silicate or sulfide iron would not be recovered by present metallurgical processes, however, the "solu- 
ble" iron content is a more significant figure when the rock is being considered as a low-grade ore. Chemical analyses by the M. A. Hanna Co. of essentially unoxidized material are below; analysis $A$ is of a composite sample representing 320 feet of drill hole; analysis $B$ is of a composite that represents 347 feet of drill hole.

\begin{tabular}{|c|c|c|c|c|c|}
\hline & $\boldsymbol{A}$ & $\boldsymbol{B}$ & & $A$ & $\boldsymbol{B}$ \\
\hline $\mathrm{Fe}$ & 35.63 & 33.55 & $\mathrm{Al}_{2} \mathrm{O}_{3}$ & 0.16 & 0.10 \\
\hline $\mathbf{P}$ & .028 & .32 & $\mathrm{CaO}$ & .53 & 1.89 \\
\hline $\mathrm{SiO}_{2}$ & 44.60 & 41.26 & MgO _--- & .21 & n.d. \\
\hline Mn - & .71 & .46 & S & .102 & .155 \\
\hline
\end{tabular}

SKUNK CREEK MEMBER AS A LOW-GRADE ORE

The Skunk Creek member is a thin iron-formation interbedded with the Lower Precambrian Solberg schist. The iron-formation does not crop out, except in one insignificant exposure, but has been entered by about half a dozen drill holes, only one of which appears to have crosscut the entire unit. According to the meager data available the rock is in part a hornblende-biotite schist with abundant magnetite, and in part it is well-banded iron-formation in which magnetite-rich layers alternate with layers composed of quartz with scattered grunerite and garnet (fig. 88). Magnetite and hematite are major constituents, the latter (martite) being mostly secondary after magnetite (figs. 89 and 90). This martite does not appear to be due to surface oxidation entirely, as it is in rock that otherwise shows no oxidation effects.

As shown in the photomicrographs, the grain size of the iron oxides is rather variable, but in general it appears to be substantially less than that of the Vulcan iron-formation in the Felch trough.

The Skunk Creek rock contains about 30 percent soluble iron; a sample from one drill hole contained an average of 29.7 percent iron for a drilled thickness of 180 feet. The stratigraphic thickness of the member is about 100 feet.

\section{RESERVES}

Much of the iron-formation of central Dickinson County can hardly be classed as ore, low-grade or otherwise, at present, but it seems worth while to estimate the amount of material that may be considered as potential ore. It must be emphasized, however, that, even assuming that commercial processes can be developed whereby iron can be profitably extracted from rock of this general type, many other factors enter into its evaluation as ore. The estimate given below simply represent approximate tonnages of material with a given iron content, without regard to modifying factors such as shape and form, topography, drainage, accessibility, and degree of oxidation.
No tonnage is estimated for the iron-formation at the Deerhunt and Hancock explorations, and in sec. 17, T. 41 N., R. 28 W., partly because of inadequacy of data and partly because of other factors such as apparent limited extent, mantling by sandstone of Cambrian age, or thorough oxidation.

Excluding these occurrences it is estimated that there is in central Dickinson County approximately $450,000,000$ tons of Vulcan iron-formation with an iron content of approximately 35 percent: About 95 percent of this is within the Felch trough, where it is contained in relatively shallow synclines, few of which place any large amount of iron-formation at depths in excess of 500 feet. The estimate includes only the main belt of the Calumet area in sec. 8, T. 41 N., R. 28 W., to a depth of 500 feet; the inferred anticlinal areas in sec. 8 are not considered.

The estimate for the tonnage of iron-formation in the Skunk Creek member is based on only a few scattered drill holes and on the apparent continuity of magnetic anomaly, as indicated by the airborne survey. In consequence, it must be regarded as little more than a guess. The magnetic anomaly appears to be virtually continuous from sec. 25, T. 42 N., R. 30 W., to sec. 17 , T. 42 N., R. 27 W., a distance of about 14 miles. The thickness of the formation is assumed to be 100 feet. Calculated to a depth of 500 feet, approximately $300,000,000$ tons is indicated. The iron content is about 30 percent.

\section{POSSIBILITIES FOR IRON ORE IN THE AREAS EAST OF CENTRAL DICKINSON COUNTY}

East of central Dickinson County, the Precambrian formations are completely mantled by flat or lowdipping strata of Paleozoic age. For the most part, the nature of Precambrian rocks beneath this cover can only be inferred. The geologic map accompanying this report shows that the east end of Felch trough is completely closed off by older granite and gneiss, and although a reversal in plunge could cause the younger strata to reappear to the east (beneath the cover), there is nothing in the map pattern to suggest that such actually is the case. In contrast, the Calumet trough shows every indication of continuing to the east beneath the Paleozoic rocks. The character of the magnetic profiles revealed by the aeromagnetic survey (Wier and others, 1952) suggests that the ironformation that causes the anomaly in sec. 17, T. 41 N., R. $28 \mathrm{~W}$., has an anticlinal structure. The anomaly dies out rapidly within a mile or so east of sec. 15 , T. 41 N., R. 28 W., which indicates an eastward plunge to the anticline in that area. But this anomaly reappears in sec. 18, T. 41 N., R. 27 W., and increases 


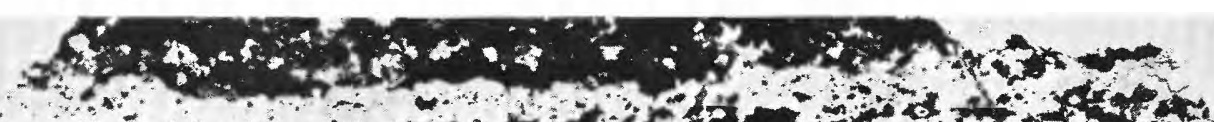

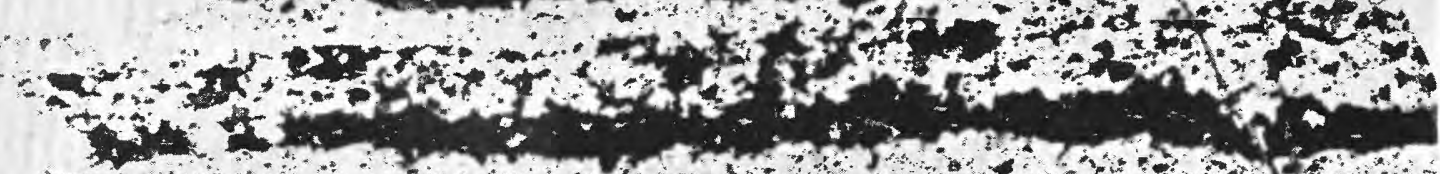

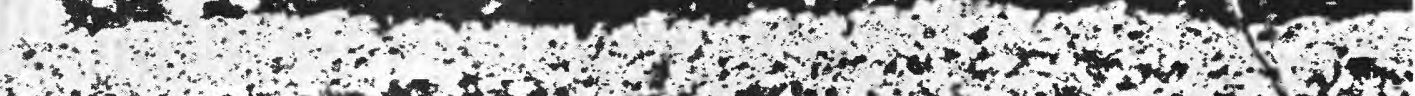

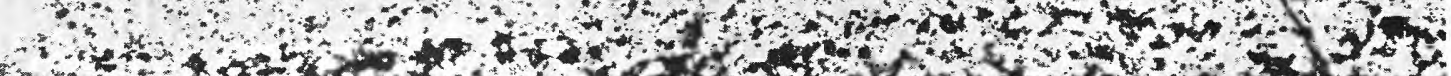

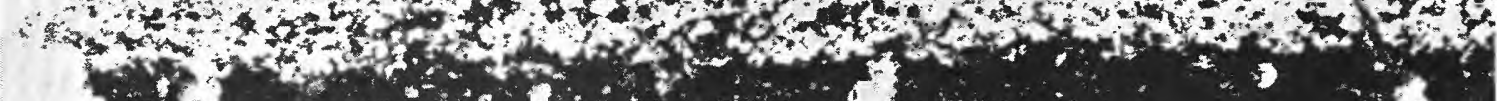

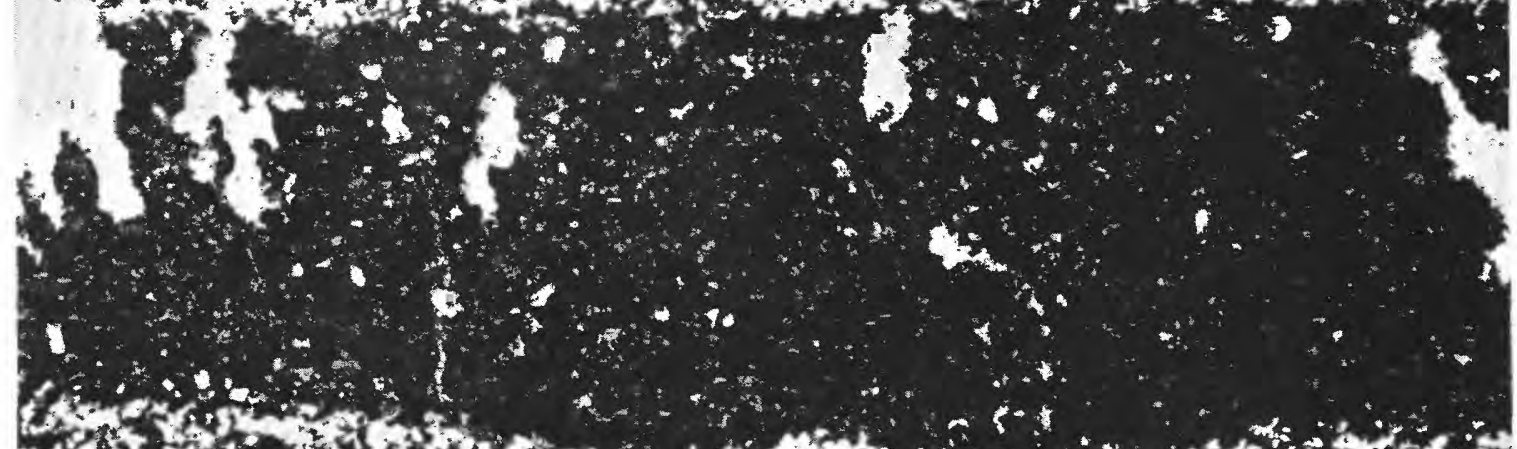

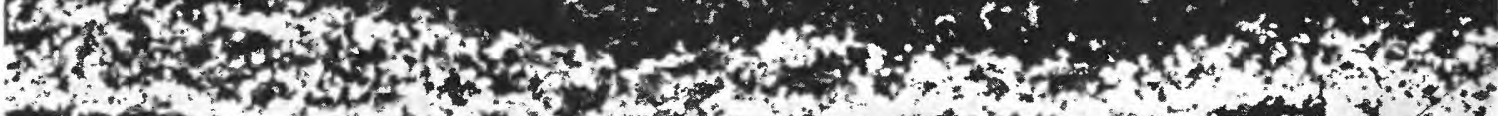
(m.

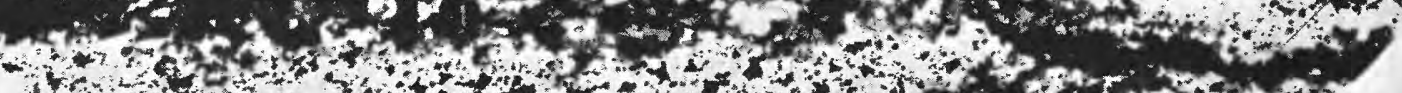

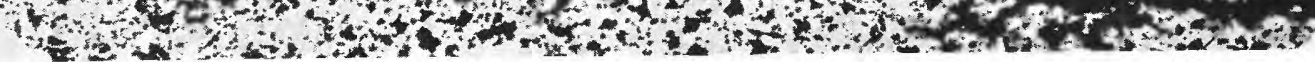

FTGURE 88

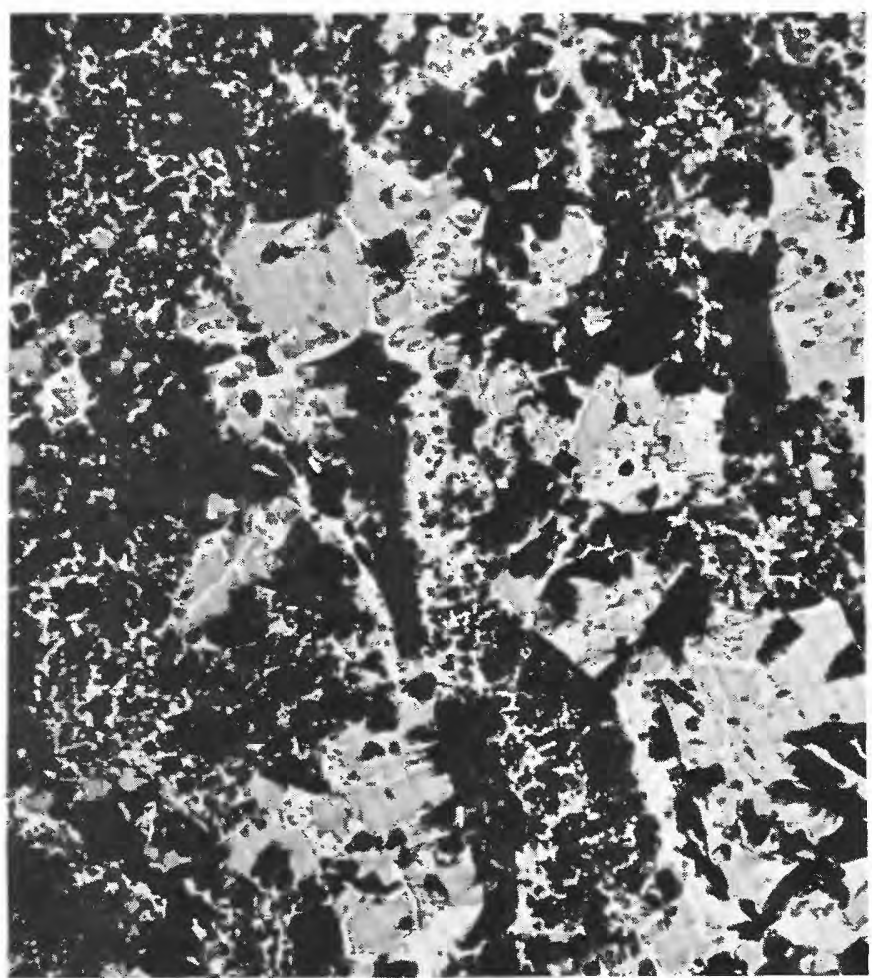

FIGURE 89

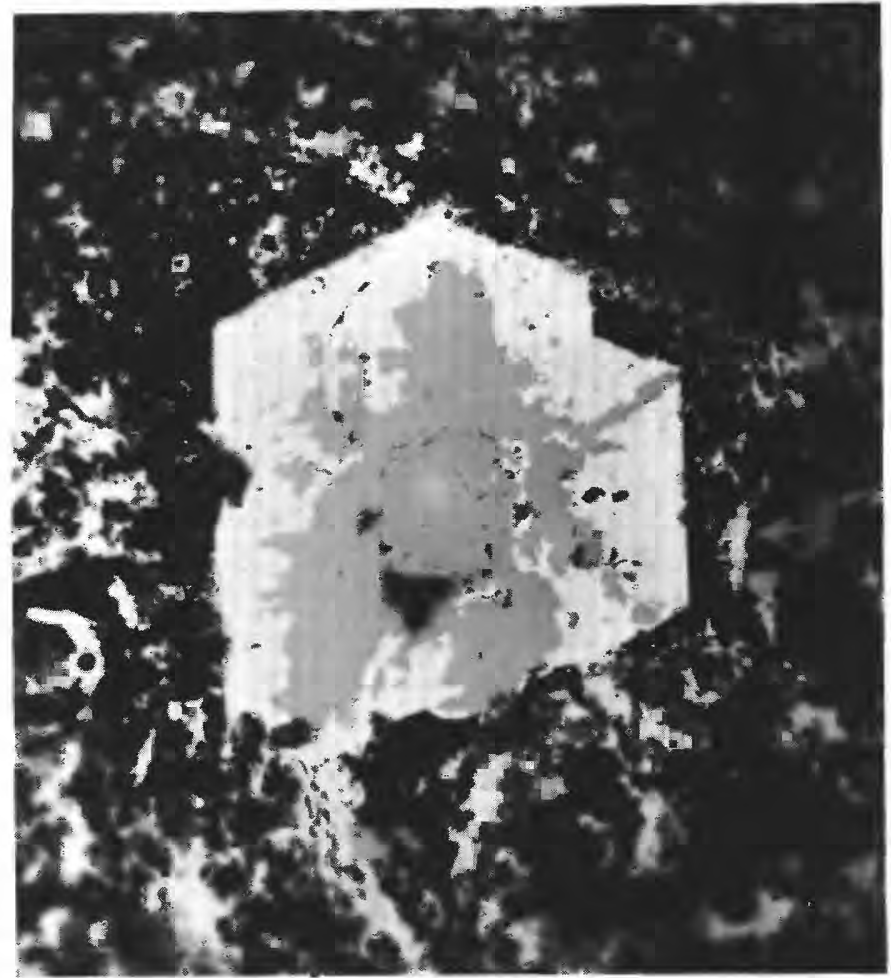

Figure 90

FISURES 88-90.-PHOTOMICROGRAPHS OF THE IRON-RICH SKUNK CREEK MEMBER OF THE SELBERG SCHIST.

88. View at low magnification showing magnetite-rich layers (dark) alternating with layers consisting of quartz with seattered grunerite, garnet, and magnetite. Thin section. Ordinary light, $\times 12$. Specimen $\mathrm{HJ}-86-50$.

89. Hematite (white) replacing magnetite (gray). Polished section, $\times 500$. Speci- 90 . Detail of hematite replacement of magnetite. Polished section, $X 500$. Specimen HJ-87a-50. 
in strength eastward, which may be interpreted to indicate that the plunge of the anticline is reversed and the iron-formation may be at the Precambrian surface east of the map area. Other anomalies in the Calumet trough show similar increase in intensity eastward.

Large magnetic anomalies are known in the area mantled by Paleozoic rocks, as shown on the 1936 geologic map of northern Michigan (Martin, 1936). The principal anomalies related to the Calumet trough are in T. 41 N., Rs. 25 and 26 W., and T. 40 N., Rs. 26 and $27 \mathrm{~W}$. The only anomaly drilled, to the writer's knowledge, is that in the northeastern part of T. 40 N., R. $26 \mathrm{~W}$., near the village of La Branche. Some of the drill holes entered metamorphosed iron-formation after passing through approximately 300 feet of dolomite and sandstone of Paleozoic age; others entered garnetiferous schists.

The Precambrian rocks cut by the drilling at La Branche indicate that the metamorphic grade is equally as high as that of the Felch and Calumet areas. It seems reasonable to assume, therefore, that exploration for direct-shipping ore will not be successful in this area, for reasons discussed earlier, but the ironformation may be suitable as a potential low-grade ore. Iron-formation of low metamorphic grade has been cut by drilling in sec. 28 , T. 39 N., R. 23 W., near Escanaba. The anomaly tested by this drilling is, however, on the eastward extension of the Menominee range of southern Dickinson County.

\section{OTHER MATERIALS OF ECONOMIC INTEREST}

\section{DOLOMITE}

Dolomite has been quarried intermittently in central Dickinson County for 60 years, although the total output is not large. At present two quarries are being worked. The principal operation is the Metronite quarry in sec. 26, T. 42 N., R. $28 \mathrm{~W}$. The pit is several hundred feet long and about 100 feet deep, but some of the material is drawn from underground workings. The mining is selective; only the white dolomite is taken. As much as 20,000 tons a year has been produced; it is used for various purposes, such as paint pigment and putty filler, although originally the rock was quarried for use as ornamental stone. The other quarry being worked is in sec. 34, T. 42 N., R. 30 W., where a small amount of rock is extracted and used in ornamental concrete aggregate. (See "Terrazzo".)

Several abandoned quarries are in secs. 34 and 35 , T. 42 N., R. 30 W., in the belt of outcropping dolomite extending northeast from Randville. Dolomite has also been produced at Rian's quarry in the $\mathrm{NE}^{\mathrm{I}} / 4 \mathrm{SW} / 4$ sec. 33, T. 42 N., R. 28 W.
“TERRAZZO"

The Superior Rock Products Co. operates three small quarries in the vicinity of Randville and the Groveland mine. "Pink rock" is taken from quarries in massive coarse-grained pegmatite near the southeast corner of sec. 19, T. 42 N., R. $29 \mathrm{~W}$. and in the SEx $/ 4$ sec. 30, T. 42 N., R. 29 W.; "black rock" is taken from several amphibolite layers in the banded gray gneiss in the SEx/4 sec. 30 , T. 42 N., R. $29 \mathrm{~W}$.; and "white rock" is taken from a quarry in Randville dolomite in the $\mathrm{SE}^{\mathrm{x} / 4}$ sec. 34, T. 42 N., R. $30 \mathrm{~W}$. The material from each quarry is crushed separately and shipped for use in ornamental concrete. About 5,000 tons is produced annually. The waste product from the crushing is used for poultry grit and fertilizer.

\section{URANIUM}

Central.Dickinson County has been widely prospected for uranium, but with little or no success. In a number of places, joints in granite contain thin, widely separated patches of a yellow-brown radioactive material, but careful investigation has shown that the amount of uranium is quantitatively far too small to be possibly considered of economic importance. Similar yellowish-brown material from an area adjacent to central Dickinson County has been tentatively identified by $\mathrm{X}$-ray examination as rutherfordine, the uranium carbonate. Its occurrence along irregular open joints suggests that it may have been deposited by ground water and probably was leached originally from the adjacent granite.

Many observers have noted that most of the granites of the region yield readings on a Geiger counter of two to three times normal background, which is distinctly higher than other rocks in the area. A typical sample of such granite shows an equivalent uranium content of 0.004 percent, which, although higher than that for ordinary granite, is negligible from an economic viewpoint.

\section{MAGNETIC SURVEYS}

Magnetic measurements have been used to assist in geologic interpretation in the Lake Superior region for a hundred years, and a vast amount of surveying has been done. In many areas the inferred distribution of the iron-formations has been based almost entirely on magnetic surveys, and one range - the Cuyunawas discovered by magnetic methods. The earliest known reference to magnetic surveying in central Dickinson County is in Brooks' report (1873), noted previously under the heading "History of mining and exploration." 


\section{GROUND SURVEYS}

\section{METHODS}

The principal instrument used in the ground magnetic surveys made in the course of this study was the common dip needle, Lake Superior model, used in conjunction with the solar compass in areas of strong magnetic attraction. The dip needle is a relatively insensitive instrument-sensitivities range from 150 to 400 gammas a scale division-but it is admirably suited to rapid measurement of strong magnetic fields, as it does not require a tripod mount. The instrument is oriented so as to swing in the plane of the magnetic meridian, with the recorded reading being the mean of the values reached on the forward and reverse swings. The value plotted on the maps is the difference between this and an arbitrary base value for the area.

As described by Lamey, Chapter D of this report, the Felch trough was traversed for its entire length along lines an eighth of a mile apart, with dip-needle readings taken at 40 -foot intervals. A similar survey, made by the M. A. Hanna Co. of the area in the vicinity of the Calumet mine, is the source of the magnetic data on plate 4 .

More sensitive magnetic instruments were used to survey some local areas. The Hotchkiss Superdip was used to survey an area of about 2 square miles in the northern part of T. 42 N., R. 30 W., and adjacent parts of T. 43 N., R. 30 W. (pl. 7). The instrument, which is tripod-mounted, was used with east-west orientation (see James, 1948) and a "sigma" angle of $2^{\circ}$. Readings are taken by averaging the total of the first two forward swings plus the first back swing doubled, and the difference in scale divisions between this value and the regional base value is recorded. The sensitivity of the instrument so adjusted and operated is 35 gammas per scale division.

Several smaller areas were surveyed using Schmidttype vertical-component magnetometers. These instruments were used with sensitivities of 30 to 40 gammas a scale division. The readings, corrected to a regional base, are converted to gammas and are so shown on the maps.

\section{INTERPRETATION}

The information obtained from the various magnetic surveys has been interpreted empirically; no attempts have been made to analyze the data mathematically, although simple depth calculations have been made for some areas.

Many types of rock in central Dickinson County contain sufficient magnetite to yield magnetic anomalies. The actual anomaly recorded is principally a function of magnetite content, the relationship of induced to remanent magnetization, the geometric form of the rock mass, and the distance from the point of measurement to the magnetic poles of the rock mass. In table 8 are listed the various rock types that give rise to magnetic anomalies within the map area. In the column "magnetic anomalies", the designation "strong" is applied to anomalies that typically attain an intensity at ground level of 2,500 gammas or more (roughly 10 dip-needle units) "moderate", an intensity of 1,000 gammas or more (roughly 4 dip-needle units); "small", an intensity of less than 1,000 gammas. Values will be lower for the comparable aeromagnetic anomalies, although some that appear to be deep seated in origin, such as those in the Sagola area, are almost as strong at an elevation of 500 feet as at ground level.

The principal anomalies in the area are caused by the Vulcan iron-formation, and much of the interpretation as to the position and structure of this unit is based on magnetic data. In the Felch trough the ironformation is preserved in canoe-shaped synclines that do not contain younger strata. The recorded magnetic anomalies are due not only to the iron-formation itself but to the underlying Felch formation as well. As a result, the anomalies normally continue beyond the ends of the syncline of iron-formation. The iso-magnetic contours defining these "syncline" anomalies are rudely subparallel to structure contours on the folded strata, and the distribution pattern of iron-formation and of the Felch formation can normally be inferred with a fair degree of accuracy. Elsewhere, interpretation is not as simple. The magnetic anomalies yielded by the Vulcan iron-formation exposed at the Deerhunt exploration, in sec. 35 , T. 43 N., R. 29 W., are spotty, probably in part because of alteration of the magnetite to martite and in part because of irregular distribution of the rock itself as a result of post-Vulcan erosion. A strong magnetic anomaly is present along the north margin of the Calumet trough, in secs. 7, 8, and 9, $\mathbf{T}$. 41 N., R. 28 W., and secs. 11, 12, 14, and 15, T. 41 N., R. $29 \mathrm{~W}$. This anomaly is caused by Vulcan ironformation, but only in a few places can the magnetic crest be related to iron-formation actually at bedrock surface. Between sec. 15, T. 41 N., R. 29 W., and sec. 8 , T. 41 N., R. 28 W., a distance of more than 3 miles, the anomaly is above bedrock composed of graywacke and schist or of granite. Some of the graywacke and schist contains magnetite but not in sufficient quantity to account for the magnitude of the anomaly. The major part of the anomaly must be due to Vulcan ironformation that appears at depth along the North Calumet fault. In the $\mathrm{N}^{\mathrm{x}} / 2$ sec. 9, T. 41 N., R. $28 \mathrm{~W}$., iron-formation is again cut out by the fault, but the strata south of the fault are folded into a syncline so that a large broad anomaly is recorded in an area underlain by nonmagnetic graywacke. 
TABLE 8.-Types of rock giving rise to magnetic anomalies in central Dickinson County

\begin{tabular}{|c|c|c|c|}
\hline Strong - & $\begin{array}{l}\text { Vulcan iron-forma- } \\
\text { tion. }\end{array}$ & $\begin{array}{l}\text { Felch trough; eastern part of } \\
\text { Calumet trough. }\end{array}$ & $\begin{array}{l}\text { Locally only weakly magnetic or even non-magnetic in } \\
\text { areas of deep oxidation, as in sec. } 31, T .41 \mathrm{~N} \text {., R. } 28 \mathrm{~W} \text {. }\end{array}$ \\
\hline $\begin{array}{l}\text { Strong to mod- } \\
\text { erate. }\end{array}$ & Felch formation $\ldots$ & $\begin{array}{l}\text { Felch trough, north margin of } \\
\text { Calumet trough. }\end{array}$ & $\begin{array}{l}\text { The Felch formation has a large range in lithology and } \\
\text { thickness. The magnetic properties likewise are } \\
\text { variable, but wherever the unit is present in consider- } \\
\text { able mass, it yields a magnetic anomaly. }\end{array}$ \\
\hline $\begin{array}{l}\text { Strong to mod- } \\
\text { erate. }\end{array}$ & $\begin{array}{l}\text { Skunk Creek mem- } \\
\text { ber of Solberg } \\
\text { schist (iron-for- } \\
\text { mation). }\end{array}$ & $\begin{array}{l}\text { Eastward-trending belt, cross- } \\
\text { ing central parts of T. } 42 \\
\text { N., Rs. } 27-29 \text { W. }\end{array}$ & $\begin{array}{l}\text { Rock known only from drill holes. Map pattern of } \\
\text { unit based chiefly on aeromagnetic survey. }\end{array}$ \\
\hline Moderate..... & $\begin{array}{l}\text { Volcanic rocks in } \\
\text { the Sagola area. }\end{array}$ & $\begin{array}{l}\text { Northern part of T. } 42 \mathrm{~N} ., \mathrm{R} . \\
30 \mathrm{~W} . \text { and areas adjacent } \\
\text { to the north. }\end{array}$ & $\begin{array}{l}\text { Rock very poorly exposed. Test pits indicate extensive } \\
\text { alteration of magnetite to martite, which. may ac- } \\
\text { count for broadness of the anomalies. }\end{array}$ \\
\hline $\begin{array}{l}\text { Moderate to } \\
\text { small. }\end{array}$ & $\begin{array}{l}\text { Metadiabase (post- } \\
\text { Baraga age). }\end{array}$ & $\begin{array}{l}\text { Throughout mapped area, but } \\
\text { most clearly shown in secs. } \\
15,16,20,21, T .41 \text { N., R. } \\
30 \text { W.; southwestern part } \\
\text { of T. } 41 \text { N., R. } 29 \text { W.; and } \\
\text { secs. } 31,32, T .41 \text { N., R. } 30 \\
\text { W. }\end{array}$ & $\begin{array}{l}\text { In areas of high metamorphic grade, as in the Felch } \\
\text { trough, the diabase has been completely metamor- } \\
\text { phosed to amphibolite, with loss of magnetic proper- } \\
\text { ties. }\end{array}$ \\
\hline $\begin{array}{l}\text { Moderate to } \\
\text { small. }\end{array}$ & $\begin{array}{l}\text { Upper part of } \\
\text { Sturgeon quartz- } \\
\text { ite. }\end{array}$ & $\begin{array}{l}\text { Anomaly flanks the north } \\
\text { side of quartzite belt in the } \\
\text { northern part of T. } 41 \mathrm{~N} . \text {, } \\
\text { R. } 30 \mathrm{~W} \text {. }\end{array}$ & $\begin{array}{l}\text { Fine-grained, magnetite-bearing quartzite exposed in } \\
\text { secs. } 7 \text { and } 10, \text { T. } 41 \text { N., R. } 30 \mathrm{~W} \text {. }\end{array}$ \\
\hline $\begin{array}{l}\text { Moderate to } \\
\text { small. }\end{array}$ & $\begin{array}{l}\text { Slate associated } \\
\text { with Randville } \\
\text { dolomite. }\end{array}$ & $\begin{array}{l}\text { Secs. } 5 \text { and } 6, \text { T. } 42 \text { N., R. } 28 \\
\text { W., and sec. } 1, \text { T. } 42 \text { N., R. } \\
29 \text { W. }\end{array}$ & $\begin{array}{l}\text { Magnetite-bearing rocks associated with conglomerate; } \\
\text { may be stratigraphically part of Felch schist. }\end{array}$ \\
\hline
\end{tabular}

The major anomaly recorded in the east part of the Calumet trough, in sec. 15, 16, 17, and 18, T. 41 N., R. $28 \mathrm{~W}$., is caused by Vulcan iron-formation, as indicated by drilling. The anomaly is very broad, which can only in small part be accounted for by the effect of a thick cover of Cambrian sandstone. Both the known general geology of the area and the form of the anomaly indicate that the iron-formation reaches the Precambrian surface on an anticlinical structure. As discussed under "Aeromagnetic survey," the progressive broadening and lowering of the anomaly to the east indicate that the anticline plunges in that direction; probably east of sec. 16 the iron-formation will be mantled by the Michigamme at the Precambrian surface.
Traverses with a ground magnetometer over the fresh diabase dike that crosses the central part of sec. 29 , T. 42 N., R. 28 W., reveal a strong negative anomaly over the rock. The diabase appears polarized in a direction about opposite that of the present magnetic field of the earth. Similar anomalies have been recorded over other diabase dikes of this age in the region (Balsley, James, and Wier, 1949).

\section{AEROMAGNETIC SURVEY}

\section{By K. L. WIER}

The U.S. Geological Survey, in cooperation with the Geological Survey Division of the Michigan Department of Conservation, made an aeromagnetic survey of most of Dickinson County, including the 
area of this report, during June 1948. The results of this survey were published in 1953 (Wier, Balsley, and Pratt, 1953). Many of the geologic interpretations of the central Dickinson County area are based on this aeromagnetic data; therefore the results of this survey are summarized here.

The magnetic measurements were made with an AN/ASQ-3A continuous-recording magnetometer installed in a Beecheraft AT-11 airplane. Flight traverses at an altitude of 500 feet north and south were flown along lines spaced one-third of a mile apart. Aerial photographs were used for flight control, and the actual flight paths were recorded by a gyrostabilized continuous-strip-film camera.

The aeromagnetic data are presented as total magnetic intensity profiles (pl. 8). On the general map of the area (pl. 2), the crest-positions of the anomalies are shown as red dots with sizes in proportion to the strength of the anomaly they represent. Crests of anomalies that extend from profile to profile are connected by a solid line where correlation is probable and by a dashed line where correlation is less certain.

\section{RELIABILITY OF THE AFROMAGNETIC DATA}

The profiles accurately represent the total intensity of the earth's magnetic field at the position of the airborne magnetometer along each traverse. Magnetic features are precisely measured, and anomalies as small as 10 gammas are accurately recorded on the profiles. However, the magnetic pattern at ground level commonly is much different. The amount of difference depends mainly on the physical and magnetic properties of the magnetic body, on its distance beneath the earth's surface, and the positional relationship between adjacent magnetic units. The attenuation of a magnetic field from its source makes the aeromagnetic profiles smoother and more generalized than those obtained by ground measurements; and anomalies that are closely spaced at ground level tend to merge at greater heights.

The method of crest designation as shown on plate 2 does not distinguish between narrow, sharply defined anomalies with steep magnetic gradients and those that are of equal maximum value but show as broad domes in profile. It should also be pointed out that the assignment of a gamma value to an anomaly is to some extent arbitrary, since it depends largely upon the assumed magnetic "base". level. For example, a subsidiary crest on the flank of a large anomaly may attain a large apparent value, yet actually be a relatively small anomaly. On plate 2 such crests are assigned values based on measurements above the general slope of the magnetic profile, rather than on values above the regional base level. These aspects can be appraised by study of the profiles shown on plate 8.

The uncertainty in connecting anomalies across profiles spaced a third of a mile apart should be recognized as a limitation of the aeromagnetic method, and some of the connections shown on plate 2 are probably wrong. Some anomalies are the resultant of two or more closely spaced ground-level anomalies and may be due to more than one magnetic rock. Supplementary ground magnetic surveys are usually necessary to determine the actual magnetic correlations, especially where an anomaly changes radically in shape and intensity from one profile to the next.

Aeromagnetic data are obtained and compiled along a continuous line, whereas ground surveys are made at separate points. Errors within the normal limits of any magnetic measurement may cause slight discrepancies between flight lines on an aeromagnetic map, which would be more obvious than similar discrepancies between points in a ground magnetic map. For this reason as much care should be exercised in evaluating magnetic features along a single aeromagnetic traverse as in interpreting an anomaly indicated by a single ground station. The continuous-strip-film camera permits accurate location of marks on the magnetic record with respect to identifiable points on the ground, and in the compilation process a constant ground speed and straight flight path between such points are assumed. These assumptions are not always valid and positional errors may exist where the located ground points are too far apart.

Major errors of location in this survey are believed to be caused by inadequacies in the available base maps. In many places the base map is too generalized to enable accurate plotting of the flight paths. Most of the magnetic crests on plate 2 probably are plotted within an error of about 300 feet, but some may be mislocated by as much as a quarter of a mile.

\section{CORRELATION OF ANOMALIES WITH GBOLOGY}

The data yielded by the aeromagnetic survey have been of considerable help in interpreting the geology of the area. In essence, the aeromagnetic pattern provides a framework in which scattered items of geologic information can be placed. Where possible, the specific rock units causing anomalies have been located, generally by traversing with ground magnetometer along lines selected so as to cross areas for which outcrop or exploration data are available. Once the origin of an anomaly is established, the particular rock unit can be extended on the basis of correlation of crests on the profiles; in this manner, for example, 
the Skunk Creek member of the Solberg schist is inferred for a distance of about 15 miles, even though the direct information concerning the unit is confined to one small outcrop and 7 drill holes.

In general, magnetic anomalies are stronger and more numerous in areas of Animikie sedimentary and volcanic rocks than they are in areas underlain chiefly by granite and gneiss. About 40 percent of the individual anomalies for which crests are recorded on plate 2 can be directly or indirectly correlated with observed magnetic rocks, and about 60 percent-most of which are relatively small-remain unexplained.

Most of the large magnetic anomalies can be directly related to geology on the basis of ground observations, but a few appear to have deep-seated sources the nature of which can only be inferred. Many of the small anomalies cannot be accounted for on the basis of information available at the present time. In the paragraphs that follow, the principal anomalies recorded on the profiles (pl. 8) are discussed separately. The anomalies are labeled according to the principal geologic units in which they occur, as follows:

$\begin{array}{ll}\text { Geologic unit (see fig. 74) } & \begin{array}{c}\text { Designa- } \\ \text { tion }\end{array} \\ \text { Sagola basin } & \text { A } \\ \text { Northern crystalline block } & \text { Felch trough } \\ \text { Central crystalline block } & \text { Calumet trough } \\ \text { Southern crystalline block }\end{array}$

The individual anomalies are given numerical subscripts that in general increase in value from north to south ( $\mathbf{A}_{1}, \mathbf{A}_{2}$, and so on). The designations of anomalies in this report are not the same as in the previously published report on the aeromagnetic survey of Dickinson County (Wier, Balsley, and Pratt, 1953), in which a larger area was described.

\section{SAGOLA BASIN}

The Sagola basin, only part of which is included in the central Dickinson County map area, is underlain by Animikie metavolcanic and metasedimentary rocks. These rocks are separated from the older crystalline rocks to the south partly by a fault and partly by an unconformity. Outcrops are scarce, and the geology is poorly known.

Anomaly $A_{1}$ trends southeast from sec. 32, T. 43 N., R. 30 W., to sec. 1 , T. 42 N., R. 30 W., where it appears to end. Profiles 46,47 , and 48 clearly show that $A_{1}$ is superimposed on the south side of $A_{2}$. The anomaly cannot be definitely related to known rocks, but rhyolitic tuffaceous volcanic rock containing magnetite is exposed slightly north of the magnetic crest in the SE1/4 sec. 2, T. 42 N., R. 30 W., and south of the projected crest in sec. 32, T. 43 N., R. 30 W. Recent drilling approximately on the crest a short distance to the east encountered similar though nonmagnetic material. These rocks have been assigned to the Hemlock formation, magnetic parts of which probably cause the $A_{1}$ anomaly. The abrupt termination of this anomaly in sec. 1, T. 42 N., R. 30 W., is part of the evidence on which the existence of the Bush Creek fault is based.

Anomaly $A_{2}$ extends eastward from sec. 2, T. 42 N., R. $30 \mathrm{~W}$., for a distance of about 4 miles and gradually dies out in sec. 33, T. 43 N., R. 29 W. Westward it decreases in amplitude, whereas the sharper anomalies $A_{1}$ and $B_{1}$ increase. Anomaly $A_{2}$ does not conform to the pattern of the other anomalies in the area in which it is situated, and the profiles indicate that the material producing it is at a depth of $6,000-10,000$ feet. It may be caused by deeply buried Lower Precambrian rocks, some of which are known to be magnetic in adjacent areas or to a deeply buried intrusive body.

Anomaly $A_{3}$ is a small anomaly in secs. 1 and $2, \mathrm{~T}$. $42 \mathrm{~N}$., R. $29 \mathrm{~W}$., whose continuity across the profiles is somewhat uncertain. Ground magnetic surveys in this area by Clark (see chapter $\mathrm{C}$ of this report) show magnetic anomalies that are caused by a magnetitebearing slate member of the Randville dolomite, and $A_{3}$ is almost certainly the aeromagnetic equivalent. Anomaly $\mathbf{A}_{4}$, in secs. 5 and 6, T. 42 N., R. 28 W., is also in an area of dolomite exposures, and being on the eastward projection of $A_{3}$ may also be related to the magnetic slate member. The $\mathbf{A}_{5}$ group of anomalies in the northeastern part of the map area display definite trends although they are small and discontinuous. Presumably this area is underlain by Middle Precambrian sedimentary rocks, but the cause of the anomalies is not known.

Anomalies $\mathbf{A}_{6}$ and $\mathbf{A}_{7}$, in the northern part of $\mathrm{T} .42$ N., Rs. 29 and $30 \mathrm{~W}$., are small anomalies whose cause could not be determined, although $\mathbf{A}_{7}$ is along a westward extension of $B_{6}$ and might possibly indicate a westward continuation of the magnetic dike that causes $\mathbf{B}_{6}$.

The Vulcan iron-formation is present in test pits of the Deerhunt exploration in sec. 35, T. 43 N., R. $29 \mathrm{~W}$., but it must be limited in extent as no indication of this usually magnetic formation is shown by either the aeromagnetic profiles or, except very locally, by the ground magnetic survey.

\section{NORTHERN CRYSTALLINE BLOCK}

The northern crystalline block lies between the Sagola basin and the Felch trough. It is underlain by 
Lower Precambrian rocks of the Dickinson group and by post-Dickinson granite and is bordered on the north and south by Animikie metasedimentary rocks. It is characterized by many small to moderate magnetic anomalies.

Anomaly $\mathrm{B}_{1}$, in secs. 31 and 32 , T. 43 N., R. 30 W., is part of a large composite anomaly that includes $\mathbf{A}_{1}$, and its interpretation is far from clear. The composite anomaly is believed to be caused in part by magnetic beds in the Hemlock formation $\left(A_{1}\right)$, and in part by magnetic zones in the older rocks $\left(B_{1}\right)$. The composite anomaly continues northwestward into Iron County where it is even more complex. A drill hole in the $\mathrm{NE} 1 / 4$ sec. $25, \mathrm{~T}$. $43 \mathrm{~N}$., R. $31 \mathrm{~W}$., encountered strongly magnetic gray and green schist, which, on the basis of recent geologic and magnetic mapping in the Lake Mary and Kiernan quadrangles (Bayley, 1959; Gair and Wier, 1956), has been assigned to the Lower Precambrian complex, whereas a hole in the NW1/4 sec. 30, T. 43 N., R. 30 W., cut a magnetic iron-rich quartzite that is much similar to the Goodrich quartzite in the Kiernan quadrangle. Anomaly $B_{1}$, therefore, might be due either to the Goodrich quartzite, which is stratigraphically immediately below the Hemlock formation in the Kiernan quadrangle, or to magnetite-rich parts of older schists.

It is possible that at least some of the strength of $A_{1}$ and $B_{1}$ is due to the westward extension at depth of the deep-seated magnetic rocks that cause $\mathbf{A}_{2} ; \mathbf{A}_{1}$ and $B_{1}$ may be merely smaller anomalies superimposed on a large broad "basement" anomaly. A ground magnetometer traverse through sec. 33, T. 43 N., R. 30 W. (fig. 91) indicates that the $B_{1}$ connection between profiles 57 and 58 is somewhat doubtful; perhaps the eastern end of $B_{1}$ (profiles 56 and 57 ) is part of the deep-seated $A_{2}$ anomaly, and the western part of $\mathrm{B}_{2}$ is caused by a shallower magnetic zone. The almost complete lack of geologic information and scarcity of ground magnetic data in this area prohibits other than a very generalized interpretation of these complex aeromagnetic anomalies.

Anomalies $\mathrm{B}_{2}, \mathrm{~B}_{3}, \mathrm{~B}_{4}$, and $\mathrm{B}_{5}$, in the northwestern part of T. 42 N., R. 30 W., are rather discontinuous but exhibit well-defined southeast trends parallel to $B_{1}$ for distances of 1 to 3 miles. They probably are caused by magnetic beds in the Lower Precambrian rocks of the Dickinson group. The southeastward termination of $\mathrm{B}_{3}$ and $\mathrm{B}_{5}$ (also $\mathrm{A}_{1}$ ) along a common line helps define the inferred Bush Lake fault.

Anomaly $B_{6}$ trends northeastward through sec. 4 into sec. 3, T. 42 N., R. 29 W. It is caused by a magnetic metadiabase dike that is exposed in several places. From the northern end of $B_{6}$, the small $B_{7}$ anomaly extends eastward into sec. 2 through an area of pre-Dickinson granite gneiss. Its cause is not known, but it may possibly represent an eastward continuation of the magnetic dike.

Anomaly $B_{8}$ trends along the northern edge of secs. 7 and 8 , T. 42 N., R. 28 W. parallel to and a short distance south of the inferred fault that separates gneisses from younger sediments. The crest of $B_{8}$ lies close to or between gneiss outcrops, but the rock causing it is not exposed. Less than a half mile to the south in sec. 7 , anomaly $B_{9}$ closely follows the contact between the granite gneiss and the younger East Branch arkose. The cause of the anomaly could not be determined.

Anomaly $\mathrm{B}_{10}$, with its several branches, trends eastward from sec. 14 , T. 42 N., R. 30 W., across Rs. 29 and $28 \mathrm{~W}$. to the edge of the map area in sec. 5, T. 42 N., R. 27 W. Through Rs. 27 and $28 \mathrm{~W}$. it is essentially a single anomaly with double peaks on profiles 14 , 15 , and 16 ; but from profile 25 westward it separates into two major branches. The southern one appears to decrease and end in sec. 17, R. $29 \mathrm{~W}$.; the northern one continues into R. $30 \mathrm{~W}$., although it is double crested through most of R. $29 \mathrm{~W}$. The anomaly and its various branches are within the area underlain by the East Branch arkose of the Dickinson group. In T. 42 N., R. 28 W., $B_{10}$ is related to magnetic basic metavolcanic rock that is especially well exposed in the SW1/4 sec. 8 and NW1/4 sec. 17 where it is interbedded with the arkose. To the west, in R. $29 \mathrm{~W}$., the branches coincide with tongues of arkose that are separated by granite gneiss, and although no magnetic rocks are exposed, the anomalies are probably caused by interbedded basic volcanic rock as in R. $28 \mathrm{~W}$. Two drill holes near the crest of the anomaly in sec. 18, T. 42 N., R. 29 W., failed to encounter magnetic material, although the one on the west section line passed through sheared granite into partly oxidized, laminated, chloritic schist which contained scattered crystals of martite. This rock may be an altered tuff associated with the magnetic metavolcanic beds in the arkose.

Anomalies $\mathrm{B}_{11}, \mathrm{~B}_{12}, \mathrm{~B}_{13}, \mathrm{~B}_{14}$, and $\mathrm{B}_{15}$ are mostly in T. 42 N., R. 30 W., between the Carey's Spur trough and the porphyritic gneiss domes to the south. These anomalies are small and discontinuous with general northeast trends that are in contrast to the northwesterly trends of the " $B$ " anomalies on the north side of the Bush Lake fault. The $B_{11}-B_{15}$ group is within an area that is mapped as undifferentiated Dickinson group but exposures are exceedingly scarce or absent. As the anomalies are along the westward 

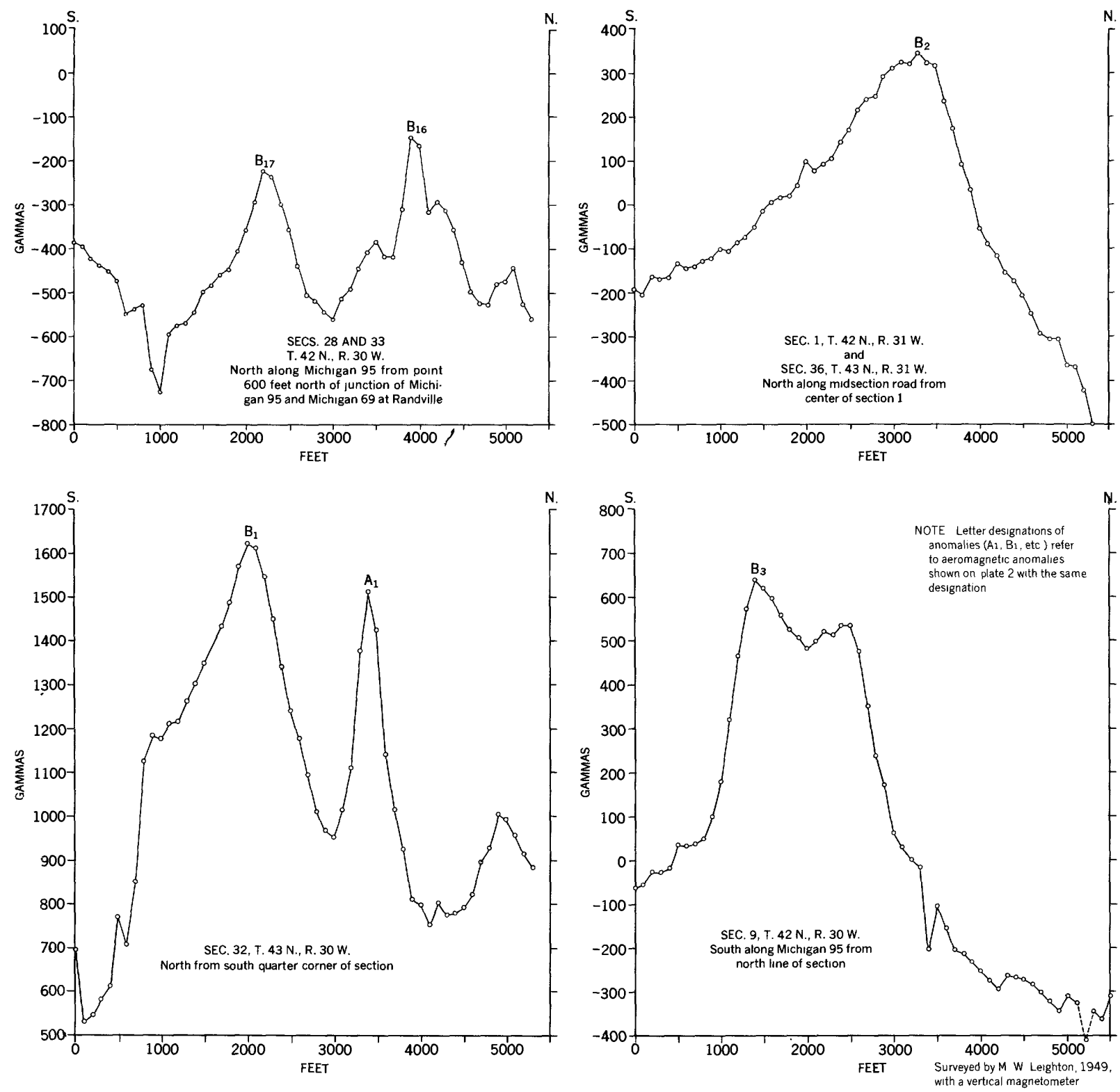

Fiqure 91.-Magnetic profiles in the Randville-Sagola area, Dickinson County. Michigan.

projection of $B_{10}$, they probably are due to westward continuation of the magnetic metavolcanic beds of the East Branch arkose.

The group of small scattered anomalies in secs. 20, 29 , and 30, T. 42 N., R. 30 W., reveal somewhat northeasterly trends. They could not be related to specific rocks; but, with the exception of the northernmost, which seems to lie within the smaller porphyritic gneiss dome, they are probably caused by magnetic rocks of the Dickinson group.

One of the major anomalies in the map area is $B_{16}$, which lies just south of and essentially parallel to $B_{10}$. It can be followed with reasonable assurance from sec. 33, T. 42 N., R. 30 W., eastward across that town- ship and with more certainty across Rs. 29 and 28 W. to sec. 17, T. 42 N., R. 27 W., at the edge of the map area. From profile 43 to profile 54 it appears to be "twinned" with anomaly $\mathrm{B}_{17}$. Anomalies $\mathrm{B}_{18}$ and $\mathrm{B}_{19}$ may possibly be the westward continuation of $B_{16}$ and $\mathrm{B}_{17}$, although there is no obvious connection across profile 55. East of R. $30 \mathrm{~W}$. anomaly $\mathrm{B}_{16}$, with minor exceptions, is strong along its entire length. The sharpness of its profile indicates that the rock causing it is at bedrock surface in many places, but only one exposure of magnetic rock is known along its trend. This outcrop, which is in the $\mathrm{NE}_{1 / 4} \mathrm{NE}_{1} 1 / 4$ sec. $23, \mathrm{~T}$. 42 N., R. 29 W., is a phase of the iron-rich Skunk Creek member of the Solberg schist. Several drill 
holes along the crest of the anomaly in Rs. 28 and $29 \mathrm{~W}$. definitely tie the anomaly to the iron-formation.

Several small scattered anomalies are present in T. 42 , N., Rs. 27,28 , and $29 \mathrm{~W}$., between anomaly $\mathrm{B}_{16}$ and $\mathrm{B}_{10}$, within the area of Solberg schist. Similarly, south of $\mathrm{B}_{16}$, in T. 42 N., Rs. 27, 28, and 29 W., anomalies $\mathrm{B}_{20}, \mathrm{~B}_{21}, \mathrm{~B}_{22}$, and $\mathrm{B}_{23}$ are confined mainly to the area of Solberg schist and Six-Mile Lake amphibolite. With the exception of $\mathrm{B}_{20}$, whose crest lies over scattered outcrops of magnetic hornblendebiotite schist in the $\mathrm{SW}^{1} / 4$ sec. 24 , R. $29 \mathrm{~W}$., none of these anomalies could be correlated with exposed rocks, although they undoubtedly are caused, for the most part, by magnetic rocks of the Dickinson group.

Anomaly $\mathrm{B}_{24}$, which extends across most of T. 42 N., R. $29 \mathrm{~W}$., is within the gneissic granite belt immediately north of the Felch trough. Although it is well defined and of moderate intensity, it occurs where outcrops are scarce. The cause of the anomaly is not known.

Anomalies $B_{25}$ and $B_{26}$ are in an area of few rock exposures near the east margin of the map. They could not be related to known magnetic rocks but are presumably within the gneissic granite. However, $B_{26}$ is about on the eastward projection of the Felch trough and conceivably could represent the western end of another syncline of Animikie sedimentary rocks infolded in the granite.

\section{FELCH TROUGH}

The Felch trough is a narrow, complexly folded and faulted syncline of Middle Precambrian rocks. It is bordered on the north, east, and south by older gneissic granite. Magnetically, it is characterized by strong linear anomalies that are caused chiefly by the Vulcan iron-formation and the Felch formation. Detailed dip-needle surveys by Lamey (see chapter D of this report) reveal many details in the magnetic pattern that are not evident from the aeromagnetic data.

Anomaly $\mathrm{C}_{1}$ is the dominant magnetic feature in the western half of the trough. It extends from sec. 7, T. 41 N., R. 30 W., at the western edge of the mapped area, eastward to sec. 34, T. 42 N., R. 29 W. Many rock exposures, test pits, and drill holes reveal that $\mathrm{C}_{1}$ is caused by the Vulcan iron-formation and by the underlying Felch formation, which locally is extremely magnetic. The break in the anomaly and the connections of the crests in secs. 35 and 36, T. 42 N., R. $30 \mathrm{~W}$., are based on the geologic interpretation of that area.

$\mathrm{C}_{2}$ is a small anomaly or a series of disconnected small magnetic highs along the southern margin of the trough in secs. $33,34,35$, and 36 , T. 42 N., R. 29
W.; where, except in sec. 36 , no Vulcan iron-formation or Felch formation is known to be present. Ground magnetometer traverses in the SE1/4 sec. 34 located the magnetic crest between outcrops of Sturgeon quartzite and gneissic granite to the south. Lamey associates the anomalies in this vicinity with a magnetite-bearing phase of the Sturgeon quartzite, but at no place could magnetic crests be located directly over outcrops of quartzite by ground magnetometer traverses; an alternate consideration is that the anomalies in the quartzite areas are partly due to magnetite mineralization along fault zones, as many of the anomalies lie close to known or inferred faults.

Anomaly $\mathrm{C}_{3}$, in sec. 36 , T. 42 N., R. 30 W., and in secs. 31 and 32 , T. 42 N., R. 29 W., is also along the south margin of the trough within the quartzite belt and probably has the same origin as $\mathrm{C}_{2}$.

Anomaly $\mathrm{C}_{4}$ is confined to the eastern part of the Felch trough, from sec. 31 to sec. 36, T. 42 N., R. $28 \mathrm{~W}$; like $\mathrm{C}_{1}$, it is also caused mainly by the Vulcan iron-formation and the Felch formation. In the SW $1 / 4$ sec. 31 the anomaly lies over known iron-formation, but continuity eastward into sec 32 is uncertain as the anomaly becomes small on profile 23 and starts to divide into two crests on profile 22 . The northern crest coincides with the ridge of iron-formation exposed north of Felch in secs. 32 and 33. The southern crest continues eastward over known Vulcan ironformation and Felch formation in secs. 33 and 34 and decreases rapidly before it apparently dies out in sec. 36. The reason for the continuation of the anomaly into the area of gneissic granite east of the Felch trough proper is not understood. A possible explanation, given in some detail previously (see fig. 79), is that a buried wedge of magnetic Animikie rocks may be present beneath the granite along faults.

Two magnetic lows occur along the north side of the Felch trough; one in sec. 31, T. 42 N., R. 29 W. north of $\mathrm{C}_{1}$, and the other in secs. 28 and 29, T. $42 \mathrm{~N}$., R. $28 \mathrm{~W}$., north of $\mathrm{C}_{4}$. Both are adjacent to large positive anomalies that are caused by extremely magnetic and permanently magnetized Vulcan ironformation. The lows are features related to the magnetic highs; they are not produced by the rock directly beneath the magnetic troughs.

\section{CENTRAL CRYSTALLINE BLOCK}

The area between the Felch and Calumet troughs is underlain almost entirely by gneissic granite. In general the anomalies are small and discontinuous but do exhibit definite trends.

Anomaly $\mathrm{D}_{1}$, in the northwestern part of T. $41 \mathrm{~N}$., R. $30 \mathrm{~W}$., is close to and roughly parallel to the 
southern border of the Felch trough. It appears to lie within the granite, although it is partly obscured by the strong $\mathrm{C}_{1}$ anomaly to the north. Anomalies $\mathrm{D}_{2}$ and $\mathrm{D}_{3}$, in sec. 1 , T. 41 N., R. $30 \mathrm{~W}$., and secs. 5 and 6, T. 41 N., R. 29 W., are well within the gneissic granite and, like $\mathrm{D}_{1}$, evidently are caused by magnetic zones in the granite complex.

Anomaly $\mathrm{D}_{4}$ follows the southern contact of the narrow tongue of Animikie rocks that lie within the gneissic granite in the northern part of T. 41 N., R. $30 \mathrm{~W}$. Its crest in the SW $1 / 4$ sec. 10 lies between low outcrops of granite which are several hundred feet apart. A small patch of slightly magnetic granite pegmatite was found in one of these outcrops. About a half mile to the east, in the SE1/4 sec. 10, the crest is on the north slope of a prominent ridge of Sturgeon quartzite, although not directly over actual exposures of the rock. Some of this quartzite contains magnetite crystals, and hand specimens tested with the ground magnetometer are slightly magnetic. $\mathrm{D}_{4}$ is likely made up of more than one separate anomaly, as it seems due partly to magnetic material in the sediments and partly to magnetic zones in the granite.

Anomaly $\mathrm{D}_{5}$, although small, appears to be continuous from sec. 12, T. 41 N., R. 30 W., for a distance of about 5 miles to sec. 11 , T. 41 N., R. 29 W. It crosses the Toby Lake fault with no noticeable offset, which suggests it may be caused by a magnetic dike that was intruded after the major movement of the fault.

The $\mathrm{D}_{6}$ group of small anomalies is scattered through the gneissic granite along a 7 -mile belt extending from sec. 20 , T. 41 N., R. 30 W., to sec. 9 , T. 41 N., R. $29 \mathrm{~W}$. In secs. 20 and 21, R. $30 \mathrm{~W}$., the anomaly parallels a basic dike that is slightly magnetic and, at least in that vicinity, the apparent cause of the anomaly. The dike is known to cross the cuartzite in sec. 20 , but, unfortunately, profile 57 did not record at this place and the gap of almost a mile between profiles 56 and 58 makes the continuity of $\mathrm{D}_{6}$ somewhat uncertain. The small magnetic anomaly along the northern edge of sec. 19, T. 41 N., R. 30 W., may possibly be due to westward continuation of the dike.

$\mathrm{D}_{7}$ is a small anomaly in an area of few rock exposures in secs. 5 and 6, T. 41 N., R. 27 W. Its cause is not known, and even its apparent eastward trend is questionable inasmuch as it does not coincide with known geologic trends in that area.

\section{CALUMET TROUGH}

The Calumet trough, like the Felch trough, is a block of Animikie rocks bordered on both the north and south by gneissic granite. The trough is under- lain chiefly by metamorphosed sediments of the Baraga group, some of which are in some degree magnetic. The Vulcan iron-formation and Felch formation are only locally present; in most parts of the area these units are absent because of post-Vulcan erosion or because of faulting.

Anomaly $\mathrm{E}_{1}$ parallels the North Calumet fault for a distance of six miles, from sec. 16, T. 41 N., R. 29 W., to sec. 9 , T. 41 N., R. 28 W. It is caused mainly by the Vulcan iron-formation and partly by magnetic schists in the Michigamme slate; both are known to be present along its trend. The ground level equivalent of $\mathrm{E}_{1}$, and the magnetic rocks causing it, are described in considerable detail in Chapter 6 of this report.

Anomaly $\mathrm{E}_{2}$, one of the strongest anomalies in the central Dickinson County area, appears on profiles 24 and 25 as the southern part of $\mathrm{E}_{1}$ in sec. 18, T. 41 N., R. $28 \mathrm{~W}$. $\mathrm{E}_{2}$ may continue westward a short distance into R. $29 \mathrm{~W}$. as part of the southern slope of $\mathrm{E}_{1}$, but this is not clear from the aeromagnetic data. Eastward, across R. 28 W., $\mathrm{E}_{2}$ develops into a large separate anomaly that gradually decreases in strength, although it appears to continue as a small broad anomaly as far as sec. 12, T. 41 N., R. 28 W., where it seems to swing southeast and die out at the east edge of the township. Little is known about the geology of this area, but drilling in sec. 17, T. $41 \mathrm{~N}$, R. $28 \mathrm{~W}$, near the crest of $\mathrm{E}_{2}$ encountered ironformation below several hundred feet of Paleozoic strata; the anomaly is evidently caused, to a large extent, by the Vulcan iron-formation. The iron-formation is believed to be present on an anticlinical structure, which would account for the width and great strength of the a 1omaly. The profiles suggest that the anticline plunges both east and west from the sec. 17 area where the anomaly reaches its maximum value. Profile 8 , at the east end of the anomaly, indicates that the magnetic rock there is at a depth of several thousand feet. Anomaly $\mathrm{E}_{3}$, in secs. 17 and 18, T. $41 \mathrm{~N}$., R. $27 \mathrm{~W}$., is along the eastward projection of $\mathrm{E}_{2}$, and inasmuch as the Calumet trough continues eastward, $\mathrm{E}_{3}$ may be a continuation of $\mathrm{E}_{2}$, although profile 7 fails to show a connection between the two.

Anomalies $\mathrm{E}_{4}, \mathrm{E}_{5}, \mathrm{E}_{6}, \mathrm{E}_{7}$, and $\mathrm{E}_{8}$ make up an irregular, discontinuous group in the southern part of T. 41 N., Rs. 29 and $30 \mathrm{~W}$. The anomalies lie within an area underlain by sedimentary and volcanic rocks of the Baraga group. $\mathrm{E}_{6}$ and $\mathrm{E}_{7}$ through R. 30 W., and $\mathrm{E}_{5}$ and $\mathrm{E}_{4}$ through R. $29 \mathrm{~W}$., form a fairly continuous moderately strong broad magnetic belt. The general shape of the aeroprofiles over this area suggest that the magnetic material causing anomalies lies at considerable depth beneath the surface. Per- 
haps buried remnants or patches of the magnetic rocks of the Menominee group-or even of the Baraga group-are responsible for the main part of these anomalies. Slightly magnetic graywacke crops out in the SW $1 / 4$ SW $1 / 4$ sec. $26, T .41 \mathrm{~N}$., R. 30 W., and some of the irregular minor crests are probably related to surface or near-surface exposures of this or a similar magnetite-bearing rock.

Many scattered anomalies are present south of $\mathrm{E}_{2}$ and $\mathrm{E}_{3}$ in the south half of T. 41 N., Rs. 27 and $28 \mathrm{~W}$. They are collectively designated $\mathrm{E}_{9}$. For the most part, these anomalies are small, discontinuous, and poorly defined, but they do reflect definite though varied trends. They are in an area inferred to be underlain by Animikie strata, but exposures are practically absent, and none of the anomalies have definitely been related to specific rocks. At the Hancock exploration, in the SW1/4S1/4 sec. 30, T. 41 N., R. 27 W., a magnetic iron-rich rock is exposed in test pits, and this rock may be the cause of the magnetic highs in secs. 30 and 29.

\section{SOUTHERN CRYSTALLINE BLOCK}

The southern crystalline block lies in the southern part of T. 41 N., Rs. 28 and 29 W.. It consists chiefly of granite gneiss. Several small anomalies occur within this granite mass, the largest and most clearly defined of which is labeled $F_{1}$. This anomaly can be traced northeastward from sec. 32 at the south margin of the map area, for a distance of about 5 miles to sec. 25, T. 41 N., R. 29 W. Ground magnetometer traverses located its crest close to exposures of slightly magnetic fine-grained porphyritic metagabbro in sec. 27 , and slightly magnetic metadiabase was found near the minor magnetic crests north of $F_{1}$. It seems likely that these anomalies are related to basic intrusives in the gneissic granite. 


\title{
Chapter C. PREGAMBRIAN GEOLOGY OF THE NORWAY LAKE AREA
}

\author{
By Lorin D. Clark
}

The area covered by this report extends from 1 mile north of the north line of T. $42 \mathrm{~N}$. to 3 miles south of that line, and from 1 mile west of the east line of R. $28 \mathrm{~W}$. to the west line of R. $29 \mathrm{~W}$., Dickinson County, Mich. (See fig. 1.) It is crossed in a northerly direction by county road 581 , and in an easterly direction by county road 422 and an unnumbered county road. Norway Lake is the best known geographical feature of the area. This report is based on fieldwork done during the summers of 1947 and 1948.

Most exploratory work in the Norway Lake area has centered on the Deerhunt exploration, which consists of a group of test pits and trenches dug about 1905 , a series of diamond-drill holes drilled by the Jones and Laughlin Co. in 1930, and a series of holes drilled by the M. A. Hanna Co. in 1950-53.

Geologic mapping was done on aerial photographs, and the base for the geologic map of the area, used in compiling plates 2 and 9, was compiled from the photographs by standard photogrammetric methods. Land sections 1 mile square were assumed except in the vicinity of county road 581 where the road survey was used for control. An area of excellent exposures of arkose and associated rocks on the East Branch of the Sturgeon River near the northwest corner of sec. 17, T. 42 N., R. 28 W., was mapped by plane table (pl. 10). Magnetic-survey stations were located by pace-compass traverses adjusted to the geologic base map.

The generous cooperation of the Jones and Laughlin Ore Co., Cleveland-Cliffs Iron Co., and M. A. Hanna Co. in permitting access to their files of drilling data is gratefully acknowledged. R. B. Hall ably assisted in the fieldwork for one month in 1947 , and E. R. Jacobus operated a magnetometer during the summer of 1948.

The Norway Lake area was first mapped by Bayley (1899) as part of his study of the Sturgeon River tongue. His report lists brief references to the area by earlier workers and contains petrographic descriptions of most of the rocks in the area. Bayley's description of the area is briefly reviewed by Van Hise and Leith (1911), and his map is used with slight modification by these authors in compilation of their map of the Crystal Falls district (1911, pl. 22). Later regional geologic maps (Leith, Lund, and Leith, 1935, pl. 1; and Martin, 1936) show a similar interpretation of the geology in the vicinity of Norway Lake.

The Norway Lake area is included in an aeromagnetic survey of Dickinson County made by the Geological Survey (Wier, Balsley, and Pratt, 1953). Pettijohn (1951) has studied the geology of T. 42 N., R. 30 W. adjoining the Norway Lake area on the west.

\section{GENERAL GEOLOGY}

The Norway Lake area is on the south margin of an embayment of Animikie sedimentary rocks into the west side of an older complex of crystalline and metamorphic rocks. The name Sagola basin, suggested by Pettijohn (1951), is used to designate this embayment in the present report in preference to the earlier term "Sturgeon River tongue" used by Bayley (1899, p. 458$)$.

The northern part of the mapped area is underlain by Animikie strata that include the Randville dolomite, Vulcan iron-formation and associated slates (socalled footwall slates), and Michigamme slate. (See table 10.) The Animikie rocks comprise the southern part of the Sagola basin. Lower Precambrian rocks, consisting of granite gneiss, arkose, and hornblende and biotite schists, form the northern part of a block of crystalline and metamorphic rocks that separates the Sagola basin from the Felch trough of Animikie sedimentary rocks. The older rocks are strongly sheared, and the bedding is vertical or nearly so. The structure of the Animikie rocks is complex, and dips are generally steep. The rocks are not sheared, however, and the metamorphic grade is lower than that of the older series.

The principal structural elements appear to be highangle faults. Within the area underlain by Lower Precambrian rocks, some of these faults can be mapped with a reasonable degree of certainty, but within the Sagola basin area of Animikie rocks, exposures are not plentiful enough to indicate whether repetition of beds has been caused predominantly by folding or by faulting. 
TABLE 9.-Sequence of Precambrian rocks in the Norway Lake area

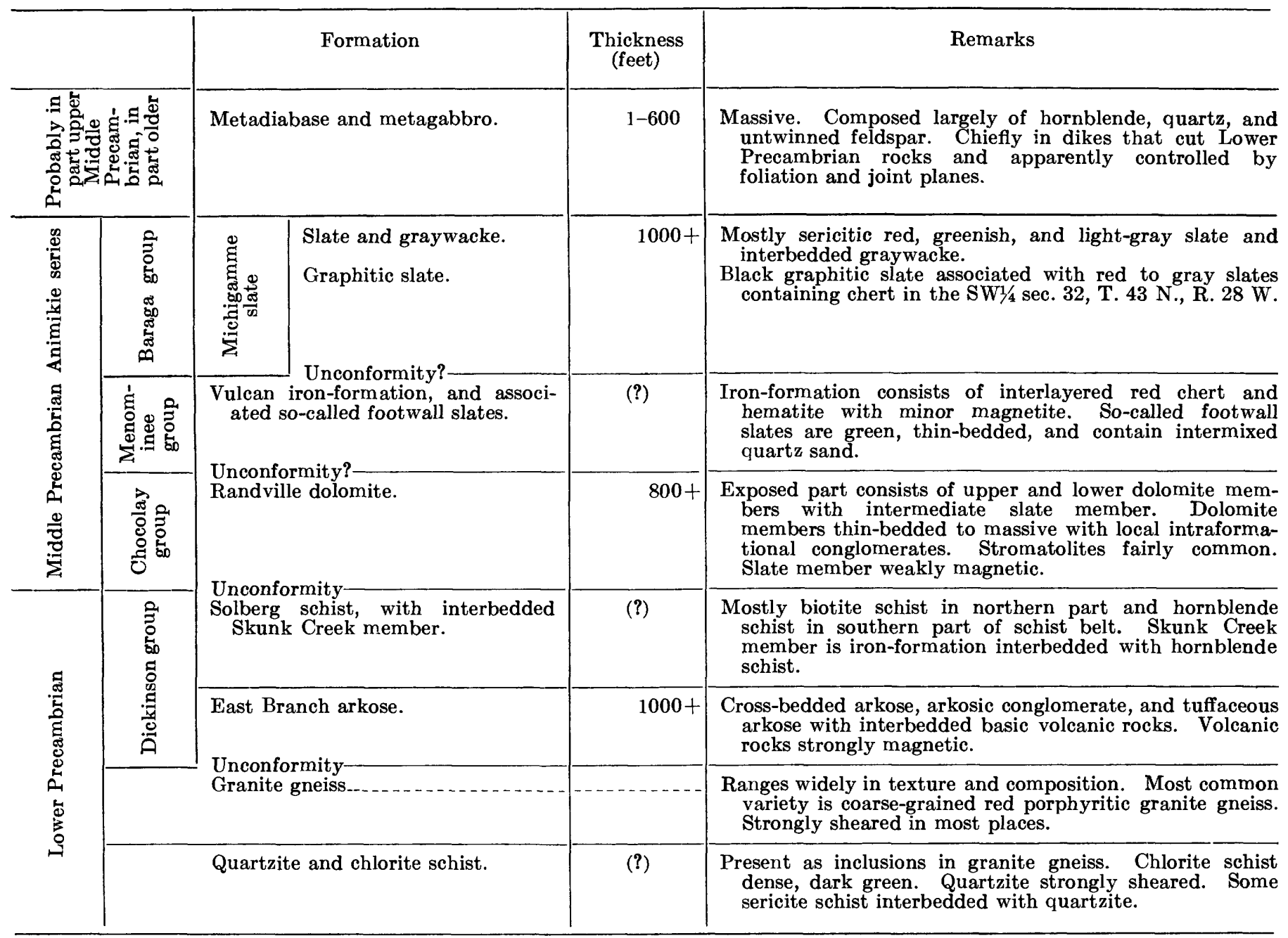

Metadiabase dikes cut the older rocks, but in this area none are exposed in the area underlain by Animikie rocks.

Flat-lying sandstone of Cambrian age caps some of the hills in the central part of the Norway Lake area. The sandstone is permeable, and springs are common at the base of the formation.

Glacial deposits consist of till and outwash sand and gravel, the thickness of which is unknown in most of the area. The last ice sheet covering the area was a westward-moving part of the Green Bay lobe of the last Wisconsin glaciation.

The absence of strong persistent magnetic anomalies in the part of the Norway Lake area that is underlain by Animikie rocks suggests that the Vulcan ironformation is absent in most places. Exploration for any iron-ore bodies that might occur is likely to prove tedious and expensive because of the difficulty of determining the structure and stratigraphy on the basis of available magnetic and outcrop data.

\section{LOWER PRECAMBRIAN ROCKS}

\section{CHLORITE SCHIST AND QUARTZITE}

Chlorite schist and quartzite occur as inclusions in the gneiss. Although it was not practical to map the inclusions separately, exposed portions of some are measurable in terms of tens of feet in width and length.

Exposures of the chlorite schist almost invariably contain some granite gneiss, despite the size of some of the schist masses. This relation indicates that the schist is not sufficiently resistant to erosion to be exposed except where protected by stronger rock. Probably, therefore, the chlorite schist is much more abundant than the outcrop data indicate.

The chlorite schist is dark green to black, is fine grained, and has well-developed schistose structure. Contacts of the schist with the enclosing gneiss are sharp or, in some places, interlaminated in a zone a few inches thick. The gneiss is commonly fine grained 
at the contact. Thin sections show that the chlorite schist is composed chiefly of chlorite and quartz, with some cloudy untwinned feldspar. Calcite, leucoxene, and magnetite are commonly present, and epidote, colorless garnet, and titanite occur in some specimens.

A fine-grained light-red quartzite is exposed about 200 feet north of the south quarter corner of sec. 1 , T. 42 N., R. 29 W., and occurs as angular pebbles in the Cambrian sandstone in the $\mathrm{NW}^{1 / 4} \mathrm{SW}^{1 / 4}$ of the same section.

Two masses of interbedded quartzite and muscovite schist are included in the granitic rock in the SW1/4 SW $1 / 4$ sec. 2 , T. 42 N., R. 28 W. One, about 10 by 25 feet, is composed of white vitreous granular quartz. Near one corner of this body thin layers of muscovite schist are interbedded with the quartz. The interbedded zone is drag-folded. The other inclusion, about 2 feet thick, is composed of muscovite schist containing granular quartz in layers 2 inches thick. The association with muscovite schist suggests that the quartz masses are quartzite.

Neither the chlorite schist nor the quartzite in sec. 2, T. 42 N., R. 28 W., can be correlated with other stratigraphic units in the mapped area. The only clues to their age are their lithologic character and the fact that they are older than the Lower Precambrian gneiss in which they form inclusions.

It has not been established whether the quartzite that forms the isolated outcrop in sec. 1, T. $42 \mathrm{~N}$., R. $29 \mathrm{~W}$., is of Sturgeon age or is older than the granite gneiss.

\section{GRANITE GNEISS}

Granite gneiss underlies much of the area north of Randville (pl. 2) and forms a thin wedge that extends to the map boundary east of Norway Lake, separating the dolomite and slate to the north from the arkose and schist to the south. The gneiss is exposed as glacier-sculptured knolls, the highest of which projects about 30 feet above the surrounding superficial deposits.

\section{GENERAL CHARACTER}

Although the composition and texture of the gneiss range widely, a coarse brick-red to very light red rock of porphyritic aspect is most common (figs. 5,6). The largest phenocrysts which are $11 / 2$ inches long, are microcline and albite. Other light-colored constituents are quartz, plagioclase, and muscovite. Dark minerals are generally present in minor amounts, but chlorite is locally abundant.

A marked cataclastic texture with strong secondary foliation is characteristic. Many of the large feldspar grains are fractured and rounded (figs. 5, 6) and are separated by laminae of micaceous or chloritic min- erals in which are embedded microcline fragments and thin tabular quartz grains. Foliation in the laminae conforms to the boundaries of the large mineral grains. The foliation of the rock as a whole results from the parallel arrangement of microcline, albite, quartz, and mica grains.

The gneiss of secs. 15 and 16, T. 42 N., R. 29 W. is similar in appearance to that described above, but biotite rather than muscovite is the dominant micaceous mineral, and the effects of shearing are less pronounced. The rocks are light gray to light red.

Less common varieties of granite gneiss exposed in T. 42 N., R. 28 W. include fine-grained granite and quartz-rich granite. A fine-grained, nonporphyritic granite is exposed near the center of the $\mathrm{SE} 1 / 4$ sec. 2. This rock is light orange and composed largely of potash feldspar and tabular quartz (figs. 3, 4). The quartz grains are about $2 \mathrm{~mm}$ long. Parallel arrangement of the quartz grains in an apparently massive groundmass of feldspar gives the rock a distinct planar structure. A similar rock is exposed north of the road in the $\mathrm{NE} 1 / 4 \mathrm{NE} 1 / 4$ sec. 7 .

A granite unusually rich in quartz is exposed in the $\mathrm{SW}_{1} 1 / 4 \mathrm{SW} 1 / 4$ sec. 2. Although the fresh feldspar is red, the rock weathers to a much lighter color than the other gneisses in that vicinity. In addition to feldspar and quartz, the only other common mineral is muscovite. The original texture was medium grained and massive, but the rock is now sheared to the extent that this texture has been destroyed except in rounded cobblelike fragments, which are enclosed in a granulated matrix. This material resembles the sheared arkosic conglomerate except that bedding and foreign pebbles are absent. Quartz veins and illdefined bodies of pegmatite are abundant. Quartzite and muscovite schist inclusions in this exposure were described previously. Similar granitic rocks are exposed 1,100 feet north of the south quarter corner sec. 2 , in the southeast part of the NW1/4 NE $1 / 4$ sec. 7 , and in the $\mathrm{NE}_{1} 1 / 4$ sec. 10 , all in T. $42 \mathrm{~N}$., R. $28 \mathrm{~W}$.

A rock composed largely of microcline and calcite with minor chlorite is exposed 200 feet east of the west quarter corner of sec. 12 , T. 42 N., R. 29 W., immediately north of an arkose outcrop. The microcline grains are brick red and similar in appearance to those of the red porphyritic granite. The calcite occurs interstitially and as fracture-filling in the microcline grains. Quartz is absent. A similar rock is associated with red porphyritic granite 700 feet east of the center of sec. 3, T. 42 N., R. 29 W. In this exposure the relation between the two rock types is not clear, but the calcite-bearing rock is probably a phase of the red porphyritic granite. 


\section{PETROGRAPHY}

Most of the granite gneiss is composed chiefly of microcline, albite, and quartz, with subordinate amounts of white mica, green biotite partly altered to chlorite, and calcite (table 10). Minor minerals include specular hematite, zoisite, titanite, and monazite. Myrmekite and micrographic intergrowths of quartz and albite are found in some specimens. Effects of cataclasis are marked (figs. 5, 6) and are shown by the fractured and granulated feldspar grains, by tabular aggregates of quartz showing strong undulatory extinction, and by bent mica grains, as well as by the foliated character of the rock as a whole.

TABLE 10.-Chemical and mineralogical composition of the
porphyritic red granite gneiss

[Analyst, Leonard Shapiro, U.S. Geological Survey. Chip sample weighing in excess of 5 pounds, from NE1/4NE1/4 sec. 7, T. 42 N., R. $28 \mathrm{~W}$.]
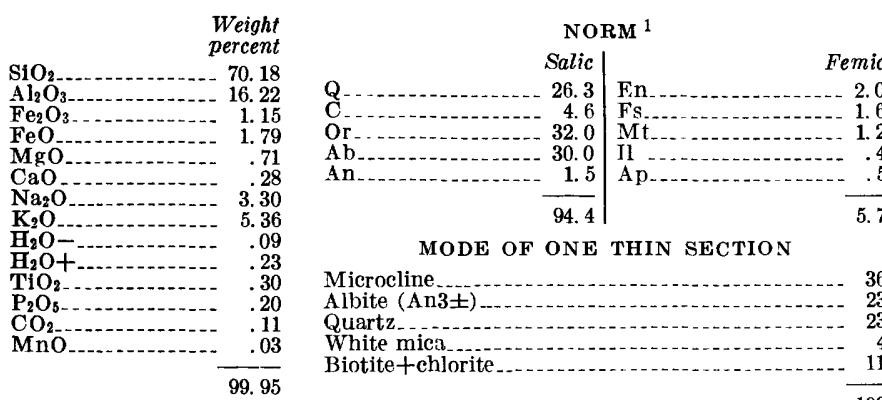

Microcline

Albite (An3

Quartz mic

Biotite+chlorite

1 Calculated according to Barth (1952, p. 79-81.)

Much of the microcline is present as fractured and granulated porphyroblasts. It is generally clear, but a slight cloudiness is produced in some grains by minute liquid inclusions. Locally, as in the SW1/4 SE1/4 sec. 2, T. 42 N., R. 28 W., unfractured grains of microcline, about one-quarter of the average size of the porphyroblasts, are present. The clearness, lack of fracturing, absence of replacement perthite, and the very irregular shape of these grains suggest that they were formed after the deformation.

Albite is present in the following forms:

1. Subheadral randomly-oriented inclusions in the microcline, and separate grains in the groundmass.

2. String-and-stringlet type perthite of Alling (1938).

3. Veinlet and patch type perthite of Alling (1938).

4. Elongate anhedral grains related to fractures and to veinlet and patch perthite.

5. Chessboard albite.

6. Granoblastic mosaic of anhedral grains between microcline and quartz grains.

The first three types of albite are widespread in the granite and the last three are present locally. The composition of all types of albite seems to be very nearly the same. The extinction angle of twinned forms measured normal to $(010)$ is $15^{\circ}$, and the indices are less than 1.54, indicating a composition of about $\mathbf{A} b_{95}$, a value in accord with the chemical analysis (table 10). Untwinned albite has the same belief as the twinned forms, where the two are in contact.

The randomly oriented inclusions of albite (figs. 92, 93) are probably of primary origin. Many of these grains are.fractured as is the host microcline, but they show no evidence of being genetically related to the fractures in the microcline. Nearly all the albite grains contain abundant inclusions of white mica, but have clear rims in which the inclusions are absent.

The string and stringlet type perthite is common and widespread. No particular spacial relation to the boundaries of the microcline grains, inclusions, or fractures, was noted.

Albite forming the veinlet and patch type perthite is probably of replacement origin. It has formed preferentially in fractures and near the boundaries of microcline grains. The fact that all the albite in the fractures in a single microcline grain extinguishes simultaneously indicates that the orientation of the albite was controlled by the host microcline. Albite of this type is clear, owing to the absence of inclusions and alteration. The elongate grains of albite found within the microcline grains and the clear rims on the randomly oriented inclusions show the same features as the veinlet and patch type perthites and probably are also of secondary origin.

Chessboard albite has been found in only one thin section of the granite gneiss from the Norway Lake area. This specimen is from the $\mathrm{SE}^{1} / 4 \mathrm{NW}^{1 / 4}$ sec. 15 , T. 42 N., R. 29 W., and is megascopically typical of most of the granite in the north part of section 15 . The chessboard albite contains randomly oriented, rimmed inclusions of albite, as does the microcline of the red porphyritic granite, and also contains veinlets of albite (fig. 93). These features indicate that the chessboard albite was formed by the replacement of microcline. The less-sheared appearance of this rock in exposures may well be due to the healing of some of the fractures during the crystallization of the secondary albite.

Albite forms a granoblastic mosaic with microcline and quartz in a medium-grained granite exposed in the $\mathrm{NE} 1 / 4 \mathrm{SE} 1 / 4$ sec. 2, T. $42 \mathrm{~N}$., R. $28 \mathrm{~W}$. Albite is the dominant mineral of the mosaic. Most of the albite grains do not show twinning and are extensively altered to white mica. These grains have the same relief as scattered unaltered twinned grains. Albite is also present as veinlet type perthite in the microcline of 


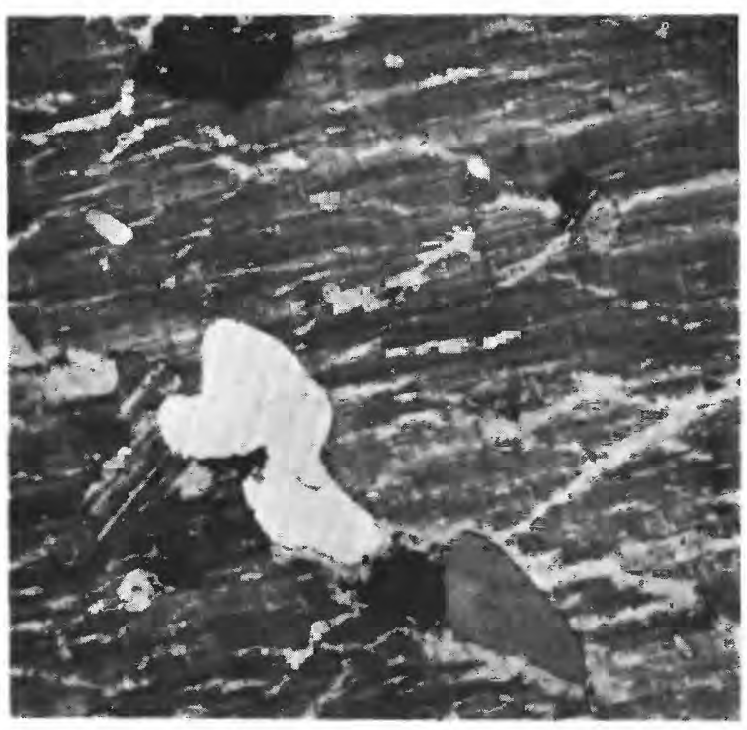

FIGURE 92

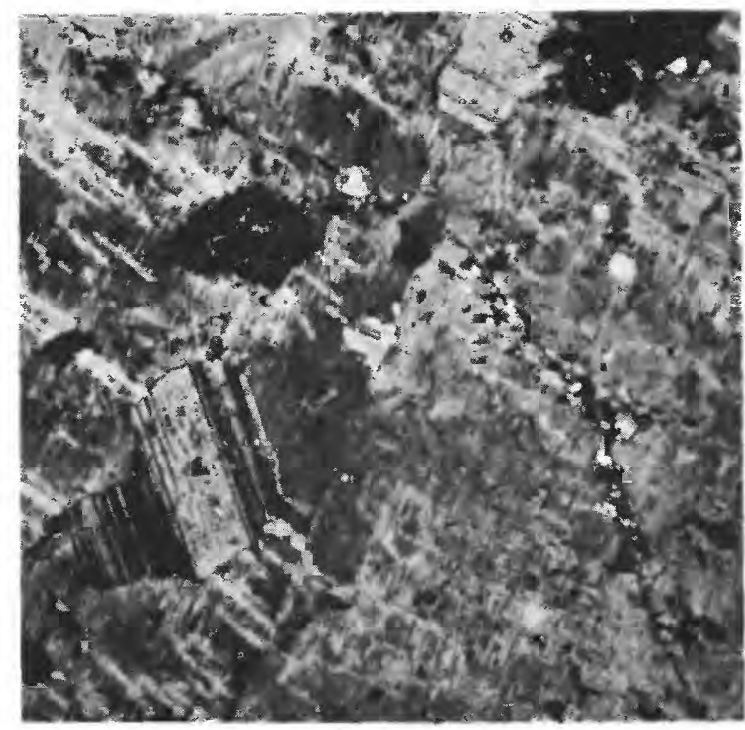

Figure 93

FiguRES 92, 93.-PHOTOMICROGRAPHS OF FELDSPARS IN GRANITE GNEISS AND ARKOSE.

92. Microcline perthite with albite (twinned), quartz (white to gray), and biotite (black) inclusions. White veinlets are albite. Note clear rims on albite inclusions. From NE1/4NE1/4 sec. 7, T. 42 N., R. 28 W. Crossed nicols, $\times 30$ Specimen LC-64-48.

this rock. Here again the effects of shearing are less pronounced than in rocks containing less albite, suggesting that the albite is of post-deformation origin

Albite extensively altered to white mica is also present in the calcite-rich gneiss in the $\mathrm{NW}_{1} / 4 \mathrm{SE} 1 / 4$ sec. 3, T. 42 N., R. 29 W. This albite is untwinned, but has the same relief as that forming veinlets and inclusions in the microcline of this rock.

\section{STRUCTURAL RELATIONS}

The granite gneiss is in fault contact with the Randville dolomite and Michigamme slate to the north and is overlain unconformably by the East Branch arkose to the south. Only one exposure that shows the contact of granite gneiss with younger sedimentary rocks has been found. This exposure is at the south edge of the wedge of granite gneiss in sec. 10, T. 42 N., R. 28 W., where the gneiss is in contact with East Branch arkose in part of the outcrop. The contact is apparently depositional, for the lithologic change at the contact is sharp, and there is no evidence of faulting or intrusion of the arkose by the gneiss.

In the SE1/4NE1/4 sec. 7 , T. 42 N., R. 28 W., typical arkosic conglomerate with quartzite and gneiss pebbles is in contact with chlorite schist that is bordered on the north by gneiss. The contact is not diagnostic, as the schist appears to be an altered dike rock. Similar rocks cut both gneiss and arkose.
93. Chessboard albite (mottled gray field) with albite inclusions. Diagonal white streaks in upper part of picture are also albite. Granular secondary quartz along diagonal fracture. Note clear rims on albite inclusions with cores partly altered to white mica. From NW1/4 sec. 15, T. 42 N., R. 29 W. Crossed nicols, $\times 30$. Specimen LC-47-48.

AGE

No evidence is available to show whether the gneisses of different composition are of the same age or different ages. In this report they are assumed to be of the same age. Bayley (1899) considered the gneisses to be Archean in age, and in the absence of evidence to the contrary, they are here assigned to the Lower Precambrian.

\section{EAST BRANCH ARKOSE}

The East Branch arkose forms an eastward-trending belt, which is in places more than a mile wide (see pl. 8). It is well exposed at many places along the East Branch of the Sturgeon River. In parts of secs. 7, 8, 17, and 18, T. 42 N., R. 28 W., where the exposures are especially good, the area was mapped by plane table (pl. 10). Like the gneiss, the arkose is exposed in glacier-sculptured knolls. In general, however, the arkose knolls have lower relief than those of the gneiss, and few project more than 10 feet above the surrounding surficial material.

\section{GeNERAL Chara CTER}

The East Branch arkose includes arkose, arkosic conglomerate, and interbedded metamorphosed basalt flows and basic tuffs. The sedimentary rocks are characterized by coarseness of grain, poor sorting, crossbedding (fig. 7), and recurrent beds of conglom- 
erate throughout most of its belt of exposure. Conglomerate beds are absent only in the southern part of sec. 2, T. 42 N., R. 28 W., and in the most southerly 500 feet of the exposed section of the formation where basic tuffs are interbedded with the arkose. Beds more than a few inches thick in which argillaceous material was the predominant constituent are rarely exposed, either because they are absent from the section or because they are easily eroded. A muscovite schist about 100 feet thick with abundant coarse grains of quartz and feldspar exposed near the NE cor. sec. 10 , T. 42 N., R. 28 W., is probably the metamorphosed equivalent of an originally argillaceous bed.

Most clastic fragments in the conglomerate are less than 4 inches in length, but some are boulders more than a foot long. Except in the northern part of sec. 10, T. 42 N., R. 28 W., where boulders of gneiss are relatively abundant, about 75 percent of the clastic fragments more than an inch long are quartzite. The rest are chiefly gneiss and sericite slate. Many of the pebbles less than an inch long are fragments of feldspar crystals. Fragments of milky-white, opalescent quartz containing small lenses of white mica are common. Rare pebbles and cobbles of hematite chert or quartzite are present. No fragments of dolomite, hematite, jasper, or jaspilite occur in the East Branch arkose. The matrix of the conglomerate and the nontuffaceous coarse arkose is composed largely of clastic grains of quartz, quartzite, and microcline (figs. 9, 10). Muscovite is abundant on parting surfaces.

Most of the quartzite pebbles are light orange and contain small amounts of feldspar. Many of the quartzite pebbles are thin bedded, and some show crossbedding.

The pebbles of gneiss range as widely in composition and texture as the gneiss mass north of the arkose. Pebbles of fine-grained felsitelike rocks, coarse pegmatitic or porphyritic granite, medium-grained quartz-rich granitic rock, and rare graphic granite are included.

In the upper part of the exposed section of the East Branch arkose, thin-bedded basic tuffs are interbedded with thick-bedded arkose. The tuffs are dark gray and are composed of feldspar, quartz, epidote, biotite, carbonate, and pyrite. Small tabular bodies of microcline-hornblende pegmatite occur in this part of the section. The feldspars are more abundant in the pegmatite than in the arkose, commonly constituting more than 50 percent of the rock. The arkose inter bedded with the tuff is better sorted than that lower in the section, resulting in a coarse-grained rock of fairly uniform grain size. Recrystallization of these beds has formed a rock closely resembling granite gneiss in texture and composition. The assemblage of recrystallized arkose and dark micaceous tuff beds about 1,100 feet south of the northwest corner of sec. 17, T. 42 N., R. 28 W. (pl. 10), can easily be mistaken for a granite gneiss, but well- preserved crossbedding in several of the arkose beds proves the sedimentary origin of these rocks (fig. 7).

Metamorphosed basalt flows are interbedded with the arkose. The best exposures showing the character of the metabasalt and its relations to the arkose are in the northwest corner of sec. 17, T. 42 N., R. 28 W. (pl. 10). The metabasalt is conformable with the bedding of the arkose and has a zone of calcite an quartz amygdules near the top of the flow. The metabasalt is composed of hornblende, biotite, plagioclase feldspar, epidote, quartz, carbonate, and magnetite (fig. 11). In the upper 6 feet of the flow, apparently in the originally scoriaceous zone, a very coarsegrained skarnlike rock consisting of microcline, hornblende, epidote, calcite, quartz, and pyrite is present.

A group of rocks that has the general appearance of metabasalt is exposed in the southern part of the SW $1 / 4 \mathrm{SW}^{1} / 4$ sec. 8, T. 42 N., R. $28 \mathrm{~W}$., north of the basalt flow described above and separated from it by an arkosic conglomerate bed. In places, however, these rocks appear to be bedded, and in the northeast corner of the area shown on plate 10 they have a structure suggestive of volcanic breccia. These rocks probably are a series of basic flows and pyroclastics whose original texture has been largely destroyed by recrystallization. In the southwest corner of sec. 8, T. 42 N., R. 28 W., (pl. 10), a conglomerate is interbedded with these rocks. The conglomerate contains quartzite pebbles in a nearly black matrix of quartz, feldspar, biotite, chlorite, and epidote.

Adjacent to the flows, and in places to metadiabase dikes intrusive into the East Branch arkose, the arkose has been altered to a dark-gray to black vitreous rock, resembling quartzite. This rock is composed largely of quartz, with subordinate feldspar, green biotite, and epidote.

Arkose beds in the group of exposures in the SE1/4 sec. 16, T. 42 N., R. 29 W., contain pebbles of vein quartz, feldspar, and granitic rock as much as threefourths of an inch in diameter. Interbedded with the arkose are tuff beds and layers of biotite schist and hornblende schist. The hornblende schist is identical in appearance with the hornblende schist in the belt south of the East Branch arkose.

The arkose exposed in the $\mathrm{SW} 1 / 4$ sec. 3, T. 42 N., R. 29 W., contains pebbles of quartz, red granitic rock, sericite slate, and red feldspar. The pebbles average one-half inch in diameter. Gradational bedding and 
poor crossbedding suggest that the tops of the beds face south. Other outcrops in this arkose belt are less easily identifiable as to original rock. They consist of muscovite schist with coarse feldspar grains and recrystallized quartz-feldspar rocks with a texture resembling that of the sand phases of the arkose sequence.

\section{PETROGRAPHY AND PETROLOGX}

The most common lithologic types of the East Branch arkose-poorly sorted coarse arkose and arkosic conglomerate-have essentially the same mineralogic character as the granite gneiss except that quartz is more abundant. Determinations in two slides of representative coarse arkose show 57 to 65 percent quartz, 22 to 32 percent microcline, and 10 to 11 percent white mica. Albite is present but rarely forms as much as 1 percent of the rock. Biotite and magnetite occur in most specimens, and ilmenite, leucoxene, garnet, titanite, and epidote are present in some. Most of the rock is strongly sheared.

In thin section, the quartz derived from quartzite cannot be distinguished with certainty from that derived from the granite. Both consist of elliptical aggregates of elongate grains showing strong undulatory extinction and sutured contacts (figs. 9, 10). Secondary quartz, in the form of roughly equidimensional grains showing no undulatory extinction, is common, but overgrowths on clastic quartz grains have not been identified.

Most of the microcline grains are clear, but liquid inclusions are common. Thin perthite lamellae are present in most grains, and many show veinlets and borders of secondary albite, although these are less common than in the granite and in some other phases of the arkose. Some of the small grains show no evidence of deformation and may be of secondary origin.

In detail, the margins of the microcline grains are irregular, penetrated by white mica and interlocking with the quartz. Obviously, this interlocking character requires local overgrowth or local replacement by quartz, perhaps both, at the margins of the detrital microcline grains. The origin of the interlocking quartz-microcline contacts probably is similar to that of the sutured contacts between two adjacent quartz grains, although definite overgrowths on microcline grains have not been distinguished.

The dominant textural features seen in thin section are those resulting from deformation. The general rounded outline of many of the microcline grains suggests a clastic origin, but comparison with some of the grains in the gneiss (figs. 5,6) indicates that the rounded character could be either primary or the result of cataclasis.

An interesting feature is the contrast in the reaction of quartz and microcline to stress. The quartz grains have been stretched, and redistribution of the quartz from original clastic grains to secondary, unstrained grains has been extensive. Most grains of microcline, on the other hand, have yielded by fracturing, although many grains show undulatory extinction, much weaker than that of the quartz. In spite of the fracturing, however, the microcline grains are much more nearly equidimensional than the quartz grains. The presence of aggregates of secondary quartz, in the pressure shadows of the microcline gneiss - that is, on the sides of the grains that are normal to the schistosity, emphasizes the different behavior of the two minerals.

Only one thin section of a quartzite pebble from the arkosic conglomerate has been examined. This specimen contains about 10 percent microcline and 90 percent quartz. Liquid inclusions are abundant in the quartz but are less common in the microcline; within grains of both microcline and quartz the inclusions are distributed uniformly. The quartz grains are elongate, like those of the smaller detrital fragments, and the contacts are strongly sutured. The microcline grains are also elongate, like those of the smaller detrital fragments, and the contacts are strongly sutured. The microcline grains are also elongate parallel to the quartz and to the schistosity of the enclosing rock. The microcline grains do not show undulatory extinction. It is uncertain whether the microcline was present in the quartzite pebbles before deformation of the arkose, or whether it was deposited there during deformation of the arkose.

In general the arkose of the zone containing interbedded tuff and tuffaceous arkose is less foliated than the coarse arkose and conglomerate. The feldspar and quartz grains of the tuffaceous zone are more nearly equidimensional and the rocks commonly have a granoblastic texture.

The arkose of the tuffaceous zone contains about the same minerals as the conglomeratic arkose, but biotite and epidote are much more abundant and microcline is more abundant at least locally. Pyrite cubes occur in some of the biotite-rich layers and titanite is present locally. Microcline forms relatively large, probably clastic grains, as well as veinlets, anhedral grains in the granoblastic mosaic of quartz and feldspar, and overgrowths on rounded, apparently clastic grains. Most of the grains identified as clastic microcline contain abundant liquid inclusions, some of which contain gas bubbles. Liquid inclusions are far less abun- 
dant in the overgrowths on these grains, making the overgrowth much less cloudy.

The microcline in the veinlets is water-clear and contains few liquid inclusions. These grains are not fractured, and the texture is granoblastic. Some very thin lamellae in the microcline in the veinlets apparently have a higher relief and birefringence than the enclosing microcline, but these lamellac have not been proved to be plagioclase. Many of the clear anhedral microcline grains in the groundmass of these rocks appear to be identical with the microcline in the veinlets and the overgrowths on the clastic grains and are probably of secondary origin.

Scattered grains of untwinned feldspar, showing the same birefringence as the replacement albite, are present as separate grains in some of the tuffaceous arkose.

Locally, in zones extending about 5 feet into the arkose from contacts with altered basalt or diabase, microcline is absent or deeply embayed by albite, and the quartz contains blebby inclusions of albite. Some of the feldspar grains consist entirely of albite and others contain irregular patches of microcline in a sea of albite. Grain boundaries are very irregular and interlocking. These relations indicate that the microcline has been extensively replaced by albite. That the replacement took place after the deposition of the microcline grains in the arkose series is indicated by-

1. The restricted distribution of microcline grains showing such extensive replacement by albite.

2. Widespread occurrence of albite rims on microcline grains in the arkose, showing that replacement of microcline by albite did occur in the arkose sequence.

3. The absence of fractures in the secondary abite, although fractures are common in the clastic feldspars.

4. The fact that microcline is absent or far less common in thin sections from this zone, although it is by far the most abundant feldspar in most of the arkose.

The most abundant minerals in the altered basalts interbedded with the arkose are albite, poikilitic hornblende, epidote, and biotite. The order of abundance differs from one specimen to the next. Quartz constitutes as much as 25 percent of the rock and euhedral magnetite as much as 10 percent. Chlorite is present in all specimens. A mineral with a granular habit similar to some of the epidote but showing higher relief and birefringence is present in most specimens and is tentatively identified as titanite. The structure of the rock ranges from schistose to massive. Complete recrystallization is shown by the absence of evidence of deformation of any of the mineral grains.

The albite in most specimens forms a fine-grained granoblastic groundmass. In places it is clear, and twinning is apparent only in rare grains. In other places it is dusty owing to alteration. Locally, alongate twinned grains are present. These grains contain abundant inclusions of other minerals in the rock, and their outline is very irregular, strongly suggesting secondary origin.

The hornblende is apparently a sodic variety with pleochroism as follows: $X$, light yellow green; $Y$. deep yellow green; and $Z$, blue green.

The rock that superficially resembles skarn and is associated with the vesicular zone of the flows contains small masses of clear undeformed and perthitic microcline in a groundmass mineralogically similar to that of the rest of the basalt.

The recrystallized arkose that strongly resembles granite in appearance is for convenience hereafter referred to as "recomposed granite." The recomposed granite is compared with representative coarse arkose in table 11. The recomposed rock does not posses foliation and the arkose selected for comparison was one with minimum evidence of deformation.

TABLE 11.-Comparison of physical characteristics of arkose and recomposed granite

Arkose Recomposed granite Outcrop and hand specimen

Bedded. Crossbedding well Massive. Poorly preserved preserved and widespread.

Grains range from $3 \mathrm{~mm}$ to less than $0.5 \mathrm{~mm}$ in diameter.

Microcline grains are equidimensional, grain boundaries are smooth. crossbedding present locally. Majority of grains range from 0.5 to $1.5 \mathrm{~mm}$ in diameter.

Microcline grains are equidimensional to elongate, grain boundaries are feathered.

\section{Thin section}

Wide range in grain size Restricted range in grain size. Microcline grains fractured but Microcline grains fractured but not granulated.

Secondary overgrowths on mi- Secondary overgrowths on microcline absent or rare. crocline common. Clear, Clear, probably secondary, probably secondary, micromicrocline rare. cline common.

Margins of feldspar grains shal- Margins of feldspar grains lowly cuspate. deeply cuspate.

The chief difference between most of the arkose and the recomposed granite are in the range of grain size and the amount of secondary microcline. If it is true that the amount of cataclasis of the two rocks chosen for comparison is similar, as it appears to be, the range in grain size is largely a primary feature and shows that the recomposed granite was a well-sorted sediment, whereas the arkose was poorly sorted. Good sorting of the original arkose could facilitate the de- 
velopment of an equigranular recomposed rock by providing (1) a raw material of fairly uniform grain size and (2) maximum porosity (Pettijohn, 1949) and the largest pores for a given average grain size.

It is possible that the abundance of visible overgrowth on the microcline grains in the recomposed granite in contrast to the absence of such overgrowths in the arkose gives a false notion of the relative amount of redistribution of microcline in the two rocks; in the well-sorted sediment more space and larger interstices would be available for the development of recognizable overgrowths than in the poorly sorted sediment. However, Gilbert (1949) has shown that solution and redeposition of quartz and feldspar in reservoir sands of Tertiary age in California oil fields has been greater in the "clean" porous sands than in those with an argillaceous matrix and low porosity. He argues (1949, pl 14) :

The existence of clay between the sand grains would tend to prevent or make less effective the mechanism of differential solution and complementary deposition just outlined. Compact clay tends to transmit more uniformly the stress due to overburden and thus to reduce the heterogeneity of the stress and its concentration at points of solid contact between grains.

Although the matrix in all but the finest arkose beds was apparently silt and fine sand rather than clay, the same argument appears valid.

\section{THICKNESS}

The thickness of the East Branch arkose is difficult to measure because of drag-folding and repetition of beds by faulting; probably it is more than 1,000 feet thick.

STRUCTURAI AND STRATIGRAPHIC RELATIONS

Most of the granitic pebbles in the conglomerate are composed of the quartz-rich, nonporphyritic granitic rocks common in the northeastern part of the mapped area. Some pebbles in the conglomerate are either coarse porphyritic granite or pegmatite, however, and the abundant small pebbles of microcline in the arkose could have been derived from the coarse porphyritic red granite. The quartzite pebbles in the conglomerate probably were derived from the quartzite beds that are now known only as inclusions in the granite. The East Branch arkose is therefore younger than some of the granite gneiss and can reasonably be considered younger than all such rocks, unless gneisses of more than one age are present.

The contact between the East Branch arkose and the Solberg schist to the south is not exposed. Some interbedded schists in the upper part of the arkose resemble the Solberg schist, which suggests that this formation may conformably overlie the East Branch arkose.

\section{AGE AND CORRIGLTION}

The unit referred to here as the East Branch arkose was mapped as Sturgeon quartzite by earlier investigators (Bayley, 1899, p. 471; Van Hise and Leith, 1911, p. 301), but the present studies indicate that it is of pre-Sturgeon age.

The primary lithologic features of the arkose sequence suggest the following conclusions regarding depositional environment:

1. Diastrophism with rapid erosion and deposition. 2. The sediments were derived from a terrane underlain by granitic gneiss, quartzite, and slate.

3. Jaspilite (thin-bedded jasper and specular hematite) was absent, and dolomite was probably absent from the source area.

Diastrophism causing rapid erosion and deposition is indicated by the recurrent beds of conglomerate, abundance of feldspar, and thickness of the formation. Such conditions probably would not be limited to a small local area but should be reflected in any Middle Precambrian rock with which the arkose sequence could be correlated in Dickinson or adjacent counties.

The composition of the terrane that supplied the sediments is indicated by the rock types that occur as pebbles in the conglomerate. Thus granitic rock, quartzite, and slate were exposed at the erosion surface, but jaspilite was absent. Dolomite was probably absent, for probably at least a few pebbles would survive rapid erosion and transportation. The absence of dolomite and jaspilite pebbles suggests that the Randville dolomite and the Vulcan iron-formation were not deposited prior to deposition of the arkose sequence. The quartzite and slate pebbles cannot be taken as evidence that the arkose sequence is Middle Precambrian, because these pebbles could have been derived from the quartzite and schist of probable Lower Precambrian rocks now seen as inclusions in the gneiss.

Throughout much of northern Michigan the Sturgeon quartzite, Mesnard quartzite, and Sunday quartzite form the basal part of the Middle Precambrian rocks. These quartzites are very uniform and are composed almost entirely of quartz. They are typical of deposits formed under stable conditions. Although the Sturgeon quartzite has not been recognized in the Sagola basin, it occurs in the Felch trough about 5 miles south of the belt underlain by the arkose sequence. Correlation of the East Branch arkose with the Sturgeon quartzite would require that active uplift prevailed in a small area while the rest of the region was essentially stable.

Other Middle Precambrian formations with which the arkose sequence might be correlated on the basis of primary lithologic features are the Ajibik quartzite 
and the Goodrich quartzite. Both of these formations contain conglomerates and rest unconformably upon underlying rocks. The Ajibik quartzite has local conglomerate members, but it is composed largely of quartz sand and is lithologically similar to the Sturgeon and Mesnard quartzites rather than to the arkose sequence. Conglomeratic beds in the Ajibik quartzite are thin, and the pebbles are of local origin. These beds are basal conglomerates and intraformational conglomerates, unlike the hundreds of feet of mixed-pebble conglomerate in the arkose sequence. Further, the angular discordance between the Ajibik quartzite and underlying beds is small, indicating little folding or uplift during the time interval represented by the unconformity. Moreover, the Ajibik is not known to be present in the Central Dickinson County area.

The Goodrich quartzite of the Marquette range and Republic trough resembles the East Branch arkose more closely than do other Animikie formations. The Goodrich contains important conglomerate beds and overlies older rocks with an angular discordance, which in some places is large. Abundant granitic detritus occurs locally, indicating that strata deposited earlier in the Animikie have been stripped away in some areas, although the Goodrich in most places rests on Negaunee iron-formation without profound discordance. The Goodrich, however, is commonly rich in iron-formation debris.

The difference in intensity of deformation and in metamorphic grade between the arkose sequence and the Randville dolomite is striking. Comparison of two primary sedimentary features-the stretched pebbles in the arkosic conglomerate (fig. 8) and the undeformed stromatolites in the dolomite (fig. 32) shows that the arkose sequence has undergone much greater deformation than the dolomite. The significantly higher metamorphic grade of the East Branch arkose in contrast to that of the dolomite is indicated by such metamorphic minerals as epidote, hornblende, biotite, muscovite, and microcline in the arkosic conglomerate and interbedded volcanics. The low metamorphic grade of the dolomite is indicated by its fine-grained character as well as by the absence of metamorphic minerals. The East Branch arkose, therefore, cannot be Animikie.

Correlation of the arkose sequence with other preAnimikie conglomerates of the Lake Superior region is not attempted.

\section{SOLBERG SCHIST}

Biotite and hornblende schists occur in the southern part of the Norway Lake area. As noted in chapter B of this report, these rocks are called the Solberg schist, a name derived from Solberg Lake in secs. 17 and 20,
T. 42 N., R. 29 W. The Solberg apparently forms a nearly eastward trending belt parallel to the East Branch arkose. The area underlain by the Solberg schist is covered largely by dense black spruce swamps. Schist is exposed in low knolls and ridges rising above the swampy ground.

\section{GENERAL CHARACTER}

Only the lower part the Solberg schist is present within the Norway Lake area. The rock is predominantly biotite schist to the north and hornblende and hornblende-biotite schist to the south. The biotite schist is fine grained and is composed largely of biotite, quartz, and feldspar. Light-colored minerals comprise more than 50 percent of the rock. In many places the schist is layered parallel to the schistosity. The layering is caused by variations in the proportions of light and dark minerals, but it is not clear whether this layering represents a primary feature such as bedding or is caused by metamorphism. The hornblende schist is coarser grained than the biotite schist and is not. as well layered. It is composed largely of green hornblende and andesine, and minor quartz.

A coarse-grained schist composed of greenish-brown biotite, fibrous amphibole, quartz, and zoisite or clinozoisite is exposed in the $\mathrm{SW} 1 / 4 \mathrm{NW}^{1 / 4}$ sec. $17, \mathrm{~T} .42 \mathrm{~N}$., R. $28 \mathrm{~W}$, and in the roadside exposures in the NW1/4 sec. 16, T. 42 N., R. 28 W. The fibrous amphibole occurs in feltlike masses replacing large crystals that may have been pyroxene.

In the exposure about 300 feet northeast of the south quarter corner sec. 18, T. 42 N., R. 28 W., a band of rock resembling a fine-grained sheared augen gneiss is present in the hornblende schist. This rock contains grains of feldspar about $2 \mathrm{~mm}$ in diameter and tabular quartz aggregates in a groundmass of biotite and finegrained quartz and untwinned feldspar. The large feldspar grains are seen in thin section to be microcline, oligoclase, and untwinned feldspar. They are irregular in outline, fractured, and cut by irregular masses and veins of calcite. Several contain grains of biotite, zoisite or clinozoisite, and quartz. The feldspar grains have obviously been fractured and altered, but it is not clear whether they represent clastic grains in a feldspathic sediment, phenocrysts in an igneous rock, or early-formed porphyroblasts. Most quartz grains, both in the tabular aggregates and in the groundmass mosaic, show undulatory extinction. A similar rock is well exposed one-fourth a mile south of the center of sec. 16, T. 42 N., R. 28 W.

In the easternmost exposure in the $\mathrm{SE} 1 / 4$ sec. $16, \mathrm{~T}$. 42 N., R. 28 W., a zone in the biotite-hornblende schist contains subspherical grains of a dark-gray vitreous mineral, probably garnet. These grains range from 2 to $12 \mathrm{~mm}$ in diameter and are embedded in coarse 
biotite or, at one place, in radiating fibrous aggregates of a light-colored mineral tentatively identified as grunerite. The rock has a high density and is similar to the iron-rich Skunk Creek member which causes the strong magnetic anomaly a short distance to the south.

The schists have been considered to be Archean (Lower Precambrian of this report) by previous investigators (Bayley, 1899, p. 463; Van Hise and Leith, 1911 , p. 301), and their assignment is accepted here. The Solberg schist apparently overlies the East Branch arkose, but exposures are sparse near the contact and relationships between the formations are not well established. Mafic schist interbedded with the upper part of the East Branch arkose is similar to some of the Solberg schist, suggesting that the lower part of the Solberg may intertongue with the East Branch. The strike of the bedding in the Solberg schist, shown by the trend of the Skunk Creek member, is parallel to that of the East Branch arkose.

\section{MIDDLE PRECAMBRIAN ROCKS STURGEON QUARTZITE}

The Sturgeon quartzite is widespread elsewhere in Dickinson County but has not been identified in the Sagola basin, although a small outcrop of quartzite in the SW $1 / 4$ SW $1 / 4$ sec. 3 , T. 42 N., R. 28 W., tentatively included with the Randville dolomite, may be Sturgeon, as may be the quartzite in sec. 1, T. 42 N., R. 29 W. The Sturgeon quartzite is resistant to erosion and would probably be well exposed if it were present in any great amount. It is to be noted that a short distance north of the mapped area, in sec. 15, T. 43 N., R. 29 W., the Randville dolomite rests directly on older gneiss without any intervening Sturgeon quartzite.

\section{RANDVILLE DOLOMITE}

The Randville dolomite is exposed in several widely separated groups of outcrops near the northern limit of the mapped area. This rock forms hills as much as 40 feet high on the present land surface and apparently had the same topographic expression on the Precambrian surface, for several low pinnacles of dolomite project more than 20 feet into the sandstone of Cambrian age.

In the south part of the Sagola basin, the exposed part of the Randville dolomite is apparently divisible into three members: (1) an upper member and (2) a lower member of dolomite with minor interbedded slate, separated by (3) a slate member with minor interbedded dolomite. This division is apparent in the west-central part of sec. 1 and the east-central part of sec. 2, T. 42 N., R. 29 W. (fig. 94). The division is suggested in places where two dolomite outcrops, 300 to 500 feet apart across the strike, are separated by swamps or low ground, as in the $\mathrm{SW} 1 / 4 \mathrm{SW}^{1 / 4} \mathrm{sec}$. 3, T. 42 N., R. 28 W., near the NW cor. sec. 4 , T. 42 N., R. 28 W., and in the NE $1 / 4$ sec. 4 , T. 42 N., R. 29 W. The total thickness is more than 800 feet in the Norway Lake area. Neither the top nor the bottom of the formation is exposed, and the character of the rocks that immediately underlie and overlie the Randville dolomite is not known.

The most nearly complete section of the Randville in the vicinity of Norway Lake is exposed in the west-central part of sec. 1 and the east-central part of sec. 2 , T. 42 N., R. 29 W. (fig. 94), where the structure is a syncline that plunges southeast at an angle of about $45^{\circ}$.

Most of the dolomite is massive to thin bedded, and stromatolites (algal structures) and intraformational conglomerate are common. The dolomite is light gray to red on fresh surfaces and weathers white to light brown. It has a fine sugary texture. Grains of quartz sand, most of which show undulatory extinction, are abundant in some beds and in some places comprise more than 50 percent of the rock. No oolites were found.

The stromatolites, in sections normal to bedding planes, are concentrically banded structures with domal or columnar form, and in sections parallel to bedding planes they are concentrically banded elliptical forms. Most are 1 to 3 inches in diameter and 2 to 6 inches high. The banding of the stromatolites is convex upward, providing a reliable criterion for tops of beds. Where the structures are partly replaced by chert the forms are accentuated on weathered surfaces. Richardson (1949) has described stromatolites from the Norway Lake area and believes them to be of organic origin. Stromatolites are shown best in the $\mathrm{NW}^{1 / 4} \mathrm{NW}^{1 / 4}$ sec. 4, T. 42 N., R. 28 W. (see fig. 32), where the algal biostromes are interbedded with massive dolomite, dolomitic slate, and dolomite conglomerate. A section across the biostromes, with numbers increasing upward in the section, is as follows:

11. Thin-bedded slate and dolomite............ 20

10. Thin-bedded dolomite

9. Biostrome

8. Red slate

7. Biostrome ...

6. Cherty red to gray slate

5. Dolomite conglomerate. Well-rounded pebbles of massive dolomite in sandy dolomite matrix $\ldots . . .12$

4. Massive dolomite

3. Dolomite conglomerate, like bed 5 . . . . . . . . 16

2. Thin-bedded dolomite.

1. Cherty, red to gray slate 


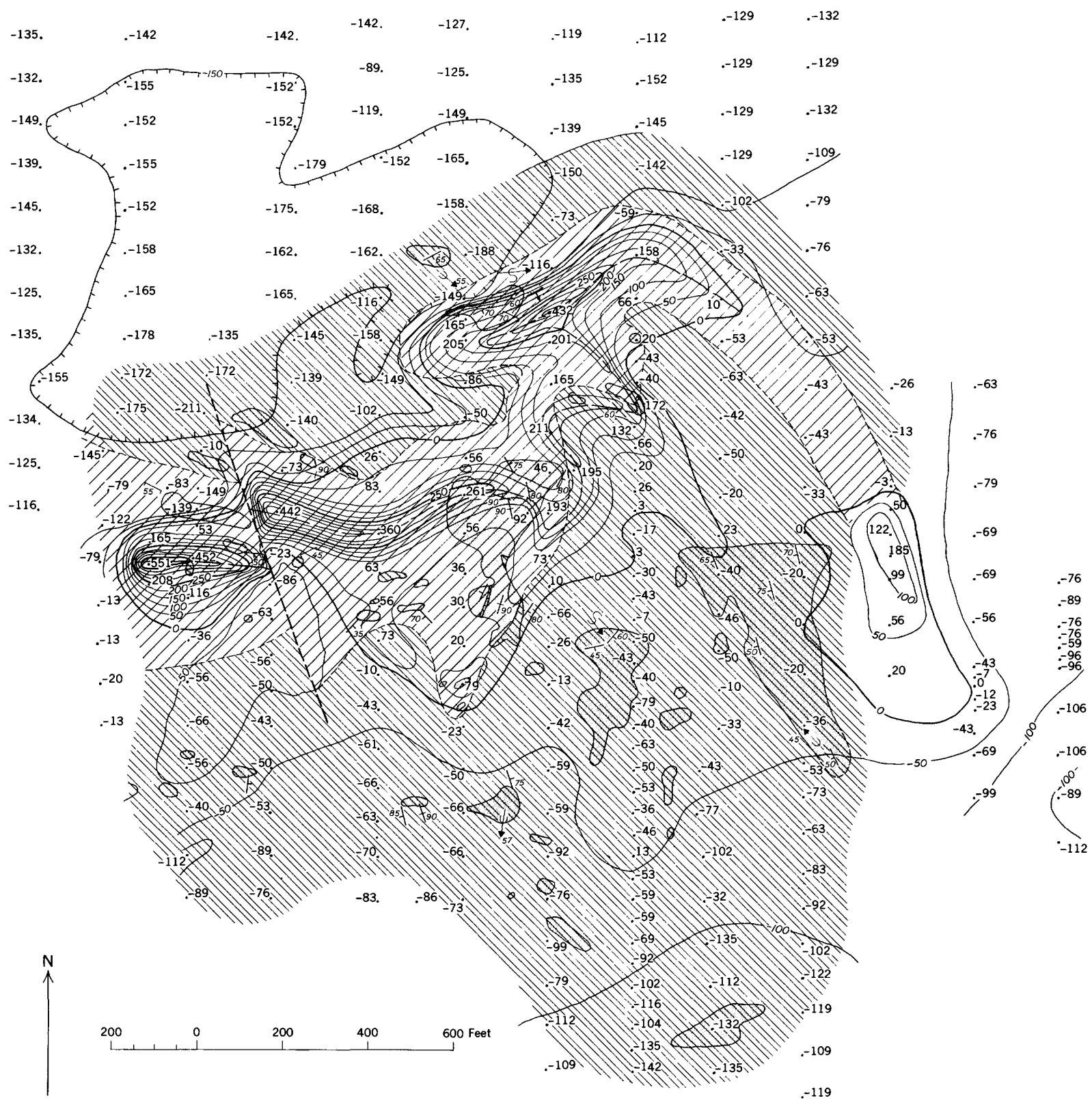

EXPLANATION

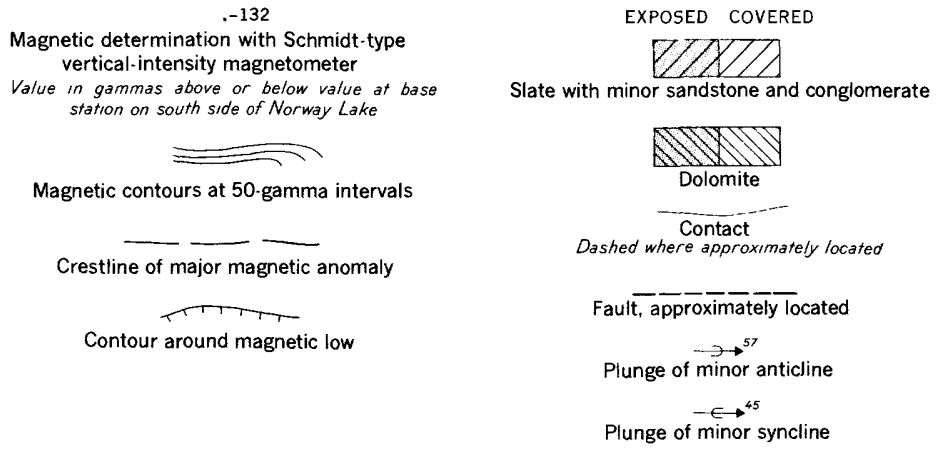

Plunge of minor-fold pair Strike and dip of beds 90

Strike of vertical beds Strike and dip of cleavage

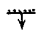

Top direction shown by graded bedding

FigURE 94.-Geologic and magnetic map of parts of sec. 1 and 2, T. 42 N., R. 29 W., showing slate within the Randville dolomite. 
The biostromes are composed almost entirely of stromatolites partly replaced by chert. The thicker biostrome (No. 7) is exposed for about 150 feet along the strike, and the thinner one (No. 9) for about 25 feet. Stromatolites also are present in the NE and SW cors. SW1/4 SW $1 / 4$ sec. 3 , T. 42 N., R. 28 W., and in the NW1/4 SE $1 / 4$ sec. 35 , T. 43 N., R. 29 W. Structures that may be stromatolites are found in dolomitic slate beds interbedded with dolomite and dolomite conglomerate in the outcrop on the north edge of the swamp in the NE $1 / 4$ NW1 $1 / 4$ sec. 6 , T. 42 N., R. 28 W. These structures are irregular, concentrically laminated, flat domes, convex to the northwest. They are about 1 foot thick and 2 to 4 feet in diameter.

Intraformational conglomerates or breccias (see fig 31) are present in the NW $1 / 4, \mathrm{SE} 1 / 4$ sec. $35, \mathrm{~T} .43 \mathrm{~N}$., R. $29 \mathrm{~W}$., and in the NE1/4NE1/4 sec. 2 , T. $42 \mathrm{~N}$., $29 \mathrm{~W}$., in addition to the previously mentioned localities where they are associated with stromatolites. Most of the pebbles are dolomite, but a few pebbles of dolomitic slate occur. The pebbles are 1 to 4 inches in diameter and are well rounded. No strong dimensional orientation is evident. The matrix is dolomite with intermixed coarse quartz sand.

Outcrops of the dolomite are too scattered to show whether or not the conglomerate and stromatolite phases of the dolomite are restricted to certain horizons.

In general, silicification of the dolomite has been confined to partial replacement of organic structures and the formation of small nodular masses of chert in the dolomite and dolomitic slate. However, silicification has been complete in the exposures on the north line of sec. 6, T. 42 N., R. 28 W., one-fourth mile east of the northwest corner of the section. These exposures consist of several small outcrops and a large number of residual boulders of chert and two test pits in slate. The chert shows textural features commonly found in limestone and dolomites, such as intraformational breccia and interbedded sandy and nonsandy material. The intraformational breccia now consists of angular fragments of chert in a matrix of chert with scattered grains of quartz. Other rocks in these exposures show a complete gradation from a quartz sandstone cemented by chert, through massive chert containing abundant quartz grains (fig. 34), to completely nonsandy massive chert. Many of the quartz grains show secondary overgrowths.

A small exposure of vitreous quartzite and fine quartz conglomerate is present at the west end of the dolomite outcrop near the SW cor. sec. 3, T. 42 N., R. $28 \mathrm{~W}$. It is here included with the Randville dolomite and may be part of the basal bed of this formation.

The dolomite near the north quarter corner sec. 9 ,
T. 42 N., R. 29 W., is poorly exposed. It consists of typical fine-grained, thin-bedded dolomite and strongly sheared dolomite. The sheared dolomite contains much secondary quartz and microcline, and weathering produces a dense spongework of these minerals.

The slate member of the Randville dolomite is best exposed in secs. 1 and 2, T. 42 N., R. 29 W. (fig. 94). The slates are dark-gray to green-gray and are composed largely of sericite, with some quartz, chlorite, and microcline. Euhedral magnetite grains are locally abundant and cause a weak magnetic anomaly. The northernmost slate outcrop, in the $\mathrm{SW} 1 / 4 \mathrm{NW}^{1 / 4}$ sec. 1 , T. 42 N., R. 29 W. (fig. 94), shows interbedded gray sandstone and black slate in beds as much as 4 inches thick. Gradational bedding shows that the tops of beds are to the south in this exposure. A few conglomerate beds, each less than 2 inches thick and separated by beds of sandstone and slate, contain well-rounded pebbles of quartz, feldspar, and granitic rock as much as an inch in diameter. In other exposures in this vicinity, dolomite beds ranging from a few inches to approximately 5 feet in thickness are interbedded with the slate. Slate with interbedded dolomite is also exposed in the SW $1 / 4 \mathrm{SE} 1 / 4$ sec. 4 , T. 42 N., R. 28 W. The rock here is laminated quartzite and sericitic slate and contains octahedral magnetite grains.

\section{VULCAN IRON-FORMATION AND ASSOCIATED SLATES}

In the southern part of the Sagola basin, the Vulcan iron-formation is exposed only in test pits and trenches of the Deerhunt exploration in the $\mathrm{SW}^{1} / 4 \mathrm{NW}^{1 / 4} \mathrm{sec} .35$, T. 43 N., R. $29 \mathrm{~W}$. The iron-formation is composed of interlayered blue specular hematite and reddish jasper, with some associated soft hematitic slate. Some of the jasper contains well-defined concentrically banded structures about $1 \mathrm{~mm}$ in diameter that resemble oolites. In thin section the structures are concentrically banded, with subcircular to elliptical outline (figs. 40, 41). A few are irregular and consist of two or three smaller structures enclosed within a larger one. The structure is shown by concentric films of hematite in the chert and not by the texture of the chert itself.

Of several pieces of iron-formation picked at random from the test pits and tested with field instruments, some proved to have a high and others a low magnetic permeability.

A green thin-bedded sandy slate appears on the dump of the southernmost test pit of the Deerhunt group. It has not been recognized elsewhere in the Norway Lake area, it may well be a part of the Felch formation, which underlies the iron-formation in the Felch area. 


\section{MICHIGAMME SLATE}

The Michigamme slate underlies the northwestern part of the mapped area and is present locally northwest of Norway Lake (pl. 2). It is exposed chiefly along streams and in trenches and test pits. Material derived from the Michigamme slate is abundant in the glacial deposits in the northwest part of the map area.

GRAPHITIC AND ASSOCIATED SLATES

In the $\mathrm{SW}^{1 / 4}$ sec. $32, \mathrm{~T} .43 \mathrm{~N}$., R. $28 \mathrm{~W}$., is a group of poor exposures of red to gray slates and black gragraphitic slates. Some of the nongraphitic slates are cherty. The stratigraphic position of the rocks in these exposures is uncertain, but like the slate and graywacke described below, they closely resemble some of the Animikie rocks of Iron County.

\section{RED SLATES AND GRAYWACKES}

GENERAL CHARACTER

Scattered exposures of red, gray, and greenish sericitic slate with subordinate interbedded graywacke are present west of the Deerhunt exploration (pl. 2). A section of these slates and graywackes more than 500 feet thick is exposed in the banks of the East Branch of the Sturgeon River in the northern part of the SW $1 / 4$ sec. 34, T. 43 N., R. 29 W., and the total thickness is probably more than 1,000 feet. In some places the slates are red, with thin zones along joint and bedding planes leached to a light yellow-green. Slate in the test pits in the SW $1 / 4 \mathrm{SW} 1 / 4$ sec. 34, T. 43 N., R. 29 W., is light gray. Slaty cleavage is well developed in the fine-grained members of this sequence. The graywackes are fine to medium grained and are somewhat friable. They are deep red and greenish in general color and liberally dotted with white fragments, probably altered feldspars. In thin section the sand grains are seen to be angular and are mostly quartz showing strong undulatory extinction. Grains composed of radiating aggregates of a clay mineral, probably altered feldspars, are abundant. Fragments of chert and sericitic slate are common. The groundmass is a fine-grained mosaic of quartz, clay minerals, and white mica. These red slates and graywackes also occur as abundant float fragments in the southern part of sec. 31, T. $43 \mathrm{~N}$., R. $28 \mathrm{~W}$., north of the exposure of silicified dolomite, and in the upturned roots of a tree in the northeast corner of sec. 6, T. 42 N., R. 28 W. Similar rock was encountered in the north parts of secs. $31,32,33$, and 35 , T. 43 N., R. $29 \mathrm{~W}$. in a trench excavated for a pipeline in 1953 .

As these relatively nonresistant slates and graywackes are the only rocks exposed west of the Deerhunt exploration, it seems highly probable that they are the only rocks present at the surface in this part of the area.

Bayley (1899, p. 481) included the red slates and graywacke with the Randville dolomite, and Van Hise and Leith (1911, p. 301) considered them to be Keweenawan. However, the degree of folding and the presence of slaty cleavage appear incompatable with Keweenawan age for these rocks. Too, the lithologic character of the slates and graywackes resembles that of slates and graywackes of the Michigamme in Iron County, Mich., more closely than that of the nearest known Keweenawan rocks. Accordingly, these red slates and graywackes are here considered to be equivalent to some of the strata of the Michigamme slate elsewhere.

\section{METADIABASE DIKES AND RELATED ROCKS}

Metadiabase dikes intrude the gneiss, arkose sequence, and schists. They are not exposed in the part of the Norway Lake area underlain by Animikie rocks and presumably do not intrude these rocks. Metadiabase is the most resistant rock in the Norway Lake area, forming the backbone of ridges on which other rocks are also exposed. Parts of the large dike in the southern part of the mapped area form prominent hills. The metadiabase is fresh appearing, coarse grained, massive, and composed largely of well-formed hornblende crystals in a matrix of feldspar. Locally, the dikes are fine grained and schistose, but in general, the massive dikes contrast with the schistosity of the intruded rocks.

\section{GENERAL CHARACTER}

Dikes cutting the arkose sequence are seen in thin section to be dominantly composed of blue-green poikilitic hornblende, with subordinate epidote, biotite, quartz, untwinned feldspar, titanite, magnetite, and pyrite. Dark minerals comprise 60 to 90 percent of the rock. Border zones of the dikes in the area shown on plate 10 are biotite schist, composed of green biotite, epidote, blue-green hornblende, quartz, and titanite. Parallel hornblende and biotite crystals impart a planar structure to the rock but the quartz and albite in the groundmass show a granoblastic texture. Some of the quartz has undulatory extinction, but in general the evidence of mechanical shearing is weak.

Thin sections of rock from dikes that cut the hornblende schist are composed of anhedral green hornblende with a slight bluish cast, untwinned feldspar, andesine, quartz, titanite, and magnetite. Dark minerals comprise about 60 percent of the rock. The hornblende crystals are ragged in outline but do not have a marked poikilitic texture. They appear, rather, to have been fractured or partly replaced by the light 
minerals. A fine-grained mosaic of quartz and feldspars, with many small grains of hornblende, surrounds the relatively large hornblende grains. Where contacts with the schist are exposed, as in the $\mathrm{NE} 1 / 4$ sec. 16, T. 42 N., R. 28 W., the dike rock becomes finer grained near the contact.

Dikes cutting the gneiss were not mapped separately except in secs. 3 and 4 , T. 42 N., R. 29 W., and have not been studied in thin section.

In secs. 11 and 14, T. 42 N., R. 28 W. is a stocklike body of rock perhaps genetically related to the metadiabase dikes. This rock differs in composition from the dike rocks in containing minor amounts of magnetite and phlogopite. It also contains phases that are much coarser grained than the dike rocks.

\section{STRUCTURAL RELATIONS}

A large metadiabase dike, about 500 feet thick and more than 5 miles long, intrudes the schist about 2 miles south of Norway Lake. A smaller dike closely parallels the larger one for $21 / 2$ miles, and both dikes are parallel to the foliation in the schist. These dikes apparently extend outward from a stocklike mass of similar rock to the east.

Dikes that intrude the arkose sequence are smaller and more lenticular than those that intrude the schists. They apparently are associated with a nearly vertical joint system and with strike faults.

The contact of the stocklike mass in secs. 11 and 14, T. 42 N., R. 20 W., with the surrounding schists is apparently not regular or well defined. Within the mapped area the approximate contact is exposed only in the group of outcrops in the SW1/4 sec. 11, T. 42 N., R. $28 \mathrm{~W}$., where biotite schist is interlayered with hornblende-feldspar rock that - closely resembles the metadiabase of the dikes. The contacts of the interlayered rocks are not sharp but gradational. The contact of the stocklike mass can be located only approximately through these exposures because of the mixture of schist and metadiabase. A coarse-grained hornblende-feldspar pegmatite similar to that in the upper part of the East Branch arkose also occurs at this locality.

\section{AGE}

Minor differences in composition between the metadiabase dikes that intrude the arkose sequence and those that intrude the schists may be due to metamorphism and do not give adequate reason to assume more than one period of diabase intrusion. The structural relations of the dikes, together with the fact that the dike rocks are of the same metamorphic grade as the intruded rocks, indicate that most of the dikes were emplaced during or subsequent to the last Middle Precambrian period of deformation and metamorphism.

\section{PEGMATITES}

Small and widely scattered pegmatite pods have been found in the tuffaceous parts of the East Branch arkose and in the Solberg schist as well as in the granite gneiss. Most of those in the East Branch arkose are less than 1 foot thick and only a few feet long. In outcrop they appear to consist chiefly of amphibole and microcline. The amphibole crystals, as much as 2 inches long, commonly form rosettes. Thin sections show that this pegmatite consists largely of epidote, quartz, microcline, and homblende with some variation in the relative amounts of the various minerals. Pyrite is common. The microcline is of the clear, apparently secondary type, and most of the quartz grains are unstrained. The hornblende crystals are skeletal. The extinction angle is about $24^{\circ}$ and the pleochroism is $X$, light green; $Y$, deep green; and $Z$, fairly deep blue green. The microcline contains inclusions or replacement masses of quartz and epidote.

Coarse-grained pegmatites such as those that cut the hornblende schist west and south of the Norway Lake area are not common in this area, although one very coarse pegmatite 30 inches thick cuts the biotite-hornblende schist one-fourth mile north of the SW. cor. sec. 16, T. 42 N., R. 28 W.

One-fourth mile south of the center of sec. 16, T. 42 N., R. 28 W., lenticular masses 2 to 4 feet long and about 6 inches thick composed of quartz and red feldspar are associated with rock that resembles augen gneiss. The rock of the lenses has a pegmatitic texture, although the quartz-feldspar ratio is approximately 4 to 1 . The quartz is granular.

\section{STRUCTURAL GEOLOGY}

Most structural features in the Norway Lake area trend eastward. In the Lower Precambrian rocks this trend is followed by strong secondary foliation, by contacts between lithologic units, by bedding in the East Branch arkose, and by major faults. In the area underlain by Middle Precambrian rocks measured in the southern part of the Sagola basin, strikes of the Randville dolomite suggest a general eastward trend for that unit.

\section{FOLIATION AND IINEATION}

In most places foliation in the gneiss, East Branch arkose, and Solberg schist dips more than $80^{\circ}$. In the gneiss the foliation is due to parallel arrangement of tabular feldspar and quartz grains and thin layers of micaceous minerals. The texture of the gneiss is in 
most places clearly cataclastic (figs. 3-6). Foliation in the arkose is due to parallelism of micaceous laminae (see figs. 9-11) and stretched ellipsoidal pebbles and smaller clastic fragments. In the Solberg schist the schistosity is due chiefly to parallel arrangement of biotite and amphibole crystals, but some of the quartz grains are also tabular or elongate parallel to the schistosity (figs. 12-13).

Lineation was not found in the gneiss but is well developed in the arkose and hornblende schist. In the arkose the lineation consists of striations that resemble slickensides on the sides of quartzite and gneiss pebbles. Most of the lineation plunges about $80^{\circ} \mathrm{NW}$ in the plane of foliation and is probably parallel to the direction of relative movement during deformation. This orientation is suggested by the appearance of the lineations and by the deeply dentate ends of some of the pebbles, which indicate that the pebbles were deformed by shearing rather than rolling. Nearly vertical movement is also suggested by the rare minor folds that can be seen in the arkose. Most of these folds plunge at low angles, either eastward or westward.

Lineation in the hornblende schist was not mapped, but it lies in the planes of foliation and is caused by parallel hornblende crystals.

\section{FAULTS}

The principal structural features of the Norway Lake area are high-angle faults. Relative movement on the faults has brought a block of highly deformed Lower Precambrian rocks on the south into juxtaposition with less-deformed Animikie rocks on the north. The steep dip of the faults is indicated by the foliation planes in the sheared rocks in the southern part of the area and by the regularity of the traces of the faults. The movement on the faults was probably almost vertical, parallel to the lineation in the arkose.

A fault that extends from the southern part of sec. 11, T. 42 N., R. 29 W., to the northern part of sec. 11, T. 42 N., R. 28 W., offsets the gneiss-arkose contact in secs. 11, 12, 13, and 14, T. 42 N., R. 29 W. A small block of gneiss in the center of the arkose belt in the SE1/4 NE1/4 sec. 10, T. 42 N., R. $28 \mathrm{~W}$., is apparently a sliver along this fault. This gneiss exposure is not in the core of an anticline, for excellent crossbedding shows that the tops of beds in the arkose face south on both sides of the gneiss sliver.

The fault extending from the northern part of sec. 8, T. 42 N., R. 29 W., to the southern part of sec. $2, T$. $42 \mathrm{~N}$., R. $28 \mathrm{~W}$., forms part of the contact between Lower and Middle Precambrian rocks. The fault truncates the Randville dolomite in sec. 3, T. 42 N., R. 28 W., and secs. 1 and 2, T. 42 N., R. 29 W. This fault is further indicated by the fact that the top of the dolomite beds in the SW1/4 SW1/4 sec. 3, T. $42 \mathrm{~N}$., R. $28 \mathrm{~W}$., face south, toward the Lower Precambrian rocks.

The Bush Lake fault, which crosses the north part of T. 42 N., R. 30 W., is extended into secs. 34 and 35 , T. 43 N., R. 29 W. on the basis of relations shown by outcrops and drill holes between Animikie sedimentary rocks and the older granite gneiss.

No evidence was found to indicate whether the narrow band of arkose in the SW1/4 sec. 3, T. 42 N., R. $29 \mathrm{~W}$., is folded into the granite or bordered on one or both sides by a fault.

\section{STRUCTURE OF THE EAST BRANCH ARKOSE}

Beds in the East Branch arkose are nearly vertical in most places. Crossbedding is abundant all the way across the belt underlain by the East Branch arkose in sec. 10, T. 42 N., R. 28 W., except in the southernmost exposure of the arkose in that section. It is also common in the area shown on plate 10 and in the eastern part of sec. 12, T. 42 N., R. $29 \mathrm{~W}$. Crossbedding (fig. 7) invariably indicates that the tops of beds face south, showing that the arkose sequence is not isoclinally folded although several small folds (fig. 8) have been found. Axes of the small folds are parallel to the general strike of the beds and plunge eastward or westward at angles of less than $20^{\circ}$.

\section{STRUCTURE OF MIDDLE PRECAMBRIAN ROCKS}

The structure of the Middle Precambrian rocks is not well known. In the northeastern part of the mapped area the Randville dolomite, the only formation in this group for which much usable structural information is available, is exposed in several widely separated areas. Tops of beds in the northernmost and southernmost exposures, as indicated by stromatolites, are to the south. The field evidence is not sufficient to show whether the repetition of the Randville dolomite is caused by folding, faulting, or a combination of both. Structures that are probably stromatolites suggest that tops of beds in the NW1/4 of sec. 6, T. 42 N., R. 28 W., are to the north. No evidence of the direction of tops of beds was found in the exposures in the $\mathrm{NE} 1 / 4 \mathrm{NE}^{1} / 4$ sec. 2 , T. 42 N., R. 29 W.

Near the west quarter corner of sec. 1, T. 42 N., R. $29 \mathrm{~W}$., the Randville dolomite forms a syncline that is truncated on the south by a high-angle fault. The orientation of the syncline appears anomalous inasmuch as it plunges about $\mathrm{S} .30^{\circ} \mathrm{E}$. at an angle of about $45^{\circ}$, in contrast with the more nearly eastward general trend of the dolomite. 


\section{MAGNETIC ANOMALIES}

The Norway Lake area is included in an aeromagnetic survey of Dickinson County made by the Geological Survey in 1948 (Wier, Balsley, and Pratt, 1953). Crests of anomalies shown on the north-south aeromagnetic profiles have been plotted on plate 2 . Wherever possible, crests on adjacent profiles have been joined to indicate trends of individual anomalies.

Within the area underlain by granite gneiss only small anomalies have been found, and these are rare. The anomaly in the northern parts of secs. 7 and 8 , T. $42 \mathrm{~N}$., R. $28 \mathrm{~W}$., may be related to chlorite schist inclusions in the gneiss. Some of the chlorite schist has been found to contain magnetite.

Within the area underlain by the East Branch arkose (pl. 9), magnetic anomalies that are locally strong are associated with interbedded metavolcanic rocks. Anomalies in T. 42 N., R. 29 W., on the apparent extension of the arkose belt, may be related to interbedded metavolcanic rock (See chapter B of this report.) or possibly to dikes (Pettijohn, 1951).

The strong magnetic anomaly in the southern parts of secs. $14,15,16$, and 17, T. 42 N., R. 28 W., is caused by the magnetite-bearing Skunk Creek member of the Solberg schist.

Within the part of the Norway Lake area underlain by Animikie one strong anomaly and several weak anomalies were disclosed by the aeromagnetic survey. The strong anomaly extending westward from sec. 33, T. 43 N., R. 29 W., is very broad, and therefore the rock causing it is probably deeply buried. Small anomalies in the vicinity of dolomite exposures are tentatively assigned to the magnetic-bearing slate member of the Randville dolomite.

Lack of agreement is evident in some places between aeromagnetic data and positions of geologic contacts and magnetic crests as determined by ground surveys. This may be due in part to errors in position of aeromagnetic determinations.

The results of a magnetic survey of a limited part of the Norway Lake area, made before results of the aeromagnetic survey were available, are shown on plate 11. The survey was made with a Schmidt-type vertical component magnetometer with a sensitivity of about 35 gammas per scale division. In this survey, only the anomaly associated with the magnetite-bearing slate member of the Randville dolomite in the western part of sec. 1, T. 42 N., R. 29 W., is definitely correlated with a stratigraphic unit. The anomalies in the $\mathrm{SE} 1 / 4$ sec. $34, \mathrm{~T} .43 \mathrm{~N}$., R. $29 \mathrm{~W}$., and the $\mathrm{NE} 1 / 4$ sec. 4 , T. 42 N., R. 29 W., are assumed to be associated with the same beds, but they are not definitely so correlated.

Anomalies found at the Deerhunt exploration, where the iron-formation is present at the surface, are so small that they can be missed with magnetometer stations located at 100 -foot intervals. It is not known whether the very local character of the anomalies is due to a range in magnetic permeability of different parts of the iron-formation or to different thicknesses of iron-formation under the various stations.

\section{POSSIBILITIES FOR EXPLORATION}

There is no positive evidence that the Vulcan ironformation occurs at or near the bedrock surface anywhere in the south part of the Sagola basin except at the Deerhunt exploration. Rare boulders of hard blue hematite ore have been found in glacial deposits east of the Deerhunt exploration; and inasmuch as the ice moved westward in this area, a source east of the Deerhunt exploration is indicated. It is not known, however, whether the source was within the mapped area. Pebbles of jaspilite, obviously derived from exposures at the Deerhunt exploration, are abundant in the glacial drift for some distance west of that locality.

Elsewhere in Dickinson County the Vulcan ironformation is characterized by strong persistent magnetic anomalies. Accordingly, the absence of such anomalies in the part of the Norway Lake area underlain by Animikie rocks suggests that the iron-formation is absent in most of the area. Conditions outside the Norway Lake area suggest that the iron-formation, except for isolated patches, may have been removed also in the southern part of the Sagola basin area by erosion prior to deposition of the slates and graywackes of the Baraga group. If so, targets for exploration will be small. This, coupled with the difficulty of determining the geologic structure on the basis of magnetic and outcrop data, will make an exploration program tedious and expensive and the results doubtful. 



\title{
Chapter D. GEOLOGY OF THE FELCH MOUNTAIN DISTRICT
}

\author{
By Carl A. Lamey
}

\section{INTRODUCTION}

The Felch Mountain district, which includes the Felch trough, forms the central strip of the central Dickinson County map area (fig. 1). The district has been only a minor producer of iron ore and has been inactive since 1913. Increased demand for iron ore, however, coupled with a decline of available high-grade material in the United States and the development of methods for concentrating and utilizing ore of lower grades, made reexamination of the area desirable.

The present investigation was started in the summer of 1945 as a part of the strategic minerals program of the U. S. Geological Survey, in cooperation with the Geological Survey Division, Michigan Department of Conservation. Fieldwork was continued during successive summers through 1950. During the course of the work, several progress maps and reports were prepared and placed on open file in the offices of the U. S. Geological Survey, Washington, D. C., and Madison, Wisc., and in the office of the Geological Survey Division, Michigan Department of Conservation, Lansing, Mich.

\section{PREVIOUS WORK AND IITERATURE}

A discussion of previous work and a summary of the literature for central Dickinson County appears in chapter $\mathbf{A}$ of this report. Many of the references there cited apply to the Felch Mountain district, but it seems well to include here a brief discussion of material that may be especially pertinent.

The previously published material on the geology of the area consists almost entirely of (1) the early articles by Burt (1849), Foster and Whitney (1851), Credner (1869), Brooks (1873 and 1880), Rominger (1881 and 1895), Irving (1887 and 1888), Van Hise (1891 and 1892), and Wadsworth (1893); and (2) the more extensive account by Smyth (Clements and Smyth), 1899). Since 1899 some additional material regarding the geology of part of the district has been presented by Van Hise and Leith (1911), Lamey (1931, 1933, 1934, and 1937), Leith, Lund, and Leith (1935), and Dickey (1936).
The work prior to 1899 has been summarized by Smyth (Clements and Smyth, 1899, p. 375-383). The discovery of iron-formation in the district is attributed to land surveyor William A. Burt in 1846. Burt (1849) also gave a brief description of some of the other rocks of the area, and this was supplemented by the descriptions of Foster and Whitney (1851). Much of the early geologic work that paved the way for future investigations was done by Credner (1869), Brooks (1873 and 1880), and Rominger (1881 and 1895). Classifications of the rocks and their correlation with formations of other districts was undertaken by Irving (1887 and 1888), Van Hise (1891 and 1892), and to some extent by Wadsworth (1893). The most detailed accounts are those of Rominger.

Smyth (Clements and Smyth, 1898, 1899) has presented the only detailed report of the district. His earlier account (1898) is essentially a preliminary summary of the later one (1899). He prepared a topographic and geologic map of the district (1899, pl. 49, opp. p. 374) and presented a discussion of the distribution and characteristics of the rock units and their relationships.

Material published since Smyth's work deals chiefly with some details of correlation and with the age of the granitic rocks of the area. Van Hise and Leith (1911) summarized the geology and added some details; Leith, Lund, and Leith (1935) summarized the new material published to 1935; and papers by Lamey (1931, 1933, 1934, and 1937), and Dickey (1936), dealt with the age of the granitic rocks.

\section{SCOPE OF PRESENT INVESTIGATION}

The area mapped (see fig. 1) during the present investigation includes the area mapped by Smyth (Clements and Smyth, 1899, pl. 49, opp. p. 374), an extension of this area to the east, southeast, and west, and part of the area to the north previously mapped by Bavley (1899, pl. 51, facing p. 458).

Throughout the course of the work, the principal emphasis was placed on the sedimentary-rock units, 
with specific attention to the iron-formation. As the work progressed, however, it became increasingly apparent that a better understanding of the nature and relationship of the adjoining crystalline complexes was desirable. Therefore, some detailed work was done in the areas underlain by those complexes. In addition to the work done in those areas by the writer, two small parts of the complexes were studied by Lehner (1950), and by Roseboom (1951), under the writer's supervision.

\section{FIELD AND LABORATORY METHODS}

In the area containing the principal iron-formation, and in some parts of the crystalline complexes, the field methods used were compass and pace traverse, and notebook mapping at a scale of 200 feet to the inch except in small areas where more detail was desirable. Control was maintained by dial compass, locating section corners, taping section lines and establishing markers every eighth of a mile, and by the use of air photographs. Dip-needle observations were made at intervals of 40 feet along north-south lines usually spaced an eighth of a mile apart, and also along such east-west lines and diagonal roads as appeared necessary. Locally, more detailed dip-needle work was done, and one small area was surveyed with a magnetometer.

Throughout most of the area of the crystalline complexes, outcrops were plotted at a scale of 1,000 feet to the inch on base maps compiled from air photographs. No detailed magnetic work was done in these areas, but the results of the aeromagnetic survey were available (Wier, Balsley, and Pratt, 1953).

Laboratory work included the study of hand specimens and about 200 thin sections.

\section{PERSONNEL AND ACKNOWLEDGMENTS}

During the course of the fieldwork, the writer was assisted at various times by G. E. Siple, A. F. Trites, John Folger, Arthur Lamey, Donald Bergman, and R. W. Bayley, and some magnetometer work was done by K. L. Wier. Field maps and petrographic studies of small parts of the area were made available by Robert Lehner and Eugene Roseboom. Valuable suggestions and inspiration were given by Geological Survey colleagues and other geologists who visited the area during the course of the work. The writer is particularly grateful to the M. A. Hanna Co. for its excellent cooperation in placing at his disposal invaluable information obtained from diamond drilling. Without these data, the writer's work would have been far more difficult and less effective.

\section{GENERAL DESCRIPTION OF THE AREA MAPPED}

TOPOGRAPHY AND SURFACE FEATURES

The maximum relief of the area is about 400 feet and the highest elevation about 1,500 feet above sea level, yet in some respects the area is surprisingly rough. The topography is controlled chiefly by rock character and geologic structure, and subordinately by glacial erosion and deposition. An alternation of weak and resistant rocks in part of the area, combined with a general eastward structural trend, close folding, and major faults trending eastward, has given rise to a series of ridges and intervening lowlands. In rocky areas slopes are steep and changes in relief abrupt; in areas of much drift the slopes are gentle. Most of the ridges are not long, being broken at intervals of a mile or so by small gaps and lowland areas. In some parts of the area, where the rocks are more uniform, the topography is controlled chiefly by glacial erosion and deposition, and is characterized locally by northward-trending morainic ridges that completely obliterate and bury some of the eastward-trending rock ridges; by minor winding esker ridges; and by hummocky morainic and outwash deposits.

The drainage of the area is relatively poor. Swamps abound between the eastward-trending ridges and in some of the flatter areas covered by glacial deposits. The major stream of the area is the Sturgeon River, the West Branch and its tributaries draining the western part of the area, the East Branch and its tributaries draining the eastern part. Both branches flow generally toward the east and southeast.

\section{OUTLINE OF THE GEOLOGY}

The Felch Mountain district is characterized by four major geologic subdivisions that trend generally eastward. For convenience, these are designated, from south to north, (1) the southern granitic complex, which is the extreme northern part of the central crystalline block described in chapter B; $(2)$ the Felch trough; (3) the banded gray-gneiss complex, which forms the southern part of the northern crystalline block (chapter B) ; and (4) the volcanic-sedimentary rock complex, which is the central part of the northern crystalline block (see chapter B and fig. 74).

The southern granitic complex consists chiefly of granitic rocks, most of which are rather massive and coarse grained, but some of which are gneissic. Irregularly disposed throughout these granitic rocks are eastward-trending lenticular stringers and masses of amphibolite, ranging in thickness from less than a foot to 150 feet. Quartz veins and granite-pegmatite dikes cut the granitic rocks and the amphibolite, and in places the granitic rocks grade imperceptibly into small 
areas of granite pegmatite. Rare diabase dikes cut all of the other rocks.

The Felch trough is underlain almost entirely by closely folded and metamorphosed Animikie sedimentary rocks. These are subdivided into (1) the Chocolay group, composed of the Sturgeon quartzite and associated schists, and the Randville dolomite, and (2) the Menominee group, consisting of the Felch formation and the Vulcan iron-formation. In parts of the area, the Animikie rocks are cut by metadiabase, chiefly as sills. The sedimentary rocks trend generally, eastward; and these, as well as some of the metadiabase, are cut by granite and granite-pegmatite dikes that usually trend northward. Here and there, especially in the eastern part of the area, small patches of nearly horizontal sandstone and dolomite of Cambrian and possible Ordovician age overlie the Precambrian rocks of the Felch trough.

The banded gray gneiss complex consists chiefly of well-foliated, strongly layered granitic gneiss that has a general eastward trend. Associated with this gneiss are stringers and lenses of amphibolite. These amphibolite bodies, which are very subordinate in the southern part of this area, increase in size and abundance northward until they make up as much as half of the complex, and finally make up almost the entire mass. Lying within and apparently surrounded by the gneiss is a large body of vitreous quartzite. The rocks of the complex are cut by many granite-pegmatite dikes, ranging in thickness from less than an inch to more than 100 feet, and in a few places by larger irregular masses of granite pegmatite and fine-grained granite. Most of these pegmatite dikes trend nearly northward, but some of them trend nearly eastward, and many change from one trend to another as they traverse the rocks. Locally, diabase dikes cut the gneiss, the amphibolite, and the pegmatite.

The volcanic-sedimentary rock complex may be subdivided into a southern belt of amphibolite about 2,000 feet wide-the Six-Mile Lake amphibolite-and a northern belt of sedimentary rocks-the Solberg schist. The amphibolite contains some layers of gray gneiss similar to the gneiss that adjoins the amphibolite to the south. The Solberg schist contains quartzose mica schist and micaceous quartzite, accompanied by magnetite-bearing mica schists, quartzose iron-formation, and hornblende schist. Locally, all the rocks of the volcanic-sedimentary complex are cut by granite pegmatite, sometimes in great profusion.

\section{STRATIGRAPHIC SUCCESSION}

One of the most troublesome problems encountered during the study of the Felch Mountain area was the attempt to establish, accurately and completely, the stratigraphic succession. It has long been known that in the Felch trough the succession is, from the bottom upward, the Sturgeon quartzite, the Randville dolomite, the Felch formation, and the Vulcan iron-formation. The only rocks that are well known, however, are the resistant ones: the vitreous quartzite of the Sturgeon, the massive dolomite of the Randville, and the Vulcan iron-formation. These resistant rocks are known to be separated by schists, and at no place is there exposed an uninterrupted sequence from one formation into another; in many places the resistant rocks are separated from one another by major faults that pass through schist zones, at least in part. Also, although the Sturgeon quartzite and the Randville dolomite are thought to lie unconformably below the Felch formation and the Vulcan iron-formation, at no place is there absolutely clear evidence of such relations. In addition, the metamorphic grade throughout the area is relatively high, thus making it necessary to attempt stratigraphic correlation between various metamorphic rocks. Furthermore, the original nature of some of the rocks has been obscured by hydrothermal alteration or retrograde metamorphism, as well as by changes produced by ground water and deep weathering before deposition of the rocks of Paleozoic age.

Three principal stratigraphic successions have been previously proposed by Smyth (Clements and Smyth, 1899), by Van Hise and Leith (1911, p. 302), and by Leith, Lund, and Leith (1934, chart facing, p. 10). Those are shown in tables 12,13 , and 14 . The succession used by Smyth was not presented in the manner given in this table; the tabulation is compiled from Smyth's discussion and descriptions. Also, to the other successions the writer has added some comments, in italics, taken from the text material.

A description of the units in central Dickinson County is presented in Chapter B. For convenience, a tabulation of this succession is presented in table 15 . Those rocks not known to be present in the Felch Mountain district are shown in italics in the table. It will be noted that for the first time there is introduced into the stratigraphic succession of the Felch Mountain district a group of pre-Animikie sedimentary and volcanic rocks (the Dickinson group), and a post-Dickinson granite. Also, there is proposed a somewhat more definite statement regarding the age relations of other igneous rocks. Minor changes are the grouping together in the Felch formation all schists between the Randville dolomite and the Vulcan iron-formation, and the delineation of schists above 
TABLE 12.-Stratigraphic succession in the Felch Mountain district according to Smyth (1899)

Cambrian Age

TABLE 12.-Stratigraphic succession in the Felch Mountain district
Description

Algonkian:

Intrusive

Sandstone and dolomite.

Granite.

Diabase.

Upper Huronian......... Undivided: Mica schists and thin-bedded ferruginous quartzites.

Lower Huronian......... Groveland formation: Chiefly quartzose iron-bearing formation; some of it containing grunerite.

Mansfield schists (200 feet thick): Fine-grained mica schists, locally containing abundant garnets, especially near basic intrusives.

Randville dolomite (500 to 1,000 feet thick): Chiefly dolomite, more or less pure; probably a very small amount of interbedded schists.

Sturgeon quartzite (average thickness 450 feet): Massive quartzites and sheared quartzites or micaceous quartz schists; locally muscovite-biotite gneiss near bottom.

Archean ................. Granites or granitic gneisses; gneisses with banding or distinct lamination; mica schists; hornblende gneisses or amphibolites.

TABLE 13.-Stratigraphic succession in the Felch Mountain district, according to Van Hise and Leith (1911)

Age $\quad$ Description

Cambrian

Intrusive rocks. ............. Basic and acidic rocks.

Algonkian system:

Keweenawan series(?) _._. Mica schists and ferruginous and micaceous quartzites. (These are the schists that Smyth classed

Unconformity. as Upper Huronian.)

Huronian series:

Upper Huronian......... Vulcan formation, iron bearing Felch schist. Not more than 200 feet thick. (Lies between the Randville dolomite and the Vulcan formation. Described as fine-grained mica schists containing garnet and tourmaline.)

Unconformity(?).

Lower Huronian........ Randville dolomite (500 to 1,000 feet thick). Sturgeon quartzite. Less than 500 feet thick. (Principally quartzite, but contains conglomerate near the lower contact; mashed quartzites or

Unconformity. micaceous quartz schists closely associated.)

Archean system:

Laurentian series . . ...... Granites and gneisses.

TABLE 14.--Stratigraphic succession in the Felch Mountain district, according to Leith, Lund, and Leith (1995) [Use of an asterisk $\left(^{*}\right)$ indicates doubt as to stratigraphic position]

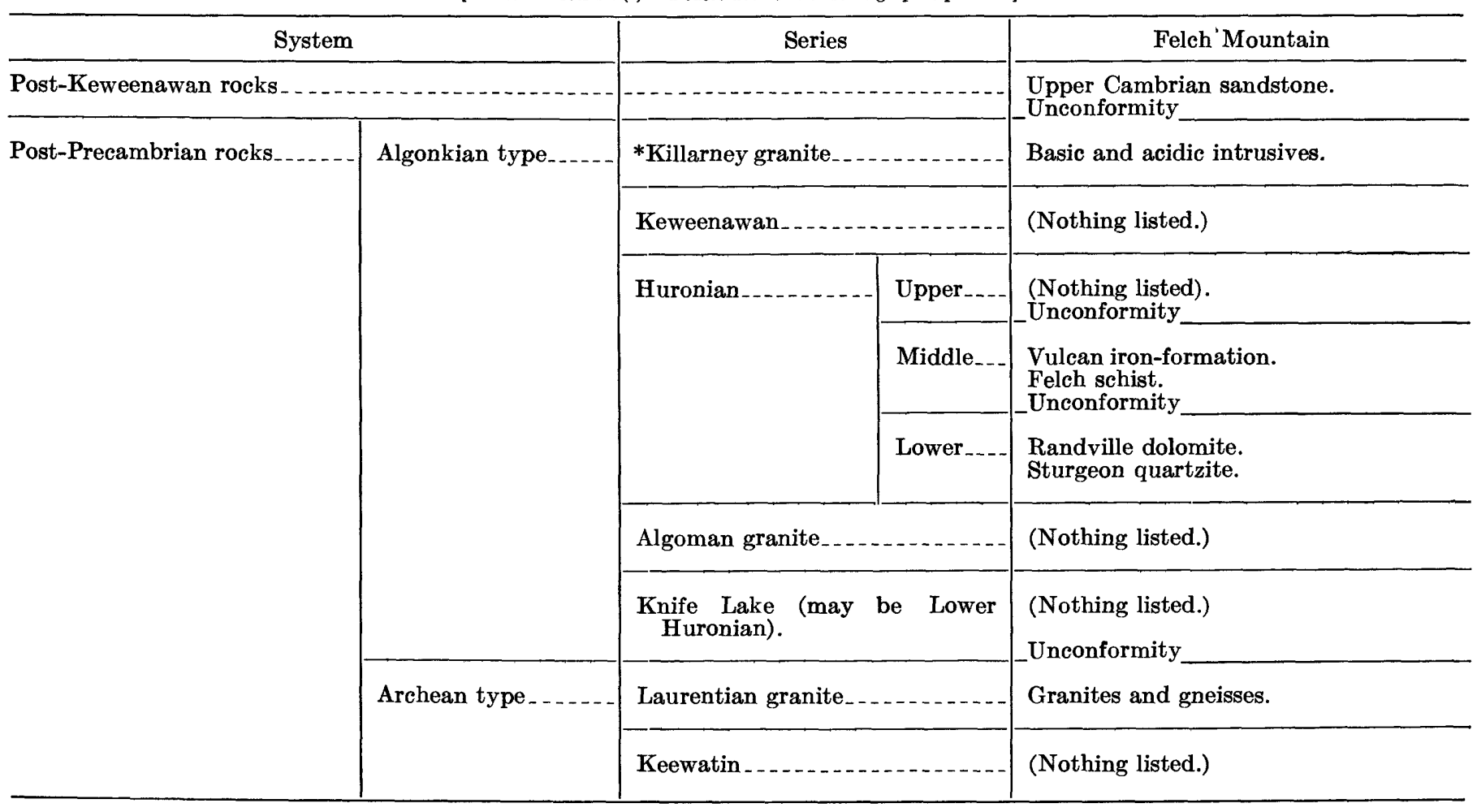


and below the vitreous Sturgeon quartzite. The concept of unconformable relations between the Chocolay group and the Menominee group has been retained, as it seems to afford the only rational explanation for the various types of schist that separate the Vulcan iron-formation from the Randville dolomite.

\section{LOWER PRECAMBRIAN ROCKS DICKINSON GROUP}

The Dickinson group is represented in the Felch Mountain district by the Six-Mile Lake amphibolite and by the upper part of the Solberg schist, which includes the iron-rich Skunk Creek member; the East Branch arkose is not present. These rocks are exposed in the north-central and northeastern parts of the area.

\section{SOLBERG SCHIST AND SKUNK CREFK MEMBER}

In this area, the principal exposures of the Solberg schist occur on a low ridge in the extreme northern part of the mapped area, in T. 42 N., Rs. 28 and 29 W.
The only known exposure of the Skunk Creek is near the west end of this line of outcrops, in the NE $1 / 4 \mathrm{NE} 1 / 4$ sec. 23, T. 42 N., R. 29 W. A second belt of schist exposures is along the East Branch of the Sturgeon River in secs. 21 and 22, T. 42 N., R. 28 W. The Skunk Creek member is known further through information gained from several diamond-drill holes.

DESCRIPTION OF THE SOLBERG SCHIST

The Solberg schist exposed in this area is mostly light to dark gray and is somewhat quartzitic in appearance. It weathers to lighter gray or to slightly pink or brown and breaks into rather thick slabs, some of which show good foliation and abundant mica (see figs. 12, 13), whereas others are quartzitic. Some of the more deeply weathered outcrops consist of gray mica schist, and similar schist is present along the margins of other outcrops. A small amount of arkosic rock is interbedded with more typical quartzose and schistose rock in a small outcrop in the southeastern part of sec. 13 , T. 42 N., R. 29 W. The rock
System and series

Quaternary _

Unconformity.

Cambrian and Ordovician

Unconformity.

Upper Precambrian rocks:

Keweenawan.

Unconformity (not defined in this area).

Middle Precambrian:

Post-Animikie

Animikie series:

Baraga group

Unconformity.

Menominee group

Unconformity.

Chocolay group.

Unconformity.

Lower Precambrian rocks:

"Algoman"(?).

Dickinson group

Unconformity.

Pre-Dickinson
TABLE 15.-Probable rock succession in the Felch Mountain district [Italicized rock units not known to be present in this area]

Glacial deposits.

Sandstone and dolomite.

Diabase.

Granite pegmatite

Massive granite.

Metadiabase and metagabbro.

Badwater greenstone.

Michigamme slate.

Hemlock formation.

Vulcan iron-formation.

Felch formation (includes schists of at least four types, believed to be correlative).

Randville dolomite.

Sturgeon quartzite (includes schist below and above vitreous quartzite).

Fern Creek formation.

Gneissic granite.

Six-Mile Lake amphibolite.

Solberg schist and Skunk Creek member.

East Branch arkose.

Granite gneiss. 
contains many grains of red feldspar in addition to those of quartz. Some of the feldspar grains are as much as $60 \mathrm{~mm}$ in diameter but most are 20 to $30 \mathrm{~mm}$. The rock is similar to some of the East Branch arkose, which occurs farther north.

As seen under the microscope, the typical Solberg schist of this area consists chiefly of quartz, oligoclase (about $A b_{72}$ ), biotite, muscovite, and hornblende. Minor constituents are orthoclase, magnetite, titanite, epidote, tourmaline, apatite, carbonate, chlorite, sericite, and pyrite. Some of the more micaceous schists are distinctly layered, quartz-rich and micarich layers alternating. The biotite and muscovite are sometimes crystallized together in parallel position. The more quartzose rocks are much like the micaceous schists except that they are richer in quartz. Some specimens have been much mashed, and the quartz is in elongate bands separated from one another at intervals of about $3 \mathrm{~mm}$ by narrower zones of crushed quartz; or lenticular areas of strained quartz may be separated from one another by contorted streaks of biotite and hornblende, along with some chlorite and sericite. A specimen of the arkosic rock interbedded with schist in sec. 13, T. 42 N., R. 29 W., is composed of grains of quartz and feldspar, 1.0 to $2.0 \mathrm{~mm}$ in diameter, in a matrix of quartz and subordinate feldspar, along with biotite, hornblende, titanite and epidote. Some of the larger grains are composed of a single crystal of feldspar or quartz, but others are composed of an aggregate of crystals. The large single feldspar crystals are chiefly orthoclase, but a few are oligoclase. The feldspar of the matrix and of the grain aggregates is chiefly microcline and microperthite. Some of the larger aggregates may represent original single grains of orthoclase or plagioclase that have been entirely converted to microcline.

\section{DESCRIPTION OF THE SKUNK CREEK MEMBER}

The nature of the Skunk Creek member, whose extent is known mainly from the magnetic anomaly it causes, has been determined almost entirely from examination of drill core. The rock is interbedded with and gradational into biotite-hormblende schist at both contacts. The unit contains many rock types and is defined chiefly on the basis of its high content of magnetite. In part it is a hornblendic schist, similar to other parts of the Solberg schist but characterized by abundant magnetite, and in part it is typical banded iron-formation, with white to gray layers dominantly of granular quartz alternating with dark layers dominantly of magnetite (fig. 88) or of amphibole and magnetite.
In thin section, the more strikingly banded ironformation consists of layers of (1) quartz and some magnetite, with interstitial carbonate; (2) magnetite, quartz, and epidote; (3) quartz and magnetite; and (4) any of the above combinations and a nonpleochroic tremolitic amphibole in large poikilablastic plates. Epidote is commonly present as single crystals 0.02 to $0.05 \mathrm{~mm}$ in diameter and as poikiloblastic crystals measuring 0.4 by $1.0 \mathrm{~mm}$. The magnetite ranges from mere dust to crystals $0.4 \mathrm{~mm}$. in diameter, and some of it forms chains or aggregates about 0.6 $\mathrm{mm}$ wide, extending the length of the slide. In some of the rocks the dark layers are amphibolitic. The amphibole generally is in slender, crisscross bundles, sheaves, and partial rosettes-occasionally in single crystals. It is pleochroic in shades of light bluish green to colorless and shows parallel extinction. Some of the larger single crystals, however, are pleochroic in shades of light greenish brown to brownish or grayish green, and show extinction of $15^{\circ}$, and some of these crystals are fringed with minute fibers of the other amphibole. The larger single crystals may be near actinolite in composition, whereas the fringing amphibole may be anthophyllite. Garnet is scattered through the rock, as is magnetite; both show greater concentration in the amphibolitic layers. Variations noted in some slides are poikiloblastic hornblende in crystals 1.7 by $0.4 \mathrm{~mm}$, enclosing quartz and magnetite, and large garnets. A variant of this type also contains large tourmaline crystals; one crystal measures 3.2 by $0.8 \mathrm{~mm}$ and encloses quartz, amphibole, and magnetite. The amphibole of this specimen is in part hormblende and in part a fibrous gruneritic type. which, however, shows very slight pleochroism.

\section{SIX-MILE LAKE AMPHIBOLITE}

The Six-Mile Lake amphibolite is well exposed throughout much of the area north of the Felch trough. It is easily accessible south of a secondary road in secs. 19 and 24, T. 42 N., Rs. 28 and 29 W., where it forms a series of ridges that trend generally eastward and rise from 10 to 25 feet or more above the surrounding area.

\section{GENERAL DESCRIPTION}

The amphibolite is nearly black, generally medium to somewhat coarse in grain, and appears to be composed chiefly of hornblende with some feldspar. It is cut by numerous tiny light-colored veins. As a rule it is not well foliated, but it does show strong lineation that plunges from $15^{\circ}$ to $25^{\circ}$ toward the east. The tiny veins may trend in the same direction as the lineation, but not uncommonly they cut across and 
form a netlike pattern on gray to slightly brown weathered surfaces.

In some parts of the outcrop area, especially near its southern margin, the amphibolite is cut by many veinlike discontinuous stringers of white to reddish feldspar, which are parallel to the lineation and give the rock a somewhat foliated appearance. Here and there along these stringers, irregular porphyroblasts of pink to red feldspar are apparent, some of which attain a size of several millimeters. Again, some of the rock is characterized by numerous conspicuous porphyroblasts of feldspar, which are usually pink to white near their centers and reddish toward their edges. These may be as much as an inch across. They weather more readily than the enclosing amphibolite, and give rise to pitted surfaces that at least superficially resemble the weathered surfaces of amygdaloidal lavas.

Rocks lighter in color than the typical amphibolite are found locally, but they have no regular pattern of distribution. They show either a more granular texture, a more fibrous amphibole, the presence of considerable biotite, or a combination of these characteristics.

\section{PETROGRA PHY}

The common type of amphibolite has a granoblastic texture and is composed chiefly of amphibole, feldspar, and quartz. Grain size ranges from 0.2 to $0.5 \mathrm{~mm}$ (see figs. 14, 15). Usually the amphibole and feldspar are about half as wide as they are long, whereas the quartz is more nearly equidimensional, although its length also is generally somewhat more than its width. These minerals are usually arranged roughly in parallel position. Although this orientation often is not conspicuous, in some specimens it is pronounced.

Strongly pleochroic blue-green hornblende is the most conspicuous and also the most abundant mineral present, making up at least half of the rock. Minor constituents are titanite, epidote, magnetite, leucoxene, and perhaps ilmenite and rutile. As a rule these minerals are small, ranging in length from 0.01 to $0.05 \mathrm{~mm}$, but occasionally as much as $0.1 \mathrm{~mm}$. Titanite is common and may be relatively abundant. Although some of it occurs in small single crystals, it is much more characteristically present in chains and masses of crystals associated with the amphibole.

Plagioclase is the most abundant feldspar, but it is accompanied by potassium feldspar in some specimens, and possibly in all. Most of the plagioclase is andesine $\left(\mathrm{An}_{30-40}\right)$, which commonly grades outward to oligoclase and albite.

Considerable variation from the usual type of amphibolite is shown by some specimens, and, indeed, variation may be shown within a single thin section. In one specimen, subordinate grunerite occurs with the usual hornblende, accompanied by an abnormal amount of apatite; in another, layers of the usual hornblende alternate with layers composed of a confused aggregate of hornblende, epidote, quartz, orthoclase, titanite, and some carbonate. Again, the feldspars may show much more than the usual amount of sericitization, and some of the amphibole may be altered to chlorite. Practically without exception, where much epidote and sericite are present they are close to little veins which contain either sericite, epidote, chlorite, orthoclase, quartz, or some combination of these minerals. Frequently alteration is confined closely to these little veins and is not present in other parts of the slide.

Estimates of the composition of the typical amphibolite indicate that hornblende makes up 50 to 60 percent of the rock, that quartz probably always is present, ranging in amount from only 2 or 3 percent to as much as 23 percent, and that plagioclase makes up most of the remainder. The quartz content is most typically 10 to 15 percent; the 23-percent value was obtained for a specimen that contains a small amount of grunerite, and the quartz may be in part detrital.

\section{BANDED GRAY GNEISS}

The banded gray gneiss is exposed at many localities north of the Felch trough. Exposures are particularly large and abundant in secs. 28, 29, and 30, T. 42 N., R. $28 \mathrm{~W}$., and in the adjacent sec. 25, T. 42 N., R. 29 $\mathrm{W}$. The belt of gneiss is approximately a mile wide.

\section{DESCRIPTION}

Most of the gneiss is light gray, or alternating light and dark gray, and is thinly layered (see fig. 21). The rock typically contains thin rather discontinuous biotitic and hornblendic layers, not more than a millimeter thick, alternating with quartz-feldspar layers several millimeters thick. Both on fresh breaks and on weathered surfaces the gneiss is somewhat mottled as a result of segregation of feldspar into patches a few millimeters across and 5 or $6 \mathrm{~mm}$ long. Near some dikes of granite pegmatite, the gneiss contains layers a few millimeters wide composed of pinkish feldspar, some of which cut across the gneissic layering.

In some places, particularly near the southern margin of the gray gneiss belt, the gneiss contains lenses and pods of amphibolite as much as 100 feet thick and a quarter of a mile or more long. A detail of the more coarsely layered gneiss cut by younger granite and pegmatite is shown in plate 5 . 


\section{PETROGRA Phy}

The light-colored layers of the gneiss are composed chiefly of feldspar, quartz, and biotite. The texture is exceedingly irregular and the abundance of the various constituents varies widely from place to place. The larger grains-quartz, plagioclase, and microcline-vary in size from about $0.5 \mathrm{~mm}$ to $1.5 \mathrm{~mm}$. The microcline, which usually occurs as smaller crystals than the other constituents, is unaltered. The plagioclase in two specimens is oligoclase, whereas in a third it is probably albite. Other minerals, present in small quantities, are muscovite, chlorite, epidote, zircon, leucoxene, apatite, and iron oxides. A Rosiwal analysis by Lehner (1950) shows 26 percent plagioclase, 23 percent potassium feldspar, 42 percent quartz, and 8 percent biotite.

The amphibolite that makes up the dark layers and pods in the banded gray gneiss is virtually identical to the Six-Mile Lake amphibolite previously described. The rock is medium grained, with strong preferred orientation of the minerals. Hornblende, plagioclase, and quartz are the chief constituents. Three Rosiwal analyses of typical material made by Lehner (1950) are given in table 16 .

TABLE 16.-Rosiwal analyses showing compositions of three samples of amphibolite from the banded gray gneiss in sec. 29 , T. $42 N$., R. $28 \mathrm{~W}$.

[Values are in percent by volume. From Lehner, 1950]

\begin{tabular}{|c|c|c|c|}
\hline & 1 & 2 & 3 \\
\hline $\begin{array}{l}\text { Hornblende } \\
\text { Feldspar, chiefly plagioclase } \\
\text { Quartz } \\
\text { Titanite } \\
\text { Epidote. } \\
\text { Chlorite } \\
\text { Apatite } \\
\text { Iron oxide }\end{array}$ & $\begin{array}{r}60.0 \\
24.0 \\
11.0 \\
1.5 \\
\text { Tr. } \\
\text { Tr. } \\
\text { Tr. }\end{array}$ & $\begin{array}{r}63.0 \\
23.0 \\
10.0 \\
1.5 \\
1.4 \\
\text { Tr. } \\
\text { Tr. } \\
\text { Tr. }\end{array}$ & $\begin{array}{r}48.3 \\
34.9 \\
15.5 \\
.5 \\
.1 \\
\text { Tr. } \\
\text { Tr. } \\
\text { Tr. }\end{array}$ \\
\hline
\end{tabular}

ORIGIN

The gray gneiss certainly is in part a product of dynamothermal metamorphism, and clearly was formed at the time of granitic invasion and deformation of the rocks of the Dickinson group. It is not entirely clear, however, whether the layered gneiss represents injections into and partial granitization of the amphibolite alone, or of injection and partial granitization of amphibolite and sedimentary or tuffaceous rocks that were interbedded with the original basic igneous rocks.

Origin by granitic injection during orogeny, or gradual encroachment of granitic material, resulting in the formation of a mixed gneiss or migmatite, is indicated by general field relations and mineralogical transformations. From the principal mass of amphibolite in the northern part of the area there is gradual progression southward into granitic gneiss, and even in the southernmost outcrops patches of amphibolite are present with the gneiss. Near the gneiss-amphibolite boundary, the rocks are intimately mixed (pl. $5)$. The contact between amphibolite patches and the gneiss is often marked by thin streaks of biotite which formed from the amphibolite. Also, as the gneissic areas are approached, many porphyroblasts and lenticular stringers and chains of feldspar appear in the amphibolite, and the rock becomes an intermediate type between typical granitic gneiss and typical amphibolite. The limited petrographic study of the amphibolite and gneiss and field observations indicate progressive development of feldspar at the expense of hornblende and plagioclase of the amphibolite.

Although all the mineralogical changes demanded by transformation of the amphibolite into granitic gneiss by injection or gradual encroachment of granitic material are possible, some difficulty may be experienced in an attempt to apply such changes on the quantitative scale necessary for the development of the gneiss. The granitic gneiss is composed of nearly 50 percent feldspar, 40 percent quartz, and slightly less than 10 percent biotite. The feldspar is chiefly microcline and oligoclase. Generally the gneiss contains no hornblende. The amphibolite probably contains 50 to 60 percent hornblende, 30 to 35 percent feldspar, and 10 to 15 percent quartz, although the proportions of feldspar and quartz may vary considerably. The feldspar is chiefly andesine. Therefore, to convert the amphibolite into granitic gneiss would necessitate transformation of large amounts of hornblende and andesine into feldspar more sodic than andesine, and in part into potassic feldspar, and the formation of biotite from part of the hornblende. Such a change would not be particularly difficult on a small scale, since the magnesia, some of the iron, and some of the alumina of the hornblende could pass into the biotite, and any soda of the hornblende, along with the soda of the andesine, could pass into the more sodic oligoclase. Silica could be contributed to the gneiss from the quartz of the amphibolite and also from the incoming granite, and potash could be supplied by the granite. On the large scale needed, however, it seems almost certain that both iron and magnesia, and perhaps also lime, would be left over from the amphibolite and could not be accounted for in the gneiss.

An alternative explanation for the formation of the gneiss is dynamothermal metamorphism of an original mixed series of sedimentary and basic igneous rocks. Thus, the northern part of the amphibolitegneiss complex, now occupied chiefly by amphibolite, 
might have been chiefly basic igneous rocks, whereas the southern part, now occupied chiefly by granitic gneiss, might have been chiefly sedimentary rocks, and the central part, composed of mixed amphibolite and granitic gneiss, might have been the transition zone between the two original types. Sedimentary rocks similar to the Solberg schist, which lirs just north of the Six-Mile Lake amphibolite, and the East Branch arkose, still farther north in the area mapped by Clark (chapter C), might well have been converted into granitic gneiss by dynamothermal metamorphism. Indeed, the present amphibolite-granitic gneiss complex could well be the southern, more metamorphosed and injected part of the same or similar rocks as those now present to the north. Evidence that the granitic complex originally contained such a sedimentary series is indeed meager. Some areas within the amphibolite seem to contain metamorphosed sedimentary material, and one thin section of such material contains some grunerite and an unusual amount of quartz.

In view of all of the evidence, it seems most likely that the gray gneiss is a mixed gneiss formed from rocks of the Dickinson group by dynamothermal metamorphism and injection of granitic material. These rocks may have been entirely amphibolite or an alternation of amphibolite and sediments. The second possibility seems more plausible, and the gneiss would thus be the product of injection into and partial granitization of such rocks.

\section{SOUTHERN GRANITIC COMPLEX}

The area here described by the term "southern granitic complex" lies south of the Felch trough and is the north part of the "central crystalline block" of chapter B. The rocks are well exposed, and the terrain is rugged even though the relief is not more than a few hundred feet. Good exposures can be seen along State Route M-69 in secs. 1 and 2, T. 41 N., R. $28 \mathrm{~W}$., and secs. 34 and 35 , T. 42 N., R. 28 W., and also along the county road leading south from Felch.

\section{DESCRIPTION}

In approximate order of abundance, the rocks of the southern granitic complex are (1) rather massive coarse-grained granite, (2) gneissic granite and granitic rock similar to parts of the banded gray gneiss north of the Felch trough, and (3) amphibolite. The massive coarse-grained granite is the principal rock along the south border of the Felch trough for about 11 miles in Rs. 28 and $29 \mathrm{~W}$. The detailed aspect of the outcrops in secs. 31 and 32, T. $42 \mathrm{~N}$., R $29 \mathrm{~W}$. is given in plate 12 .
The massive granite ranges from red to nearly white, but most of it is pink or gray. It is generally moderately granitoid to porphyritic. In places it grades into irregular bodies of pegmatitic aspect. Locally, these bodies have sufficiently sharp contacts to be classed as dikes, but most have indefinite borders. The chief minerals of the massive granite are feldspar, quartz, and biotite; the pegmatitic rock differs mainly in containing muscovite in addition to biotite or muscovite in place of biotite.

Gneissic phases of the southern granitic complex are particularly well developed in the southern part of secs. 32 and 33, T. 42 N., R. 28 W. Much of the rock is mineralogically similar to the massive granite; the chief difference lies in the much stronger foliate and linear structure of the gneissic rock. Some, however, contains a greater proportion of dark minerals, and, in general, layers of amphibolite are more numerous than in the massive granite.

The amphibolite, a dark medium-grained rock, forms narrow septae within the granite. These are commonly 10 to 50 feet thick but range in thickness from mere stringers less than 1 foot wide to large masses that form ridges as much as 150 feet across. Many of the layers are remarkably continuous, the thicker ones extending toward the east and west for as much as a quarter of a mile, and even the thinner ones continuing for several hundred feet. However, probably all are lenticular and are cut across by the massive granite. The characteristics of the amphibolite are much the same as those of the Six-Mile Lake amphibolite except that porphyroblasts, granular texture, and gradation into gneissic material were not observed. At some places, particularly near the margin of the Felch trough that lies to the north, and along the contact with granite, the amphibolite contains considerable visible biotite.

\section{PETROGRAPHy}

The massive granite, and most of the gneissic granite, is an equigranular rock that consists chiefly of quartz and feldspar, which together make up 95 percent of the rock. The feldspar comprises orthoclase, most of which shows a peculiar mottling; microcline, as smaller clear grains; well-twinned oligoclase, which in many specimens is partly sericitized; and albite, which is not common. The quartz occurs as irregular clear grains; the amount present ranges from about 25 percent to 50 percent. Except for small amounts of accessory minerals, the rest of the rock is composed of mica, usually both biotite and muscovite. The biotite is in isolated grains, most of which show a preferred orientation, and is commonly altered in part to chlorite. Much of the muscovite occurs as a sericitic alteration of 
plagioclase and orthoclase. Accessory minerals are apatite, titanite, and zircon.

A chemical analysis of a sample of the massive granite is given in table 17. The material analyzed differs somewhat from the typical rock described above. The texture is irregular, and myrmekitic patches are common. The feldspar is chiefly microcline and oligoclase. The microcline, which appears to be the only potash feldspar, is in abundant clear grains that are a little smaller than the quartz and plagioclase grains. The oligoclase is very strongly sericitized and almost every grain is surrounded by a very narrow rim of clear albite. Both biotite and muscovite are present: the biotite is in isolated grains that are extensively altered to chlorite; the muscovite forms isolated grains as well as the sericitic alteration of oligoclase.

TABLE 17.-Chemical analysis of massive granite from the southern
granitic complex, Felch Mountain district, in Michigan

[Analyst, Leonard Shapiro, U.S. Geological Survey. Location, 3,600 ft. south, $250 \mathrm{ft}$. west of north quarter corner, sec. 31, T. 42 N., R. 28 W.]
Composition

$\mathrm{SiO}_{2} \ldots \ldots \ldots$

$\mathrm{Al}_{2} \mathrm{O}_{3} \ldots \ldots$

$\mathrm{Fe}_{2} \mathrm{O}_{3}$

$\mathrm{FeO}$

$\mathrm{MgO}$

$\mathrm{CaO}$

$\mathrm{Na}_{2} \mathrm{O}$

$\mathrm{K}_{2} \mathrm{O}$

\begin{tabular}{r|} 
Percent \\
70. 24 \\
16. 21 \\
1.09 \\
2.00 \\
.14 \\
1.30 \\
3.12 \\
5.32
\end{tabular}

Composition

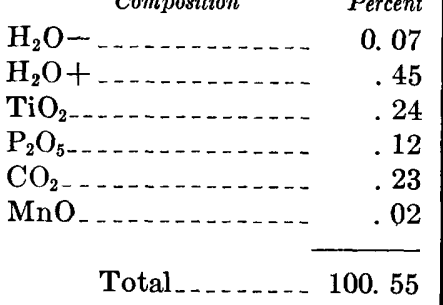

The petrographic characteristics of the amphibolite of the southern granitic complex are much like those cited for the amphibolite of the banded gray gneiss and the Six-Mile Lake amphibolite, but some is more strongly micaceous. The typical amphibolite is composed of hornblende, plagioclase, and quartz. The feldspar appears to be chiefly andesine. The accessories are titanite, apatite, and magnetite. Sericite and epidote occur as alteration products. Some of the epidote is in irregular aggregates that replace hornblende. The micaceous amphibolite differs only in that it contains moderate amounts of biotite, although hornblende still is the most abundant mineral present.

Rosiwal analyses of three specimens of the southern amphibolite were made by Roseboom (1951) and are given in table 18 .

\section{ORIGIN}

The origin of the granitic complex south of the Felch trough is rather obscure. The lenses of amphibolite of the southern area appear to be about the same as those of the northern area, but much of the granitic rock is distinctly different from the gray gneiss. Much of it is massive granite that shows only very faint foliation. This granite is rather clearly intrusive into the amphibolite and apparently was not involved in the folding of the rocks of the area. It appears, however, that the massive granite encroaches upon and cuts into a granitic gneiss or gneissic granite, or both, near the eastern cnd of the area. This granitic gneiss could well be the same as the granitic gneiss of the northern gray-gneiss complex, although the banding is less striking. Probably the lenses of amphibolite are the same as those in the gray gneiss, and the granitic gneiss and gneissic granite are part of the complex formed by the intrusion of granite into the rocks of the Dickinson group, part of it being a mixed gneiss, part of it a somewhat gneissic granite. The massive rock, then, may be postAnimikie granite that was intruded into the older granitic and gneissic complex.

TABLE 18.-Rosiwal analysis showing compositions of amphibolite from the southern granitic complex, Felch Mountain district, in Michigan

[From Roseboom (1951)]

\begin{tabular}{|c|c|c|c|}
\hline & 1 & 2 & 3 \\
\hline $\begin{array}{l}\text { Hornblende } \\
\text { Feldspar, chiefly plagioclase } \\
\text { Quartz } \\
\text { Biotite } \\
\text { Titanite } \\
\text { Magnetite }\end{array}$ & $\begin{array}{r}62.4 \\
17.1 \\
19.2 \\
1.3 \\
-1.3\end{array}$ & $\begin{array}{r}67.5 \\
14.1 \\
15.4 \\
.3 \\
2.7\end{array}$ & $\begin{array}{r}54.8 \\
11.4 \\
29.6 \\
2.1 \\
2.1 \\
\end{array}$ \\
\hline & 100.0 & 100.0 & 100.0 \\
\hline
\end{tabular}

1 Includes some feldspar.

1. $1,900 \mathrm{ft}$. south, $650 \mathrm{ft}$. west of center, sec. 31, T. 42 N., R. $28 \mathrm{~W}$.

3. $1,180 \mathrm{ft}$. south, $1,350 \mathrm{ft}$. west of center, sec. 31 , T. 42 N., R. $28 \mathrm{~W}$.

\section{MIDDLE AND UPPER PRECAMBRIAN ROCKS} CHOCOLAY GROUP

The rocks of the Chocolay group in the Felch Mountain district consist of vitreous quartzite and associated schists of the Sturgeon quartzite, and the overlying Randville dolomite.

\section{STURGEON QUARTZITE}

Subdivision of the Sturgeon quartzite into lithologic types is difficult, because most exposures are of vitreous quartzite only. However, from observation of all exposed parts of the formation, and to a very small extent from drill records, the writer has made the threefold subdivision given in table 19. The thicknesses given are merely estimates, as neither the upper nor the lower contact of the formation has been certainly established.

TABLE 19.-Subdivision of the Sturgeon quartzite into lithologic types, Felch Mountain district, in Michigan

$$
\text { Rock type Thickness } \begin{gathered}
\text { Tfeet) } \\
\text { (fich }
\end{gathered}
$$

1. Top. Feldspathic quartz-mica schist and ferruginous quartzite; locally contains considerable magnetite or specularite

2. Vitreous quartzite $\ldots$

3. Quartzose mica schist; locally grades downward into feldspathetic schist or gneiss .............. 200-300 
The two types of schist associated with the vitreous quartzite are so similar to other schists of the area that they may be easily confused where definite stratigraphic markers are absent. In general, the lower schist is quartzose and micaceous, but it is known to grade down ward into biotitic and amphibolitic schist and into feldspathic schist and gneissic rock. The upper schist is generally, though not always, feldspathic as well as micaceous.

\section{OCCURRENCE AND CHARACTERISTICS}

The vitreous quartzite is the part of the Sturgeon most generally exposed. It forms conspicuous ridges extending through secs. 7, 8, 5, and 4, T. 41 N., R. 30 W., into sec. 2, T. 41 N., R. 30 W., and sec. 35, T. 42 N., R. $30 \mathrm{~W}$., and low ridges extending through secs. 34 and 35, T. 42 N., R. 29 W. It is poorly exposed along the north side of the Felch trough, but does crop out along the east side of Michigan State Route 95 in secs. 33 and 34, T. 42 N., R. 30 W., near Randville, where it is cut by granite pegmatite. It makes very low outcrops just south of the Sturgeon River in sec. 26, T. 42 N., R. $29 \mathrm{~W}$., and in the adjoining sec. 27 ; crops out along the north side of Michigan State Route 69 in sec. $30, \mathbf{T}$. $42 \mathrm{~N}$., R. $28 \mathrm{~W}$.; and is poorly exposed beneath and adjacent to outcrops of sandstone of Cambrian age throughout secs. 34 and 26, T. 42 N., R. 29 W. Vitreous quartzite, presumably the Sturgeon, is also exposed in small outcrops that make a low ridge near the center of sec. 29 , T. 42 N., R. 28 W., where it is apparently surrounded by granitic gneiss.

The vitreous quartzite is chiefly grayish white, but some is pink to red, and locally it is characterized by greenish spots. Much of the quartzite is massive and so thoroughly recrystallized that it does not show individual grain outlines and may resemble vein quartz, but some of it shows individual grains rather clearly. Bedding, crossbedding, and ripple marks are visible in some outcrops.

The presence of feldspathic quartz-mica schist and ferruginous quartzite lying above the vitreous quartzite has been rather clearly established from outcrops along the northern side of the ridges that extend through secs. 7, 8, and 5, T. 41 N., R. $30 \mathrm{~W}$.; from outcrops in secs. 34 and 35 , T. 42 N., R. $30 \mathrm{~W}$.; and from outcrops and pits in sec. 32 , T. 42 N., R. 29 W. The exposures are usually poor and as a rule mark the last outcrops before the rock disappears beneath glacial deposits or swamp. Locally this rock contains considerable magnetite or specularite (see figs. 27-30). One of the best exposures of the magnetite-bearing type is a low outcrop along the west side of a ridge in sec. $18, T .41 \mathrm{~N}$., R. $30 \mathrm{~W}$., about 1,000 feet east of a gravel road, almost on the north boundary of sec. 18. Vegetation obscures much of the bedrock, however, and the outcrop is not easily found. Some of the quartzose mica schist with which specularite is associated is exposed by pits and trenches about 800 feet south of Michigan State Route 69 in sec. 32 , T. 42 N., R. 29 W.

The magnetite-bearing quartzite is commonly sugary textured and contains an abundance of well-crystallized minute magnetite octahedra, which are visible with a hand lens. The amount of magnetite is enough to produce moderate magnetic anomalies, which mark the position of the rock under cover. Usually some pyrite also is present. This quartzite apparently grades into micaceous quartzite or quartzose mica schist, most of which is light colored and may contain relatively large amounts of white mica, at some places in flakes an inch across.

Rock exposed in pits and trenches in sec. $32, T .42 \mathrm{~N}$., R. $29 \mathrm{~W}$., appears to be an unusual variation of this magnetite-bearing quartzite. There, streaks of specular hematite are intermingled with mottled red and white vitreous quartzite, gray quartzite, and mica schist. Generally the northernmost exposures are mica schist, considerably sheared, which at some places is characterized by muscovite flakes an inch across. Part of this material contains so much specular hematite that three shafts were sunk in it, one of which shows the width of the most ferruginous zone to be about 30 feet.

Exposures, pits, and discarded drill core in sec. 34, T. 42 N., R. 30 W., indicate that in part of the area the place of the ferruginous quartzite and quartz-mica schist may be occupied by quartzose micaceous schist that is not ferruginous. The probability of faulting and oyerturning of formations in that area makes the stratigraphic position of this schist doubtful, but it seems likely that it rests above the vitreous quartzite.

The existence of quartzose mica schist beneath the vitreous quartzite seems to be fairly well established, although the exposures are even poorer than are those of the schist above the quartzite. Its presence is shown by pits and small outcrops along the south side of a ridge just north of an old road in secs. 32 and 33, T. 42 N., R. $28 \mathrm{~W}$.; in poorly exposed outcrops and pits south of the Sturgeon River in secs. 26 and 27, T. 42 N., R. $29 \mathrm{~W}$.; in poorly exposed outcrops along an old road in the northern part of sec. 6, T. 41 N., R. 29 W.; and south of the Sturgeon River in sec. 36, T. 42 N., R. 29 $\mathrm{W}$. Most of it is a muscovite schist containing quartzose bands, and not infrequently it is stained reddish by hematite.

The exposures south of the Sturgeon River in sec. 36, T. 42 N., R. 29 W., are of special interest because of the information they may give regarding the relationship of the Sturgeon quartzite to the granite complex 
of that area. In those outcrops there are exposures of vitreous quartzite, quartzose mica schist, and granitic biotite gneiss, all of which are considerably deformed and are folded into an anticline plunging toward the east. The exposures close to the river, and toward the eastern end of the outcrops, are chiefly vitreous quartzite, whereas those toward the south and west are in part quartzite and quartzose mica schist, which gives way to outcrops of granitic biotite gneiss. The change from schist to gneiss is gradual, and hence the boundary shown on the map is somewhat arbitrary. These outcrops were noted by Smyth (Clements and Smyth, 1899 , p. 401-402), who stated:

In a locality already referred to, on the south bank of the Sturgeon, in sec. 36, T. 42 N., R. 29 W., where the Sturgeon formation is in visible contact with the Archean, the quartzite is underlain by a considerable thickness of very fissile muscovitebiotite-gneiss, which incloses rather sparingly obscure pebbles of granite and quartz. This gneiss, which no doubt was formerly an arkose rich in feldspar, has recrystallized and afterwards been sheared...

The writer was unable to find any pebbles of granite or quartz in the gneiss, or any bodies that suggested such pebbles, but more than 50 years have elapsed since Smyth's observations, and outcrops that were then partly exposed may now be covered by second-growth timber and brush. Regardless of the presence of pebbles, it seems rather clear that the gneiss underlies the quartzite. However, the granite in outcrops within 100 or 200 feet of the gneiss is almost entirely massive, as is the granite to the west in the same section and in sec. 35 adjoining, and it seems to the present writer that this granite must have been formed later than the time of deformation of the quartzite and the underlying gneiss, and that it is not the basement on which those rocks were deposited.

Near the center of secs. 35, T. 42 N., R. 29 W., on the east side of the Sturgeon River, a quartzose conglomerate closely associated with micaceous quartzite was mapped as part of the Sturgeon quartzite. The conglomerate is composed chiefly of elongated cobbles of quartzite, some of which appear cherty, that are set in a quartzitic and calcareous matrix. The stretched cobbles generally trend eastward and dip steeply to the north, although faint bedding in the associated quartzite strikes nearly north and dips gently to the east. In the larger outcrop, along the east bank of the Sturgeon River, the matrix of the conglomerate has been considerably metamorphosed. It is pinkish-white, mottled and streaked with light green, and usually shows granular quartz, little bunches of pale-green amphibole, and some carbonate. In places it consists chiefly of tremolitic amphibole and diopsidic pyroxene, some of which is an inch wide and several inches long.
The relation of this conglomerate to the surrounding rocks is not clear. The structural relations show that both the conglomerate and the nearby Randville dolomite to the west dip westward, indicating that the conglomerate lies beneath the dolomite, which is the normal position for the Sturgeon quartzite. The dolomite and the conglomerate may however, be separated by a fault that trends northward along the Sturgeon River, since dolomite along the river is considerably silicified.

The quartzite exposed in secs. 28 and 29, T. 42 N., R. $28 \mathrm{~W}$., apparently is an isolated body surrounded by the older gneiss. The exposed quartzite is chiefly vitreous, white to gray or pinkish, and commonly considerably shattered. Bedding is discernible in a few places. The dip appears to be steeply to the north. The relations of the quartzite to the adjoining gneiss are obscure. The quartzite near the gneiss contact contains much microcline and microperthite, and considerable biotite and muscovite.

\section{PETROGRAPHY}

A good account of the petrography of the vitreous part of the Sturgeon quartzite is given by Smyth (Clements and Smyth, 1899, p. 401-405), excerpts from which are given below. The present writer's examination was largely limited to those parts of the formation not described or only briefly mentioned by Smyth, specifically the material overlying and underlying the vitreous quartzite.

Vitreous quartzite.-As described by Smyth, the vitreous quartzite contains, in addition to quartz,

numerous accesories, including muscovite, biotite, chlorite, microcline, orthoclase, plagioclase, titanite, rutile, zircon, apatite, and the ores.... Among the large number of slides examined, a broad distinction can be made between those which show the effects of stress and those in which such effects are subordinate or hardly noticeable. . . . In the slides in which the effect of pressure is least apparent the microscopic characters are as follows: the background is composed of large irregular grains of quartz, the edges of which interlock with the most minute and sharp interpenetrations. The longest dimensions of these grains range from 1.5 to $6 \mathrm{~mm}$, averaging perhaps 2.5 to 3 . . . . Scattered very abundantly through these large quartz grains are the accessory minerals, some predominating in one slide, others in another, but mica and chlorite occurring in all.... The included micaceous minerals are usually in small plates, ranging from 0.05 to $0.75 \mathrm{~mm}$ in longest dimensions. ... The microcline inclusions are usually elongated in form, and frequently, particularly in the cases of the larger, have well-rounded clastic outlines. ... The periphery is frequently partly surrounded by a thin film of biotite. . . Besides microcline, both orthoclase and plagioclase are sometimes enclosed in the large quartzes, but much more sparingly. They are invariably more or less decomposed, and are sometimes surrounded partially or wholly by a film of ferruginous material. . . . [p. 402-403]

The pressure effects begin with the appearance of optical strain and decided elongation in the large quartzes of the 
groundmass. ... In the final stages, ... . the rock is made up of long, narrow lenses, each of which is an enormously strained quartz individual, separated by narrow anastomozing zones of very finely subdivided quartz. [p. 404]

Granitic biotite gneiss or schist.-Two thin sections of biotite gneiss or schist lying between the vitreous quartzite and the granite in sec. 35, T. 42 N., R. 30 W. show that this phase of the formation is composed chiefly of quartz, plagioclase, biotite, and hornblende, with accessory magnetite, apatite, and some secondary sericite, chlorite, and epidote. The feldspar, which is subordinate to the quartz, apparently is oligoclase, although some of it may be albite. Both the quartz and the feldspar are small, generally between 0.05 and 0.20 $\mathrm{mm}$, rarely as much as $0.5 \mathrm{~mm}$. Hornblende and biotite are relatively abundant, the hornblende in excess of the biotite, and some of it in poikiloblastic masses as much as $1.0 \mathrm{~mm}$ across. Some of the apatite is in small crystals profusely scattered throughout the rock, some of it is in veinlike chains $0.1 \mathrm{~mm}$ long, and some is in individual crystals that attain a length of $0.15 \mathrm{~mm}$. Part of the magnetite is in irregular areas about 0.5 by 0.3 $\mathrm{mm}$ across, and appears to replace amphibole or biotite.

Quartzose mica schist.-Little petrographic information was obtained regarding the quartzose mica schist that lies beneath the vitreous quartzite, because wherever encountered it was badly sheared and mashed. A single thin section shows that it is composed chiefly of quartz and muscovite in alternating streaks. The rock obviously has been much sheared, as the quartz is in angular and fractured masses, and the muscovite is in streaks around the quartz fragments. The rock is much stained by late hematite, which has impregnated some of the mica and formed a light-red coating on the quartz.

Ferruginous quartzite and quartz-mica schist.-Two thin sections of the ferruginous quartzite that lies above the vitreous quartzite show that the rock is composed chiefly of quartz and subordinate muscovite, throughout which magnetite is disseminated rather uniformly in small crystals, or irregularly in larger masses. Orthoclase and plagioclase are present in one of the specimens but not in the other, and tourmaline is present in both. In one, a fine-grained type, quartz and feldspar form a mosaic of individuals that generally range from 0.02 to $0.05 \mathrm{~mm}$ across, and rarely $0.1 \mathrm{~mm}$, through which is distributed sharply crystallized magnetite, usually ranging from 0.01 to $0.07 \mathrm{~mm}$ in diameter, but some grains are as large as $0.15 \mathrm{~mm}$. Almost half of the rock consists of feldspar, chiefly microcline, along with some oligoclase or albite. The feldspar is unaltered. In the other specimen, a coarse-grained type, quartz individuals about $0.1 \mathrm{~mm}$ across form a mosaic through which is scattered a few wisps and occasional larger flakes of muscovite, partly replaced by hematite along cleavage cracks and the margins of flakes. Magnetite crystals about $0.3 \mathrm{~mm}$ in diameter and masses about $2 \mathrm{~mm}$ by 1 $\mathrm{mm}$ are mixed with hematite. The magnetite and hematite appear to be replacement of some other material.

Quartz-mica schist is associated with the coarser type of ferruginous quartzite and is composed chiefly of quartz and muscovite. The quartz is about $0.2 \mathrm{~mm}$ across, and the muscovite is in straight-edged pieces about $0.3 \mathrm{~mm}$ long and $0.04 \mathrm{~mm}$ wide, arranged somewhat circularly around quartz areas, as if the mica were recrystallized from original interstitial material. A considerable amount of bluish tourmaline, in wellformed individuals $0.05 \mathrm{~mm}$ across, is scattered throughout the rock and in some places collected into aggregates of 6 or 8 crystals. Red hematite is present along all grain boundaries and also interlayered with muscovite, probably as a result of replacement of original biotite.

A thin section of schist associated with specularitebearing quartzite in sec. 32 , T. 42 N., R. 29 W., contains many rather angular particles of quartz about $0.1 \mathrm{~mm}$ across, some interstitial sericite, perhaps some carbonate, and a network of interstitial hematite interwoven with the sericite. Throughout the slide are scattered a few grains of magnetite and a few small patches of sericite which appear to indicate the former presence of feldspar.

Feldspathic quartz-mica schist.-The feldspathic quartz-mica schist apparently rests above the vitreous quartzite in sec. 34, T. 42 N., R. 30 W. The quartzite with which it is associated is described first, for comparison.

The vitreous quartzite is composed chiefly of quartz that is highly fractured and drawn out into lenticular and crescentic streaks showing ragged edges. In places, granulated quartz is present between these larger pieces. In addition to quartz, feldspar is present in lenticular particles and in some equidimensional pieces that resemble porphyroblasts. The feldspars are orthoclase, microcline and microperthite, and either oligoclase or albite. The rock contains some interstitial muscovite and is stained by hematite along fractures.

The adjacent schist varies considerably in composition, but the differences are chiefly in the relative amounts of quartz, feldspar, and mica. Some specimens are composed chiefly of quartz and some sericite or muscovite; others are about half quartz and half muscovite; others contain quartz, feldspar, and mica, which may be either muscovite, biotite, or both; and some contain nearly equal amounts of quartz and feldspar and but little mica. Almost all contain tourmaline, sometimes in relatively large amounts. Epidote, 
apatite, and magnetite are sometimes present. The feldspars, generally unaltered, are microcline, oligoclase or albite, or both of these, and probably orthoclase. Microcline commonly is the predominant feldspar present.

The texture varies from fine grained to moderately coarse grained. The quartz and feldspar are generally angular and range in size from 0.03 to $0.1 \mathrm{~mm}$, rarely $0.2 \mathrm{~mm}$. The mica is typically in flakes about 0.1 to $0.3 \mathrm{~mm}$ long and half as wide and, more rarely, $1.0 \mathrm{~mm}$ long. Many of the tourmalines are in small sharp crystals about $0.07 \mathrm{~mm}$ long, but some are as long as $0.3 \mathrm{~mm}$.

\section{RANDVILLE DOLOMTTE}

The Randville dolomite consists chiefly of relatively coarse grained dolomite. The formation appears to be about 500 feet thick. In some outcrops, schist is exposed above or below the dolomite, and in a few it appears to be interbedded with it. Some of this schist may be a part of the Randville dolomite, but the writer has limited that formation to the massive dolomite and any schist definitely interbedded with it. Probably the dolomite is separated from the underlying vitreous quartzite of the Sturgeon quartzite in most places by schist, but schist may be completely lacking in some part of the area, because in sec. $26, \mathrm{~T} .42 \mathrm{~N}$., R. $28 \mathrm{~W}$., close to outcrops of vitreous quartzite, are a few outcrops that appear to be dolomitic quartzite containing some tremolite, and these may indicate direct gradation of vitreous quartzite into dolomite, without intervening material from which schist would have formed.

\section{OCCURRENCE AND CHARACTERISTICS}

The Randville dolomite is exposed in a series of discontinuous outcrops which form a ridge that extends throughout parts of secs. 34,35 , and 36, T. 42 N., R. $30 \mathrm{~W}$, in a shorter ridge in the southern part of secs. 35 and 36 of the same township and range, and in scattered outcrops throughout sec. 35, T. 42 N., R. 29 W., and secs. 32,33 , and 26 , T. 42 N., R. 28 W. The dolomite is also well exposed in a large abandoned quarry in sec. 34, T. 42 N., R. 29 W., a mile east of Randville, in a small active quarry a short distance farther east, and in the large Metronite quarry in sec. 26, T. 42 N., R. 28 W.

Most of the exposed dolomite is nearly white, moderately to coarsely crystalline, and tremolitic. The tremolite is white, gray, or light green. It is present in layers which probably mark the position of bedding, in bunches, or as more or less isolated crystals. Locally, tremolite crystals are nearly an inch across and several inches long. In addition to tremolite, or in its place, some outcrops show nearly white to green pyroxene crystals that are as much as an inch across and several inches long, actinolitic or anthophyllitic amphibole, phlogopite, serpentine, pyrrhotite, pyrite, and very rarely small amounts of chalcopyrite. Serpentine is characteristically developed in moderate amounts in the vicinity of granite pegmatite dikes. In places it forms a zone a few inches to several feet wide along the margins of dikes and has replaced the silicates, which clearly were formed before the intrusion of the dike. Pyrite and pyrrhotite also appear to be concentrated near dikes, and in some places the pyrite has replaced and cut across tremolite.

Some rather dolomitic schist, associated with the dolomite, probably is a part of the Randville dolomite, and has been so mapped. This dolomitic schist is known chiefly from pits close to Michigan State Route 69 in the western part of sec. 35, T. 42 N., R. 29 W., and pits associated with dolomite outcrops in the west-central part of the same section. Other schist, which is quartzose and chloritic, is exposed in outcrops associated with dolomite along the east side of the Sturgeon River south of Michigan State Route 69 and just east of the bridge across the river, in sec. 35, T. 42 N., R. 29 W., and also farther south on the west side of the river; and in the extreme western end of a ridge of dolomite south of Michigan State Route 69 in the western part of sec. 32 , T. 42 N., R. 28 W.

The dolomitic schist is gray to pink, commonly mottled with dark gray and red. Generally it shows cleavage faces of dolomite about 0.03 inch across, but some of the material is much more finely crystalline and appears to be micaceous. Pieces from pits indicate that it is thinly bedded. Minute pyrite crystals are present in some of the dolomitic material, and their decomposition produces a ferruginous coating on weathered rock. Under a hand lens, most of the dolomitic schist shows no silicates, but some of it shows scattered tremolite crystals 0.1 inch across.

At some places the dolomite has been silicified, and at one place it has been partly replaced by iron oxide. The principal exposures of silicified dolomite are along the Sturgeon River in sec. 35, T. 42 N., R. 29 W., particularly on the west side of the river; and along an old road near the center of sec. 32, T. 42 N., R. $28 \mathrm{~W}$. The exposures of dolomite partly replaced by iron oxide are near the center of sec. $32, \mathrm{~T} .42 \mathrm{~N}$., R. $28 \mathrm{~W}$., in a structurally complex area where the rocks are partly overlain by sandstone of Cambrian age.

The silicified dolomite commonly is quartzitic in appearance. At some places considerable bluish-green to blackish chlorite is associated with it and the 
associated, less silicified, dolomite. The silicified dolomite appears to be present only adjacent to zones of faulting and brecciation.

Some outcrops show partial replacement of the dolomite by iron oxide. Some of the rock is lightbrown crystalline dolomite containing irregular areas of very dark brown to nearly black limonite or goethite, some of which shows radial structure. These areas are from a few millimeters to 20 or 30 millimeters across and are separated by streaks of light carbonate, some of which is pink. The rock as a whole has a brecciated appearance. Elsewhere, the material is reddish crystalline dolomite, spotted with brown limonite and gray to white carbonate, or it is white coarsely crystalline dolomite streaked and mottled with red, iron-stained dolomite and with black hematite formed by replacement of dolomite. The replacement in this area seems to be related to the surface of unconformity between the Precambrian and the overlying Cambrian rocks.

\section{PETROGRAPHY}

Normal dolomite-The normal dolomite is rather coarsely crystalline and contains, in addition to dolomite and calcite, abundant tremolite, either as fibrous and radiating crystals, as rather broad individuals, or in poikiloblastic masses. It may be sparingly present or may compose almost the entire slide.

Although tremolite is the most common silicate, and usually the most abundant, some slides contain amphiboles that are probably intermediate in composition between tremolite and actinolite, and some probably contain anthophyllite. Diopside is relatively abundant in some slides, and phlogopite is present in many. Minor constituents are pyrite, pyrrhotite, quartz, and chlorite. Serpentine (antigorite) has partly replaced both tremolite and diopside, and pyrrhotite and pyrite have partly replaced some of the silicates. Some quartz appears to have been introduced by granite pegmatites and contains minutely disseminated pyrite. Also, some quartz and chlorite was formed later than the general metamorphism, by hydrothermal action.

Silicified dolomite-The silicification of the dolomite is well shown in exposures on the east side of the Sturgeon River south of Michigan State Route 69 in sec. 35, T. 42 N., R. 29 W.; from the western part of the same section; and from exposures near an old road in sec. 32, T. 42 N., R. 28 W. Specimens from these localities show similar features. The less altered rock may be composed either of alternating light bands of carbonate with some quartz, and darker bands of quartz and chlorite along with with some carbonate and mica-muscovite, phlogopite, and possibly biotiteor of carbonate containing scattered chlorite flakes and quartz. Some specimens contain tremolite, and apatite is present in varying amount.

In those types not showing banding, the quartz is in small patches, streaks, and fingerlike stringers that project into the carbonate. In more advanced stages of replacement, the carbonate is riddled with quartz veinlets, or forms residual patches more or less surrounded by quartz. These patches are progressively smaller in more advanced stages of replacement, until finally only tiny particles of carbonate remain throughout the quartz. The final product resembles quartzite, but the quartz is peculiarly dusty and lusterless in appearance, and the texture of the dolomite is faithfully preserved. Tremolite also is present in some slides, some of it in poikiloblastic crystals enclosing carbonate. In some crystals the carbonate has been replaced, but the tremolite also appears to have been attacked, and some of it seems to have been entirely replaced, leaving "ghosts" that show the outlines of crystals, or the traces of cleavage cracks.

Two other features of these rocks deserve attention. In nearly all specimens the silicification appears to have been accompanied by the introduction of chlorite, and followed by the introduction of hematite in some, although the hematite introduction may well have been much later than the other changes. Two chlorites are commonly present, the one nonpleochroic, showing negative elongation and birefringence about 0.005 to 0.006 , the other pleochroic in pale blue or bluish green, showing positive elongation and birefringence about 0.013 to 0.015 .

The evidence for introduction of chlorite is not as clear as is that for introduction of quartz, but the chlorite is closely associated with the quartz, and the chlorite has partially replaced calcite along grain boundaries. The presence of chlorite and tremolite together in slides certainly indicates that chlorite and tremolite together in slides certainly indicates that chlorite was formed later than tremolite, because it represents a lower grade of metamorphism. There is some evidence that the chlorite may have been introduced slightly before quartz, as some of the chlorite itself appears to have undergone a very small amount of silicification.

After silicification and introduction of chlorite, iron oxide solutions penetrated the rock and impregnated and partly replaced some of the chlorite and some of the residual carbonate spots left in the quartz, and 
formed rims around some of the quartz. The replacement of the chlorite and carbonate started along the margins of particles and in cleavage cracks, and proceeded inward.

Iron oxide replacement.-In the $\mathrm{NW}^{1 / 4}$ sec. $32, \mathrm{~T}$. 42 N., R. 28 W., south of Michigan State Route 69 and north of an old east-west road and outcrops of silicified dolomite, the Randville dolomite has been partly replaced by iron oxide, in part limonite or goethite, in part hematite. Some of the dolomite appears brecciated, and some of it is red to white and coarsely crystalline.

The brecciated dolomite contains much secondary carbonate showing agatelike structure, which grades into limonite-impregnated areas and finally into cores of limonite. Along the margins of some of the dark limonitic areas, there are slender crystals that appear to be goethite. Also associated with the limonitic areas are a few scattered crystals of a mineral that shows rectangular, somewhat barrel-shaped outlines. Other crystals, which seem to be of the same mineral, appear to be hexagonal. This mineral shows parallel extinction, birefringerence about 0.004 to 0.006 , high indices of refraction (slightly greater than the carbonate), and negative elongation. This mineral was not positively identified, but it appears to be dahllite, $3 \mathrm{Ca}_{3}$ $\left(\mathrm{PO}_{4}\right)_{2} \cdot \mathrm{CaCO}_{3}$. The presence of dahllite along with secondary iron oxide would not be surprising, since a considerable amount of apatite is present in many of the rocks of the area and could well supply the source for a secondary phosphate of this composition.

The reddish crystalline dolomite is composed of carbonate, much of which is secondary, and shows zoned rhombs in which iron oxide zones alternate with carbonate. The carbonate in places is partly replaced or heavily impregnated with limonite. The replacement proceeded first by impregnation along cleavage cracks and subsequently by irregular engulfment of the carbonate.

Another thin section shows coarsely crystalline dolomite in individuals 0.5 to $1.5 \mathrm{~mm}$ across, some of which were replaced directly by hematite, and others apparently were replaced first by quartz, which was later replaced by hematite. Although hematite replaced carbonate directly in unsilicified areas, the major replacement by hematite took place in the areas of prior replacement by quartz. It may be that this preferential replacement actually followed areas of incomplete silicification and was in reality replacement of carbonate residuals left in the quartz. The coarse crystallization of the dolomite, the presence of tremolite in outcrops, and the complex structure and faulting in the immediate area, indicate that partial silicification of the dolomite was followed by iron oxide replacement, and that both of these processes took place later than the principal period of metamorphism.

Schists associated with the dolomite-The schist here described appears to form the lower part of the formation, near the base, and possibly may properly belong to the Sturgeon quartzite. The six thin sections studied show considerable variation, but a few things are common to nearly all. All slides show that the schist contains angular quartz, either as disseminated particles or in layers. Much of this quartz ranges from 0.03 to $0.1 \mathrm{~mm}$ in diameter, but in some layers it is as much as $0.5 \mathrm{~mm}$ across. The quartz particles are separated from one another by mica, and in some slides they are widely separated. Half of the slides contain feldspar, chiefly microcline but some plagioclase, of about the same size as the average quartz grain. Some contain brown mica, either phlogopite or biotite, intergrown in parallel position with muscovite. Tourmaline is present in crystals ranging in length from 0.01 to $0.04 \mathrm{~mm}$ in some slides, and attaining a length of 0.3 $\mathrm{mm}$ in others. Rarely, poikiloblastic garnets $2.0 \mathrm{~mm}$ across are present, some of which are almost completely altered to sericite and chlorite.

A peculiar feature in all slides are large irregular to lenticular areas of muscovite that are generally oriented obliquely to the foliation of the schist, and about which, in some slides, smaller mica is bent. These areas range in size from 0.3 by $0.5 \mathrm{~mm}$ to 0.6 by $2.0 \mathrm{~mm}$. Some of them appear to have been formed by replacement of feldspar, and even quartz, and others by replacement of garnet or some other poikiloblastic mineral. A few show indefinite central areas that resemble carbonate.

\section{MENOMINEE GROUP}

The formations included in the Menominee group are the Felch formation and the Vulcan iron-formation. The basal formation - the Felch formation-probably is separated from the Randville dolomite by a slight unconformity or disconformity, largely on the basis of the lithologic contrast between the two formations and because an unconformity is known to be present in other parts of the region. The Vulcan ironformation, which forms the upper part of the Menominee group, is the youngest of the precambrian sedimentary units in the Felch trough; strata of the overlying Baraga group are not preserved. 
The succession within the Menominee group is shown by table 20 .

TABLE 20.-Stratigraphic table of the Menominee group, Felch Mountain district, in Michigan

Formation

Estimated thickness
(feet)

Vulcan iron-formation.

$300-500$

Felch formation (includes four correlative schists):

1. Garnet-grunerite-magnetite schist

2. Quartzitic mica schist, containing quartzite bands and interbedded quartzite

3. Ferruginous quartz-mica schist and quartzite

4. Feldspathic quartz-mica schist

Total Felch formation

20-200

\section{FELCH FORMATION}

The Felch formation, originally designated the Mansfield schist by Smyth (Clements and Smyth, 1899, p. 411-412), was described as a persistent schist, known chiefly from test pits and drill holes, that occupied the interval between the Randville dolomite and the Vulcan (then Groveland) iron-formation. Smyth (p. 412-415) stated that this schist was very uniform, and that most specimens were fine-grained mica schists, either light or dark in color, depending on the predominance of muscovite or biotite. Locally, however, the schists were said to contain abundant garnet and, near the contact with the overlying ironformation, to become more siliceous and more ferruginous and to show a distinct passage into iron-formation. Smyth's microscopic descriptions indicate that he included many types of schist in the general name Felch schist. These schists present a very confusing picture unless they were formed contemporaneously in different parts of the area, since at some places each one of four different types apparently immediately underlies and grades up into the Vulcan iron-formation. These four types are designated (1) garnetgrunerite schist; (2) quartzitic mica schist, which contains thin layers of quartzite; (3) ferruginous quartz-mica schist; and (4) feldspathic quartz-mica schist. All are considered part of the Felch formation, which is defined simply as the strata lying between the Randville dolomite and the Vulcan iron-formation. The thickness of these strata differs as much as the lithology: in some places the formation may be no more than 20 feet thick, yet elsewhere it appears to be as much as 200 feet.

A typical section of the material lying between the Vulcan iron-formation and the Randville dolomite, as cut in a drill hole in sec. 34, T. 42 N., R. 30 W., is as follows:
Dark micaceous to quartzose rock; in part massive, in part well bedded with some layers rich in garnet, grunerite, and magnetite, others mostly granular quartz and magnetite. Gradational into overlying Vulcan iron-formation ........................

Schist, micaceous, gray to greenish gray. In thin section: mostly a granular aggregate of quartz and clean feldspar, both microcline and plagioclase, and abundant biotite and minor muscovite

Amphibolite. In thin section, mainly green hornblende, andesine, and reddish-brown biotite. Locally considerably altered to sericite and chlorite...........

Schist, similar to that above the amphibolite. Locally garnetiferous

The association of schist with amphibolite, which presumably is a metamorphosed sill, is a characteristic one throughout the area. Similar amphibolite, mapped separately, is present with the schist in sec. 33, T. 42 N., R. 28 W., and at several other localities amphibolite has been included within the Felch formation.

The considerable range in lithology and thickness of the Felch formation may well result from unconformable relations between the Felch and the underlying Randville dolomite. Irregularity of surface could easily cause deposition of Vulcan iron-formation almost directly on the Randville dolomite at high places on such a surface, and earlier deposition of clastic material in low places. Further, lateral changes of deposition might well account for the various types of schist that underlie the iron-formation.

\section{GARNET-GRUNERITE SCHIST}

The garnet-grunerite schist (see figs. $35,37,38$ ) is the most distinctive rock in the Felch formation. It is well exposed near the SW cor. sec. 5, T. 41 N., R. $30 \mathrm{~W}$., and is present in smaller outcrops in the westcentral part of sec. 36, T. 42 N., R. 30 W., and in the southeastern part of sec. 33, T. 42 N., R. 28 W. At each of these places it is associated with amphibolite which apparently represents metamorphosed basic sills within the schist.

The garnet-grunerite schist is greenish gray to brown. In part it is thin bedded, but the bedding is inconspicuous except on weathered surfaces and some joint faces. The material varies considerably, even in a single outcrop. Some is very micaceous and contains many garnets, which are as much as an inch across (fig. 35); other parts are finer grained and appear to consist chiefly of grayish-green or brownishgreen fibrous and radiating grunerite and fine-grained magnetite, usually accompanied by some dark-red to nearly black garnet. Such material often weathers brown to red, as a result of oxidation of the grunerite. 
Other exposures show chiefly fine-grained black mica, which may be accompanied by small garnets.

Some of the schist has been considerably altered. This alteration is rarely shown in outcrops but is well shown by some drill cores, especially where the schist is covered by sandstone of Cambrian age or is near faults. Much of the material is a soft red ferruginous rock that appears sericitic or kaolinitic and through which are distributed soft reddish spots resembling garnets. In a number of drill holes this type of material grades into progressively less altered rock and finally into the common type of garnetiferous schist.

The amphibolite associated with the schist appears in part to be sharply interbedded with the schist and in part to show gradational and lenticular relations with it.

In thin section the garnet-grunerite schist (figs. 37, 38) shows considerable diversity in mineralogic composition and in texture. Amphibole of some type, biotite or a similar mica, garnet, magnetite, and quartz are the most characteristic constituents. Tourmaline and orthoclase are much less common. Chlorite is not infrequently present as an alteration of some of the amphiboles, biotite, or garnet. At least four different amphiboles are present, but not always in the same thin section. These are grunerite, cummingtonite, anthophyllite, and hornblende. Almost certainly, amphiboles intermediate in composition between some of these types are also present.

Some specimens are composed of large rosettes or sheaves of amphibole scattered through a mass of small, interlocking quartz, along with biotite, some garnet, and some poikiloblastic crystals of amphibole. The amphibole in the rosettes and sheaves is rather fibrous, and is both pleochroic and nonpleochroic, changing in character throughout the length of a single crystal or mass of fiber. The nonpleochroic amphibole is either grunerite or cummingtonite and shows extinction of about $15^{\circ}$, whereas the pleochroic amphibole appears to be hornblende showing extinction of about $20^{\circ}$. Other specimens are somewhat similar, but the amphibole in the sheaves is entirely grunerite; much garnet and magnetite are present, and quartz is practically absent. The grunerite grains of some of these sheaves are as much as $1.0 \mathrm{~mm}$ long, and some garnets are $1.0 \mathrm{~mm}$ or more across and characteristically enclose grunerite. Other slides are composed to a very large extent of garnet, between and within which there is grunerite. The garnets are rounded masses and are so distributed that the rock appears to be composed of large grains around which grunerite and quartz are packed. Irregular grains of magnetite are scattered throughout all the other minerals. Again, some thin sections show chiefly biotite, quartz, and some feldspar, and a few poikiloblastic garnets, throughout which magnetite grains are irregularly scattered.

The garnets, like the amphiboles, show considerable diversity in their occurence. Some garnets are round to elliptical, others are greatly distorted, and still others are very sharply crystallized and regular. Some are scattered generally throughout the slides, others occur in chains and clusters and form lenses and bands. Many are poikiloblastic and enclose quartz, grunerite, biotite, magnetite, or all these minerals. Some show a very dusty appearance because of profusely disseminated fine-grained magnetite, and others show zones of magnetite within the garnet crystals.

Veins of several types cut the schist. These include those composed of (1) quartz; (2) quartz, pyrite, and a partial selvage of chlorite and sericite; (3) partly sericitized feldspar (orthoclase and minor plagioclase) and some epidote; and (4) chlorite.

\section{QUARTZITIC MICA SCHIST}

The material designated quartzitic mica schist is known only from test pits and drill holes near the center of sec. 5, T. 41 N., R. $30 \mathrm{~W}$. The rock from the pits is dark to light gray and is composed of alternating micaceous and quartzitic layers. Many of the quartzitic layers are but 0.05 inch thick, but some of them attain a thickness of $0.2 \mathrm{inch}$, and drilling shows that some layers are considerably thicker. Well-rounded quartz grains are conspicuous in some of the thicker layers, and in some respects the rock resembles the quartzite that lies immediately beneath the Traders member of the Vulcan iron-formation in the Menominee range.

In thin section the quartzitic mica schist is composed of biotite and muscovite oriented in parallel position, and scattered rather widely separated quartz grains that are chiefly angular but elongate parallel to the orientation of the mica, and that are usually no larger than $0.1 \mathrm{~mm}$. This material contains layers of coarser quartz, and here and there throughout the slide are still larger, lenticular quartz areas around which mica is bent. Some of these large quartz areas are single grains of quartz, but others are quartzite, recrystallized chert, or vein quartz. Minor constituents are tourmaline, apatite, and epidote.

\section{FERRUGINOUS QUARTZ-MICA SCHIST AND QUARTZITE}

The material designated ferruginous quartz-mica schist and quartzite is known only from outcrops south of the Groveland mine in sec. 31 , T. 42 N., R. 30 W. 
These outcrops are very close to the Vulcan iron-formation, but the contact may be a fault.

The material exposed in outcrops and pits is chiefly of two types, one of which is quartzitic, and the other schistose. The more common quartzitic rock is gray to slightly reddish; it contains many minute octahedra of magnetite and characteristically displays a sandy irregular surface on weathering. Less common is a reddish to grayish medium-grained quartzite that shows a few small magnetite crystals. The schistose rock is generally crenulated, ferruginous, and micaceous. It is layered red and white and contains abundant small flakes of muscovite and, at some places, irregular areas resembling altered garnets.

Petrographic examination shows the ferruginous quartz-mica schist (fig. 36) to be composed chiefly of quartz, which is of rather uniform size throughout the entire slide or is in alternating bands of fine and coarse material. The grains of the finer bands are about 0.05 $\mathrm{mm}$ across, those of the coarser bands about $0.3 \mathrm{~mm}$ across, although some grains are as large as $0.8 \mathrm{~mm}$. Muscovite and some sericite are present interstitially, and some of the muscovite is in small nests. Magnetite is present in well-formed octahedra, in irregular to roughly recrystallized grains, in elongate pieces resembling mica, and in irregular interstitial masses. Some of the elongate pieces may be the edges of plates of specularite. Much of the quartz is considerably stained by red to brown iron oxide and appears to be partly replaced by it. In some slides considerable tourmaline is present, minute crystals usually about 0.05 mm long.

Mica schist associated with this ferruginous quartzmica schist is composed chiefly of mica, with subordinate quartz scattered throughout; or a very considerable amount of quartz; or alternating bands rich in mica and in quartz. The mica is both muscovite and biotite, the former predominating. Well-crystallized tourmaline and apatite are usually present. Red and brown iron oxide has impregnated and partly replaced some of the mica, especially the biotite.

\section{FELDSPATHIC QUARTZ-MICA SCHIST}

The feldspathic quartz-mica schist is so similar to the schist that rests upon the vitreous quartzite of the Sturgeon that the two cannot be separated without definite field relations. Unfortunately, either of these schists may be in contact with the Randville dolomite, the one above it, the other below. Hence, only where the schist lies directly beneath the Vulcan iron-formation, without faulting between, or can be shown to rest on top of the Randville dolomite, is its stratigraphic identity certain.
The feldspathic quartz-mica schist differs chiefly from the more common micaceous rocks of the Felch formation in containing abundant feldspar. A typical thin section of the rock shows it to be an interlocking mosaic of quartz, clear microcline and plagioclase, and sericitized orthoclase(?), with interspersed flakes of biotite and, less commonly, muscovite.

\section{VULCAN IRON-FORMATION}

The Vulcan iron-formation is described in chapter $B$ of this report. Since most of the Vulcan iron-formation occurs in the Felch trough, this description is largely applicable. Hence, the material here is limited chiefly to distribution and a few points not previously covered.

The distribution of the Vulcan iron-formation has been rather definitely established from outcrops, magnetic anomalies, and drilling. The rock is well exposed in two ridges along the north side of the trough. One of these, in which the Groveland mine was opened, extends through secs. 31 and 36, T. 42 N., Rs. 29 and 30 W., just north of Michigan State Route 69, and the other, which forms Felch Mountain, extends through secs. 32 and 33, T. 42 N., R. 28 W., also just north of the same highway.

The exposed iron-formation is gray and relatively thin bedded. Characteristically it is composed chiefly of magnetite and granular quartz but it may contain, also, thin seams of grunerite, seams and pockets of specularite, and granules and layers of red, purple, and yellowish-brown jasper. Some is composed chiefly of fine-grained specularite and jasper, and some contains rounded grains of detrital quartz. Locally, as in some of the northern outcrops in secs. 32 and $33, T .42$ N., R. $28 \mathrm{~W}$., near the junction of those two sections, the ironformation contains a considerable amount of carbonate that apparently is primary. This carbonate-bearing type of iron-formation in places contains bright redjasper granules and a considerable amount of specularite, partly distributed throughout the formation and partly as thin veins that cut it.

\section{PETROGRAPHY}

The Vulcan iron-formation is generally composed of interlocking quartz with scattered or interbanded layered magnetite and some specularite. (See figs. 43-48, and 85-87.) Either quartz, magnetite, or specularite may predominate. The quartz grains range from less than $0.05 \mathrm{~mm}$ to as much as $0.5 \mathrm{~mm}$. Individual magnetite crystals range from extremely minute ones less than $0.01 \mathrm{~mm}$ across, to those $0.5 \mathrm{~mm}$ or more in diameter, but some magnetite is in much larger masses. Some slides show large flat plates of specularite, or the thin edges of such plates. Others show magnetite or specularite in parallel elongate crystals, some of 
which may be merely the edges of specularite oriented in parallel position, but some of which may be replacement of biotite or grunerite.

Considerable variation from this more usual type of iron-formation is shown by some slides. Some contain grunerite in poikiloblastic aggregates that enclose carbonate, quartz, and magnetite; others contain hornblendic or actinolitic amphibole. Phlogopite associated with carbonate, and epidote (zoisite), apatite, garnet, and tourmaline are present in some slides.

Some types show distinct bedding. In one slide the layers are composed of (1) mosaic quartz; (2) quartz, much grunerite, mica, and magnetite; (3) garnet and some biotite, quartz and minute magnetite grains enclosed in the garnet; (4) much biotite, some quartz, garnet, and scattered magnetite; and (5) chiefly apatite. Considerable tourmaline and muscovite are present, as well as a pleochroic mica in plates as much as $1.0 \mathrm{~mm}$ across, the pleochroism being in shades of green and brown, somewhat mottled. Other slides are composed chiefly of an interwoven mat of unoriented grunerite, scattered through which are magnetite, some quartz, anthophyllite, and in some cases garnet, pyrite, and pyrrhotite.

Some slides show rounded, rather elliptical quartz grains scattered through a matrix of angular to interlocking quartz. Some of these grains are quartzite, recrystallized chert, or vein quartz. The long diameter of the quartz grains ranges from 0.5 to $1.3 \mathrm{~mm}$, the short diameter from 0.4 to $0.7 \mathrm{~mm}$. The interlocking quartz is much smaller ( 0.05 to $0.2 \mathrm{~mm}$ across), and probably is recrystallized chert. These slides contain, also, magnetite, specularite, or both, as well as some chlorite and sericite.

The carbonate-bearing type of iron-formation contains either calcite or dolomite, magnetite or specularite, varying amounts of quartz, and may also contain some amphibole. One specimen shows bedding; some layers are chiefly carbonate containing some scattered magnetite crystals, and others are carbonate, magnetite, amphibole, mica and very subordinate quartz. The amphibole is nonpleochroic and shows moderate birefringence and an extinction angle of about $17^{\circ}$. The mica is colorless. The greatest concentration of magnetite is in those layers that contain the most amphibole. The magnetite is in individual crystals 0.01 to $0.1 \mathrm{~mm}$ across, but also in chains of crystals that extend the entire length of the slide.

The oolitic type of iron-formation has been rather fully described and discussed by James in Chapter B, and therefore petrographic description of it is omitted here.

\section{DIKES AND SMALI INTRUSIONS}

The strata of the Chocolay and Menominee groups, as well as rocks of older age, are cut by dikes and sills of (1) metadiabase, (2) granite and granite pegmatite, and (3) diabase. The metadiabase is both the oldest and the most abundant of the three types, and the diabase is the youngest and least abundant. The metadiabase and the granite and granite pegmatite are upper Middle Precambrian and the diabase is presumably Keweenawan.

\section{METADIABASE (AMPHIBOLITE)}

The metadiabase is lithologically very similar to the amphibolites of Lower Precambrian age and has been distinguished on the maps only where it cuts Animikie strata. The largest mass forms large outcrops in and adjacent to the town of Felch. It apparently is part of a thick sill that has been intruded into the Vulcan ironformation and has been preserved only within the heart of the syncline that contains the iron-formation. A small mass that cuts the Sturgeon quartzite is exposed at several places in sec. 8, T. 41 N., R. 30 W. The most common occurrence of the metadiabase, however, is in association with the Felch formation. Most of this metadiabase is in small bodies that have not, except for the sill in the SEr/4 sec. 33, T. 42 N., R. 28 W., been mapped separately from the Felch formation.

The metadiabase is a dark medium-grained rock. Most of it is massive, but some of the smaller bodies and the margins of the larger bodies are schistose. A few, such as a sill exposed near the E1/4 sec. 36, T. 42 N., R. 30 W., and included within the Felch formation on the map, show relict porphyritic texture, but the original pyroxene phenocrysts are entirely altered to metamorphic minerals.

The principal minerals of the amphibolite are hornblende and plagioclase; other common constituents are quartz, biotite, titanite, magnetite, apatite, epidote, and tourmaline. Of these subordinate minerals, titanite is one of the most persistent, though quartz and biotite are more abundant in some slides. The hornblende is green or bluish green. In some slides it shows preferred orientation, but more commonly it is oriented at random. The plagioclase is chiefly andesine; most of it is untwinned. Titanite forms single crystals ranging in size from minute ones to some $1.0 \mathrm{~mm}$ long. Characteristically, the titanite is aggregated in chains and lenticular masses. Epidote occurs as an alteration of hornblende and commonly is associated with sericite. Epidote is also present in narrow veins accompanied by sericite and muscovite. Other veins are composed of quartz, feldspar, and sericite. 
GRANITE PEGMATITE AND GRANITE

The granite pegmatite, and some granite, is best exposed and probably most abundant as dikes in the northern gray gneiss, the Six-Mile Lake amphibolite, and the Solberg schist. It occurs as dikes ranging in width from an inch or less to as much as 300 feet, although most widths are between 5 and 20 feet. A narrow dike is shown in figure 66. Rarely can the dikes be followed for more than a few hundred feet, and some appear merely as irregular, almost equidimensional, bodies. Although most of them cut sharply across the foliation and lineation of the gneiss and the amphibolite, some parallel that direction. When examined in detail, many of them are seen to change course, branch, and in places form almost a network of small dikes. Commonly, when one dike is traced along its trend, it will be found to narrow, perhaps break into several stringers, disappear from the outcrop surface, and then reappear as small patches and stringers within 20 or more feet ( $\mathrm{pl} .5$ ). In many places the impression is gained that the exposed pegmatite probably is near the uppermost extremity of a dike, and that deeper erosion would expose much wider and more persistent masses. Indeed, it seems likely that some of the wider dikes and irregular masses may be more deeply eroded bodies.

Most of the dikes are pink to red on fresh breaks and light gray to nearly white on weathered surfaces. Feldspar, quartz, and mica are the most conspicuous minerals, and locally black tourmaline is abundant. Garnet is rare and beryl still more so, but they are present in some areas. The texture is varied: locally the rock is a graphic granite of different degrees of coarseness, in other places it is a relatively coarsegrained pegmatite, and ahmost any combination of textures of these types can be found. In the coarsest grained pegmatites the feldspar crystals are several feet in length, the mica plates occur in pockets and books 6 inches or more across, and the tourmaline crystals are several inches long and an inch across. Some of the dikes in gneiss show a faint foliation having the same orientation as that of foliation in the enclosing rock.

Well-defined granite and pegmatite dikes are rare in the granitic area south of the Felch trough. Most are small, from a few inches to a few feet wide and less than 100 feet long, but a few are 20 feet wide and several hundred feet long, and some in the northeast part of sec. 2 , T. 41 N., R. 28 W., are masses 300 to 400 feet across. Irregular pegmatitic bodies are exposed in some of the massive granite throughout the southern area, but characteristically these have no sharp boundaries and appear to grade imperceptibly into the surrounding granite.
Many small pegmatite and granite dikes cut the metasedimentary rocks of the Felch trough. Most are from a few inches to 30 feet wide. They commonly trend north and cut sharply across the trend of the sedimentary rocks, although some of them parallel that trend, and others follow irregular courses. Some of the better exposed and more accessible of these dikes may be seen cutting the Sturgeon quartzite along the east side of Michigan State Route 95 in sec. 33, T. 42 N., R. 30 W., close to the junction with Michigan State Route 69 ; cutting the Randville dolomite in a small quarry just north of the road in sec. 35, T. 42 N., R. $30 \mathrm{~W}$., and at the Metronite quarry in sec. 26, T. 42 N., R. $28 \mathrm{~W}$. (fig. 67) ; and cutting the Vulcan iron-formation in the ridge north of Michigan State Route 69 near the schoolhouse in sec. 32, T. 42 N., R. 28 W., and at the Groveland mine. These dikes cut all Animikie formations and were encountered in many drill holes.

Pegmatite is closely associated with fine-grained granite in a few places. The largest and most accessible outcrop is about 700 feet west of county road 581 in the north-central part of sec. 29 , T. 42 N., R. 28 W. (pl. 5). The relationship of this granite to the pegmatite is not clearly shown, but in at least one outcrop it appears to grade into the pegmatite.

\section{PETROGRAPHY OF THE GRANITE PEgMatite}

Thin sections of the granite pegmatite dikes show a general similarity. Nearly 90 percent of the rock consists of feldspar and quartz, the feldspar being about twice as abundant as the quartz. The feldspars are microcline and microperthite, and plagioclase. The plagioclase is either oligoclase or albite. Muscovite is typically more common and abundant than biotite, and mica generally constitutes not more than 5 percent of the total mineral composition.

Accessory minerals noted are apatite, tourmaline, garnet, magnetite, and perhaps zircon, rutile, and ilmenite partly altered to leucoxene. Apatite is generally present and usually is the most abundant accessory mineral. It ranges in size from minute crystals to those $0.4 \mathrm{~mm}$ long and $0.15 \mathrm{~mm}$ across. Tourmaline is relatively rare in the slides examined, but in some slides is present in crystals as much as $0.3 \mathrm{~mm}$ long.

Alteration and secondary products noted are sericite, chlorite, epidote, and calcite. Sericite, the most abundant of these, is present in orthoclase and plagioclase, and is particuarly abundant in the centers of some orthoclase crystals.

In a few unusual pegmatitic dikes that cut the Sturgeon quartzite in sec. 35, T. 42 N., R. 29 W., most of the plagioclase is complexly twinned andesine $\mathrm{AN}_{30-35}$ that is gradationally zoned outward to oligoclase. 
The texture of the pegmatite shows considerable irregularity, as might be expected. Some slides show large crystals, either orthoclase or plagioclase, with other minerals packed around them; others show microcline and microperthite crystals varying in length from 0.1 to $2.0 \mathrm{~mm}$ and making up most of the feldspar of the slide; still others show nests and plates of muscovite that has partly replaced feldspar; and many of them show myrmekitic intergrowths.

PETROGRAPHY OF THE FINE-GRAINED GRANITE

The fine-grained granite is composed chiefly of orthoclase, microcline and microperthite, oligoclase, quartz, and smaller amounts of biotite and muscovite. Other constituents are apatite, sericite, chlorite, and epidote. Orthoclase appears to be the most abundant feldspar, quartz makes up about 35 percent of the rock, and the micas, which are present in about equal amounts, 5 percent. The texture is rather granular, the individual crystals varying in size from about 0.2 to $1.0 \mathrm{~mm}$.

\section{DIABASE}

Diabase is the least abundant of the dike rocks of the area. It is present as scattered dikes cutting (1) the amphibolite, the granite, and the pegmatite of the southern granitic complex, chiefly in sec. $36, \mathrm{~T} .42 \mathrm{~N}$., R. 28 W.; (2) the gray gneiss, Six-Mile Lake amphibolite, and pegmatite of the areas north of the Felch trough; and (3) the amphibolite (metadiabase) of the Felch trough in the outcrops just east of the road in the extreme western part of sec. 33, T. 42 N., R. 28 W., near the Felch post office. Also, old drill records indicate that it cuts the Vulcan iron-formation in sec. 31, T. 42 N., R. 28 W., and recent drilling shows that it cuts the Solberg schist in the southeastern part of sec. 13, T. 42 N., R. 28 W. One of the most accessible dikes is in an open field about 500 feet east of county road 581, near the center of sec. 29 , T. 42 N., R. 28 W. A better but less accessible locality is along the transmission line in sec. 35 , T. 42 N., R. 28 W., north of Michigan State Route 69, where the diabase cuts amphibolite and pegmatite.

The dikes range in width from an inch or less to as much as 50 feet. They are nearly black, but characteristically weather brown. The very small ones are basaltic in appearance, and the larger ones always show very fine grained chilled borders.

In thin section the composition and texture are typical of such rocks. Rosiwal analyses of 2 specimens, one made by Lehner (1950), the other by Roseboom (1951), show respectively, plagioclase 52.8 and 53.7 percent, augite 41.8 and 41.0 percent, and magnetite 3.1 and 5.3 percent. The plagioclase is labradorite $\mathrm{An}_{54}$.

\section{ROCKS OF PALEOZOIC AGE}

The Paleozoic rocks consist of sandstone and dolomite, most of which is presumed to be of Cambrian age though some of the dolomite may be Ordovician. These rocks occur as scattered patches which are most abundant in the eastern part of the area (fig. 2).

The typical exposures consist of sandstone, but locally dolomite is present. Generally the basal part is a conglomerate, which passes upward into a sandstone that contains some interbedded conglomerate, then into dolomitic sandstone, and finally into dolomite. The basal conglomerate is commonly composed of rather angular fragments of the immediately underlying formation and is relatively thin, the maximum true thickness shown by drill holes being 15 feet. The sandstone is chiefly light tan to cream colored or whitish, but some is mottled and streaked with red and green. The lower part is relatively coarse grained, and much of it shows crossbedding. At some places the rock is well indurated, mostly quartzitic, and at others it is poorly cemented and friable. Locally it contains ferruginous and glauconitic beds. The dolomite is generally finely crystalline. Some of it contains numerous green specks that resemble glauconite, and larger brown particles that appear to be altered pyrite. Locally the dolomite shows stylolite seams; irregular, elongated, and branching structures resembling fucoidal markings; and algal structures as much as 5 inches across.

\section{PLEISTOCENE GLACIAL DEPOSITS}

Glacial deposits are widely distributed throughout the area. They are present chiefly in the lowlands, but at some places they encroach upon and completely cover Precambrian rocks that elsewhere make ridges.

The glacial deposits have not been examined in detail. They include coarse boulder moraines, till, outwash sand and gravel, and locally a few short eskers. Generally the moraines have a northward trend, as the ice movement was westward. The eskers form winding ridges perhaps as much as half a mile long.

A very good place to examine some of the outwash and one of the eskers is in the NEx/4 sec. 29 and the NWT/ 4 sec. 28, T. 42 N., R. 28 W. At the east side of county road 581, which passes through the center of section 29, glacial outwash encroaches on outcrops of granitic gneiss and finally buries all outcrops in the eastern part of that section. The esker is present farther to the east, in section 29 , and forms a winding ridge in a wooded area.

\section{AGE RELATIONS OF THE GRANITIC ROCKS}

The age relations of the granitic rocks of the Felch Mountain district have been discussed to some extent 
in preceding parts of this report, but it seems well to present here a brief summary of the relations observed in the Felch Mountain district.

It has been known since the time of the earliest workers in the area that some granite is younger than the Vulcan iron-formation (Clements and Smyth, 1899 , p. 376, summary of work by Credner), but difficulty has been encountered in attempting to delimit the amount and location of such granite (Lamey, 1931, 1933, 1934, 1937; Dickey, 1936; Leith, Lund, and Leith, 1935). Similarly, the various amphibolites have caused trouble, since these are present not only in areas of undoubted Animikie rocks, but also where the rocks have been designated Lower Precambrian.

The granites, granitic gneisses, and associated amphibolites were mapped as Archean by Smyth (1899, p. $398,401-402$ ), who cited only one place in sec. 36 , T. 42 N., R. 29 W., where the contact between the Sturgeon quartzite and the granite is exposed. This relationship has already been discussed, and the conclusion stated that it seems likely that the granitic gneiss, gneissic granite, and amphibolite are of preSturgeon age and that the massive granite of the area surrounding those outcrops is younger. Smyth also recognized that younger granite is present in the area, since he stated (Clements and Smyth, 1899, p. 389-390) :

Igneous granites of Algonkian or later age ought to be found within the Archean areas, for several granite dikes are known to penetrate various members of this overlying series. Whether the known granites within the Archean are really lower-lying and larger masses with which such dikes are genetically connected is not known, but the possibility must be admitted. The banded gneisses are often so faintly foliated and resemble the granites so closely in color and grain that the distinction can be made with only the microscope, and igneous contacts between them might easily be overlooked.

The gray granitic gnelss has been designated Lower Precambrian and probably was formed by reaction of granitic material with rocks of the Dickinson group. The granite pegmatite and granite intrusions that cut the Middle Precambrian rocks are clearly younger. The pegmatites that cut the Six-Mile Lake amphibolite and the Solberg schist are also related to the later period of granitic intrusion, for they generally cut sharply across the regional eastward-trending structure imposed on the rocks during the post-Animikie orogeny.

It is difficult to distinguish the granitic rocks of post-Animikie age from those that are pre-Animikie. The most logical approach, in the absence of radioactive age determinations, seems to be a structural one. At least two orogenies have been postulated, one of post-Dickinson age (upper Lower Precambrian), the other at the close of the Middle Precambrian. Hence, the older granites should be considerably deformed, whereas younger granites should be relatively undeformed. The deformation of the gneissic granite, discussed by James in chapter B, is one reason for classifying that gneissic granite as Lower Precambrian. For similar reasons the writer believes that a considerable amount of the massive granite south of the Felch trough, at least part of which cuts across a gneissic granite, is upper Middle Precambrian.

\section{METAMORPHISM}

All the Precambrian rocks of the area except the late igneous intrusions have been considerably metamorphosed. Apparently two major periods of regional metamorphism are represented, as well as a later retrograde or hydrothermal metamorphism. The first period of metamorphism was dynamothermal in type and is related to the post-Dickinson granitic intrusion and deformation. The second period of regional metamorphism was entirely thermal in type and is related to the post-Animikie granitic intrusion and was accomplished by granitic invasion after deformation, though probably as a late episode in the orogeny. This later metamorphism was followed by local hydrothermal retrograde metamorphism, which appears to be related in part to a late phase of the granitic invasion, during which pegmatites were injected, and in part to late faulting.

The metamorphic grade produced by the two periods of regional metamorphism is moderate to high, usually high enough to form various amphiboles, and locally high enough to form diopsidic pyroxene. During the hydrothermal or retrograde metamorphism, some earlier formed minerals were converted to more hydrous ones, and some material, notably boron and chlorine, may have been introduced.

The metamorphism in the various parts of central Dickinson County, and its general effects on formations, have been discussed in chapter B of this report. Much of the effects of metamorphism has been shown also by descriptions of formations. It seems desirable, here, to summarize the metamorphic effects in the Felch Mountain district, placing particular emphasis on certain formations so that the results of metamorphism of different rock types may be more apparent. Regional metamorphism of the Animikie sedimentary rocks is considered first, and local hydrothermal or retrograde metamorphism later.

\section{REGIONAC METAMORPHISM}

\section{STURGEON QUARTZITE}

The effects of metamorphism on the Sturgeon quartzite are not readily apparent, except as they are re- 
flected in the massiveness of the rock, the rather general lack of recognizable grains, and the crystalline and interlocking nature of the quartz. The recrystallization of the quartz was recognized by Smyth (Clements and Smyth, 1899, p. 402-404), who stated that "the background is composed of large irregular grains of quartz, the edges of which interlock with the most minute and sharp interpenetrations." Smyth recognized that this texture was not a result of stress, as he made a broad distinction between the parts of the quartzite that exhibited the effects of stress in a pronounced degree and those in which such effects are hardly noticeable, and stated that these two extreme types were connected in a perfectly graded series. Smyth clearly recognized that the Sturgeon quartzite had not been formed merely by deposition of secondary silica and enlargement of quartz grains, but he had difficulty in explaining the reason for the peculiar texture. After some discussion of the subject, he stated (idem, p. 405) :

I am compelled to believe that the rock was a sandstone in which, in some way not easy to understand, considerable numbers of adjacent quartz grains have united to form or have been absorbed into a new individual, leaving absolutely no trace of their former separate existence.

Regarded in the light of present knowledge of metamorphism, it seems clear that the Sturgeon quartzite underwent recrystallization of the original quartz grains as a result of thermal metamorphism.

Smyth also recognized the presence of microcline, orthoclase, plagioclase, muscovite, biotite, some chlorite, and various other minerals in the quartzite. He appears to have regarded all of these as original detrital constituents, but also to have realized that some difficulty existed, for at least some of the mica shows clear sharp edges, and is not oriented in parallel position with some of the other minerals. He stated that the orthoclase and plagioclase are for the most part decomposed, but made no such mention of decomposition of the microcline. It is the writer's belief that most of the minerals of the quartzite do, indeed, represent material that was originally detrital, but that many of them have been newly formed from such detrital material. The quartzite in sec. $28, T$. 42 N., R. $28 \mathrm{~W}$., contains much completely unaltered microcline, apparently newly formed, and microscopic examination indicates clearly that microcline has formed from original grains of orthoclase and plagioclase, and probably from sericitic material.

The effects of thermal metamorphism are also well shown in other rocks of the Sturgeon quartzite by the presence of sharply crystallized, disseminated mag- netite, much sharply crystallized muscovite and biotite, and an abundance of unaltered and well crystallized microcline. Much of the mica probably is recrystallized interstitial material and the microcline is either in part recrystallized orthoclase and plagioclase or original sericitic material.

\section{RANDVILLE DOLOMITE}

The Randville dolomite shows the effects of thermal metamorphism more strikingly than any other rock of the area. Most of it is rather coarsely crystalline and is definitely a marble. Tremolite is found in nearly all exposures, locally in crystals several inches long, and locally in layers composed almost wholly of tremolite. The tremolite may be accompanied by diopside, anthophyllite, actinolitic amphibole, and phlogopite. In a few places diopside is conspicuous and forms crystals several inches long and nearly an inch across.

Locally, tremolite and other silicates are accompanied by chlorite. This mineral is incompatible with the metamorphic grade shown by the other minerals, and the evidence is rather clear that it is associated with faulting and silicification of the dolomite. Chlorite should not, therefore, be included with the minerals that are characteristic of the thermal metamorphism of the dolomite.

\section{VULCAN IRON-FORMATION AND OTHER FERRUGINOUS ROCKS}

Both the Vulcan iron-formation and the underlying Felch formation show clearly the effects of thermal metamorphism by the presence of grunerite and other amphiboles, garnet, and micas, and the recrystallization of the original chert of the iron-formation. Although much of the Felch formation is foliated, some of it is rather massive, and many thin sections show grunerite and other amphiboles recrystallized in partial rosettes, sheaves, and bundles, and with crisscross and general random orientation, indicating that the crystallization was due to thermal processes with essentially no accompanying stress. Some of the garnet crystals of the schist are more than an inch across and enclose sharply crystallized magnetite and completely unoriented grunerite.

Along the north edge of the area the Solberg schist and associated Skunk Creek member show somewhat the same characteristics of thermal metamorphism as the Vulcan iron-formation and associated schists, but show also considerably greater deformation. The composition of the rocks is somewhat different; they contain much more mica and less amphibole and garnet than the Vulcan. 
LOCAL HYDROTHERMAL OR RETROGRADE METAMORPHISM

The late injection of granite pegmatite, after postAnimikie granitic invasion and accompanying thermal metamorphism, was accompanied by local hydrothermal or retrograde metamorphism adjacent to dikes and small stocklike intrusions. How extensive this metamorphism may have been is not certain. 'The impression gained from field observation and drilling is that the observed dikes represent only the fingering branches of pegmatite that is more extensive in depth. If this is so, the hydrothermal, or retrograde, metamorphism produced by the pegmatite might be widespread, although probably confined rather closely to the borders of the pegmatite masses.

Hydrothermal metamorphism, superimposed on the major metamorphism of the rocks, caused serpentinization of silicates in the Randville dolomite and, locally, replacement of silicates by pyrite and pyrrhotite. Also, probably during the time of hydrothermal metamorphism, many tiny veins of quartz, feldspar, sericite, chlorite, and some epidote, were formed, and in places earlier formed silicates were partly or wholly changed to sericite, muscovite, chlorite, and epidote. It is likely, also, that at this time the Randville dolomite was silicified along faults, and that chloritic, pyritic, and other types of alteration were produced along faults in various rocks.

Tourmaline and apatite are locally abundant, especially in areas of numerous pegmatites. It may well be that both apatite and tourmaline were introduced rather widely during the hydrothermal metamorphism that accompanied injection of the granite pegmatite.

\section{STRUCTURE}

The structure of the Felch Mountain district is best understood by a consideration of the structural picture of the area covered by this entire report. In the course of the structural analysis given by James (Chap. B of this report) the structure of the Felch Mountain district has been discussed. Therefore, only a few details will be given here.

\section{PRECAMBRIAN ROCKS}

The structure of the Precambrian rocks is complex and is but imperfectly known. The structural trend of most rocks, except granite pegmatite dikes, is in general eastward, and that of most of the pegmatite dikes is nearly northward. Most dips are steeply toward the north. Foliation of gneissic rocks and lineation of amphibolite show somewhat the same general strike, but a tendency to be more toward the northwest, especially in the eastern part of the area.
The foliation dips steeply, and the lineation plunges $10^{\circ}$ to $25^{\circ}$ toward the east. Three general directions are followed by joints: (1) nearly north; (2) northwest; and (3) nearly west. Major faults show about the same trend as the bedding and foliation but cut slightly across the bedding, and minor faults show about the same trend as the joints. Some of the general structural trends are shown by table 21 . These trends were compiled from several hundred observations but were not collected for the purpose of making a statistical study; hence, only the major and bestshown features were recorded. Nevertheless, the number of observations probably is sufficient to give a fair approximation of the conditions that exist. It will be noted that the major concentration of dikes and quartz veins is in the direction of the northwardtrending joints.

Tавт s 21.-Structural trends in the Felch Mountain district

\begin{tabular}{|c|c|c|c|}
\hline \multirow{2}{*}{ Structural feature } & \multicolumn{3}{|c|}{$\begin{array}{l}\text { Strike (measured clockwise from } \\
\text { north) }\end{array}$} \\
\hline & $\begin{array}{c}\text { Major } \\
\text { direction }\end{array}$ & $\begin{array}{l}\text { Major, but } \\
\text { less com- } \\
\text { mon, direc- } \\
\text { tion }\end{array}$ & $\begin{array}{l}\text { Minor } \\
\text { direction }\end{array}$ \\
\hline Bedding.... & $70^{\circ}-90^{\circ}$ & $90^{\circ}-100^{\circ}$ & $145^{\circ}-200^{\circ}$ \\
\hline Foliation and lineation...... & $80^{\circ}-100^{\circ}$ & $100^{\circ}-140^{\circ}$ & $\begin{array}{l}145^{\circ}-180^{\circ} \\
130^{\circ}-135^{\circ}\end{array}$ \\
\hline Joints & $145^{\circ}-200^{\circ}$ & & $\begin{array}{r}90^{\circ}-135^{\circ} \\
100^{\circ}-110^{\circ} \\
60^{\circ}-70^{\circ}\end{array}$ \\
\hline Dikes and quartz veins & $145^{\circ}-200^{\circ}$ & $90^{\circ}-100^{\circ}$ & $\begin{aligned} 110^{\circ}-135^{\circ} \\
60^{\circ}-80^{\circ}\end{aligned}$ \\
\hline
\end{tabular}

Analysis of the structure of the Felch Mountain district is difficult and uncertain because of the complexity of structure and lack of data. The following discussion, therefore, is merely an atempt to point out some of the principal features. Close folding is the rule throughout the entire area, and this is well shown by the steep dips, many of which are vertical or nearly so.

In many places the beds have been overturned, but perhaps the outstanding examples of overturning that are well supported by field data and by drilling are in the western part of the area. For about 5 miles, from the outcrops in the south-central part of sec. 7, T. 41 N., R. 30 W., to those in the southern part of sec. 35 , T. 42 N., R. 30 W., the Sturgeon quartzite is overturned. It dips toward the south at angles ranging from $27^{\circ}$ to $85^{\circ}$, but ripple marks and crossbedding show clearly that the top of the formation is to the north. The other example of overturning involves the Vulcan iron-formation, the Felch formation, and the Randville dolomite in secs. 34,35 , and $26, \mathrm{~T} .42$, N., R. 30 W. In this area the Randville dolomite lies 
north of the Vulcan iron-formation, and both the dolomite and the iron-formation dip to the north. Throughout part of this distance it is known from drill records that the Felch formation is between the dolomite and the iron-formation. Most holes show a fault contact, but one shows a continuous section from dolomite, through schist, into iron-formation. It is clear, therefore, that the formations have been overturned, although the overturning is accompanied by faulting in part of the distance.

Both folding and faulting are important in the vicinity of the Groveland mine in sec. 31, T. 42 N., R. 29 W., and secs. 35 and 36, T. 42 N., R. 30 W. The present writer believes that there are several faults in that vicinity, but they are not shown on the map (pl. 2) because of their uncertain location. In particular, it seems almost certain that there is a fault along the south side of the southern belt of ironformation in secs. 31 and 36 .

Eastward from the Groveland mine for about 4 miles the structure is obscure, but elements of it are indicated on the map (pl. 2). In sec. 35, T. 42 N., R. $29 \mathrm{~W}$., the Sturgeon quartzite and Randville dolomite appear to be involved in a cross fold that trends north. The structural picture is further complicated by an upthrust block of granitic gneiss flanked by Randville dolomite. One probable result of this complicated structure was the elevation of the ironformation and its subsequent complete removal by erosion. In addition to these features, many smaller structural complexities are shown, and farther to the south a major fault separates granite from Sturgeon quartzite.

This major fault that separates granite from Sturgeon quartzite is one of the prominent structural features of the central part of the area. The escarpmentlike character of the granite outcrops that face the valley of the small stream and of the Sturgeon River throughout secs. 34 and 35, T. 42 N., R. 29 W., was noted by Smyth (1899, p. 386-387), although he shows no fault on his map. The best evidence for this fault is to the east, in secs. 36 and 31, T. 42 N., Rs. 29 $\mathrm{W}$. and $28 \mathrm{~W}$., where the Cambrian sandstone has been involved in post-Cambrian movement along the fault, and where the Vulcan iron-formation is adjacent to granite.

The structure of the rocks of the eastern part of the area is particularly complex. The probable relations are illustrated in part by figures 78,79 and 80 , and plate 3 .

Throughout the banded gray gneiss complex north of the Felch trough, vague folds of considerable complexity are shown here and there, but in general such structures were not observed in the granitic complex south of the sedimentary rocks except at some places near the extreme eastern end of the area.

Toward the eastern end of the southern granitic area, in secs. 2 and 35, Ts. 41 and 42 N., R. 28 W., especially along the transmission line north of Michigan State Route 69, for a short distance the entire structure swings north, whereas the trend of the linear structures continues to plunge eastward. The granite appears to have intruded the amphibolite in layerlike masses, some of which also cut across the amphibolite, and differential erosion has produced a series of hogbacklike ridges that trend northward.

\section{PALEOZOIC ROCKS}

Most exposures of the Cambrian and Ordovician rocks in the area are so nearly flat lying that the dip cannot be measured with a Brunton compass, but one exposure shows a dip of $68^{\circ}$ and dips between $15^{\circ}$ and $20^{\circ}$ are not uncommon (fig. 2). The principal places where the strata are steeply dipping are (1) along the north side of the Sturgeon River in secs. 36 and 31, T. 42 N., Rs. 29 and 28 W.; (2) south of the railroad in secs. 32 and 33, T. 42 N., R. 28 W.; and (3) north of Michigan State Route 69 in the northeastern part of sec. 33, T. 42 N., R. 28 W. Wherever observed, these areas of dipping rocks are near the margins of an area of sandstone, the beds become horizontal within a short distance inward, and are horizontal in the central part of the area.

Perhaps the best example of disturbed Cambrian and Ordovician rocks, and the one that shows best the cause of the disturbance, is along the north side of the Sturgeon River. Crossbedding makes determination of strike and dip difficult, but observed strikes close to the river are westerly and conform in general to the strikes of the Precambrian rocks, and the dips are between $6^{\circ}$ and $68^{\circ} \mathrm{N}$. but chiefly near $20^{\circ} \mathrm{N}$. Toward the north, within 500 feet, the rocks are horizontal. Along the face of the sandstone cliff that forms the north side of the Sturgeon valley the sandstone is fractured and appears to be cut by many veins, which are fracture planes along which the sandstone has been more firmly cemented.

In sec. 36 the river is only about 30 feet wide, but sandstone is confined to its north side, and only Precambrian rocks are exposed along its south side. A similar relation is shown between sandstone on the north side of the mill pond in sec. 31 and Precambrian rocks that form islands just to the south. These relations, together with the northerly dips and the fracturing of the sandstone near the river, indicate 
clearly that the Cambrian sandstone has been disturbed locally by faulting, and it appears most probable that there has been post-Cambrian movement along a major Precambrian fault, since a major fault separates Vulcan iron-formation from granite in this area.

The concept of post-Cambrian movement along Precambrian faults was first advanced by Dutton (orai communication) to explain the distribution of some of the Cambrian rocks of the Menominee range, but proof of the fault relation was lacking at that time. Certainly this concept, together with the known Precambrian faulting in the Felch Mountain area, may explain the distribution of the Cambrian sandstone there. From near the Groveland mine in sec. 31, T. 42 N., R. 29 W., to the extreme east end of the area, each block of sandstone is so disposed with respect to known faults that they might well be bounded on both north and south by such faults. All these patches of Cambrian sandstone have a general eastward alinement, and usually cap ridges, and probably are downfaulted blocks in which the Cambrian sandstone was protected from erosion.

\section{SUMMARY OF GEOLOGIC HISTORY}

The geologic history of the Felch Mountain district is, of course, an integral part of the history of the entire region and can be best deciphered and understood from an analysis of the larger area. This analysis is presented in chapter B and is summarized in table 22 .

TABLE 22.-Summary of geologic history of the Felch Mountain district, in Michigan

Postglacial erosion.

Post-Keweenawan

Glaciation.

Prolonged erosion.

Slight movement along major Precambrian faults, causing fracturing and probably downfaulting of some Cambrian and younger rocks.

Probable deposition of some younger Paleozoic rocks, but record is incomplete.

Deposition of well-sorted clean quartz sand, followed by chemical deposition of calcareous sediments. Cambrian and Ordovician. Locally the basal sand was deposited around debris lying upon and derived chiefly from the underlying rock.

Prolonged erosion.

\section{Middle and Upper Precambrian}

Intrusion of diabase. Sparse diabase dikes, probably of Keweenawan age, cutting all other Precambrian rocks.

Intrusion of granite pegmatite after relaxation of stress, accompanied by hydrothermal or retrograde metamorphism.

Orogeny, followed by thermal metamorphism of Middle Precambrian rocks and intrusion of granite.

Intrusion of basic rocks into Animikie sediments. Amphibolites cutting Sturgeon quartzite, Felch formation, and Vuloan iron-formation.
TABLE 22.-Summary of geologic history of the Felch Mountain district, in Michigan-Continued

Middle and Upper Precambrian-Continued

Deposition of younger volcanic and sedimentary rocks (not shown in the Felch Mountain district).

Chemical deposition of ferruginous and siliceous sediments, accompanied by minor clastic sediments (Vulcan iron-formation). Deposition of fine-grained clastic sediments, accompanied by some chemical deposition of ferruginous material (Felch formation).

Slight uplift and erosion. Post-Randville, pre-Felch unconformity.

Chemical deposition of dolomite accompanied by some finegrained clastic material (Randville dolomite).

Deposition of well-sorted clean quartz sand (Sturgeon quartzite).

Lower Precambrian

Prolonged erosion (major unconformity).

Orogeny accompanied by intrusion of granite and dynamothermal metamorphism.

Deposition of quartzose, argillaceous, and ferruginous sediments (Solberg schist with Skunk Creek member), accompanied and followed by basic volcanic rocks (Six-Mile Lake amphibolite).

Folmation of earlier rocks. Not shown in Felch Mountain district.

\section{MAGNETIC ANOMALIES}

Magnetic anomalies throughout the area were determined from dip-needle observations, from the aeromagnetic survey, and from a few magnetometer determinations in selected areas. The discussion that follows deals principally with the dip-needle surveys; the aeromagnetic survey is described in chapter B (see also pls. 2 and 8 ).

Virtually all of the Felch trough was surveyed by dip needle along lines spaced an eighth of a mile apart. Observations were made along these lines, which were run by sundial compass, at paced intervals of 40 feet. This information is summarized by magnetic-contour maps (pl. 13). These maps, though based on many observations, are interpretative in the sense that anomalies are connected from line to line, and locally other connections may be valid.

The base value for the magnetic observations, as determined by the values obtained over nonmagnetic rocks, is between $9^{\circ}$ and $15^{\circ}$. Values in this range do not, therefore, represent anomalies; only those values that vary significantly from this base, either above or below, are to be so considered. The $6^{\circ}$ range in values obtained over nonmagnetic rocks may actually be due in part to unrecognized magnetic differences between rocks thought to be nonmagnetic, but it probably is due chiefly to other causes, such as instrumental error, magnetic storms, static electricity on the instrument, and the like.

Moderate to strong magnetic anomalies are caused by three formations or parts of formations in the area 
surveyed, namely, the Vulcan iron-formation, the Felch formation (in part), and the upper part of the Sturgeon quartzite. Of these, the Vulcan ironformation yields the largest and most consistently high anomalies; values as high as $85^{\circ}$, about $70^{\circ}$ above the base value for the area, were recorded, and values of $15^{\circ}$ to $40^{\circ}$ above base level are typical. Parts of the Felch formation, particularly the garnet-grunerite rock of that unit, cause anomalies that generally are several degrees above base value and in places are $25^{\circ}$ above base. Anomalies of several degrees are also caused by the upper member of the Sturgeon quartzite, which commonly is a schist or fine-grained quartzite containing disseminated magnetite, and locally the rock may yield anomalies of $17^{\circ}$ above base value.

Local structural conditions may cause magnetic values to be apparently inconsistent with the rock type on which they are observed. Values much higher than those expected may result from overturning of formations or from thrusting of rocks that usually show moderate to low magnetic intensity over those that show high magnetic intensity, if the thickness of the overturned or overthrust mass is not too great. Also, values much lower than those expected may result from excessive shearing and brecciation, if such action results in destruction of the magnetite in the rock. Very high values may result, also, from close folding, as, for example, tight, nearly vertical limbs of iron-formation or garnet-grunerite-magnetite schist, insofar as this folding increases the volume of the magnetic unit. Thus, the values obtained from tightly folded Felch formation of this type may approximate those of less closely folded Vulcan iron-formation.

The magnetic-contour maps (pl. 13) show a striking contrast between the central part of the area and the eastern and western parts. The central part is characterized by low magnetic intensity, the eastern and western parts by high magnetic intensity, except at the extreme east end. This striking contrast appears to be due to lack of iron-formation in the central part of the district.

The chief features of the western part of the area are a nearly continuous wide northern zone of very high anomalies (generally $10^{\circ}$ to $30^{\circ}$ above base level); a less continuous narrow southern zone of moderate anomalies $\left(1^{\circ}-5^{\circ}\right.$ above base level $)$; and a few discontinuous, narrow, extreme southern zones of small to moderate anomalies.

A few outcrops, pits, and some drill records show that the wide northern zone of high anomalies is caused chiefly by the Vulcan iron-formation and the garnet-grunerite type of Felch formation, and outcrops show that some of the disconnected areas of high anomalies along the south margin of this zone are also caused by this type of Felch formation. Outcrops also show that the principal narrow nearly continuous southern zone of moderate anomalies is caused by the magnetite-bearing part of the Sturgeon quartzite. No outcrops are present along the short strips of moderate anomalies in sec. 8, T. 42 N., R. 30 $W$., south of this zone, and hence the cause of those anomalies is not known. They may be caused by repetition of the magnetite-bearing quartzite or by basic dikes.

Several displacements of the magnetic crest are shown in the northern zone of anomalies throughout this western area. The most conspicuous of these is toward the east end of the zone, near the Groveland mine, in secs. 31 and 36, T. 42 N., Rs. 29 and $30 \mathrm{~W}$. These breaks may be caused by faults or by shallowing of the synclines containing the magnetic rock.

The chief feature of the central area is the general absence of well-defined and continuous zones of high anomalies. The zone of highest and most continuous anomalies of this central area is in the northern part of secs. 32 and 33, T. 42 N., R, 29 W. This zone is characterized by a well-marked magnetic crest. South of it in those sections, and extending eastward through sec. 34 and into sec. 35 , there is a zone of weak to moderate anomalies. The crest of this zone, although weak, is traceable continuously into sec. 35 . In the south-central part of that section the crest is broken, several short crests are present, and the zone widens to the northward. Farther east, the magnetic zones and crests are poorly defined, except in the southeastern part of sec. 31 , T. 42 N., R. 28 W., where there is a narrow but well-defined zone of moderate anomalies.

Exposures show that the zone of weak to moderate anomalies in secs. $32,33,34$, and 35 , T. 42 N., R. 29 W., is caused by the Sturgeon quartzite, and drilling and outcrops show that the narrow but well-defined zone of moderate anomalies in sec. 31 , T. 42 N., R. 28 W., is caused chiefly by Felch formation and some lean Vulcan iron-formation. No outcrops are present in the zone of highest anomalies in secs. 32 and 33, T. 42 N., R. $29 \mathrm{~W}$., but a few pits and drill holes indicate that it is caused by Felch formation and a siliceous phase of the iron-formation.

In the eastern area, there are two well-marked zones of high anomalies and a third very narrow zone of high anomalies south of the other two. Outcrops 
show that the wide northern zone and the very narrow extreme southern zone of high anomalies are caused by the Vulcan iron-formation, and both outcrops and drilling show that the wide southern belt is caused by the magnetic quartzose mica schist of the Felch formation.

No detailed magnetic work was done along the belt of Solberg schist and Skunk Creek member in the northern part of the area, but airborne-magnetometer records show that a strong magnetic anomaly is present throughout that area, and some outcrops and drill records show that the anomaly is caused by the schist and iron-formation.

\section{ECONOMIC GEOLOGY}

Materials of chief economic interest in the area are iron-formation and dolomite, and those of secondary interest are minor amounts of other rocks and the glacial deposits of sand and gravel. The economic geology has been treated in chapter $\mathrm{B}$, to which the reader is referred for details regarding the Felch Mountain district. 
, 


\title{
Chapter E. GEOLOGY OF THE CALUMET TROUGH AND VICINITY
}

\author{
By Jacob Freedman, H. L. James, and James Trow
}

\section{INTRODUCTION}

The area designated "Calumet trough and vicinity" is the southern part of the central Dickinson County map area. The Calumet trough itself refers specifically to the area underlain by Animikie sedimentary rocks, an area which is bounded on the north and, in part, on the south by older crystalline rocks. (See pl. 1 and fig. 74). The western part of the trough opens out to the broad area of Middle Precambrian rocks of eastern Iron County, Florence County (Wis.), and southern Dickinson County. The trough continues to the east beneath the overlapping mantle of Paleozoic strata. The total area described in this chapter is slightly more than 100 square miles; it overlaps to some extent the area to the north mapped by Lamey and described in chapter $\mathrm{D}$.

\section{GEOGRAPHY}

Most of the area is a wooded rolling upland with a relief of less than 300 feet. The northern and southcentral parts are rugged in detail; scattered rock bluffs and knobs rise sharply above the general level. Swamps are abundant, especially in the more rugged terrain. The western part of the area is drained by First Creek, Badwater Creek, and by Pine Creek and its tributaries. The eastern part is drained by the Sturgeon River. All these streams drain southward into the Menominee River, which empties into Lake Michigan.

All parts of the area are within three miles of a graded road. The principal highways are State Route M-95, a paved road which extends northward from Iron Mountain, and M-69 in the northeastern part of the area. In addition, the area is served by the Iron Mountain to Channing branch of the Chicago, Milwaukee, St. Paul, and Pacific Railroad, and by a spur line of the Chicago and Northwestern Railroad that enters Dickinson County from the east.

Farms are scattered throughout the area adjacent to the graded roads but are numerous only in the western third, adjacent to and west of State Route M-95, and in the vicinity of Foster City. Most are small. Foster City is the only community in the area; it has fewer than 100 inhabitants.

\section{FIELDWORK AND PREPARATION OF THE REPORT}

The eastern part of the Calumet trough and vicinity was mapped by Freedman (see fig. 1) during the field seasons 1948,1949 , and 1950 . He was assisted by John Folger in 1948, V. C. Shepps in 1949, and C. E. Brown in 1950. The fieldwork consisted of mapping outcrops and test pits on aerial photographs, from which a map was compiled at a scale of 1:20,000. All outcrops within the eastern part of the Calumet trough and in the bordering areas of the adjacent crystalline blocks were examined and mapped. Areas within the crystalline blocks, back from the borders of the Calumet trough, were either not mapped or mapped only along random traverse lines.

The western part of the area (fig. 1) was mapped by Trow. Secs. 29, 30, 31, and 32, T. 41 N., R. 29 W., were mapped in 1946 as part of a thesis problem under the supervision of F. J. Pettijohn at the University of Chicago (Trow, 1948). That mapping, with some changes, is incorporated in this report. The remainder, and larger part of the area, was mapped for the U.S. Geological Survey in cooperation with the Michigan Geological Survey Division during the field seasons of $1948,1949,1950$, and part of 1951 , with the assistance of G. A. Dawe in 1948, W. P. Pratt and V. C. Shepps in 1949, and R. W. Bayley and J. E. O'Rourke in 1950. Except for the interior parts of the blocks of older crystalline rocks, all outcrops were mapped by compass traverses spaced one-eighth mile apart. The outcrops were plotted on aerial photographs, or on a base map at 1:10,000, and later compiled at a scale of $1: 20,000$.

The present report has been prepared by James, utilizing maps and preliminary text material prepared by Freedman and Trow. Most of the critical outcrops in the area and all available drill core have been examined by James, who also made independent study of the petrography to supplement that made by Freed- 
man and Trow. The chapter will deal chiefly with the more detailed aspects of the geology in this area; for discussion of general problems the reader is referred to chapter B.

\section{GENERAL GEOLOGY}

The Calumet trough is a downfaulted and downfolded area of Animikie sedimentary strata that lie between and flank masses of Lower Precambrian granitic gneiss. The northern mass of gneiss, referred to as the "central crystalline block", is about 18 miles long and 2 to 3 miles wide; it separates the Calumet trough from the Felch trough. The southern mass, referred to as the "southern crystalline block", is 5 to 6 miles wide in this area and extends southeastward; it separates the Calumet trough from the Menominee district of southern Dickinson County (see pl. 1).

The oldest rocks in the area are amphibolites and metasedimentary rocks that occur within the dominantly gneissic granite of the two crystalline blocks. These metamorphic rocks are relics of a preexisting sedimentary and volcanic sequence that was part of, or related to, the strata of the Dickinson group north of the Felch trough. The Hardwood gneiss, at the eastern margin of the area, is a complex of layered and massive crystalline rock that is also believed to be pregranite in age.

The rocks that make up the central and southern crystalline blocks are overlain with profound unconformity by Middle Precambrian rocks. The Animikie strata include, from oldest to youngest, the Fern Creek formation, the Sturgeon quartzite, the Randville dolomite, the Felch formation, the Vulcan iron-formation, the Michigamme slate, and the Badwater greenstone. The Michigamme slate underlies by far the largest area. These strata are cut locally by upper Middle Precambrian basic intrusives and by granite. All rocks older than the granite are regionally metamorphosed.

Sandstone and dolomite of Cambrian and possible Ordovician age occur locally as flat-lying patches in the eastern part of the Calumet trough. The rock is not well exposed but some of the patches probably are several square miles in area.

Glacial deposits of Pleistocene age form a discontinuous mantle over the entire area.

The stratigraphy is summarized in table 23.

\section{LOWER PRECAMBRIAN ROCKS}

Lower Precambrian rocks occur only in the central and southern crystalline blocks. They consist chiefly of gneissic granite in which occur layers and lenses of older amphibolite and metamorphosed sedimentary rock. Migmatite is present in some places but is not abundant. The Hardwood gneiss, in the extreme east part of the area, is not in exposed contact with the granite, but it also is assumed to be pregranite in age. In general, the terrain underlain by the Lower Precambrian crystalline rocks is rocky and has undrained or partly drained swamps between groups of outcrops. The outcrops themselves are glacially scoured hills that typically rise 50 to 200 feet above the intervening swampy ground. The long dimension of most outcrops is easterly or northeasterly, parallel to the principal direction of foliation.

\section{AMPHIBOLITE}

The amphibolite occurs in the granite as lenses and layers, most of which are less than 20 feet wide. In a few places, however, outcrops 200 feet wide and several hundred feet long consist entirely of amphibolite. The amphibolite makes up close to 20 percent of the exposed rock in the eastern part of the central crystalline block, but is much less abundant in the western part. The southern crystalline block has not been sufficiently well mapped to determine relative abundance, but amphibolite is plentiful in those exposures examined.

Most of the amphibolite is black, fine to medium grained, with strongly alined needles of black hornblende and small porphyroblasts or elongate lenses of feldspar. Many of the amphibolite bodies are in sharp contact with the enclosing granite, but in others the number of feldspar porphyroblasts increases toward the granite contact and there is a continuous gradation from amphibolite to hornblende granite or hornblende quartz diorite.

The amphibolite is a fine- to medium-grained aggregate of hornblende, plagioclase, and quartz. The hornblende is in green or bluish-green subhedral grains with strong preferred orientation. The plagioclase occurs as equant or interstitial grains; in some specimens these grains show twinning, in others they do not. The composition ranges from calcic oligoclase $\left(\mathrm{An}_{28}\right)$ to calcic andesine $\left(\mathrm{An}_{45}\right)$ in different specimens, and slight gradational zoning to a more sodic border is typical. The quartz occurs as clear bleblike grains. Biotite and titanite are important constituents in some of the amphibolite examined. Epidote is locally abundant, particularly in and adjacent to crosscutting veinlets that also contain quartz and plagioclase. Minor constituents are apatite, magnetite, sericite, and chlorite, the second two as alteration products of feldspar and hornblende. Modal analyses of six samples of amphibolite are given in table 24 . 
TABLE 23.-Rock units in the Calumet trough and vicinity

[Thickness given for stratigraphic units only]

\begin{tabular}{|c|c|c|c|c|c|}
\hline \multicolumn{3}{|c|}{ Age } & Unit & Description & Thickness (feet) \\
\hline \multicolumn{3}{|c|}{ Pleistocene } & Glacial deposits & Mostly sandy to clayey boulder till; some sandy outwash. & $0-300$ \\
\hline \multicolumn{3}{|c|}{ Paleozoic } & Sandstone and dolomite.... & $\begin{array}{l}\text { Friable buff well-sorted sandstone, commonly red and } \\
\text { ferruginous near base; sandy oolitic dolomite; fine- } \\
\text { grained buff dolomite. Flat-lying remnants in eastern } \\
\text { part of area. }\end{array}$ & $0-270$ \\
\hline \multirow{11}{*}{ Middle Precambrian } & & & Granite, pegmatite. aplite........ & $\begin{array}{l}\text { Dikes and small masses. Mainly pink to gray. Not } \\
\text { abundant. }\end{array}$ & \\
\hline & & & Metadiabase and metagabbro....... & $\begin{array}{l}\text { Dikes and sills. Massive green to gray rock with relict } \\
\text { gabbroic texture in southwestern part of area. Black, } \\
\text { amphibolitic elsewhere. }\end{array}$ & \\
\hline & & & Badwater greenstone....... & $\begin{array}{l}\text { Mainly green or gray am ygdaloidal, massive fine-grained } \\
\text { greenstone with minor intercalated strata. Locally }\end{array}$ & 2,500 \\
\hline & \multirow{8}{*}{ 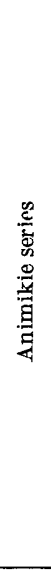 } & \multirow{5}{*}{ 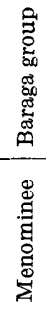 } & Michigamme slate & $\begin{array}{l}\text { Gray and buff slate and massive graywacke; muscovite- } \\
\text { biotite schist; garnetiferous schist; staurolite schist. } \\
\text { Locally contains enough magnetite to yield anomalies. }\end{array}$ & $10,000(?)$ \\
\hline & & & \multirow[t]{2}{*}{ Vulcan iron-formation } & $\begin{array}{l}\text { Thin bedded, with alternating layers of reddish quartz and } \\
\text { magnetite (martite); strongly magnetic. Only one }\end{array}$ & \multirow[t]{2}{*}{$0-200$} \\
\hline & & & & $\begin{array}{l}\text { natural exposure in area. Drined and enterea oy mute } \\
\text { workings. }\end{array}$ & \\
\hline & & & \multirow{3}{*}{$\begin{array}{l}\text { Felch formation } \\
\text {-Unconformity- } \\
\text { Randville dolomite }\end{array}$} & $\begin{array}{l}\text { Micaceous quartzose schist. No exposures in this area. } \\
\text { Known only from drilling and workings of the Calumet } \\
\text { mine. }\end{array}$ & $50-200$ \\
\hline & & & & In this area, mainly massive tremolitic marble. Exposed & $0(?)-1,000(?)$ \\
\hline & & \multirow{3}{*}{ 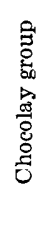 } & & of the Calumet mine. & \\
\hline & & & Sturgeon quartzite & $\begin{array}{l}\text { Mainly white, pink, or gray vitreous quartzite, cross- } \\
\text { bedded and ripple marked. Uppermost part locally } \\
\text { fine grained, magnetite bearing. Lower part typically } \\
\text { pale green or gray sericitic quartzite or quartzose slate. }\end{array}$ & $1,000-1,850$ \\
\hline & & & Fern Creek formation. & $\begin{array}{l}\text { Pink to red arkosite, gray graywacke, and conglomerate } \\
\text { with boulders, cobbles, and pebbles of gneissic granite } \\
\text { and vein quartz. }\end{array}$ & $0-70$ \\
\hline \multirow{4}{*}{\multicolumn{3}{|c|}{ Lower Precambrian }} & Gneissic granite.... & $\begin{array}{l}\text { White, gray, or pink, fine to coarse grained, locally peg- } \\
\text { matitic. Dominantly granitic, but ranges from alaskite } \\
\text { to quartz diorite ln composition. }\end{array}$ & - - \\
\hline & & & Hardwood gneiss................. & $\begin{array}{l}\text { Complex of amphibolite, garnet-quartz-mica schist, horn- } \\
\text { blende-pyroxene gneiss, pyroxenite, and possible quartz- } \\
\text { ite. Typically thinly layered but locally massive. } \\
\text { Eastern part of area only. }\end{array}$ & 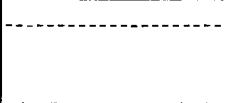 \\
\hline & & & Metasedimentary rocks. & $\begin{array}{l}\text { Quartzitic gneiss and biotite schist, commonly gradational } \\
\text { into enelosing gneissic granite. Relatively scarce. }\end{array}$ & \\
\hline & & & 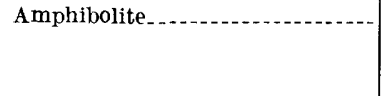 & $\begin{array}{l}\text { Black, fine-to-medium grained amphibolite with alined } \\
\text { neediles of hnrnblende and lenticular grains and por- } \\
\text { phyroblasts of plagioclase. A bundant as layers up to } \\
200 \text { feet wide in gneissic granite. }\end{array}$ & (- - - \\
\hline
\end{tabular}

TABLE 24.-Modes of amphibolites from the central crystalline block

\begin{tabular}{|c|c|c|c|c|c|c|}
\hline Mineral & 1 & 2 & 3 & 4 & 5 & 6 \\
\hline $\begin{array}{l}\text { Hornblende } \\
\text { Plagioclase }\end{array}$ & $\begin{array}{l}62.3 \\
26.6\end{array}$ & $\begin{array}{l}50.7 \\
26.6\end{array}$ & $\begin{array}{l}57.2 \\
25.3\end{array}$ & $\begin{array}{l}\text { 43. } 2 \\
15.0\end{array}$ & $\begin{array}{l}56.5 \\
20.0\end{array}$ & $\begin{array}{l}60.1 \\
20.0\end{array}$ \\
\hline $\begin{array}{l}\text { Quartz } \\
\text { Biptite }\end{array}$ & 11.1 & 14.0 & 16.8 & 9.1 & & 8.2 \\
\hline Sphene & Tr. & 4. 0 & $\mathrm{Tr}$. & 7.7 & $\begin{array}{l}8.0 \\
9.5\end{array}$ & \\
\hline $\begin{array}{l}\text { Epidote } \\
\text { Other }\end{array}$ & Tr. & $\begin{array}{l}1.2 \\
\text { Tr. }\end{array}$ & ${ }_{\text {Tr. }}^{7}$ & $\begin{array}{l}4.5 \\
1.4\end{array}$ & $\begin{array}{l}\text { 6.0 } \\
\text { Tr. }\end{array}$ & $\begin{array}{r}3.0 \\
.9\end{array}$ \\
\hline
\end{tabular}

1. NW14NW14 sec. 8, T. 41 N., R. 28 W. Sample JF-65-48.

2. SE1/NE14 sec. 12, T. 41 N., R. 29 W. Sample JF-95a-48.

4. Sec. 23 , T. 41 N., K. 30 W.; 4,400' north, 4,200' east of $\mathrm{SW}$ corner. Sample

5. As above. Sample JT-321.

6. Sec. 18, T. 41 N., R. 29 W.; 1,100' north, 1,450' east of SW corner. Sample

The modified amphibolite near contacts with the granite contrasts with the normal amphibolite in that it contains microcline and much less homblende.

\section{MICACEOUS QUARTZITE AND BIOTITE-QUARTZ SCHIST}

Rock of sedimentary or probable sedimentary origin is present as relict bodies in several areas in the western part of the central crystalline block, but is much less abundant and less easily recognized than the amphibolite. Most bodies are small-a few feet or a few tens of feet across - and are separated from the granite by a transitional zone of gneissic rock.

Most of the rock definitely of sedimentary origin is in sec. 18, T. 41 N., R. 29 W. Vitreous quartzite is present in an outcrop $400 \mathrm{ft}$ south of the north quarter corner of sec. 18, and in an outcrop $450 \mathrm{ft}$ east of that corner, where the rock shows possible crossbedding. Micaceous quartzite also is found in the southern part of sec. 18 , and near the center of sec. 20, T. 41 N., R. 
$30 \mathrm{~W}$. At the sec. 18 locality the quartzite is interlayered with amphibolite and with gneissic granite so as to form a migmatite. In thin section the rocks show a mosaic of quartz and some feldspar, and interstitial mica; in one or two slides the outlines of clastic grains are preserved. Modes of three specimens are given in table 25 (Nos. 1, 2, 3).

TABLE 25.-Modes of micaceous quartzite and biotite schist inclusions in the gneissic granite

\begin{tabular}{|c|c|c|c|c|c|c|}
\hline \multirow{2}{*}{ Mineral } & \multicolumn{3}{|c|}{ Micaceous quartzite } & \multicolumn{3}{|c|}{ Biotite schist } \\
\hline & 1 & 2 & 3 & 4 & 5 & 6 \\
\hline $\begin{array}{l}\text { Quartz } \\
\text { Orthoclase_- }\end{array}$ & 62 & $\begin{array}{l}73 \\
16\end{array}$ & 70 & $\begin{array}{l}20 \\
12\end{array}$ & 26 & 40 \\
\hline $\begin{array}{l}\text { Plagioclase } \\
\text { Biotite }\end{array}$ & $\begin{array}{l}15 \\
7.5\end{array}$ & $\begin{array}{l}4 \\
2.5\end{array}$ & 9 & $\begin{array}{l}1 \\
66.5\end{array}$ & 56 & $\begin{array}{r}1 \\
50\end{array}$ \\
\hline $\begin{array}{l}\text { Hornbolende... } \\
\text { Muscovite. }\end{array}$ & & .5 & 12 & .5 & & $\cdots$ \\
\hline Chlorite & 35 & 1.5 & & & 8 & \\
\hline $\begin{array}{l}\text { Ealcitete- } \\
\text { Epidote } \\
\text { Sphene }\end{array}$ & $\begin{array}{l}3.5 \\
2 \\
5\end{array}$ & .5 & & $\cdots$ & 10 & 2 \\
\hline $\begin{array}{l}\text { Magnetite- } \\
\text { Other- }\end{array}$ & 4 & $i$ & 7 & $\cdots$ & $-\cdots$ & 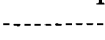 \\
\hline Other........ & 2.5 & 1 & 2 & & & \\
\hline
\end{tabular}

1. 480 feet north, 4,400 feet east of the SW corner sec. 18, T. 41 N., R. 29 W. (Sp. JT-326. feet north, 1,450 feet east of the SW corner sec. 18, T. 41 N., R. 29 W. (Sp.

JT-324). feet north, 2,740 feet east of the SW corner sec. 20, T. 41 N., R. 30 W. (Sp.
$3.2,600$.

JT. 489,800 feet north, 2,640 feet east of SW corner sec. 24, T. 41 N., R. 30 W. (Sp.

5. 2,480 feet north, 560 feet east of $\mathrm{SW}$ corner sec. 21, T. 41 N., R. $30 \mathrm{~W}$. (Sp. JT-324).

6. 4,000 feet north, 2,300 feet east of SW corner sec. 9, T. 41 N., R. 30 W. (Sp. JT-440).

Biotite schist is fairly common as thin lenses and screens in the granite. Some of the schist may represent original sedimentary material. The rocks are dark, fine to medium grained, and most are strongly schistose. Biotite and quartz are the chief constituents. Modes of three specimens of the schist are also given in table 25 (Nos. 4, 5, 6).

\section{HARDWOOD GNEISS}

The unit named the Hardwood gneiss in this report underlies an area of approximately one square mile in secs. 5, 7, and 8, T. 41 N., R. 27 W., about a mile east of the village of Foster City and immediately west of the community of Hardwood, which lies just east of the map area. These rocks apparently are unlike those of any other rock unit in northern Michigan.

Outcrops of the gneiss are scattered but numerous. They range in size from a few square feet to knobs 30 feet high and 200 feet across. Excellent exposures of some of the more distinctive members are found as road cuts along State Route M-60 between Foster City and Hardwood.

The rocks of the Hardwood gneiss include garnethornblende-pyroxene gneiss, plagioclase-quartz gneiss, hornblende-pyroxene and pyroxenite gneiss, plagioclase amphibolite, amphibolite, garnet-quartz-mica schist, and micaceous quartzite. The mineral compositions of these rocks are summarized in table 26. Some of the amphibolitic varieties are massive, but much of the gneiss is marked by strong compositional layering. (See figs. 16 and 17.) All rock types except the quartzite and the garnet-quartz-mica schist are repeatedly interlayered. The Hardwood gneiss has been compressed into eastward-plunging folds. Dips are relatively low-in general less than $45^{\circ}$-and repeated minor faults are plentiful.

TABLE 26.-Modes of the Hardwood gneiss

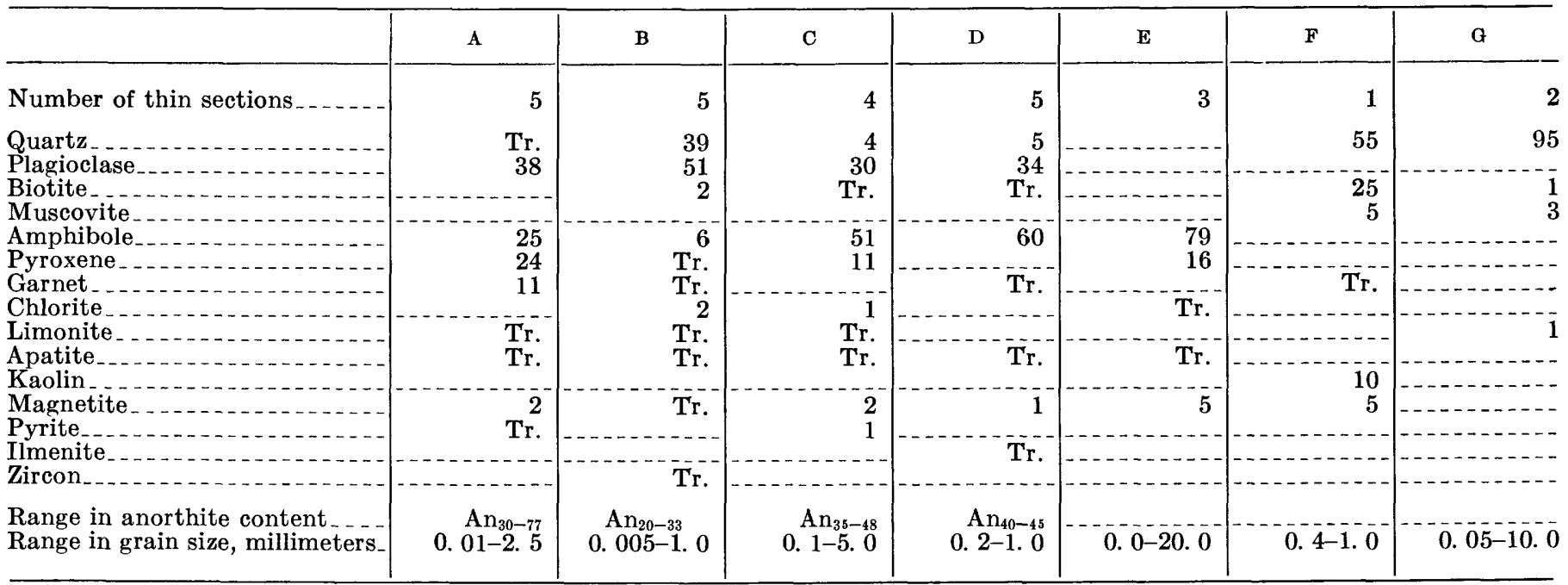

A. Garnet-hornblende-pyroxene gneiss.

B. Plagioclase-quartz gneiss.

C. Hornblende-pyroxene gneiss.

D. Plagioclase amphibolite.

E. Amphibolite.

F. Garnet-quartz-mica schist.

G. Micaceous quartzite. 
DESCRIPTION

\section{GARNET-HORNBLENDE-PYROXENE GNEISS}

The garnet-hornblende-pyroxene gneiss is well exposed in the most westerly outcrop south of State Route M-69 in sec. 8, T. 41 N., R. 27 W. In hand specimens it is a dark gray to black, fine-to medium-grained rock with light-colored laminae or lenses of plagioclase and scattered porphyroblasts of garnet. In thin section (fig. 18), pyroxene, garnet, and plagioclase form large grains that are set in a fine-grained matrix of hornblende and plagioclase.

Euhedral almandine garnets range in diameter from 1.0 to $2.5 \mathrm{~mm}$; many are surrounded by wide kelyphitic rims of amphibole, or amphibole and feldspar, and a few enclose quartz grains.

The amphibole in most specimens is hornblende, which occurs in part as uralitic replacements of pyroxene, peripherally or along cleavages, and in part as aggregates of small subhedral grains that form a mosaic with feldspar. The optical properties of an amphibole from an outerop along the powerline north of State Route $\mathrm{M}-69$ are as follows: $2 V_{(X)}=80^{\circ} ; \alpha=1.666$, $\beta=1.674, \gamma=1.683$; pleochroism: $X=$ pale yellow, $Y=$ pale green, $Z=$ dark green; $Z \wedge c=14^{\circ}$.

Pyroxene occurs as scattered large grains that are partly replaced by hornblende. Most of the pyroxene is augite, but in one specimen from a roadcut on the north side of M-69, the pyroxene is enstatite, with optic properties as follows: $2 V_{(Z)}=50^{\circ} ; \alpha=1.648$, $\beta=1.653, \gamma=1.660$; faint pink pleochroism.

Plagioclase occurs as large twinned grains 0.25 to $0.65 \mathrm{~mm}$ in diameter surrounded by a mosaic of more numerous untwinned small grains 0.015 to $0.065 \mathrm{~mm}$ in diameter. Most of the plagioclase is andesine, but some of the larger grains are labradorite-bytownite. The texture suggests that the larger twinned grains were phenocrysts, which have in part been broken up cataclastically to form the fine-grained matrix.

Magnetite is a minor accessory mineral.

\section{PLAGIOCLASE-QUARTZ GNEISS}

The plagioclase-quartz gneiss is a light-colored fineto medium-grained rock that forms layers ranging from a millimeter to a meter in thickness in almost all the exposed parts of the formation.

In thin section the most prominent feature is a laminated structure defined by ribbons of granular quartz. These ribbons are separated by fine-grained quartz and untwinned plagioclase, and interspersed through the rock are large twisted grains of twinned plagioclase. In some layers these plagioclase crystals are abundant, and the rock is porphyritic in aspect.

Relict grains of pyroxene are present in some specimens, but in most the pyroxene has been altered to green hornblende that makes up as much as 10 percent of the rock.

Biotite as scattered flakes and thin layers makes up 8 percent of one specimen and occurs as traces in a few others. The optical indices of the biotite are $\alpha=1.615$, $\beta=\gamma=1.658$.

\section{HORNBLENDE-PYROXENE GNEISS}

The hornblende-pyroxene gneiss occurs in most of the roadcuts along State Route M-69 and in many other outcrops. The rock is layered, fine to medium grained, and black and white or dark gray. Some of it contains scattered glassy feldspar grains.

Hornblende makes up 25 to 70 percent of most specimens. It occurs in networks, clusters, and scattered small grains. It is similar in habit and appearance to the hornblende in the garnet-hornblende-pyroxene gneiss.

Pyroxene, chiefly augite but enstatite in one specimen, occurs as relict grains surrounded by a mosaic of smaller hornblende grains. Typically it ranges in amount from 5 to 25 percent, but in one specimen (not included in table 22 ) augite makes up nearly 90 percent of the rock.

Plagioclase occurs in all but one of the sections examined, as large distorted grains of twinned andesine and as finer grained matrix material, also andesine. Quartz is present in only one of the rocks, where it is vermicular and interstitial to hornblende. Pyrite and magnetite are accessory minerals.

\section{PLAGIOCLASE AMPHIBOLITE}

The plagioclase amphibolite is exposed in several places along the power line north of State Route M-69; in the most easterly outcrop south of the East Branch of the Sturgeon River; and in the most northerly outcrop in the NEx/4 SW $1 / 4$ sec. 5 T. 41 N., R. 27 W. The rock is a dark-green to black fine- to medium-grained layered gneiss.

Hornblende is the dominant mineral, ranging in amount from 45 to 67 percent in the specimens studied petrographically. The optical properties of hornblende from one specimen are as follows: $2 V_{(X)}=70^{\circ} ; \alpha=1.671$, $\beta=1.693, \quad \gamma=1.698 ;$ pleochroism: $X=$ pale greenish yellow, $Y=$ olive green, $Z=$ grass green; $Z \wedge c=21^{\circ}$. Most grains are subhedral to anhedral and are well oriented. Commonly the hornblende is slightly altered to brown biotite.

The plagioclase is andesine. It occurs chiefly as grains interstitial to the hornblende. Most of the plagioclase is slightly altered to sericite. Quartz is present in two specimens examined as a minor constituent as grains enclosed in hornblende. Magnitite and ilmenite are the principal accessory minerals. 


\section{AMPHIBOLITE}

Amphibolite forms part of a large irregular outcrop near the south edge of sec. 5, T. 41 N., R. 27 W. Its distribution suggests that it originally was a dike or sill. The rock is massive, dark gray to black, and medium to very coarse grained.

Actinolitic hornblende is the chief constituent of the rock. Its optical properties are as follows: $2 V_{(X)}=75^{\circ}$; $\alpha=1.621, \beta=1.638, \gamma=1.647$; faint green pleochroism; $Z \wedge c=15^{\circ}$. Some slides contain as much as 15 percent relict pyroxene from which the amphibole has formed. Magnetite makes up to 5 percent of the rock by volume, and a trace of apatite is present.

\section{GARNET-QUARTZ-MICA SCHIST}

The garnet-quartz-mica schist is exposed in deeply weathered outcrops near the west edge of sec. 8, T. 41 N., R. $27 \mathrm{~W}$. The schist is fine to medium grained, iron stained, white streaked, and coarsely foliated; it consists principally of quartz and biotite (table 25, F), but locally is studded with garnets that weather out of the softer matrix. The white streaks are kaolin, probably derived from feldspar.

\section{QUARTZITE}

Quartzite crops out near the east margin of sec. 7, T. 41 N., R. 27 W. Most of the rock is reddish brown and vitreous, and contains scattered flakes and laminae of muscovite. The quartzite in the most westerly of the outcrops contains lenslike pods of quartz as much as $1 \frac{1}{2}$ inches long. This rock, which is poorly exposed, could be either a sheared conglomerate with stretched quartz pebbles or simply a shear zone in the quartzite. It grades within 2 feet into more normal quartzite.

\section{ORIGIN AND RELATIONS TO OTHER ROCKS}

The Hardwood gneiss, before metamorphism, appears to have consisted of basic and acidic volcanic rocks, some interlayered sedimentary rocks, and intrusive basic sills and dikes.

The pronounced layering characteristic of much of the rock appears to be original and probably reflects original alternations of tuffaceous material that ranged from dacite to basalt in composition. Much of the present mineralogic composition and texture of these banded rocks is metamorphic or cataclastic, but the pyroxene and the large twisted crystals of twinned plagioclase almost certainly are primary in origin, and the containing rocks probably were formed as crystal tuffs.

Rocks definitely of sedimentary origin, now quartzite and garnet-quartz-mica schist, are present at the extreme western margin of the area of outcrop. These rocks, which are structurally conformable with the more typical gneiss to the east, originated as sands and sandy muds.

Some of the more massive amphibolitic varieties of the gneiss appear to have been composed originally of augite for the most part-enstatite or hypersthene in one or two; these rocks presumably were pyroxenite dikes and sills before metamorphism.

The relationship of the Hardwood gneiss to other lithologic units in central Dickinson County can only be inferred. The structure of the gneiss is conformable with that in the mass of gneissic granite that adjoins on the west, so the two rocks presumably were deformed together. The plunge of linear structures in both is easterly at a low angle, so that the gneiss actually lies on the nose of an eastward-plunging structure. The gneiss, therefore, may be part of the original roof rock of the granite batholith, but the existence of possible conglomerate between the granite and most of the gneiss makes this conclusion uncertain; the gneiss conceivably is the younger rock.

\section{GNEISSIC GRANITIC ROCKS}

The rocks mapped as gneissic granite range in composition from alaskite to quartz diorite. Except for scattered aplitic and pegmatitic dikes that occur as narrow irregular but sharp-walled dikes, these rock types are gradational into each other and separation into distinct map units would be difficult, if not impossible. Much of the heterogeneity is local and appears due to assimilation of or reaction with included material, particularly amphibolite. Most of the rocks are faintly to distinctly gneissic. In places the gneissic structure is the result of compositional layering, but more commonly it is due to dimensional orientation of lenslike feldspar and quartz and to biotite-coated shear planes.

The principal rock type is gray to pink gneissic granite, with gneissic quartz diorite next in abundance; rocks intermediate between quartz diorite and granite, though widespread, are relatively scarce. Migmatite, consisting of interlayered granitic rock with darker hornblende-rich material, is of widespread occurrence but is a relatively minor constituent of the complex.

\section{GNEISSIC GRANITE}

The gneissic granite is a massive pink or gray medium- to coarse-grained rock, very uniform in appearance. It is well exposed in large bold outcrops, the most readily accessible of which are adjacent to the county road in sec. 22, T. 41 N., R. 30 W. Much of the gneissic granite is slightly to strongly porphyritic and locally it contains feldspar crystals as much as 4 inches in length. The rock is foliated, very strongly so in some exposures. The foliation is marked 
by dimensional orientation of the larger feldspar grains, which are augen-shaped, and by discontinuous foils of dark mica, which curve around the augen. In some places, but most notably in the east part of sec. 3, T. 41 N., R. 28 W., foliation is subordinate to a linear structure that is due to parallel alinement of spindle-shaped quartz and feldspar.

The gneissic granite is characterized by irregular textures and by great variations in grain size that are not particularly evident except under the microscope. Potash feldspar and quartz are the principal minerals, plagioclase commonly is present but rarely in excess of 10 percent, and biotite is the typical mica though not uncommonly accompanied by muscovite. Most specimens show scattered large anhedral phenocrysts of potash feldspar with exceedingly irregular outlines separated by a relatively fine grained matrix composed of microcline, quartz, and plagioclase. Some rocks also contain large albite crystals of similar habit (fig. 24). The potash feldspar in the phenocrysts commonly is slightly perthitic and shows microcline twinning, but in some specimens it is obscurely mottled and not recognizably twinned. The plagioclase of the larger crystals in albite $\left(\mathrm{AN}_{5-10}\right)$ and may or may not be twinned. The matrix between the large feldspars consists chiefly of quartz and clear nonperthitic subhedral microcline grains that show characteristic grid structure under crossed nicols. Albite or albite-oligoclase is a minor constituent of the matrix. Biotite and muscovite occur both as small interstitial flakes in the matrix and as larger flakes intermediate in size between the matrix and the large feldspars. Accessory minerals are scarce; they include zircon, titanite, apatite, and the iron ores. Most samples of the gneissic granite show considerable alteration, particularly of the plagioclase and the biotite. The plagioclase is sericitized, almost completely in some slides, and not uncommonly is stained by finely disseminated red hematite dust, and the biotite is partly or completely altered to green chlorite. The average mode of gneissic granite is given in table 27 ; in the table, alteration products are included with the mineral in which they occur.

TABLE 27.-Modes of rocks from the gneissic granite complex

\begin{tabular}{|c|c|c|c|c|}
\hline Rock composition & Granite & Syenite & $\begin{array}{c}\text { Quartz } \\
\text { monzonite }\end{array}$ & $\begin{array}{l}\text { Quartz } \\
\text { diorite }\end{array}$ \\
\hline $\begin{array}{l}\text { Quartz } \\
\text { Potash feldspar 1 } \\
\text { Plagioclase } \\
\text { Biotite } \\
\text { Muscovite- } \\
\text { Hornblende- } \\
\text { Other }\end{array}$ & $\begin{array}{r}32 \\
54 \\
27 \\
5 \\
2\end{array}$ & $\begin{array}{r}\text { Tr. } \\
86 \\
35 \\
6 \\
2\end{array}$ & $\begin{array}{r}36 \\
28 \\
425 \\
4 \\
7\end{array}$ & $\begin{array}{r}34 \\
2 \\
450 \\
6 \\
3 \\
5\end{array}$ \\
\hline Other-................ & $-1-1$ & 1 & $\cdots-\cdots$ & $\ldots$ \\
\hline $\begin{array}{l}\text { Grain size } \\
\text { Number of thin sections. }\end{array}$ & $\begin{array}{r}0.01-2.5 \\
10\end{array}$ & $\begin{array}{r}0.5-5.0 \\
1\end{array}$ & $\begin{array}{r}0.2-2.0 \\
3\end{array}$ & $\begin{array}{r}0.2-2.5 \\
9\end{array}$ \\
\hline
\end{tabular}

The granite appears to have been granulated and recrystallized. The finer grained matrix material has in part replaced the broken edges of the larger feldspar grains and a few of these large grains show actual fracturing and distortion of twin lamellae.

\section{QUARTZ DIORITE}

The rock of quartz diorite composition is massive, medium grained, and gray. It is not readily distinguishable in the field from rock of more granitic composition, into which it appears to grade imperceptibly, but most of it is nonporphyritic, and foliation is not as pronounced as in the granitic rock. The abundance of the quartz diorite is difficult to estimate, but it probably does not make up more than 20 percent of the granitic complex.

The quartz diorite, as seen in thin section, typically is a medium-grained somewhat irregular mosaic of interlocking plagioclase and quartz. Potash feldspar is rare or absent. Biotite is present as scattered flakes in all slides examined and muscovite is present in some. Greenish hornblende occurs locally as large grains of irregular outline but is entirely absent in many slides. The plagioclase, which forms clear welltwinned equant grains, shows a range in composition from sodic oligoclase to calcic andesine in samples from different locations, but oligoclase is the most common variety. The plagioclase is rarely zoned, though in many slides an occasional grain is partly bordered by albite. Accessory minerals are scarce. The average mode of the quartz diorite is given in table 27 .

The quartz diorite, to judge from the thin sections available, is less altered to secondary minerals than is the granite, and most specimens show little or no evidence of shearing.

\section{ROCKS OTHER THAN GRANITE AND QUARTZ DIORITE}

Rocks intermediate between granite and quartz diorite are not abundant, but all gradations of texture and composition can be found. These intermediate rocks in general partake of the features common to one or the other of the two principal rock types in the complex and consequently are not given separate description. The remarks that follow concern only those rocks that depart from the gradational sequence.

Most of the gneisses transitional between granite and included material (generally amphibolite) have gradational boundaries or are migmatitic, with screens of undigested rock separated by granitic material. Some, however, have a spotted, or "fruit-cake", structure, with spherical nests of randomly oriented biotite flakes about a quarter of an inch in diameter in a matrix that contains much less potash feldspar than the normal granitic rock. Another unusual variety of 
gneiss is a mafic-free granite that surrounds some of the more quartzose inclusions in the western part of the central crystalline block. This rock is an inequigranular assemblage of heavily perthitic potash feldspar, albite, and quartz.

Migmatite is found at many localities in the area but probably constitutes less than 5 percent of the exposed rock in the granitic complex. Near the center of the SWT/4 sec. 18, T. 41 N., R. 29 W., amphibolite, biotitic feldspathic quartzite, and gneissic granite are interlayered in units $1 / 2$ to 8 inches in thickness. This migmatite is contorted into folds 1 to 4 feet in width. The more typical migmatite, however, contains layers that are less sharply defined; in them, layers of granitic material alternate with and are gradational into darker layers that are richer in hornblende or biotite.

The rocks of the granitic complex are cut by dikes of aplite, pegmatite, and metadiabase and by many irregular quartz veins and stringers.

\section{ORIGIN AND RHLATIONS TO OTHER ROCKS}

The oldest materials within the Lower Precambrian crystalline complexes are the inclusions of amphibolite and quartzitic rock in the gneissic granite, and the Hardwood gneiss. These rocks, in part of volcanic and in part of sedimentary origin, are remnants of the original terrane into which the granitic rocks were emplaced. Presumably these older strata originally were part of the succession now described as the Dickinson group. Foliation and linear structures in the included rock are parallel to those in the granite, so the two rocks have been deformed together. This deformation is shown to be earlier than the Animikie by the fact that the structures in the gneiss are truncated and the gneiss unconformably overlain by Fern Creek formation or by Sturgeon quartzite.

The mechanism by means of which the gneissic granite was emplaced is not entirely clear. Almost certainly it was complex. The uniform granitic composition of large parts of the crystalline mass and the clearcut evidence of local truncation of amphibolite and migmatite by offshoots of the gneissic granite indicate magmatic origin, yet gradations of one granitic rock into another, transitional boundaries between granite and many inclusions, and apparent retention of original structural position by the inclusions all suggest that other mechanisms were operative. The field evidence leads to the conclusion that the granitic rock originated in part by actual magmatic intrusion, and that this intrusion was accomplished during a period of intense deformation, during which time some of the older rocks underwent extensive alteration and replacement and others, of appropriate composition, were partially melted. The amount of actual magma that existed at any one time may not have been large. The entire mass, granite and country rock alike, appears to have been plastic. Deformation continued after much of the granite was emplaced, as attested to by the foliation that is in part due to granulation of feldspar, so that the structures within the granite are parallel to both the internal structures and the gross outlines of the inclusions.

\section{MIDDLE PRECAMBRIAN ROCKS}

The Middle Precambrian strata-the Animikie series-rest with profound unconformity on the Lower Precambrian crystalline rocks.

The Animikie strata are divided into three groups. From oldest to youngest these are: (1) Chocolay group, comprising the Fern Creek formation, the Sturgeon quartzite, and the Randville dolomite; (2) Menominee group, comprising the Felch formation and Vulcan iron-formation; and (3) the Baraga group, comprising the Michigamme slate and the Badwater greenstone. These groups are separated by disconformities or unconformities.

\section{CHOCOLAY GROUP}

\section{FERN CREEK FORMATION}

The Fern Creek formation was described first by Pettijohn (1943), who applied the term to a thin sequence of strata that includes tillite, conglomerate, arkosite, and argillite, which in parts of southern Dickinson County lie between the typical Sturgeon quartzite and the older gneisses. The only exposure in the area under discussion is a 500-foot-long plaster on a high bluff of gneissic granite in sec. 32, T. 41 N., R. $29 \mathrm{~W}$. The outcrop was described by Bayley (1904, p. 191), who considered the rock merely the basal phase of the Sturgeon quartzite. About 70 feet of conglomerate is exposed. The rock contains gneiss, coarse pink granite, and vein quartz as angular to rounded boulders, cobbles, and pebbles as much as $1 \frac{1}{2} \mathrm{ft}$ in diameter. The percentage of pebbly material ranges from about 30 percent near the base to about 10 percent in the uppermost rock exposed. The basal contact of the conglomerate trends northward and truncates the northeastward-trending foliation of the underlying gneissic granite. Some quartz veins in the granitic rock are truncated at the contact. Other quartz veins and a westward-trending metadiabase dike cross both the gneissic granite and the conglomerate.

More complete sequences of the Fern Creek occur at localities southeast of the one described above. Detailed descriptions are given by Pettijohn (1943) and by Trow $(1948$, p. 8-31). The tillite recognized by Pettijohn in the sequence at the type locality of the 
Fern Creek in secs. 27 and 34, T. 40 N., R. 29 W., apparently is not represented in the one exposure of Fern Creek in central Dickinson County.

\section{STURGEON QUARTZITE}

The Sturgeon quartzite is the basal formation of the Middle Precambrian rocks in most parts of the map area where relationships are known. The rock is well exposed in a series of large bluffs along and adjacent to Pine Creek in the south-central part of the area and in outcrops along a 5 -mile belt in the northwestern part of the area. The terrane underlain by the quartzite is rocky and more like that of the older gneissic granite than that of other Animikie formations.

Massive vitreous quartzite is the principal rock type in the formation, but greenish sericitic quartzite forms the lower part of the formation in places, particularly in the southwest part of T. 41 N., R. 29 W. Finegrained magnetite-bearing quartzite is present locally in both the upper and lower parts of the formation, and diopside-bearing quartzite occurs locally in the upper parts.

\section{LOWER SERICITIC QUARTZITE}

The lower part of the Sturgeon quartzite in the Pine Creek area is exposed in secs. 29, 31, and 32, T. 41 N., R. $29 \mathrm{~W}$., as scattered low relatively small outcrops or on the eastern flanks of larger outcrops of vitreous quartzite. The maximum thickness is 350 feet. The most complete exposure of the unit is in the southwest quarter of sec. 29 , T. 41 N., R. 29 W., about 1,100 feet north of the south line of the section. At this locality most of the rock is fine-grained gray or green sericitic quartzite or quartzose schist with a few layers that are of coarser grain. Some of the rock is decidedly schistose, some contains octahedra of martite after magnetite, and a 20 -foot thickness of silvery argillite occurs near the upper part of the section. Crossbedding, which is typical of the more massive part of the Sturgeon quartzite, was observed only in nonschistose quartzite layers near the middle of the lower unit.

In thin section the typical sericitic quartzite is seen to be composed of 75 percent quartz and 25 percent sericite. Most of the sericite is colorless but some is faintly green. Euhedral crystals of magnetiteor martite after magnetite-are present in some specimens. One slide contains aggregates of quartz, which appear to be pseudomorphs after andalusite, and abundant chlorite ( 17 percent) that probably is secondary after biotite. The specimen was collected from sericitic quartzite adjacent to a metadiabase dike; conceivably the andalusite and biotite were formed by contact metamorphism prior to regional metamorphism, but more likely the minerals were formed during the regional metamorphism and the alteration to quartz and chlorite is a later retrograde effect.

The relationship between the sericitic member of the Sturgeon quartzite and the locally underlying Fern Creek formation appears to be one of conformity, and in fact the two are in gradational contact at Loretto dam on the Sturgeon River in sec. 8, $\mathbf{T}$. 39 N., R. 28 W. (Trow, 1948). At the latter locality the contrast between the feldspar-rich arkosite and conglomerate of the Fern Creek formation with the green sericitic nonfeldspathic Sturgeon quartzite is marked.

\section{VITREOUS QUARTZITE}

Most of the Sturgeon quartzite is a nonsericitic white vitreous medium- to coarse-grained quartzite. Outcrops of this rock are massive and some are a thousand feet or more in length. In almost all outcrops some layers can be found that show crossbedding, though in general bedding is quite indistinct. The rock rarely parts on bedding planes except along ripple-marked surfaces, which are fairly numerous, and here chiefly because of the presence of a micaceous film. These ripple-marked surfaces commonly are the only ones on which reliable measurements of bedding direction can be made. Jointing is strongly developed and is the dominant structural feature. Some outcrops, especially those near faults, are crossed by networks of quartz veins that have indistinct contacts with the enclosing quartzite.

Thin layers of pebble conglomerate, a foot or so thick, are locally present in the lower part of the formation. Most of the pebbles are quartz, and few are more than an inch in diameter. In the Browning Creek area (sec. 20, T. 41 N., R. 30 W.) a conglomerate layer, here studded with black pebbles of tourmalinerich rock, is separated from underlying gneissic granite by perhaps 50 feet of a schistose quartzsericite rock. Similar schistose rock underlies the lower sericitic member of the Sturgeon in the NE1/4 sec. 32, T. 41 N., R. 29 W., in outcrops 4,100 feet north and 3,500 feet east of the southwest corner.

Petrographic examination shows that the typical vitreous quartzite consists of about 98 percent quartz, which forms a sutured mosaic, and 2 percent sericite, most of which is interstitial (fig. 27). The quartz grains in any one specimen, though irregular in outline, are fairly uniform in size, but the size range in different specimens is large: the range in mean diameter is from less than $0.1 \mathrm{~mm}$ to $1.0 \mathrm{~mm}$, which indicates that the present grains reflect the original differences in size of clastic particles even though no outlines of those particles are preserved. The quartz 
grains, except in zones of shearing, do not show undulant extinction. Some specimens contain scattered flakes of biotite, commonly altered in part to chlorite, in addition to sericite. Zircon, titanite, and tourmaline occur as widely scattered clastic grains.

The less common finer-grained quartzite is much more varied in texture and composition. Some specimens consist of a fine-grained quartz mosaic studded with small crystals of magnetite, similar to that illustrated in figure 30 . Others consist of fine-grained clastic quartz and feldspar in a matrix of sericite, biotite, interstitial potash feldspar, and magnetite, and one specimen examined contains layers rich in pale-green actinolite.

Diopside-bearing schistose quartzite is exposed near the east quarter corner sec. 10, T. 41 N., R. 30 W., and in the outcrops adjacent to county highway 607 in the $\mathrm{SE} / 4$ sec. 9 of the same township. At both places the rock appears to be in the upper part of the formation, and probably is a transitional phase between the Sturgeon quartzite and the Randville dolomite. The rock contains irregular granules of diopside, blades of tremolite, and some muscovite in a quartz matrix.

\section{THICKNESS AND RELATIONS TO ADJACENT FORMATIONS}

The thickness of the Sturgeon quartzite appears to range from about 500 feet to about 1,850 feet. The greatest thickness is attained in the belt adjacent to Pine Creek, in the south-central part of the area, which is also the only area in which it has been possible to separate a lower sericitic member and also the only place at which the Fern Creek formation is present. The great thickness of the Sturgeon at this locality is due only in small part to the presence of the sericitic member, which attains a maximum thickness of 350 feet; the amount of vitreous quartzite is much greater here than elsewhere. The coincidence of thickening of the vitrous quartzite with the distribution of the sericitic member and of the Fern Creek formation suggests strongly that during Sturgeon and Fern Creek time the depositional basin in this particular area subsided more rapidly than elsewhere. That it does not represent simply an originally deeper part of the basin is shown by the presence of crossbedding, indicative of shallow water, throughout the entire formation.

Except for the small area in which the Sturgeon is conformably underlain by the Fern Creek formation, the basal contact of the unit is a surface of profound unconformity. The actual contact with the pre-Sturgeon gneissic granite is exposed at only one place in this area, namely, in sec. 20, T. 41 N., R.
$30 \mathrm{~W}$. The relations at this locality are described by Pettijohn (1943, p. 395-396) as follows:

In the southeast one-quarter of the northwest one-quarter of Section 20 the contact of the quartzite and the granite gneiss may be studied in detail. It is unsheared and unfaulted. Below the usual fine-grained vitreous quartzite of the Sturgeon and above the gneiss is a very coarse, greenish yellow sericitic quartzite. The weathered surface is minutely pitted and roughened, and it superficially resembles the granite. Large clastic quartz grains, $1 / 8-1 / 2$ inch in diameter, weather into relief, while the sericite-filled interstices are responsible for the pits. This phase is massive and devoid of bedding, though a rude foliation due to pressure is apparent. It appears to grade, in a distance of a few feet, into granite. That this rock is neither a phase of the granite nor a granitized quartzite, however, is proved by its sharp contact with the normal Sturgeon and its reappearance in a lesser bed above typical quartzite.

Remapping of the area during the present study has resulted in some slight modification of the map pattern from that shown by Pettijohn (1943, fig. 4), but the essential conclusion remains the same-that is, that the Sturgeon quartzite is here unquestionably in unconformable contact with the granite. However, the sericitic material that separates the granite from the more typical vitreous quartzite of the Sturgeon probably is not of sedimentary origin but represents the surface material produced in place by preSturgeon weathering of the gneissic granite. Repetition of similar material at a higher position in the Sturgeon quartzite, noted by Pettijohn, is due to movement along a fault that is nearly parallel to bedding.

The relationship between the Sturgeon quartzite and the overlying Randville dolomite is not known, although the presence of the diopside-rich quartzite, previously described in the upper part of the formation suggests that this upper part was originally calcareous and that the contact is transitional.

\section{RANDVILLE DOLOMITE}

Only three outcrops of Randville dolomite are known in the southern part of central Dickinson County, although the unit is assumed to have an areal extent comparable to that of the Sturgeon quartzite. These outcrops are in the northeastern part of sec. 11, T. 41 N., R. 30 W., in the NE $1 / 4$ sec. 30 , T. 39 N., R. $29 \mathrm{~W}$., and in the southern part of sec. $31, \mathrm{~T} .41 \mathrm{~N}$., R. $29 \mathrm{~W}$. The dolomite was encountered in workings of the old Calumet mine in sec. 8 , T. 41 N., R. 28 W., and in several drill holes in the Calumet area.

\section{DESCRIPTION}

The rock exposed in sec. 32, T. 41 N., R. 29 W., is a thin-bedded buff granular dolomite with thin interbeds or laminae of more argillaceous material. 
Some of the dolomite layers contain quartz grains as much as an eighth of an inch in diameter. The rock is cut by quartz-tourmaline veins. Further description is given by Bayley $(1904$, p. 193). The rock exposed in sec. 30 , T. 39 N., R. 30 W., appears to be deeply weathered silicified dolomite; most of it is a porous mass made up of pods and stringers of fine-grained quartz with limonite-stained surfaces.

The rock in the outcrop area in sec. 11 and that encountered in the mine workings and drill holes is, for the most part, a massive white coarse-grained dolomite marble with varying amounts of tremolite and diopside. In the sec. 11 outcrops, however, this dolomite appears to be interbedded with brownweathering vitreous to micaceous quartzite and with hornblende schist. The most northerly exposures are of quartzite, which presumably is in fault contact with the older gneissic granite. The composition of this quartzite, as determined from four samples examined petrographically, is 74 percent quartz, 7 percent muscovite, 5 percent hornblende, 4 percent each of tremolite, biotite, and pyrite, and 2 percent diopside. The hornblende schist forms six small outcrops near the southeast end of the outcrop area. The exposures probably are the faulted segments of an originally continuous layer less than 20 feet thick. The rock is dark gray to black, faintly foliated, fine to medium grained. It is very similar in megascopic appearance to the amphibolite layers in the older gneissic granite, but under the microscope it is seen that the rock contains no plagioclase. The composition is approximately 45 percent hornblende, 25 percent quartz, 30 percent biotite (partly altered to chlorite).

\section{THICKNESS AND RELATIONS TO ADJACENT FORMATIONS}

The thickness of the Randville in this part of central Dickinson County is assumed to be 500 to 1,000 feet. The greatest thickness known from direct evidence is about 150 feet, disclosed by drill hole $64 \mathrm{C}$ in sec. 8 , T. 41 N., R. 28 W. (see pl. 4.)

No information is available in this area as to the relationship between the Randville dolomite and the underlying Sturgeon quartzite, but the contact between the dolomite and the overlying Felch schist has been crossed by several drill holes in the Calumet mine area. (See pl. 4.) The contact is abrupt, and no transitional rocks are present between the coarse white dolomite marble and the quartzite or quartz-mica schist of the Felch. Although no direct indications of unconformity, such as conglomerate, have been observed, the sharpness of the contact and absence of transitional material bear out the conclusion stated elsewhere in this report-namely, that the relation- ship between the two formations is one of disconformity or unconformity.

\section{MENOMINEE GROUP}

FELCH FORMATION

The Felch formation is not exposed at any place within the south part of central Dickinson County, but it has been entered by underground workings and by many drill holes in the Calumet mine area (see pl. 4).

Quartz-mica schist with layers of dark vitreous quartzite is the major rock type in the Felch formation, as indicated from the descriptions in table 28 of core from drill holes that passed from ironformation through the Felch formation and into Randville dolomite. These holes cut the formation approximately normal to bedding, so that the thicknesses given represent approximately true stratigraphic thickness. Most of the rock examined is deeply oxidized. Magnetite is present as scattered euhedral crystals in most of the schist, and locally it forms layers so that the rock resembles the Vulcan iron-formation.

The thickness of the Felch formation in the Calumet mine area appears to range from 50 to 100 feet. The nature of the contact with the underlying Randville dolomite has been described in preceding pages: it is an abrupt break that probably is a surface of disconformity or unconformity. The contact with the overlying Vulcan iron-formation is gradational with at least local interbedding of schist and ironformation.

TABLE 28.-Thickness and description of Felch formation from drill holes that passed from Vulcan iron-formation through schist into Randville dolomite

[In sec. 8, T. 41 N., R. 28 W.]

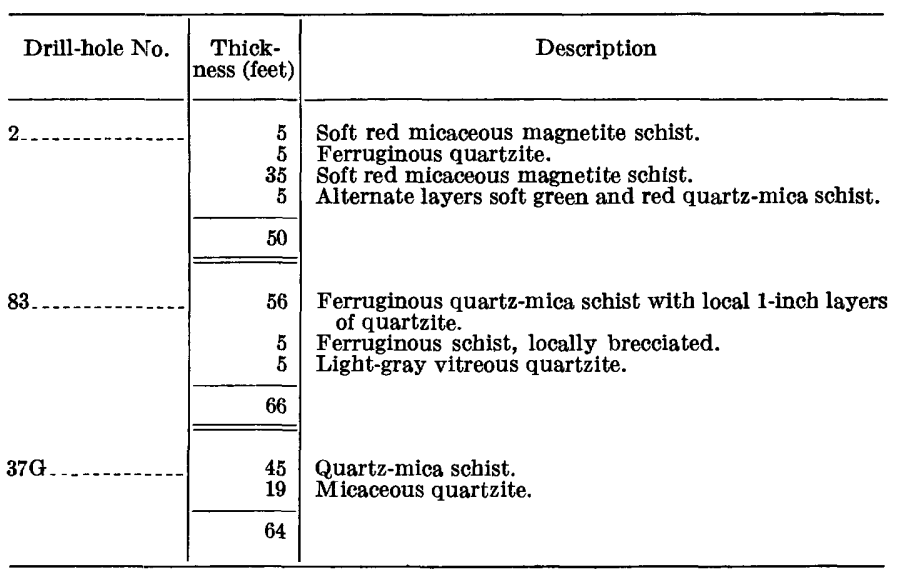

VULCAN IRON-FORMATION

The known outcrop of the Vulcan iron-formation in the area is in the north part of sec. 15, T. $41 \mathrm{~N}$., 
NW.
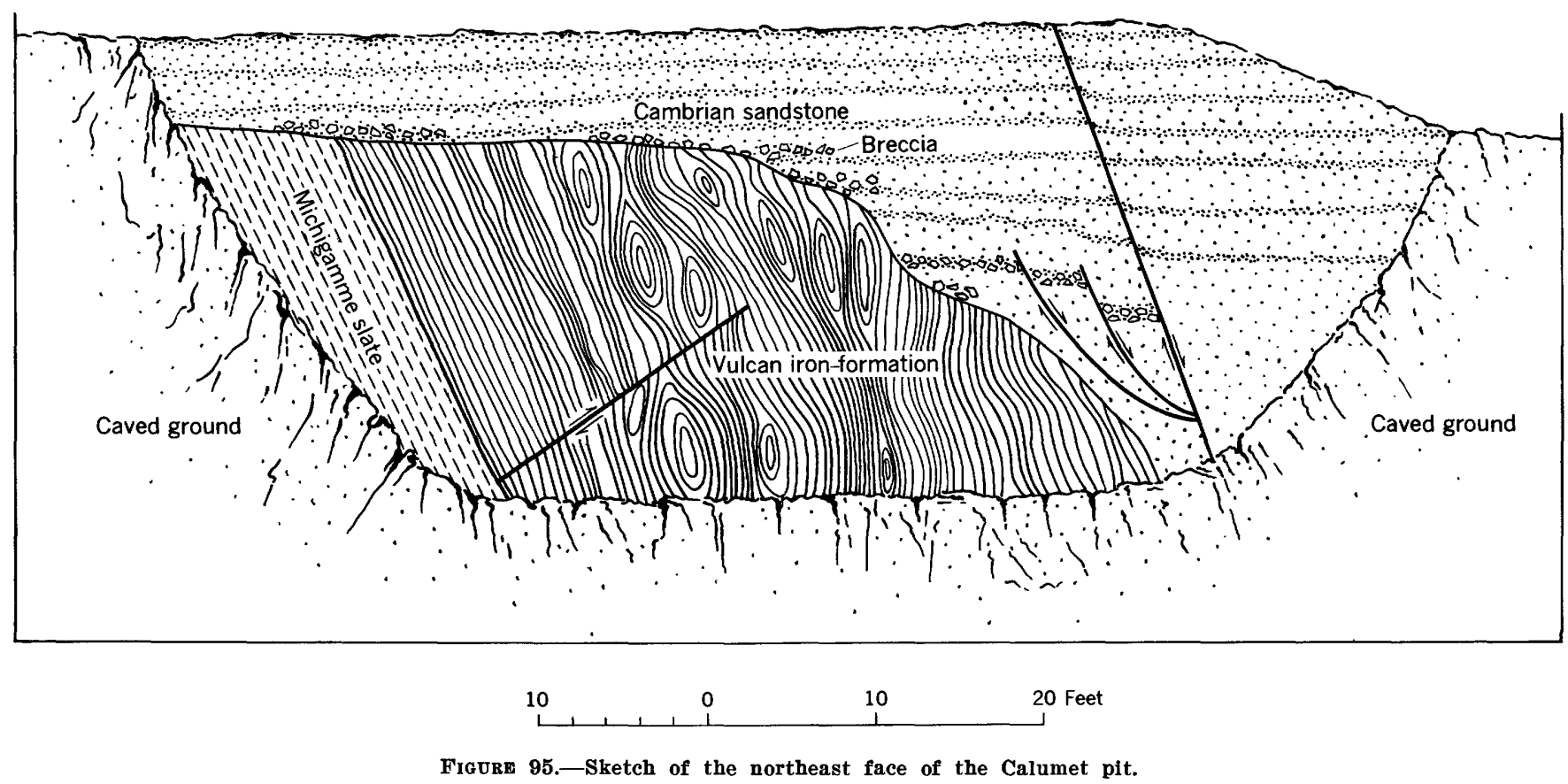

R. 29 W. (pl. 4), but the formation is also exposed in the caved workings of the old Calumet mine, in sec. 8, T. 41, N., R. 28 W., and has been entered by drill holes in secs. 8, 9, and 17, T. 41 N., R. 28 W., and in sec. 15, T. 41 N., R. 29 W. The iron-formation is strongly magnetic, and the lack of magnetic anomalies in areas that otherwise seem appropriate for the occurrence of this unit is interpreted to indicate that the iron-formation is absent except at the localities enumerated above.

\section{DESCRIPTION}

The Vulcan iron-formation is a thin-bedded rock made up essentially of alternate layers of magnetite and recrystallized cheri. Most of the material examined has been oxidized, so that the layers that originally were magnetite now consist of bluish-gray or silvery-gray hematite, and the metachert layers, which are dark gray in unaltered material, are reddish. Individual layers typically are 0.1 to 0.5 inches thick; some are uniform in thickness along the strike but others pinch and swell, and irregular lenses are common.

In thin sections, the metachert layers are seen to be an aggregate of quartz grains with irregular sutured or mosaic texture. The grain size of the quartz ranges from 0.005 to $20 \mathrm{~mm}$, but most are 0.10 to $0.20 \mathrm{~mm}$. Most chert layers are peppered with small euhedral magnetite crystals and some contain scattered blades of grunerite. The magnetite-rich layers consist of aggregates of euhedral to subhedral magne- tite grains separated by quartz or by bladed grunerite. The latter mineral forms as much as 10 percent of some slides; locally it has been replaced by calcite and limonite in a manner as to suggest that both are supergene. One specimen of iron-formation, taken from drill hole $27 \mathrm{C}$ in sec. 15, T. 41 N., R. $29 \mathrm{~W}$. shows magnetite-quartz layers that contain about 10 percent apatite as well-formed crystals, most of which are less than $0.1 \mathrm{~mm}$ in diameter. In the same layers with the apatite are abundant grains of a green amphibole, which is different in character from any observed elsewhere, and which is not readily classified. Some of the optical properties of this amphibole are as follows: Pleochroism very slight, $2 \mathrm{~V}$ near $90^{\circ}$, negative elongation, $\mathrm{c} \wedge X=33^{\circ}(?)$, strong dispersion.

\section{THICKNESS AND RELATIONS TO ADJACENT FORMATIONS}

The thickness variations in the Vulcan iron-formation in this area are shown by the cross-sections on plate 4. The maximum thickness is on the order of 200 feet in the areas explored.

The gradational contact of the Vulcan iron-formation with the underlying Felch formation has been described in the discussion of the latter unit. The contact between the Vulcan iron-formation and the overlying Michigamme slate is visible in the walls of the caved ground at the old Calumet Mine, and though some details are obscured because of deep oxidation, the two formations appear to be strictly conformable (fig. 95). The contact has been intersected by a dozen or more drill holes in the area. 
The contact as seen in the core is abrupt, but, as in the pit exposure, it is not marked by angular relations between the beds or by conglomerate. Nevertheless, the areal relations show that the two formations are unconformable. The absence of ironformation in most of the area, and features such as the exceedingly rapid local decrease in thickness shown in sec. 8, T. 41 N., R. 28 W. (pl. 4), are interpreted as being due to pre-Michigamme stripping rather than to non-deposition, largely on the basis of the nature of the formation-a chemical precipitate that would not be expected to thin or thicken so rapidly-and because of the regional pattern: in the Menominee district, about 10 miles to the south, the thickness is 600 to 700 feet (Bayley, 1904, p. 359361), and even in the Felch trough, where the formation is present only in synclines that contain no younger formations, a thickness possibly of as much as 400 feet is preserved.

\section{BARAGA GROUP}

\section{MICHIGAMME SLATE}

The Michigamme slate underlies a larger part of the southern part of central Dickinson County than any other rock unit. It underlies all but an areally insignificant part of the Calumet trough proper. The principal areas of outcrop are (1) secs. 23, 24, and 26, T. 41 N., R. $30 \mathrm{~W}$. and the adjacent sec. 19 , T. 41 N., R. 29 W., (2) sec. 15 , T. 41 N., R. 29 W., and (3) a narrow belt along the West Branch of the Sturgeon River, in sec. 24, T. 41 N., R. 29 W., and secs. 19,20 , and 21, T. 41 N., R. 28 W. In general, the rock is not resistant to erosion, and most exposures are small and inconspicuous.

\section{DESCRIPTION}

The principal rocks of the Michigamme slate are graywacke and biotite-muscovite schist. Garnetiferous schist, magnetite-bearing schist and graywacke, staurolite schist, and biotite-chlorite schist are present but are less common. These rocks are interbedded in units ranging in thickness from a fraction of an inch to several feet, and many beds show graded bedding from a more siliceous, and originally coarser grained, base to a micaceous top. Graywacke and schist are present in roughly equal proportions in the exposures, but schist is probably the dominant rock in the unexposed parts of the formation. Biotitegarnet schist, some of which contains abundant magnetite, is virtually restricted to the extreme north margins of the Calumet trough; this rock occurs abundantly in the outcrops in secs. 12 and 15, T. 41 N., R. 29 W. and in sec. 7, T. 41 N., R. 28 W., and is cut by drill holes in the Calumet mine area. Iron- formation has been exposed by test pits at the old Hancock exploration in sec. 30, T. 41 N., R. 27 W.; the rock is included within the Michigamme slate on the maps and is described here, but it possibly is a part of the Vulcan iron-formation.

Most of the variations in rock characteristics are reflections of original differences in the sediment, but some are due to differences in metamorphic grade (see pl. 6). It is difficult to place the boundaries between the metamorphic zones precisely, in part because of scarcity of outcrops but principally because the appearance of characteristic minerals is dependent upon appropriate bulk composition of the rock. Most of the exposed part of the Michigamme slate in this area is within the garnet and staurolite zones, but some outcrops in the southwestern part of the area are within the biotite zone. The zones are distributed with respect to the principal areas of outcrop approximately as follows: (1) The exposures in the westernmost part of the area, west of State Route M-95, are in the biotite zone except for the most northerly exposures in sec. $24, \mathrm{~T} .41 \mathrm{~N}$., R. 31 W.; (2) the exposures in the south half of sec. 24 , T. 41 N., R. 30 W., and those between this area and State Route $\mathrm{M}-95$ are in the garnet zone; (3) the exposures in the north half of sec. 24 , and all those east of this area, are in the staurolite zone. One point must be stressed: assignment of an area to, say, the garnet zone does not mean that all rocks within that zone will contain this index mineral; actually only a very small percentage are of appropriate bulk composition for garnet to have developed.

Graywacke.-The typical graywacke is a massive dark gray fine- to medium-grained rock, yellowish gray on weathered surfaces. The megascopic appearance ranges from quartzitic to schistose, but the bulk of the rock is a fine- to medium-grained granulite in which original clastic grains are not recognizable. The graywacke from the garnet and staurolite zones is not notably different in general aspect from that in the biotite zone.

The differences between specimens of graywacke are much more evident in thin section than in hand specimen. Graywacke from the biotite zone has an irregular texture. Some of the larger grains of quartz and feldspar retain angular to subrounded outlines, but the smaller grains form a sutured mosaic through which are scattered small flakes of chloritized biotite and occasional grains of epidote, calcite, magnetite, and apatite. One specimen from sec. 24, T. 41 N., R. 31 W., contains about 20 percent clinozoisite. Most of the larger feldspar grains are twinned 
albite, and the plagioclase of the matrix is untwinned albite. Graywacke from the garnet and staurolite zones is typically granulitic in texture; quartz and untwinned oligoclase (sodic andesine in rock from the staurolite zone) form an equigranular mosaic with flakes of biotite and muscovite and scattered crystals of magnetite. Potash feldspar is present in some of the coarser-grained rocks as mottled clastic grains, but it does not occur in the recrystallized mosaic. Only the coarse-grained graywacke retains original clastic textures (figs. 54, 55); the larger quartz grains, which are of clastic origin, typically show undulatory extinction, whereas those of the matrix are unstrained.

The average mineral composition of the graywacke, determined from 10 samples and excluding those from the westernmost part of the area, is as follows:

Quartz Percent,
$b y$ volume

Feldspar (mostly oligoclase)

Biotite (partly altered to chlorite)

Muscovite

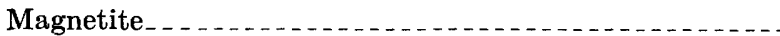

Others (apatite, hornblende, pyrite; epidote)

Graywacke from the western part of the area differs in that it contains less biotite and more epidote (or clinoziosite), and clastic feldspar that is different in composition from that of the groundmass.

Small ellipsoidal or lenticular concretions have been observed in a few exposures of graywacke. These concretions, originally calcareous, differ mainly from the enclosing graywacke in that they contain more quartz and feldspar and less biotite. Some are fringed with needlelike hornblende; garnet, which is of rare occurrence in the graywacke, is present as sparse crystals around the margins of a few.

Biotite-muscovite schist.-The biotite schist interbedded with the graywacke is a gray or brownishgray fine- to medium-grained rock with well-defined schistosity. A linear structure marked by elongated biotite flakes commonly is apparent.

The schist consists of parallel folia of biotite and muscovite, in part as separate flakes and in part intergrown, separated by ribbons and lenticles of quartz and feldspar (see fig. 58). The quartz grains within the ribbons and lenticles typically are tabular in form, with the greatest dimension in the direction of foliation. The feldspar occurs as single lenslike grains. The identity of the feldspar is uncertain, as in all specimens examined it is considerably altered to sericite and stained with iron oxide; some grains show zcning, so they presumably are plagioclase, but probably both plagioclase and potash feldspar are present. Magnetite is the most abundant accessory mineral; it occurs as scattered small subhedral crystals, and may make up as much as several percent of the rock. Chlorite derived by alteration of biotite is present in all slides. It is a clear green low-birefringent variety. The pattern of chlorite alteration is erratic: in some slides all the biotite flakes are partly altered; in others, the biotite flakes that lie athwart the schistosity may be completely chloritized, whereas those in the plane of schistosity may be altered only slightly or not at all. Apatite and tourmaline occur as minor accessories.

The average mineralogic composition of the biotite-muscovite schist is approximately as follows:

Biotite (in part altered to chlorite)

Muscovite (including sericite)

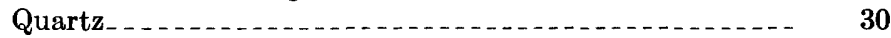

Feldspar (both plagioclase and potash feldspar) _...... 10

Magnetite _................................. 5

Others (such as apatite, epidote, tourmaline)

All gradations between rock of this composition and graywacke can be found.

Biotite-garnet schist.-Most of the biotite-garnet schist that has been observed occurs in the lower part of the formation. The rock occurs in outcrop in the NW1/4 sec. 15, and SE1/4 sec. 12, T. 41 N., R. 29 W., and has been cut by drill holes in sec. 8, T. $41 \mathrm{~N}$., R. $28 \mathrm{~W}$. In the drill core the rock is seen to be interbedded with biotite-muscovite schist and with graywacke in units typically 5 to 15 feet thick and rarely more than 30 feet thick.

The rock is a dark foliated schist studded with pink garnets 1 to $2 \mathrm{~mm}$ in diameter. Quartz constitutes about half the rock; it occurs as grains and sutured aggregates that are elongate in the direction of the foliation. The garnet occurs as subhedral to euhedral porphyroblasts that contain small inclusions of quartz. Biotite typically makes up 15 to 20 percent of the rock; it occurs as scattered flakes or aggregates parallel to foliation or as clusters of flakes around garnet. The garnet does not appear to have thrust aside biotite during growth. Feldspar is absent in most of the specimens studied, but in one it made up nearly 20 percent of the rock. Magnetite is a common minor constituent.

Biotite-magnetite schist.-Biotite-magnetite schist is exposed in a group of small outcrops on and adjacent to the line between sec. 12 , T. 41 , N., R. 29 W., and sec. 7, T. 41 N., R. $28 \mathrm{~W}$ : The rock is light to dark gray, laminated or thin banded, and schistose. It is interbedded with biotite-garnet schist and with thin layers of graywacke. The rock contains abundant 
magnetite as scattered euhedral or subhedral crystals.

Staurolite schist.-Staurolite schist forms part of some outcrops in sec. 24 , T. 41 N., R. 30 W., sec. 19 , T. 41 N., R. 29 W., and in sec. 24 , T. 41 N., R. 28 W. The rock is silvery schist much similar to the biotitemuscovite schist described previously. Foliation planes curve around crystals of altered staurolite 5 to $10 \mathrm{~mm}$ in length. Locally these crystals are weathered into relief on exposed surfaces.

The rock is composed chiefly of biotite, muscovite, and quartz, and accessory magnetite. The original staurolite crystals are entirely altered; the outlines of the crystals are well preserved (fig. 59) but not a trace of the original material remains. The alteration is most commonly to sericite with a small amount of quartz, but some crystals are altered in part to chlorite. Garnet, largely altered to chlorite, occurs in several of the slides examined.

Biotite-chlorite schist.-The rock exposed along First Creek, in sec. 24, T. 41 N., R. 31 W., is a dark, fine-grained, thin-bedded schist, some of which is magnetic. Some of the schist is strikingly laminated and in outcrop appearance resembles a bedded tuff. A few graywacke layers are present in the large outcrops along the north side of the creek, and in the outcrops about 500 feet south of the creek laminated schist and graywacke are contorted into exceedingly complicated minor folds, with much distortion and boudinage of the graywacke layers.

The schist consists principally of biotite, chlorite, and quartz. The biotite, which occurs as small brown flakes oriented in the plane of lamination, is the principal constituent of some laminae and is present as at least a minor constituent in all. The chlorite is in part, perhaps entirely, secondary after biotite. The quartz forms a fine-grained mosaic in the lighter colored laminae and occurs as scattered anhedra elsewhere. A small amount of oligoclase has been identified; it is untwinned and almost identical in appearance to the quartz. Scattered throughout the rock, but most abundant in the darker laminae, are the relict outlines of preexisting porphyroblasts. Most consists now of biotite with small amounts of quartz and sericite, but a few contain cores of a blue-green, strongly pleochroic hornblende. In one slide a single large grain of garnet was observed. Some layers in the biotite-chlorite schist contain abundant magnetite as small subhedral grains. A second opaque mineral, probably ilmenite, is common as small tabular grains.

Iron-formation at the Hancock exploration.-Ironformation is poorly exposed in old test pits and trenches at the old Hancock exploration in sec. 30, T. 41 N., R. 27 W., together with schist and quartzite (see fig. 60). The rocks are deeply weathered. The iron- formation is a thin-bedded rock that contains layers of soft bluish-gray hematite alternating with layers of stained recrystallized chert and layers that are light colored and clayey. Patches of greenish and yellowish material impart a somewhat mottled appearance to the rock. Under the microscope the hematite is clearly pseudomorphous after magnetite - that is, it is martite. The clayey material, which occurs as layers and as scattered patches, is isotropic or nearly so in thin section; presumably it has been derived from original silicates by the same deep weathering that produced the martite.

The rocks that are associated with the iron-formation at the Hancock exploration are, except for being deeply oxidized, much similar to the normal graywacke and schist of the Michigamme slate. Biotitemuscovite schist shows complete oxidation of the biotite to iron oxides and some slides show relict outlines of garnet, which also is completely altered. The muscovite shows not the slightest alteration, and textures are faithfully preserved. Tourmaline, in small green euhedral crystals, is a surprisingly common accessory; it also is unaltered.

\section{THICKNESS AND RELATIONS TO ADJACENT FORMATIONS}

The thickness of the Michigamme slate appears to be at least about $5,000 \mathrm{ft}$., and it may be as much as $11,000 \mathrm{ft}$.

The relationship between the Michigamme slate and the underlying Vulcan iron-formation, reviewed in the discussion of the latter unit, is one of regional unconformity so that in places the Michigamme rests on preVulcan rocks. The relationship to the overlying Badwater greenstone is not well known in this area, because of poor exposures in the critical area along the Menominee River, but the evidence suggests interbedding with volcanic tuffs. Much of the rock exposed in sec. 24 , T. 41 N., R. 31 W.-for example, that exposed along First Creek-is a dark laminated biotite schist that may be tuffaceous in origin. This rock is interbedded with graywacke in the outcrops south of First Creek, but the most southerly exposures, which presumably represent the stratigraphically highest part of the Michigamme slate, are of graywacke. The rock exposed in outcrop and test pits near the center of sec. 33, T. 41 N., R. 30 W., contains graywacke, slate, and a laminated rock similar to the probable tuff described above. On the basis of this evidence, it would appear that the volcanic activity, which was to culminate in extrusion of the lavas that now make up the Badwater greenstone, began during deposition of the upper part of the Michigamme slate, by eruption of volcanic ash which became interbedded with graywacke and slate. The relationship between the two formations is, there- 
fore, one of conformity, with interbedding at the contact.

\section{BADWATER GREENSTONE}

The Badwater greenstone, a metamorphosed sequence of basic volcanic rocks, is the youngest Precambrian stratigraphic unit in central Dickinson County. The rock is present only in the southwest corner of the map area, and the principal exposures are along and adjacent to the Menominee River. The formation is named for Badwater Lake, just south of this area.

Most of the greenstone is massive, dark gray to dark green, and dense to fine grained. At a few places ellipsoidal structures are evident, though not sufficiently well preserved to permit determination of top directions; locally the rock is amygdaloidal. Individual flows cannot be distinguished with certainty. Under the microscope original volcanic textures are clearly evident, but the rock now consists of pale-green actinolitic hornblende, albite, clinozoisite, biotite, calcite, chlorite, and leucoxene (fig. 61). Typical specimens contain 30 to 40 percent albite, both as partial pseudomorphs after original laths of labradorite and as groundmass material; 15 to 25 percent hornblende, most of which occurs as shreds and small flakes; 10 to 20 percent clinozoisite, some of which is in small wellformed crystals; 5 to 10 percent biotite as small flakes in the groundmass; 5 to 20 percent chlorite similar in habit to the biotite; and as much as 5 percent leucoxene as disseminated small grains. Quartz, magnetite, and pyrite are minor constituents. The amygdules typically contain subhedral to euhedral clinozoisite, calcite, biotite, and chlorite (fig. 62), with grain sizes much larger than those of the enclosing rock.

The relationship of the Badwater greenstone to the underlying Michigamme slate is one of conformity, and there is some interbedding of volcanic material with the upper part of the Michigamme slate. The top of the greenstone is not present within this area, so that the total thickness of the formation cannot be determined; within central Dickinson County a maximum thickness of approximately 5,000 feet is represented.

\section{UPPER MIDDLE PRECAMBRIAN INTRUSIVE ROCKS}

\section{BASIC INTRUSIVE ROCKS}

Basic intrusive rocks occur as scattered dikes in most parts of the area. They are most numerous in the granitic block between the Toby Lake fault and the North Calumet fault and in the granitic block south of the South Calumet fault, but the largest of the dikes, which is about $800 \mathrm{ft}$. thick, is intrusive into the Badwater greenstone in the southwest corner of the area. The dikes in the granitic terranes are not easily distinguished from much older amphibolite layers; doubtless many dikes have been overlooked and, on the other hand, some of those mapped as dikes actually may be pregranite amphibolite.

The dikes are most numerous near zones of faulting, and some follow preexisting faults. Where evidence is available, as in secs. 29 and 32, T. 41 N., R. 29 W., some of the dikes clearly are later than the faults. The majority of the dikes are characterized by small to moderate magnetic anomalies. Traverses with ground magnetometers in parts of the crystalline block south of the South Calumet fault have shown that relatively large anomalies, such as that which trends northeastward through Rock Lake, are due to unmapped basic intrusive rocks, and in fact, most of the magnetic anomalies within the granitic areas can be related to dikes.

The basic intrusive rocks all have been metamorphosed. As with the Michigamme slate described previously, the present character of the rocks depends upon their position with respect to the metamorphic zones (pl. 6). Most of the dikes are in areas that lie above the garnet isograd and consequently are now amphibolite, but the largest dike in the area-that which intrudes the Badwater greenstone-lies within a lower metamorphic zone and is mineralogically of the greenschist facies. These two classes of rock are described separately.

\section{METAGABBRO IN THE BIOTITE ZONE}

The only known body of basic intrusive rock within the biotite zone is the 800 -foot-thick dike in secs. 31 and 32, T. 41 N., R. $30 \mathrm{~W}$. The rock is massive, grayish green on fresh breaks, and medium to coarse grained. The original gabbroic texture, which is evident even in hand specimen, is well defined in thin section (fig. $63)$. Hornblende, albite, and sphene are the essential constituents. The original pyroxene, which occurred as large plates 2 to $3 \mathrm{~mm}$ in diameter, has been altered to pale-green actinolitic hornblende (uralite) with retention of the general outlines of the original material. The albite occurs chiefly as anhedral grains smaller than, and interstitial to, the uralite. The sphene forms small granules and, more rarely, subhedral crystals that rarely exceed $0.1 \mathrm{~mm}$ in length. Other minerals that may or may not be present are clinozoisite, biotie, chlorite, calcite, quartz, and magnetite. In general, the minerals present are the same as those in the enclosing Badwater greenstone, and the rocks are distinguished mainly on the basis of a grain size that is in large part inherited from the premetamorphic material. 
METADIABASE AND METAGABBRO IN THE GARNET AND STAUROLITE ZONES

Most of the basic dikes are in areas that lie above the biotite isograd. In consequence the rocks are now amphibolites, much similar in general aspect to the older amphibolites that form part of the Lower Precambrian crystalline blocks. Most of the dikes are less than a hundred feet wide, but at least one-that which gives rise to a moderately large magnetic anomaly in the Rock Lake area-in sec. 33, T. 41 N., R. 29 W.- probably is several hundred feet wide.

The rock is massive and appears nearly black on fresh breaks, but on exposed surfaces the rock has a mottled or speckled dark and light appearance because of the bleaching of feldspar to white or gray. The grain size ranges from fine to coarse. Except locally at the margins of some dikes, the minerals do not show preferred orientation, and the texture is that of the original diabase or gabbro. The lack of dimensional orientation, plus the gross relationship of the dikes to structures in the enclosing rock, are the principal criteria for separating dike rock in the crystalline blocks from the older but mineralogically similar amphibolite. In areas where the dikes have been intruded parallel to preexisting foliation and where the postdike metamorphism has been accompanied by appreciable structural movement, these criteria fail.

Metadiabase from a dike in sec. 20, T. 41 N., R. 30 W., is shown in figure 64. The material is typical of metadiabase within the garnet zone of metamorphism. The essential constituents are blue-green hornblende and oligoclase $\left(A n_{15}\right)$, which are in large part pseudomorphic after primary pyroxene and labradorite. The oligoclase retains the twinning habit of the labradorite where secondary after that mineral, but isolated grains in the groundmass are untwinned. Other constituents of importance are epidote, quartz, biotite, muscovite, and apatite. Grains of magnetite-ilmenite, in skeletal crystals typical of diabase, commonly are preserved.

Dikes from areas within the staurolite zone of metamorphism, as in secs. 9 and 10, T. 41 N., R. 30 W., differ from the rock described above in several respects. One of the most obvious differences is that the rock rarely shows obvious relict textures, and some specimens show strong preferred orientation of minerals. The texture is entirely metamorphic. Mineralogically the rock differs in that the hornblende is darker green, the plagioclase is andesine rather than oligoclase, and epidote is rare or absent except as a later alteration. The plagioclase typically occurs as twinned anhedra, approximately equidimensional, and in most slides examined, the plagioclase grains are gradationally zoned from an andesine core to an albite or oligoclase rim. Brown biotite and sphene, the latter in granular aggregates that enclose magnetite grains, are less abundant constituents. Quartz is present in some slides, typically occurring as small blebs within the hornblende.

\section{GRANITIC INTRUSIVE ROCKS}

Pegmatite, aplite, and granite of post-Baraga age occur throughout the area as scattered thin dikes, pods, and lenses. Most of these bodies occur within the older crystalline blocks, and most are too small to be mapped separately. The rocks are undeformed and in general appear to postdate the late Middle Precambrian metamorphism.

\section{PEGMATITE AND APITE}

The pegmatite and aplite, which commonly are closely associated or gradational into each other, typically form small pods or lenses a few feet across. They are of common occurrence in the Lower Precambrian crystalline blocks, but in those areas they are not readily distinguished from pegmatite and aplite that may be of much older age. A 1-inch dike of pegmatite and an aplite dike several feet wide cut the Sturgeon quartzite in the NW1/4 sec. 12 , T. 41 N., R. 30 W., about 3,500 feet north and 1,000 feet east of the southwest corner of the section. Pegmatite pods and lenses cut the graywacke exposed in sec. 29 , 'T. 41 N., R. 30 W., about 900 feet south of the northwest corner of the section, and similar material cuts graywacke exposed about a thousand feet north of the south quarter of section 19 , in the same township.

Both the pegmatite and aplite are light gray to pink. Only a few thin sections of the rocks have been examined, but they indicate that the rocks are normal in character. A specimen of pegmatite from sec. 29 , T. 41 N., R. 30 W., consists of oligoclase, orthoclase, quartz, and biotite. The feldspars are coarse grainedas much as an inch in length-and the quartz is interstitial for the most part. The aplite is a fine-grained aggregate of microcline, albite, and quartz anhedra, with scattered flakes of biotite and muscovite. The potash feldspar in both the pegmatite and the aplite is nonperthitic in the slides examined. Tourmaline has been observed as a very minor constituent in some pegmatite lenses.

Quartz veins containing a small amount of pink feldspar have been observed at many places in the area, and other quartz veins contain abundant black tourmaline. Some of these veins grade into rock of pegmatitic aspect.

\section{GRANITE}

Granite that can definitely be assigned a post-Animikie age is rare, but bodies of considerable size might be present within areas of older granite and not be 
recognized. The granite known to be of younger age occurs as narrow dikes cutting the Randville dolomite and Sturgeon quartzite in secs. 10 and 11, T. 41 N., R. $30 \mathrm{~W}$. The dike that cuts the dolomite is 30 feet thick.

The rock is massive, equigranular, fine- to mediumgrained, light-gray granite. It contains about 35 percent quartz, 35 percent oligoclase, 20 percent potash feldspar, and 5 percent each of muscovite and biotite. The oligoclase grains show slight gradational zoning from about $\mathrm{An}_{18}$ in the core to about $\mathrm{An}_{10}$ at the rim (fig. 70). The potash feldspar is microcline in some specimens, orthoclase in others, and some specimens contain both. Biotite and muscovite are present in about equal amounts.

The chemical composition of a sample of granite from the 30-foot dike that cuts the Randville dolomite is given below. The sample is a gray, medium-grained biotite-muscovite granite from an outcrop in NE1/4NE1/4 sec. 11, T. 41 N., R. $30 \mathrm{~W}$. The analyst was Leonard Shapiro, of the U.S. Geological Survey.

\begin{tabular}{|c|c|c|c|}
\hline $\mathrm{SiO}_{2}$ & 70.09 & $\mathrm{H}_{2} \mathrm{O}^{-}$ & 0.08 \\
\hline $\mathrm{Al}_{2} \mathrm{O}_{3} \ldots$ & 15. 46 & $\mathrm{H}_{2} \mathrm{O}^{+} \ldots$ & .34 \\
\hline $\mathrm{Fe}_{2} \mathrm{O}_{3 \ldots} \ldots$ & 1. 92 & $\mathrm{TiO}_{2} \ldots$ & .28 \\
\hline $\mathrm{FeO}_{\ldots} \ldots$ & 2. 46 & $\mathrm{P}_{2} \mathrm{O}_{5-}$ & .13 \\
\hline $\mathrm{MgO}_{-}$ & .31 & $\mathrm{CO}_{2-}$ & .26 \\
\hline $\mathrm{CaO}_{-}$ & 2. 26 & $\mathrm{MnO}_{2}$ & .02 \\
\hline $\mathrm{Na}_{2} \mathrm{O}_{-}$ & 4. 10 & & \\
\hline $\mathrm{K}_{2} \mathrm{O}_{\ldots}$ & 2. 20 & & 99. 91 \\
\hline
\end{tabular}

UPPER PRECAMBRIAN ROCKS

The only Upper Precambrian rock in the area is diabase, and it is known at only one locality. In the NE $1 / 4$ NW $1 / 4$ sec. 14, T. 41 N., R. 30 W., about 500 feet south of the north quarter corner, the gneissic granite is cut by a thin dike of fresh diabase. The dike is 2 to $3 \mathrm{ft}$. wide and has a chilled border against the granite. The rock is assumed to be Keweenawan in age.

\section{ROCK OF PALEOZOIC AGE}

Flat-lying strata of Cambrian and probable Ordovician age mantle the Precambrian rocks in large areas east of the west boundary of R. 28 W., but in general, outcrops are scattered and scarce (fig. 2). No fossils have been found in this area, but on the basis of fossils found elsewhere, Van Hise and Leith (1911, p. 307) refer to the rocks as Potsdam sandstone of Late Cambrian age and Hermansville limestone of Cambrian and Ordovician age.

The lowest unit of the Paleozoic strata is sandstone, which rests with profound unconformity on the beveled surface of older rocks. The sandstone is exposed in the Calumet mine cave; in many test pits east and west of the Calumet cave; in low bluffs north of the Calumet pit; in outcrops north of State Route M-69 in the
SE $1 / 4 N^{N} 1 / 4$ sec. 7 , T. 41 N., R. 27 W.; and in outcrops in the $\mathrm{S} 1 / 2$ sec. $12, \mathrm{~T} .41 \mathrm{~N}$., R. $28 \mathrm{~W}$. It has been cut by drill holes in the Calumet Mine area and in sec. 17, T. 41 N., R. 28 W. The relations to older rocks can be observed best at the old Calumet mine cave, where the sandstone rests with sharply defined angular unconformity on the Vulcan iron-formation (fig. 95). The sandstone in the Calumet mine area is generally 10 to 50 feet thick, but according to drill-hole records as much as 250 feet of sandstone is present in sec. 17, T. 41 N., R. 28 W.

The rock is a thick-bedded friable buff to reddishbrown well-sorted fine- to medium-grained sandstone. Crossbedding and ripple marks are common. Fxcept for locally derived breccia at the base of the formation the rock is composed almost entirely of quartz. The original grains have enlarged by growth of secondary quartz in optical continuity, but the original wellrounded outlines are preserved by rims of reddish dust.

Dolomite is exposed in road cuts on the hill immediately south and southwest of Foster City, and adjacent to an old road in the NE1/4 sec. 30, T. 41 N., R. 27 W. The rock in these exposures is light gray to buff, fine grained, massive, and crystalline; it consists chiefly of dolomite grains 0.1 to $0.5 \mathrm{~mm}$ in diameter, with a mosaic texture, and scattered rounded quartz grains that make up less than 2 percent of the rock. The rock exposed south of Foster City is oolitic, and it contains chert nodules that range from 2 to 4 inches in diameter. Most of the ooliths have structureless cores of crystalline dolomite surrounded by rims of finer grained brownish dolomite, and lie in a matrix of dolomite of comparable grain size (fig. 73). Well-rounded grains of clastic quartz are abundant, and tabular grains of untwinned authigenic feldspar, probably adularia, are not rare.

\section{PLEISTOCENE GLACIAL DEPOSITS}

A very large part of the area is mantled with glacial deposits, but no detailed study of these materials has been made in this investigation.

Most of the glacial material is ground moraine that consists of sand or clay till studded with boulders, but the high ridge that lies between Crystal Lake, in sec. 15, T. 41 N., R. 28 W., and the Sturgeon River in T. 41 N., R. 28 W., probably is a terminal or recessional moraine. The material that makes up the ridge, which is 200 to $300 \mathrm{ft}$. high, is unsorted till with local sand beds. An esker more than a mile long extends in a westerly direction across the $\mathrm{N} 1 / 2$ sec. $10, T$. 41 N., R. $28 \mathrm{~W}$, and there is a small area of recessional moraine in the $\mathrm{N} 1 / 2$ section 9 , immediately to the west. 


\section{STRUCTURE}

The general outline of the structure has been given in chapter B of this report, so that the following discussion consists largely of more detailed description of features within the map area. However, so as to provide a proper background for the more detailed discussion, a summation of the major structural aspects of the southern part of central Dickinson County is given as follows:

1. The principal structure is the Calumet trough, which is a downfolded and downfaulted block of Animikie metasedimentary rocks. The trough is separated from the crystalline block on the north (the central crystalline block of chapter B) by the North Calumet fault; on the south, it is separated from the southern crystalline block in part by the South Calumet fault and in part by sedimentary contacts. The trough is clearly defined only in the central part of the map area; on the east, southeast, west, and southwest it has no natural limits within the boundaries of central Dickinson County.

2. A second structural feature of major importance is the reentrant of Animikie metasedimentary rocks that projects into the west end of the crystalline block in the north-central part of T. 41 N., R. 30 W. This reentrant, or trough, has as its north limit the Toby Lake fault; on the south the metasedimentary rocks are in overturned unconformable contact with the older gneissic granite.

3. The structure of the crystalline block that lies north of the Calumet trough is part of a great elongate foliation dome (fig. 75) that is truncated on the south by the North Calumet fault and on the west by the unconformable contact of the younger metasedimentary rocks. The Hardwood gneiss lies at the east end of this granitic block and its structure appears conformable with that of the granitic rocks.

4. The principal faults-the Toby Lake fault, the North Calumet fault, and the South Calumet fault - are moderate- to high-angle reverse faults, nonsimultaneous in origin, along which the older granitic blocks have ridden out and over the bordering Animikie strata.

5. The principal structures of the area are of Precambrian age, as the Cambrian strata are in general flatlying and profoundly unconformable on a truncated surface of the deformed older rocks. The Toby Lake fault and its extension to the east along the North Calumet fault was, however, reactivated at a later date, as it is marked by a low fault scarp - not a fault-line scarp-within the granitic block and by a downdrop of the Paleozoic strata east of the Calumet mine relative to the granitic block on the north.

\section{STRUCTURES IN THE CRYSTALLINE BLOCKS}

Virtually all the granitic rock and included amphibolite of the crystalline blocks is foliated, the foliation being marked by compositional layering, dimensional orientation of feldspars and quartz, and by discontinuous mica-plaited shear planes. The foliation is most readily apparent on exposures of migmatite and least apparent in homogeneous granite and amphibolite, but in nearly all it is present to a degree that permits measurement. Lineation is best developed in the amphibolite, in which it is due to preferred orientation of hornblende needles; quite typically lineation in amphibolite is much better developed than foliation. Lineation is not as obvious in most of the granitic rock, and in many exposures it cannot be determined. In the east part of the central crystalline block, howevermost notably in secs. 2 and 3, T. 41 N., R. 28 W.-a lineation that is due to spindle-shaped feldspar and quartz is the dominant structure.

The foliation in the central crystalline block trends westward and is steeply dipping in most of the area, but at the east end of the block it swings into a northwest-to-north orientation and the dip becomes low to the east. The uniformity in dominant direction of the attitudes of both foliation and lineation in the west half of the block is shown clearly by figure $96 \mathrm{~A}$ and $\mathrm{B}$. The similarity between diagrams $A$ and $B$, which are for areas separated by the Toby Lake fault-and, for much of the area, by the reentrant of younger rocksdemonstrates the structural unity of these two areas. Diagram $C$ is markedly different from $A$ and $B$, in part perhaps because most of the plotted measurements are from the granitic complex adjacent to the vertical or overturned contact with the unconformably overlying metasedimentary rocks, and older structural features such as foliation may have undergone rotation at the time of deformation of the metasedimentary rocks. Somewhat similar changes in trend are present at the western end of the central crystalline block.

Joints are well developed in the crystalline rocks. The dominant direction is $\mathrm{N} .10^{\circ}-20^{\circ} \mathrm{W}$, with a dip nearly vertical, but a coordinate set that strikes about N. $20^{\circ} \mathrm{E}$. is also strong, and a set that strikes about N. $70^{\circ} \mathrm{W}$. with a dip to the south of $70^{\circ}$ to $80^{\circ}$ is persistent. The dominant joint directions of the Michigamme slate in the Calumet trough are similar in attitude (fig. 97). The parallelism suggests that the joints in the crystalline rocks are not related to the deformation that produced the foliation and lineation, as these latter structural features are of proved pre-Michigamme age. 


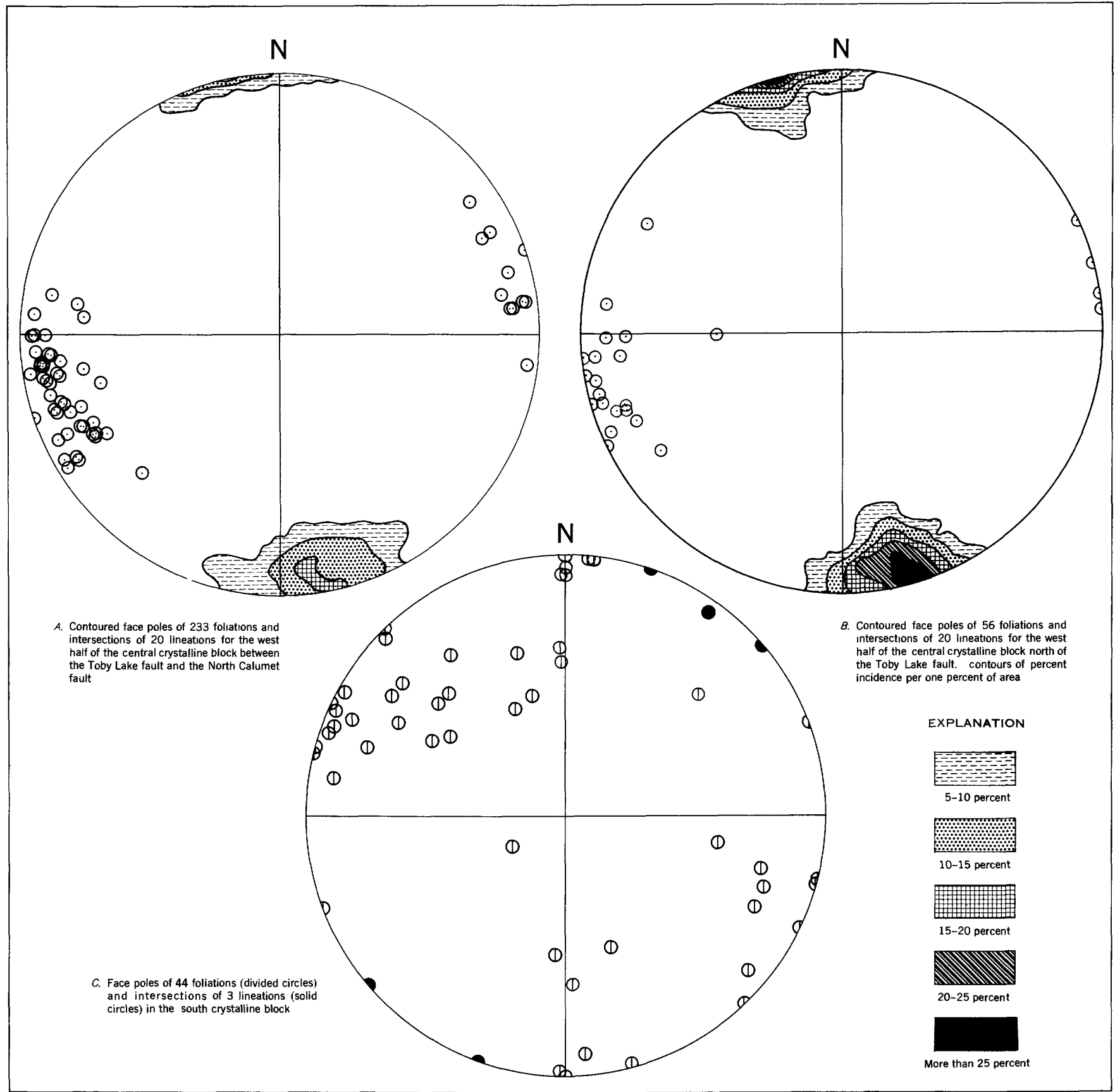

Frgure 96.-Orientation diagrams of foliations and lineations in the western parts of the central and southern crystalline blocks. Plotted on the lower hemisphere. $A$. Contoured face poles of 233 foliations and intersections of 20 lineations for the west half of the central crystalline block between the Toby Lake fault and the North Calumet fault. $B$. Contoured face poles of 56 foliations and intersections of 55 lineations measured for the west half of the central crystalline block north of the Toby Lake fault. Contours of percent incidence per 1 percent of area. $C$. Face poles of 44 foliations (divided circles) and intersections of 3 lineations (solid circles) in the southern crystalline block. 


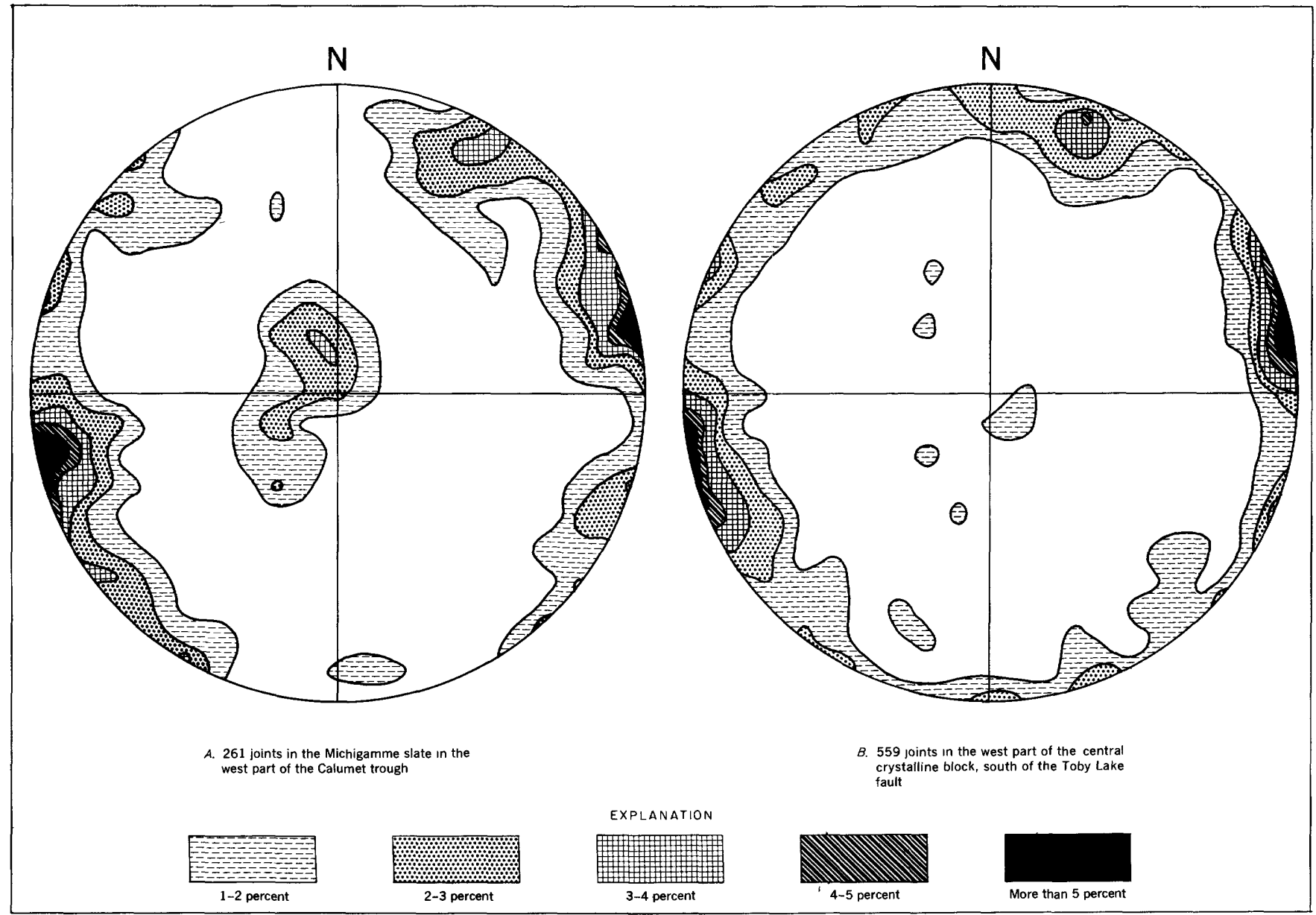

Figure 97.-Orientation diagrams of joints in gneissic granite and in the Michigamme slate. Poles of perpendiculars plotted on lower hemisphere of equal-area net, and contoured. $A .261$ joints in the Michigamme slate, western part of the Calumet trough. $B$. 559 joints in the west part of the central crystalline block, south of Toby Lake fault.

Many of the joints in the granitic rocks are filled with veins of coarse-grained milky quartz, which also must be post-Michigamme in age.

\section{STRUCTURES IN THE CALUMET TROUGH}

The Calumet trough is occupied largely by the Michigamme slate, which in general is very poorly exposed, and structural data consequently are scarce. The only areas where information is sufficiently adequate for even an elementary analysis are: (1) the First Creek area, in secs. 24 and 25, T. 41 N., R. 31 W., and sec. 19 , T. 41 N., R. 30 W.; (2) the area between State Route M-95 and Pine Creek, in secs. 23, 24, and 26, T. 41 N., R. 30 W., and sec. 19, T. 41 N., R. 29 W.; (3) the Crystal Lake-Calumet mine belt, extending from sec. 15, T. 41 N., R. 29 W., to sec. 9 , T. 41 N., R. $28 \mathrm{~W}$.; and (4) the east-central part of the Calumet trough. The well-exposed highly faulted belt of Sturgeon quartzite in the southeastern part of the area is described here as the Pine Creek belt of Sturgeon quartzite, though it is hardly a part of the trough proper.

\section{FIRST CREEK AREA}

The relatively few outcrops in the First Creek area, particularly those in the south-central part of sec. 24, T. 41 N., R. 31 W., show a general northwesterly or northerly trend, in contrast to the westerly trend in the outcrop areas a few miles to the east. Dips are to the northeast, and several rather poor determinations of graded bedding indicate that the beds are overturned. Some of the rocks in the First Creek area show very strong internal deformation. The finer grained rocks are schistose, and layers of interbedded graywacke are segmented into pods and lenses. This type of deformation is well shown in the exposures about 1,000 feet north of the south quarter corner of sec. 24, T. 41 N., R. 31 W., where the general trend of bedding is nearly north and the direction of cleavage and stretching is nearly west. 
The northerly trend of bedding in the First Creek area probably is the reflection of the anticlinal nose of granite a mile or so to the east, and the internal deformation of the beds probably is due to the stretching along or near the axis of this structure.

\section{AREA BETWEEN STATE ROUTE M-95 AND PINE CREEK}

This area contains most of the exposures of Michigamme slate in central Dickinson County. The beds strike east or slightly north of east in most places and dips are vertical or steep toward the north. Graded bedding has been observed at several dozen localities in the area, and all determinations show that the stratigraphic tops are to the south. The cleavage direction varies considerably with the nature of the rock; in the most strongly schistose rocks - that is, those that originally were the finer-grained sediments-the cleavage is nearly parallel to the bedding, whereas in the rocks that originally were silty or sandy the cleavage trends northwestward, at a strong angle to the bedding. The exposed rocks do not show particular evidence of squeezing or significant internal deformation; thicknesses of individual layers do not vary within observable limits, and rare concretionary structures, originally calcareous, retain their original lenticular forms.

Major folds and faults appear to be absent, and the overall structure of this block of Michigamme slate is simple -in fact this is one of the few large areas of Michigamme slate in the region for which a reliable thickness estimate can be made.

\section{CRYSTAL LAKE-CALUMET MINE BELT}

The block of metasediments that extends from the Crystal Lake area to the Calumet mine area, immediately south of the North Calumet fault, is marked by the appearance of Vulcan iron-formation, Felch formation, and Randville dolomite. Exposures are not abundant, but a considerable amount of additional information is available from magnetic surveys, drilling, and (in the Calumet area) mine workings. The deduced structures are shown on a series of geologic-magnetic maps (pl. 4).

The general trend in the Crystal Lake-Calumet block is easterly, but a considerable amount of folding is known to be present. The rocks exposed in the NW1/4 sec. 15, T. 41 N., R. 29 W., are in places intensely folded on a small scale: in one of the larger outcrops in the western part of this outcrop area the schist is folded into a broad syncline with many minor folds in the limbs; in another outcrop, interbedded graywacke and garnetiferous schist are contorted into many isoclinal overturned folds. Folding of the Vulcan iron-formation in this area is indicated from drill-hole data (see section $A-A^{\prime}$, pl. 4).
The structure in the Calumet mine area is depicted in plate 4. The Randville dolomite and Felch formation, as well as the Vulcan iron-formation, reach bedrock surface just south of the North Calumet fault, which here has a trace that is concave to the south. The fault itself is crossed by a drill hole, which passes through a considerable amount of sheared rock, vein quartz, and infiltrated sandstone of Cambrian age. South of the fault the principal structure is the syncline defined by the drilling in section 9. (See pl. 4.) The axis of this structure is about 400 feet south of the fault in sec. 9, but because of the divergence in trend between the fault and the probable trace of the axial plane, it would be a greater distance from the fault in section 8. The syncline-anticline in the Calumet mine (pl. 4, $\left.A-A^{\prime}\right)$ and the folds inferred from drilling in the NE $1 / 4$ section 8 (pl. $\left.4, B-B^{\prime}\right)$ are on the north flank of this syncline. Some of the folds, possibly all of them, are overturned, with the axial planes dipping steeply toward the south.

\section{EAST-CGNTRAL PART OF THE CALUMET TROUGH}

Little is known of the structure in the eastern part. of the Calumet trough. The Michigamme slate is locally exposed along and adjacent to the West Branch of the Sturgeon for a distance of about 4 miles, but little can be made of the structural pattern. The rocks are intensely contorted in many places, and in the NW1/4 $\mathrm{SE}^{1} 1 / 4$ sec. 21 , 'T. 41 N., R. 28 W., recumbent folds are present. The minor folds plunge eastward at angles less than $15^{\circ}$. In general, the minor structures appear to be drag folds on the south flank of a major anticline to the north. Cleavage in the schists is parallel to bedding or nearly so.

The broader outlines of structure in the eastern part of the trough are inferred largely from the aeromagnetic data (pl. 8) supplemented by drill-hole data in sec. 17, T. 41 N., R. 28 . W. A major eastward-trending anticline extends through section 17 . It is marked by a strong aeromagnetic anomaly that is due to the appearance of the Vulcan iron-formation at bedrock surface at the crest of this anticlinal fold. The magnetic anomaly, as measured by ground instruments, is very large and very broad, which is in keeping with the inferred structure. Drill holes located on or near the crest of this anomaly in section 17 entered Vulcan iron-formation, which is flanked by schist. To judge from the nature of the magnetic anomaly, the anticline, from its culmination in section 17 , plunges at a steep angle toward the west and at a moderate or low angle toward the east. The related aeromagnetic anomaly can be traced less than 1 mile toward the west, but it can be traced for at least 2 miles and possibly 6 miles toward the east. If the anomaly in secs. 17 and 18, $T$. 
41 N., R. $27 \mathrm{~W}$., is in fact a continuation of that in sec. 17, T. 41 N., R. 28 W., then it would appear that the plunge of the anticline reverses somewhere between the two areas, and that at the east margin of the map area the plunge is toward the west.

The drag folding in the rocks exposed along the West Branch of the Sturgeon River in secs. 19, 20, and 21, T. 41 N., R. $28 \mathrm{~W}$., as noted previously, is systematic with respect to an anticline to the north. Presumably the sec. 17 anticline is that structure. The fact that the direction of stratigraphically older rocks is to the north in the West Branch exposures is a measure of proof for the existence and magnitude of the South Calumet fault; the older granitic rocks of the Southern crystalline block are areally closer to the West Branch exposures, which show "top" directions toward that block, than the West Branch exposures of the Michigamme slate are to the sec. 17 occurrence of the Vulcan iron-formation, which is the next older Middle Precambrian formation. Furthermore, the absence of any magnetic anomaly between the West Branch exposures and the crystalline block shows that neither the Vulcan iron-formation nor the Felch formation is present in that area; these formations, and probably the Randville dolomite and Sturgeon quartzite, probably are cut out by the fault, though it is always possible that their absence is due to post-Vulcan, pre-Michigamme erosion.

'The structure of the remainder of the eastern part of the Calumet trough is entirely unkown.

\section{PINE CREEK BELT OF STURGEON QUARTZITE}

The Pine Creek belt of Sturgeon quartzite (pl. 2); also (fig. 81) shows more recognizable structural complexity than any other area in central Dickinson County. The Sturgeon quartzite and the unconformably underlying gneissic granite are well exposed and at least the main features of the structure can be defined with a considerable degree of certainty.

In general, the Sturgeon quartzite trends northward and in most places is overturned so that it dips beneath the granite. The belt is broken by several faults with apparent displacement of as much as half a mile and is terminated at the north by the South Calumet fault. The attitudes of bedding define an eastward trending synclinal flexure-the strike swings from northeast at the south margin of the map area, through north, to west-northwest at the north end of the belt. Only locally, and here probably fortuitously, are these changes in strike direction in the proper sense to be interpreted as drag effects on the faults, and the conclusion seems justified that the flexure predates the faulting. The axial region of this flexure is in the north part of sec. 31, and it will be noted that in this block the quartzite is not overturned. The westerly dip of bedding there ranges from $35^{\circ}$ to $70^{\circ}$, which is also the plunge of the flexure. South of this axial region, most dips are normal rather than overturned, whereas north of it, the reverse is true. It appears then, that the principal prefault structure was an eastward-trending syncline, overturned to the south (axial plane dipping north), with a steep westerly plunge.

Two main sets of faults offset the belt. The most readily apparent set strikes east or northeast, or roughly in the same direction as the South Calumet fault, and the dip is probably nearly vertical. The horizontal offset on these faults, which is clearly apparent from the map pattern, is not consistent in direction, but the aggregate throw is right hand-that is, the northern part of the belt is offset toward the east. The second and much less obvious fault set trends northward to northwestward, parallel in strike to the bedding, and is represented only by two small segments, one in the north part of section 32 and the other in the north part of section 29. These faults repeat virtually the entire thickness of the quartzite, and, though they do not result in offsets as obvious as those produced by the northeast faults, the amount of movement must be very large. They are truncated by the northeast faults and therefore are older, but their relationship to the folding is not known. The movement on the faults is probably high-angle reverse, with the east side moving up. The two small segments of the northwestwardtrending fault set that are preserved might well be part of a once-continuous shear that was, for the most part, in the upper part of the Sturgeon quartzite or at the base of the Randville dolomite.

\section{ECONOMIC GEOLOGY}

The Vulcan iron-formation is the only material of economic interest within the southern part of central Dickinson County. The iron-formation occurs in two principal areas: (1) in the vicinity of the Calumet mine, and other areas to the west immediately south of the North Calumet fault (see pl. 4); and (2) sec. 17, T. 41 N., R. 28 W., where the iron-formation, on the basis of drill-hole and magnetic data, probably is present beneath the capping of Paleozoic strata and Pleistocene deposits. (See pl. 2.) Iron-rich rock is also present at the old Hancock exploration in sec. 30, T. 41 N., R. 27 W., but the identity of these strata as Vulcan iron-formation is uncertain. Test pits have been sunk in ferruginous material in secs. 32 and 33 , T. 41 N., R. $30 \mathrm{~W}$., but the material appears to be principally oxidized slate and graywacke (section 33), and oxidized volcanic rock (section 32). 


\section{EXPLORATION AND PRODUCTION}

The only ore produced from the area came from the Calumet mine, in sec. 8, T. 41 N., R. 28 W. Exploration was begun in this area about 1880 , and ore was shipped in 1882, 1883, and 1884. (See table 4.) Total shipments during this period aggregated 38,713 tons, most of which probably was high-grade residual ore (50 to 65 percent $\mathrm{Fe}$ ) lying near the surface of the Vulcan iron-formation (and possibly other formations) immediately below the base of the sandstone (Cambrian) that mantles the area. In 1905, the Calumet mine was reopened by Pickands, Mather \& Co., operating for the Calumet Ore Co., and the mine was active sporadically until 1914. During this period 137,204 tons was shipped. The large pit at the Calumet mine actually is caved ground over these later workings.

The known workings of the Calumet mine are shown in figure 98 . All workings are now caved. The 1882-84 production probably came, in large part at least, from the "adit level" (fig. 98 $A$ ), and workings related to it. The adit was driven southward at shallow depth from a portal facing a small creek. (See pl. 4.) Cambrian sandstone is exposed in a ledge immediately above the portal, and it appears that the adit was driven in the weathered Precambrian material at the base of the sandstone. It is notable that although Randville dolomite is known to underlie much of the area (below the sandstone) between the portal and the Vulcan ironformation to the south, little or no dolomite is found on the dumps of the adit level, nor is there any notation on the maps to indicate that dolomite was actually encountered. In this connection it may be noted also that many test pits and drill holes in this vicinity are reported to have encountered "iron-formation" in tracts that are known from later exploration to be underlain by Felch formation, Randville dolomite, or Michigamme slate. Presumably these pits entered the deeply oxidized material at the base of the Cambrian sandstone.

The 1905-14 development of the Calumet mine (see fig. $98 \mathrm{~B}, \mathrm{C})$ produced iron-formation significantly lower in iron content than that produced from the near-surface workings. The composition of the ore shipped in 1913 was as follows:

\begin{tabular}{c|c|c|c|c|c|c|c|c|c}
\hline $\mathrm{Fe}$ & $\mathrm{P}$ & $\mathrm{SiO}_{2}$ & $\mathrm{Mn}$ & $\mathrm{Al}_{2} \mathrm{O}_{3}$ & $\mathrm{CaO}$ & $\mathrm{MgO}$ & $\mathrm{S}$ & $\begin{array}{c}\text { Loss on } \\
\text { ignition }\end{array}$ & $\begin{array}{c}\text { Mois- } \\
\text { ture }\end{array}$ \\
\hline 37.72 & 0.020 & 36.39 & 0.24 & 1.67 & 0.67 & 0.55 & 0.011 & 1.28 & 4.50 \\
\hline
\end{tabular}

The Hecla property, in $\mathrm{NE} 1 / 4 \mathrm{NE} 1 / 4$ sec. 8 , immediately northeast of the Calumet Mine, also was the site of considerable exploration in the early days of the district. Many test pits and several shafts were sunk. Most are reported to have found "iron-formation", but there was no recorded production and it is likely that most of the ferruginous material developed actually was residual on Randville dolomite and Felch formation.

Very little information is available concerning the Hancock exploration, in sec. 30, T. 41 N., R. 27 W. The work dates back at least 50 years. The distribution of test pits and trenches is shown on figure 60 . Some banded martite-rich rock is present.

The broad high magnetic anomaly in sec. 17, T. 41 N., R. 28 W., was tested by drilling in 1900. Eight drill holes were sunk, several of which are recorded as having iron-formation after passing through as much as 270 feet of Cambrian sandstone.

In the early 1930's, the Jones \& Laughlin Ore Co. tested the area adjacent to the Calumet Mine by 12 drill holes (see pl. 4), and in the period 1948-52 the area was drilled extensively by the M. A. Hanna Co. The drill cores from these two explorations were examined during the course of the present study.

\section{CHARACTER OF THE IRON-FORMATION AND ORE}

Virtually no iron ore is known to be present in the area under discussion, insofar as "ore" is defined by standard blast-furnace requirements. As mentioned above, the ore shipped in the 1880's probably was a surface enrichment of shallow depth. The material now exposed in the pits consists of alternating thin layers of iron oxides and of quartz (recrystallized chert). The iron oxide is principally hematite and the rock is generally nonmagnetic or only slightly magnetic. In polished section, however, the hematite is seen to have the form of magnetite (see fig. 87), from which it apparently has been derived by oxidation. Designation of magnetite as the original iron oxide is further borne out by the fact that the core from deeper drill holes is strongly magnetic; apparently at depths of a few hundred feet below the Precambrian surface the magnetite is largely unaltered.

The hematitic (martitic) iron-formation in the Calumet area typically assays 35 to 40 percent $\mathrm{Fe}$; the magnetitic rock is slightly lower, averaging about 34 percent $\mathrm{Fe}$. None of this rock can be classified as ore at the present time, although the material may be of interest in the future as a possible low-grade ore for concentration. The iron-formation exposed and drilled in sec. 15, T. 41 N., R. 29 W., is similar to that in the Calumet area. Information is not adequate to define the composition of the iron-formation drilled in sec. $17, T$. 41 N., R. 28 W., or that of the iron-rich strata at the Hancock exploration in sec. 30, T. 41 N., R. 27 W. 


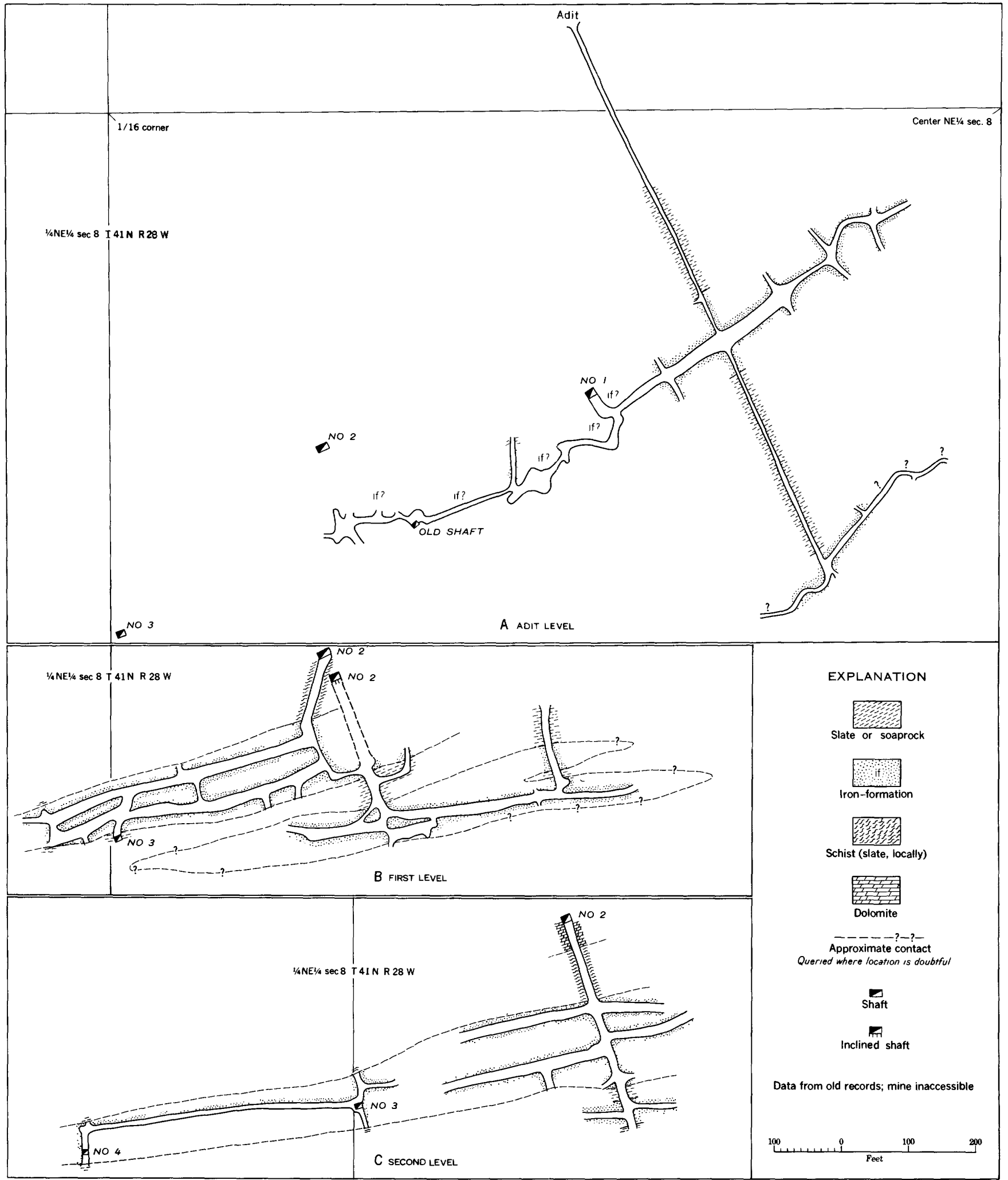

Figure 98.-Level maps of the Calumet mine. A. Adit level. $B$. First level. $\quad$. Second level. 


\section{MAGNETIC ANOMALIES AND EXTENT OF THE IRON-FORMATION}

The major magnetic anomalies in the area are pro duced by the Vulcan iron-formation, although the iro! formation actually exposed may be nonmagnetic kecause of near-surface oxidation of the magnetite to nonmagnetic martite. Magnetite-rich beds are present in parts of the Michigamme slate and locally give rise to moderate anomalies, but in general the anomalies are not as large or as continuous as those that are due to the Vulcan iron-formation.

The magnetic anomalies known or believed by many to be caused by iron-formation are described under the following headings: (1) The Calumet belt-adjacent to the North Calumet fault, from sec. 15, T. 41 N., R. $29 \mathrm{~W}$., to sec. 9, T. 41 N., R. $28 \mathrm{~W}-(2)$ the Middle belt-centering on sec. 17 , T. 41 N., R. 28 W-and (3) the Hancock belt--at and adjacent to the Hancock exploration in sec. 30, T. 41 N., R. 27 W.

\section{CALUMET BeLT}

The Calnmet belt of magnetic anomalies has been delineated by a magnetic survey made by the $\mathbf{M}$. A. Hanna Co. The magnetic data of this survey are given in a series of maps (pl. 4), each of which covers a strip 1 mile wide, on which the geology is shown. There can be little doubt that the principal anomalies in this belt are due to the Vulcan iron-formation that lies immediately south of the North Calumet fault, but in detail many complexities are indicated. Some of the complexities are due to the influence of folding of the iron-formation, some are due to the effect of truncation of the iron-formation by the North Calumet fault, and others are due to surficial oxidation of the ironformation.

The anomaly reaches its peak value in sec. 9, T. 41 N., R. 28 W. (pl. 4), where an intensity of about 64 scale-division units on a Gurley dip needle is recorded. Yet drilling at this locality shows that the Vulcan ironformation is not at the bedrock surface. As shown on cross section $A-A^{\prime}$, plate 4 , the iron-formation appears to be present in a synclinal fold. That the magnetic rock is at considerable depth might also be inferred from the fact that the anomaly, though strong, is very broad.

In sec. 8 , T. 41 N., R. 28 W., immediately to the west, the iron-formation is known from pits, mine workings, and drill holes to be present at the PreCambrian surface, beneath a relatively thin mantle of sandstone. Inspection of the map (pl. 4) shows that the anomaly crest is not over the suboutcrop. Instead, as in sec. 9, it reaches a maximum along a line that in general lies south of the suboutcrop belt, although in a few places, the crest is over the suboutcrop of ironformation. West of the Calumet Mine the anomaly dies out rapidly. The interpretation offered, based in considerable part on interpretation of the mine and drill-hole records, is that the Vulcan iron-formation is thinned here by pre-Michigamme erosion. A broad relatively low anomaly recorded in the west part of the section may be due to magnetite-bearing beds in the Michigamme slate, or it may be due to Vulcan ironformation at depth. This anomaly continues to the west into sec. 7, T. 41 N., R. 28 W. (pl. 4), reaching a maximum of 44 dip-needle units in the NW1/4 SE $1 / 4$ sec. 7. A drill hole at this locality (see cross section $A-A$ ', pl. 4) entered Michigamme slate, not notably magnetic. The west part of sec. 7 was not surveyed, but the aeromagnetic survey shows that the anomaly continues. In sec. 12 , T. 41 N., R. 29 W. (pl. 4), the anomaly is of only small or moderate intensity. In part at least it is related to magnetite-bearing beds in the outcropping Michigamme slate. A short distance west of the north-south center line of sec. 12, however, the crestline of the anomaly crosses to the north side of the North Calumet fault and dies out after entering a short distance into sec. 11, T. 41 N., R. 29 W. (pl. 4). The anomaly reappears in the west part of sec. 11 and increases in intensity as the area of known Vulcan iron-formation is approached in sec. 15 (pl. 4), beyond which it again dies out.

At each end of this 5-mile belt of anomalies between sec. 8 , T. 41 N., R. 28 W., and sec. 15, T. 41 N., R. 29 $W$., the anomaly is clearly related to Vulcan ironformation. In between, the interpretation is not certain. Locally, as in sec. 7, the anomaly is in part due to magnetic beds in the Michigamme slate. However, the major part of the anomaly probably is caused by Vulcan iron-formation at depth along the north-dipping North Calumet fault in a manner such as shown on cross section $B-B$ ', plate 2. This interpretation would account for the fact that in some areas the crestline of the anomaly actually is over nonmagnetic granite; the magnetic rock would be vertically below but on the down-thrown side of the fault.

The anomalies in the $\mathrm{S} 1 / 2 \mathrm{NE} 1 / 4$ and $\mathrm{NW} 1 / 4$ sec. 15 are evidently due to the Michigamme slate, part of which is observed to be magnetic in outcrop.

\section{MIDDLE BELT}

The "Middle belt" of magnetic anomaly, in and adjacent to sec. 17 , T. 41 N., R. 28 W., has not been mapped in detail with ground instruments. The anomaly, as known from a few ground traverses, is strong but very broad. As shown on plate 2 , eight holes have been drilled in sec. 17, and four entered iron-formation 
after passing through as much as 270 feet of Cambrian sandstone. The interpretation, indicated by cross section $C-C^{\prime}$, plate 2 , is that the Vulcan iron-formation here reaches the Precambrian surface on a complex anticlinal fold. West of sec. 17 the anomaly, as determined by the aeromagnetic survey, becomes broader and lower (see pl. 8), and dies out in the western part of sec. 18. Similarly, east of sec. 17, the anomaly becomes less pronounced, as shown by the aeromagnetic profiles, but it can be traced much farther-in fact, the anomaly probably continues to the east edge of the map area in sec. 17, T. 41 N., R. 27 W. The pattern of the anomaly is interpreted to indicate that the anticlinal fold that brings the Vulcan iron-formation to a suboutcrop position in sec. 17, T. 41 N., R. 28 W., is doubly plunging, and that the iron-formation does not reach the Precambrian surface except in that area.

\section{HANCOCK BELT}

The Hancock belt of magnetic anomaly is a poorly defined series of crests in the extreme southeastern part of the map area. The distribution of the anomalies located by the aeromagnetic survey is shown on plate 2, and the results of a small amount of ground surveying are shown on figure 60 . A very pronounced high was located immediately adjacent to the area of test pitting and probably was the reason for the original exploration. The structural trends revealed by the test pits are generally southeasterly, but the aeromagnetic survey does not record a crest along the strike from the pronounced high in the test-pit area.

The data are too few and too uncertain to provide a basis for interpretation of the magnetic anomalies of the area or to hazard an estimate as to the significance of the occurrence of iron-formation.

\section{REFERENCESI CITED}

Allen, R. C., 1920, Correlation of formations of Huronian group in Michigan: Am. Inst. Min. Met. Eng. Trans., v. 63, p. 188-212. Discussion by A. C. Lane, W. O. Hotchkiss, E. F. Burchard, L. P. Barrett, Carl Zapffe, C. E. Siebenthal, and E. C. Harder: Min. Met., v. 157, p. 1-6.

Allen, R. C., and Barrett, L. P., 1914, Contributions to the geology of Northern Michigan and Wisconsin: Michigan Geol. and Biol. Survey pub. 18, chap. 2, Geol. ser. 15.

Allen, R. C., and Leith, C. K., 1915, Discussion of correlation of pre-Cambrian formations of Lake Superior region: Jour. Geology, v. 23, p. 703-729.

Allen, R. C., Smith, R. A., and Barrett, L. P., 1916, Geological map of Michigan: Michigan Geol. Survey pub. 23 (Geol. ser. 19).

Baker, M. B., 1939, The floor of the Paleozoic in Canada: Royal Soc. Canada Trans., 3d ser., v. 33, sec. 4, p. 10-18.

Balk, Robert, 1952, Fabric of quartzites near thrust faults: Jour. Geology, v. 60, p. 415-435.
Balsley, J. R., James, H. L., and Wier, K. L., 1949, Aeromagnetic survey of parts of Baraga, Houghton, and Iron Counties, Michigan, with preliminary geologic interpretations: U. S. Geol. Survey Geophys. Inv. Rept.

Bayley, R. W., 1959, Geology of the Lake Mary quadrangle, Michigan: U. S. Geol. Survey Bull. 1077.

Bayley, W. S., 1899, The Sturgeon River tongue, in Clements and Smyth, The Crystal Falls iron-bearing district of Michigan: U. S. Geol. Survey Mon. 36, chap. 6.

1904, The Menominee iron-bearing district of Michigan: U. S. Geol. Survey Mon. 46, 513 p.

Brooks, T. B., 1873, Iron-bearing rocks : Michigan Geol. Survey, v. 1, 1869-73, pt. 1,319 p.

1880, the geology of the Menominee iron region, east of the center of Range 17 E., Oconto County, Wisconsin: Geology of Wisconsin, 1873-79, v. 3, pt. 7, p. 429-599.

Burt, W. A., 1819, Geological report of the survey, "with reference to mines and minerals," of a district of township lines in the State of Michigan, in the year 1846, and tabular statement of specimens collected, dated March 20, 1847 : U. S. 31st Cong., 1st sess., S. Doc. 1, pt. 3, p. 842-875. Clements, J. M., and Smyth, H. L., Jr., 1898, The Crystal Falls iron-bearing district of Michigan: U.S. Geol. Survey 19th Anll. Rept., pt. 3, p. 89-145.

1899, The Crystal Falls iron-bearing district of Michigan : U. S. Geol. Survey Mon. 36, 512 p.

Cloos, Ernst, 1946, Lineation. A critical review and annotated bibliography: Geol. Soc. America Mem. 18.

Credner, Hermann, 1869, Die vorsilurische Gebilde der "Oberen Halbinsel von Michigan" in Nord Amerikas: Deutsche geol. Gesell. Zeitschr., v. 21, p. 516-568.

Dickey, R. M., 1936, The granitic sequence in the southern complex of Upper Michigan: Jour. Geology, v. 44, p. 317-340.

1938, The Ford River granite of the southern complex of Michigan: Jour. Geology, v. 46, p. 321-335.

Dutton, C. E., 1950, Progress of geologic work in Iron and Dickinson Counties, Michigan: U. S. Geol. Survey Circ. 84. 1958. Precambrian geology of parts of Dickinson and Iron Counties, Michigan: Mich. Basin Geol. Soc., 40 p.

Engineering and Mining Journal, v. 153, no. 7, p. 164, July 1952. Eskola, P. E., 1949, The problem of mantled gneiss domes: Geol. Soc. London Quart. Jour., v. 104, p. 461-476.

Foster, J. W., and Whitney, J. C., 1851, Report on the geology and topography of the Lake Superior land district. Part 2. The iron region, together with the general geology. Dated November 12, 1851 : U. S. 32d Cong., spec. sess., 1851, S. Ex. Doc. 4.

Gair, J. E., and Wier, K. L., 1956, Geology of the Kiernan quadrangle: U. S. Geol. Survey Bull. 1044.

Grout, F. F., Gruner, J. W., Schwartz, G. M., and Thiel, G. A., 1951, Pre-cambrian stratigraphy of Minnesota: Geol. Soc. America Bull., v. 62, p. 1017-1078.

Gruner, J. W., 1922, Paragenesis of the martite ore bodies and magnetites of the Mesabi Range, Minnesota: Econ. Geologv, v. 17, p. 1-14.

Hamblin, W. K., 1958, The Cambrian sandstones of northern Michigan: Mich. Dept. Conserv., Geol. Survey Div., Publ. $51,1+6 \mathrm{p}$.

Higgins, J. W., 1947, Structural petrology of the Pine Creek area. Dickinson County, Michigan: Jour. Geology, v. 55, p. $476-189$. 
Irving, R. D., 1887, Is there a Huronian group?: Am. Jour. Sci., v. 34, p. 256 .

- 1888, On the classification of the early Cambrian and Pre-cambrian formations: U.S. Geol. Survey 7th Ann., Rept., p. 435 .

Jackson, C. T., 1849, Report on the geological and mineralogical survey of the mineral lands of the United States in the State of Michigan: U.S. 31st Cong., 1st sess., S. Doc. 1, p. 371-935.

James, H. L., 1948, Field comparisons of some magnetic instruments, with analysis of Superdip performance: Am. Inst. Min. Met. Eng. Tech. Pub. 2293; Trans., v. 178, p. 490-500. 1954, Sedimentary facies of iron-formation: Econ. Geology, v. 49, p. 235-293.

1955, Zones of regional metamorphism in the Precambrian of northern Michigan: Geol. Soc. America Bull. v. 66 , p. $1455-1488$.

1958, Stratigraphy of pre-Keweenawan rocks in parts of northern Michigan : U.S. Geol. Survey Prof. Paper 314-C.

Lake Superior Iron Ore Association, 1938, Lake Superior Iron Ores: Cleveland, Ohio, 364 p.

1952, Lake Superior Iron Ores: Cleveland, Ohio, $326 \mathrm{p}$.

Lamey, C. A., 1931, Granite intrusions in the Huronian formations of northern Michigan: Jour. Geology, v. 39, p. 288-295. 1933, The intrusive relations of the Republic granite: Jour. Geology, v. 41, p. 487-500.

1934, Some metamorphic effects of the Republic granite : Jour. Geology, v. 42, p. 248-263.

_ 1937, Republic granite or basement complex?: Jour. Geology, v. 45, p. 487-510.

Lehner, R. E., 1950, Geology of a part of the gneissic complex north of Felch Mountain, Michigan: Master's thesis on file at The Ohio State University, Columbus.

Leith, C. K., Lund, R. J., and Leith, Andrew, 1935, Pre-Cambrian rocks of the Lake Superior region: U.S. Geol. Survey Prof. Paper 184.

Leverett, Frank, 1917, Surface geology and agricultural conditions of Michigan: Michigan Geol. and Biol. Survey Pub 25, Geol. ser. 2.

1929, Moraines and shore lines of the Lake Superior basin: U. S. Geol. Survey Prof. Paper 154A.

Martin, H. M., 1936, The centennial geological map of the northern peninsula of Michigan: Michigan Dept. Conserv., Geol. Survey Div. Pub. 39, Geol. ser. 33.

Mining Engineering, v. 4, no. 7, p. 643, July 1952.
Pettijohn, F. J., 1943, Basal Huronian conglomerates of Menominee and Calumet districts, Michigan: Jour. Geology, v. 51, p. 387-397.

- 1951, Geology and magnetic anomalies of T. 42 N., R. 30 W., Dickinson County, Michigan: U. S. Geol. Survey open-file report.

Richardson, E. S., Jr., 1949, Some Lower Huronian stromatolites of northern Michigan: Fieldiana Geology, Chicago Nat. History Mus., v. 10, no. 8, p. 47-62.

Rominger, C. L., 1881, Menominee iron region: Geol. Survey of Michigan, v. 4, pt. 2, p. 155-241.

- 1895, Geological report on the Upper Peninsula of Michigan, exhibiting the progress of work from 1881 to 1884. Iron and copper regions: Geol. Survey of Michigan, v. 5 , pt. 1, p. 1-94.

Roseboom, F. H., 1951, Geology of an area of granitic complex south of the Felch Mountain range, Michigan: Master's thesis, on file at The Ohio State University, Columbus.

Stead, F. W., Davis, F. J., Nelson, R. A., and Reinhardt, P. W., 1950, Airbone radioactivity survey of parts of Marquette, Dickinson, and Baraga Counties, Michigan: U.S. Geol. Survey (Map and brief text printed on map sheet).

Trow, J. W., 1948, The Sturgeon quartzite of the Menominee district, Michigan: Ph.D. thesis on file at Univ. of Chicago, $60 \mathrm{p}$.

Turner, F. J., and Verhoogen, Jean, 1951, Igneous and metamorphic petrology: New York, N.Y., MeGraw-Hill Book Company, Inc.

Tyler, S. A., 1949, Development of Lake Superior soft iron ores from metamorphosed iron formation: Geol. Soc. America Bull., v. 60, p. 1101-1124.

Tyler, S. A., Marsden, R. W., Grout, F. F., and Thiel, G. A., 1940, Studies of the Lake Superior pre-Cambrian by accessory mineral methods: Geol. Soc. America Bull., v. 51, p. 1429-1538.

Van Hise, C. R., and Leith, C. K., 1911, Geology of the Lake Superior region: U.S. Geol. Survey Mon. 52.

Wadsworth, M. E., 1893, Report of the State geologist for 1891-1892: Michigan State Board of Geol. Survey for the years 1891 and 1892 , p. 59-73.

Wier, K. L., Balsley, J. R., and Pratt, W. P., 1953, Aeromagnetic survey of Dickinson County, Michigan, with preliminary geologic interpretation: U.S. Geol. Survey Geophys. Invest. Prelim. Rept. GP 115.

Wier, K. L., and Kennedy, B. E., 1951, Geologic and magnetic data of the Sholdeis-Doane and Red Rock explorations, Iron County, Michigan: U.S. Geol. Survey open-file rept. 


\section{INDEX}

A

Abstract

Accessibility

Acknowledgments

eromagnetic survey, by K. L. Wier

correlation with geology

reliability.

total-intensity profiles

Ajibik quartzite, Marquette district

Albite ............................ 100-101

Algal structures . . . . .

Algoman granite, Minnesota.

Amphibolite, analyses

146-147, 149-150

Six-Mile Lake . . . . . .

See also Six-Mile Lake amphibolite.

Analyses, chemical, amphibolite.

chemical, granite

granite gneiss...

iron ore

tholeiite.

-27
$-\quad 128,124$

Rosiwal, amphibolite............ 122, 124

Aplite.

Arkose. See East Branch arkose.

Au Train formation.

161

50

description . . . . .

147,160

Balk, Robert, quoted.................... 70

Baraga group, Calumet trough .

depositional conditions . . . . .

stratigraphic units . . . . .

See also Badwater greenstone, Hemlock formation, Michigamme slate

Bibliography, annotated

Brier member, Vulcan iron-formation... 43

Browning Creek area, conglomerate

Michigamme slate

Paleozoic rocks. . . . .

production history

Randville dolomite $\ldots \ldots \ldots \ldots \ldots$.

Vulcan iron-formation.......... 40, 43, 77, 156, 167

Calumet mine area, structural geology ..................................... 166

Calumet trough, aeromagnetic survey . . . . amphibolite . . . . aplite

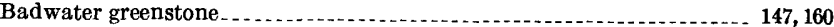

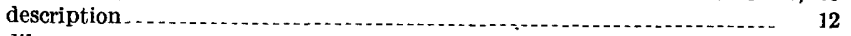

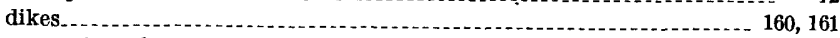

economic geology ... ...

Felch formation. ......... 147, 155

Fern Creek formation

geography $\ldots \ldots \ldots$

geology

glacial deposits $\ldots \ldots \ldots$.

gneiss . . . . . .

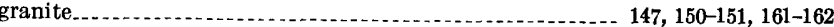

graywacke.................................. 157-158

Hardwood gneiss............ 147, 148-152

introduction.....................

investigation, previous

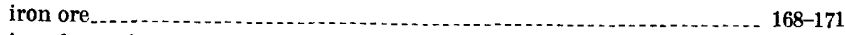

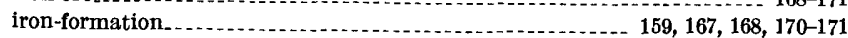

magnetic anomalies. ......... 68, 88-89, 91, 95-96, 166-167, 170-171

metamorphism.

Michigamme slate
Calumet trough-Continued $\quad$ Page pegmatite

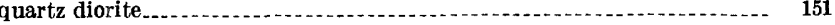
quartzite. Randville dolomite................ 147, 154-155 schist .......................... 147-148, 150, 158-159 structural geology Sturgeon quartzite............................................ 147, 153-154, 167 Vulcan iron-formation . . .

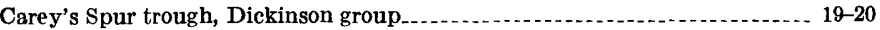
location 61

Central crystalline block, aeromagnetic survey

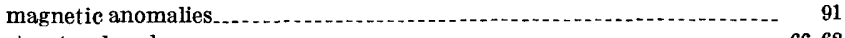
structural geology

Chlorite schist..................... $98-99$

Chocolay group, Calumet trough

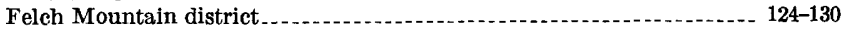

stratigraphic units............................... 10, 31

See also Fern Creek formation, Randville dolomite, Sturgeon quartzite for detailed listirgs.

Clark, Lorin D., Pi ecambrian geology of the Norway Lake area _..._. . . . . . 97-115 Crystal Lake, glacial deposits near._Crystal Lake area, structural geology

Deerhunt exploration, Felch formation magnetic data.... 11 red slates and graywackes. Vulcan iron-formation ............................. 43, 45, 88, 91, 109, 113

Diabase, Felch Mountain district.................................. 119, 136

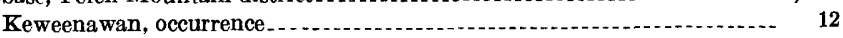
Precambi ian

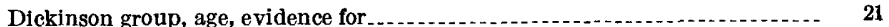

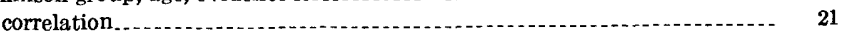
depositional conditions . distribution _... 13

Felch Mountain district._.......................................... 119-121 metamorphism

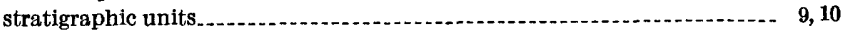
undivided .

See also East Branch arkose, Six-Mile Lake amphibolite, Solberg schist.

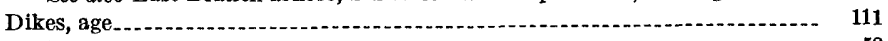

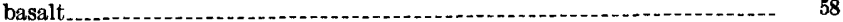

character granite and pegmatite.......... 135-136 metadiabase............................................... 12, 54, 110-111, 134, 161

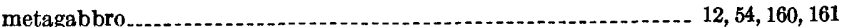

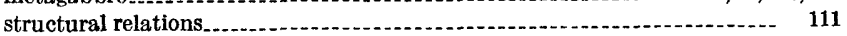
See also particular area.

Diorite, quartz. See Quartz diorite.

Dolomite, iron-oxide replacement. production.

See also Randville dolomite.

$\mathbf{E}$

East Branch arkose, description $\ldots . . . . . . . . . . . . . .9,10,13-17,101-103$

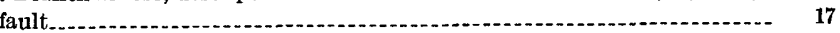

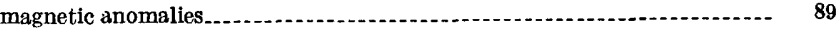

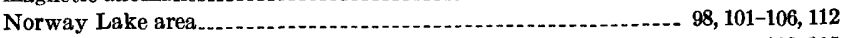
petrography and petrology

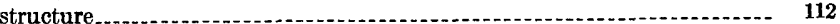
structural and stratigraphic relations.

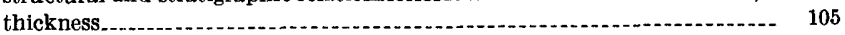
Economic geology See also particular area.

Eparchean interval.

Fault, Bush Creek. F Bush Lake. 
Fault-Continued East Branch arkose

Page North Calumet

Norway Lak South Calumet Toby Lake

Felch, Mich

Felch formation, Calumet trough conditions of deposition

description

Felch Mountain district

magnetic anomalies

occurrence.

schist in

thickness and stratigraphic relations.

Felch Mountain district, diabase

Dickinson group.

dikes

119,136

dolomite...

$119,134-136$

economic geology

Felch formation

$119,128-130,138$

$119,131+13$

geologic histor

general geology

141

glacial deposits

116-117

gneiss.

119,136

granite pegmatite

introduction . 115-116

Investigation, methods and scope

Investigation, previous...........

magnetic anomalies _... 141-143

magnetic maps. . - .

metamorphism

quartzite . . .

Randville dolomite.

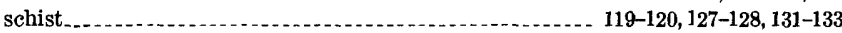
See also Solberg schist.

Six-Mile Lake amphibolite

Solberg schist.....

stratigraphic succession.

structural geology $\ldots . . \ldots \ldots \ldots$

Sturgeon quartzite

topography

Vulcan iron-formation.

119, 133-134, 138

description.

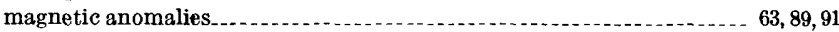

metamorphism

structural geology, central segment

eastern segment

western segment

Fern Creek formation, Calumet trough

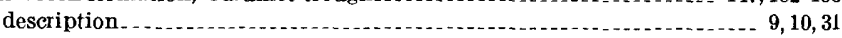

Fieldwork, in Calumet trough area. ..................... 145

in Felch Mountain district ...

time

First Creek area, Badwater greenstone.

structural geology

Foliation . . . . 111-112

Fossils. See Algal structures, Stromatolites.

Foster City, Paleozoic rocks near

Freedman, Jacob, James, Harold L., and Trow, James, Geology of the Calumet trough and vicinity

$145-171$

General geology, by H. L. James and F. J. Pettijohn

Geography .

$9-97$ eologic history

See also Felch Mountain district.

Geology of the Calumet trough and vicinity, by Jacob Freedman, Harold L.

James, and James Trow

Geology of the Felch Mountain district, by Carl A. Lamey

Glacial deposits

See also particular area.

$98,113,119,136$

Glacial features
Gneiss, banded gray, description. Page banded gray, petrography

origin $24,122-123$

garnet-hornblende-pyroxene. .

hornblende-pyroxene $\ldots$

plagioclase-quartz

See also Granite gneiss, Hardwood gneiss ard particular area.

Gneissic granite. See Granite, gneissic.

Goodrich quartzite

Granite, age

chemical composition......... $29,57,124,162$

description............ 57

distribution................ 55

gneissic, age relations.

chemical composition.

description . . . . . . .

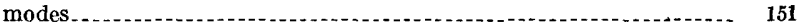

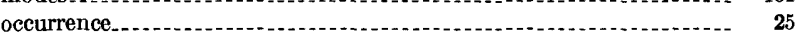

See also Granite gneiss.

porphyritic red, age relations...- 29

analyses.......... 29

description ....... 28-29

pre-Animikie, description

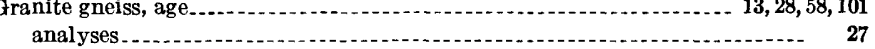

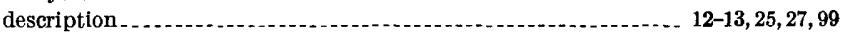

Norway Lake area _ 12-13, 99-101

occurrence...

petrography .

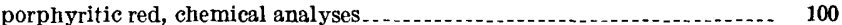

structural relations. ........

See also Granite, gneissic.

Granite pegmatite, Felch Mountain district.

Granitic complex, description

origin

petrography .................... 123-124

Graywacke, Calumet trough

description. . . . . .

Norway Lake area...... 110

Green Bay lobe.................... 79

Ground surveys, interpretation

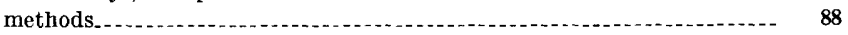

Groveland mine, dikes.

faulting -............ 140, 141

Felch formation. ...................... 36, 37,132

iron-formation

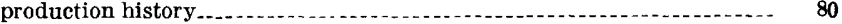

Randville dolomite ............... 34,63

Groveland syncline, iron-formation.

H

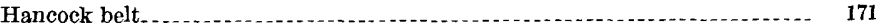

Hancock exploration, history

iron-formation

Michigramme slate

Hardwood gneiss, Calumet trough $\quad 147,148-152$ description . . .

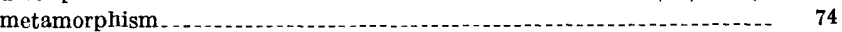

modes.................... 148

origin .................. 150, 152

relations to other rocks

Hecla property, exploration history

Hemlock formation, description. ............. 9, 10,12, 46-48

Hermansville limestone.

Higgins, J. W., quoted . 68,70

Hornblende diorite, age and description

distribution . . . .

Hotchkiss Superdip, use-1

Introduction, by $\mathrm{H}$. L. James

See also Calumet trough, Felch Mountain district.

Intrusive rocks, age.

Calumet trough

description $54,161-162$

Felch Mountain district

Precambrian . ...

Investigation, previous....

See also particular area. 
Page

Iron ore, chemical analyses.

\section{definition}

high-grade, occurrence and origin

history of mining.

low-grade, iron-formation

Skunk Creek member of Solberg schist

possibilities in areas east of central Dickinson County

production

See also Calumet mine, Groveland mine.

reserves

James, H. L., Introduction.

James, H. L., and Pettijohn, F. J., General geology

James, H. L., with Freedman, Jacob, and Trow, James, Geology of the Calumet trough and vicinity

$\mathrm{K}$

Knife Lake group, Minnesota

Kona dolomite, Marquette district

La Branche, magnetic anomaly near.

Lamey, Carl A., Geology of the Felch Mountain district

Lineation.

Loretto member, Vulcan iron-formation.

Location and accessibility

Magnetic anomalies, Calumet trough $\ldots . . \ldots \ldots$.... 68, 88-89,91, 95-96, 166-167, 170-171 Felch Mountain district.

141-143

Hancock belt.

Norway Lake area......... 113

northern crystalline block

rock types..

southern crystalline block

Vulcan iron-formation

$170-171$

Magnetic surveys. See Ground surveys, Aeromagnetic survey.

Magnetometers, Schmidt-type vertical-component, use

Mapping methods

Marquette Range

Menominee group, Calumet trough

Felch Mountain district

stratigraphic units.

See also Felch formation, Vulcan iron-formation

Menominee River, Michigamme slate near

Mesnard quartzite, Marquette district........ 31, 105, 106

Metadiabase, age. description . . .

occurrence outcrops... . . structural relations.

Metagabbro, description and age relations

Metamorphism, Felch Mountain district. history . ...

hydrothermal

intrusive rocks.
iron-formations........

late lower Precambrian

late middle Precambrian, description

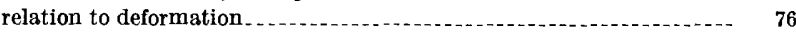

relation to granitic intrusion

retrograde.

Metronite quarry $\ldots \ldots \ldots \ldots, 54,135$

Michigamme Mountain, Hemlock formation. . . . .

Michigamme slate, Calumet tr ough............................. 48, 147, 157-160 concretionary structures $\ldots \ldots \ldots \ldots \ldots$ description. . . . distribution ..................................... 48,157

graywacke . .........

magnetic anomalies

Marquette district

Norway Lake area.

schis

8, 110-111

$49,158-159$
$53,159-160$

stratigraphic relation

thickness

$51,53,159$

Mining, iron ore, history -

Munising formation
$\mathbf{N}$

Page

Negaunee fron-formation, Marquette district ............ 31, 54, 106

Northern crystalline block, aeromagnetic survey

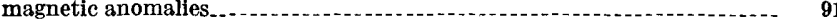

structural geology _........ 61-63

Norway Lake area, chlorite schist .

dikes. . . . . . . . . .

East Branch arkose................................ 10, 13-17, 98, 101-106, 112

faults

geology

glacial deposits $\ldots$

granite gneiss................. 12-13, 99-101

graywacke._-_. 110

investigation, previous........ 97

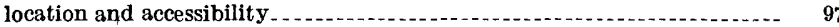

magnetic anomalies

Michigamme slate

pegmatite ...

quartzite . . .

Randville dolomite, description

red slate

Skunk Creek member of Solberg schist _........................ 98, 106-107

structural geology

Sturgeon quartzite...................... 107

Vulcan iron-formation, description $\ldots . . . . \ldots \ldots, 109$

O

Orogenic activity

$71-73,78$

Paleozoic rocks $\ldots$

Peavy node............ 74

Pegmatite, age relations.

Calumet trough $\ldots \ldots \ldots 1$

description .

distribution. . . . . . .

Felch Mountain district.

Norway Lake area........... 111

See also Granite pegmatite.

Pettijohn, F. J., quoted........ 154

Pettijohn, F. J., and James, H. L., General geology .................. 9-97

Pine Creek area, Michigamme slate _....................... 166 Sturgeon quartzite.

Population . .

Precambrian geology of the Norway Lake area, by Lorin D. Clark

Precambrian geology of the Norway Lake area, by Lorin
Precambrian rocks. See under names of the formations.

Quartz diorite

$\mathbf{Q}$

(151

Quartzite, Calumet trough $\ldots \ldots \ldots$. ferruginous . . .

Norway Lake area

sericitic ...

vitreous . . . . .

See also Sturgeon quartzite.

$\mathbf{R}$

Randville, dolomite quarries near................

Randville dolomite, Calumet trough

depositional conditions

description . . ....................... 9, 10, 34-36, 128-129, 154-155

Felch Mountain district.

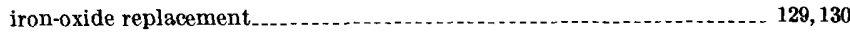

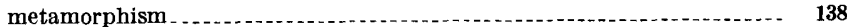

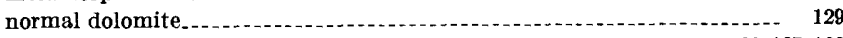

Norway Lake area......... 98, 107-109

occurrence_.

petrography - .

silicified . . .

slate, magnetic anomalies.................... 34, 89

thickness and stratigraphic relations

Rand ville syncline, location . . .

trend. 63

Rian's quarry ............... 34, 37, 87, pl.

Rock Lake area, magnetic anomalies

Sagola basin aeromagnetic survey 
Sagola basin-Continued description. magnetic anomalies

Michigamme slate struct ural geology

Schist, associated with dolomite

biotite

biotite-chlorite

biotite-garnet.

biotite-magnetite

biotite-muscovite

feldspathic quartz-mica.............................................. 127-128, 133

garnet-grunetite

garnet-quartz-mica.

granitic biotite

in Felch formation $\ldots . . . \ldots \ldots \ldots \ldots$ 119-120, 127-128, 131-133

quartz-mica

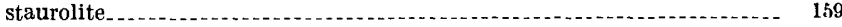

See also Solberg schist and particular area.

Siamo slate, Marquette district.

Sills, metadiabase metagabbro
Page 89,91

48
$60-61$

130

-159

158

59

59
Stun

Six-Mile Lake amphiout 54

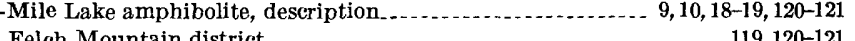

(119,120-121

$\begin{array}{ll}\text { petrography } \ldots \ldots \ldots & 121 \\ \text { stratigraphic succession } & 119\end{array}$

Skunk Creek member, Solber g schist, description............. 18

Felch Mountain district... . . . . . . .

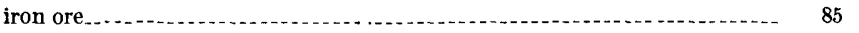

magnetic anomalies.......... 17, 20,80, 85, 89, 113, 143

Norway Lake district $\quad$ 98, 107 Slate. See Michigamme slate, Randville dolomite, Vulcan iron-formation.

Smyth, H. L., Jr., quoted . . . . . . . . . . . . . . 28, 126, 137, 138

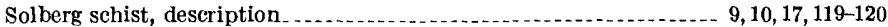

Felch Mountain district

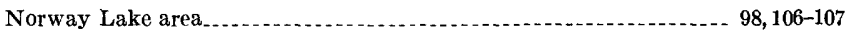

stratigraphic succession...................... 119

See also Skunk Creek member.

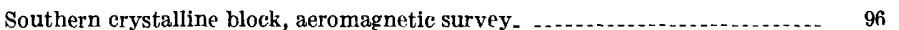

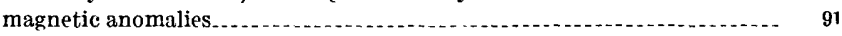

str uctural geology . . . . . .

Stromatolites $35-36,60,106,107,109,112$

Structural geology, Calumet trough

development, summary

Folch Mountain district. ............. 139-141

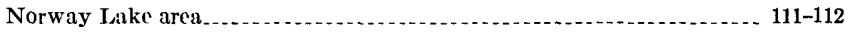

Sturgeon Pond area, Felch formation. 37

Sturgeon quartzite, Calumet trough ............................ 147, 153-154, 167

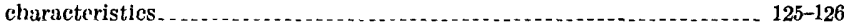

depositional conditions

description . . . . . . . . . . . . . 10, 31-33, 153-154

Felch Mountian district................................... 119, 124-128, 137-138

Sturgeon quartzite-Continued $\quad$ Page

lithologic classification. . . . .

magnetic anomalies................................ 89, 125

metamorphism . . -

Norway Lake area................. 107

occurrence ................ 107, 125-126, 153

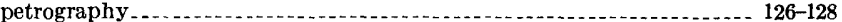

stratigraphic succession ........................... 119

thickness ............. 33,154

Sturgeon Pond area, Vulcan iron-formation........................... 40, 84

turgeon River, East Branch, amphibolite near................ 149

East Branch, slates and graywackes near.

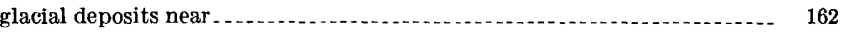

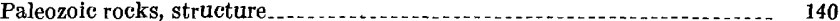

Randville dolomite near......................... 129

Sturgeon quartzite near........ 125, 126

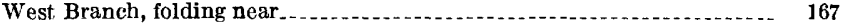

Michigamme slate near.................................... 48, 157, 166

Sunday quartzite

Terrazzo," production

Topography _...

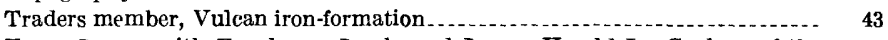

Trow, James, with Freedman, Jacob, and James, Harold L., Geology of the

Calumet trough and vicinity

$\mathrm{U}$

Uranium, occurrence.

$\mathbf{V}$

Vegetation

Volcanic rocks, magnetic anomalies..... 89

Vulcan iron-formation, Calumet trough description . . . . . . . distribution . . . . . . . . . . . .

economic geology . .

Feich Mountain district...................................... 119, 133-134, 138 gray-banded rocks. . . . . . . . . . . . . . . . . . . iron ore, low-grade magnetic anomalies..................................... 89, 170-171

metamorphism ....... $45-46$

Norway Lake area........................ 98,109

oolitic rocks

origin, conditions of .......... 43

petrography . ....... 133-134

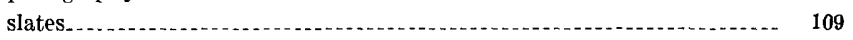

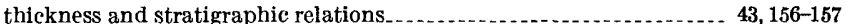

W

Weathering, Precambrian

Wier, K. L., Aeromagnetic survey $89-96$ 